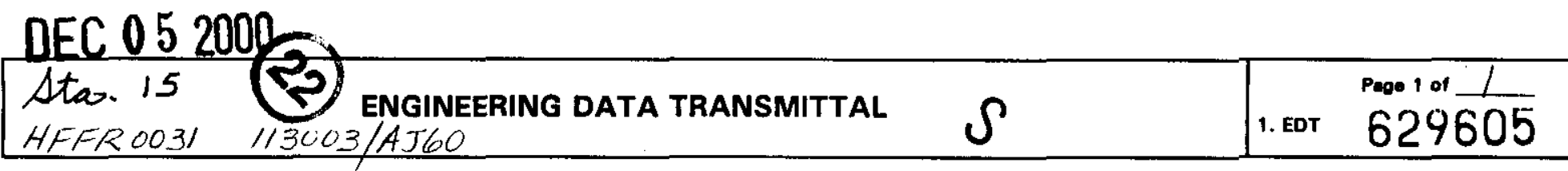

\begin{tabular}{|l|l|}
\hline $\begin{array}{l}\text { 2. To: (Receiving Organization) } \\
\text { Distribution }\end{array}$ & $\begin{array}{l}\text { 3. From: (Originating Organization) } \\
\text { Duratek Federal Services, Inc. }\end{array}$ \\
\hline $\begin{array}{l}\text { 5. Proj./Prog./Dept./Div.: } \\
\text { Uranium Disposition Project }\end{array}$ & $\begin{array}{l}\text { 6. Design Authority/Design Agent/Cog. Engr.: } \\
\text { P. C. Ferrell }\end{array}$ \\
\hline $\begin{array}{l}\text { 8. Originator Remarks: } \\
\text { The Steel Banded Wooden Shipping Containers SARP has completed the } \\
\text { DOE-HQ certification process and can now be released. }\end{array}$
\end{tabular}

11. Receiver Remarks: 11A. Design Baseline Document? $\bigotimes$ Yes $\square$ No

\begin{tabular}{|c|c|c|c|}
\hline \multicolumn{4}{|c|}{$\begin{array}{l}\text { 4. Related EDT No.: } \\
\text { NA }\end{array}$} \\
\hline \multicolumn{4}{|c|}{$\mathrm{NA}$} \\
\hline \multicolumn{4}{|c|}{ 9. Equip./Component No.: } \\
\hline \multicolumn{2}{|c|}{333} & & \\
\hline \multicolumn{4}{|c|}{$\begin{array}{l}\text { 12. Major Assm. Dwg. No.: } \\
\text { NA }\end{array}$} \\
\hline \multicolumn{4}{|c|}{$\begin{array}{l}\text { 13. Permit/Permit Application No.: } \\
\text { NA }\end{array}$} \\
\hline \multicolumn{4}{|c|}{$\begin{array}{l}\text { 14. Required Response Date: } \\
\text { NA }\end{array}$} \\
\hline (F) & (G) & $(\mathrm{H})$ & (l) \\
\hline $\begin{array}{l}\text { Approval } \\
\text { Desig- } \\
\text { nator }\end{array}$ & $\begin{array}{l}\text { Reason } \\
\text { for Trans- } \\
\text { mittal }\end{array}$ & $\begin{array}{c}\text { Origi- } \\
\text { nator } \\
\text { Dispo- } \\
\text { stion }\end{array}$ & $\begin{array}{l}\text { Receiv- } \\
\text { er } \\
\text { Dispo- } \\
\text { sition }\end{array}$ \\
\hline$S, Q$ & 1,2 & 1 & 1 \\
\hline & & & \\
\hline & & & \\
\hline & & & \\
\hline & & & \\
\hline & & & \\
\hline & & & \\
\hline
\end{tabular}

16.

KEY

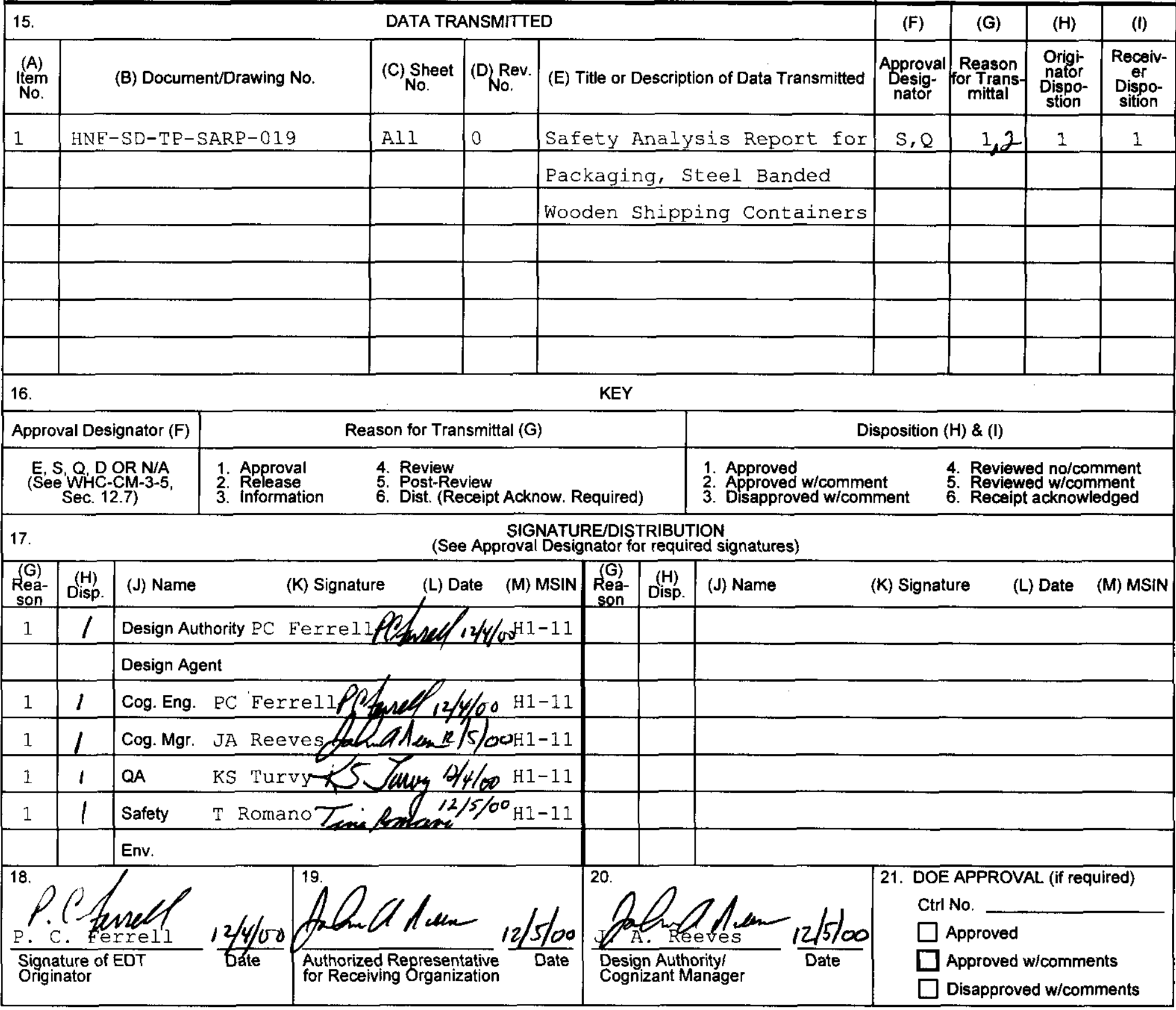


$S$

HNF-SD-TP-SARP-019

Revision 0

Safety Analysis Report for

Packaging, Steel Banded

Wooden Shipping

Containers

USA/5467/AF-85 (DOE)

Prepared for the U.S. Department of Energy

Assistant Secretary for Environmental Management

Project Hanford Management Contractor for the

U.S. Department of Energy under Contract DE-AC06-86RL13200

Fluor Hanford

P.O. Box 1000

Richland, Washington 
TRADEMARK DISCLANMER

Reference herein to any specific commercial product, process, or service by trade name, trademark, manufacturer, or

otherwise, does not neceeserily conatitute or imply its

endorsement, recommendation, or favoring by the United

States Government or any agency thereof or its contractors or subcontractors.

This report has been reproduced from the best avallable copy.

Printed in the United States of America

Total Pages: $\quad 232$ 


\title{
Safety Analysis Report for Packaging, Steel Banded Wooden Shipping Containers
}

\author{
USA/5467/AF-85 (DOE) \\ Document Type: SARP \\ Division: WM \\ P.C. Ferrell \\ Duratek Federal Services, Inc. Northwest Operations for Fluor Hanford
}

Date Published

December 2000

Prepared for the U.S. Department of Energy

Assistant Secretary for Environmental Management

Project Hanford Management Contractor for the

U.S. Department of Energy under Contract DE-AC06-96RL13200

Fluor Hanford

P.O. Box 1000

Richland, Washington
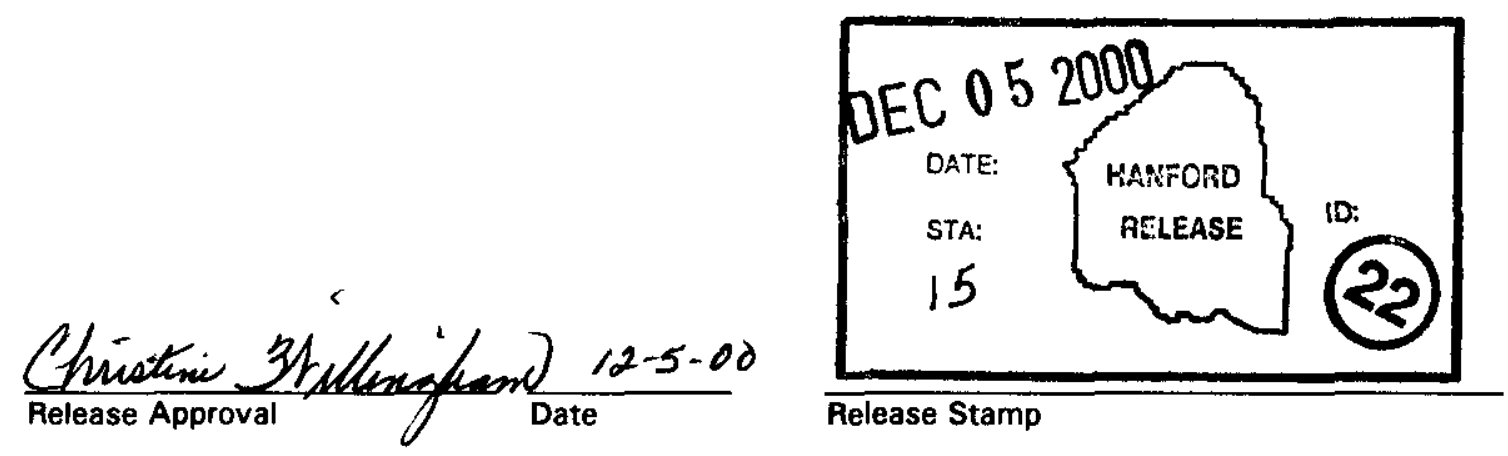
Key Words: uranium, Type AF, enriched uranium, ingots, billets, extrusions

Abstract: This safety analysis report for packaging describes the steel banded wooden shipping containers, which are certified as Type AF packagings. The authorized payload for these containers is unirradiated, slightly enriched, uranium ingots, billets, extrusions, and scrap materials. The amount of uranium in the containers will not exceed the LSA-Il material requirements as defined in 49 CFR 173.403. 


\section{CONTENTS}

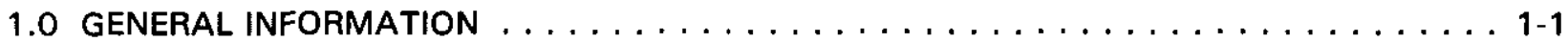

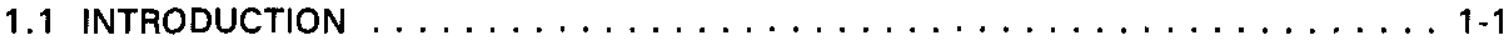

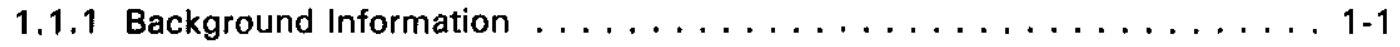

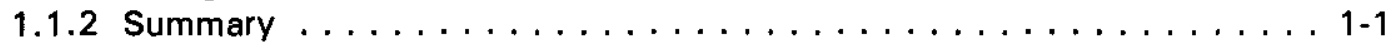

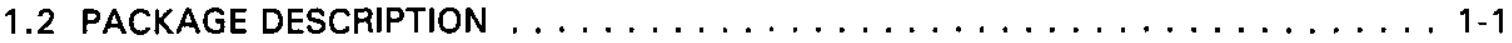

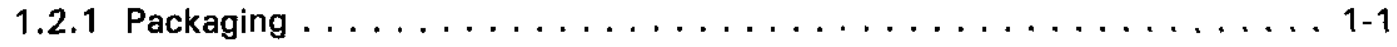

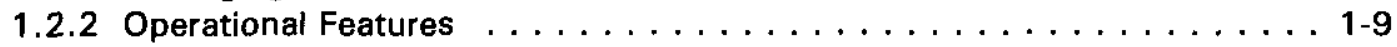

1.2 .3 Package Contents . . . . . . . . . . . . . . . 1-9

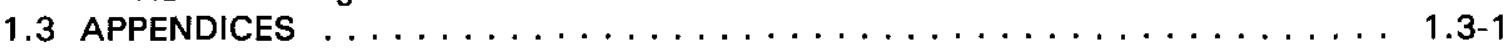

1.3.1 References . . . . . . . . . . . . . . . . . . 1.1

1.3.2 General Arrangement Drawings . . . . . . . . . . . . 1.3-2

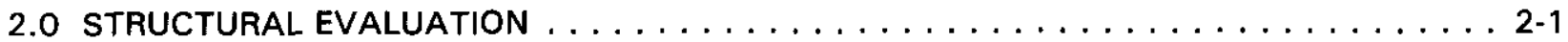

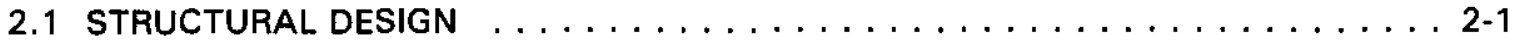

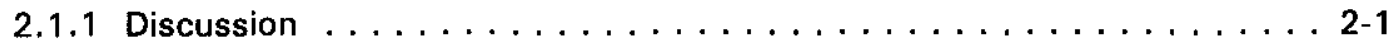

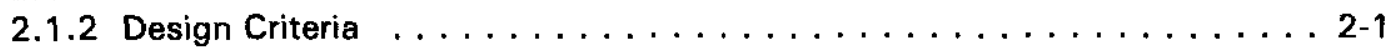

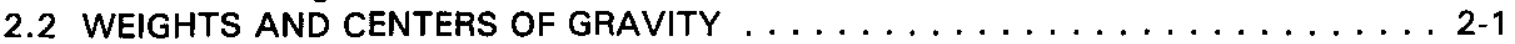

2.3 MECHANICAL PROPERTIES OF MATERIALS $\ldots \ldots \ldots \ldots \ldots \ldots \ldots \ldots \ldots \ldots \ldots$

2.4 GENERAL STANDARDS FOR ALL PACKAGES $\ldots \ldots \ldots \ldots \ldots \ldots \ldots \ldots \ldots \ldots \ldots$

2.4.1 Minimum Package Size . . . . . . . . . . . . . . . . 2-2

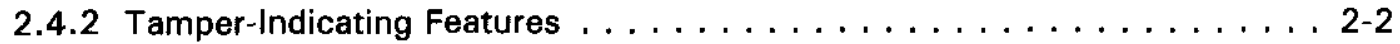

2.4.3 Positive Closure . . . . . . . . . . . . . . . . . . 2-2

2.4.4 Chemical and Galvanic Reactions . . . . . . . . . . . . 2-2

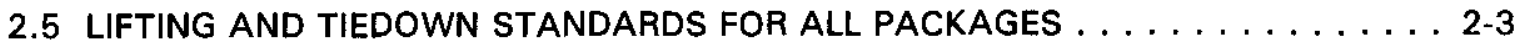

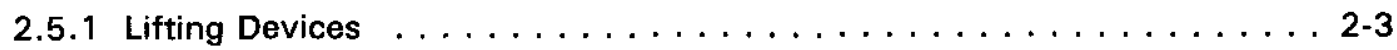

2.5 .2 Tiedown Devices ..................... 2-3

2.6 NORMAL CONDITIONS OF TRANSPORT $\ldots \ldots \ldots \ldots \ldots \ldots \ldots \ldots \ldots \ldots$

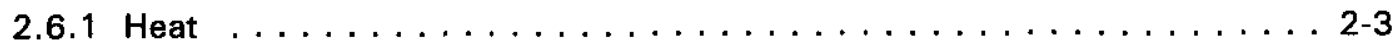

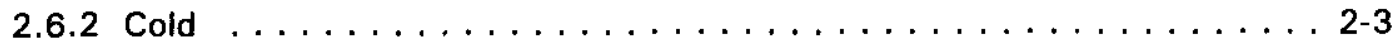

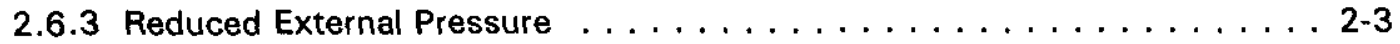

2.6.4 Increased External Pressure . . . . . . . . . . . . . . 2-3

2.6 .5 Vibration . . . . . . . . . . . . . . . . . 2-4

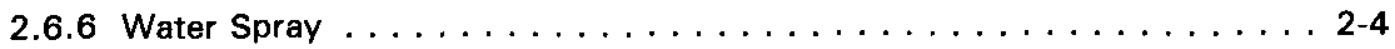

2.6.7 Free Drop ....................... 2-4

2.6.8 Corner Drop . . . . . . . . . . . . . . . . . . 2-10

2.6.9 Compression . . . . . . . . . 2-10

2.6.10 Penetration ..................... 2-16

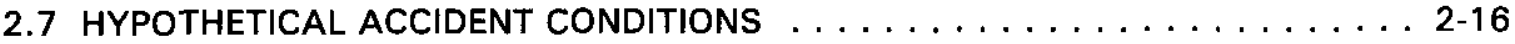

2.7.1 Free Drop . . . . . . . . . . . . . . . . . . . . .

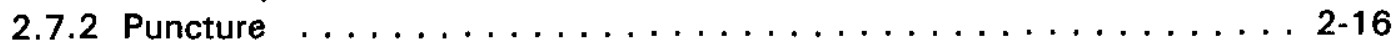

2.7.3 Thermal ....................... 2-16

2.7.4 Immersion - Fissile Material . . . . . . . . . . . . 2-16

2.7.5 Immersion - All Packages . . . . . . . . . . . . . 2-17

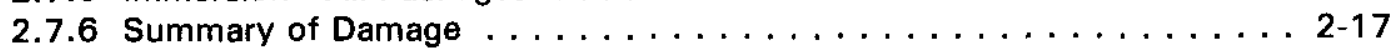

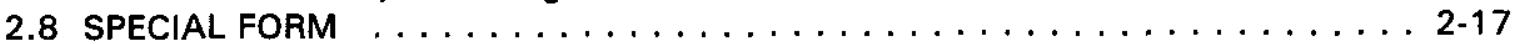

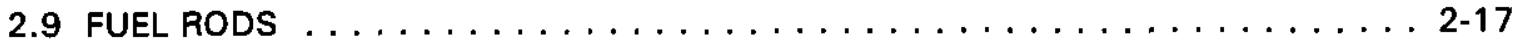

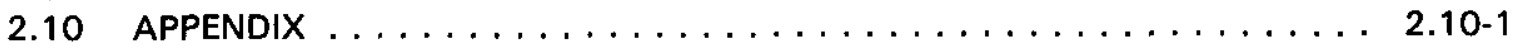

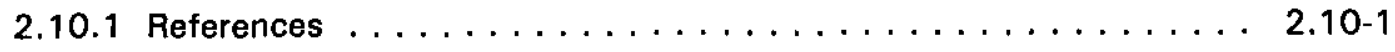


CONTENTS, cont.

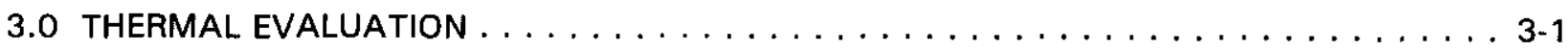

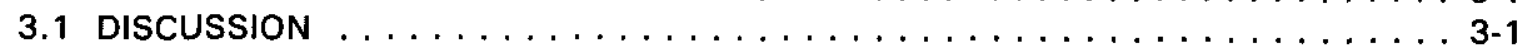

3.2 SUMMARY OF THERMAL PROPERTIES OF MATERIALS $\ldots \ldots \ldots \ldots \ldots \ldots \ldots$. $\ldots \ldots$

3.3 TECHNICAL SPECIFICATIONS OF COMPONENTS $\ldots \ldots \ldots \ldots \ldots \ldots \ldots . . \ldots \ldots$

3.4 THERMAL EVALUATION FOR NORMAL CONDITIONS OF TRANSPORT . . . . . 3-1

3.5 HYPOTHETICAL ACCIDENT THERMAL EVALUATION $\ldots \ldots \ldots \ldots \ldots \ldots \ldots$ 3-1

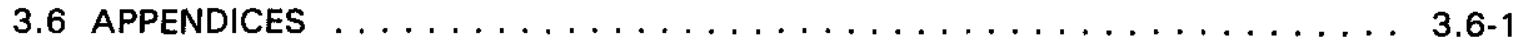

3.6.1 Reference . . . . . . . . . . . . . . . . . . .

3.6.2 Decay Heat from Metallic Uranium inside a Package . . . . . . . . 3.6-1

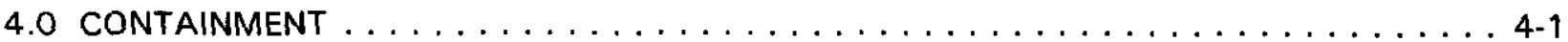

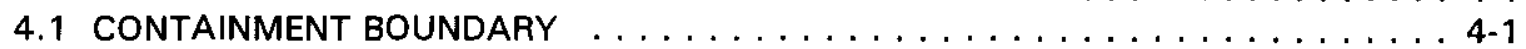

4.2 REQUIREMENTS FOR NORMAL CONDITIONS OF TRANSPORT . . . . . . . 4-1

4.3 CONTAINMENT REQUIREMENTS FOR HYPOTHETICAL ACCIDENT

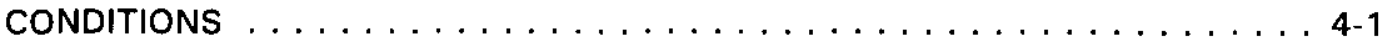

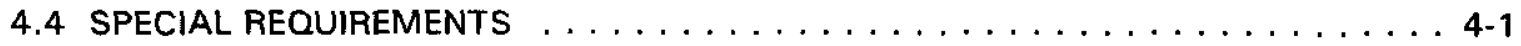

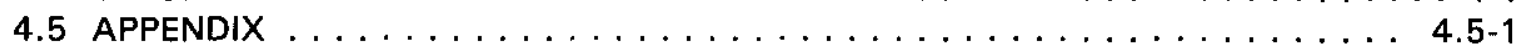

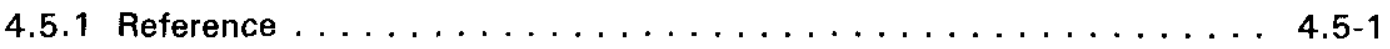

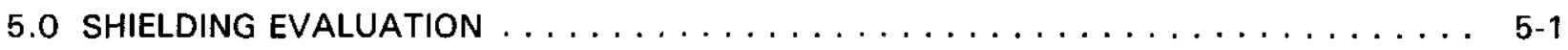

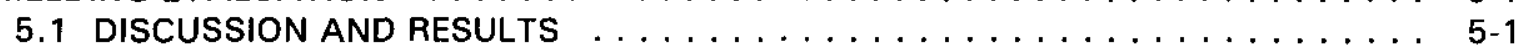

$5.1 .1 \mathrm{~N}$ Reactor Mark I and IV Ingots $\ldots \ldots \ldots \ldots \ldots \ldots \ldots \ldots \ldots$ 5-2

5.1 .2 RMI Forged Billets . . . . . . . . . . . . . . . . . 5 -2

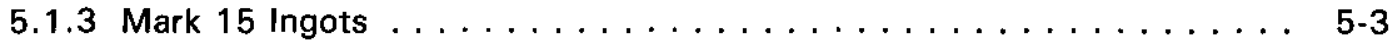

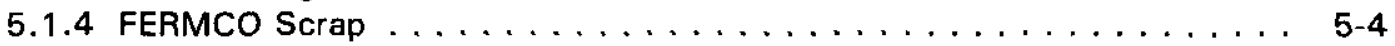

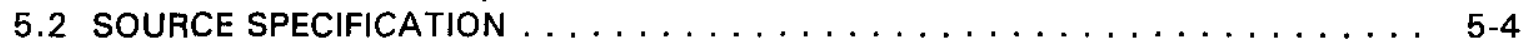

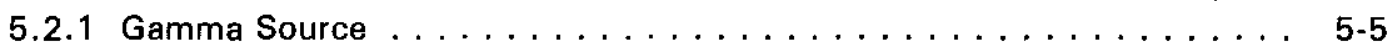

5.2 .2 Neutron Source . . . . . . . . . . . . . . . . . 5-8

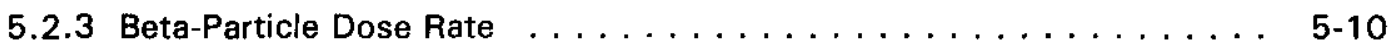

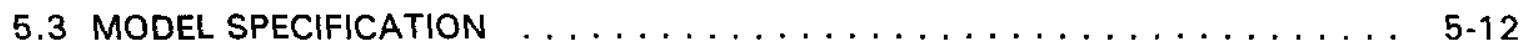

5.3.1 Description of Radial and Axial Shielding Configuration . . . . . . . 5-12

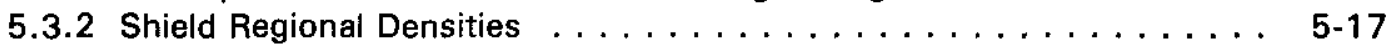

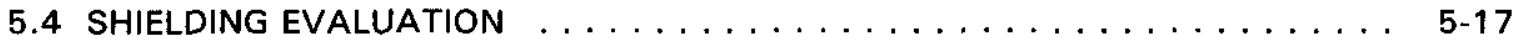

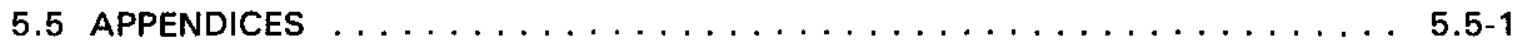

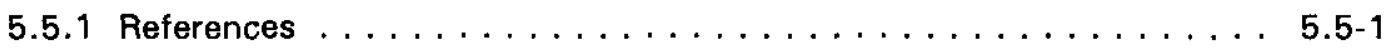

5.5 .2 Tables of All Calculated Dose Rates . . . . . . . . . . . . 5.5-2

5.5 .3 ORIGEN2 Input File for $0.95 \%$ Enriched Uranium . . . . . . . . . 5.5-6

5.5 .4 ORIGEN2 Input File for $1.1 \%$ Enriched Uranium . . . . . . . . . . 5.5-7

5.5 .5 ORIGEN2 Input File for $1.25 \%$ Enriched Uranium . . . . . . . . . . 5.5-8

5.5.6 MCNP Input File for Single Ingot/Billet Photon Dose Rates . . . . . . . 5.5-9

5.5.7 MCNP Input File for Single Ingot/Billet Neutron Dose Rates . . . . . 5.5-11

5.5.8 MCNP Input File for 135 Billet Lattice Photon End Dose Rates . . . . 5. 5-13

5.5.9 MCNP Input File for 117 Cylinder Lattice Side Dose Rate . . . . . . 5.5-16

5.5.10 MCNP Input File for 117 Cylinder Lattice Top Dose Rate ... . . . 5. 5.5-19

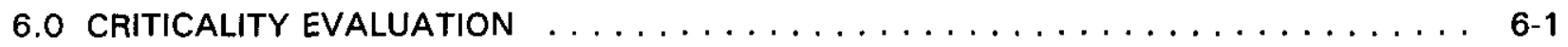

6.1(A) DISCUSSION AND RESULTS - N REACTOR MARK I AND MARK IV INGOTS . . 6-3

6.2(A) PACKAGE FUEL LOADING - N REACTOR MARK I AND MARK IV INGOTS . . . $6-4$

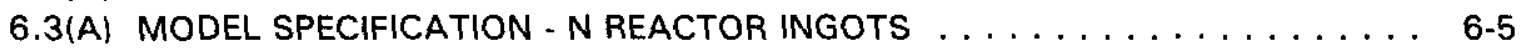

6.3.1(A) Description of Calculational Model . . . . . . . . . . . 6-5

6.3.2(A) Package Regional Densities . . . . . . . . . . . . . . . 6-7 
CONTENTS, cont.

6.4 (A) CRITICALITY CALCULATIONS - N REACTOR INGOTS . . . . . . . . . 6-7

6.4.1(A) Calculational Method ..................... 6-7

6.4.2(A) Contents Loading Optimization ................. 6-8

$6.4 .3(\mathrm{~A})$ Criticality Results . . . . . . . . . . . . . . . . . . 6-8

6.1 (B) DISCUSSION AND RESULTS - RMI BILLETS $\ldots \ldots \ldots \ldots \ldots \ldots \ldots \ldots .6 \ldots$

6.2 (B) PACKAGE FUEL LOADING - RMI BILLETS $\ldots \ldots \ldots \ldots \ldots \ldots \ldots \ldots \ldots . \ldots \ldots$

6.3 (B) MODEL SPECIFICATION - RMI BILLETS $\ldots \ldots \ldots \ldots \ldots \ldots \ldots \ldots \ldots \ldots . \ldots \ldots$

6.3.1(B) Description of Calculational Model . . . . . . . . . . . . . 6-20

6.3.2(B) Package Regional Densities . . . . . . . . . . . . . . . 6-21

6.4 (B) CRITICALITY CALCULATIONS - RMI FORGED BILLETS . . . . . . . 6 6-21

6.4.1(B) Calculational Method . . . . . . . . . . . . . . 6-21

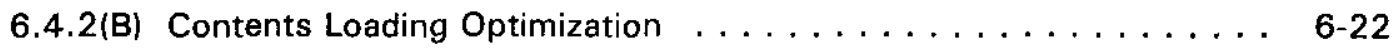

6.4 .3 (B) Criticality Results . . . . . . . . . . . . . . . . . . 6-22

6.1 (C) DISCUSSION AND RESULTS - MARK 15 INGOTS $\ldots \ldots \ldots \ldots \ldots \ldots \ldots$ 6-36

6.2 (C) PACKAGE FUEL LOADING - MARK 15 INGOTS $\ldots \ldots \ldots \ldots \ldots \ldots \ldots$ 6-37

6.3 (C) MODEL SPECIFICATION - MARK 15 INGOTS $\ldots \ldots \ldots \ldots \ldots \ldots \ldots \ldots .6 .37$

6.3.1(C) Description of Calculational Model . . . . . . . . . . . 6-37

6.3.2(C) Package Regional Densities . . . . . . . . . . . . . 6. 6-38

6.4 (C) CRITICALITY CALCULATIONS - MARK 15 INGOTS $\ldots \ldots \ldots \ldots \ldots \ldots \ldots .6 .39$

6.4 .1 (C) Calculational Method . . . . . . . . . . . . . . 6.39

6.4 .2 (C) Contents Loading Optimization . . . . . . . . . . . 6-39

$6.4 .3(C)$ Criticality Results . . . . . . . . . . . . . . . . . 6. 6. 69

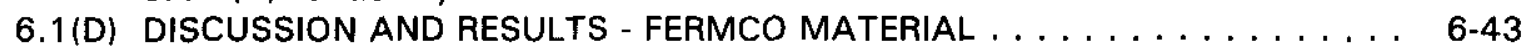

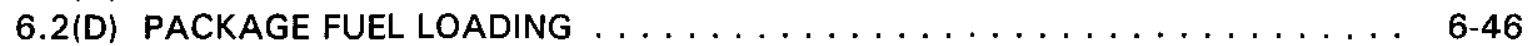

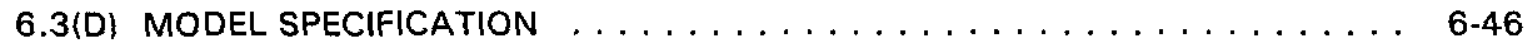

6.3.1(D) Description of Calculational Model . . . . . . . . . . 6 6-46

6.3.2(D) Package Regional Densities . . . . . . . . . . . . . . . 6.46

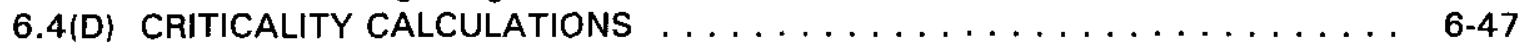

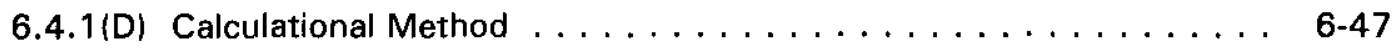

$6.4 .2(D)$ Contents Loading Optimization ............... 6-47

6.4.3(D) Criticality Results . . . . . . . . . . . . . . . . . 6-47

6.1 (E) DISCUSSION AND RESULTS - FERMCO DERBIES MATERIAL . . . . . . . 6-65

6.2 (E) PACKAGE FUEL LOADING $\ldots \ldots \ldots \ldots \ldots \ldots \ldots \ldots \ldots \ldots \ldots \ldots$

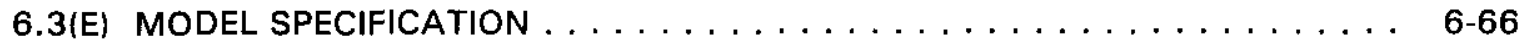

6.3.1(E) Description of Calculational Model . . . . . . . . . . . 6-66

6.3.2(E) Package Regional Densities . . . . . . . . . . . . . 6. 6-66

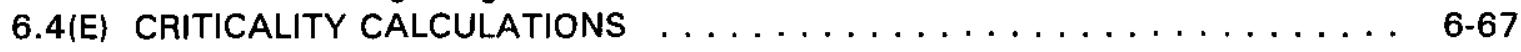

6.4.1(E) Calculational Method ................... 6-67

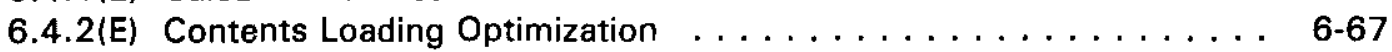

6.4.3(E) Criticality Results . . . . . . . . . . . . . . . . . . 6-67

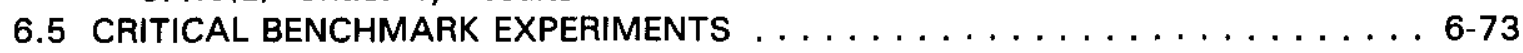

6.5.1 Benchmark Experiments and Applicability . . . . . . . . 6.73

6.5.2 Details of Benchmark Calculations . . . . . . . . . . . 6.74

6.5.3 Results of Benchmark Calculations . . . . . . . . . . . . 6-74

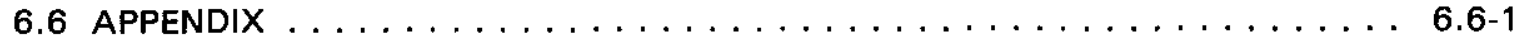

6.6 .1 References . . . . . . . . . . . . . . . . . . . 6.6.

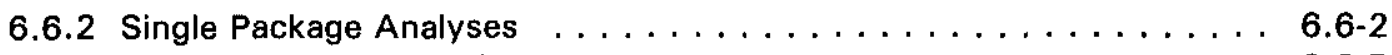

6.6.3 MCNP Code Input Listings . . . . . . . . . . . . . 6.6-5 
CONTENTS, cont.

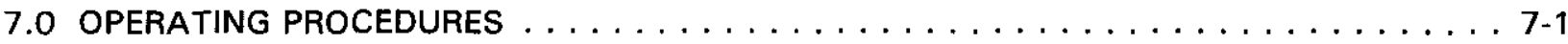

7.1 PROCEDURE FOR LOADING THE PACKAGES $\ldots \ldots \ldots \ldots \ldots \ldots \ldots \ldots$ 7-1

7.1 .1 General Information . . . . . . . . . . . . . . . 7-1

7.1 .2 Loading the Package $\ldots \ldots \ldots \ldots \ldots \ldots \ldots$. $\ldots \ldots \ldots$

7.2 PROCEDURES FOR UNLOADING THE PACKAGE $\ldots \ldots \ldots \ldots \ldots \ldots \ldots \ldots$

7.3 PREPARATION OF EMPTY PACKAGE FOR TRANSPORT $\ldots \ldots \ldots \ldots \ldots \ldots 7-3$

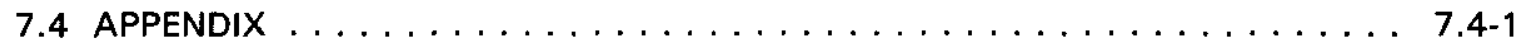

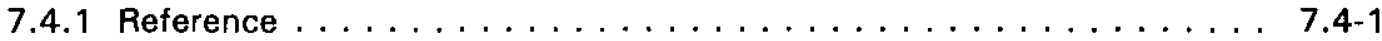

8.0 ACCEPTANCE TESTS AND MAINTENANCE PROGRAM $\ldots \ldots \ldots \ldots \ldots \ldots$

8.1 ACCEPTANCE TESTS $\ldots \ldots \ldots \ldots \ldots \ldots \ldots \ldots \ldots \ldots \ldots \ldots \ldots$

8.1 .1 Visual Inspection . . . . . . . . . . . . . . . . 8-1

8.1.2 Structural and Pressure Tests . . . . . . . . . . . . . 8-1

8.1 .3 Leak Tests . . . . . . . . . . . . . . . . . . . 8-1

8.1 .4 Component Tests $\ldots \ldots \ldots \ldots \ldots \ldots \ldots \ldots \ldots \ldots \ldots \ldots$ 8-1

8.1.5 Tests for Shielding Integrity $\ldots \ldots \ldots \ldots \ldots \ldots \ldots \ldots \ldots \ldots$ 8-1

8.2 MAINTENANCE PROGRAM $\ldots \ldots \ldots \ldots \ldots \ldots \ldots \ldots \ldots \ldots \ldots \ldots \ldots$

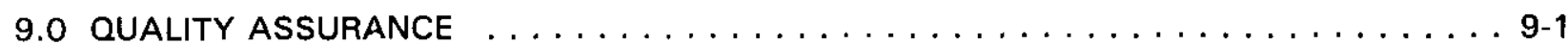

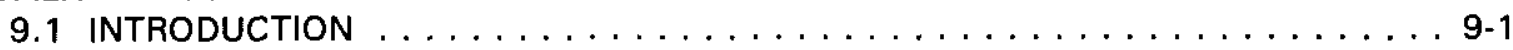

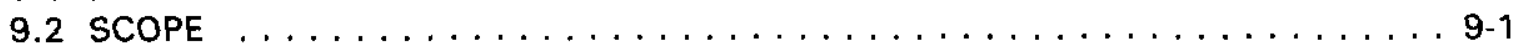

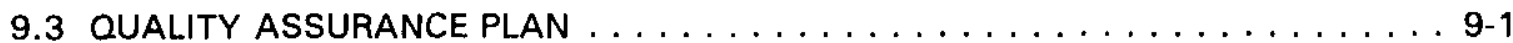

9.3.1 Quality Element 1.0, Organization . . . . . . . . . . . . 9-1

9.3.2 Quality Element 2.0, Quality Assurance Program . . . . . . . . . . . 9-1

9.3.3 Quality Element 3.0, Package Design Control . . . . . . . . . . . . 9-3

9.3.4 Quality Element 4.0, Procurement Document Control .......... . 9-3

9.3.5 Quality Element 5.0, Instructions, Procedures, and Drawings . . . . . . 9. 9-4

9.3.6 Quality Element 6.0, Document Control ... . . . . . . . . . . . 9-4

9.3.7 Quality Element 7.0, Control of Purchased Material, Equipment and Services . . . . . . . . . . . . . . . . . . . . 9-4

9.3.8 Quality Element 8.0, Identification and Control of Material, Parts and Components . . . . . . . . . . . . . . . . . 9-5

9.3.9 Quality Element 9.0, Control of Special Processes . . . . . . . . . 9-5

9.3.10 Quality Element 10.0, Inspection . . . . . . . . . . . . . 9-6

9.3.11 Quality Element 11.0, Test Control . . . . . . . . . . . . . 9-6

9.3.12 Quality Element 12.0, Control of Measuring and Test Equipment . . . . 9-7

9.3.13 Quality Element 13.0, Handling, Storage, and Shipping Control . . . . 9-7

9.3.14 Quality Element 14.0, Inspection, Test, and Operating Status . . . . . . 9-7

9.3.15 Quality Element 15.0, Nonconforming Materials, Parts, or

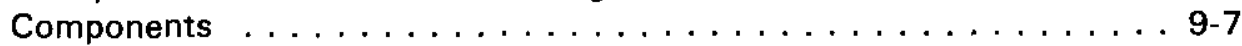

9.3.16 Quality Element 16.0, Corrective Action . . . . . . . . . . . . 9-8

9.3.17 Quality Element 17.0, Quality Assurance Records . . . . . . . . 9-8

9.3.18 Quality Element 18.0, Audits . . . . . . . . . . . . . 9-9

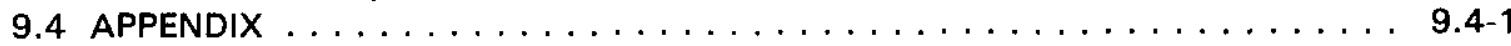

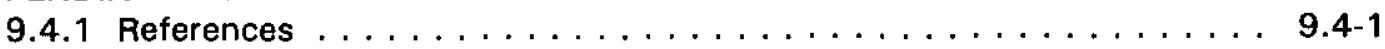




\subsection{GENERAL INFORMATION}

\subsection{INTRODUCTION}

Steel banded wooden shipping containers (also known as wooden boxes) have been used by U.S. Department of Energy (DOE) contractors for many years. These packagings have been certified for shipments of unirradiated, slightly enriched uranium ingots, billets, extrusions, and scrap materials. However, the certification for the wooden boxes, Certificate of Compliance (CoC) USA/5467/AF expired in 1989. This Safety Analysis Report for Packaging (SARP) will be used to recertify the steel banded wooden boxes. The amount of radioactive uranium metal in the packages will meet the low specific activity (LSA)-II material requirements as defined in Part 49 Code of Federal Regulations Section 173.403 (49 CFR 173.403). This SARP follows the guidelines provided by the U.S. Nuclear Regulatory Commission (NRC) Regulatory Guide 7.9, Standard Format and Content of Part 71 Applications for Approval of Packaging for Radioactive Material (NRC 1986).

\subsubsection{Background Information}

CoC USA/5467/AF (DOE 1988) provided the authority for the use of the wooden boxes as Type AF packagings. The original certificate was granted upon approval of the SARP produced by National Lead of Ohio (NLO), Inc. in July 1974 (Dunaway 1974). Several amendments to the SARP over the years led to seven revisions to the CoC. In 1982, NLO, Inc. revised the original SARP to incorporate all previous amendments and include a new material, Mark 15 ingots, that needed to be shipped. The revision was published in October 1983 as NLCO-1107, Rev. 1 (Dolan 1983).

This SARP is a new document and includes only those steel banded wooden boxes designated G-4214, G-4255, G-4245, G-4273, and G-4292. The approved contents are limited to uranium billets, ingots, derbies, and scrap. All approved contents are enriched to $1.25 \mathrm{wt} \%$ or less with ${ }^{235} \mathrm{U}$.

\subsubsection{Summary}

Steel banded wooden shipping boxes are used to package uranium billets, ingots, derbies, and scrap metal enriched to a maximum of $1.25 \mathrm{wt} \%{ }^{236} \mathrm{U}$ (see Section 1.2.3). This SARP demonstrates compliance with the requirements for normal conditions of transport (NCT) and hypothetical accident conditions (HAC) for Type AF packages. The criticality evaluation in this SARP demonstrates that all packages remain subcritical under the HAC events and that any shipment of packages remains subcritical under optimum moderation conditions. The wooden boxes are the containment boundary for each package. Dose rates are low and contents meet the LSA-II material requirements.

\subsection{PACKAGE DESCRIPTION}

\subsubsection{Packaging}

The steel banded wooden shipping boxes are divided into two classes. The first class is the box with a lid. The second is the pallet with a cover. A box with a lid is used primarily for the metal scrap of the $\mathrm{N}$ Reactor product, but may be used to package billets and ingots. The pallet 
with a cover is essentially an upside-down box with a pallet for a "lid". It is used primarily to package ingots and billets. Both classes of boxes are horizontally and vertically banded with $1 \frac{1}{4}$ in. $(3.18 \mathrm{~cm})$ steel bands that meet the requirements of ASTM D-3953 (ASTM 1991) and have a minimum tensile strength of $6750 \mathrm{lb}(30,025 \mathrm{~N})$. Each band is secured with at least one seal that is closed with two pairs of notches per ASTM D-3953, Figure 1. The steel bands are installed using the manufacturers guidelines and the guidelines in ASTM D-4675 (ASTM 1993). Table 1.2.1-1 contains a summary of the container dimensions and weights. Construction drawings in Appendix 1.3 provide more detailed information. Since the payload $A_{2}$ value is unlimited, the packaging is a Category III container (NRC 1991).

The wooden boxes are the containment boundary for each package, and the package does not experience any internal pressure above ambient. Also, as presented in Chapter 3 , Appendix 3.6.2, the decay heat and associated temperature of the package content is negligible.

All shipments are exclusive use. If a closed vehicle or cargo container is used to make the shipments, a uniquely identified tamper-indicating device (TID) shall be applied to either the door of the vehicle or cargo container or to each wooden box so that the wooden box can not be opened without irreparably damaging the uniquely identified TID or the wooden box. The tamper-indicating device must be applied to each wooden box if an open vehicle is used for the shipments.

The packagings are designed, fabricated, examined, and tested to requirements that provide design safety margins and material and fabrication control. The entire process is done in a controlled manner to ensure a quality and safe packaging is produced.

TABLE 1.2.1-1. Dimensions and Tare Weights of Empty Wooden Boxes.

\begin{tabular}{|c|c|c|c|c|c|c|c|c|}
\hline \multirow{2}{*}{$\begin{array}{l}\text { Wooden } \\
\text { Box }\end{array}$} & \multicolumn{4}{|c|}{ External Dimension } & \multicolumn{3}{|c|}{ Internal Dimension } & \multirow{2}{*}{$\begin{array}{c}\text { Approx Tare } \\
\text { Weight } \\
\text { lb (kg) }\end{array}$} \\
\hline & $\begin{array}{l}\text { Width } \\
\text { in. }(\mathrm{cm})\end{array}$ & $\begin{array}{l}\text { Length } \\
\text { in. }(\mathrm{cm})\end{array}$ & $\begin{array}{l}\text { Height } \\
\text { in. }\{\mathrm{cm} \text { \} }\end{array}$ & $\begin{array}{l}\text { Skid } \\
\text { in. }(\mathrm{cm})\end{array}$ & $\begin{array}{l}\text { Width } \\
\text { in. (cm) }\end{array}$ & $\begin{array}{l}\text { Length } \\
\text { in. }(\mathrm{cm})\end{array}$ & $\begin{array}{l}\text { Height } \\
\text { in. }(\mathrm{cm})\end{array}$ & \\
\hline G-4214 & $\begin{array}{l}163 / 8 \\
\{41.59\}\end{array}$ & $\begin{array}{l}341 / 2 \\
(87.63)\end{array}$ & $\begin{array}{l}97 / 8 \\
(25.08)\end{array}$ & $\begin{array}{l}4 \\
(10.16)\end{array}$ & $\begin{array}{l}141 / 8 \\
(35.88)\end{array}$ & $\begin{array}{l}30 \\
(76.20)\end{array}$ & $\begin{array}{l}83 / 8 \\
(21.27)\end{array}$ & $60(27)$ \\
\hline G-4245 & $\begin{array}{l}121 / 4 \\
(31.12)\end{array}$ & $\begin{array}{l}181 / 2 \\
(46.99)\end{array}$ & $\begin{array}{l}10 \\
(25.40)\end{array}$ & $\begin{array}{l}31 / 8 \\
(7.94)\end{array}$ & $\begin{array}{l}10 \\
(25.40)\end{array}$ & $\begin{array}{l}14 \\
(35.56)\end{array}$ & $\begin{array}{l}81 / 2 \\
(21.59)\end{array}$ & $25(11)$ \\
\hline G-4255 & $\begin{array}{l}255 / 8 \\
(65.09)\end{array}$ & $\begin{array}{l}35 \\
(88.90)\end{array}$ & $\begin{array}{l}93 / 4 \\
(24.77)\end{array}$ & $\begin{array}{l}31 / 4 \\
(8.26)\end{array}$ & $\begin{array}{l}241 / 8 \\
(61.28)\end{array}$ & $\begin{array}{l}303 / 4 \\
(78.11)\end{array}$ & $\begin{array}{l}8 \\
(20.32)\end{array}$ & $120(54)$ \\
\hline G-4273-5 & $\begin{array}{l}27 \\
(68.58)\end{array}$ & $\begin{array}{l}41 \quad 1 / 4 \\
(104.78)\end{array}$ & $\begin{array}{l}133 / 4 \\
(34.93)\end{array}$ & $\begin{array}{l}31 / 4 \\
(8.26)\end{array}$ & $\begin{array}{l}251 / 2 \\
(64.77)\end{array}$ & $\begin{array}{l}37 \\
(93.98)\end{array}$ & $\begin{array}{l}12 \\
(30.48)\end{array}$ & $140(64)$ \\
\hline G-4273-6 & $\begin{array}{l}27 \\
(68.58)\end{array}$ & $\begin{array}{l}41 \quad 1 / 4 \\
(104.78)\end{array}$ & $\begin{array}{l}153 / 4 \\
(40.00)\end{array}$ & $\begin{array}{l}31 / 4 \\
(8.26)\end{array}$ & $\begin{array}{l}251 / 2 \\
(64.77)\end{array}$ & $\begin{array}{l}37 \\
(93.98)\end{array}$ & $\begin{array}{l}14 \\
(35.56)\end{array}$ & $144(65)$ \\
\hline G-4292 & $\begin{array}{l}163 / 8 \\
(41.59)\end{array}$ & $\begin{array}{l}341 / 2 \\
(87.63)\end{array}$ & $\begin{array}{l}181 / 8 \\
(46.04)\end{array}$ & $\begin{array}{l}35 / 8 \\
(9.23)\end{array}$ & $\begin{array}{l}141 / 8 \\
(35.88)\end{array}$ & $\begin{array}{l}30 \\
(76.20)\end{array}$ & $\begin{array}{l}161 / 8 \\
(40.96)\end{array}$ & $80(36)$ \\
\hline
\end{tabular}

\subsubsection{Boxes with Lids.}

1.2.1.1.1 Boxes G-4214 and G-4292. These two boxes have the same width and length but differ in height. The ends and sides of each are constructed of $11 / 8 \mathrm{in} .(2.86 \mathrm{~cm})$ thick clear white pine. The bottoms are $1 \mathrm{in} .(2.54 \mathrm{~cm})$ thick maple hardwood. The G-4292 box uses a 1 in. $(2.54 \mathrm{~cm})$ thick exterior plywood lid. The G-4214 box uses two sheets of $1 / 2 \mathrm{in} .(1.27 \mathrm{~cm})$ exterior 
Three horizontal bands around each box provide support for the sides and ends. After loading and with the lid in place, a T-55 griffolyn clear plastic cover is placed over the top (see drawing 0OF-5500-X-01753). Six vertical steel bands secure the lid and strengthen the box. The

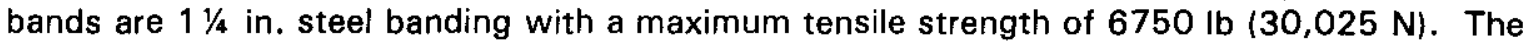
reduced " $\mathrm{N}$ " strapping version of the G-4214 and G-4292 boxes will not be certified by this SARP. See drawings OOF-5500-X-00431 and G-4292 in Section 1.3.2. Wood or masonite shoring secures the contents of a partially-filled box. Each package rests on three maple hardwood skids. Box G-4214 may be lined with 0.032 in. thick, Type 6061-T6 aluminum to prevent wood corrosion of the metal (see drawing 0OF-5500-X-01490). Figures 1.2.1-1 and 1.2.1-2 show schematics of boxes $\mathrm{G}-4214$ and G-4292, respectively.

1.2.1.1.2 Box G-4245. This box is the smallest. It is similar to G-4214 and G-4292 except that it uses only one $1 / 2$ in. $(1.27 \mathrm{~cm})$ thick exterior plywood lid. Two horizontal bands support the sides. The lid closes the box and a T-55 griffolyn clear plastic cover fits over the top (see drawing 00F-5500-X-01753). Two vertical bands secure the plastic cover and lid. The bands are $1 \frac{1 / 4}{\mathrm{in}}$. wide steel banding with a minimum tensile strength of $6750 \mathrm{lb}(30,025 \mathrm{~N})$. The box rests on two native hardwood skids that are nailed to the bottom. The box ends and sides are constructed of $11 / 8 \mathrm{in} .(2.86 \mathrm{~cm})$ thick clear white pine. The bottoms are $1 \mathrm{in} .(2.54 \mathrm{~cm})$ thick oak hardwood. A schematic drawing of wooden box G-4245 is shown in Figure 1.2.1-3.

\subsubsection{Pallets with Covers.}

1.2.1.2.1 Box G-4255. The pallet of a G-4255 container is constructed of $3 / 4$ in. $(1.91 \mathrm{~cm})$ exterior grade plywood. Native oak hardwood curbs and edges are bolted to the pallet. The pallet has native hardwood skids bolted to the bottom with $5 / 16-18$ UNC $\times 2 \frac{3 / 4}{4}$ long steel bolts. The cover is constructed of $3 / 4$ in. $(1.91 \mathrm{~cm})$ exterior grade plywood and has ends made of $11 / \mathrm{sin} .(2.86 \mathrm{~cm})$ thick clear white pine. Vertical steel bands secure the ingots or billets to the pallet. Three horizontal steel bands support the cover which is placed over the pallet to enclose the contents. Six vertical steel bands secure the cover to the pallet (see Figure 1.2.1-4). The bands are $1 \frac{1 / 4}{\mathrm{in}}$. wide steel banding with a minimum tensile strength of $6750 \mathrm{lb}(30,025 \mathrm{~N})$.

1.2.1.2.2 Box G-4273. The general construction of box G-4273 is identical to that of G-4255. However, G-4273 has two cover sizes. The standard cover, used in box G-4273-5, is used for ingots which have a diameter of $11 \mathrm{in.}(27.94 \mathrm{~cm})$ or less. An enlarged cover, used in box G-4273-6, encloses the 13 in. $(33.02 \mathrm{~cm})$ diameter ingots. Steel bands secure the ingots to the

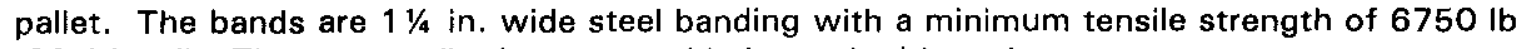
$(30,025 \mathrm{~N})$. The same pallet base assembly is used with each cover.

The box base assembly is constructed of an upper $3 / 4 \mathrm{in.}(1.91 \mathrm{~cm})$ thick exterior plywood panel and a lower $1 \mathrm{in} .(2.54 \mathrm{~cm})$ thick exterior plywood panel. Side chocks, made of native oak and 2024-T351 or 6061-T651 aluminum, and end stops, made of native oak, are bolted to the base with steel $1 / 4$ in. lag screws and bolts. The three native hardwood skids are bolted to the plywood base using $5 / 16-18$ UNC $\times 3 \frac{3 / 4}{4}$ long steel bolts.

Both cover assemblies are constructed of $3 / 4$ in. $(1.91 \mathrm{~cm})$ thick exterior plywood with $11 / 8$ in. $(2.86 \mathrm{~cm})$ thick clear white pin ends. The lids are banded to the pallets using $1 \frac{1}{4} \mathrm{in}$. wide steel bands having a minimum tensile strength of $6750 \mathrm{lb}(30,025 \mathrm{~N})$. A schematic drawing of the G-4273 boxes is shown in Figure 1.2.1-5. 


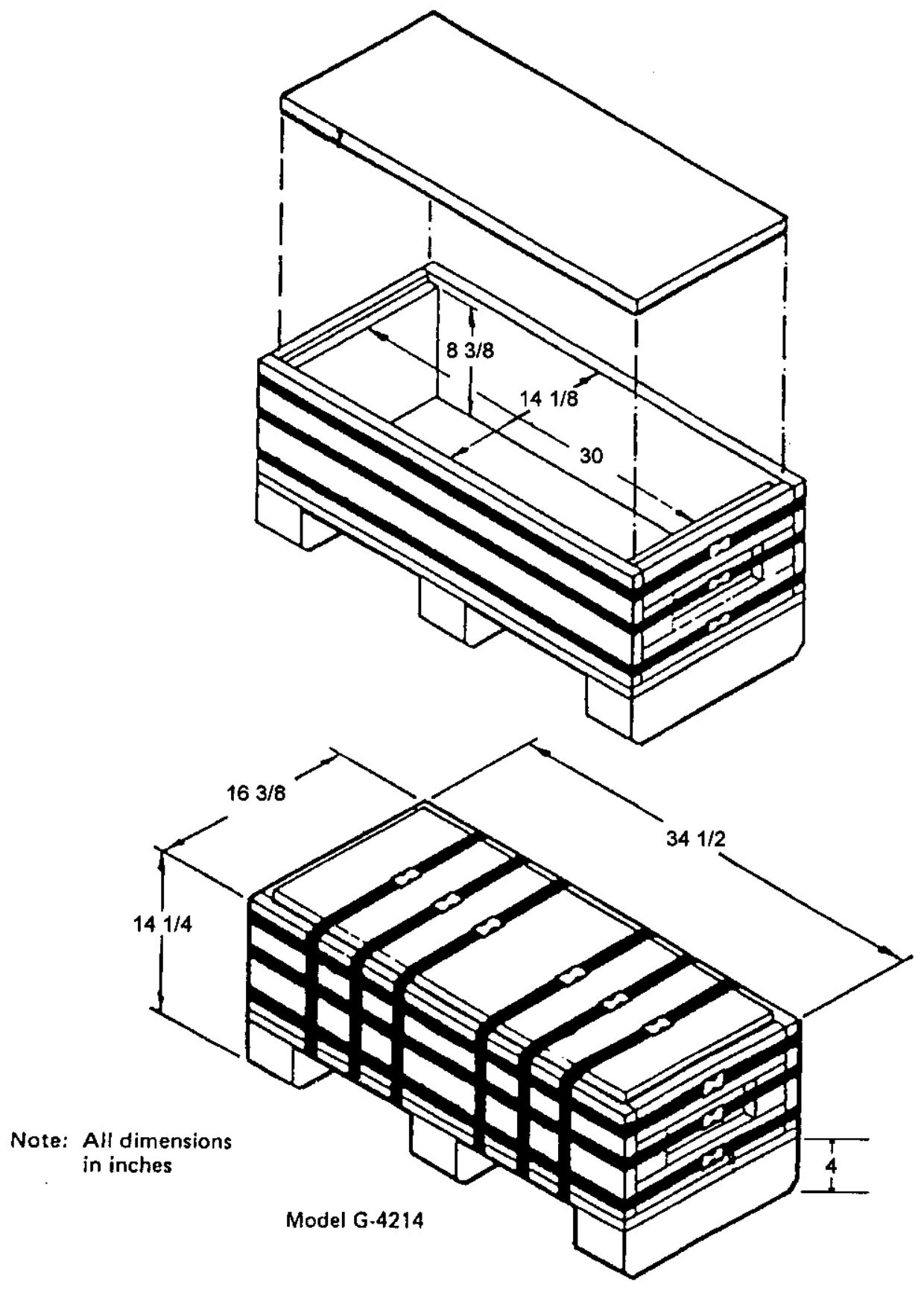

FIGURE 1.2.1-1. Wooden Box G-4214. 


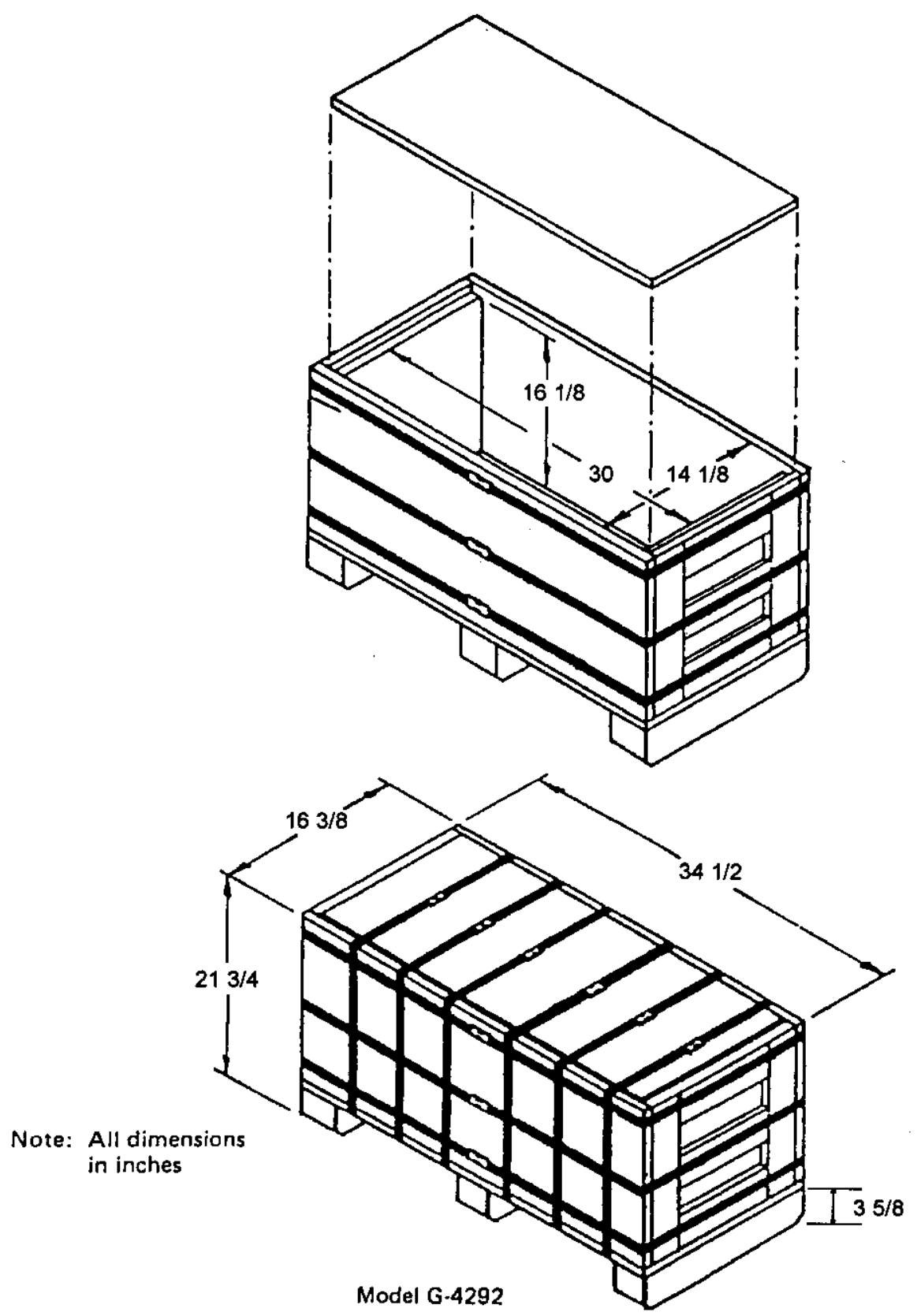

FIGURE 1.2.1-2. Wooden Box G-4292. 
Note: All dimensions in inches

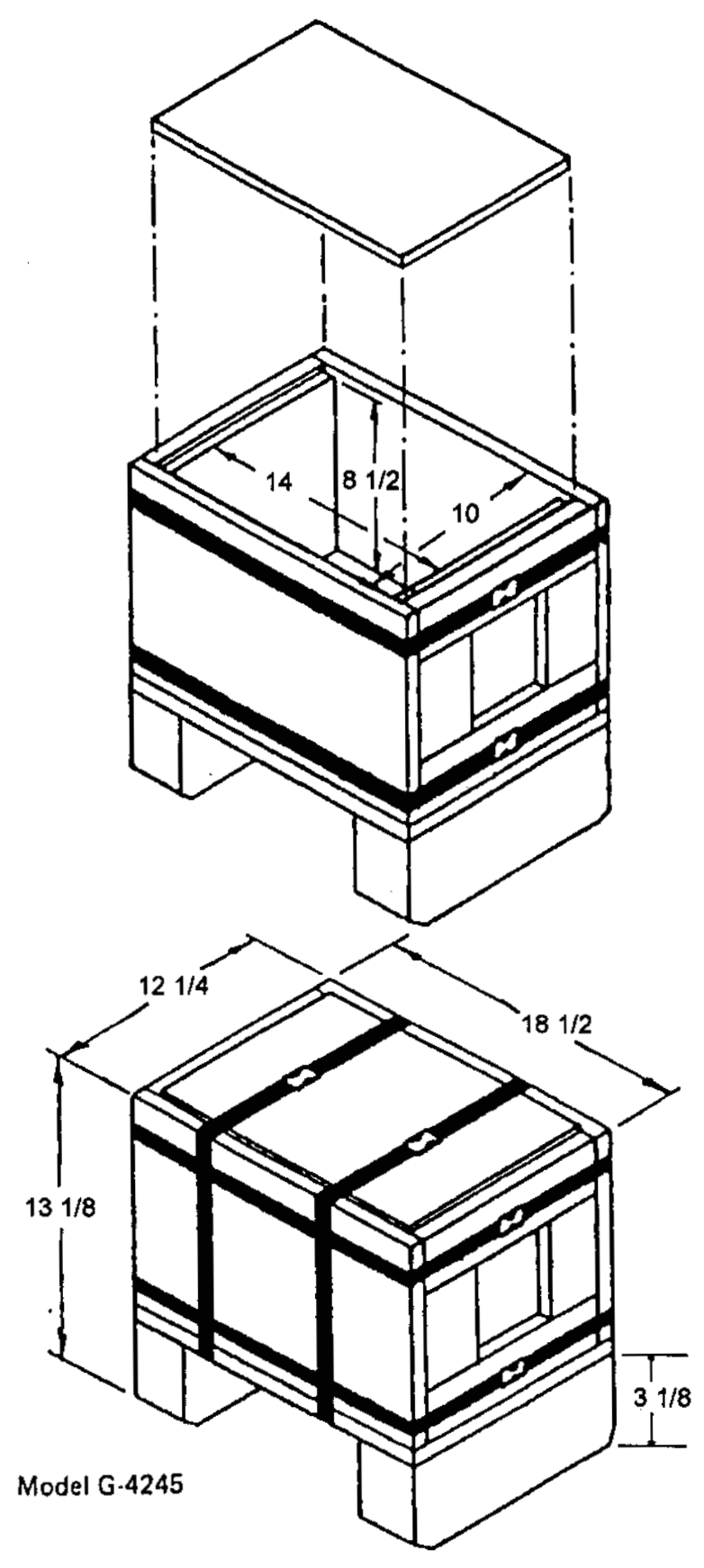

FIGURE 1.2.1-3. Wooden Box G-4245. 

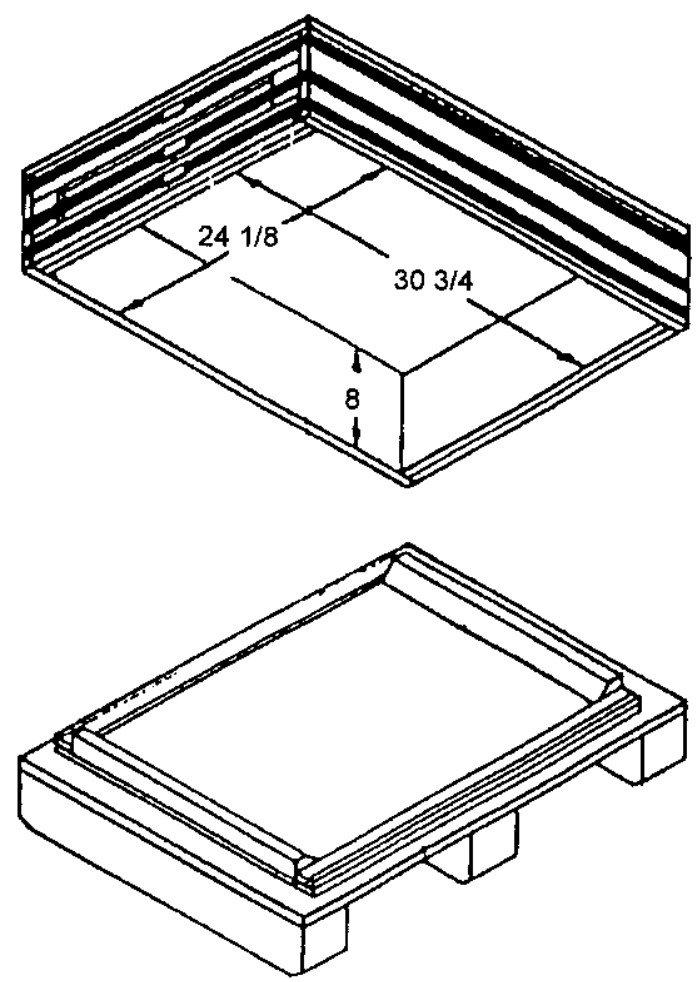

Note: All dimensions in inches

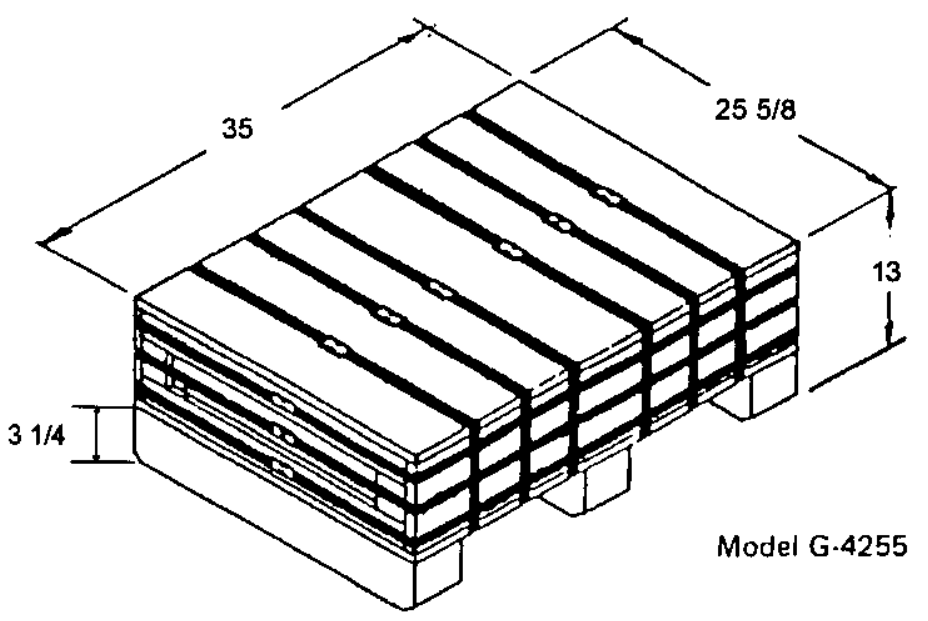

FIGURE 1.2.1-4. Wooden Box G-4255. 

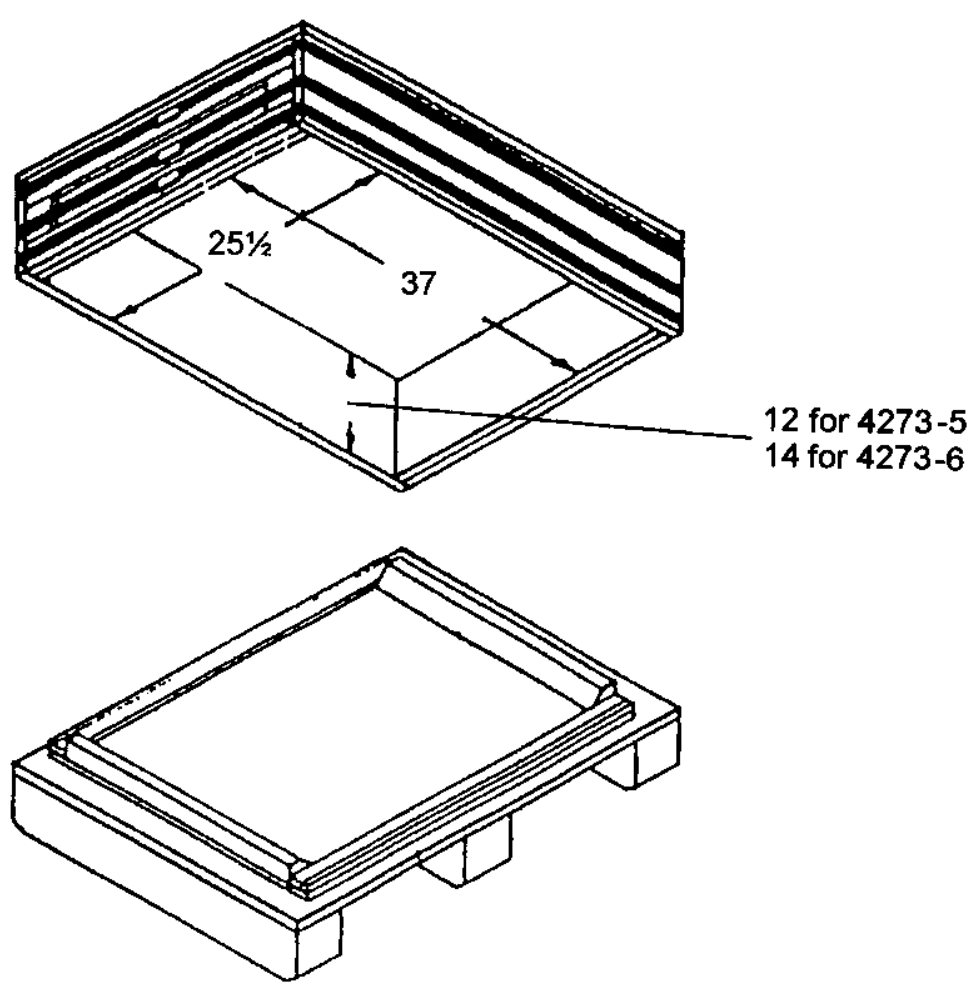

Note: All dimensions in inches

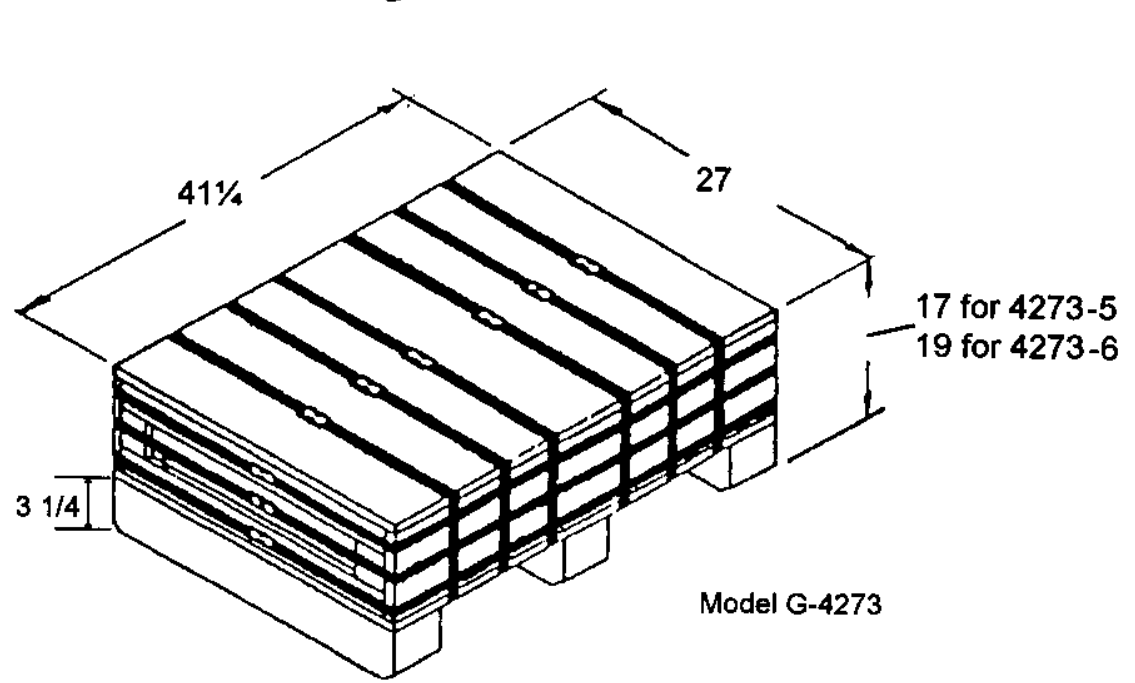

FIGURE 1.2.1-5. Wooden Box G-4273. 


\subsubsection{Operational Features}

The steel banded wooden boxes are a simple packaging system and have no special operational features.

\subsubsection{Package Contents}

Steel banded wooden boxes are to be used to package and ship uranium metal products left over from the $\mathrm{N}$ Reactor program. Table 1.2.3-1 lists materials approved for shipment in the boxes. Table 1.2.3-2 lists the recommended packaging for each payload and the maximum number of packages per shipment. The maximum number of packages per shipment is based on either the criticality evaluation (see Chapter 6) or the shielding evaluation (see Chapter 5). The shielding evaluation is based on anticipated shipment of not greater than $42,000 \mathrm{lb}(19,051 \mathrm{~kg})$ of each payload. Table 1.2.3-2 also lists the transport index and associated number of packages per shipment based on the criticality evaluation performed in Chapter 6 . The recommended packagings can hold the largest number of each indicated payload. As noted in Sections 1.2.3.1 through 1.2.3.5, other wooden boxes can be used to ship certain payloads. However, these alternate boxes hold a reduced quantity of the indicated payload. Payload material less than $12 \mathrm{in} .(30.48 \mathrm{~cm})$ in length will not be shipped in the G-4273 or G-4255 boxes. The subcritical mass limits determine the amount of material allowed per package. Table 1.2.3-3 lists the maximum payload weight and gross weight for each box. Table 1.2.3-4 lists the isotopic content of the payloads. All of the payloads listed in Table 1.2.3-2 meet the low specific activity - II material requirements specified in 49CFR 173.403. The density of all payloads is $18.96 \mathrm{~g} / \mathrm{cm}^{3}$.

1.2.3.1 N Reactor Ingots and Mark 15 Ingots. Unirradiated $0.95,1.1$, and $1.25 \mathrm{wt} \%{ }^{235} \mathrm{U}$ enriched uranium metal N Reactor and Mark 15 Inner and Outer Ingots were packaged in box G-4273 for shipment from the Feed Materials Production Center (FMPC) in Fernald, Ohio to Radioactive Materials Incorporated (RMI) Co. in Ashtabula, Ohio. RMI returned ingots not meeting specifications to FMPC in box G-4273.

1.2.3.2 RMI Forged Billets and Hanford RMI Billets. RMI extruded the ingots received from FMPC into forged billets which were packaged for shipment in container G-4255. The RMI forged billets have various lengths ranging from approximately $16 \mathrm{in} .(40.64 \mathrm{~cm})$ to $21 \mathrm{in} .(53.34 \mathrm{~cm})$. The Hanford RMI billets are RMI forged billets with specific weights $(174$ to $189.5 \mathrm{~kg})$ and have lengths ranging from approximately $18 \mathrm{in.}(45.72 \mathrm{~cm})$ to $19 \mathrm{in} .(48.26 \mathrm{~cm})$. RMI sent the billets to the Hanford Site in Richland, Washington.

1.2.3.3 FERMCO Derbies. FERMCO derbies are slugs of uranium metal enriched to $1.25 \mathrm{wt} \%{ }^{235} \mathrm{U}$. Each derby has a $12 \mathrm{in} .(30.48 \mathrm{~cm})$ outer diameter and is $5 \mathrm{in.}(12.70 \mathrm{~cm})$ long and is shaped like a brimless derby hat. The derbies are shipped in either the G-4214 or G-4292 box.

1.2.3.4 FERMCO Primary Ingots, Product Ingots and Ingot Sections. FERMCO primary ingots and ingot sections are cylindrical pieces or uranium metal enriched to $1.25 \mathrm{wt} \%{ }^{235} \mathrm{U}$. The product ingots are the same as the $\mathrm{N}$ Reactor Mark I outer ingots, except their lengths range from 12 to 17 in. $(30.48$ to $43.18 \mathrm{~cm})$. The ingots and ingot sections have outer diameters measuring 9 in. $(22.86 \mathrm{~cm})$ to $13 \mathrm{in.}(33.02 \mathrm{~cm})$ and lengths between $3 \mathrm{in.}(7.62 \mathrm{~cm})$ and $30 \mathrm{in} .(76.20 \mathrm{~cm})$. The ingots and ingot sections with lengths of $12 \mathrm{in.}(30.48 \mathrm{~cm})$ or greater are shipped in the $\mathrm{G}-4255$ or G-4273 boxes. Ingots or ingot sections less than $12 \mathrm{in.}(30.48 \mathrm{~cm})$ in length are shipped in the G-4214 or G-4292 boxes.

1.2.3.5 Scrap. FERMCO scrap is made of the same material as FERMCO ingots and ingot sections. The scrap is also cylindrically shaped. The length of the scrap cylinders can vary from 1 in. $(2.54 \mathrm{~cm})$ to $30 \mathrm{in} .(76.20 \mathrm{~cm})$. Scrap from $1 \mathrm{in.}(2.54 \mathrm{~cm})$ to less than $12 \mathrm{in.}(30.48 \mathrm{~cm})$ in length 
is shipped in the G-4292 box. Scrap with lengths equal to and greater than $12 \mathrm{in.}(30.48 \mathrm{~cm})$ and up to $30 \mathrm{in}$. $(76.20 \mathrm{~cm})$ are shipped in either the G-4255 or G-4273-6 box.

TABLE 1.2.3-1. Wooden Box Payload Descriptions. (2 sheets total)

\begin{tabular}{|c|c|c|c|c|c|c|}
\hline Payload & Type & $\begin{array}{c}{ }^{235} \mathrm{U} \\
\text { Enrichment }\end{array}$ & $\begin{array}{l}O D \\
\text { in. }(\mathrm{cm})\end{array}$ & $\begin{array}{l}\text { ID } \\
\text { in. }(\mathrm{cm})\end{array}$ & $\begin{array}{l}\text { Length } \\
\text { in. }(\mathrm{cm})\end{array}$ & $\begin{array}{c}\text { Approximate } \\
\text { Weight } \\
\text { to (kg) }\end{array}$ \\
\hline \multirow{4}{*}{$\begin{array}{l}\text { N Reactor } \\
\text { Ingots }\end{array}$} & Mark I Outer & $1.25 \%$ & $13.05(33.15\}$ & $2.87(7.29)$ & $17(43.18)$ & $1,482(672)$ \\
\hline & Mark I Inner & $0.95 \%$ & $10.85(27.56)$ & $1.38(3.49)$ & $24.75(62.87)$ & $1,543(700)$ \\
\hline & Mark IV Outer & $0.95 \%$ & $13.05(33.15)$ & $2.58(6.55)$ & 17 (43.18) & $1,497(679)$ \\
\hline & Mark IV Inner & $0.95 \%$ & $10.85(27.56)$ & $1.30(3.30)$ & $25.5(64.8)$ & $1,592(722)$ \\
\hline \multirow[t]{4}{*}{$\begin{array}{l}\text { RMI Forged } \\
\text { Billets }\end{array}$} & Mark I Outer & $1.25 \%$ & $6.98(17.73)$ & $2.8(7.1)$ & $\begin{array}{c}16 \text { to } 21 \\
\text { (40.64 to } 53.34 \text { ) }\end{array}$ & $\begin{array}{l}352 \text { to } 462 \\
(160 \text { to } 210)\end{array}$ \\
\hline & Mark I Inner & $0.95 \%$ & $5.37(13.64)$ & $1.34(3.40)$ & $\begin{array}{c}16 \text { to } 21 \\
\text { (40.64 to } 53.34 \text { ) }\end{array}$ & $\begin{array}{c}233 \text { to } 306 \\
(106 \text { to } 139)\end{array}$ \\
\hline & Mark IV Outer & $0.95 \%$ & $6.98(17.73)$ & $2.51(6.38)$ & $\begin{array}{c}16 \text { to } 21 \\
(40.64 \text { to } 53.34)\end{array}$ & $\begin{array}{l}365 \text { to } 480 \\
\text { (166 to } 219 \text { ) }\end{array}$ \\
\hline & Mark IV Inner & $0.95 \%$ & $5.46(13.87)$ & $1.26(3.20)$ & $\begin{array}{c}16 \text { to } 21 \\
(40.64 \text { to } 53.34)\end{array}$ & $\begin{array}{c}243 \text { to } 319 \\
(110 \text { to } 145)\end{array}$ \\
\hline $\begin{array}{l}\text { Hanford } \\
\text { RMI Billets }\end{array}$ & Mark I Outer & $1.25 \%$ & $6.98(17.73)$ & $2.8(7.1)$ & $\begin{array}{c}18 \text { to } 19 \\
\text { (45.72 to } 48.26)\end{array}$ & $\begin{array}{c}383 \text { to } 418 \\
(174 \text { to } 189.5)\end{array}$ \\
\hline \multirow{2}{*}{$\begin{array}{l}\text { Mark } 15 \\
\text { Ingots }\end{array}$} & Outer & $1.1 \%$ & $9(22.86)$ & $3.19(8.10)$ & $29(73.66)$ & $1,105(501)$ \\
\hline & Inner & $1.1 \%$ & $8(20.32)$ & $2.04(5.18)$ & $19(48.26)$ & $612(278)$ \\
\hline $\begin{array}{l}\text { FERMCO } \\
\text { Derbies }\end{array}$ & --- & $1.25 \%$ & $12(30.48)$ & $-\cdots$ & $5(12.70)$ & $382(173)$ \\
\hline \multirow{4}{*}{$\begin{array}{l}\text { FERMCO } \\
\text { Primary } \\
\text { Ingots }\end{array}$} & $-\cdots$ & $1.25 \%$ & $12(30.48)$ & $\ldots$ & $17(43.18)$ & $1,298(589)$ \\
\hline & $-\cdots-$ & $1.25 \%$ & $12(30.48)$ & ---- & $26(66.04)$ & $1,980(900)$ \\
\hline & ---- & $1.25 \%$ & $13(33.02)$ & --- & $30(76.20)$ & $2,689(1,220)$ \\
\hline & --- & $1.25 \%$ & $9(22.86)$ & $\cdots$ & $30(76.20)$ & $1,289(585)$ \\
\hline $\begin{array}{l}\text { FERMCO } \\
\text { Product } \\
\text { Ingots }\end{array}$ & --- & $1.25 \%$ & $13.05\{33.15\}$ & $2.87(7.29)$ & $\begin{array}{c}12 \text { to } 17 \\
(30.48 \text { to } 43.18)\end{array}$ & $\begin{array}{l}1046 \text { to } 1482 \\
(474 \text { to } 672)\end{array}$ \\
\hline \multirow{2}{*}{$\begin{array}{l}\text { FERMCO } \\
\text { Ingot } \\
\text { Sections }\end{array}$} & $\ldots$ & $1.25 \%$ & $13(33.02)$ & $\cdots$ & $\begin{array}{l}3(7.62) \text { or } \\
6(15.24)\end{array}$ & $\begin{array}{l}273(124) / \\
546(248)\end{array}$ \\
\hline & .... & $1.25 \%$ & $10(25.40\}$ & $\ldots$ & $6(15.24)$ & $318(144)$ \\
\hline
\end{tabular}


TABLE 1.2.3-1. Wooden Box Payload Descriptions. (2 sheets total)

\begin{tabular}{|c|c|c|c|c|c|c|}
\hline Payload & Type & $\begin{array}{c}{ }^{235} \mathrm{U} \\
\text { Enrichment }\end{array}$ & $\begin{array}{l}O D \\
\text { in. }(\mathrm{cm})\end{array}$ & $\begin{array}{l}\text { ID } \\
\text { in. }(\mathrm{cm})\end{array}$ & $\begin{array}{l}\text { Length } \\
\text { in. }(\mathrm{cm})\end{array}$ & $\begin{array}{l}\text { Approximate } \\
\text { Weight } \\
\text { lb (kg) }\end{array}$ \\
\hline \multirow[t]{10}{*}{$\begin{array}{l}\text { FERMCO } \\
\text { Scrap }\end{array}$} & --- & $1.25 \%$ & $13(33.02)$ & $\cdots-$ & $\begin{array}{c}1 \text { to }<2 \\
(2.54 \text { to }<5.08)\end{array}$ & $\begin{array}{l}90 \text { to }<182 \\
(40 \text { to }<83)\end{array}$ \\
\hline & --- & $1.25 \%$ & $13(33.02)$ & ---- & $\begin{array}{c}2 \text { to }<3 \\
(5.08 \text { to }<7.62)\end{array}$ & $\begin{array}{l}182 \text { to }<273 \\
(83 \text { to }<124)\end{array}$ \\
\hline & $\cdots$ & $1.25 \%$ & $13(33.02)$ & ---- & $\begin{array}{c}3 \text { to }<4 \\
(7.62 \text { to }<10.16)\end{array}$ & $\begin{array}{c}273 \text { to }<364 \\
(124 \text { to }<165)\end{array}$ \\
\hline & --- & $1.25 \%$ & $\cdot 13(33.02)$ & $\ldots$ & $\begin{array}{c}4 \text { to }<6 \\
(10.16 \text { to } \\
<15.24)\end{array}$ & $\begin{array}{c}364 \text { to }<546 \\
(165 \text { to }<248)\end{array}$ \\
\hline & ---- & $1.25 \%$ & $13(33.02)$ & ---- & $\begin{array}{c}6 \text { to }<30 \\
(15.24 \text { To } \\
<76.20)\end{array}$ & $\begin{array}{c}546 \text { to }<2727 \\
(248 \text { to }<1237)\end{array}$ \\
\hline & --- & $1.25 \%$ & $11(27.94)$ & $-\cdots$ & $\begin{array}{c}1 \text { to }<2 \\
(2.54 \text { to }<5.08)\end{array}$ & $\begin{array}{l}65 \text { to }<130 \\
(29 \text { to }<59)\end{array}$ \\
\hline & --- & $1.25 \%$ & $11(27.94)$ & $\cdots$ & $\begin{array}{c}2 \text { to }<3 \\
(5.08 \text { to }<7.62)\end{array}$ & $\begin{array}{l}130 \text { to }<195 \\
\text { (59 to }<88)\end{array}$ \\
\hline & --- & $1.25 \%$ & $11(27.94)$ & $-\cdots$ & $\begin{array}{c}3 \text { to }<4 \\
(7.62 \text { to }<10.16)\end{array}$ & $\begin{array}{l}195 \text { to }<260 \\
(88 \text { to }<118 \text { ) }\end{array}$ \\
\hline & --- & $1.25 \%$ & $11(27.94)$ & $-\cdots$ & $\begin{array}{c}4 \text { to }<6 \\
(10.16 \text { to } \\
<15.24)\end{array}$ & $\begin{array}{c}260 \text { to }<390 \\
(118 \text { to }<177)\end{array}$ \\
\hline & --- & $1.25 \%$ & $11(27.94)$ & $\cdots$ & $\begin{array}{l}6 \text { to }<30 \\
(15.24 \text { to } \\
<76.20)\end{array}$ & $\begin{array}{l}390 \text { to }<1953 \\
(177 \text { to }<886)\end{array}$ \\
\hline
\end{tabular}

aAl uranium is enriched to the indicated ${ }^{235} \mathrm{U}$ enrichment value $+0.006 \%$, e.g., $1.25+0.006 w t \%{ }^{235} \mathrm{U}$.

For each payload, any ${ }^{235} \mathrm{U}$ enrichment up to and including the maximum indicated value can be shipped. 
TABLE 1.2.3-2. Recommended Packagings. (2 sheets total)

\begin{tabular}{|c|c|c|c|c|c|}
\hline Payload & Type & $\begin{array}{l}\text { Amount } \\
\text { Per } \\
\text { Package }\end{array}$ & $\begin{array}{l}\text { Maximum } \\
\text { Packages } \\
\text { Per } \\
\text { Shipment }\end{array}$ & $\begin{array}{l}\text { Recom- } \\
\text { mended } \\
\text { Packaging }\end{array}$ & $\begin{array}{l}\text { Criticality } \\
\text { Transport } \\
\text { Index/Package } \\
\text { Limit }\end{array}$ \\
\hline \multirow{4}{*}{$\begin{array}{l}\text { N Reactor } \\
\text { ingots }\end{array}$} & Mark I Outer & 2 & $13^{6}$ & G-4273-6 & $4.6 / 21$ \\
\hline & Mark I Inner & 2 & $13^{b}$ & G-4273-6 & O/Unlimited \\
\hline & Mark IV Outer & 2 & $13^{b}$ & G-4273-6 & O/Unlimited \\
\hline & Mark IV Inner & 2 & $13^{6}$ & G.4273-6 & O/Unlimited \\
\hline \multirow{4}{*}{$\begin{array}{l}\text { RMI Forged } \\
\text { Billets }\end{array}$} & Mark I Outer & 2 & $7^{a}$ & G-4255 & $14.3 / 7$ \\
\hline & Mark I Inner & 4 & $19^{\circ}$ & G-4255 & $5.1 / 19$ \\
\hline & Mark IV Outer & 2 & $25^{a}$ & G.4255 & $4.0 / 25$ \\
\hline & Mark IV Inner & 4 & $18^{a}$ & G-4255 & $5.3 / 18$ \\
\hline $\begin{array}{l}\text { Hanford RMI } \\
\text { Billets }\end{array}$ & Mark I Outer & $3,2,1$ & $5^{a}, 7^{a}, 15^{a}$ & $G-4255$ & $\begin{array}{c}19.5 / 5,13.0 / 7 \\
6.5 / 15 \\
\end{array}$ \\
\hline \multirow[t]{2}{*}{ Mark 15 Ingots } & Outer & 2 & $10^{a}$ & G-4273-5 & $9.2 / 10$ \\
\hline & Inner & 4 & $9^{a}$ & G-4273-5 & $10.2 / 9$ \\
\hline $\begin{array}{l}\text { FERMCO } \\
\text { Derbies }(1.25 \% \\
\left.{ }^{235} \mathrm{U}\right)\end{array}$ & $\begin{array}{l}12 \mathrm{in.}(30.48 \mathrm{~cm}) \text { OD } \times 5 \mathrm{in} . \\
(12.70 \mathrm{~cm}) \text { long }\end{array}$ & 2 & $24^{a}$ & $\begin{array}{l}\text { G-4214, } \\
\text { G-4292 }\end{array}$ & $4.1 / 24$ \\
\hline \multirow{4}{*}{$\begin{array}{l}\text { FERMCO } \\
\text { Primary Ingots } \\
\left(1.25 \%{ }^{235} \mathrm{U}\right)\end{array}$} & $\begin{array}{l}12 \mathrm{in.}(30.48 \mathrm{~cm}) \text { OD } \times 17 \mathrm{in.} \\
(43.18 \mathrm{~cm}) \text { long }\end{array}$ & 2 & $7^{a}$ & G-4273-6 & $14.0 / 7$ \\
\hline & $\begin{array}{l}12 \mathrm{in.}(30.48 \mathrm{~cm}) \text { OD } \times 26 \mathrm{in} . \\
(66.04 \mathrm{~cm}) \text { long }\end{array}$ & 1 & $4^{a}$ & G-4273-6 & $21.4 / 4$ \\
\hline & $\begin{array}{l}13 \mathrm{in.}(33.02 \mathrm{~cm}) \text { OD } \times 30 \mathrm{in} . \\
(76.20 \mathrm{~cm}) \text { long }\end{array}$ & 1 & $9^{a}$ & G-4273-6 & $10.1 / 9$ \\
\hline & $\begin{array}{l}9 \mathrm{in.}(22.86 \mathrm{~cm}) \text { OD } \times 30 \mathrm{in} . \\
(76.20 \mathrm{~cm}) \text { long }\end{array}$ & 2 & $11^{a}$ & G-4273-5 & $9.0 / 11$ \\
\hline $\begin{array}{l}\text { FERMCO } \\
\text { Product Ingots }\end{array}$ & $\begin{array}{l}13.05 \mathrm{in} .(33.15 \mathrm{~cm}) \mathrm{OD} \times 2.87 \mathrm{in} . \\
(7.29 \mathrm{~cm}) \mathrm{ID} \times 12 \mathrm{in.}(30.48) \text { to } \\
17 \mathrm{in.}(43.18 \mathrm{~cm}) \text { long }\end{array}$ & 2 & $13^{b}$ & G-4273-6 & $6.3 / 15$ \\
\hline \multirow{2}{*}{$\begin{array}{l}\text { FERMCO Ingot } \\
\text { Sections } \\
\left(1.25 \%{ }^{235} \mathrm{U}\right)\end{array}$} & $\begin{array}{l}13 \mathrm{in.}(33.02 \mathrm{~cm}) 00 \times 3 \mathrm{in} . \\
(7.62 \mathrm{~cm}) \text { or } 6 \mathrm{in.}(15.24 \mathrm{~cm}) \text { long }\end{array}$ & 4 and 2 & $8^{a}, 24^{a}$ & $\begin{array}{l}\text { G-4214, } \\
\text { G-4292 }\end{array}$ & $\begin{array}{c}11.5,4.11 \\
8,24 \\
\end{array}$ \\
\hline & $\begin{array}{l}10 \text { in. }(25.40 \mathrm{~cm}) \text { OD x } 6 \text { in. } \\
(15.24 \mathrm{~cm}) \text { long }\end{array}$ & 2 & $24^{a}$ & $\begin{array}{l}\text { G-4214 } \\
\text { G-4292 }\end{array}$ & $4.1 / 24$ \\
\hline
\end{tabular}


TABLE 1.2.3-2. Recommended Packagings. (2 sheets total)

\begin{tabular}{|c|c|c|c|c|c|}
\hline Payload & Type & $\begin{array}{l}\text { Amount } \\
\text { Per } \\
\text { Package }\end{array}$ & $\begin{array}{c}\text { Maximum } \\
\text { Packages } \\
\text { Per } \\
\text { Shipment }\end{array}$ & $\begin{array}{l}\text { Recom- } \\
\text { mended } \\
\text { Packaging }\end{array}$ & $\begin{array}{c}\text { Criticality } \\
\text { Transport } \\
\text { Index/Package } \\
\text { Limit }\end{array}$ \\
\hline \multirow[t]{12}{*}{$\begin{array}{l}\text { FERMCO Scrap } \\
\left\{1.25 \%{ }^{236} \mathrm{U}\right\}\end{array}$} & $\begin{array}{l}13 \text { in. }(33.02 \mathrm{~cm}) O D \times 1 \mathrm{in} . \\
(2.54 \mathrm{~cm}) \text { to }<2 \text { in. }(5.08 \mathrm{~cm})\end{array}$ & $\begin{array}{r}1180 \mathrm{lb} \\
\{535 \mathrm{~kg}\}\end{array}$ & $2^{2}$ & $\begin{array}{l}\mathrm{G}-4292 \\
\mathrm{G}-4214\end{array}$ & $50.0 / 2$ \\
\hline & $\begin{array}{l}13 \mathrm{in.}(33.02 \mathrm{~cm}) O D \times 2 \mathrm{in} . \\
(5.08 \mathrm{~cm}) \text { to }<3 \text { in. }(7.62 \mathrm{~cm})\end{array}$ & $\begin{array}{c}1200 \mathrm{lb} \\
(544 \mathrm{~kg})\end{array}$ & $4^{a}$ & $\begin{array}{l}\text { G-4292 } \\
\text { G-4214 }\end{array}$ & $23.5 / 4$ \\
\hline & $\begin{array}{l}13 \text { in. }(33.02 \mathrm{~cm}) \text { OD } \times 3 \text { in. } \\
(7.62 \mathrm{~cm}) \text { to }<4 \text { in. }(10.16 \mathrm{~cm})\end{array}$ & $\begin{array}{c}1200 \mathrm{lb} \\
(544 \mathrm{~kg})\end{array}$ & $7^{2}$ & $\begin{array}{l}G-4292 \\
G-4214\end{array}$ & $12.7 / 7$ \\
\hline & $\begin{array}{l}13 \text { in. }(33.02 \mathrm{~cm}) O D \times 4 \text { in. } \\
(10.16 \mathrm{~cm}) \text { to }<6 \text { in. }(15.24 \mathrm{~cm})\end{array}$ & $\begin{array}{l}1200 \mathrm{lb} \\
(544 \mathrm{~kg})\end{array}$ & $11^{\mathrm{s}}$ & $\begin{array}{l}\text { G-4292 } \\
\text { G-4214 }\end{array}$ & $9.0 / 11$ \\
\hline & $\begin{array}{l}13 \mathrm{in} .(33.02 \mathrm{~cm}) O D \times 6 \text { in } \\
(15.24 \mathrm{~cm}) \text { to }<12 \mathrm{in} .(30.48 \mathrm{~cm})\end{array}$ & $\begin{array}{r}1252 \mathrm{lb} \\
(568 \mathrm{~kg})\end{array}$ & $21^{\circ}$ & G-4292 & $4.7 / 21$ \\
\hline & $\begin{array}{l}13 \mathrm{in} .(33.02 \mathrm{~cm}) \text { OD } \times 120<30 \\
\text { in. }(76.20 \mathrm{~cm})\end{array}$ & $\begin{array}{r}3488 \mathrm{lb} \\
(1582 \mathrm{~kg}) \\
\end{array}$ & $7^{a}$ & G-4273-6 & $13.1 / 7$ \\
\hline & $\begin{array}{l}11 \text { in. }(27.94 \mathrm{~cm}) \text { OD } \times 1 \text { in. } \\
(2.54 \mathrm{~cm}) \text { to }<2 \text { in. }(5.08 \mathrm{~cm})\end{array}$ & $\begin{array}{r}1180 \mathrm{lb} \\
(535 \mathrm{~kg})\end{array}$ & $2^{a}$ & $\begin{array}{l}\text { G-4292 } \\
\text { G-4214 } \\
\end{array}$ & $50.0 / 2$ \\
\hline & $\begin{array}{l}11 \mathrm{in.}(27.94 \mathrm{~cm}) \text { OD } \times 2 \text { in. } \\
(5.08 \mathrm{~cm}) \text { to }<3 \mathrm{in} .(7.62 \mathrm{~cm})\end{array}$ & $\begin{array}{r}1200 \mathrm{lb} \\
(544 \mathrm{~kg}) \\
\end{array}$ & $4^{a}$ & $\begin{array}{l}\text { G-4292 } \\
\text { G-4214 } \\
\end{array}$ & $23.5 / 4$ \\
\hline & $\begin{array}{l}11 \mathrm{in.}(27.94 \mathrm{~cm}) \mathrm{OD} \times 3 \mathrm{in} . \\
(7.62 \mathrm{~cm}) \text { to }<4 \text { in. }(10.16 \mathrm{~cm})\end{array}$ & $\begin{array}{r}1200 \mathrm{lb} \\
\{544 \mathrm{~kg}\}\end{array}$ & $6^{\circ}$ & $\begin{array}{l}G .4292 \\
G .4214 \\
\end{array}$ & $15.2 / 6$ \\
\hline & $\begin{array}{l}11 \mathrm{in} .(27.94 \mathrm{~cm}) \text { OD } \times 4 \text { in. } \\
(10.16 \mathrm{~cm}) \text { to }<6 \text { in. }(15.24 \mathrm{~cm})\end{array}$ & $\begin{array}{r}1200 \mathrm{lb} \\
(544 \mathrm{~kg}) \\
\end{array}$ & 9 & $\begin{array}{l}G-4292 \\
G-4214 \\
\end{array}$ & $10.8 / 9$ \\
\hline & $\begin{array}{l}11 \text { in }(27.94 \mathrm{~cm}) O D \times 6 \text { in. } \\
(15.24 \mathrm{~cm}) \text { to }<12 \text { in. }(30.48 \mathrm{~cm})\end{array}$ & $\begin{array}{l}1252 \mathrm{lb} \\
568 \mathrm{~kg})\end{array}$ & $17^{a}$ & G-4292 & $5.8 / 17$ \\
\hline & $\begin{array}{l}11 \text { in. }(27.94 \mathrm{~cm}) \text { OD } \times 12 \mathrm{in} . \\
(30.48 \mathrm{~cm}) \text { to }<30 \text { in. }(7.20 \mathrm{~cm})\end{array}$ & $\begin{array}{c}3488 \mathrm{lb} \\
(1582 \mathrm{~kg})\end{array}$ & $7^{*}$ & G-4273-6 & $16.0 / 6$ \\
\hline
\end{tabular}

a - Based on criticality transport index and exclusive use trailer (see Chapter 6).

b - Based on anticipated shipment weight of not greater than $42,000 \mathrm{lb}$ of each payioad (see Chapter 5). 
TABLE 1.2.3-3. Maximum Payload and Gross Weight for Each Wooden Box.

\begin{tabular}{|l|c|c|}
\hline \multicolumn{1}{|c|}{ Wooden Box } & $\begin{array}{c}\text { Maximum Payload Weight } \\
\mathrm{lb}(\mathrm{kg})\end{array}$ & $\begin{array}{c}\text { Maximum Package } \\
\text { Gross Weight } \\
\mathrm{lb}(\mathrm{kg})\end{array}$ \\
\hline \hline G-4214 & $1,200(544)$ & $1,260(572)$ \\
\hline G-4245 & $197(89)$ & $222(101)$ \\
\hline G-4255 & $1,344(610)$ & $1,464(664)$ \\
\hline G-4273-5 & $2,880(1,306)$ & $3,020(1,370)$ \\
\hline G-4273-6 & $3,488(1,582)$ & $3,632(1,647)$ \\
\hline G-4292 & $1,252(568)$ & $1,332(604)$ \\
\hline
\end{tabular}

TABLE 1.2.3-4. Payload Isotopic Content.

\begin{tabular}{|c|c|c|c|}
\hline \multirow{2}{*}{ Isotope } & \multicolumn{3}{|c|}{ Isotopic Content (g/g of payload) } \\
\cline { 2 - 4 } & $0.95 \mathrm{WT} \%{ }^{235} \mathrm{U}$ & $1.1 \mathrm{WT} \%{ }^{235} \mathrm{U}$ & $1.25 \mathrm{WT} \%{ }^{235} \mathrm{U}$ \\
\hline \hline${ }^{234} \mathrm{U}$ & $1.33 \mathrm{E}-04$ & $1.33 \mathrm{E}-04$ & $1.34 \mathrm{E}-04$ \\
\hline${ }^{235} \mathrm{U}$ & $9.56 \mathrm{E}-03$ & $1.106 \mathrm{E}-02$ & $1.256 \mathrm{E}-02$ \\
\hline${ }^{236} \mathrm{U}$ & $1.00 \mathrm{E}-03$ & $1.00 \mathrm{E}-03$ & $1.00 \mathrm{E}-03$ \\
\hline${ }^{238} \mathrm{U}$ & $9.91 \mathrm{E}-01$ & $9.89 \mathrm{E}-01$ & $9.88 \mathrm{E}-01$ \\
\hline${ }^{241} \mathrm{Pu}$ & $4.14 \mathrm{E}-11$ & $4.14 \mathrm{E}-11$ & $4.14 \mathrm{E}-11$ \\
\hline${ }^{99} \mathrm{Tc}$ & $2.58 \mathrm{E}-05$ & $2.58 \mathrm{E}-05$ & $2.58 \mathrm{E}-05$ \\
\hline${ }^{90} \mathrm{Sr}$ & $1.56 \mathrm{E}-10$ & $1.56 \mathrm{E}-10$ & $1.56 \mathrm{E}-10$ \\
\hline
\end{tabular}




\subsection{APPENDICES}

\subsubsection{References}

10 CFR 71, 1995, "Packaging and Transportation of Radioactive Materials," Code of Federal Regulations, as amended.

49 CFR 173, 1995, "Shippers-General Requirements for Shipments and Packagings," Code of Federal Regulations, as amended.

ASTM, 1993, Standard Guide for Selection and Use of Flat Strapping Materials, ASTM D-4675, American Society for Testing and Materials, Philadelphia, Pennsylvania.

ASTM, 1991, Specification for Strapping, Flat Steel and Seals, ASTM D-3953, American Society for Testing and Materials, Philadelphia, Pennsylvania.

DOE, 1988, Certificate of Compliance No. USA/5467/AF (DOE), Rev. 7., U.S. Department of Energy, Washington, D.C.

Dolan, L. C., 1983, Safety Analysis Report for Packaging - Steel Banded Wood Shipping Containers for Slightly Enriched Uranium Metal, NLCO-1107, Rev. 1, Category UC-71, National Lead of Ohio, Inc., Cincinnati, Ohio.

Dunaway, D. L., 1974, Safety Analysis Report for Packaging - Steel Banded Wooden Shipping Containers for Slightly Enriched Uranium Metal, NLCO-1107, National Lead of Ohio, Inc., Cincinnati, Ohio.

NRC, 1986, Standard Format and Content of Part 71 Applications for Approval of Packaging for Radioactive Material, Regulatory Guide 7.9, Proposed Rev. 2, U.S. Nuclear Regulatory Commission, Washington, D.C.

NRC, 1991, Fracture Toughness Criteria of Base Material for Ferritic Steel Shipping Cask Containment Vesse/s With a Maximum Wall Thickness of 4 /nches $(0.1 \mathrm{~m})$, Regulatory Guide 7.11, U.S. Nuclear Regulatory Commission, Washington, D.C. 


\subsubsection{General Arrangement Drawings}

\begin{tabular}{|c|c|c|c|c|}
\hline $\begin{array}{l}\text { Wooden } \\
\text { Box }\end{array}$ & Drawing Number & $\begin{array}{l}\text { Drawing Index } \\
\text { Code }\end{array}$ & Rev. & Drawing Title \\
\hline G-4214 & $\begin{array}{l}\text { OOF-5500-X- } \\
00431\end{array}$ & $\begin{array}{l}06 C-5500-X- \\
07460\end{array}$ & 23 & Shipping Container \\
\hline G-4245 & G-4245 & $\begin{array}{l}\text { OOF-5500-X- } \\
00460\end{array}$ & 8 & SRP Samples Shipping Container \\
\hline G-4255 & $\begin{array}{l}\text { OOF-5500-X- } \\
00468\end{array}$ & -- & 9 & $\begin{array}{l}\text { NPR Billet Shipping Container } \\
\text { Packaging Assembly Isometric }\end{array}$ \\
\hline G.4255 & G-4256 & $\begin{array}{l}\text { OOF-5500-X- } \\
00469\end{array}$ & 2 & $\begin{array}{l}\text { NPR Billet Shipping Container Base } \\
\text { Assembly (Base for G-4255) }\end{array}$ \\
\hline G-4255 & G-4257 & $\begin{array}{l}\text { OOF-5500-X- } \\
00470\end{array}$ & 0 & $\begin{array}{l}\text { NPR Billet Shipping Container Cover } \\
\text { Assembly (Cover for G-4255) }\end{array}$ \\
\hline G-4273 & $\begin{array}{l}\text { OOF-5500-X- } \\
00471\end{array}$ & $\cdots$ & 18 & $\begin{array}{l}\text { Ingot Shipping Container Packaging } \\
\text { Assembly }\end{array}$ \\
\hline G-4273 & $\begin{array}{l}\text { OOF-5500-X- } \\
00472\end{array}$ & -- & 7 & $\begin{array}{l}\text { Ingot Shipping Container Base } \\
\text { Assembly (Base for G-4273) }\end{array}$ \\
\hline G-4273 & $\begin{array}{l}\text { OOF-5500-X- } \\
00473\end{array}$ & -- & 6 & $\begin{array}{l}\text { Ingot Shipping Container Cover } \\
\text { Assembly (Cover for G-4273) }\end{array}$ \\
\hline G-4292 & G-4292 & $\begin{array}{l}\text { OOF-5500-X- } \\
00491\end{array}$ & 14 & Shipping Container No. 4 \\
\hline $\begin{array}{l}\text { G-4214, } \\
\text { G-4292, } \\
\text { G-4245 }\end{array}$ & $\begin{array}{l}\text { OOF-5500-X- } \\
01753\end{array}$ & -- & 0 & $\begin{array}{l}\text { Plastic Covers for Wooden } \\
\text { Container }\end{array}$ \\
\hline G-4214 & $\begin{array}{l}\text { OOF-5500-X- } \\
01490\end{array}$ & $\begin{array}{l}06 \mathrm{C}-5500-\mathrm{X}- \\
07459\end{array}$ & 3 & $\begin{array}{l}\text { Aluminum Interior Liner for Shipping } \\
\text { Containers, Details }\end{array}$ \\
\hline
\end{tabular}




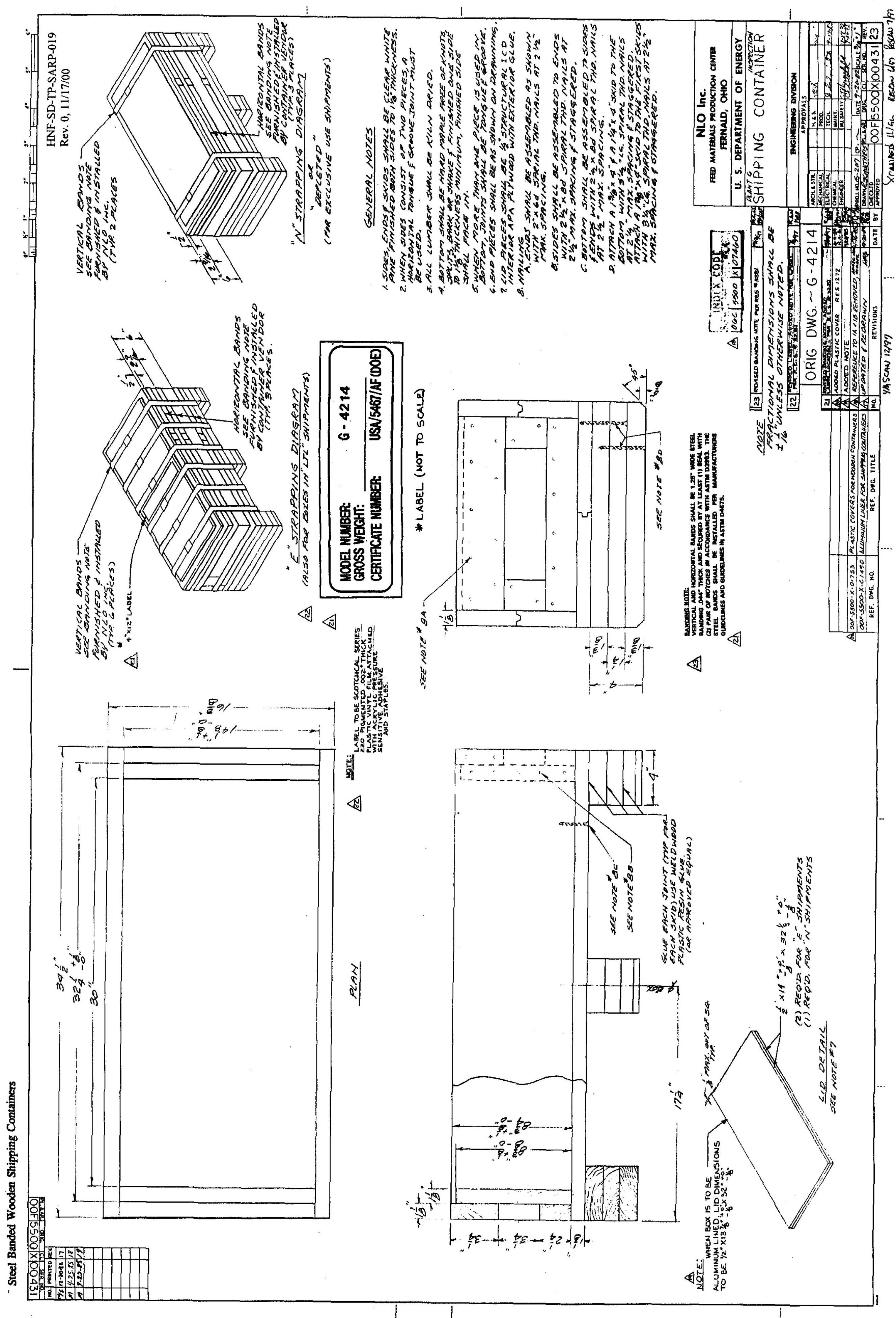




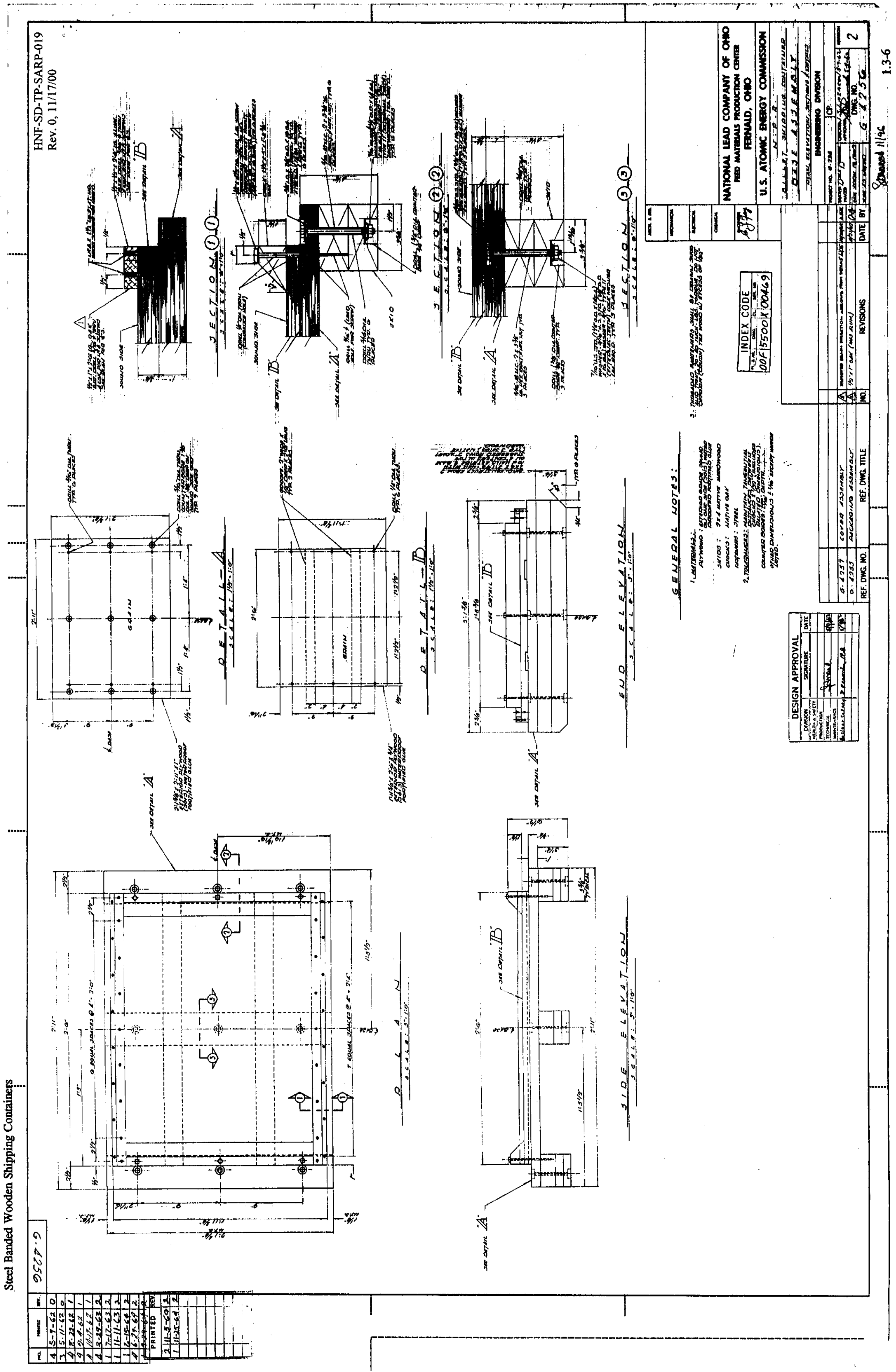




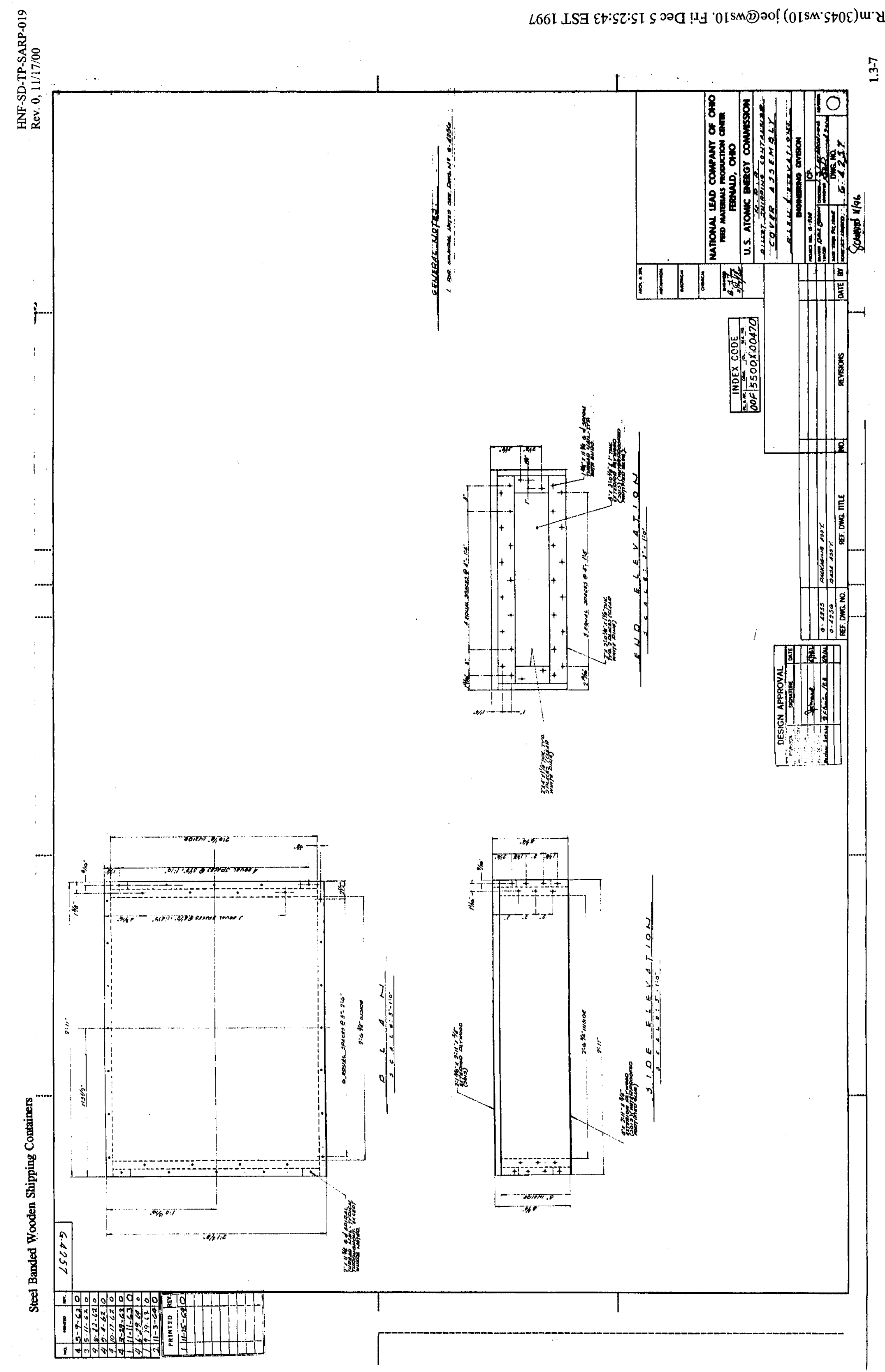




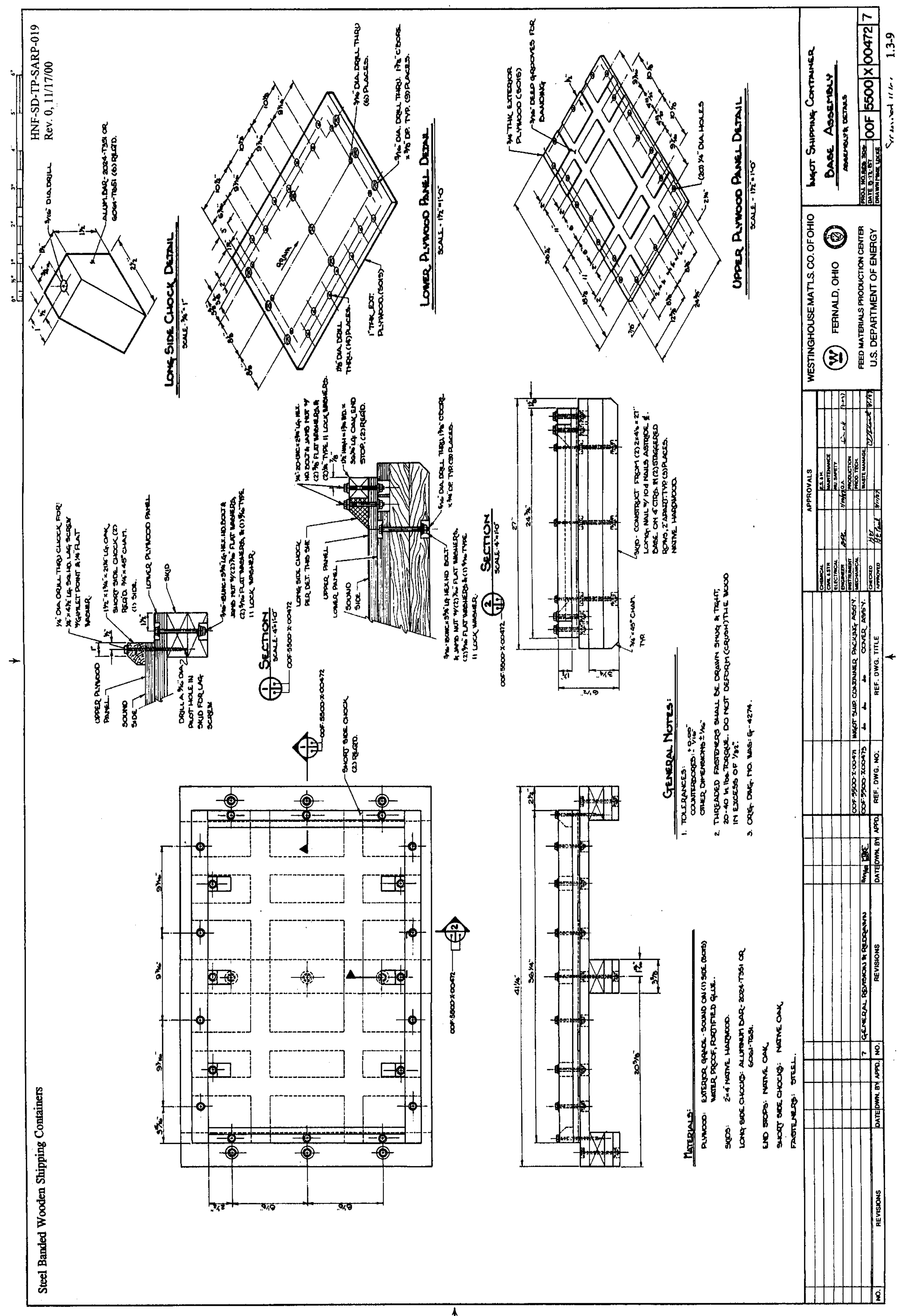




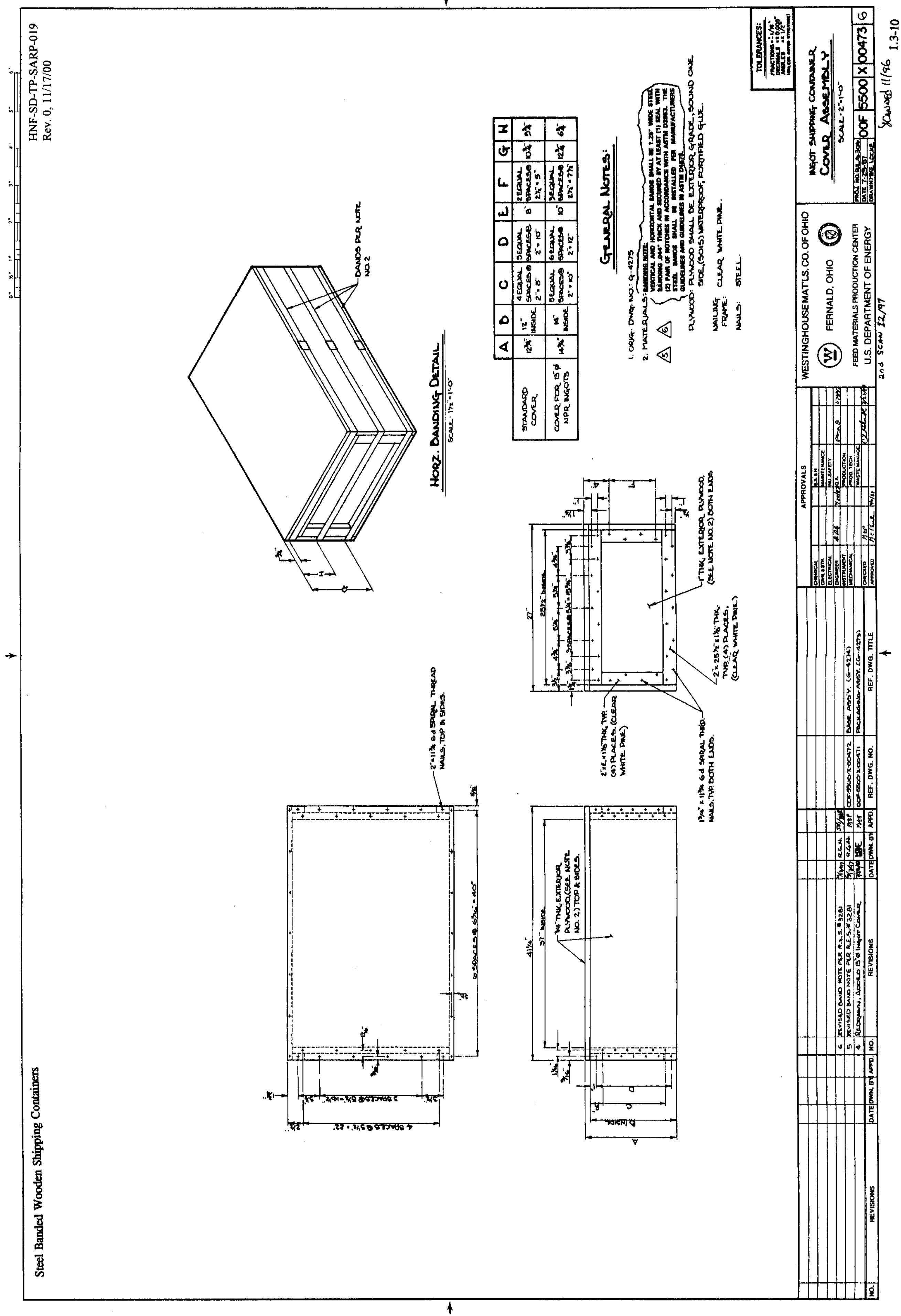





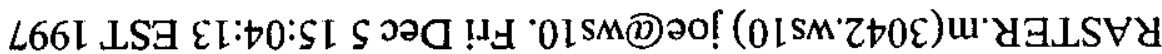

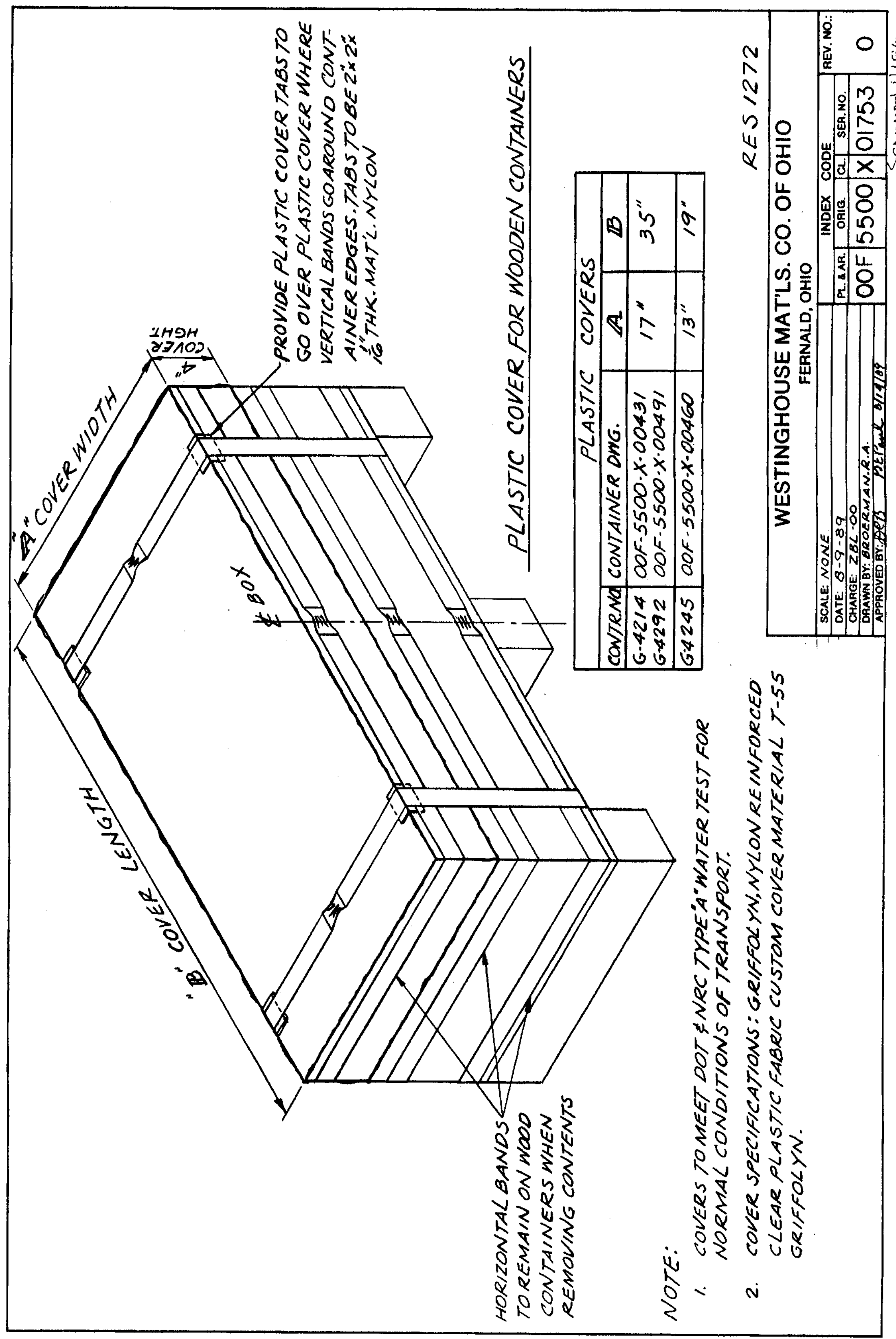




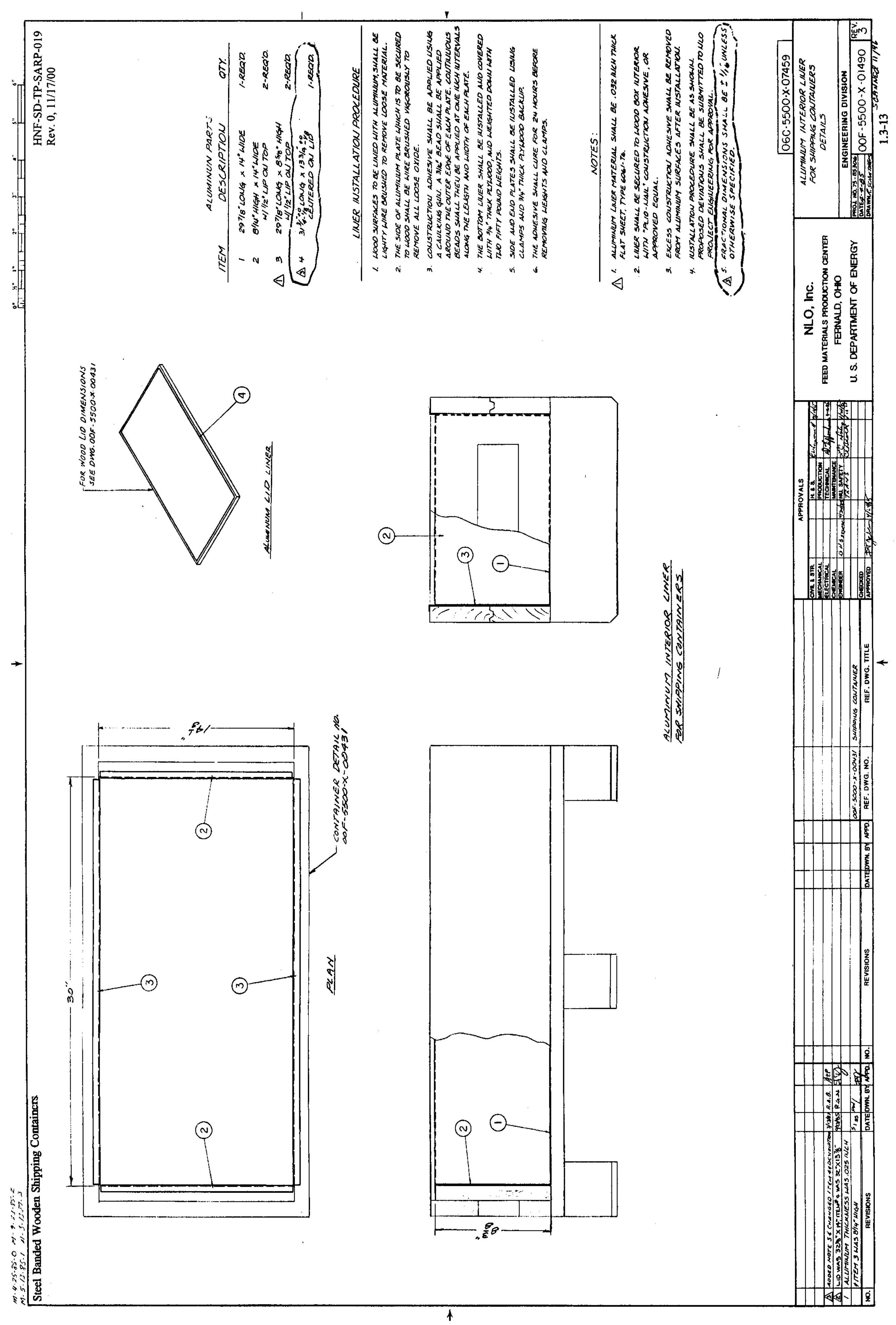




\subsection{STRUCTURAL EVALUATION}

\subsection{STRUCTURAL DESIGN}

\subsubsection{Discussion}

The structural design of the steel banded wooden boxes is a simple one. The wooden boxes have no pressure vessels, impact limiters, valves, etc. that are vital to the safety of the packages. The design of each box is described in more detail in Chapter 1.0, Section 1.2.1.

\subsubsection{Design Criteria}

The following criteria were used in the design of the wooden boxes:

- The packagings shall retain the payload when subjected to the NCT requirements in 10 CFR 71

- The requirement that the package be loaded and unloaded by a forklift

For NCT, the confinement of the package contents is the main design objective. The package does not fail if the contents remain confined, even though portions of the package may be damaged. For HAC, the package is assumed to fail and the payload is dispersed. The criticality evaluation in Chapter 6.0 shows that the payload will remain subcritical even though the payload is completely removed from the package. Allowable package stresses or strains are not specified for the wood because the packages are qualified by test. However, a tensile strength of $6,750 \mathrm{lb}$ $(30,025 \mathrm{~N})$ is specified for the steel banding. Testing and evaluation considered the loadings on full containers. Section 2.2 gives weights and centers of gravity of packagings and contents.

The packagings are designed, fabricated, examined, and tested to requirements that provide design safety margins, and material and fabrication control. The entire process is done in a controlled and documented manner to ensure that safe and quality packagings are produced. The design was done to standard engineering practices, fabrication drawings were produced and controlled to ensure that the desired product was obtained, and testing was conducted to verify the packagings meet the requirements for Type AF packagings.

\subsection{WEIGHTS AND CENTERS OF GRAVITY}

Tare and fully loaded weights for the boxes are listed in Table 2.2-1. The center of gravity of a package is located at the geometric center of the box.

\subsection{MECHANICAL PROPERTIES OF MATERIALS}

A main structural component of a packaging is the steel strapping. The steel strapping meets the requirements of ASTM D-3953 (ASTM 1991) and has a tensile strength of $6,750 \mathrm{lb}$ $(30,025 \mathrm{~N})$. Each steel band is secured with at least one seal that is closed with two pairs of notches per ASTM D-3953, Figure 1. The steel bands are installed per the manufacturers guidelines and the guidelines in ASTM D-4675 (ASTM 1993). Typical mechanical properties of dry white pine used for the boxes themselves are listed Table 2.3-1. 
TABLE 2.2-1. Tare and Gross Weights of Boxes.

\begin{tabular}{|l|c|c|}
\hline \multicolumn{1}{|c|}{ Packaging } & $\begin{array}{c}\text { Tare Weight } \\
\text { lb }(\mathrm{kg})\end{array}$ & $\begin{array}{c}\text { Maximum Gross Weight } \\
\mathrm{lb}(\mathrm{kg})\end{array}$ \\
\hline \hline G-4214 & $60(27)$ & $1,260(572)$ \\
\hline G-4245 & $25(11)$ & $222(101)$ \\
\hline G-4255 & $120(54)$ & $1,464(664)$ \\
\hline G-4273-5 & $140(64)$ & $3,020(1,370)$ \\
\hline G-4273-6 & $144(65)$ & $3,632(1,647)$ \\
\hline G-4292 & $80(36)$ & $1,332(604)$ \\
\hline
\end{tabular}

TABLE 2.3-1. Mechanical Properties of Dry White Pine.

\begin{tabular}{|l|c|}
\hline Density & $23.29 \mathrm{lb} / \mathrm{ft}^{3}$ \\
\hline Modulus of Elasticity & $1,260,000 \mathrm{Ib} / \mathrm{in}^{2}$ \\
\hline Modulus of Rupture & $9,000 \mathrm{lb} / \mathrm{in}^{2}$ \\
\hline
\end{tabular}

\subsection{GENERAL STANDARDS FOR ALL PACKAGES}

\subsubsection{Minimum Package Size}

The minimum overall dimension of any wooden box described in this SARP exceeds the 4 in. $(10.16 \mathrm{~cm})$ minimum required for Type AF packaging.

\subsubsection{Tamper-Indicating Features}

If a closed vehicle or cargo container is used to make the shipments, a uniquely indentified tamper-indicating device (TID) shall be applied to either the door of the vehicle or cargo container or to each wooden box so that the wooden box cannot be opened without irreparably damaging the uniquely identified TID or the wooden box. The tamper-indicating device must be applied to each wooden box if an open vehicle is used for the shipments.

\subsubsection{Positive Closure}

The steel bands, which have a minimum tensile strength of $6,750 \mathrm{lb}(30,025 \mathrm{~N})$, hold the lids and covers in place and prevent inadvertent opening of a package.

\subsubsection{Chemical and Galvanic Reactions}

The uranium metal does not react with any of the package components. The interior of a wooden box may be lined with aluminum sheet or the finished uranium wrapped in aluminum foil to prevent pitting of finished pieces. 


\subsection{LIFTING AND TIEDOWN STANDARDS FOR ALL PACKAGES}

\subsubsection{Lifting Devices}

The steel banded wooden boxes have no lifting devices that are structural parts of the packages. The bottom skids allow the boxes to be lifted and moved by a forklift. The wooden boxes have been lifted and moved successfully many times.

\subsubsection{Tiedown Devices}

There are no tiedown devices that are a structural part of the package. Nylon or steel straps or other similar strapping is used to secure the packages to the trailers.

\subsection{NORMAL CONDITIONS OF TRANSPORT}

This SARP demonstrates that the steel banded wooden boxes satisfy the applicable requirements of 10 CFR 71.43 when subjected to the normal conditions of transport specified in 10 CFR 71.71. The boxes therefore satisfy the applicable requirements of 49 CFR 173 and DOE Order 460.1. Tests performed at EG\&G Mound Applied Technologies, Miamisburg, Ohio, demonstrate in part that the packages are capable of withstanding the normal conditions of transport (DOE 1996). The packages also have a long history of successful use.

\subsubsection{Heat}

The steel banded wooden boxes and their contents are not affected by direct sunlight at an ambient temperature of $100^{\circ} \mathrm{F}\left(37.8^{\circ} \mathrm{C}\right)$. The amount of decay heat from the payload, $0.039 \mathrm{~W}$ (Appendix 3.6.2), is negligible.

\subsubsection{Cold}

The steel banded wooden boxes and their contents are not affected by an ambient temperature of $-40^{\circ} \mathrm{F}\left(-40^{\circ} \mathrm{C}\right)$ in still air and in the shade.

\subsubsection{Reduced External Pressure}

Because the packages cannot contain pressure, a reduced external pressure of 3.5 psia will not affect the packages.

\subsubsection{Increased External Pressure}

Increased external pressure will not affect the packages because the packagings cannot contain pressure. 


\subsubsection{Vibration}

The wooden packages are not adversely affected by the vibration normally incident to transportation. The wooden skids upon which a package rests provide significant damping.

\subsubsection{Water Spray}

The water spray test simulates exposure to rainfall of approximately $2 \mathrm{in.}$ per hour for at least one hour. Water spray tests were conducted on all six types of packages (DOE 1996). (The water spray tests preceded the drop tests, the compression tests, and the penetration tests.) The boxes with lids were tested without plastic covers and water therefore leaked into these packages. The standard design of the boxes with lids has a plastic cover which was added after the water spray tests. Note that all packaged uranium metal was either depleted or normal $10.71 \%{ }^{235} \mathrm{U}$ enriched or less) and was pickled to remove any removable contamination which could be transported by any water that may leak into the wooden boxes. Figure 2.6.6-1 shows a water test of the packages.

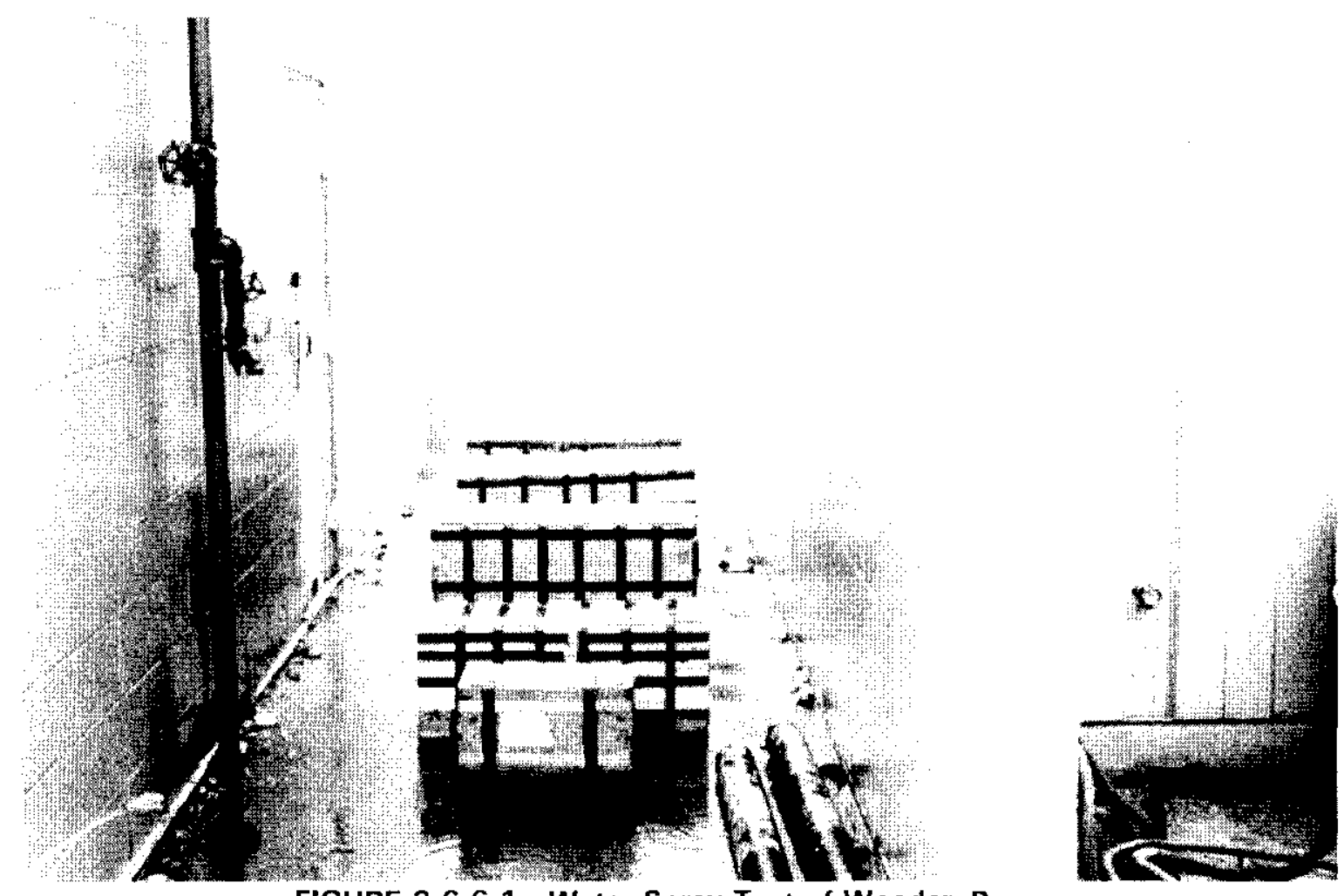

FIGURE 2.6.6-1. Water Spray Test of Wooden Boxes.

\subsubsection{Free Drop}

The free drop tests for the packages consist of $4 \mathrm{ft}(1.2 \mathrm{~m})$ free-falls onto a flat, unyielding, horizontal surface following the water spray tests. Each of the six package designs was drop tested within $2 \frac{1}{2}$ hours after the water spray tests were completed. The tests consisted of oblique drops, directed at the package's top and bottom corners, and end drops. The evaluation of the drop tests concludes that all packages passed the tests (DOE 1996). Wooden boxes G-4292 and 
G-4273 suffered significant distortion. However, no package experienced a loss of contents as the result of a drop. The uranium metal used for the drop tests (depleted or natural) has the same physical characteristics as the proposed payloads. The only difference between the two is the amount of ${ }^{235} \mathrm{U}$ enrichment, which does not have any effect on the drop test results. All of the test boxes were assembled and banded per the drawings in Appendix 1.3.2, Chapter 1.0.

Two G-4214 boxes were loaded with uranium metal (inner elements) for a gross weight of $1,260 \mathrm{lb}(572 \mathrm{~kg})$ and $1,252 \mathrm{lb}(568 \mathrm{~kg})$, respectively. Wood shoring was placed in the box to prohibit movement of the contents. The first package was subjected to two oblique drops; one on the top corner and one on its bottom corner. The first impact dented the top corner approximately $1 \frac{1}{4} \mathrm{in} .(3.18 \mathrm{~cm})$. The second impact broke off a skid and produced a visible gap in the package. The second package was dropped flat on its side and then on the opposite top corner. The side drop did not damage the package. The second impact dented the top corner and produced a visible gap in the top edge. All steel bands remained intact and there was no damage that allowed the release of package contents. Figure 2.6.7-1 shows the damage caused by an impact on a top corner. Figure 2.6.7-2 shows the damage caused by an impact on a bottom corner.

Two G-4245 boxes were loaded with miscellaneous uranium metal sample pieces for a gross weight of $222 \mathrm{lb}(101 \mathrm{~kg})$ and $198 \mathrm{lb}(90 \mathrm{~kg}$ ), respectively. Wood shoring was placed in the box to prohibit movement of the contents. One package was subjected to two oblique drops; one on its top corner and then one on its bottom corner. The top oblique drop caused a minor dent. The bottom oblique drop tore off a skid but otherwise caused only minor damage. The other package was dropped flat on its side and then on a top corner. The top oblique drop caused a minor dent. The side drop caused no significant damage. In all cases, the banding remained intact and no contents escaped. Figure 2.6.7-3 shows the damage caused by an impact on a top corner. Figure 2.6.7-4 shows the damage caused by an impact on a bottom corner.

Two G-4292 boxes were loaded with uranium metal (inner elements) for gross weights of $1,332 \mathrm{lb}(604 \mathrm{~kg})$ and $1,328 \mathrm{lb}(602 \mathrm{~kg})$, respectively. Wood shoring was placed in the box to prohibit movement of the contents. The first package was subjected to an oblique drop on a top corner. The impact distorted the box $3 \mathrm{in} .(7.62 \mathrm{~cm})$ lengthwise and caused a $3 / 4 \mathrm{in} .(1.91 \mathrm{~cm}) \mathrm{gap}$ in the edge of the box. The impact also detached all of the skids. The second package was subjected to an oblique drop on a bottom corner. All skids were broken off, the bottom corner was dented in about $1 \frac{1}{2}$ in. $(3.81 \mathrm{~cm})$, the box was distorted $2 \mathrm{in.}(5.08 \mathrm{~cm})$ lengthwise, and a $3 / 4$ in. $(1.91 \mathrm{~cm})$ gap was created in the edge. All bands remained intact for both drops and no contents escaped. Figure 2.6.7-5 shows the damage caused by the impact on the top corner.

Figure 2.6.7-6 shows the damage caused by the impact on the bottom corner.

Two G-4255 boxes were loaded with five inner billets per box for gross weights of $1,440 \mathrm{lb}$ $(653 \mathrm{~kg})$ and $1,464 \mathrm{lb}(664 \mathrm{~kg})$, respectively. The billets were banded in place per the drawing in Chapter 1.0, Appendix 1.3.2. One package was subjected to an oblique drop on a top corner. The corner was dented in approximately $1 \mathrm{in.}(2.54 \mathrm{~cm})$ and the corner seam developed a $3 / 8 \mathrm{in}$. $(0.95 \mathrm{~cm})$ gap. The other package was subjected to an oblique drop on a bottom corner. The skid was pushed in $2 \mathrm{in.}(5.08 \mathrm{~cm}$ ) at the point of contact (but did not break off) and there was a $11 / \mathrm{s}$ in. $(2.86 \mathrm{~cm})$ dent in the corner. Interior and exterior steel banding remained intact in both drop tests. Figure 2.6.7-7 shows the damage caused by the impact on the top corner. Figure 2.6.7-8 shows the damage caused by the impact on the bottom corner.

Two G-4273-5 containers with standard covers were loaded with two inner $N$ Reactor ingots for a gross weight of $3,020 \mathrm{lb}(1,370 \mathrm{~kg})$ and $2,964 \mathrm{lb}(1,344 \mathrm{~kg})$, respectively. The ingots were banded in place per the drawing in Chapter 1.0. Appendix 1.3.2. The first package was subjected to an oblique drop on its top corner. The impact significantly distorted the package, but no contents escaped. The corner was dented $13 / 4 \mathrm{in} .(4.45 \mathrm{~cm})$, the package was distorted 


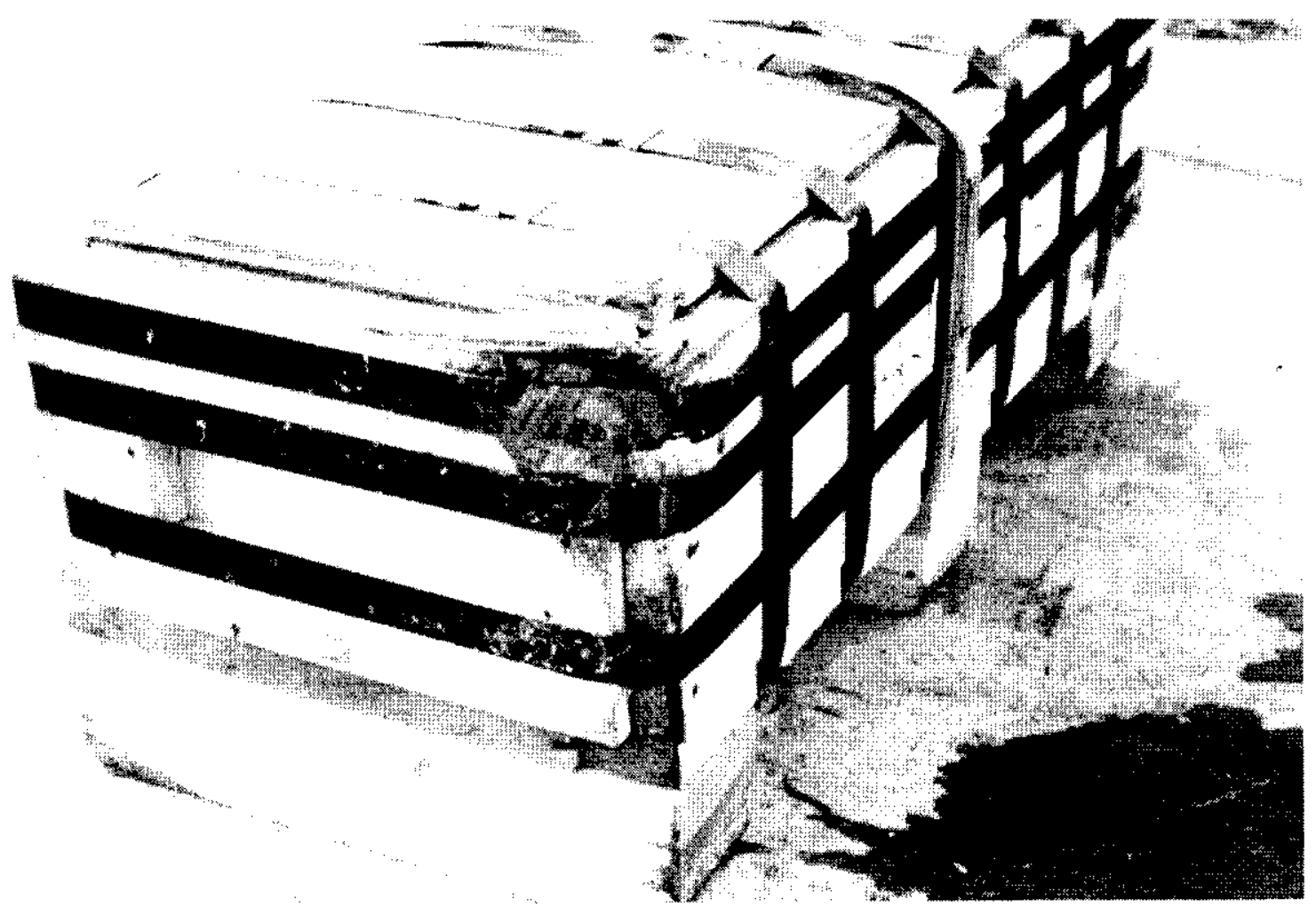

FIGURE 2.6.7-1. Box G-4214 Damaged by Top Oblique Drop.

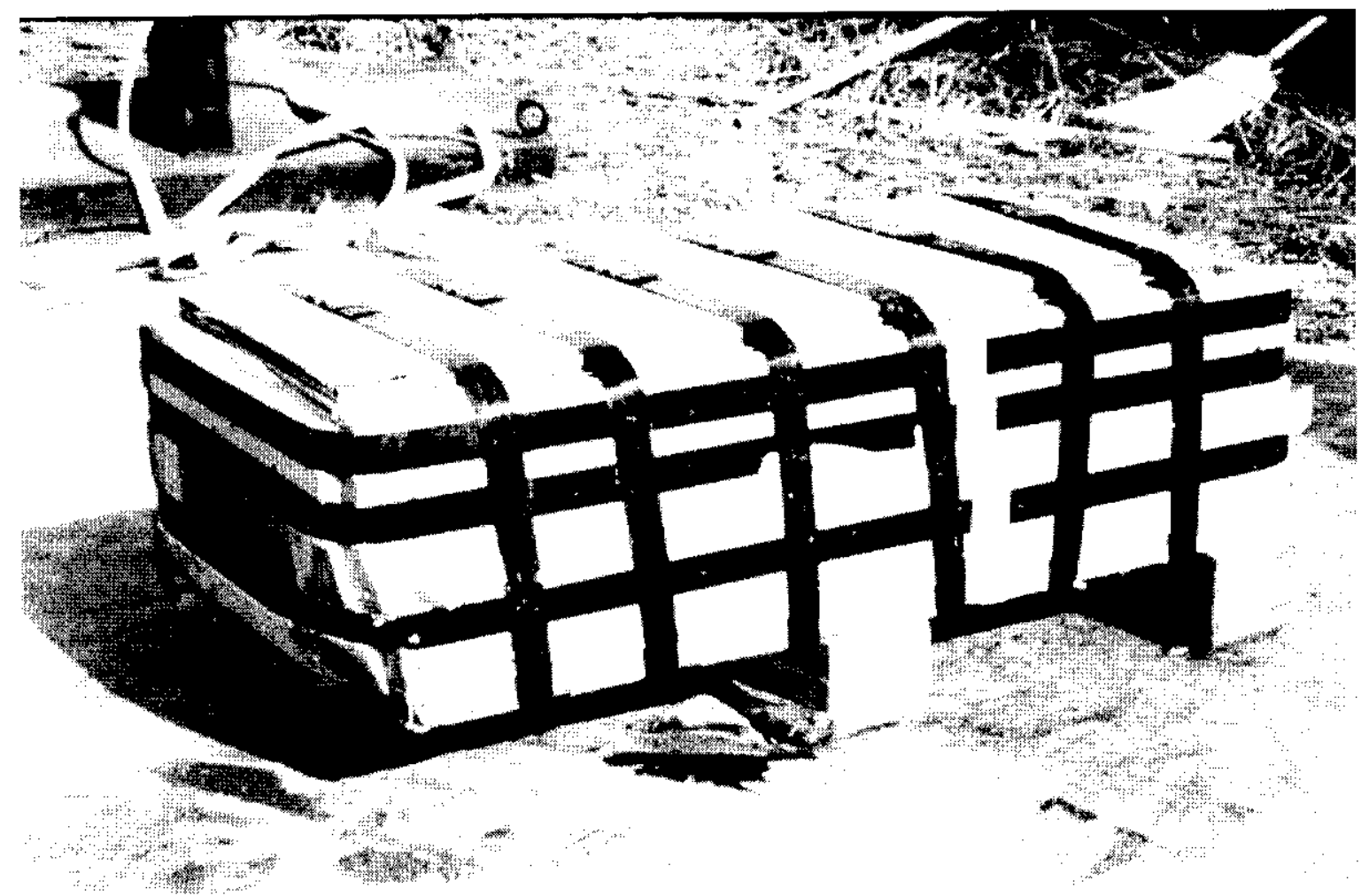

FIGURE 2.6.7-2. Box G-4214 Damaged by Bottom Oblique Drop. 


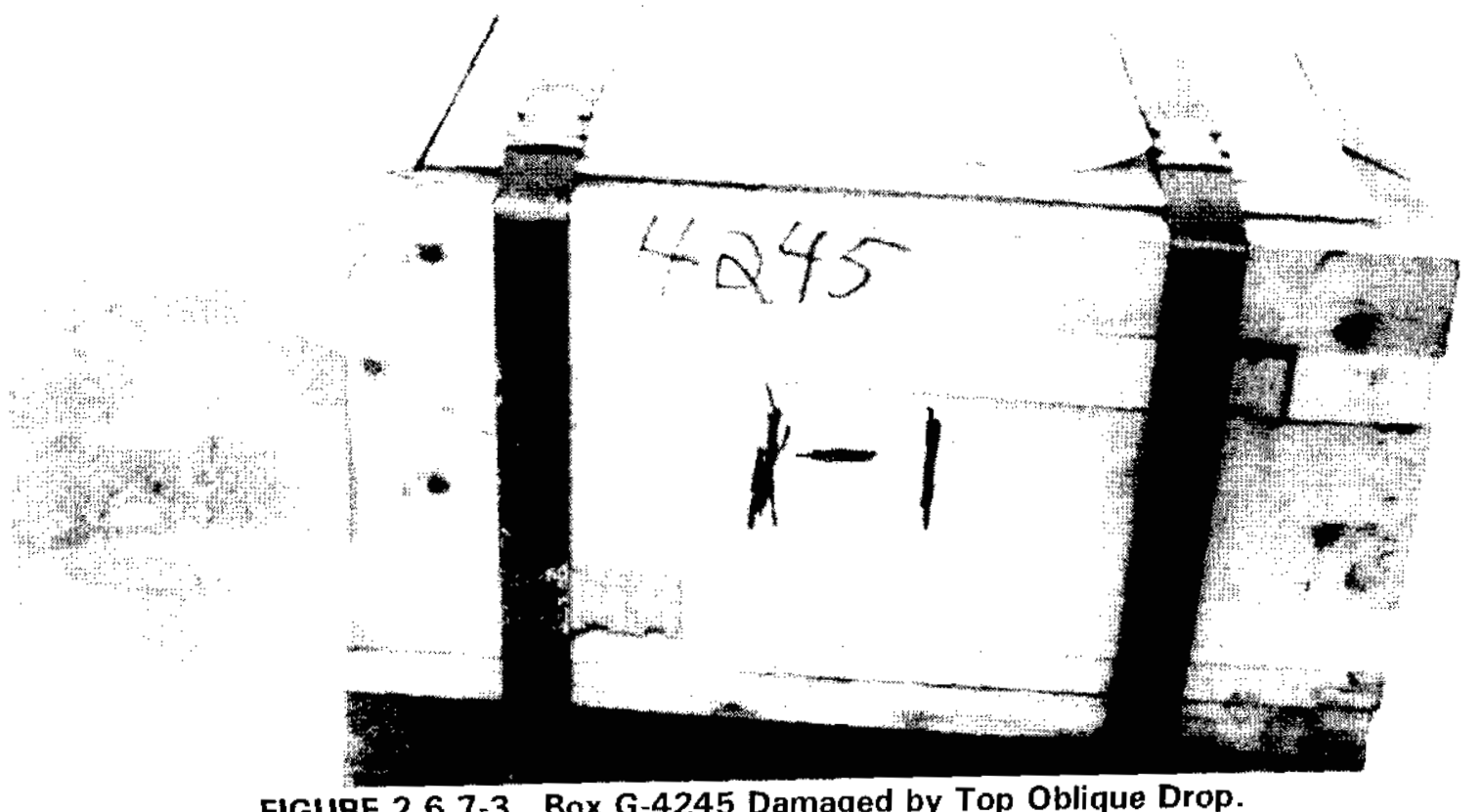

FIGURE 2.6.7-3. Box G-4245 Damaged by Top Oblique Drop.

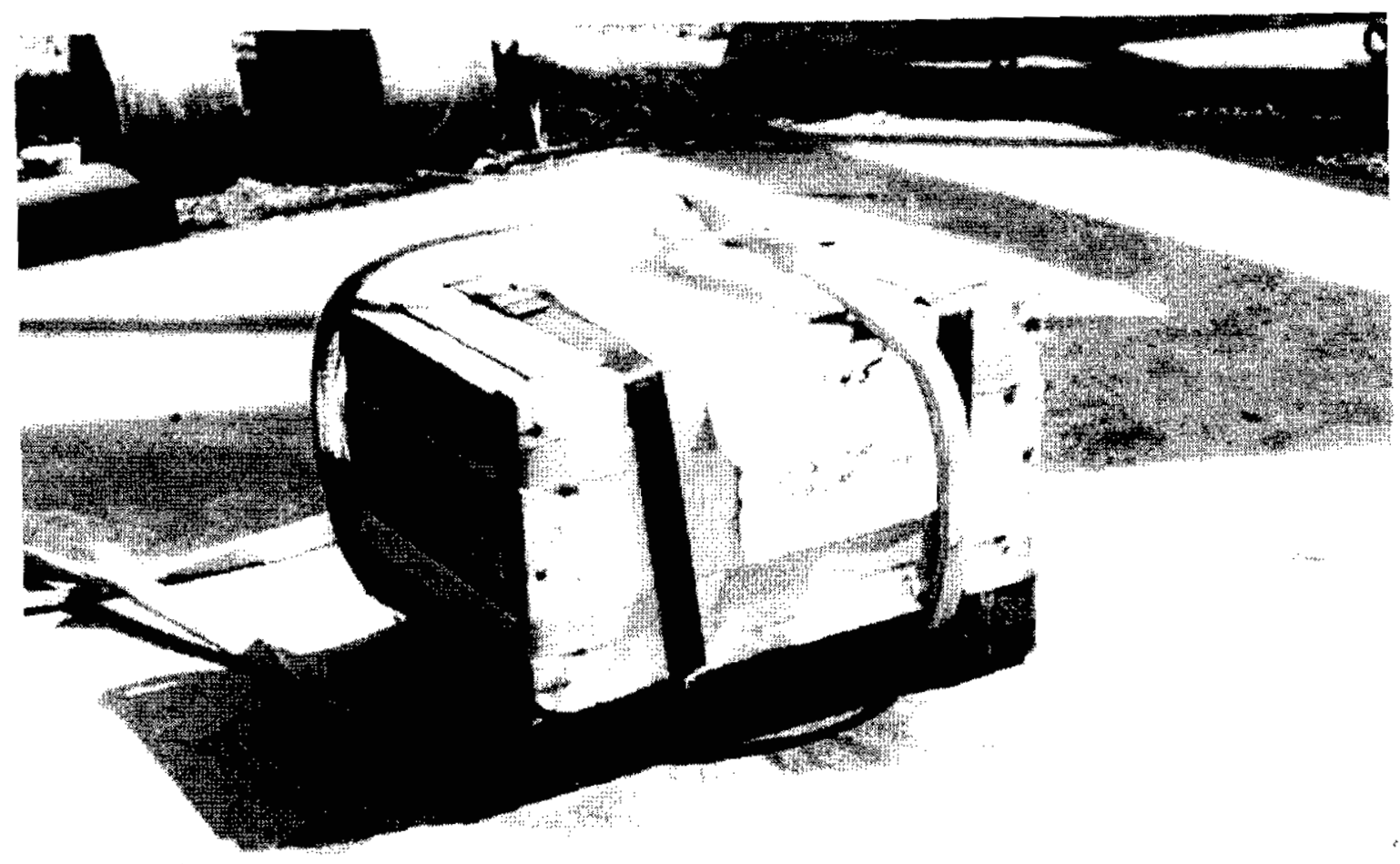

FIGURE 2.6.7-4. Box G-4245 Damaged by Bottom Oblique Drop. 


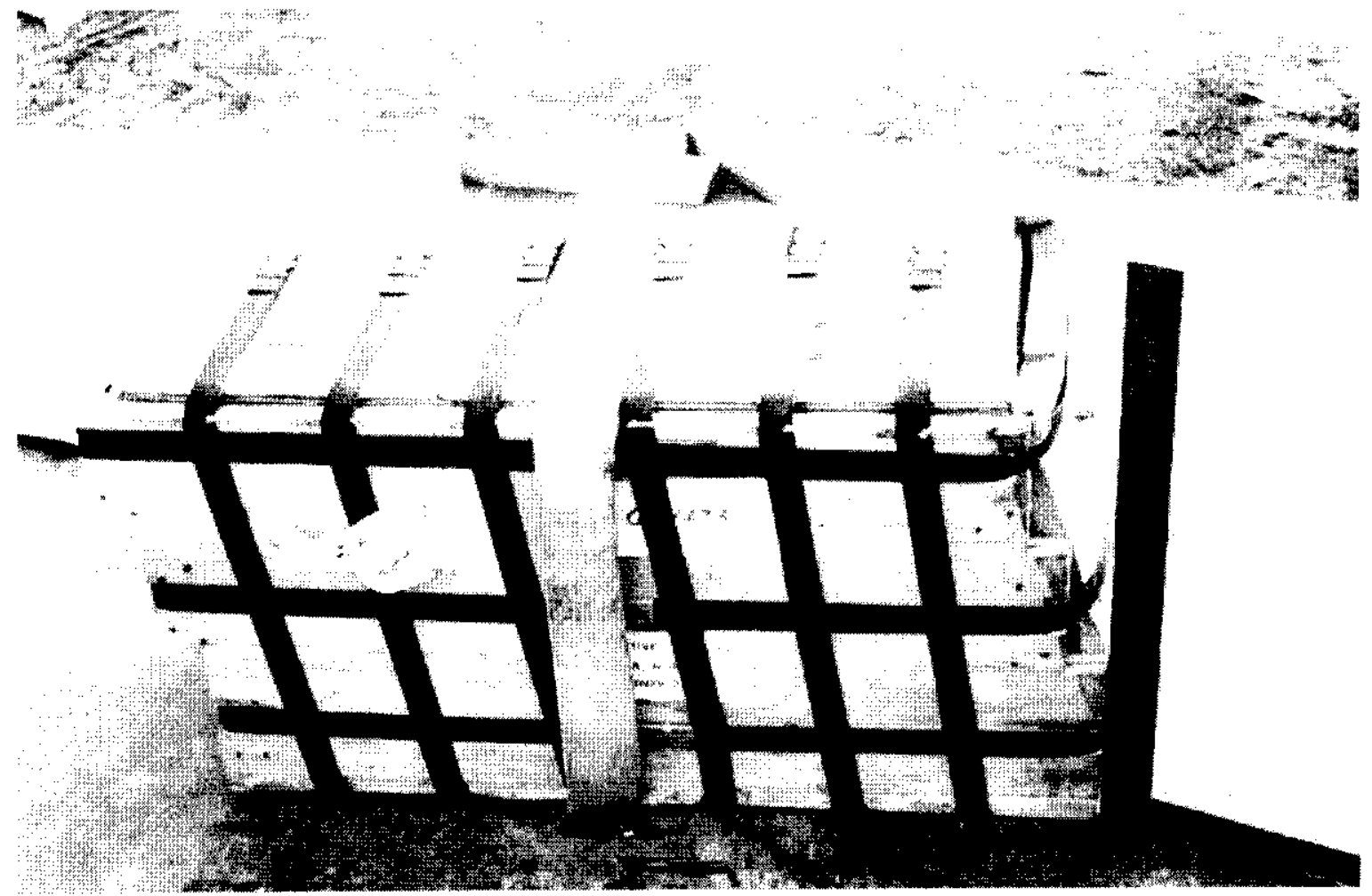

FIGURE 2.6.7-5. Box G-4292 Damaged by Top Oblique Drop.

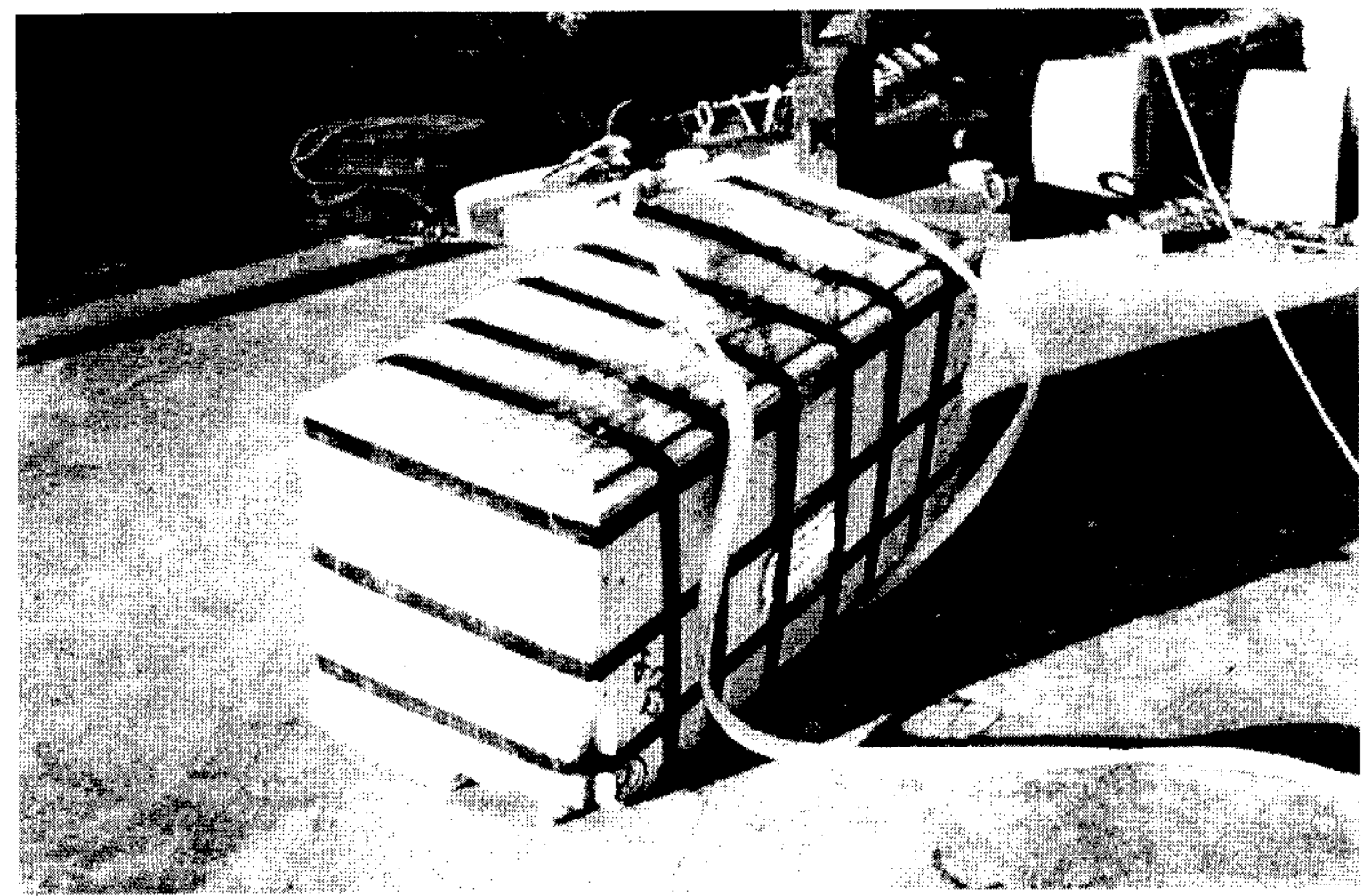

FIGURE 2.6.7-6. Box G-4292 Damaged by Bottom Oblique Drop. 


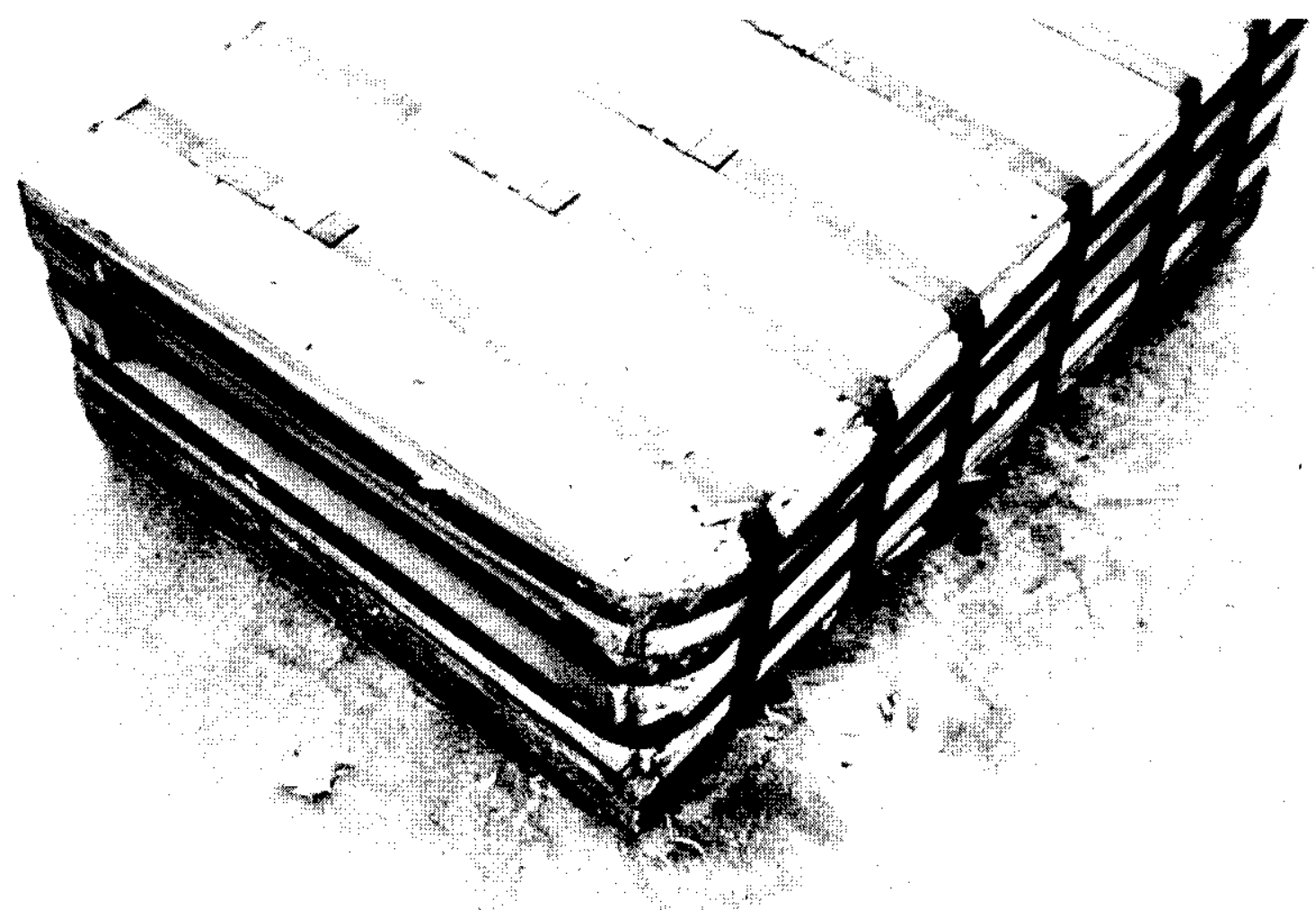

FIGURE 2.6.7-7. Box G-4255 Damaged by Top Oblique Drop.

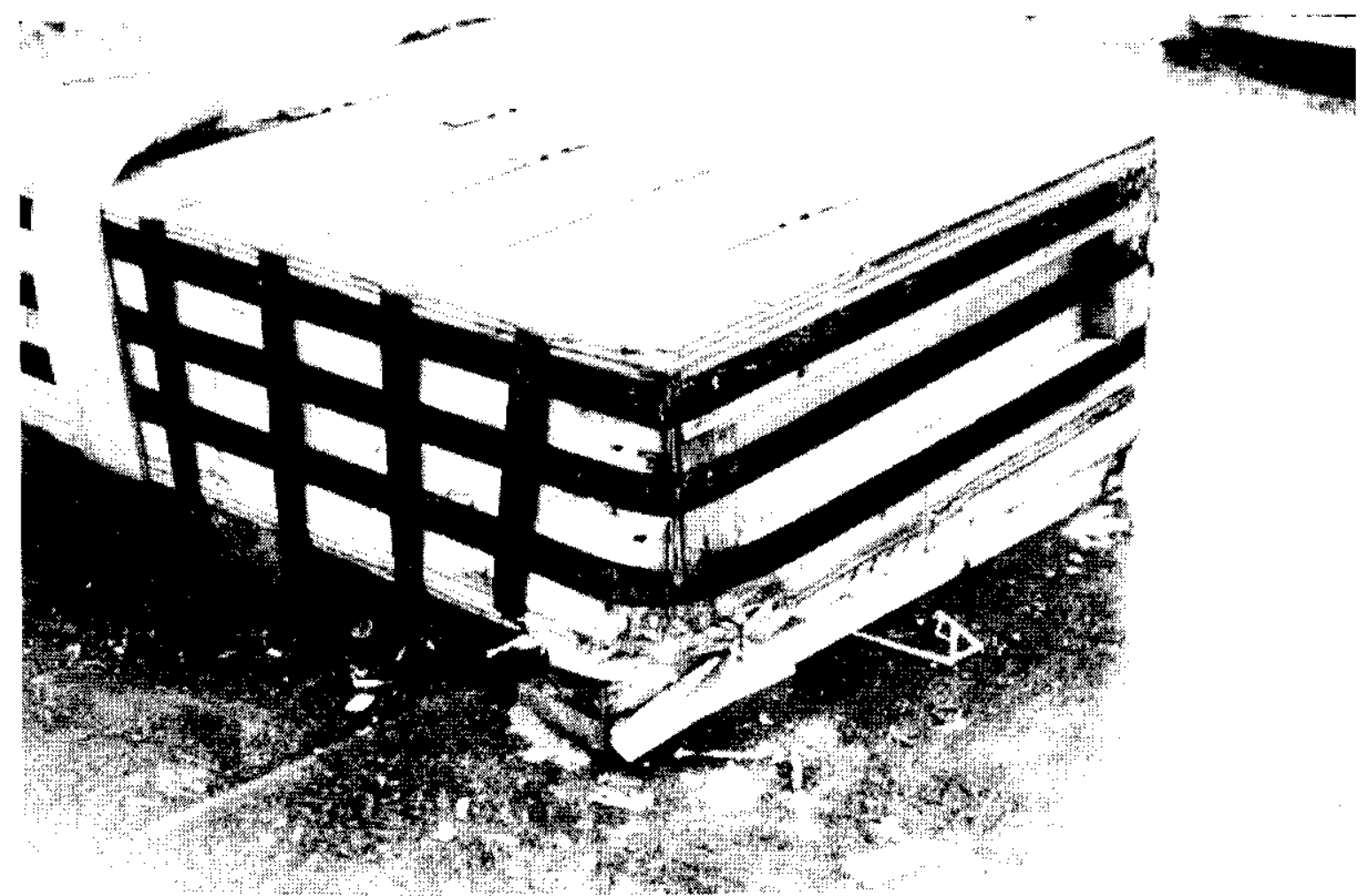

FIGURE 2.6.7-8. Box G-4255 Damaged by Bottom Oblique Drop. 
lengthwise $2 \frac{1}{4} \mathrm{in} .(5.72 \mathrm{~cm})$, and gaps which developed on the top edge and in the bottom impact area exposed the ingots. The top horizontal steel band broke. The second package was subjected to an oblique drop on a bottom corner. All exterior steel bands remained intact, a skid was partially torn off, the corner was dented in $1 \mathrm{in.}(2.54 \mathrm{~cm})$, and the box was distorted 2 in. $(5.08 \mathrm{~cm})$ lengthwise. In both drops, all interior bands remained intact, confining the contents to the pallets. Figure 2.6.7-9 shows the damage caused by the impact on the top corner. Figure 2.6.7-10 shows the damage caused by the impact on the bottom corner.

Two G-4273-6 containers (with the enlarged covers) were loaded with two outer $N$ Reactor ingots for a gross weight of $3,632 \mathrm{lb}(1,647 \mathrm{~kg})$ and $3,620 \mathrm{lb}(1,642 \mathrm{~kg})$, respectively. The ingots were banded in place per the drawing in Chapter 1.0. Appendix 1.3.2. The first package was subjected to an oblique drop on a top corner. The impact significantly distorted the package, but no contents escaped. Two horizontal steel bands and one vertical steel band broke. Gaps of approximately $2 \mathrm{in} .(5.08 \mathrm{~cm})$ developed in the top and bottom edges of the box. The impact also dented in the corner approximately $1 \frac{1}{2} \mathrm{in} .(3.81 \mathrm{~cm})$. The second package was subjected to an oblique drop on a bottom corner. The impact nearly tore off a skid, produced gaps of $1 \frac{134}{\mathrm{in}}$. $(3.18 \mathrm{~cm})$ and $2 \mathrm{in} .(5.08 \mathrm{~cm})$ at the edges, and dented in the corner $1 \frac{1}{2} \mathrm{in} .(3.81 \mathrm{~cm})$. All exterior bands remained intact and there was minimal lengthwise distortion. In all cases, the interior bands remained intact and no contents escaped from the packages. Figure 2.6.7-11 shows the damage caused by the impact on the top corner. Figure 2.6.7-12 shows the damage caused by the impact on the bottom corner.

\subsubsection{Corner Drop}

Corner drop tests are not specifically required for this SARP because of the package weight.

\subsubsection{Compression}

The compression test consists of a compressive load on the package of at least five times the applicable package weight for a period greater than 24 hours. In all cases, five times the package weight is greater than $1.85 \mathrm{lb} / \mathrm{in}^{2}$ acting on the vertically projected area of the package. The packages were tested in the normal upright position. All packages passed the compression tests with no visible damage and no loss of contents (DOE 1996). Figures 2.6.9-1 through 2.6.9-6 show the packages being compression tested. The gross weights and compressive test weights are given in Table 2.6.9-1.

TABLE 2.6.9-1. Gross and Compressive Test Weights.

\begin{tabular}{|l|c|c|}
\hline \multicolumn{1}{|c|}{ Packaging } & $\begin{array}{c}\text { Gross Weight } \\
\mathrm{lb}(\mathrm{kg})\end{array}$ & $\begin{array}{c}\text { Compressive Test Weight } \\
\mathrm{lb}(\mathrm{kg})\end{array}$ \\
\hline \hline G-4245 & $222(101)$ & $1,262(572)$ \\
\hline G-4214 & $1,260(572)$ & $7,144(3,240)$ \\
\hline G-4292 & $1,332(604)$ & $7,650(3,470)$ \\
\hline G-4255 & $1,464(664)$ & $10,230(4,640)$ \\
\hline G-4273-5 & $3,020(1,370)$ & $17,700(8,029)$ \\
\hline G-4273-6 & $3,632(1,647)$ & $18,500(8,391)$ \\
\hline
\end{tabular}




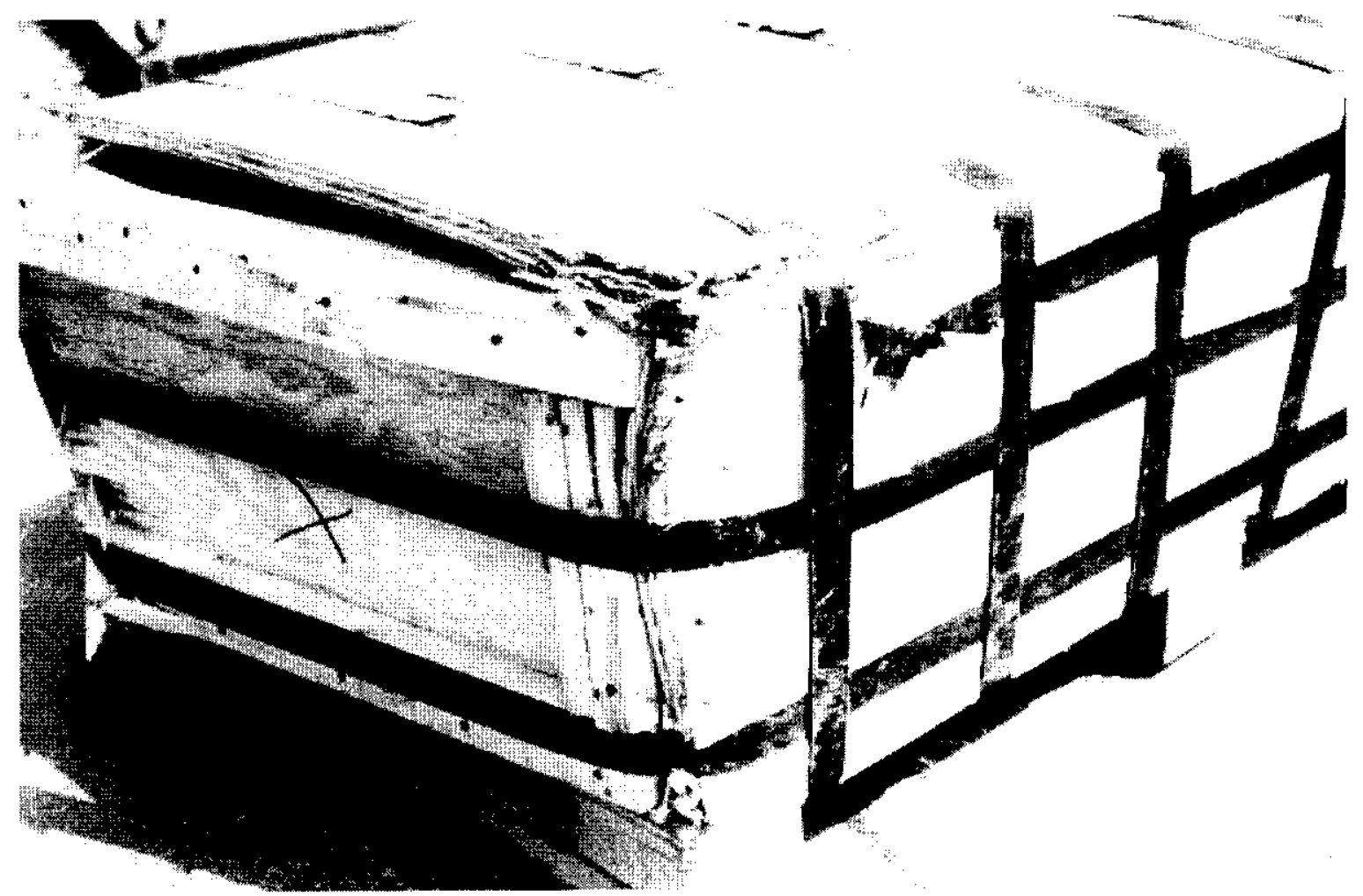

FIGURE 2.6.7-9. Box G-4273-5 Damaged by Top Oblique Drop.

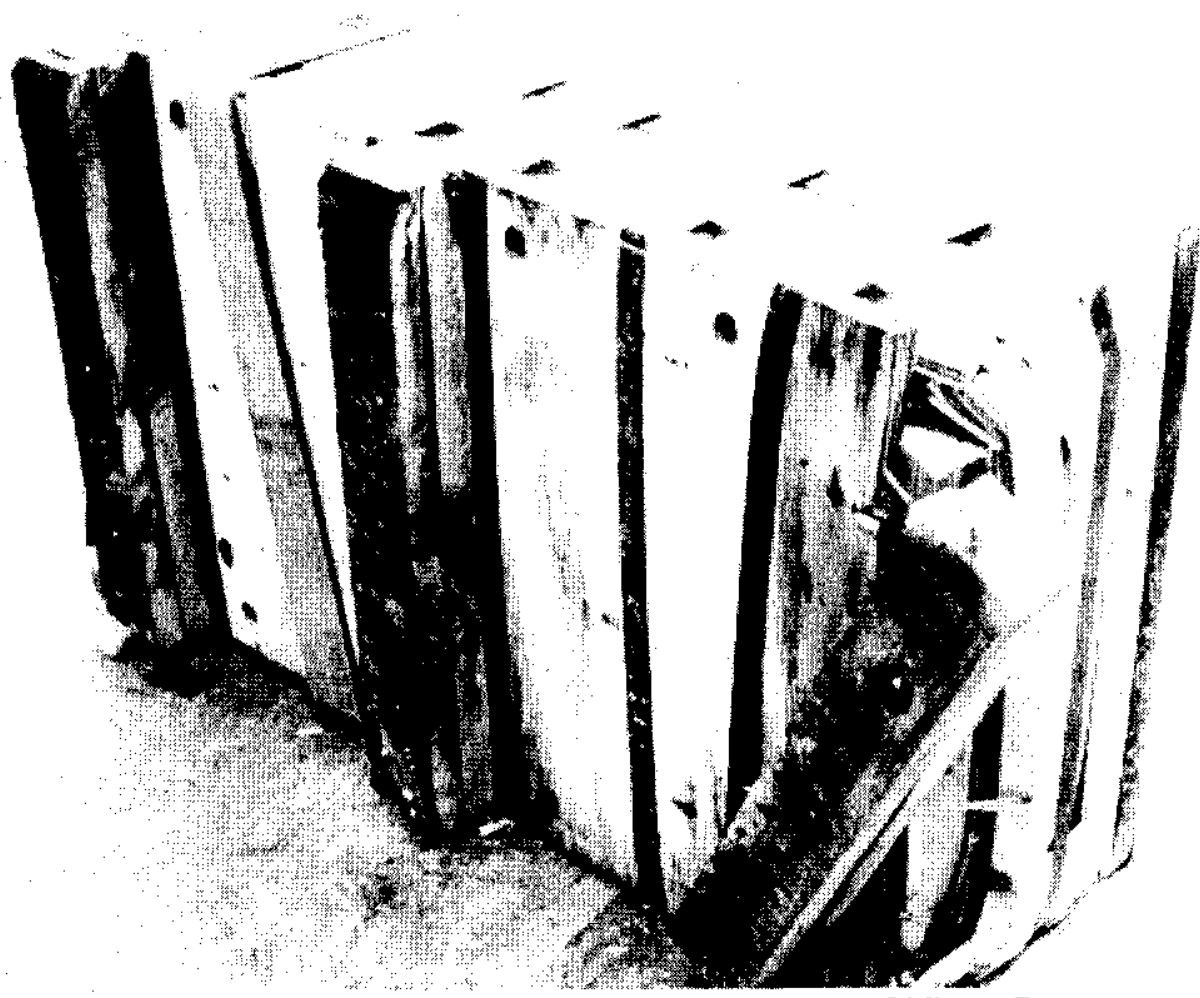

FIGURE 2.6.7-10. Box G-4273-5 Damaged by Bottom Oblique Drop. 


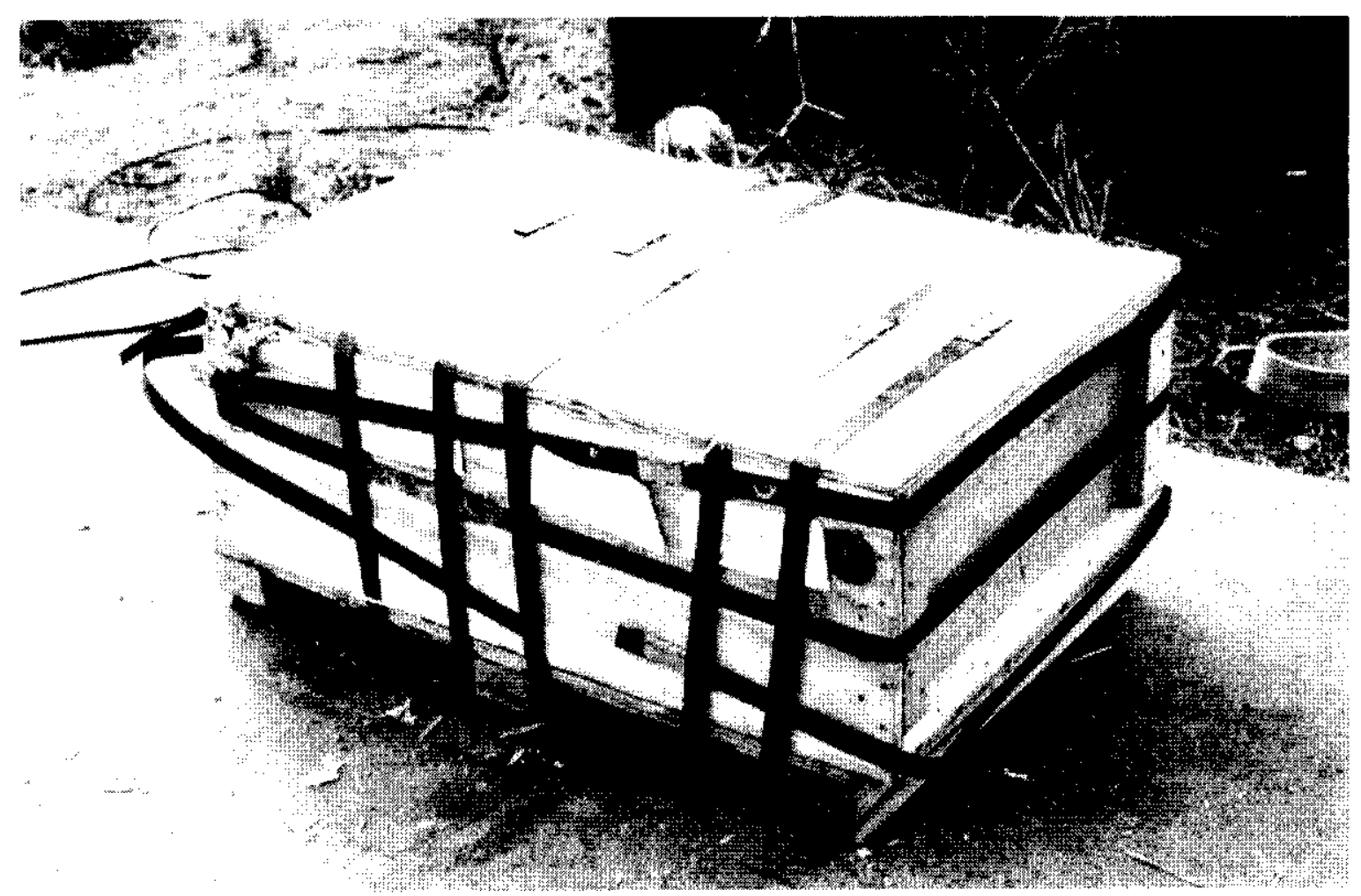

FIGURE 2.6.7-11. Box G-4273-6 Damaged by Top Oblique Drop.

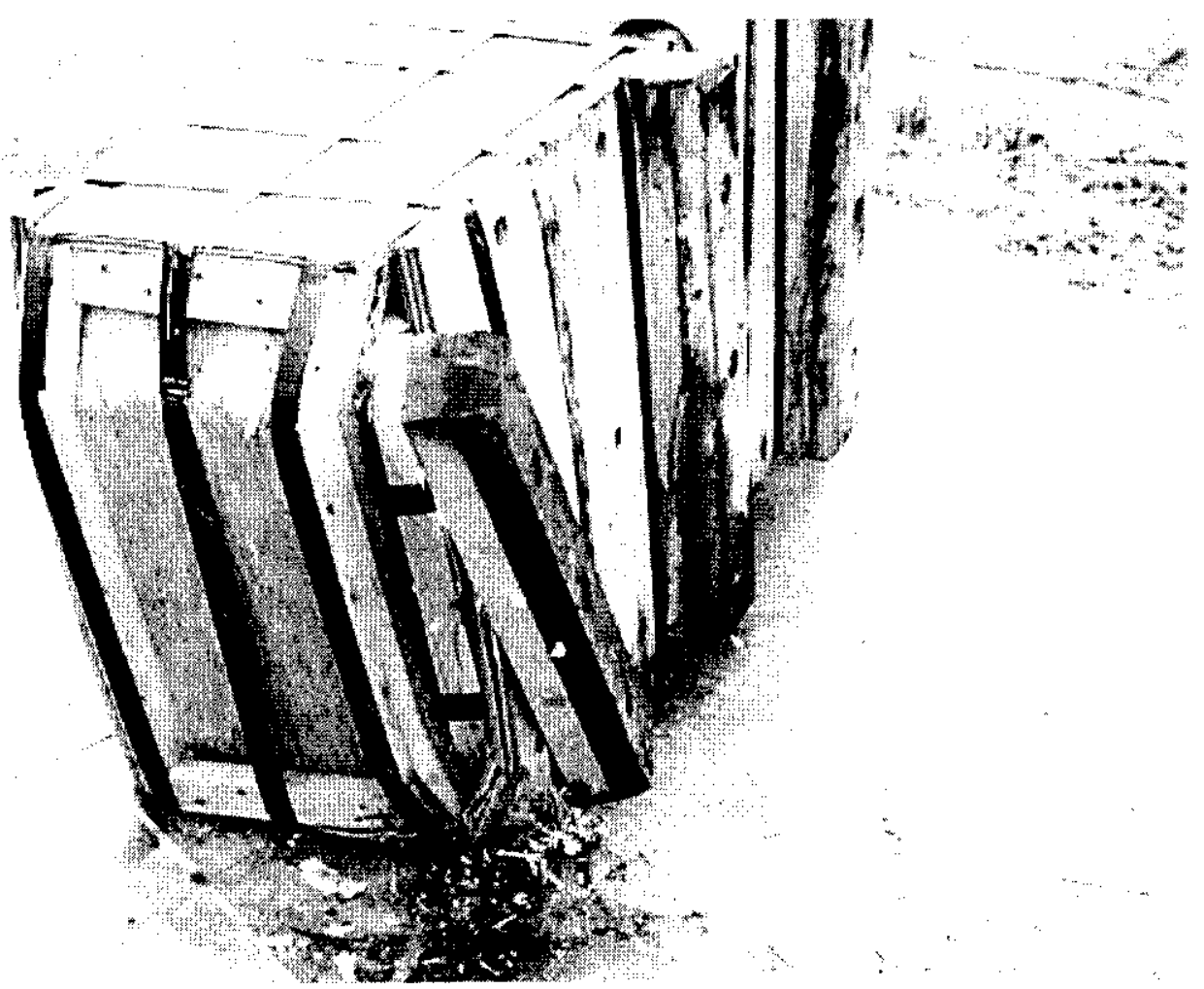

FIGURE 2.6.7-12. Box G-4273-6 Damaged by Bottom Oblique Drop. 


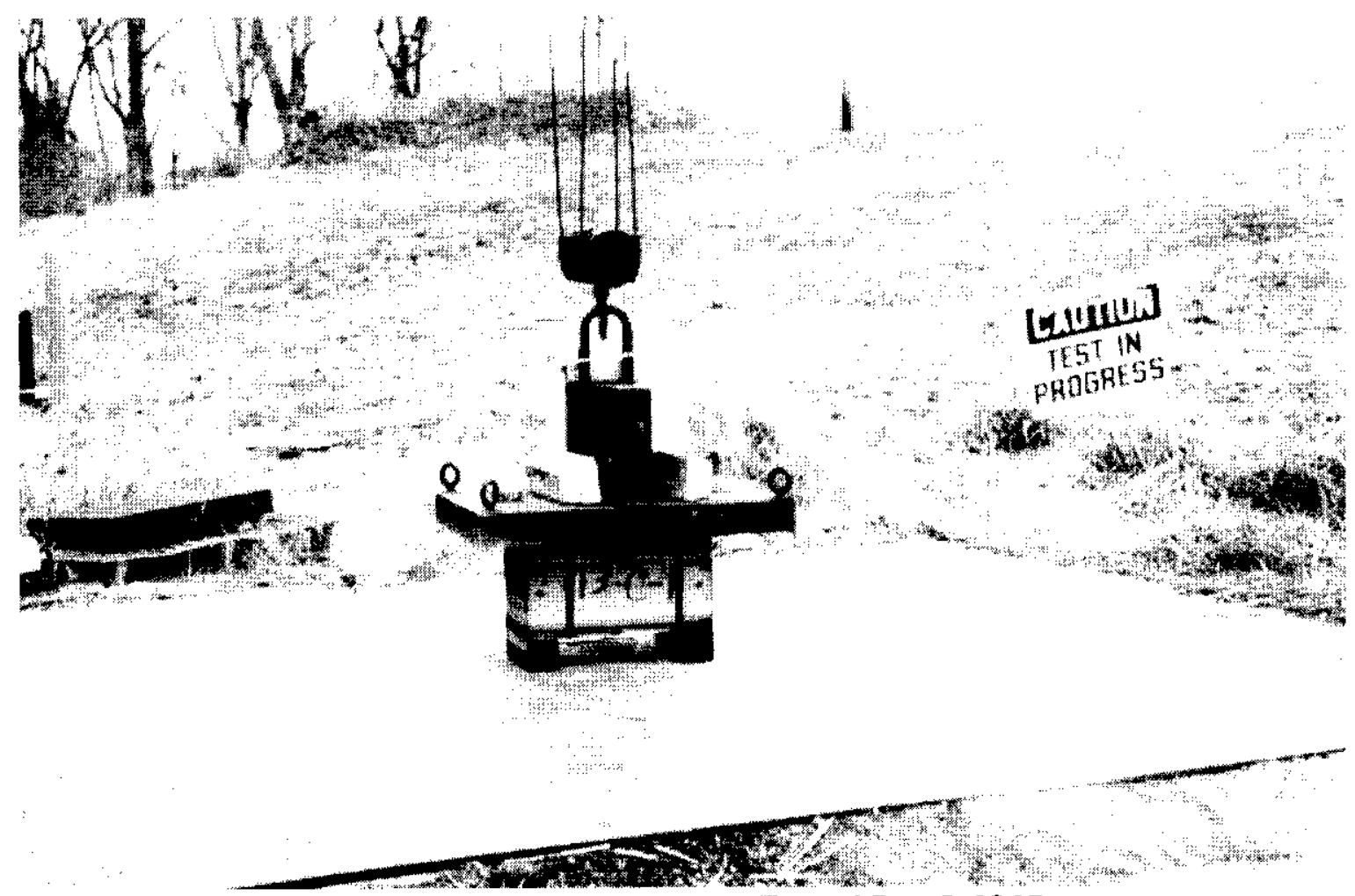

FIGURE 2.6.9-1. Compression Test of Box G-4245.

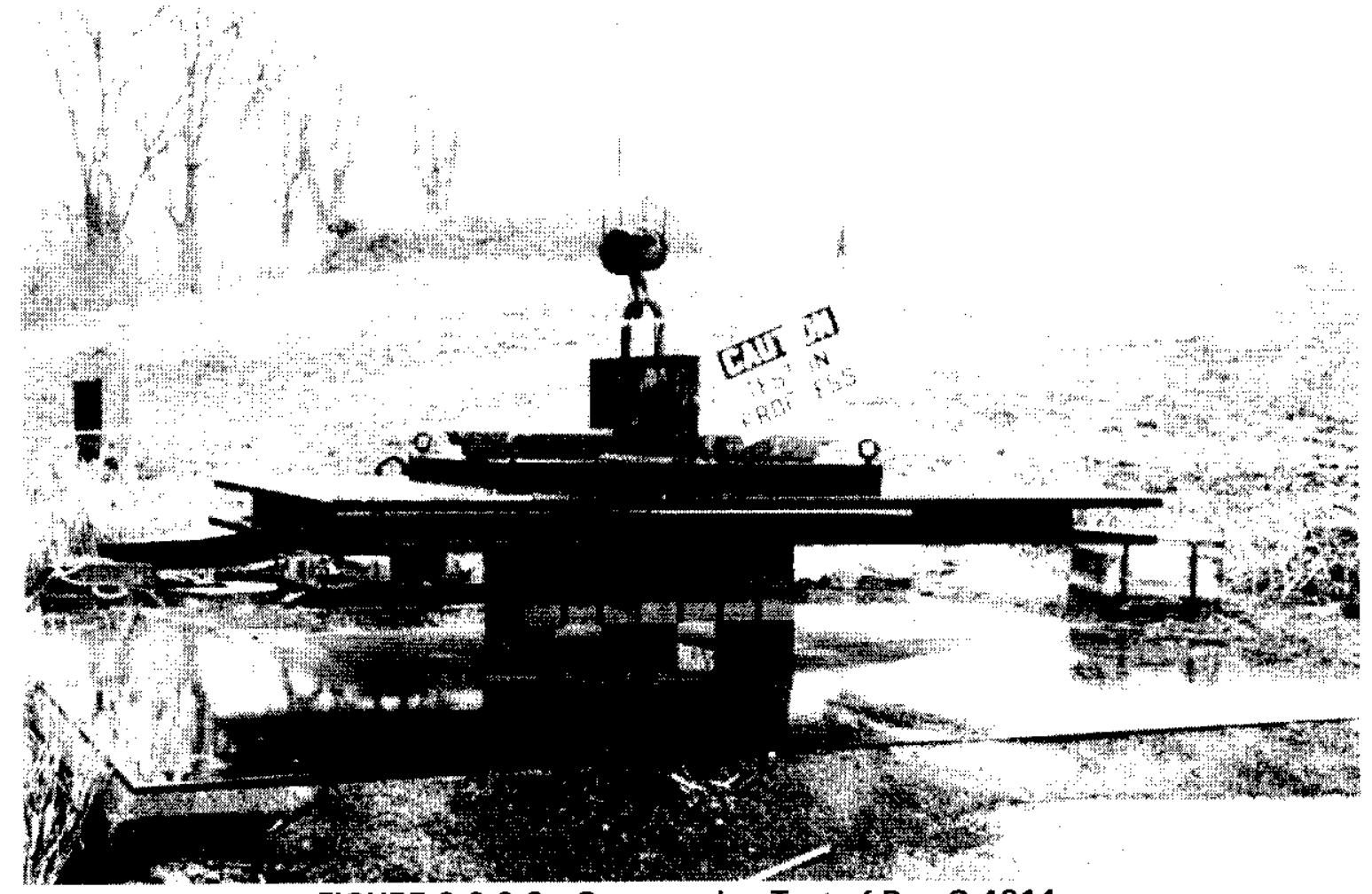

FIGURE 2.6.9-2. Compression Test of Box G-4214. 


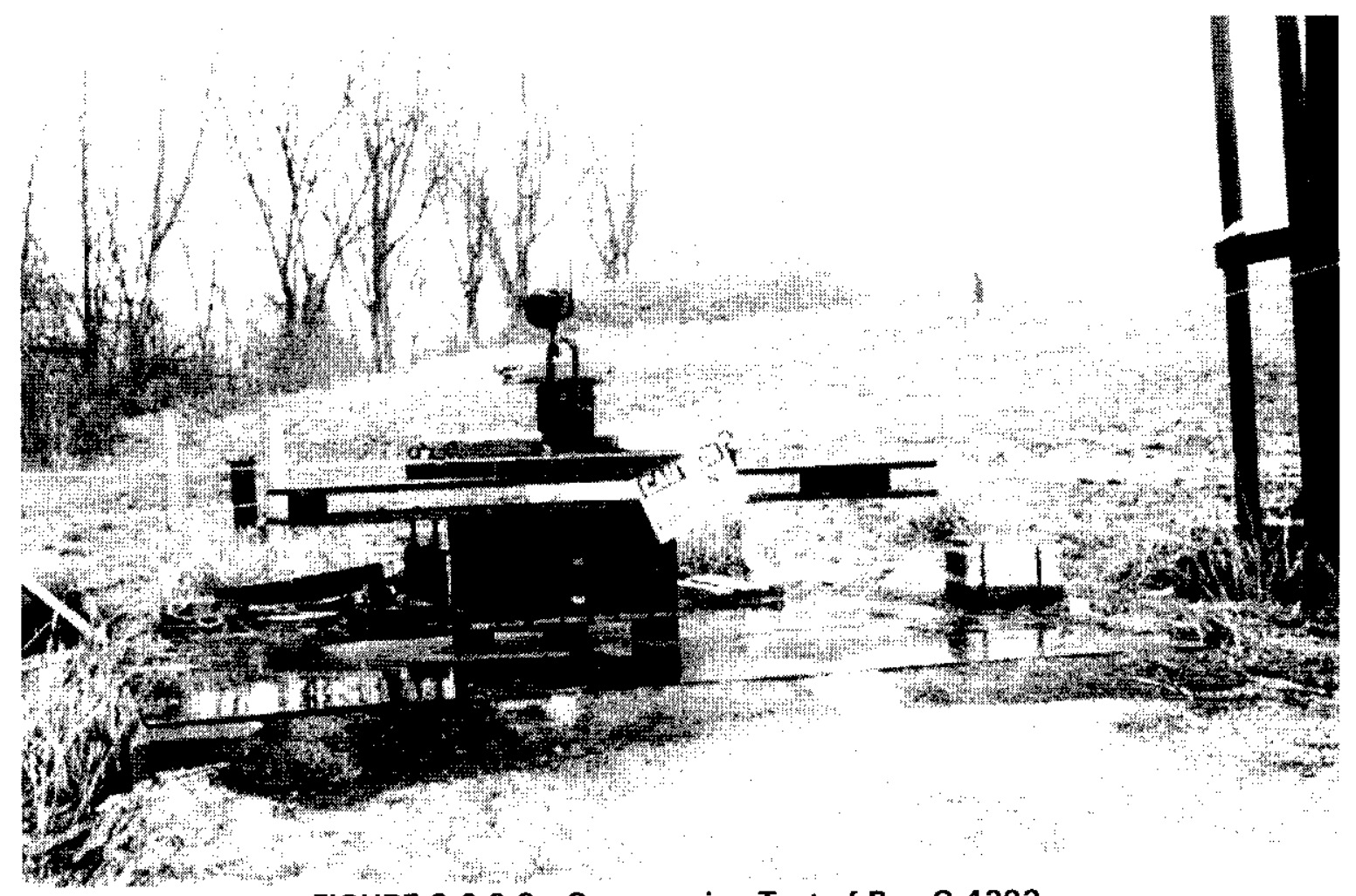

FIGURE 2.6.9-3. Compression Test of Box G-4292.

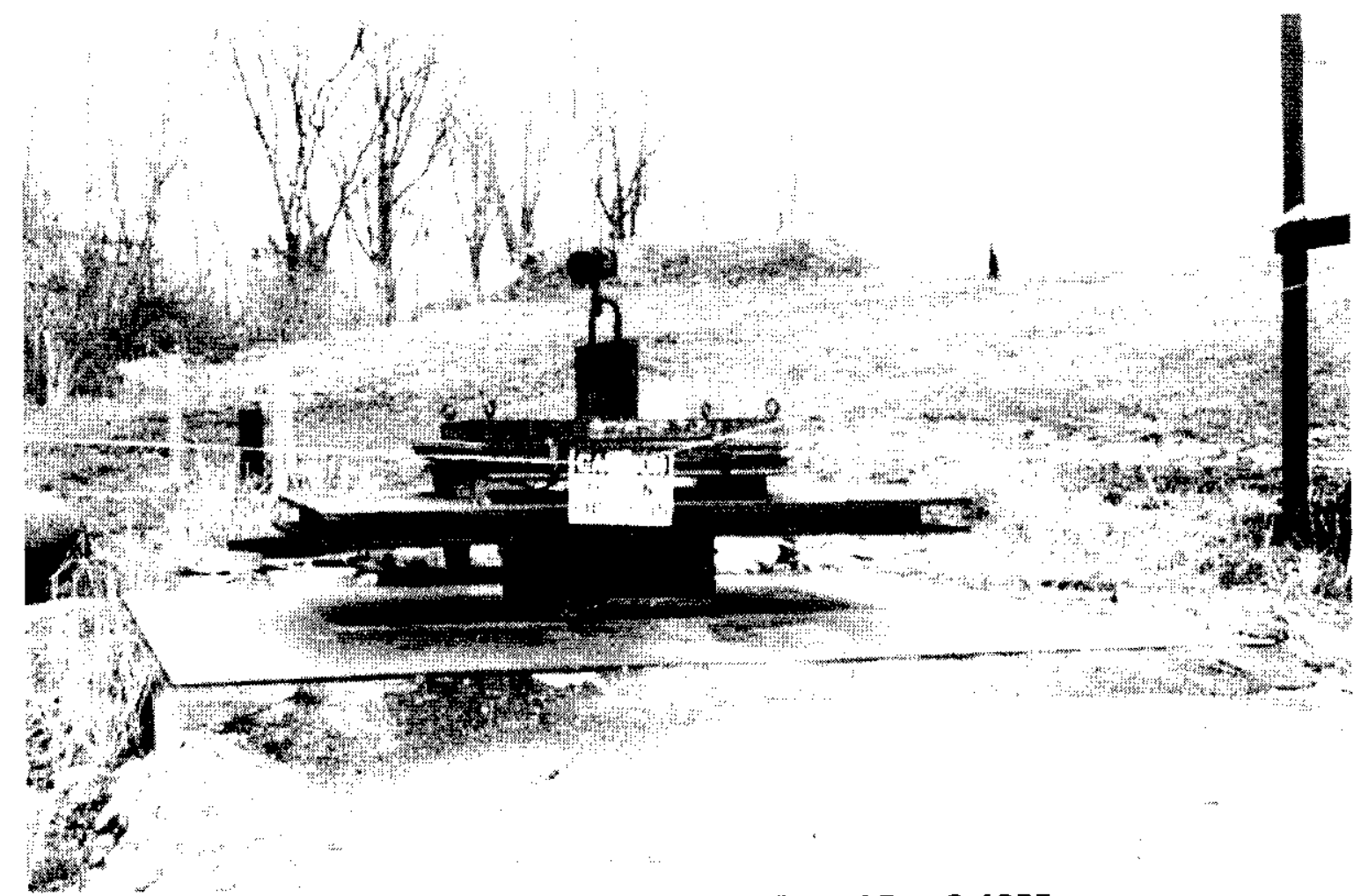

FIGURE 2.6.9-4. Compression Test of Box G-4255. 


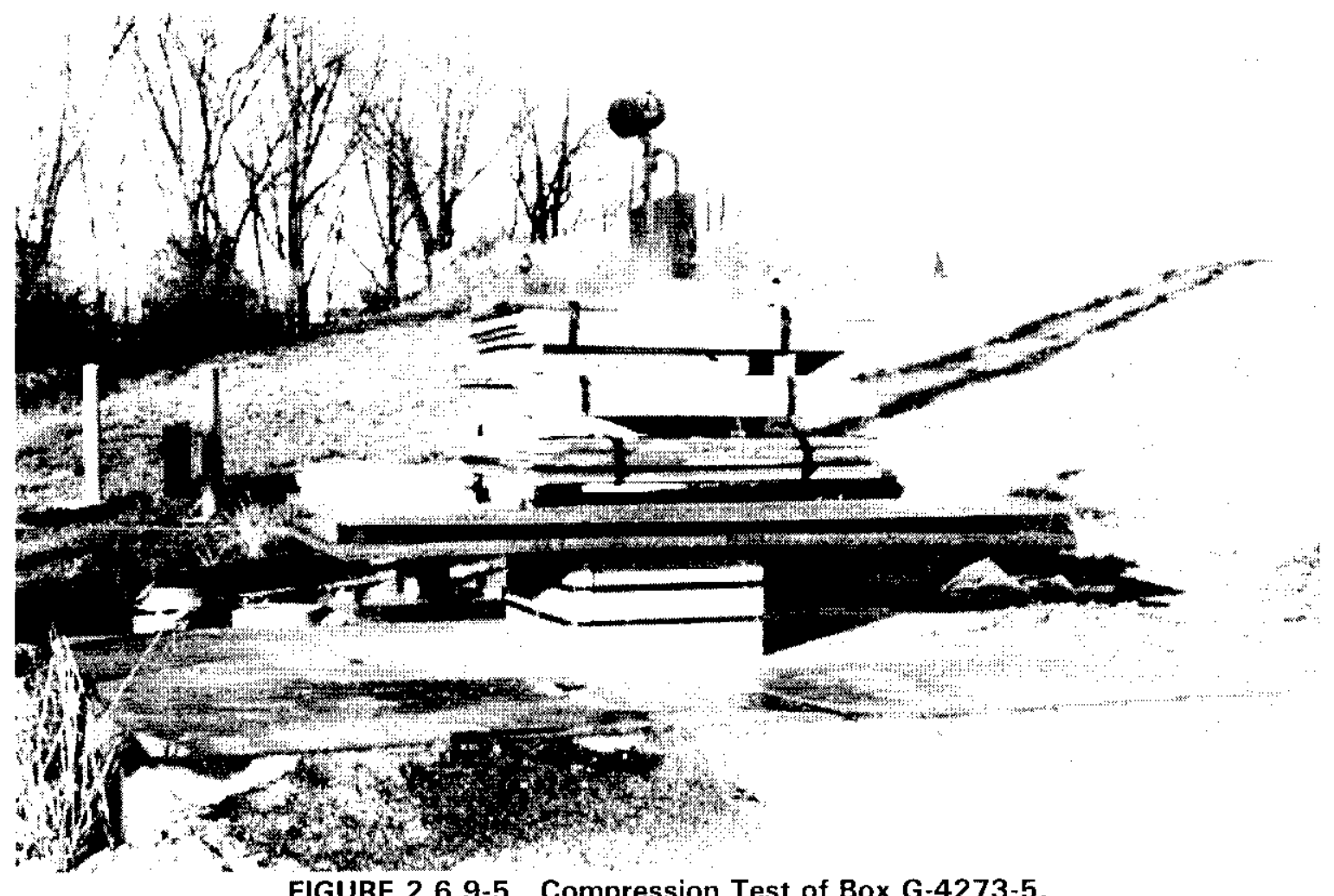

FIGURE 2.6.9-5. Compression Test of Box G-4273-5.

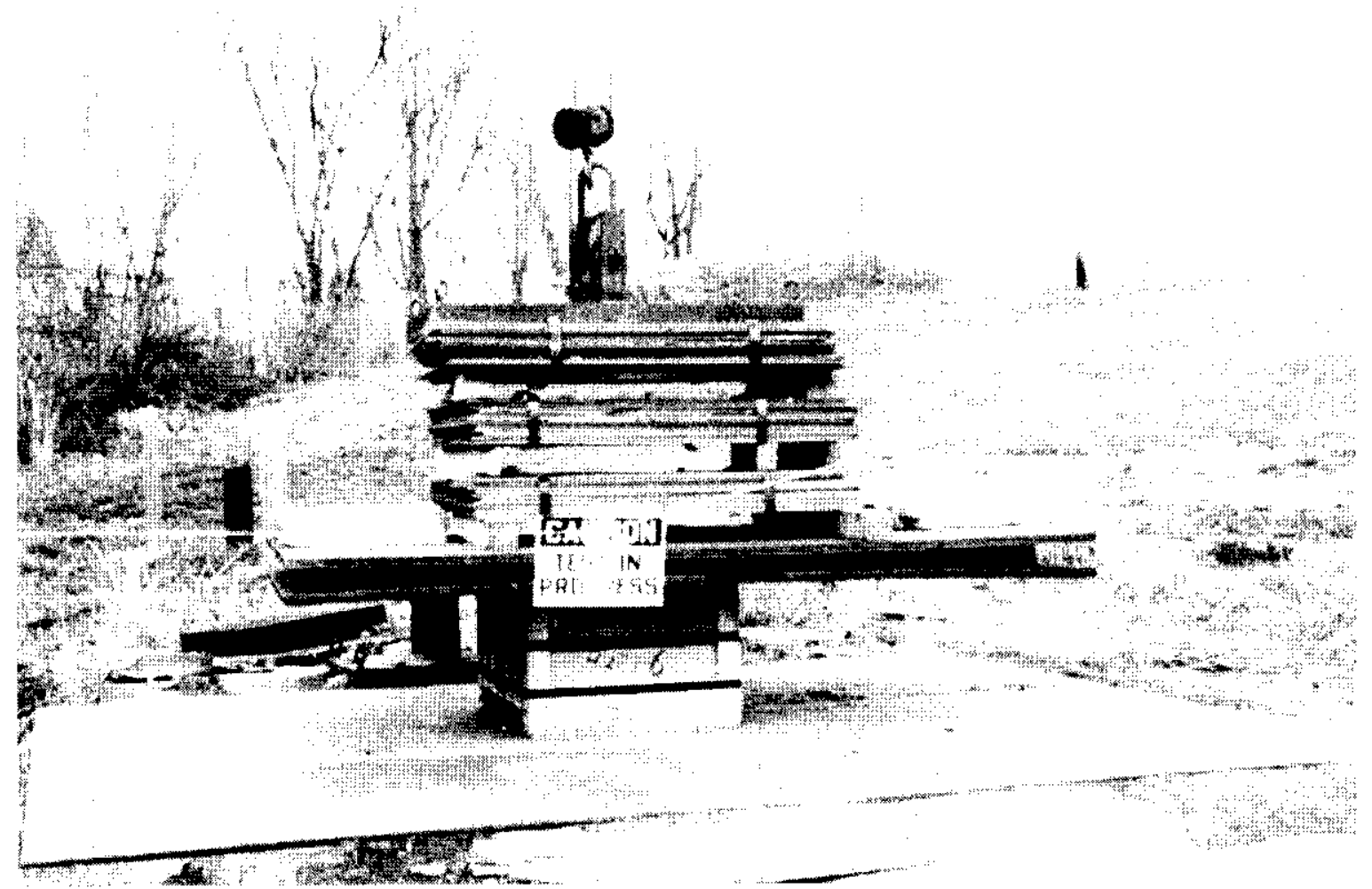

FIGURE 2.6.9-6. Compression Test of Box G-4273-6. 


\subsubsection{Penetration}

For the penetration test, the hemispherical end of a $13 \mathrm{lb}(6 \mathrm{~kg})$ steel rod with a $1 \frac{1}{4} \mathrm{in} .13 .2$ $\mathrm{cm}$ ) diameter was dropped from a height of $40 \mathrm{in.}(1 \mathrm{~m})$ onto the most vulnerable exposed surface of the wooden packages following the water test. All styles of packaging were subjected to this test and all passed (DOE 1996). The damage was limited to minor dents and in one case a crack of the top board. In no case did the impacts degrade the ability of the packaging to contain the contents.

\subsection{HYPOTHETICAL ACCIDENT CONDITIONS}

A Type AF package is required to remain subcritical when subjected to the HAC specified in 10 CFR 71.73. The wooden box packages meet the requirements of 10 CFR 71.55 (e).

The criticality evaluation in Chapter 6.0 demonstrates that subcriticality is maintained for all material described in this SARP in the most reactive credible configuration and the most reactive conditions of water moderation and reflection. The criticality evaluations neglect the presence of a package; i.e., the evaluations credit the packages with no ability to maintain the shipping configuration of the material and with no ability to prevent the incursion of water moderation. Therefore, the performance of the packages when subjected to the HAC events is not relevant.

\subsubsection{Free Drop}

The behavior of the packages when subjected to the free drop is not relevant because the criticality evaluations credit the packages with no ability to maintain the shipping configuration of the material.

\subsubsection{Puncture}

The behavior of the packages when subjected to the puncture test is not relevant because the criticality evaluations credit the packages with no ability to maintain the shipping configuration of the material.

\subsubsection{Thermal}

The behavior of the packages when subjected to the thermal test is not relevant because the criticality evaluations credit the packages with no ability to maintain the shipping configuration of the material.

The exposure of uranium metal to a fire is not considered to be of significance to criticality safety. Tests conducted in the late 1950's indicate that only a small fraction of the uranium metal would be oxidized after 30 minutes at $1481^{\circ} \mathrm{F}\left(805^{\circ} \mathrm{C}\right.$ ) (Hillard 1958). Because oxides are less reactive than uranium metal, their presence does not affect criticality safety.

\subsubsection{Immersion - Fissile Material}

The behavior of the packages when subjected to water immersion is not relevant because the criticality evaluations credit the packages with no ability to prevent the incursion of water moderation. 


\subsubsection{Immersion - All Packages}

The behavior of the packages when subjected to water immersion is not relevant because the criticality evaluations credit the packages with no ability to prevent the incursion of water moderation.

\subsubsection{Summary of Damage}

The criticality evaluations assume that the packagings are completely destroyed by the HAC events.

\subsection{SPECIAL FORM}

The package contents are not special form material.

\subsection{FUEL RODS}

The authorized package contents do not include fuel rods. 


\subsection{APPENDIX}

\subsubsection{References}

10 CFR 71, 1995, "Packaging and Transportation of Radioactive Materials," Code of Federal Regulations, as amended.

49 CFR 173, 1994, "Shippers-General Requirements for Shipments and Packagings," Code of Federal Regulations, as amended.

ASTM, 1993, Standard Guide for Selection and Use of Flat Strapping Materials, ASTM D-4675, American Society for Testing and Materials, Philadelphia, Pennsylvania.

ASTM, 1991, Specification for Strapping, Flat Steel and Seals, ASTM D-3953, American Society for Testing and Materials, Philadelphia, Pennsylvania.

DOE, 1995, Packaging and Transportation Safety, DOE Order 460.1, U.S. Department of Energy, Washington, D.C., September 27, 1995.

DOE, 1996, Test and Evaluation Document for DOT Specification 7A Type A Packaging, DOE/RL-96-57, Volume 1, Rev. O, U.S. Department of Energy, Richland Operations Office, Richland, Washington, August 1996.

Hillard, R. K., 1958, Oxidation of Uranium in Air at High Temperatures, HW-58022, General Electric Company, Hanford Atomic Products Operations, Richland, Washington. 


\subsection{THERMAL EVALUATION}

\subsection{DISCUSSION}

The steel banded wooden shipping containers have no special thermal design features. The normal conditions of transport present no significant thermal problems. This SARP assumes the HAC fire completely consumes the packaging. Decay heat loads, and associated payload temperatures, are insignificant because of the nature of the contents.

\subsection{SUMMARY OF THERMAL PROPERTIES OF MATERIALS}

Table 3.2-1 contains the thermal properties of the materials used in the wooden containers.

TABLE 3.2-1. Thermal Properties of Packaging Materials.

\begin{tabular}{|c|c|c|c|c|}
\hline Material & $\begin{array}{l}\text { Ignition } \\
\text { Temperature } \\
{ }^{\circ} \mathrm{F}\left({ }^{\circ} \mathrm{C}\right)\end{array}$ & Thermal Conductivity & $\begin{array}{l}\text { Melting Point } \\
{ }^{\circ} \mathrm{F}\left({ }^{\circ} \mathrm{C}\right)\end{array}$ & $\begin{array}{c}\text { Coefficient of Thermal } \\
\text { Expansion }\end{array}$ \\
\hline White Pine & $525(274)$ & $0.72 \mathrm{BTU}-\mathrm{in} / \mathrm{h}-\mathrm{ft}^{2} \cdot{ }^{\circ} \mathrm{F}$ & $-\cdots$ & $\cdots-$ \\
\hline Plywood & $525(274)$ & $0.68 \mathrm{BTU}$-in $/ \mathrm{h}-\mathrm{ft}^{2}{ }^{\circ} \mathrm{F}$ & $\cdots$ & ---- \\
\hline $\begin{array}{l}\text { Aluminum Foil } \\
\text { and Sheeting }\end{array}$ & ---- & $\begin{array}{l}132-212^{\circ} \mathrm{F}\left(\mathrm{O}-100^{\circ} \mathrm{C}\right) \mid \\
1509 \mathrm{BTU}-\mathrm{in} / \mathrm{h}-\mathrm{ft}^{2}-{ }^{\circ} \mathrm{F}\end{array}$ & $1188(660)$ & $\begin{array}{l}{\left[68-212^{\circ} \mathrm{F}\left(20-100^{\circ} \mathrm{C}\right)\right]} \\
13.2 \times 10^{6} /{ }^{\circ} \mathrm{F}\end{array}$ \\
\hline
\end{tabular}

\subsection{TECHNICAL SPECIFICATIONS OF COMPONENTS} evaluation.

Package components require no technical specifications which are related to the thermal

\subsection{THERMAL EVALUATION FOR NORMAL CONDITIONS OF TRANSPORT}

The NCT temperatures as defined by $10 \mathrm{CFR} 71.71$ range from $-40^{\circ} \mathrm{F}\left(-40^{\circ} \mathrm{C}\right)$ to $100^{\circ} \mathrm{F}$ $\left(38^{\circ} \mathrm{C}\right)$ in still air. The thermal properties of the components indicate that the packages are able to withstand temperatures within the NCT temperature range. The insignificance of decay heat from the metallic uranium inside a package is demonstrated in Appendix 3.6.2. Since the decay heat of the payload is negligible, the maximum surface temperature of the package in still air at $100^{\circ} \mathrm{F}$ and in the shade will be no greater than the surrounding ambient temperature of $100^{\circ} \mathrm{F}$. Therefore, the accessible surface temperature of the package will not exceed the requirements in $10 \mathrm{CFR} 71.43(\mathrm{~g})$. Package performance will not be affected by NCT thermal conditions.

\subsection{HYPOTHETICAL ACCIDENT THERMAL EVALUATION}

Packages are to be evaluated for the HAC thermal defined in 10 CFR 71.73. The wooden boxes would most probably not survive a $1475^{\circ} \mathrm{F}\left(802^{\circ} \mathrm{C}\right)$ fire lasting 30 minutes. However, the packages do not have to survive since the criticality evaluation in Chapter 6.0 shows that the package contents will remain subcritical in an optimum array (loss of packaging) when optimally moderated. Therefore, no analytical modelling of the HAC fire is necessary. 
Criticality safety is unaffected by the exposure of the metallic uranium contents to the HAC fire. Tests, mentioned previously in Section 2.7.3, conducted in the late 1950's indicate that only a small fraction of the uranium metal would be oxidized after 30 minutes at $1483^{\circ} \mathrm{F}\left(805^{\circ} \mathrm{C}\right)$. The oxides do not affect the safety of damaged packages because they are less reactive than the uranium metal. 


\subsection{APPENDICES}

\subsubsection{Reference}

10 CFR 71, 1995, "Packaging and Transportation of Radioactive Materials," Code of Federal Regulations, as amended.

\subsubsection{Decay Heat from Metallic Uranium inside a Package}

The decay heat was calculated using a maximum payload of $3,600 \mathrm{lb}\left(1.633 \times 10^{6} \mathrm{~g}\right)$ of $1.25 \mathrm{wt} \%{ }^{235} \mathrm{U} \mathrm{N}$ Reactor ingots. The resulting maximum decay heat is $0.039 \mathrm{~W}$ (see Table 3.6.2-1\}.

TABLE 3.6.2-1. Decay Heat.

\begin{tabular}{|l|c|c|c|c|c|}
\cline { 2 - 5 } \multicolumn{1}{c|}{} & $\begin{array}{c}\text { g/g of fuel } \\
1.25 \mathrm{wt} \%\end{array}$ & $\mathrm{~g}$ & $\mathrm{Ci} / \mathrm{g}$ & W/Ci & \multirow{2}{*}{} \\
\hline${ }^{234} \mathrm{U}$ & $8.000 \mathrm{E}-05$ & $1.306 \mathrm{E}+02$ & $6.25 \mathrm{E}-03$ & $2.83 \mathrm{E}-02$ & 0.023106 \\
\hline${ }^{235} \mathrm{U}$ & $1.249 \mathrm{E}-02$ & $2.040 \mathrm{E}+04$ & $2.16 \mathrm{E}-06$ & $2.71 \mathrm{E}-02$ & 0.001194 \\
\hline${ }^{236} \mathrm{U}$ & $3.300 \mathrm{E}-04$ & $5.389 \mathrm{E}+02$ & $6.47 \mathrm{E}-05$ & $2.67 \mathrm{E}-02$ & 0.000931 \\
\hline${ }^{238} \mathrm{U}$ & $9.871 \mathrm{E}-01$ & $1.612 \mathrm{E}+06$ & $3.36 \mathrm{E}-07$ & $2.49 \mathrm{E}-02$ & 0.013486 \\
\hline \multicolumn{2}{|l}{} & & & $0.038717 \mathrm{~W}$ \\
\hline
\end{tabular}




\subsection{CONTAINMENT}

\subsection{CONTAINMENT BOUNDARY}

A package's containment boundary is the wooden structure. A package is designed, constructed, and contents limited so that under NCT there will be no release of radioactive materials.

The steel banded wooden packagings are not pressure vessels. They have no penetrations except for the cracks and seams between wooden pieces. The packages are not sealed but they do have plastic covers to divert rainfall. Positive closure is provided by the steel banding.

\subsection{REOUIREMENTS FOR NORMAL CONDITIONS OF TRANSPORT}

The results of the tests mentioned in Section 2.6 demonstrate that the packages meet the requirements of $10 \mathrm{CFR} 71.43(\mathrm{f})$ for Type AF packages. No unacceptable release of radioactive materials results from NCT and the effectiveness of the packagings is not reduced by the NCT tests. The wooden boxes are not subjected to leak tests prior to shipment.

\subsection{CONTAINMENT REQUIREMENTS FOR HYPOTHETICAL ACCIDENT CONDITIONS}

As explained in Section 2.7 and Chapter 6.0, the steel banded wooden packages remain subcritical when subjected to the HAC events as defined in 10 CFR 71.73. The packagings are not expected to survive the HAC events and thus the escape of radioactive material in the form of uranium oxides could occur. The escape is acceptable because the uranium contents meet the LSA-II material requirements.

\subsection{SPECIAL REQUIREMENTS}

The special requirements of 10 CFR 71.63 do not apply because the package payloads do not include plutonium in excess of $20 \mathrm{Ci}$. 


\subsection{APPENDIX}

\subsubsection{Reference}

10 CFR 71, 1995, "Packaging and Transportation of Radioactive Materials," Code of Federal Regulations, as amended. 


\subsection{SHIELDING EVALUATION}

This shielding evaluation supports the transportation of $\mathrm{N}$ Reactor uranium metal fuel in steel banded wooden shipping containers. The $\mathrm{N}$ Reactor uranium metal products as packaged in steel banded wooden shipping containers comply with the limits for exclusive use stated in 10 CFR 71.47 and 10 CFR 71.51.

\subsection{DISCUSSION AND RESULTS}

The unirradiated fuel to be shipped in steel banded wooden shipping containers include N Reactor Mark I, Mark IV, and Mark 15 inner and outer ingots, RMI billets, and FERMCO material including derbies, ingots, and scrap. The uranium fuel is assumed to contain ${ }^{234} \mathrm{U},{ }^{235} \mathrm{U},{ }^{236} \mathrm{U}$, and ${ }^{238} \mathrm{U}$ decayed for one year. There is no cladding.

No gamma or neutron shielding was assumed from the wooden containers. Only self shielding was considered in this calculation. Dose rates were calculated for each piece at the surface, $3.28 \mathrm{ft}(1 \mathrm{~m}), 6.56 \mathrm{ft}(2 \mathrm{~m})$, and $19.69 \mathrm{ft}(6 \mathrm{~m})$ from both the end and the side using the MCNP transport code (Breismeister 1993; Carter 1995). The end $19.69 \mathrm{ft}(6 \mathrm{~m})$ receptor represents the space normally occupied by the driver. Because the exact configuration of the pieces will vary for the different shipment types, total dose rates were conservatively determined by one of two methods. The first method was to conservatively multiply the dose rates for a single piece by the maximum number of pieces in a shipment. This would give an absolute maximum dose rate for any configuration. If the results from this method exceeded the limits, the second method was used. The second method was to place the maximum number of pieces in a square array, and calculate the dose rates off the array. The total weight of each type of material was initially limited to $42,000 \mathrm{lb}(19,051 \mathrm{~kg})$.

Since no shielding from the shipping container is accounted for, the NCT and HAC shielding analyses will be the same. The only exception is for the HAC which assume a contribution from the beta source. Because the wooden container will stop the beta particles, the beta dose was not calculated for NCT. A summary of the maximum dose rates for all material types being shipped is provided in Table 5.1. All of the dose rates are below the dose rate limits. The maximum dose rate for NCT is $1,700 \mu \mathrm{Sv} / \mathrm{h}$ at the end surface of an array of Mark 15 ingots.

The original shielding evaluation was done with slightly different uranium isotopic compositions than those listed in Table 5.2. Table 5.2.1-1 contains the photon energy spectra from ORIGEN2 for one gram of fuel with the revised uranium isotopic compositions from Table 5.2. The photon emission rates for the revised source term are greater than those for the original uranium composition. The revised photon emission rates exceed the original values by amounts which vary from a maximum of $28 \%$ for the lowest energy group (1.5E-02 MeV), down to $1 \%$ for the 2.25 $\mathrm{MeV}$ energy group. The photon emission rates for energies above $2.25 \mathrm{MeV}$ remain unchanged. This results in the following maximum increase in the gamma dose rates for the different payloads: $5.5 \%$ for the Mark I and IV Ingots, $14.2 \%$ for the RMI Mark I and IV Billets, $19.7 \%$ for the Mark 15 Ingots, and $34.5 \%$ for the FERMCO Scrap [this increase occurs for $12 \mathrm{in.}(30.48 \mathrm{~cm})$ Ingot Sectionsl.

The total neutron source terms increase by about $5 \%$ for each of the three compositions. This results in the following maximum increases in the neutron dose rates for the different payloads: $1.1 \%$ for the Mark I and IV Ingots, 3.9\% for the RMI Mark I and IV Billets, $2.5 \%$ for the Mark 15 Ingots, and $13.6 \%$ for the FERMCO Scrap [this increase occurs for $12 \mathrm{in.}(30.48 \mathrm{~cm})$ Derbies]. Note that several FERMCO Scrap array cases were rerun with corrected detector locations along with the change in neutron source terms. This results in some payloads having larger differences 
between the original and revised dose rates than would be expected from the change in photon/neutron emission rates alone.

The maximum increases in the total dose rates (i.e., gamma plus neutron) for each payload are as follows: $4.4 \%$ for the Mark I and IV Ingots, 13.5\% for the RMI Mark I and IV Billets, $15.9 \%$ for the Mark 15 Ingots, and 28.7\% for the FERMCO Scrap [this increase occurs for 12 in. $(30.48 \mathrm{~cm})$ Ingot Sections]. The revised dose rates are still well within the transportation dose rate limits and the increases do not impact the total allowable weight of each type of material which remains at $42,000 \mathrm{lb}(19,051 \mathrm{~kg}\}$.

\subsubsection{N Reactor Mark I and IV Ingots}

Table 5.1.1 summarizes the dose rates for the N Reactor Mark I and Mark IV inner and outer ingots. The ingots were modeled as annular cylinders. A complete listing of the dose rates including the neutron and gamma ray contributions is provided in Appendix 5.5.2. The dose rates were multiplied by 26 , the maximum number of ingots in a shipment, to determine the maximum dose rates for a shipment.

\subsubsection{RMI Forged Billets}

Table 5.1.2 summarizes the dose rates for an array of Mark I and Mark IV RMI forged billets. The billets were modeled as annular cylinders. A complete listing of the dose rates including the neutron and gamma ray contributions is provided in Appendix 5.5.2. Note that the worst case loading for the shielding evaluation, which consisted of 96, 21-in. RMI Mark I outer billets, bounds the loading of 15 Hanford RMI Mark I outer billets, which is the maximum allowable loading from the criticality evaluation in Section 6.4-3.

TABLE 5.1. Maximum Dose Rate $(\mu \mathrm{Sv} / \mathrm{h})$ for All Material Types.

\begin{tabular}{|c|c|c|c|c|c|}
\hline \multirow{2}{*}{$\begin{array}{l}\text { Dose Rate } \\
\text { Location }\end{array}$} & \multirow[t]{2}{*}{ Package } & \multicolumn{3}{|c|}{ Dose Rates $(\mu \mathrm{Sv} / \mathrm{h})$} & \multirow{2}{*}{$\begin{array}{c}\text { Regulatory } \\
\text { Limits } \\
(\mu \mathrm{Sv} / \mathrm{h})\end{array}$} \\
\hline & & Neutron & Gamma & Total & \\
\hline \multicolumn{6}{|c|}{ Normal Conditions of Transport (NCT) } \\
\hline $\begin{array}{l}\text { Maximum Package Surface } \\
\text { Dose Rate }\end{array}$ & 64 Mark 15 Inner Ingots & 90 & 1,600 & 1,700 & 10,000 \\
\hline $\begin{array}{l}\text { Maximum Trailer Surface } \\
\text { Dose Rate }{ }^{1}\end{array}$ & -- & & & & 2,000 \\
\hline $\begin{array}{l}\text { Maximum Dose Rate at } \\
6.56 \mathrm{ft}(2 \mathrm{~m}) \text { from the } \\
\text { Package }\end{array}$ & $\begin{array}{l}\text { FERMCO } 13 \mathrm{in} .(33.02 \mathrm{~cm}) \text { OD } \times \\
6 \mathrm{in.}(15.24 \mathrm{~cm}) \text { long } S \mathrm{crap}\end{array}$ & 1.8 & 21 & 23 & 100 \\
\hline $\begin{array}{l}\text { Maximum Driver Dose Rate } \\
\text { (19.69 ft }[6 \mathrm{~m}])\end{array}$ & $\begin{array}{l}\text { FERMCO } 13 \mathrm{in} .(33.02 \mathrm{~cm}) \text { OD } \times \\
6 \mathrm{in.}(15.24 \mathrm{~cm}) \text { long Scrap }\end{array}$ & 0.4 & 4.8 & 5.3 & 20 \\
\hline \multicolumn{6}{|c|}{ Hypothetical Accident Conditions ( $\mathrm{HAC})$} \\
\hline $\begin{array}{l}\text { Maximum Accident Dose } \\
\text { Rate }(3.28 \mathrm{ft}[1 \mathrm{~m}]\}\end{array}$ & 64 Mark 15 Inner Ingots & 2.8 & 42 & $140^{2}$ & 10,000 \\
\hline
\end{tabular}

1 - For all payloads, the maximum trailer surface dose rate was not calculated because the total calculated dose rate at the surface of the packages is less than the regulatory dose limit for the trailer surface. 2 - Includes maximum beta effective dose equivalent of $93 \mu \mathrm{Sv} / \mathrm{h}$ and subsequent rounding to two significant figures. 
TABLE 5.1.1. Mark I and Mark IV Ingot Total Dose Rate Summary.

\begin{tabular}{|l|c|c|c|c|}
\hline \multirow{2}{*}{ Type } & \multirow{2}{*}{$\begin{array}{c}\text { Number of } \\
\text { Ingots }\end{array}$} & \multicolumn{3}{|c|}{ Maximum Dose Rates $(\mu \mathrm{Sv} / \mathrm{h})$} \\
\cline { 3 - 5 } & & Surface & $2 \mathrm{~m}$ & Driver $(6 \mathrm{~m})$ \\
\hline \hline Mark I Outer & 26 & 920 & 6.8 & 0.8 \\
\hline Mark I Inner & 26 & 840 & 8.3 & 1.0 \\
\hline Mark IV Outer & 26 & 910 & 6.8 & 0.8 \\
\hline Mark IV Inner & 26 & 830 & 8.5 & 1.0 \\
\hline
\end{tabular}

* Surface dose rate was calculated $2 \mathrm{in.}\langle 5.08 \mathrm{~cm}\rangle$ from the surface, which is representative of a typical surface measurement.

TABLE 5.1.2. RMI Billet Total Dose Rate Summary.

\begin{tabular}{|l|c|c|c|c|}
\hline \multirow{2}{*}{ Type } & \multirow{2}{*}{$\begin{array}{c}\text { Number of } \\
\text { Billets }\end{array}$} & \multicolumn{3}{|c|}{ Maximum Dose Rates $(\mu \mathrm{Sv} / \mathrm{h})$} \\
\cline { 3 - 5 } & & Surface & $2 \mathrm{~m}$ & Driver $(6 \mathrm{~m})$ \\
\hline \hline Mark I Outer & 96 & 58 & 12 & 2.0 \\
\hline Mark I Inner & 135 & 51 & 13 & 2.2 \\
\hline Mark IV Outer & 96 & 58 & 13 & 2.0 \\
\hline Mark IV Inner & 135 & 51 & 13 & 2.2 \\
\hline
\end{tabular}

* Surface dose rate was calculated 2 in. $(5.08 \mathrm{~cm})$ from the surface, which is representative of a typical surface measurements

\subsubsection{Mark 15 Ingots}

Table 5.1.3 summarizes the surface dose rates for Mark 15 inner and outer ingots. The ingots were modeled as annular cylinders. A complete listing of the dose rates including the neutron and gamma ray contributions is provided in Appendix 5.5.2. The dose rates were multiplied by the maximum number of ingots in a shipment ( 32 or 64), to determine the maximum dose rate for a shipment.

TABLE 5.1.3. Mark 15 Ingot Total Dose Rate Summary.

\begin{tabular}{|c|c|c|c|c|}
\hline \multirow{2}{*}{ Type } & \multirow{2}{*}{$\begin{array}{c}\text { Number of } \\
\text { Ingots }\end{array}$} & \multicolumn{3}{|c|}{ Maximum Dose Rates $(\mu \mathrm{Sv} / \mathrm{h})$} \\
\cline { 3 - 5 } & & Surface $^{*}$ & $2 \mathrm{~m}$ & Driver (6 m) \\
\hline \hline Mark 15 Outer & 32 & 1,100 & 10 & 1.2 \\
\hline Mark 15 Inner & 64 & 1,700 & 12 & 1.4 \\
\hline
\end{tabular}

* Surface dose rate was calculated 2 in. $\{5.08 \mathrm{~cm}\}$ from the surface, which is representative of a typical surface measurement. 


\subsubsection{FERMCO Scrap}

Table 5.1 .4 summarizes the dose rates for $1.25 \%{ }^{235} \mathrm{U}$ FERMCO derbies, ingots, ingot sections, and scrap. The scrap were modeled as cylinders, except for the FERMCO Product ingots which were modeled as annular cylinders. A complete listing of the dose rates including the neutron and gamma ray contributions is provided in Appendix 5.5.2. Dose rates were conservatively calculated by multiplying the dose rate for each type of scrap by the maximum number of pieces of scrap in a shipment. For several cases (FERMCO derbies, FERMCO ingot sections, FERMCO scrap), this approximation was too conservative, for these cases the dose rate was calculated for an array of scrap pieces.

The FERMCO product ingots are virtually identical in all respects to the Mark I Outer $N$ Reactor ingots. The Mark I outer $N$ Reactor ingot dose rates from Table 5.1 .1 are reproduced in Table 5.1.4 for the FERMCO product ingots. Also the $13 \mathrm{in.}(33.02 \mathrm{~cm})$ FERMCO scrap dose rate is covered by the $13 \mathrm{in.}(33.02 \mathrm{~cm})$ FERMCO ingot section dose rate, so the values for these two cases are the same.

TABLE 5.1.4. FERMCO Scrap Dose Rate Summaries.

\begin{tabular}{|c|c|c|c|c|}
\hline \multirow[t]{2}{*}{ Type } & \multirow{2}{*}{$\begin{array}{l}\text { Number } \\
\text { of Pieces }\end{array}$} & \multicolumn{3}{|c|}{ Maximum Dose Rates $(\mu \mathrm{Sv} / \mathrm{h})$} \\
\hline & & Surface ${ }^{*}$ & $2 \mathrm{~m}$ & Driver $\{6 \mathrm{~m}\rangle$ \\
\hline $\begin{array}{l}\text { FERMCO Derbies (array) } 12 \text { in. }(30.48 \mathrm{~cm}) \text { OD } \times 5 \text { in. }\{12.7 \\
\mathrm{cm} \text { long }\end{array}$ & 132 & 51 & 13 & 2.2 \\
\hline \multicolumn{5}{|c|}{ FERMCO Primary Ingots } \\
\hline $12 \mathrm{in.}(30.48 \mathrm{~cm}) \mathrm{OD} \times 17 \mathrm{in} .(43.18 \mathrm{~cm})$ long & 22 & 740 & 8.2 & 0.98 \\
\hline $13 \mathrm{in.}(33.02 \mathrm{~cm})$ OD $\times 30 \mathrm{in} .(76.20 \mathrm{~cm})$ long & 14 & 470 & 6.5 & 0.79 \\
\hline $9 \mathrm{in.}(22.86 \mathrm{~cm})$ OD $\times 30 \mathrm{in.}(76.20 \mathrm{~cm})$ long & 30 & 890 & 9.9 & 1.2 \\
\hline \multicolumn{5}{|c|}{ FERMCO Product Ingots } \\
\hline $\begin{array}{l}13.07 \mathrm{in.}(33.20 \mathrm{~cm}) \mathrm{OD}, 2.885 \mathrm{in} .(7.33 \mathrm{~cm}) \mathrm{tD} \times 17 \mathrm{in} . \\
(43.18 \mathrm{~cm}) \text { length }\end{array}$ & 26 & 920 & 6.8 & 0.8 \\
\hline \multicolumn{5}{|c|}{ FERMCO Ingot Sections } \\
\hline $\begin{array}{l}13 \mathrm{in.}(33.02 \mathrm{~cm}) \text { OD } \times 3 \text { in. }(7.62 \mathrm{~cm}) \text { o } 26 \mathrm{in} .(15.24 \mathrm{~cm}) \\
\text { long (array) }\end{array}$ & 294 & 60 & 23 & 5.3 \\
\hline $10 \mathrm{in.}(25.40 \mathrm{~cm})$ OD $\times 6$ in. $(15.24 \mathrm{~cm})$ long (arrav) & 117 & 54 & 9.6 & 1.4 \\
\hline \multicolumn{5}{|c|}{ FERMCO Scrap } \\
\hline 13 in. $(33.02 \mathrm{~cm})$ OD $\times 4$ in. $(10.16 \mathrm{~cm})$ long \{array\} & 294 & 60 & 23 & 5.3 \\
\hline 11 in. $(27.94 \mathrm{~cm})$ OD $\times 4$ in. $(10.16 \mathrm{~cm})$ long (array) & 154 & 53 & 13 & 2.1 \\
\hline
\end{tabular}

* Surface dose rate was calculated $2 \mathrm{in.}(5.08 \mathrm{~cm})$ from the surface, which is representative of a typical surface measurement.

\subsection{SOURCE SPECIFICATION}

The source terms used in these calculations consist of unirradiated $\mathrm{N}$ Reactor fuel with one of three different uranium enrichments. Table 5.2 shows the isotopic composition for each fuel 
enrichment, as derived from OR/GEN2 Predictions of $N$ Reactor Fuel Actinide Composition (Goldberg and Hedengren 1987). The $1.1 \%$ enriched uranium was not listed in this document, but the isotopic composition was determined using a range of values commonly found in $1.1 \%$ fuel. The isotopic composition per gram of fuel was entered into ORIGEN2 (Goldberg and Hedengren 1987) to produce a gamma ray source and neutron source. The resulting source strengths were multiplied by the number of grams in each piece to determine the total source strength for that piece.

TABLE 5.2. Isotopic Composition of the Uranium.

\begin{tabular}{|c|c|c|c|}
\hline \multirow{2}{*}{ Isotope } & \multicolumn{3}{|c|}{ Isotopic Content (g/g of payload) } \\
\cline { 2 - 4 } & $0.95 \mathrm{Wt} \%{ }^{235} \mathrm{U}$ & $1.1 \mathrm{Wt} \%{ }^{235} \mathrm{U}$ & $1.25 \mathrm{Wt} \%{ }^{235} \mathrm{U}$ \\
\hline \hline${ }^{234} \mathrm{U}$ & $1.33 \mathrm{E}-04$ & $1.33 \mathrm{E}-04$ & $1.34 \mathrm{E}-04$ \\
\hline${ }^{235} \mathrm{U}$ & $9.56 \mathrm{E}-03$ & $1.106 \mathrm{E}-02$ & $1.256 \mathrm{E}-02$ \\
\hline${ }^{236} \mathrm{U}$ & $1.00 \mathrm{E}-03$ & $1.00 \mathrm{E}-03$ & $1.00 \mathrm{E}-03$ \\
\hline${ }^{238} \mathrm{U}$ & $9.91 \mathrm{E}-01$ & $9.89 \mathrm{E}-01$ & $9.88 \mathrm{E}-01$ \\
\hline${ }^{241} \mathrm{Pu}$ & $4.14 \mathrm{E}-11$ & $4.14 \mathrm{E}-11$ & $4.14 \mathrm{E}-11$ \\
\hline${ }^{99} \mathrm{Tc}$ & $2.58 \mathrm{E}-05$ & $2.58 \mathrm{E}-05$ & $2.58 \mathrm{E}-05$ \\
\hline${ }^{90} \mathrm{Sr}$ & $1.56 \mathrm{E}-10$ & $1.56 \mathrm{E}-10$ & $1.56 \mathrm{E}-10$ \\
\hline
\end{tabular}

\subsubsection{Gamma Source}

The ORIGEN2 computer code was used to calculate the gamma ray source based on the uranium compositions found in Table 5.2. The input files for the three different enrichments are listed in Sections 5.5.3, 5.5.4, and 5.5.5. Cases were run for the fuel decayed at different intervals to determine the maximum shielding source term. At one year, the total MeV per second and photon strength reach their peak. Energy bins were also inspected and a few bins did increase with time after one year. However, these bins strengths are orders of magnitude less than other surrounding bins and because the total photon per second and $\mathrm{MeV}$ per second decreased over time after one year, the one year source term was determined to represent the worst case. Therefore, a decay time of one year was used to represent the worst case gamma ray source term.

Table 5.2.1-1 lists the resulting gamma ray spectrum and the total photon strength per gram calculated by ORIGEN2 for each enrichment.

The mass of each piece was calculated from its geometrical volume and the theoretical density of uranium $(18.96 \mathrm{~g} / \mathrm{cc})$. The total photon strength per gram was multiplied by the calculated mass to obtain the total photon strength (see Table 5.2.1-2), which was then used in the MCNP calculation.

The flux to dose rate conversion factors used in MCNP for the photon dose calculations are listed in Table 5.2.1-3. These conversion factors are the American National Standards Institute/American Nuclear Society (ANSI/ANS)-6.1.1-1991 conversion factors and conservatively assume the radiation exposure is from an anterior-posterior exposure. The 1991 values were used since they represent a whole body rather than extremity dose rate and is more representative for this application. 
TABLE 5.2.1-1. Photon Energy Spectrum for One Gram of Fuel.

\begin{tabular}{|c|c|c|c|}
\cline { 2 - 4 } \multicolumn{1}{c|}{} & $0.95 \%{ }^{235} \mathrm{U}$ & $1.1 \%{ }^{235} \mathrm{U}$ & $1.25 \%{ }^{235} \mathrm{U}$ \\
\hline \hline Energy $(\mathrm{MeV})$ & photons/sec & photons/sec & photons/sec \\
\hline $1.00 \mathrm{E}-\mathrm{O} 2$ & $1.55 \mathrm{E}+04$ & $1.54 \mathrm{E}+\mathrm{O} 4$ & $1.55 \mathrm{E}+\mathrm{O4}$ \\
\hline $2.50 \mathrm{E}-\mathrm{O} 2$ & $1.72 \mathrm{E}+03$ & $1.70 \mathrm{E}+03$ & $1.72 \mathrm{E}+03$ \\
\hline $3.75 \mathrm{E}-02$ & $1.02 \mathrm{E}+03$ & $1.02 \mathrm{E}+\mathrm{O} 3$ & $1.02 \mathrm{E}+03$ \\
\hline $5.75 \mathrm{E}-02$ & $2.02 \mathrm{E}+03$ & $2.03 \mathrm{E}+03$ & $2.02 \mathrm{E}+03$ \\
\hline $8.50 \mathrm{E}-02$ & $1.84 \mathrm{E}+03$ & $1.82 \mathrm{E}+03$ & $1.84 \mathrm{E}+03$ \\
\hline $1.25 \mathrm{E}-01$ & $7.76 \mathrm{E}+02$ & $7.58 \mathrm{E}+02$ & $7.76 \mathrm{E}+02$ \\
\hline $2.25 \mathrm{E}-01$ & $1.32 \mathrm{E}+03$ & $1.26 \mathrm{E}+03$ & $1.32 \mathrm{E}+03$ \\
\hline $3.75 \mathrm{E}-01$ & $3.39 \mathrm{E}+02$ & $3.39 \mathrm{E}+02$ & $3.39 \mathrm{E}+02$ \\
\hline $5.75 \mathrm{E}-01$ & $1.82 \mathrm{E}+02$ & $1.82 \mathrm{E}+02$ & $1.82 \mathrm{E}+02$ \\
\hline $8.50 \mathrm{E}-01$ & $1.14 \mathrm{E}+02$ & $1.14 \mathrm{E}+02$ & $1.14 \mathrm{E}+02$ \\
\hline $1.25 \mathrm{E}+00$ & $7.92 \mathrm{E}+01$ & $7.93 \mathrm{E}+01$ & $7.92 \mathrm{E}+01$ \\
\hline $1.75 \mathrm{E}+00$ & $1.21 \mathrm{E}+01$ & $1.21 \mathrm{E}+01$ & $1.21 \mathrm{E}+01$ \\
\hline $2.25 \mathrm{E}+00$ & $3.50 \mathrm{E}-03$ & $3.50 \mathrm{E}-03$ & $3.50 \mathrm{E}-03$ \\
\hline $2.75 \mathrm{E}+00$ & $1.99 \mathrm{E}-03$ & $1.99 \mathrm{E}-03$ & $1.99 \mathrm{E}-03$ \\
\hline $3.50 \mathrm{E}+00$ & $1.78 \mathrm{E}-03$ & $1.78 \mathrm{E}-03$ & $1.78 \mathrm{E}-03$ \\
\hline $5.00 \mathrm{E}+00$ & $7.63 \mathrm{E}-04$ & $7.64 \mathrm{E}-04$ & $7.63 \mathrm{E}-04$ \\
\hline $7.00 \mathrm{E}+00$ & $8.78 \mathrm{E}-05$ & $8.79 \mathrm{E}-05$ & $8.78 \mathrm{E}-05$ \\
\hline $9.50 \mathrm{E}+00$ & $1.01 \mathrm{E}-05$ & $1.01 \mathrm{E}-05$ & $1.01 \mathrm{E}-05$ \\
\hline \hline TOTAL & $2.49 \mathrm{E}+04$ & $2.47 \mathrm{E}+04$ & $2.49 \mathrm{E}+04$ \\
\hline
\end{tabular}


TABLE 5.2.1-2. Gamma Strength for Each Payload Piece.

\begin{tabular}{|c|c|c|c|c|}
\hline & \multirow{2}{*}{$\frac{\text { Enrichment }}{\%{ }^{235} \mathrm{U}}$} & \multirow{2}{*}{ Mass } & \multicolumn{2}{|c|}{ Photons } \\
\hline & & & photon/s/g & total photon $/ \mathrm{s}$ \\
\hline \multicolumn{5}{|c|}{ N Reactor Ingot } \\
\hline Mark I Outer & 1.25 & 672,000 & $2.49 E+04$ & $1.67 E+10$ \\
\hline Mark I Inner & 0.95 & 700,000 & $2.49 E+04$ & $1.74 \mathrm{E}+10$ \\
\hline Mark IV Inner & 0.95 & 722,000 & $2.49 E+04$ & $1.8 E+10$ \\
\hline Mark IV Outer & 0.95 & 679,000 & $2.49 E+04$ & $1.69 E+10$ \\
\hline \multicolumn{5}{|c|}{ RMI Forged Billet } \\
\hline Mark I Outer & 1.25 & 209,000 & $2.49 E+04$ & $5.21 E+09$ \\
\hline Mark I Inner & 0.95 & 139,000 & $2.49 E+04$ & $3.46 E+09$ \\
\hline Mark IV Inner & 0.95 & 145,000 & $2.49 E+04$ & $3.61 E+09$ \\
\hline Mark IV Outer & 0.95 & 217,000 & $2.49 E+04$ & $5.41 E+09$ \\
\hline \multicolumn{5}{|c|}{ Mark 15 Ingot } \\
\hline Mark 15 Inner & 1.1 & 277,000 & $2.47 E+04$ & $6.85 E+09$ \\
\hline Mark 15 Outer & 1.1 & 501,000 & $2.47 E+04$ & $1.24 E+10$ \\
\hline \multicolumn{5}{|c|}{ FERMCO Derbies } \\
\hline Derbies & 1.25 & 176,000 & $2.49 E+04$ & $4.39 E+09$ \\
\hline \multicolumn{5}{|c|}{ FERMCO Primary Ingots } \\
\hline $\begin{array}{l}12 \mathrm{in.}(30.48 \mathrm{~cm}) \text { OD } \times 17 \mathrm{in.}(43.18 \mathrm{~cm})- \\
26 \mathrm{in.}(66.04 \mathrm{~cm}) \text { long }\end{array}$ & 1.25 & 914,000 & $2.49 E+04$ & $2.28 E+10$ \\
\hline $\begin{array}{l}13 \mathrm{in.}(33.02 \mathrm{~cm}) \mathrm{OD} \times 30 \mathrm{in.}(76.20 \mathrm{~cm}) \\
\text { long }\end{array}$ & 1.25 & $1,237,000$ & $2.49 E+04$ & $3.08 E+10$ \\
\hline $9 \mathrm{in.}(22.86 \mathrm{~cm}) \mathrm{OD} \times 30 \mathrm{in} .(76.20 \mathrm{~cm})$ long & 1.25 & 593,000 & $2.49 E+04$ & $1.48 E+10$ \\
\hline \multicolumn{5}{|c|}{ FERMCO Ingot Sections } \\
\hline $\begin{array}{l}13 \mathrm{in} .(33.02 \mathrm{~cm}) \text { OD } \times 3 \text { in. }(7.62 \mathrm{~cm}) \text { or } \\
6 \text { in. }(15.24 \mathrm{~cm}) \text { long }\end{array}$ & 1.25 & 247,000 & $2.49 E+04$ & $6.16 \mathrm{E}+09$ \\
\hline $10 \mathrm{in} .(25.40 \mathrm{~cm})$ OD $\times 6$ in. $(15.24 \mathrm{~cm})$ long & 1.25 & 146,000 & $2.49 \mathrm{E}+04$ & $3.64 E+09$ \\
\hline \multicolumn{5}{|c|}{ FERMCO Scrap } \\
\hline $\begin{array}{l}13 \mathrm{in} .(33.02 \mathrm{~cm}) \mathrm{OD} \times 1.5 \mathrm{in} .(3.81 \mathrm{~cm}) \text { or } \\
4 \mathrm{in.}(10.16 \mathrm{~cm}) \text { long }\end{array}$ & 1.25 & 61,900 & $2.49 E+04$ & $1.54 E+09$ \\
\hline $11 \mathrm{in.}(27.94 \mathrm{~cm})$ OD $\times 4$ in. $(10.16 \mathrm{~cm}\}$ long & 1.25 & 118,000 & $2.49 E+04$ & $2.94 E+09$ \\
\hline
\end{tabular}


TABLE 5.2.1-3. Photon Dose Rate Conversion Factors.

\begin{tabular}{|c|c||c|c|}
\hline Energy (MeV) & $\begin{array}{c}\text { Flux to Dose Rate } \\
(\mathrm{mrem} / \mathrm{h}) /\left(\mathrm{p} / \mathrm{cm}^{2} / \mathrm{s}\right)^{*}\end{array}$ & Energy $(\mathrm{MeV})$ & $\begin{array}{c}\text { Flux to Dose Rate } \\
(\mathrm{mrem} / \mathrm{h}) /\left(\mathrm{p} / \mathrm{cm}^{2} / \mathrm{s}\right)\end{array}$ \\
\hline \hline 0.01 & $2.232 \mathrm{E}-05$ & 0.50 & $9.144 \mathrm{E}-04$ \\
\hline 0.015 & $5.652 \mathrm{E}-05$ & 0.60 & $1.076 \mathrm{E}-03$ \\
\hline 0.02 & $8.568 \mathrm{E}-05$ & 0.80 & $1.379 \mathrm{E}-03$ \\
\hline 0.03 & $1.184 \mathrm{E}-04$ & 1.0 & $1.656 \mathrm{E}-03$ \\
\hline 0.04 & $1.314 \mathrm{E}-04$ & 1.5 & $2.246 \mathrm{E}-03$ \\
\hline 0.05 & $1.382 \mathrm{E}-04$ & 2.0 & $2.758 \mathrm{E}-03$ \\
\hline 0.06 & $1.440 \mathrm{E}-04$ & 3.0 & $3.672 \mathrm{E}-03$ \\
\hline 0.08 & $1.624 \mathrm{E}-04$ & 4.0 & $4.500 \mathrm{E}-03$ \\
\hline 0.10 & $1.919 \mathrm{E}-04$ & 5.0 & $5.292 \mathrm{E}-03$ \\
\hline 0.15 & $2.797 \mathrm{E}-04$ & 6.0 & $6.012 \mathrm{E}-03$ \\
\hline 0.20 & $3.708 \mathrm{E}-04$ & 8.0 & $7.488 \mathrm{E}-03$ \\
\hline 0.30 & $5.616 \mathrm{E}-04$ & 10. & $8.892 \mathrm{E}-03$ \\
\hline 0.40 & $7.416 \mathrm{E}-04$ & 12 & $1.040 \mathrm{E}-02$ \\
\hline
\end{tabular}

* - ANSI/ANS-6.1.1-1991

\subsubsection{Neutron Source}

The ORIGEN2 computer code was used to calculate the neutron source based on the uranium compositions found in Table 5.2. $(a, n)$ reactions in metal (non-oxide) uranium fuel are negligible. The spontaneous fission source was calculated to be approximately $1.3 \times 10^{-2}$ neutrons/s/g. Criticality evaluations (Chapter 6.0) show that $k_{\infty}$ for a dry infinite array of ingots or billets is approximately 0.5 . For this shielding analysis $k_{\text {et1 }}$ is assumed to be 0.5 for a shipment. This means the number of induced fissions will equal the number of spontaneous fissions.

Therefore the total number of neutrons per second from ORIGEN2 was doubled for each calculation.

The neutron source results from the ORIGEN2 calculation (see Sections 5.5.3,5.5.4, and 5.5.5) and the calculated total neutrons/s are shown in Table 5.2.2-1. 
TABLE 5.2.2-1. Neutron Strength for Each Payload Piece.

\begin{tabular}{|c|c|c|c|c|}
\hline & \multirow{2}{*}{$\frac{\text { Enrichment }}{\%{ }^{235} \mathrm{U}}$} & \multirow{2}{*}{$\frac{\text { Mass }}{\mathrm{g}}$} & \multicolumn{2}{|c|}{ Spontaneous Fission } \\
\hline & & & $\begin{array}{l}\text { neutron/s/g } \\
\text { (ORIGEN2) }\end{array}$ & $\begin{array}{l}2 \times \text { total } \\
\text { neutron } / \mathrm{s}\end{array}$ \\
\hline \multicolumn{5}{|c|}{ N Reactor Ingot } \\
\hline Mark I Outer & 1.25 & 672,000 & $1.255 \mathrm{E}-02$ & $1.69 E+04$ \\
\hline Mark I Inner & 0.95 & 700,000 & $1.258 \mathrm{E}-02$ & $1.76 E+04$ \\
\hline Mark IV Inner & 0.95 & 722,000 & $1.258 \mathrm{E}-02$ & $1.82 E+04$ \\
\hline Mark IV Outer & 0.95 & 679,000 & $1.258 \mathrm{E}-02$ & $1.71 E+04$ \\
\hline \multicolumn{5}{|c|}{ RMI Forged Billet } \\
\hline Mark I Outer & 1.25 & 209,000 & $1.255 \mathrm{E}-02$ & $5.25 E+03$ \\
\hline Mark I Inner & 0.95 & 139,000 & $1.258 \mathrm{E}-02$ & $3.50 E+03$ \\
\hline Mark IV Inner & 0.95 & 145,000 & $1.258 \mathrm{E}-02$ & $3.65 E+03$ \\
\hline Mark IV Outer & 0.95 & 217,000 & $1.258 \mathrm{E}-02$ & $5.46 E+03$ \\
\hline \multicolumn{5}{|c|}{ Mark 15 Ingot } \\
\hline Mark 15 Inner & 1.1 & 277,000 & $1.256 \mathrm{E}-\mathrm{O} 2$ & $6.96 \mathrm{E}+03$ \\
\hline Mark 15 Outer & 1.1 & 501,000 & $1.256 \mathrm{E}-02$ & $1.26 \mathrm{E}+04$ \\
\hline \multicolumn{5}{|c|}{ FERMCO Derbies } \\
\hline Derbies & 1.25 & 176,000 & $1.255 \mathrm{E}-02$ & $4.42 \mathrm{E}+03$ \\
\hline \multicolumn{5}{|c|}{ FERMCO Primary Ingots } \\
\hline $\begin{array}{l}12 \text { in. }(30.48 \mathrm{~cm}) \text { OD } \times 17 \mathrm{in.}(43.18 \mathrm{~cm})-26 \mathrm{in} . \\
(66.04 \mathrm{~cm}) \text { long (calculated } 26 \mathrm{in.}[66.04 \mathrm{~cm}))\end{array}$ & 1.25 & 914,000 & $1.255 \mathrm{E}-\mathrm{O} 2$ & $2.29 E+04$ \\
\hline $13 \mathrm{in.}(33.02 \mathrm{~cm})$ OD $\times 30 \mathrm{in} .(76.20 \mathrm{~cm})$ long & 1.25 & $1,237,000$ & $1.255 \mathrm{E}-02$ & $3.10 \mathrm{E}+04$ \\
\hline 9 in. $\{22.86 \mathrm{~cm}\}$ OD $\times 30 \mathrm{in.}(76.20 \mathrm{~cm})$ long & 1.25 & 593,000 & $1.255 \mathrm{E}-02$ & $1.49 \mathrm{E}+04$ \\
\hline \multicolumn{5}{|c|}{ FERMCO Ingot Sections } \\
\hline $\begin{array}{l}13 \mathrm{in} .(33.02 \mathrm{~cm}) \text { OD } \times 3 \text { in. }(7.62 \mathrm{~cm}) \text { or } 6 \text { in. } \\
(15.24 \mathrm{~cm}) \text { long (calculated } 6 \mathrm{in} .[15.24 \mathrm{cml})\end{array}$ & 1.25 & 247,000 & $1.255 \mathrm{E}-02$ & $6.20 \mathrm{E}+03$ \\
\hline 10 in. $(25.40 \mathrm{~cm}) O D \times 6$ in. $(15.24 \mathrm{~cm})$ long & 1.25 & 146,000 & $1.255 E-02$ & $3.66 \mathrm{E}+03$ \\
\hline \multicolumn{5}{|c|}{ FERMCO Scrap } \\
\hline $\begin{array}{l}13 \mathrm{in.}(33.02 \mathrm{~cm}) \mathrm{OD} \times 4 \mathrm{in} .(10.16 \mathrm{~cm}) \text { long } \\
\text { (calculated } 1.5 \mathrm{in} .[3.81 \mathrm{~cm}])\end{array}$ & 1.25 & 61,900 & $1.255 \mathrm{E}-02$ & $1.55 E+03$ \\
\hline 11 in. $(27.94 \mathrm{~cm})$ OD $\times 4$ in. $(10.16 \mathrm{~cm})$ long & 1.25 & 118,000 & $1.255 \mathrm{E}-02$ & $2.96 \mathrm{E}+03$ \\
\hline
\end{tabular}



${ }^{240} \mathrm{Pu}$.

The spontaneous fission energy spectrum for ${ }^{238} \mathrm{U}$ was approximated using the spectrum for

The flux to dose rate conversion factors used in MCNP for the neutron calculations are listed in Table 5.2.2-2. These conversion factors are the ANSI/ANS-6.1.1-1977 conversion factors and come from MCNP--A General Monte Carlo Code N-Particle Transport Code (Breismeister 1993). The 1977 conversion factors were used instead of the 1991 factors as in the gamma analysis because they are more conservative.

TABLE 5.2.2-2. Neutron Flux to Dose Rate Conversion Factors.

\begin{tabular}{|c|c||c|c|}
\hline Energy (MeV) & $\begin{array}{c}\text { Flux to Dose Rate } \\
(\mathrm{mrem} / \mathrm{h}) /\left(\mathrm{r} / \mathrm{cm}^{2} / \mathrm{s}\right)\end{array}$ & Energy (MeV) & $\begin{array}{c}\text { Flux to Dose Rate } \\
(\mathrm{mrem} / \mathrm{h}) /\left(\mathrm{n} / \mathrm{cm}^{2} / \mathrm{s}\right)\end{array}$ \\
\hline \hline $2.5 \mathrm{E}-08$ & $3.67 \mathrm{E}-03$ & 0.5 & $9.26 \mathrm{E}-02$ \\
\hline $1.0 \mathrm{E}-07$ & $3.67 \mathrm{E}-03$ & 1.0 & 0.132 \\
\hline $1.0 \mathrm{E}-06$ & $4.46 \mathrm{E}-03$ & 2.5 & 0.125 \\
\hline $1.0 \mathrm{E}-05$ & $4.54 \mathrm{E}-03$ & 5.0 & 0.156 \\
\hline $1.0 \mathrm{E}-04$ & $4.18 \mathrm{E}-03$ & 7.0 & 0.147 \\
\hline 0.001 & $3.76 \mathrm{E}-03$ & 10.0 & 0.147 \\
\hline 0.01 & $3.56 \mathrm{E}-03$ & 14.0 & 0.208 \\
\hline 0.1 & $2.17 \mathrm{E}-02$ & 20.0 & 0.227 \\
\hline
\end{tabular}

* - ANSI/ANS-6.1.1-1977

\subsubsection{Beta-Particle Dose Rate}

For NCT, the beta particles will be absorbed by the wood containers and will not contribute to the dose rate. For HAC, a very conservative approximation of the beta dose rate was made.

The International Atomic Energy Agency (IAEA) methodology (IAEA 1990; Jaeger et al. 1968) for calculating beta dose rates assumes the material is a point source. Due to the limited range of beta particles as compared to photons, a shielding factor due to residual shielding from material such as package debris is used (IAEA 1990). The betas source is conservatively assumed to be at $3.28 \mathrm{ft}(1 \mathrm{~m})$ from the dose point.

To calculate the beta dose rate, the beta dose as a function of energy is divided by the shielding factor as a function of energy both of which are included in the IAEA reference. This result is then multiplied by the number of curies.

Because of the significant amount of self shielding in the uranium, much of the beta source can be ignored. The maximum distance a $2.2 \mathrm{MeV}$ beta can travel in uranium is $0.02 \mathrm{in} .(1 / 19 \mathrm{~cm})$ as obtained from the Radiological Health Handbook (U.S. Department of Commerce 1970). The total external surface area was calculated for all the pieces in a shipment. This was divided by two because only half the surface of any given piece is visible from a given point. This was then multiplied by the number of pieces in a shipment, and then by the beta dose rate from $0.04 \mathrm{oz}(1 \mathrm{~g})$. Also, this is a skin dose which by itself is counted as an organ dose and, when 
being included in the EDE, is multiplied by the tissue weighting factor for skin (0.01) to determine the effective dose equivalent. The major contributor to the beta dose rate is ${ }^{234 m} \mathrm{~Pa}$. The beta effective dose equivalents are shown in Table 5.2.3-1.

The maximum beta effective dose equivalent was calculated as being $93 \mu \mathrm{Sv} / \mathrm{h}$ which (even with the gamma and neutron dose rates) does not exceed the maximum HAC dose rate of $10,000 \mu \mathrm{Sv} / \mathrm{h}$ at $3.28 \mathrm{ft}(1 \mathrm{~m})$.

TABLE 5.2.3-1. Beta Effective Dose Equivalents.

\begin{tabular}{|c|c|}
\hline Piece & $\begin{array}{c}\text { Maximum Beta Effective Dose } \\
\text { Equivalent }(\mu \mathrm{Sv} / \mathrm{h})\end{array}$ \\
\hline \multicolumn{2}{|l|}{ N Reactor Ingot } \\
\hline Mark I Outer & 35 \\
\hline Mark I Inner & 42 \\
\hline Mark IV Inner & 43 \\
\hline Mark IV Outer & 35 \\
\hline \multicolumn{2}{|l|}{ RMI Forged Billet } \\
\hline Mark I Outer & 85 \\
\hline Mark I Inner & 92 \\
\hline Mark IV Inner & 93 \\
\hline Mark IV Outer & 85 \\
\hline \multicolumn{2}{|l|}{ Mark 15 Ingot } \\
\hline Mark 15 Inner & 59 \\
\hline Mark 15 Outer & 50 \\
\hline \multicolumn{2}{|l|}{ FERMCO Derbies } \\
\hline Derbies & 48 \\
\hline \multicolumn{2}{|l|}{ FERMCO Primary Ingots } \\
\hline $\begin{array}{l}12 \mathrm{in.}(30.48 \mathrm{~cm}) \mathrm{OD} \times 17 \mathrm{in.}(43.18 \mathrm{~cm})-26 \mathrm{in.}(66.04 \mathrm{~cm}) \\
\text { long }\end{array}$ & 41 \\
\hline $13 \mathrm{in.}(33.02 \mathrm{~cm})$ OD $\times 30 \mathrm{in} .(76.20 \mathrm{~cm})$ long & 33 \\
\hline 9 in. $(22.86 \mathrm{~cm})$ OD $\times 30 \mathrm{in.}(76.20 \mathrm{~cm})$ long & 49 \\
\hline \multicolumn{2}{|l|}{ FERMCO Ingot Sections } \\
\hline $13 \mathrm{in.}(33.02 \mathrm{~cm})$ OD $\times 3$ in. $(7.62 \mathrm{~cm})$ or 6 in. $(15.24 \mathrm{~cm})$ long & 62 \\
\hline $10 \mathrm{in.}(25.40 \mathrm{~cm}) \mathrm{OD} \times 6$ in. $(15.24 \mathrm{~cm})$ long & 42 \\
\hline \multicolumn{2}{|l|}{ FERMCO Scrap } \\
\hline $13 \mathrm{in.}(33.02 \mathrm{~cm})$ OD $\times 4 \mathrm{in} .(10.16 \mathrm{~cm})$ long & 34 \\
\hline $11 \mathrm{in.}(27.94 \mathrm{~cm})$ OD $\times 4$ in. $\{10.16 \mathrm{~cm})$ long & 41 \\
\hline
\end{tabular}




\subsection{MODEL SPECIFICATION}

It is assumed that there is no external shielding, and all shielding is from uranium self shielding.

\subsubsection{Description of Radial and Axial Shielding Configuration}

Mark I, IV, and 15 ingots and RMI billets were modeled as an annulus. The FERMCO ingots and scrap piece were modeled as a cylinder. The sizes of the pieces are shown in Table 5.3.1.

For the array calculations, two calculations were made, one for an array of cylinders/annular cylinders on their side, and a second for an array of cylinders/annular cylinders on their ends. These are two different arrays, in the first case all of the cylinders in the array have their ends facing the dose point and in the second case all of the cylinders have their sides facing the dose point. By doing this the most conservative side and end dose rate is calculated. Array sizes were based on the weight restrictions of the shipments. The maximum amount of fuel per shipment, by weight, was used to determine the number of items in the modeled arrays.

Figure 5.3.1-1 shows an array of annular billets placed on their ends. In the figure, points inside the annular billets represent the location of the first 20,000 source points generated by MCNP. The 20,000 source points are used for plotting only. In the actual calculations, MCNP generated the number of source points necessary to reach good statistics, which for these cases was approximately an order of magnitude larger than 20,000. The source points help define the source region and verify that the source was modeled correctly. Figure 5.3.1-2 shows an array of cylindrical billets placed on their sides. Included in this figure is a top view and side view with the first 20,000 source points generated by MCNP included in the figure. The dose rates were taken at the center of the arrays, extending out away from the page. Figure 5.3.1-3 shows an array of 294 FERMCO ingots and scrap pieces modeled as $13 \mathrm{in} .(33.02 \mathrm{~cm}$ ) diameter $\times 6 \mathrm{in} .(15.24 \mathrm{~cm})$ long cylinders placed on their ends, with the first 20,000 source points generated by MCNP included in this figure.

The detectors used were ring and point detectors. End dose rates were made using ring detectors taken at the surface $(2 \mathrm{in} .[5.08 \mathrm{~cm}]), 3.28 \mathrm{ft}(1 \mathrm{~m}), 6.56 \mathrm{ft}(2 \mathrm{~m})$, and $19.69 \mathrm{ft}(6 \mathrm{~m})$ from the outside annular or cylindrical surface of the piece at the axial center. Side dose rates were made using point detectors at the surface $(2 \mathrm{in}$. $[5.08 \mathrm{~cm}]), 3.28 \mathrm{ft}(1 \mathrm{~m}), 6.56 \mathrm{ft}(2 \mathrm{~m})$, and $19.69 \mathrm{ft}(6 \mathrm{~m})$ from the end of the annulus or cylinder at the radial center. The surface dose rate was calculated $2 \mathrm{in}$. $(5.08 \mathrm{~cm})$ from the surface, which is representative of a typical surface measurement.

All of the $13 \mathrm{in.}(33.02 \mathrm{~cm})$ OD FERMCO ingot and scrap sections were conservatively calculated in one model. This model consisted of an array of 294, $13 \mathrm{in}$. (33.02 cm) diameter $x$ $6 \mathrm{in.}(15.24 \mathrm{~cm})$ long pieces for the top dose rate calculation, and 147, $13 \mathrm{in}$. (33.02 cm) diameter $x 6 \mathrm{in} .(15.24 \mathrm{~cm})$ long pieces for the side dose rate calculation. This is conservative for the 294,3 in. $(7.62 \mathrm{~cm})$ long pieces, conservative for the $132,6 \mathrm{in} .(15.24 \mathrm{~cm})$ long pieces, and conservative for the $154,4 \mathrm{in} .(10.16 \mathrm{~cm})$ pieces. The side dose rates for the $147,6 \mathrm{in} .(15.24 \mathrm{~cm})$ pieces is the same calculation as $294,3 \mathrm{in} .(7.62 \mathrm{~cm})$ pieces, and $220,4 \mathrm{in}$. pieces, stacked end on end. 
TABLE 5.3.1. Sizes of Ingots and Billets Used in MCNP Calculations.

\begin{tabular}{|c|c|c|c|c|}
\hline Type & $\begin{array}{c}O D \\
\text { in. }(\mathrm{cm})\end{array}$ & $\begin{array}{c}I D \\
\text { in. }(\mathrm{cm})\end{array}$ & $\begin{array}{l}\text { Length } \\
\text { in. }(\mathrm{cm})\end{array}$ & $\begin{array}{l}\text { Maximum Shipping } \\
\text { Limit per Vehicle } \\
\text { (pieces) }\end{array}$ \\
\hline \multicolumn{5}{|c|}{ Mark I and Mark IV Ingots } \\
\hline Mark I Outer & $13.05(33.15)$ & $2.87(7.29)$ & $17(43.18)$ & 26 \\
\hline Mark I Inner & $10.85(27.56)$ & $1.375(3.49)$ & $24.75(62.87)$ & 26 \\
\hline Mark IV Inner & $10.85(27.56)$ & $1.30(3.30)$ & $25.5(64.77)$ & 26 \\
\hline Mark IV Outer & $13.05(33.15)$ & $2.58\{6.55\}$ & $17(43.18)$ & 26 \\
\hline \multicolumn{5}{|c|}{ RMI Forged Billet } \\
\hline Mark I Outer & $6.98(17.73)$ & $2.80\{7.11\}$ & $21(53.34)$ & 96 \\
\hline Mark I Inner & $5.37\{13.64\}$ & $1.34(3.40)$ & $21(53.34)$ & 135 \\
\hline Mark IV Inner & $5.465(13.88)$ & $1.265\{3.21\}$ & $21\{53.34\}$ & 135 \\
\hline Mark IV Outer & $6.98(17.73)$ & $2.51(6.38)$ & $21(53.34)$ & 96 \\
\hline \multicolumn{5}{|c|}{ Mark 15 ingot } \\
\hline Mark 15 Inner & $8(20.32)$ & $2.045(5.19)$ & $19(48.26)$ & 64 \\
\hline Mark 15 Outer & $9(22.86)$ & $3.19(8.10)$ & $29(73.66)$ & 32 \\
\hline \multicolumn{5}{|c|}{ FERMCO Derbies } \\
\hline Derbies & $12(30.48\rangle$ & $-\cdots$ & $5(12.70)$ & 132 \\
\hline \multicolumn{5}{|c|}{ FERMCO Primary Ingots } \\
\hline $\begin{array}{l}12 \mathrm{in.}(30.48 \mathrm{~cm}) \text { OD } \times 17 \mathrm{in} . \\
(43.18 \mathrm{~cm})-26 \mathrm{in} .(66.04 \mathrm{~cm}) \text { long }\end{array}$ & $12(30.48\rangle$ & $\cdots$ & $26(66.04)$ & 22 \\
\hline $\begin{array}{l}13 \mathrm{in.}(33.02 \mathrm{~cm}) \text { OD } \times 30 \mathrm{in} . \\
(76.20 \mathrm{~cm}) \text { long }\end{array}$ & $13(33.02)$ & --- & $30(76.20)$ & 14 \\
\hline $\begin{array}{l}9 \text { in. }(22.86 \mathrm{~cm}) \text { OD } \times 30 \mathrm{in} . \\
(76.20 \mathrm{~cm}) \text { long }\end{array}$ & $9(22.86)$ & $-\cdots$ & $30(76.20)$ & 30 \\
\hline \multicolumn{5}{|c|}{ FERMCO Product Ingots } \\
\hline $\begin{array}{l}13.07 \mathrm{in.}(33.20 \mathrm{~cm}) \text { OD, } 2.885 \mathrm{in} . \\
(7.33 \mathrm{~cm})(\mathrm{D} \times 17 \mathrm{in} .(43.18 \mathrm{~cm}) \text { long }\end{array}$ & $13.07(33.20)$ & $2.885(7.33)$ & $17(43.18)$ & 26 \\
\hline \multicolumn{5}{|c|}{ FERMCO ingot Sections } \\
\hline $\begin{array}{l}13 \mathrm{in} .(33.02 \mathrm{~cm}) \text { oD } \times 3 \text { in. }(7.62 \mathrm{~cm}) \\
\text { or } 6 \text { in. }(15.24 \mathrm{~cm}) \text { long }\end{array}$ & $13(33.02\rangle$ & --- & $6(15.24)$ & 132 \\
\hline $\begin{array}{l}10 \mathrm{in.}(25.40 \mathrm{~cm}) \text { OD } \times 6 \mathrm{in} . \\
(15.24 \mathrm{~cm}) \text { long }\end{array}$ & $10(25.40)$ & $\cdots$ & $6(15.24)$ & 117 \\
\hline \multicolumn{5}{|c|}{ FERMCO Scrap } \\
\hline $\begin{array}{l}13 \mathrm{in.}(33.02 \mathrm{~cm}) \text { OD } \times 1.5 \mathrm{in} . \\
(3.81 \mathrm{~cm}) \text { or } 4 \mathrm{in} .(10.16 \mathrm{~cm}) \text { long }\end{array}$ & $13(33.02)$ & $\cdots--$ & $\begin{array}{c}1.5(3.81) \text { or } \\
4(10.16)\end{array}$ & 294 \\
\hline $\begin{array}{l}11 \mathrm{in} .(27.94 \mathrm{~cm}) \text { OD } \times 4 \mathrm{in} . \\
(10.16 \mathrm{~cm}) \text { long }\end{array}$ & $11(27.94)$ & --- & $4(10.16)$ & 154 \\
\hline
\end{tabular}




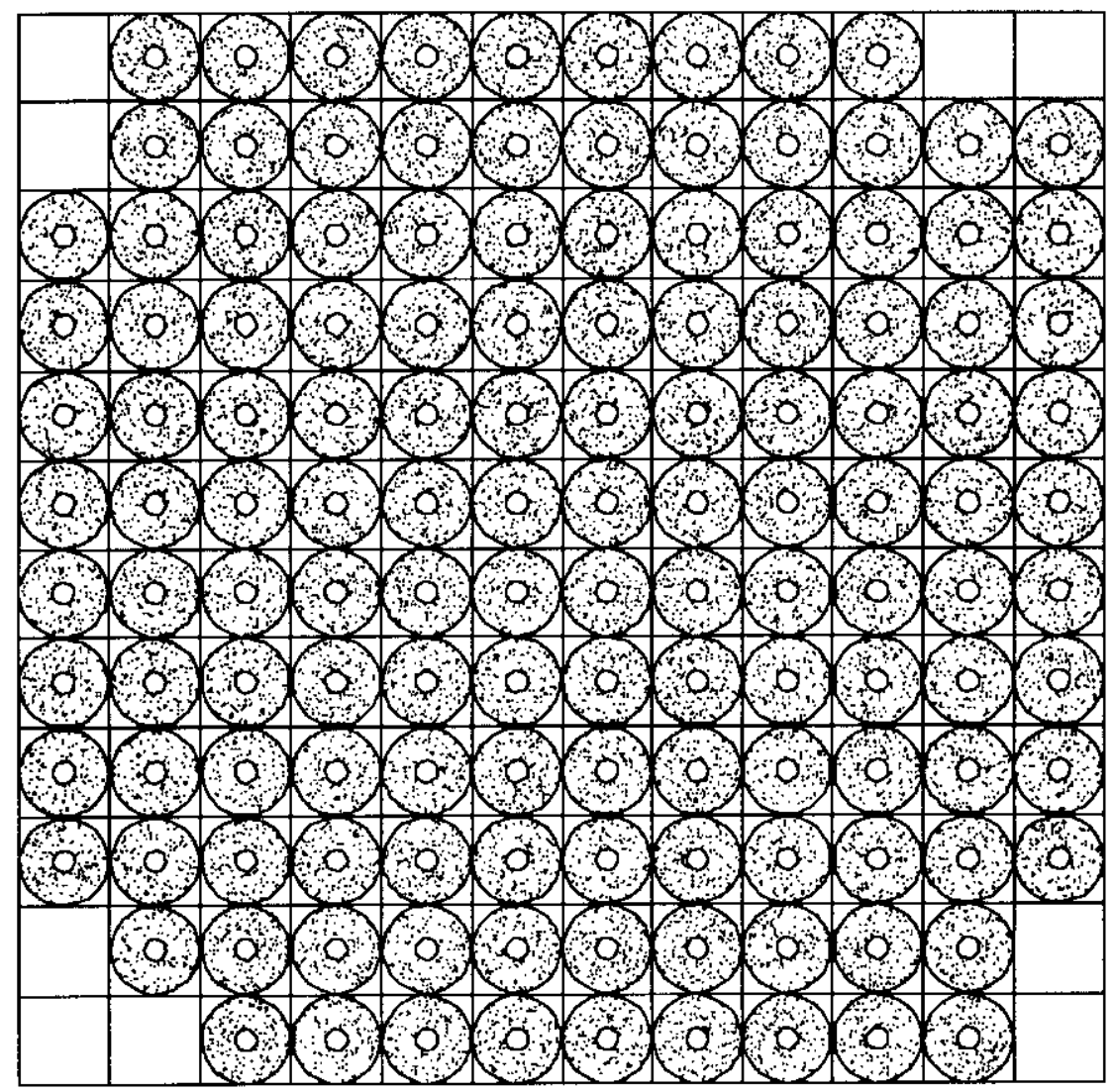

FIGURE 5.3.1-1. Configuration for an Array of Annular Billets on the Ends. 


\section{Top View}

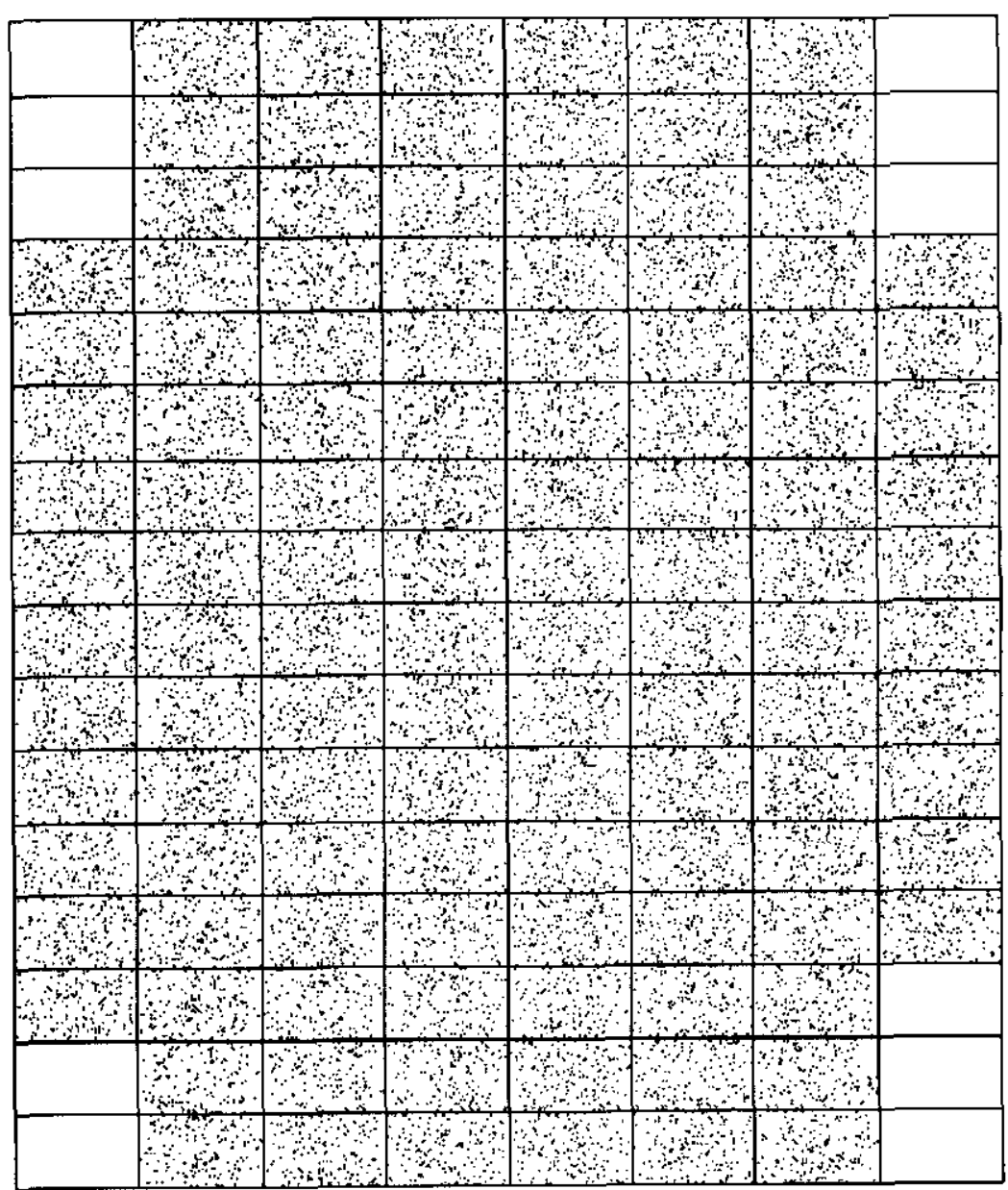

Side View

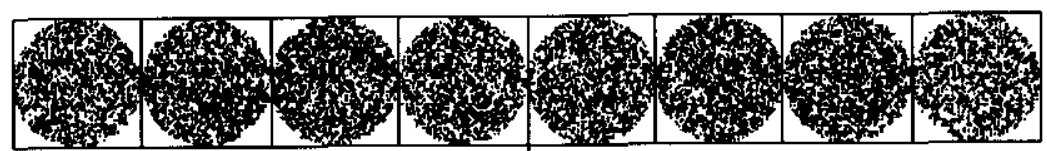

FIGURE 5.3.1-2. Configuration for an Array of Cylindrical Billets on their Sides. 


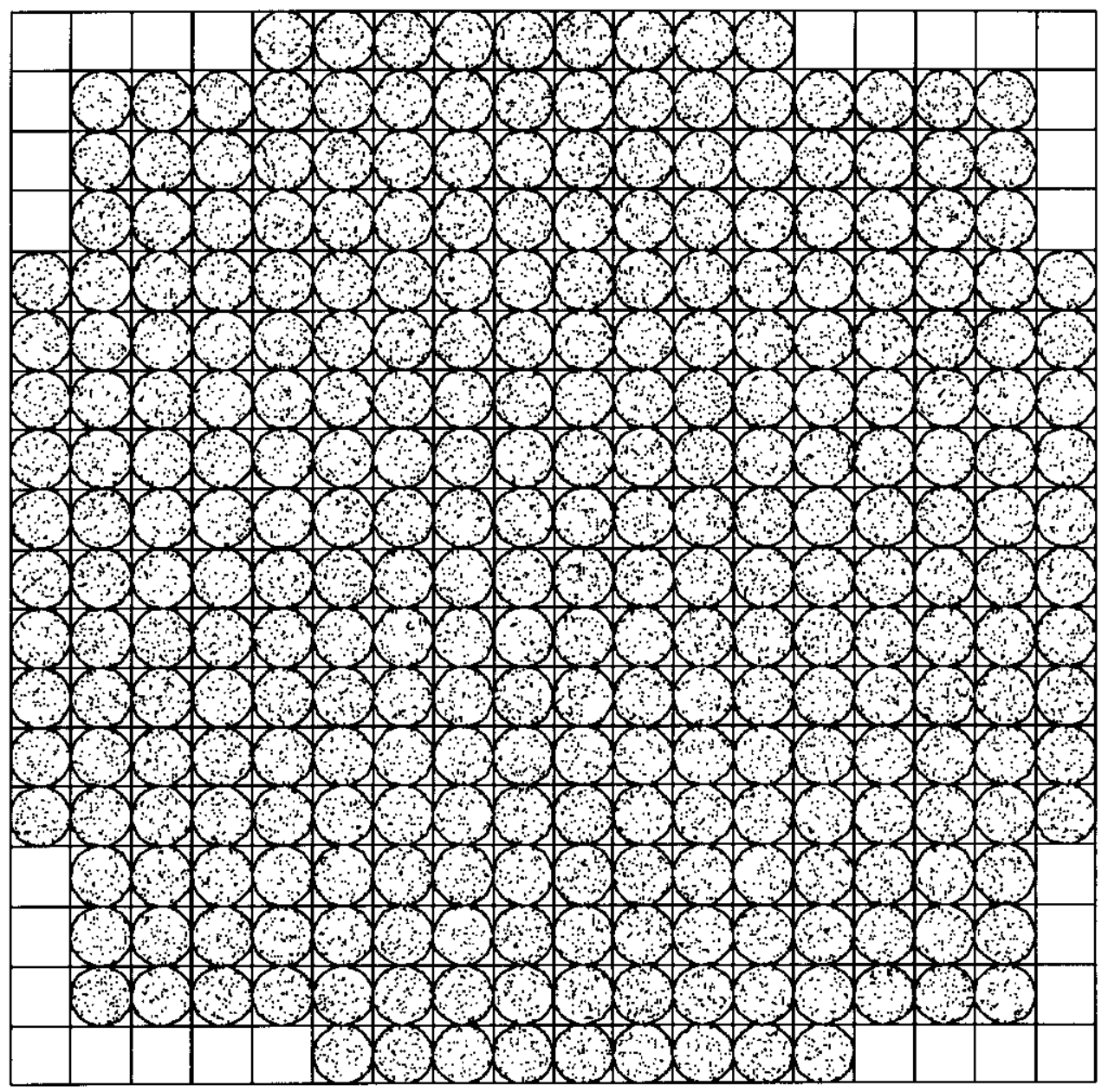

FIGURE 5.3.1-3. Configuration for an Array of FERMCO Ingot and Scrap Pieces. 


\subsubsection{Shield Regional Densities}

The only shielding material used was uranium with a density of $18.96 \mathrm{~g} / \mathrm{cm}^{2}$. It was modeled with ${ }^{238} \mathrm{U}$ and ${ }^{235} \mathrm{U}$ at the enrichment levels provided in Table 5.2.1-2.

\subsection{SHIELDING EVALUATION}

ORIGEN2 was used to determine the source for this calculation (Schmittroth 1994). The MCNP transport code is a three-dimensional Monte Carlo transport code (Breismeister 1993; Carter 1995) and was used to determine the dose rates.

No shielding other than uranium self shielding is assumed for each calculation. The total dose rate per shipment was initially determined by multiplying the single piece dose rate by the maximum number of pieces on a shipment (assuming a limit of $40,000 \mathrm{lb}[18,144 \mathrm{~kg}]$ ). This is conservative because not all of the pieces in a shipment are the same distance away, they will provide shielding for each other, and there will be attenuation in the air. If the dose rate calculation exceeded the limits using this conservative method, then a less conservative but more realistic calculation was performed using an array of the pieces. This array was modeled as a square array and was configured to give the worst case dose rates for both pieces placed on their ends, and pieces placed on their sides. The dose rate at $3.28 \mathrm{ft}(1 \mathrm{~m})$ was used for HAC. 


\subsection{APPENDICES}

\subsubsection{References}

Breismeister, J. F., Editor, 1993, MCNP--A General Monte Carlo Code N-Partic/e Transport Code, Version 4a, LA-12625, Los Alamos National Laboratory, Los Alamos, New Mexico, November 1993.

Carter, L. L., 1995, Certification of MCNP Version 4A for WHC Computer Platforms, WHC-P-SD300001, Rev. 5, Westinghouse Hanford Company, Richland, Washington, May 1995.

Goldberg, H. J., and D. C. Hedengren, 1987, ORIGEN2 Predictions of N Reactor Fuel Actinide Composition, SD-CP-TI-105, Rockwell Hanford Operations, Richland, Washington, June 1987.

IAEA, 1990, Explanatory Material for the IAEA Regulations for the Safe Transport of Radioactive Material, IAEA Safety Series No. 7, 1985 Edition as amended in 1990, International Atomic Energy Agency, Vienna, Austria.

Jaeger, R. G., et al., 1968, Engineering Compendium on Radiation Shielding, Volume 1, SpringerVerlag, New York.

Schmittroth, F. A., Conversion of ORIGEN2 to the Sun Workstations, WHC-SD-SWD-006, Rev. 1, Westinghouse Hanford Company, Richland, Washington, August 1994.

U.S. Department of Commerce, 1970, Radiological Health Handbook, Pb-230-846, U.S. Department of Commerce, National Technical Information Service, January 1970. 


\subsubsection{Tables of All Calculated Dose Rates}

TABLE 5.5.2-1. Dose Rates for Mark I and Mark IV N Reactor Ingots.

\begin{tabular}{|c|c|c|c|c|c|c|c|c|c|}
\hline \multirow{2}{*}{\multicolumn{2}{|c|}{ Description }} & \multicolumn{4}{|c|}{ Side Dose Rates $(\mu \mathrm{Sv} / \mathrm{h})$} & \multicolumn{4}{|c|}{ End Dose Rates ( $\mu \mathrm{Sv} / \mathrm{hr})$} \\
\hline & & 2 in. & $1 \mathrm{~m}$ & $2 \mathrm{~m}$ & $6 \mathrm{~m}$ & 2 in. & $1 \mathrm{~m}$ & $2 \mathrm{~m}$ & $6 \mathrm{~m}$ \\
\hline \multicolumn{10}{|c|}{ Mark I N Reactor Outer Ingot } \\
\hline 1 Ingot & Photon & $2.5 \mathrm{E}+01$ & $9.1 \mathrm{E}-01$ & $2.4 \mathrm{E}-01$ & $2.9 \mathrm{E}-02$ & $3.3 E+01$ & $6.3 \mathrm{E}-01$ & $1.6 \mathrm{E}-01$ & $1.7 \mathrm{E}-02$ \\
\hline 1 Ingot & Neutron & $2.1 \mathrm{E}+00$ & $7.2 \mathrm{E}-02$ & $2.0 \mathrm{E}-02$ & $2.4 \mathrm{E}-03$ & $2.6 E+00$ & $4.8 \mathrm{E}-02$ & $1.2 \mathrm{E}-02$ & $1.4 \mathrm{E}-03$ \\
\hline 1 Ingot & Total & $2.7 E+01$ & $9.8 \mathrm{E}-01$ & 2.6 E-01 & $3.1 \mathrm{E}-02$ & $3.5 E+01$ & $6.8 \mathrm{E}-01$ & $1.7 \mathrm{E}-01$ & $1.9 \mathrm{E}-02$ \\
\hline 26 Ingots & Total & $7.0 E+02$ & $2.5 E+01$ & $6.8 E+00$ & 8.2 E-01 & $9.2 \mathrm{E}+02$ & $1.8 E+01$ & $4.4 \mathrm{E}+00$ & $4.9 \mathrm{E}-01$ \\
\hline \multicolumn{10}{|c|}{ Mark I N Reactor Inner Ingot } \\
\hline 1 Ingot & Photon & $2.4 \mathrm{E}+01$ & $1.1 E+00$ & $2.9 \mathrm{E}-01$ & $3.5 \mathrm{E}-02$ & $3.0 \mathrm{E}+01$ & $4.5 \mathrm{E}-01$ & 1.1 E-01 & $1.2 \mathrm{E}-02$ \\
\hline 1 Ingot & Neutron & $2.0 \mathrm{E}+00$ & $8.7 \mathrm{E}-02$ & $2.4 \mathrm{E}-02$ & $2.9 \mathrm{E}-03$ & $2.1 E+00$ & $3.2 \mathrm{E}-\mathrm{O} 2$ & 8.3 E-03 & $9.4 \mathrm{E}-04$ \\
\hline 1 Ingot & Total & $2.6 E+01$ & $1.2 \mathrm{E}+00$ & $3.2 \mathrm{E}-01$ & $3.8 \mathrm{E}-02$ & $3.2 \mathrm{E}+01$ & $4.8 \mathrm{E} \cdot 01$ & $1.2 \mathrm{E}-01$ & 1.3 E-02 \\
\hline 26 Ingots & Total & $6.7 E+02$ & $3.0 \mathrm{E}+01$ & $8.3 E+00$ & $1.0 E+00$ & $8.4 E+02$ & $1.3 E+01$ & $3.2 E+00$ & $3.5 \mathrm{E}-01$ \\
\hline \multicolumn{10}{|c|}{ Mark IV N Reactor Outer Ingot } \\
\hline 1 Ingot & Photon & $2.5 E+01$ & 9.0 E-01 & $2.4 \mathrm{E}-01$ & $2.9 \mathrm{E}-02$ & $3.2 E+01$ & $6.3 \mathrm{E}-01$ & $1.6 \mathrm{E}-01$ & $1.8 \mathrm{E}-02$ \\
\hline 1 Ingot & Neutron & $2.1 E+00$ & 7.2 E-02 & $2.0 \mathrm{E}-02$ & 2.4 E.03 & $2.7 E+00$ & $4.8 \mathrm{E}-02$ & $1.3 \mathrm{E}-02$ & $1.4 \mathrm{E}-03$ \\
\hline 1 Ingot & Total & $2.7 E+01$ & $9.8 \mathrm{E}-01$ & 2.6 E-01 & $3.1 \mathrm{E}-02$ & $3.5 E+01$ & $6.8 \mathrm{E}-01$ & $1.7 \mathrm{E}-01$ & $1.9 \mathrm{E}-02$ \\
\hline 26 Ingots & Total & $7.0 E+02$ & $2.5 E+01$ & $6.8 E+00$ & $8.1 \mathrm{E}-01$ & $9.1 E+02$ & $1.8 \mathrm{E}+01$ & $4.4 E+00$ & $4.9 \mathrm{E}-01$ \\
\hline \multicolumn{10}{|c|}{ Mark IV N Reactor Inner Ingot } \\
\hline 1 Ingot & Photon & $2.3 E+01$ & $1.1 E+00$ & $3.0 \mathrm{E}-01$ & $3.6 \mathrm{E}-02$ & $3.0 \mathrm{E}+01$ & $4.4 \mathrm{E}-01$ & $1.1 \mathrm{E}-01$ & $1.2 \mathrm{E}-02$ \\
\hline 1 Ingot & Neutron & $2.0 E+00$ & $9.0 \mathrm{E}-02$ & $2.5 \mathrm{E}-\mathrm{O} 2$ & $3.0 \mathrm{E}-03$ & $2.1 E+00$ & $3.2 \mathrm{E}-02$ & 8.3 E-03 & $9.4 \mathrm{E}-04$ \\
\hline 1 Ingot & Total & $2.5 E+01$ & $1.2 E+00$ & $3.3 \mathrm{E}-01$ & $3.9 \mathrm{E}-02$ & $3.2 E+01$ & $4.8 \mathrm{E}-01$ & 1.2 E-01 & $1.3 \mathrm{E}-02$ \\
\hline 26 Ingots & Total & $6.6 E+02$ & $3.1 E+01$ & $8.5 E+00$ & $1.0 E+00$ & $8.3 E+02$ & $1.2 E+01$ & $3.1 E+00$ & $3.4 \mathrm{E}-01$ \\
\hline
\end{tabular}


TABLE 5.5.2-2. Dose Rates for RMI Forged Billets.

\begin{tabular}{|c|c|c|c|c|c|c|c|c|c|}
\hline \multirow{2}{*}{\multicolumn{2}{|c|}{ Description }} & \multicolumn{4}{|c|}{ Side Dose Rates $(\mu \mathrm{Sv} / \mathrm{h})$} & \multicolumn{4}{|c|}{ End Dose Rates $(\mu \mathrm{Sv} / \mathrm{h})$} \\
\hline & & 2 in. & $1 \mathrm{~m}$ & $2 \mathrm{~m}$ & $6 \mathrm{~m}$ & $2 \mathrm{in.}$ & $1 \mathrm{~m}$ & $2 \mathrm{~m}$ & $6 \mathrm{~m}$ \\
\hline \multicolumn{10}{|c|}{ Mark I Outer RMI Forged Billet } \\
\hline Array of 96 & Photon & $5.4 E+01$ & $2.4 \mathrm{E}+01$ & $1.1 E+01$ & $1.8 E+00$ & $4.6 E+01$ & $1.3 E+01$ & $4.5 E+00$ & $5.3 \mathrm{E}-01$ \\
\hline Array of 96 & Neutron & $3.8 E+00$ & $1.9 E+00$ & 9.1 E-01 & $1.5 \mathrm{E}-01$ & $5.1 \mathrm{E}+00$ & $1.5 E+00$ & $5.5 \mathrm{E}-01$ & $6.3 \mathrm{E}-02$ \\
\hline Array of 96 & Total & $5.8 E+01$ & $2.6 E+01$ & $1.2 E+01$ & $2.0 \mathrm{E}+00$ & $5.1 E+01$ & $1.4 E+01$ & $5.1 E+00$ & $5.9 \mathrm{E}-\mathrm{O} 1$ \\
\hline \multicolumn{10}{|c|}{ Mark I Inner RMI Forged Billet } \\
\hline Array of 135 & Photon & $3.8 E+01$ & $2.4 \mathrm{E}+01$ & $1.2 E+01$ & $2.0 E+00$ & $4.6 E+01$ & $1.3 E+01$ & $4.0 E+00$ & $4.7 \mathrm{E}-01$ \\
\hline Array of 135 & Neutron & $3.4 \mathrm{E}+00$ & $1.8 E+00$ & $8.8 \mathrm{E}-01$ & $1.4 \mathrm{E}-01$ & $5.0 E+00$ & $1.4 \mathrm{E}+00$ & $4.9 \mathrm{E}-01$ & $5.8 \mathrm{E}-\mathrm{O} 2$ \\
\hline Array of 135 & Total & $4.2 \mathrm{E}+01$ & $2.6 E+01$ & $1.3 E+01$ & $2.2 \mathrm{E}+00$ & $5.1 \mathrm{E}+01$ & $1.4 \mathrm{E}+01$ & $4.5 E+00$ & $5.3 \mathrm{E}-01$ \\
\hline \multicolumn{10}{|c|}{ Mark IV Outer RMI Forged Billet } \\
\hline Array of 96 & Photon & $5.4 E+01$ & $2.4 E+01$ & $1.2 E+01$ & $1.8 E+00$ & $4.5 E+01$ & $1.3 E+01$ & $4.5 E+00$ & $5.3 \mathrm{E}-01$ \\
\hline Array of 96 & Neutron & $3.8 \mathrm{E}+00$ & $2.0 \mathrm{E}+00$ & $9.4 \mathrm{E}-01$ & $1.5 \mathrm{E}-01$ & $5.3 E+00$ & $1.6 E+00$ & $5.6 \mathrm{E}-01$ & $6.5 \mathrm{E}-02$ \\
\hline Array of 96 & Total & $5.8 E+01$ & $2.5 \mathrm{E}+01$ & $1.3 E+01$ & $2.0 \mathrm{E}+00$ & $5.1 E+01$ & $1.4 \mathrm{E}+01$ & $5.1 E+00$ & 5.9 E-01 \\
\hline \multicolumn{10}{|c|}{ Mark IV Inner RMI Forged Billet } \\
\hline Array of 135 & Photon & $3.9 \mathrm{E}+01$ & $2.4 E+01$ & $1.2 \mathrm{E}+01$ & $2.0 \mathrm{E}+00$ & $4.6 \mathrm{E}+01$ & $1.3 \mathrm{E}+01$ & $4.0 \mathrm{E}+00$ & $4.8 \mathrm{E}-01$ \\
\hline Array of 135 & Neutron & $3.4 E+00$ & $1.8 E+00$ & $9.1 \mathrm{E}-01$ & $1.5 \mathrm{E}-01$ & $5.0 \mathrm{E}+00$ & $1.4 E+00$ & 5.0 E-01 & $5.9 \mathrm{E}-02$ \\
\hline Array of 135 & Total & $4.2 E+01$ & $2.6 E+01$ & $1.3 E+01$ & $2.2 \mathrm{E}+\mathrm{OO}$ & $5.1 E+01$ & $1.4 E+01$ & $4.5 E+00$ & $5.4 \mathrm{E}-01$ \\
\hline
\end{tabular}


TABLE 5.5.2-3. Dose Rates for Mark 15 Ingots.

\begin{tabular}{|c|c|c|c|c|c|c|c|c|c|}
\hline \multirow{2}{*}{\multicolumn{2}{|c|}{ Description }} & \multicolumn{4}{|c|}{ Side Dose Rates $(\mu \mathrm{Sv} / \mathrm{h}\}$} & \multicolumn{4}{|c|}{ End Dose Rates $(\mu \mathrm{Sv} / \mathrm{h})$} \\
\hline & & $2 \mathrm{in.}$ & $1 \mathrm{~m}$ & $2 \mathrm{~m}$ & $6 \mathrm{~m}$ & $2 \mathrm{in.}$ & $1 \mathrm{~m}$ & $2 m$ & $6 \mathrm{~m}$ \\
\hline \multicolumn{10}{|c|}{ Mark 15 Outer Ingot } \\
\hline 1 ingot & Photon & $3.4 E+01$ & $1.1 E+00$ & $2.9 \mathrm{E}-01$ & $3.5 \mathrm{E}-\mathrm{O} 2$ & $2.8 E+01$ & $3.0 \mathrm{E}-01$ & $7.3 \mathrm{E}-02$ & $7.8 \mathrm{E}-03$ \\
\hline 1 ingot & Neutron & $1.7 E+00$ & $7.5 \mathrm{E}-02$ & $2.1 \mathrm{E}-02$ & $2.5 \mathrm{E}-03$ & $1.6 E+00$ & $1.9 \mathrm{E}-\mathrm{O} 2$ & $4.6 \mathrm{E}-03$ & 5.0 E-04 \\
\hline 1 ingot & Total & $3.6 E+01$ & $1.1 E+\infty 0$ & $3.1 \mathrm{E}-01$ & $3.7 \mathrm{E}-02$ & $3.0 E+01$ & $3.2 \mathrm{E}-01$ & 7.7 E-02 & $8.3 E-03$ \\
\hline 32 ingots & Total & $1.1 E+03$ & $3.7 E+01$ & $1.0 E+01$ & $1.2 \mathrm{E}+00$ & $9.5 E+02$ & $1.0 \mathrm{E}+01$ & $2.5 E+00$ & $2.7 \mathrm{E}-01$ \\
\hline \multicolumn{10}{|c|}{ Mark 15 Inner Ingot } \\
\hline 1 ingot & Photon & $2.2 E+01$ & $6.5 \mathrm{E}-01$ & $1.7 \mathrm{E}-01$ & $2.1 \mathrm{E}-02$ & $2.5 E+01$ & $2.3 \mathrm{E}-01$ & $5.8 \mathrm{E}-\mathrm{O} 2$ & $6.4 \mathrm{E}-03$ \\
\hline 1 ingot & Neutron & $1.5 E+00$ & 4.3E-02 & $1.2 \mathrm{E}-02$ & $1.4 \mathrm{E}-03$ & $1.4 \mathrm{E}+00$ & $1.4 \mathrm{E}-\mathrm{O} 2$ & $3.6 \mathrm{E}-03$ & $4.1 \mathrm{E}-04$ \\
\hline 1 ingot & Total & $2.3 E+01$ & $6.9 E-01$ & $1.8 \mathrm{E}-01$ & $2.2 \mathrm{E}-02$ & $2.7 E+01$ & 2.5 E-01 & $6.2 \mathrm{E}-02$ & $6.8 \mathrm{E}-03$ \\
\hline 64 ingots & Total & $1.5 E+03$ & $4.4 E+01$ & $1.2 E+01$ & $1.4 \mathrm{E}+00$ & $1.7 E+03$ & $1.6 \mathrm{E}+01$ & $4.0 E+00$ & 4. $3 \mathrm{E}-01$ \\
\hline
\end{tabular}


TABLE 5.5.2-4. Dose Rates for FERMCO Scrap, Derbies and Ingot Sections.

\begin{tabular}{|c|c|c|c|c|c|c|c|c|c|}
\hline \multirow{2}{*}{\multicolumn{2}{|c|}{ Description }} & \multicolumn{4}{|c|}{ Side Dose Rates $(\mu \mathrm{Sv} / \mathrm{hr})$} & \multicolumn{4}{|c|}{ End Dose Rates $(\mu \mathrm{Sv} / \mathrm{hr}\}$} \\
\hline & & $2 \mathrm{in.}$ & $1 \mathrm{~m}$ & $2 \mathrm{~m}$ & $6 \mathrm{~m}$ & $2 \mathrm{in.}$ & $1 \mathrm{~m}$ & $2 \mathrm{~m}$ & $6 m$ \\
\hline \multicolumn{10}{|c|}{ FERMCO Derbies -12 in. $(30.48 \mathrm{~cm})$ OD $\times 5$ in. $(12.70 \mathrm{~cm})$ long } \\
\hline Array of 132 & Photon & $4.0 E+01$ & $1.7 \mathrm{E}+01$ & $7.1 E+00$ & $1.1 E+00$ & $4.7 E+01$ & $2.4 \mathrm{E}+01$ & $1.2 \mathrm{E}+01$ & $2.0 E+00$ \\
\hline Array of 132 & Neutron & $4.7 E+00$ & $1.9 E+00$ & $7.8 \mathrm{E}-01$ & $1.1 \mathrm{E}-01$ & $3.9 E+00$ & $1.9 E+00$ & $9.4 \mathrm{E}-01$ & $1.6 \mathrm{E}-01$ \\
\hline Array of 132 & Total & $4.5 E+01$ & $1.9 \mathrm{E}+01$ & $7.9 E+00$ & $1.2 \mathrm{E}+00$ & $5.1 E+01$ & $2.6 \mathrm{E}+01$ & $1.3 E+01$ & $2.2 E+00$ \\
\hline \multicolumn{10}{|c|}{ FERMCO Primary Ingots -12 in. $(30.48 \mathrm{~cm})$ OD $\times 26$ in. $(66.04 \mathrm{~cm})$ long } \\
\hline 1 Ingot & Photon & $2.4 \mathrm{E}+01$ & $1.2 \mathrm{E}+00$ & $3.5 \mathrm{E}-01$ & $4.1 \mathrm{E}-\mathrm{O} 2$ & $3.1 E+01$ & $5.5 \mathrm{E}-01$ & $1.4 \mathrm{E}-01$ & $1.6 \mathrm{E}-\mathrm{O} 2$ \\
\hline 1 Ingot & Neutron & $2.1 \mathrm{E}+00$ & $1.0 \mathrm{E}-01$ & $2.9 \mathrm{E}-02$ & $3.5 \mathrm{E}-03$ & $2.4 \mathrm{E}+00$ & $4.1 \mathrm{E}-02$ & $1.1 \mathrm{E}-02$ & $1.2 \mathrm{E}-03$ \\
\hline 1 ingot & Total & $2.6 E+01$ & $1.3 \mathrm{E}+00$ & $3.7 \mathrm{E}-01$ & $4.5 \mathrm{E}-02$ & $3.4 \mathrm{E}+01$ & $5.9 \mathrm{E}-01$ & $1.5 \mathrm{E}-01$ & $1.7 \mathrm{E}-02$ \\
\hline 22 ingots & Total & $5.8 \mathrm{E}+02$ & $2.9 \mathrm{E}+01$ & $8.2 E+00$ & $9.8 \mathrm{E}-01$ & $7.4 \mathrm{E}+02$ & $1.3 E+01$ & $3.3 E+00$ & $3.7 \mathrm{E}-01$ \\
\hline \multicolumn{10}{|c|}{ FERMCO Primary Ingots 13 in. $(33.02 \mathrm{~cm}) \mathrm{OD} \times 30 \mathrm{in.}(76.20 \mathrm{~cm})$ long } \\
\hline 1 Ingot & Photon & $2.5 \mathrm{E}+01$ & $1.5 \mathrm{E}+00$ & $4.3 \mathrm{E}-01$ & $5.2 \mathrm{E}-02$ & $3.1 \mathrm{E}+01$ & $6.3 \mathrm{E}-01$ & $1.6 \mathrm{E}-01$ & $1.8 \mathrm{E}-02$ \\
\hline 1 Ingot & Neutron & $2.3 E+00$ & $1.3 \mathrm{E}-01$ & $3.7 \mathrm{E}-02$ & $4.5 \mathrm{E}-03$ & $2.6 \mathrm{E}+00$ & $5.0 \mathrm{E}-02$ & $1.3 \mathrm{E}-02$ & $1.5 \mathrm{E}-03$ \\
\hline 1 Ingot & Total & $2.7 \mathrm{E}+01$ & $1.6 \mathrm{E}+00$ & $4.6 \mathrm{E}-01$ & $5.6 \mathrm{E}-02$ & $3.3 \mathrm{E}+01$ & $6.8 \mathrm{E}-01$ & $1.7 \mathrm{E}-01$ & $2.0 \mathrm{E}-02$ \\
\hline 14 ingots & Total & $3.8 \mathrm{E}+02$ & $2.3 E+01$ & $6.5 \mathrm{E}+00$ & $7.9 \mathrm{E}-01$ & $4.7 E+02$ & $9.6 \mathrm{E}+00$ & $2.4 \mathrm{E}+00$ & $2.7 \mathrm{E}-01$ \\
\hline \multicolumn{10}{|c|}{ FERMCO Primary Ingots -9 in. $(22.86 \mathrm{~cm})$ OD $\times 30$ in. $(76.20 \mathrm{~cm})$ long } \\
\hline 1 Ingot & Photon & $2.8 \mathrm{E}+01$ & $1.1 \mathrm{E}+00$ & $3.1 \mathrm{E}-01$ & $3.6 \mathrm{E} .02$ & $2.6 \mathrm{E}+01$ & $3.1 \mathrm{E}-01$ & $7.8 \mathrm{E}-02$ & $8.8 \mathrm{E}-03$ \\
\hline 1 Ingot & Neutron & $1.8 E+00$ & $8.2 \mathrm{E}-02$ & $2.3 \mathrm{E}-02$ & $2.8 \mathrm{E}-03$ & $1.6 \mathrm{E}+00$ & $2.0 \mathrm{E}-02$ & $5.3 \mathrm{E}-03$ & $6.0 \mathrm{E}-04$ \\
\hline 1 ingot & Total & $3.0 \mathrm{E}+01$ & $1.2 \mathrm{E}+00$ & $3.3 \mathrm{E}-01$ & $3.8 \mathrm{E}-02$ & $2.8 \mathrm{E}+01$ & $3.3 \mathrm{E}-01$ & $8.4 \mathrm{E}-02$ & $9.4 \mathrm{E}-03$ \\
\hline 30 Ingots & Total & $8.9 \mathrm{E}+02$ & $3.5 E+01$ & $9.9 \mathrm{E}+00$ & $1.2 \mathrm{E}+00$ & $8.3 E+02$ & $9.9 E+00$ & $2.5 E+00$ & $2.8 \mathrm{E}-01$ \\
\hline \multicolumn{10}{|c|}{ FERMCO Ingot Sections $/$ Scrap $-13 \mathrm{in.}(33.02 \mathrm{~cm})$ OD $\times 6$ in. $(15.24 \mathrm{~cm})$ long } \\
\hline Array of 294 (end) & Photon & $5.5 E+01$ & $2.2 \mathrm{E}+01$ & $9.5 \mathrm{E}+00$ & $1.5 \mathrm{E}+\mathrm{OO}$ & $4.0 \mathrm{E}+01$ & $3.1 E+01$ & $2.1 \mathrm{E}+01$ & $4.8 E+00$ \\
\hline Array of 147 (side) & Neutron & $5.2 \mathrm{E}+00$ & $2.3 E+00$ & $1.1 \mathrm{E}+00$ & $1.7 \mathrm{E}-01$ & $3.9 E+00$ & $2.7 \mathrm{E}+00$ & $1.8 \mathrm{E}+00$ & $4.2 \mathrm{E}-01$ \\
\hline & Total & $6.0 E+01$ & $2.4 E+01$ & $1.1 \mathrm{E}+01$ & $1.6 \mathrm{E}+00$ & $4.4 E+01$ & $3.4 \mathrm{E}+01$ & $2.3 E+01$ & $5.3 E+00$ \\
\hline \multicolumn{10}{|c|}{ FERMCO Ingot Sections -10 in. $(25.40 \mathrm{~cm})$ OD $\times 6$ in. $(15.24 \mathrm{~cm})$ long } \\
\hline Array of 117 (end) & Photon & $5.0 E+01$ & $1.7 \mathrm{E}+01$ & $6.6 E+00$ & $9.3 \mathrm{E}-01$ & $4.0 \mathrm{E}+01$ & $2.0 \mathrm{E}+01$ & $8.8 E+00$ & $1.3 E+00$ \\
\hline Array of 117 (end) & Neutron & $4.4 \mathrm{E}+00$ & $1.7 E+00$ & $6.8 \mathrm{E}-01$ & $9.5 \mathrm{E} \cdot \mathrm{O} 2$ & $3.7 E+00$ & $1.7 \mathrm{E}+00$ & $7.5 \mathrm{E}-01$ & $1.1 \mathrm{E}-01$ \\
\hline Array of 117 (end) & Total & $5.4 \mathrm{E}+01$ & $1.8 E+01$ & $7.3 \mathrm{E}+00$ & $1.0 \mathrm{E}+00$ & $4.4 E+01$ & $2.2 E+01$ & $9.6 \mathrm{E}+00$ & $1.4 \mathrm{E}+00$ \\
\hline \multicolumn{10}{|c|}{ FERMCO Scrap - $11 \mathrm{in.}(27.94 \mathrm{~cm})$ OD $\times 4$ in. $(10.16 \mathrm{~cm})$ long } \\
\hline Array of 154 (end) & Photon & $4.8 \mathrm{E}+01$ & $1.5 \mathrm{E}+01$ & $6.2 \mathrm{E}+00$ & $8.9 \mathrm{E}-01$ & $4.4 E+01$ & $2.4 \mathrm{E}+01$ & $1.2 \mathrm{E}+01$ & $2.0 \mathrm{E}+00$ \\
\hline Array of 154 (end) & Neutron & $4.8 E+00$ & $1.7 \mathrm{E}+00$ & $6.8 \mathrm{E}-01$ & $9.5 E-02$ & $3.1 E+00$ & $1.6 \mathrm{E}+00$ & $8.0 \mathrm{E}-01$ & $1.3 \varepsilon-01$ \\
\hline Array of 154 (end) & Total & $5.3 E+01$ & $1.7 \mathrm{E}+01$ & $6.9 \mathrm{E}+00$ & $9.8 \mathrm{E}-01$ & $4.7 \mathrm{E}+01$ & $2.6 \mathrm{E}+01$ & $1.3 E+01$ & $2.1 \mathrm{E}+00$ \\
\hline
\end{tabular}




\subsubsection{ORIGEN2 Input File for $0.95 \%$ Enriched Uranium}

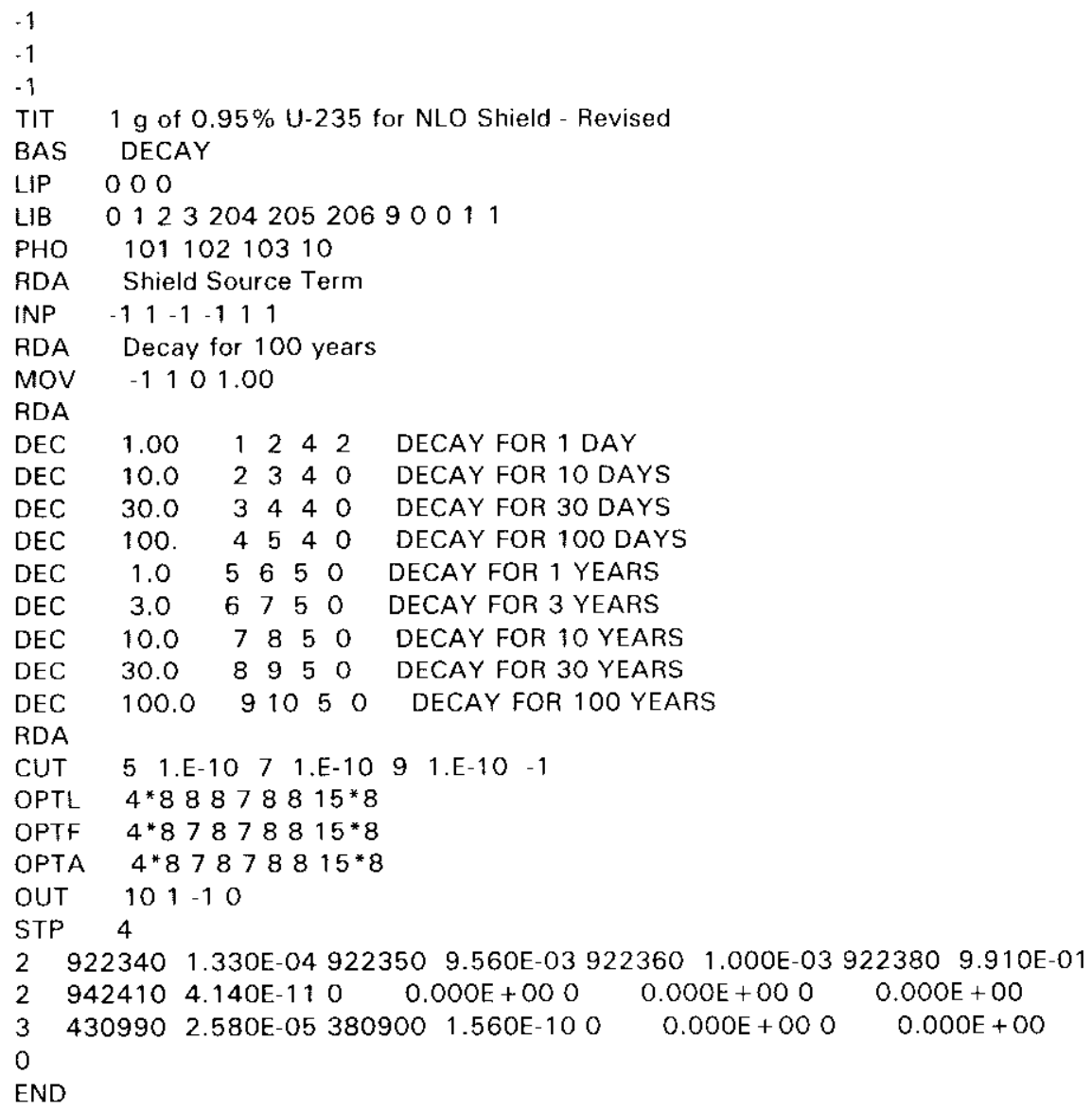




\subsubsection{ORIGEN2 Input File for $1.1 \%$ Enriched Uranium}

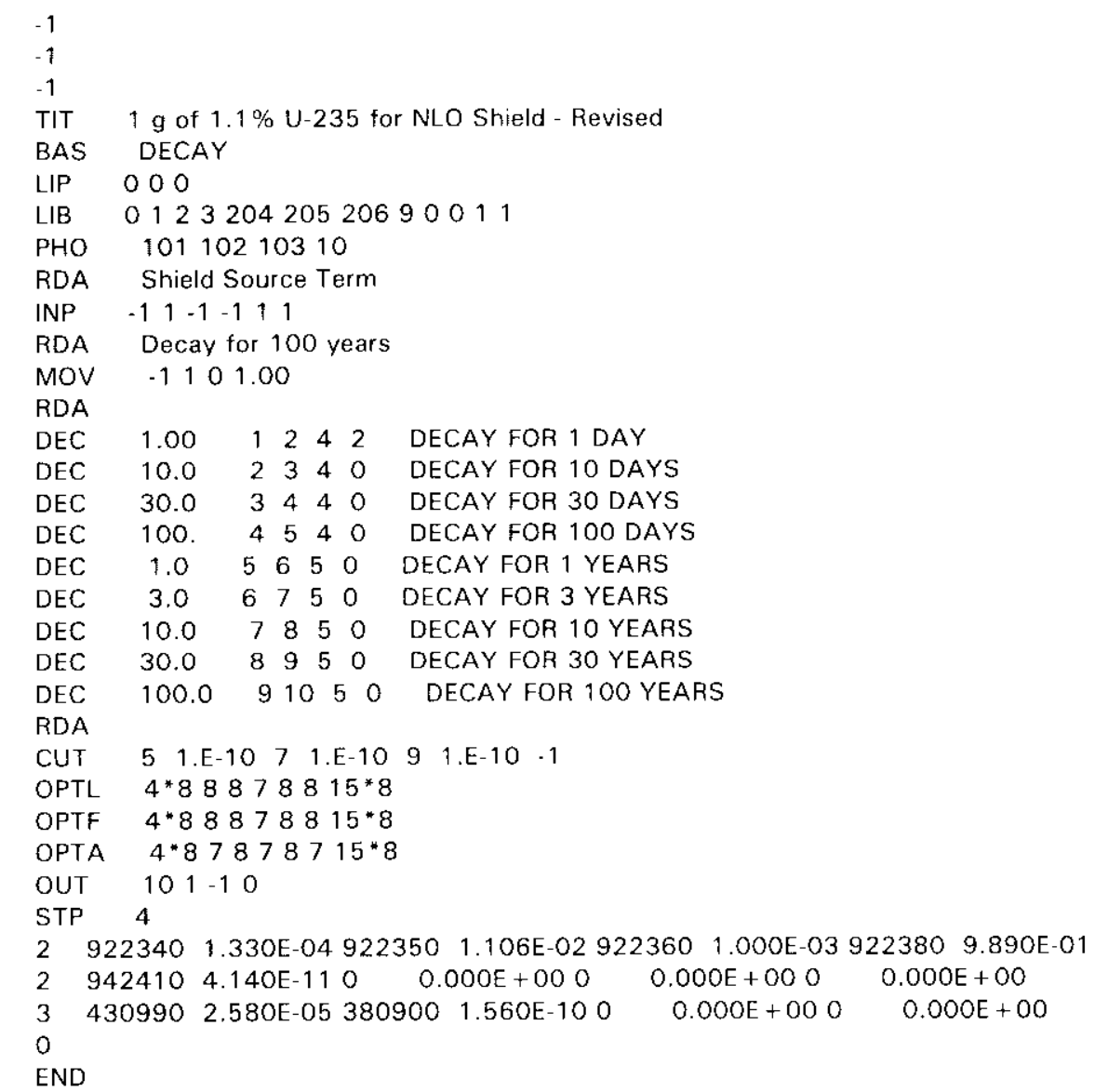




\subsubsection{ORIGEN2 Input File for $1.25 \%$ Enriched Uranium}

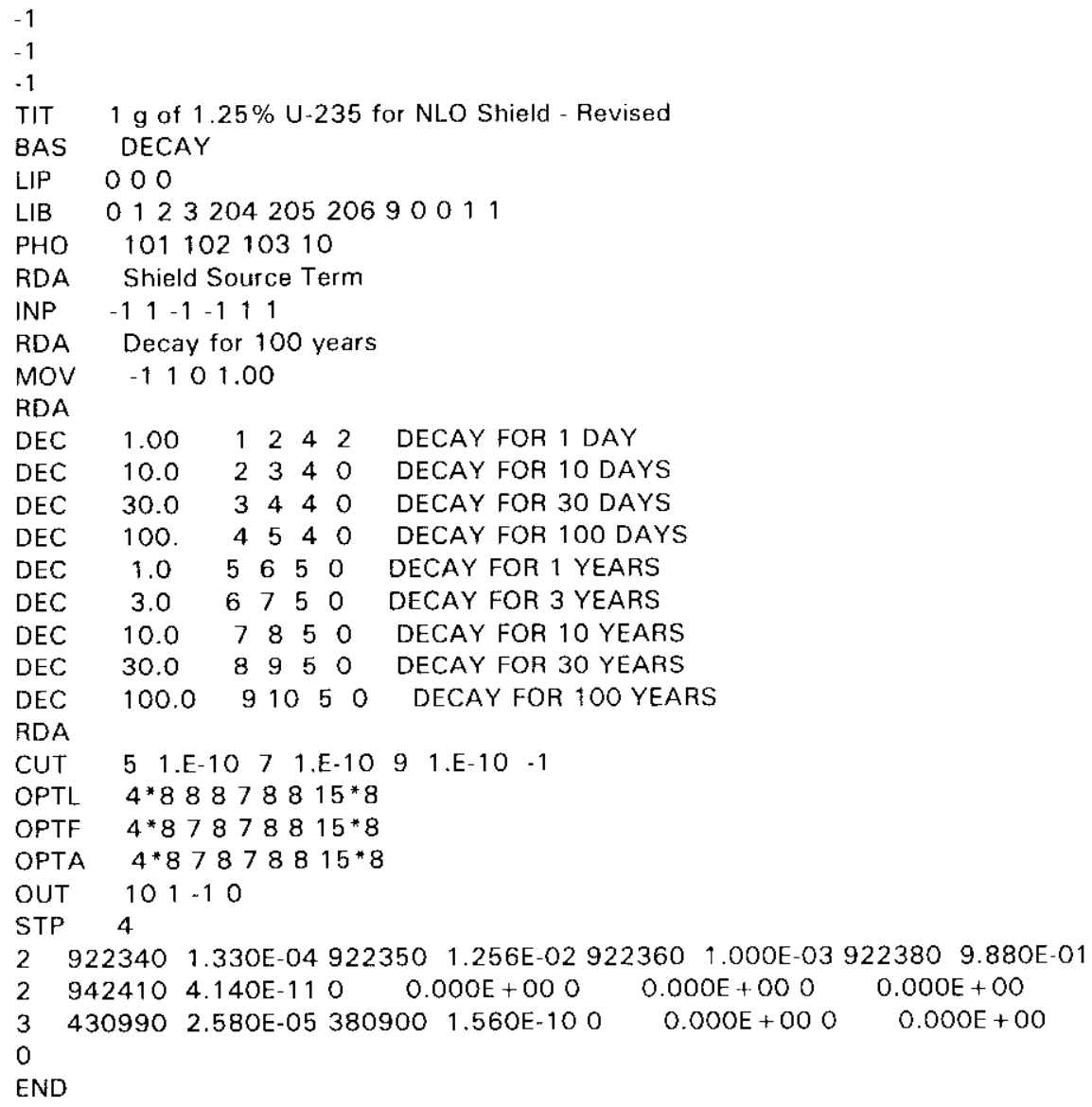




\subsubsection{MCNP Input File for Single Ingot/Billet Photon Dose Rates}

Included here are sample MCNP input files for a single piece dose rate calculation. The other files for the rest of the calculations differ only in the annulus or cylinder dimensions (as shown in Table 5.3.1), the source (shown in Tables 5.2.1-1 and 5.2.1-2), material ${ }^{238} \mathrm{U}$ and ${ }^{235} \mathrm{U}$ in the proper enrichment), and the detector positions ( $2 \mathrm{in.}, 1 \mathrm{~m}, 2 \mathrm{~m}$, and $6 \mathrm{~m}$ from the billet or ingot surfaces).

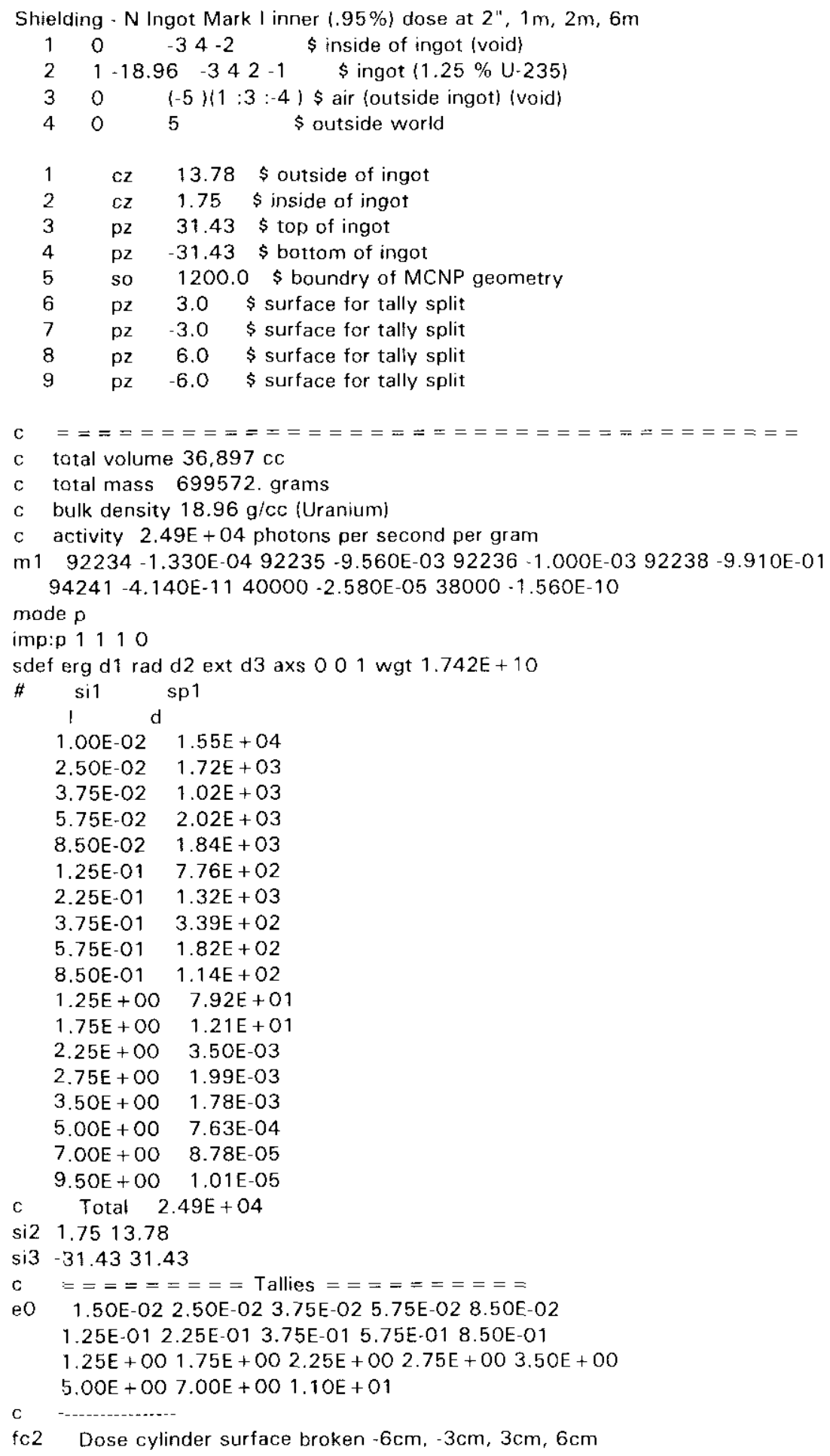


$\mathrm{f} 2: \mathrm{p} 1$

ts $2-9-7 \cdot 6-8 t$

c

fc12 Dose top surface broken at inner radius

$f 12: p 3$

fs 122

C

$f_{c} 5$ Dose 2" from ingot cylindrical surface (ring tally)

f5z:p 018.860

$c$

fc15 Dose 1 meter from ingot cylindrical surface (ring tally) $\uparrow 15 z: p \quad 0113.780$

c

fc25 Dose 2 meter from ingot cylindrical surface (ring tally)

f25z:p 0213.780

c

fc35 Dose 6 meter from ingot cylindrical surface (ring tally)

f35z:p 0613.780

c

fc45 Dose 2" from ingot top surface, offset (ring talty)

f45z:p 36.517 .760

c

fC55 Dose 2" from ingot top surface (point tally)

f55:p 0036.510

c

fc65 Dose 1 meter from ingot top surface (point tally)

f65:p 00131.430

c

fc75 Dose 2 meter from ingot top surface (point tally)

f75:p 00231.430

c

fc85 Dose 6 meter from ingot top surface (point tally)

f85:p 00631.430

c

C $\mathrm{z}=\mathrm{z}=\mathrm{=}=\mathrm{=}=\mathrm{z}=\mathrm{m}=\mathrm{m}=\mathrm{=}=\mathrm{=}=\mathrm{z}=\mathrm{m}=$

c ansi/ans-6.1.1-1991

c fluence-to-dose, photons $\left(\mathrm{mrem} / \mathrm{hr} /\left(\mathrm{p} / \mathrm{cm}^{*} * 2 / \mathrm{s}\right)\right.$

de0 $\log .01 .015 .02 .03 .04 .05$

$.06 .08 \cdot 10.15 .20 .30$

.40 .50 .60 .801 .01 .5

2.03 .04 .05 .06 .08 .0

10. 12 .

dfO $\log 2.232 \mathrm{e}-5 \quad 5.652 \mathrm{e}-5 \quad 8.568 \mathrm{e}-5 \quad 1.184 \mathrm{e}-4 \quad 1.314 \mathrm{e}-4 \quad 1.382 \mathrm{e}-4$ $1.440 \mathrm{e}-4 \quad 1.624 \mathrm{e}-4 \quad 1.919 \mathrm{e}-42.797 \mathrm{e}-4 \quad 3.708 \mathrm{e}-45.616 \mathrm{e}-4$

$7.416 \mathrm{e}-4 \quad 9.144 \mathrm{e}-4 \quad 1.076 \mathrm{e}-3 \quad 1.379 \mathrm{e}-3 \quad 1.656 \mathrm{e}-3 \quad 2.246 \mathrm{e}-3$

$2.758 \mathrm{e}-3 \quad 3.672 \mathrm{e}-3 \quad 4.500 \mathrm{e}-3 \quad 5.292 \mathrm{e}-3 \quad 6.012 \mathrm{e}-37.488 \mathrm{e}-3$ $8.892 \mathrm{e}-31.040 \mathrm{e}-2$

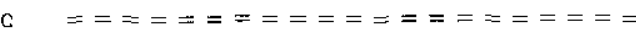

print

ctme 30 


\subsubsection{MCNP Input File for Single Ingot/Billet Neutron Dose Rates}

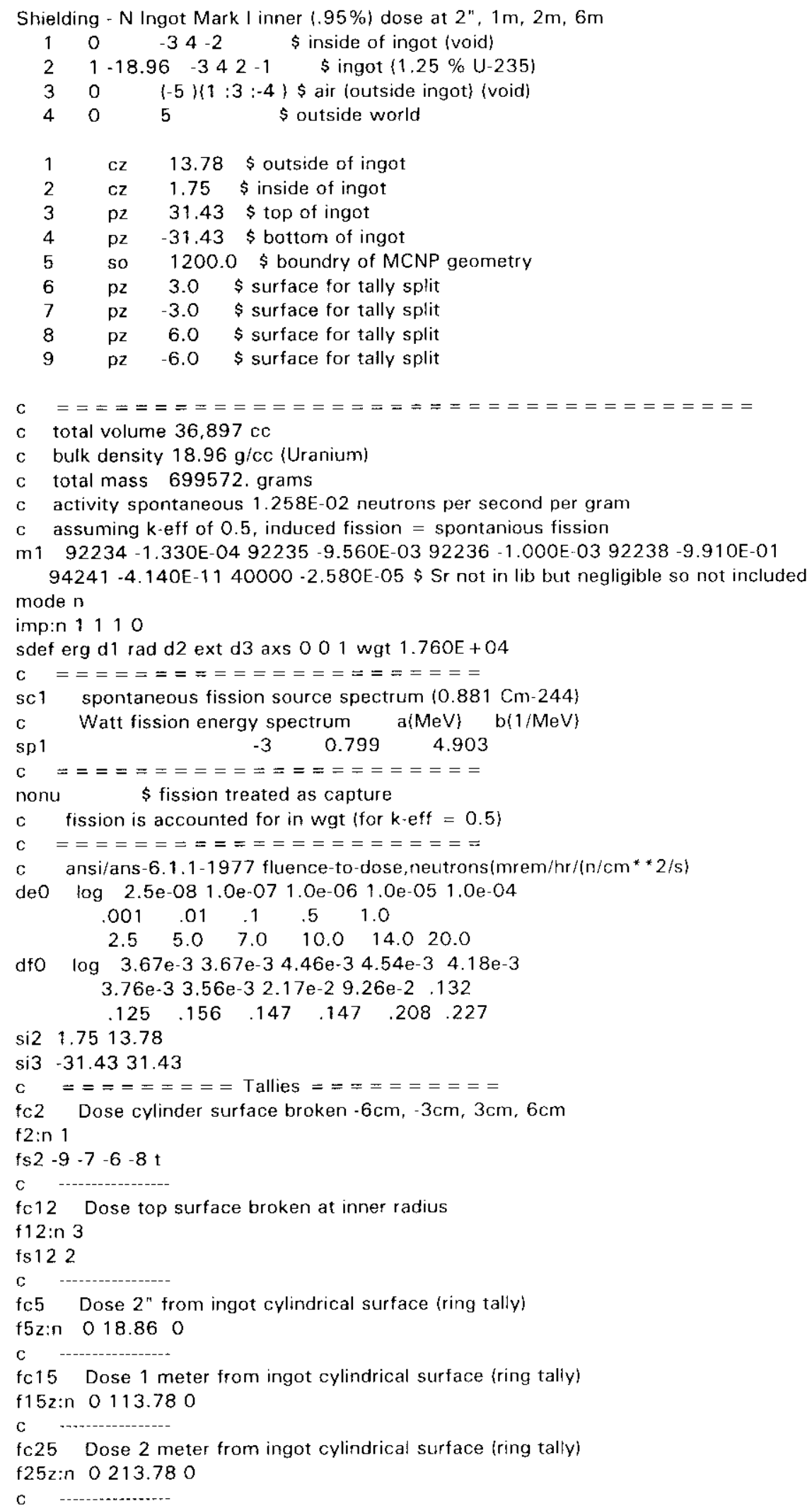


fo35 Dose 6 meter from ingot cylindrical surface (ring tally) f35z:n 0613.780

c

fc45 Dose 2" from ingot top surface, offset (ring tally)

f45z:n 36.517 .760

c

fc55 Dose 2" from ingot top surface (point tally)

f55:n 0036.510

$\mathrm{c} \quad$ -

fc65 Dose 1 meter from ingot top surface (point tally) $f 65: n \quad 00131.430$

$\mathrm{c}$...................

fc75 Dose 2 meter from ingot top surface (point tally)

$f 75: n \quad 00231.430$

$\mathrm{c}$

fc85 Dose 6 meter from ingot top surface (point tally)

f85:n 00631.430

$\mathrm{c}=\mathrm{C}=\mathrm{=}=\mathrm{e}=\mathrm{=}=\mathrm{=}=\mathrm{=}=\mathrm{=}=\mathrm{=}=\mathrm{=}$

print

ctme 30 


\subsubsection{MCNP Input File for 135 Billet Lattice Photon End Dose Rates}

Included here are sample MCNP input files for array dose rate calculations. The other files for the rest of the calculations differ in the annulus or cylinder dimensions (as shown in Table 5.3.1), the source (shown in Tables 5.2.1-1 and 5.2.1-2), material ${ }^{238} \mathrm{U}$ and ${ }^{235} \mathrm{U}$ in the proper enrichment), the detector positions ( $2 \mathrm{in}, 1 \mathrm{~m}, 2 \mathrm{~m}$, and $6 \mathrm{~m}$ from the billet or ingot surfaces), and in the lattice shape and number of pieces in the lattice.

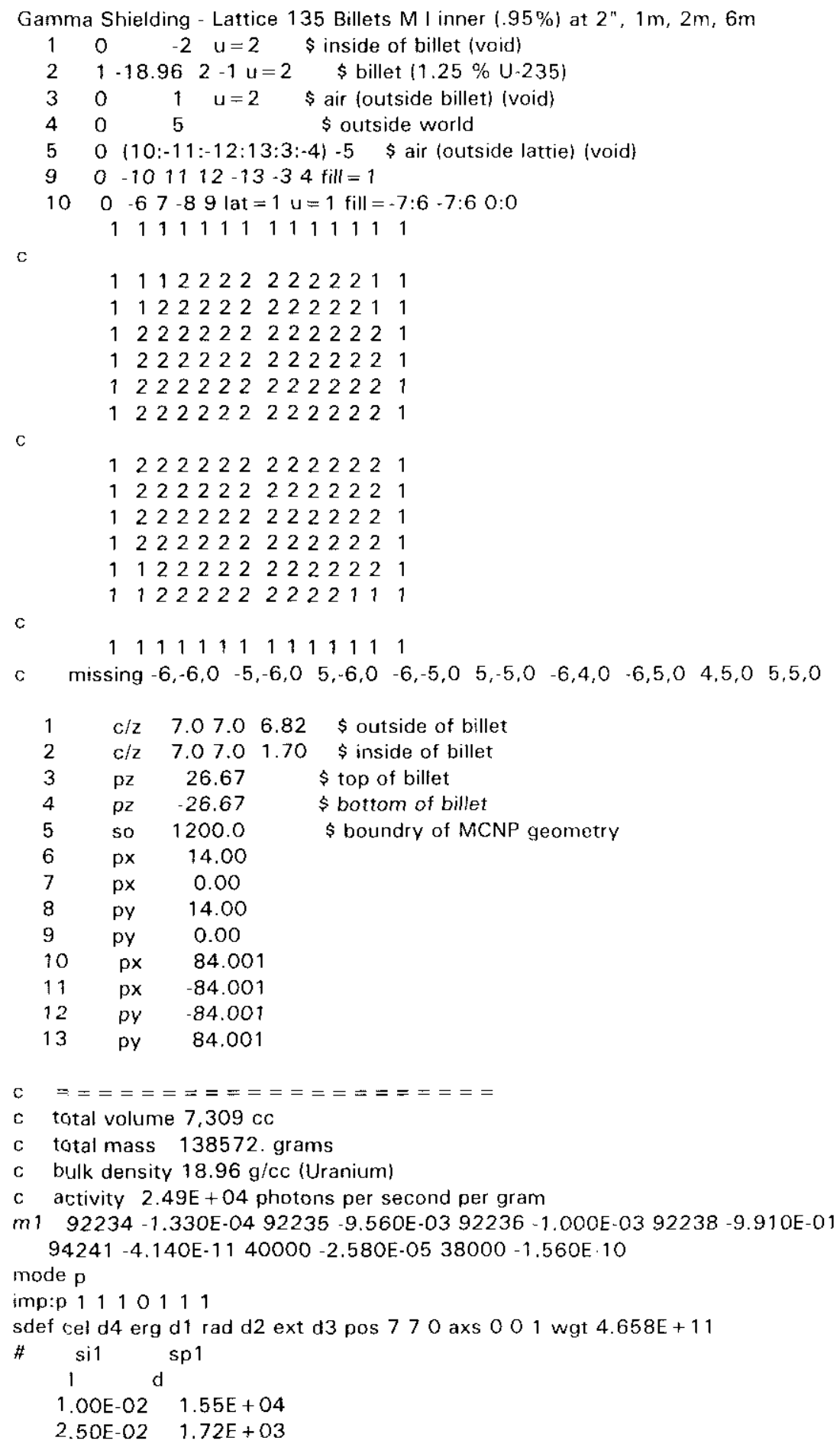




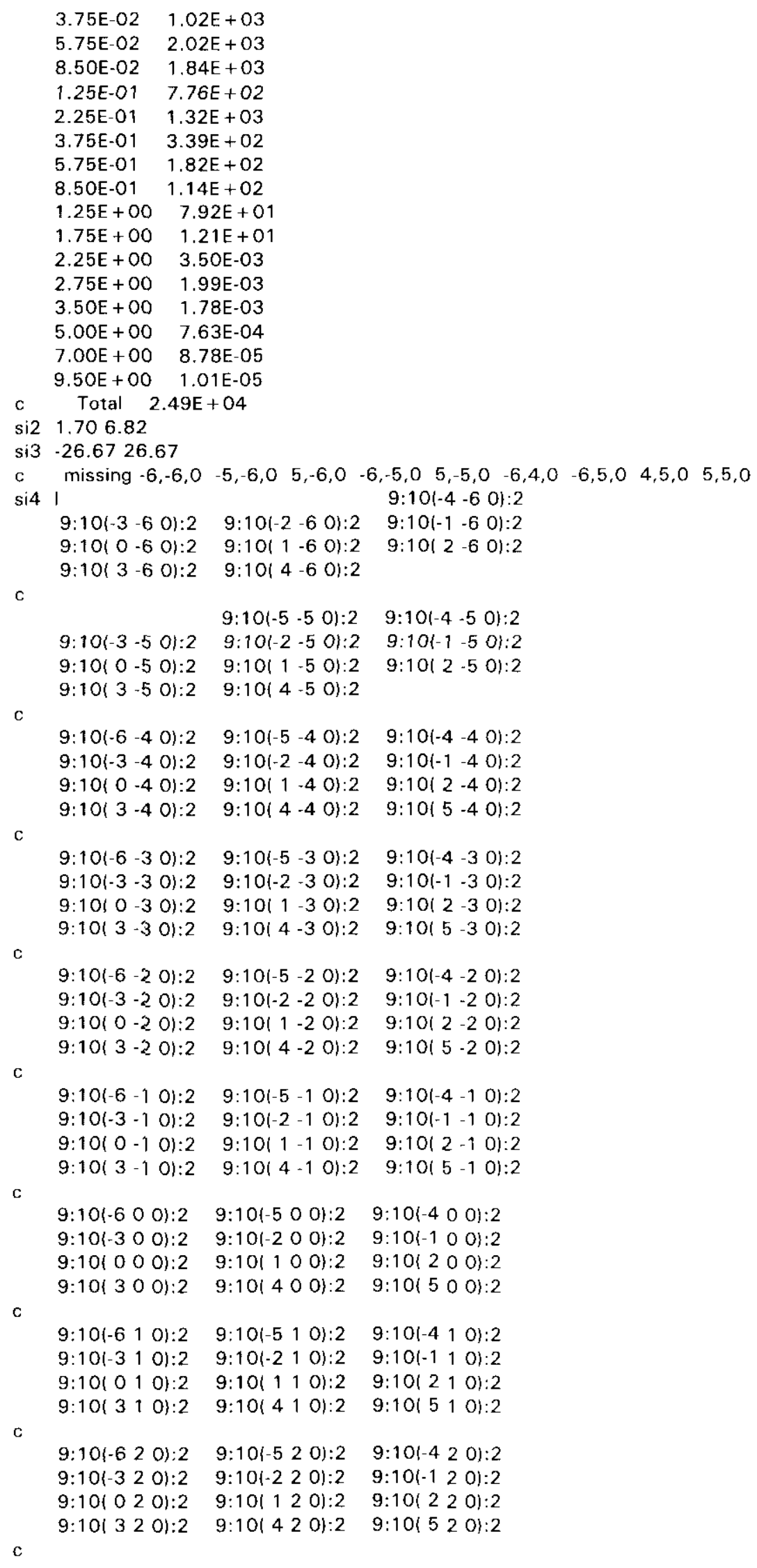




$\begin{array}{lll}9: 10(-630): 2 & 9: 10(-530): 2 & 9: 10(-430): 2 \\ 9: 10(-330): 2 & 9: 10(-230): 2 & 9: 10(-130): 2 \\ 9: 10(030): 2 & 9: 10(130): 2 & 9: 10(230): 2 \\ 9: 10(330): 2 & 9: 10(430): 2 & 9: 10(530): 2\end{array}$

$\begin{array}{lll} & 9: 10(-540): 2 & 9: 10(-440): 2 \\ 9: 10(-340): 2 & 9: 10(-240): 2 & 9: 10(-140): 2 \\ 9: 10(040): 2 & 9: 10(140): 2 & 9: 10(240): 2 \\ 9: 10(340): 2 & 9: 10(440): 2 & 9: 10(540): 2\end{array}$

9:10(-5 5 0):2 9:10(-450):2

$9: 10(-350): 2 \quad 9: 10(-250): 2 \quad 9: 10(-150): 2$

$9: 10(050): 2 \quad 9: 10(150): 2 \quad 9: 10(250): 2$ $9: 10(350): 2$

c. missing $6,-6,0 \quad-5,-6,0 \quad 5,-6,0 \quad-6,-5,0 \quad 5,-5,0 \quad-6,4,0 \quad-6,5,0 \quad 4,5,0 \quad 5,5,0$

sp4 11111111111111

11111111111

111111111111111

$\begin{array}{llllllllllll}1 & 1 & 1 & 1 & 1 & 1 & 1 & 1 & 1 & 1 & 1 & 1\end{array}$

1111111111111

1111111111111

c

1111111111111

11111111111111111

$\begin{array}{lllllllllllll}1 & 1 & 1 & 1 & 1 & 1 & 1 & 1 & 1 & 1 & 1 & 1\end{array}$

111111111111

11111111111111111

11111111111

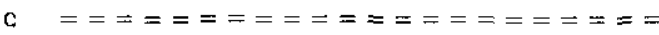

C ansi/ans-6.1.1-1991

c fluence-to-dose, photons $(\mathrm{mrem} / \mathrm{hr} /(\mathrm{p} / \mathrm{cm} * * 2 / \mathrm{s})$

deo $\log .01 .015 .02 .03 .04 .05$

.06 .08 .10 .15 .20 .30

.40 .50 .60 .801 .01 .5

2.03 .04 .05 .06 .08 .0

10. 12 .

dfo $\log 2.232 e-5 \quad 5.652 e-5 \quad 8.568 e-5 \quad 1.184 e-4 \quad 1.314 e-4 \quad 1.382 e-4$

$1.440 \mathrm{e}-4 \quad 1.624 \mathrm{e}-4 \quad 1.919 \mathrm{e}-4 \quad 2.797 \mathrm{e}-4 \quad 3.708 \mathrm{e}-45.616 \mathrm{e}-4$

$7.416 \mathrm{e}-49.144 \mathrm{e}-4 \quad 1.076 \mathrm{e}-3 \quad 1.379 \mathrm{e}-3 \quad 1.656 \mathrm{e}-32.246 \mathrm{e}-3$

$2.758 \mathrm{e}-3 \quad 3.672 \mathrm{e}-3 \quad 4.500 \mathrm{e}-35.292 \mathrm{e}-36.012 \mathrm{e}-37.488 \mathrm{e}-3$

$8.892 \mathrm{e}-3 \quad 1.040 \mathrm{e}-2$

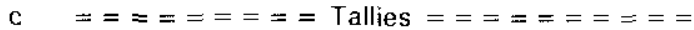

c

fc5 Dose 2" from array top surface, offset 7" (center of ingot) (point tally)

f5:p 7.07 .031 .750

c.

fc15 Dose 2 " from array top surface (point tally)

f15:p 0031.750

ci

fc25 Dose 1 meter from array top surface (point tally)

f25:p 00126.670

$c$

fc35 Dose 2 meter from array top surface (point tally)

f35:p 00226.670

c

fc45 Dose 6 meter from array top surface (point tally)

f45:p 00626.670

$c \quad-$

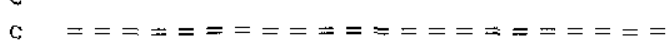

ctme 30 


\subsubsection{MCNP Input File for 117 Cylinder Lattice Side Dose Rate}

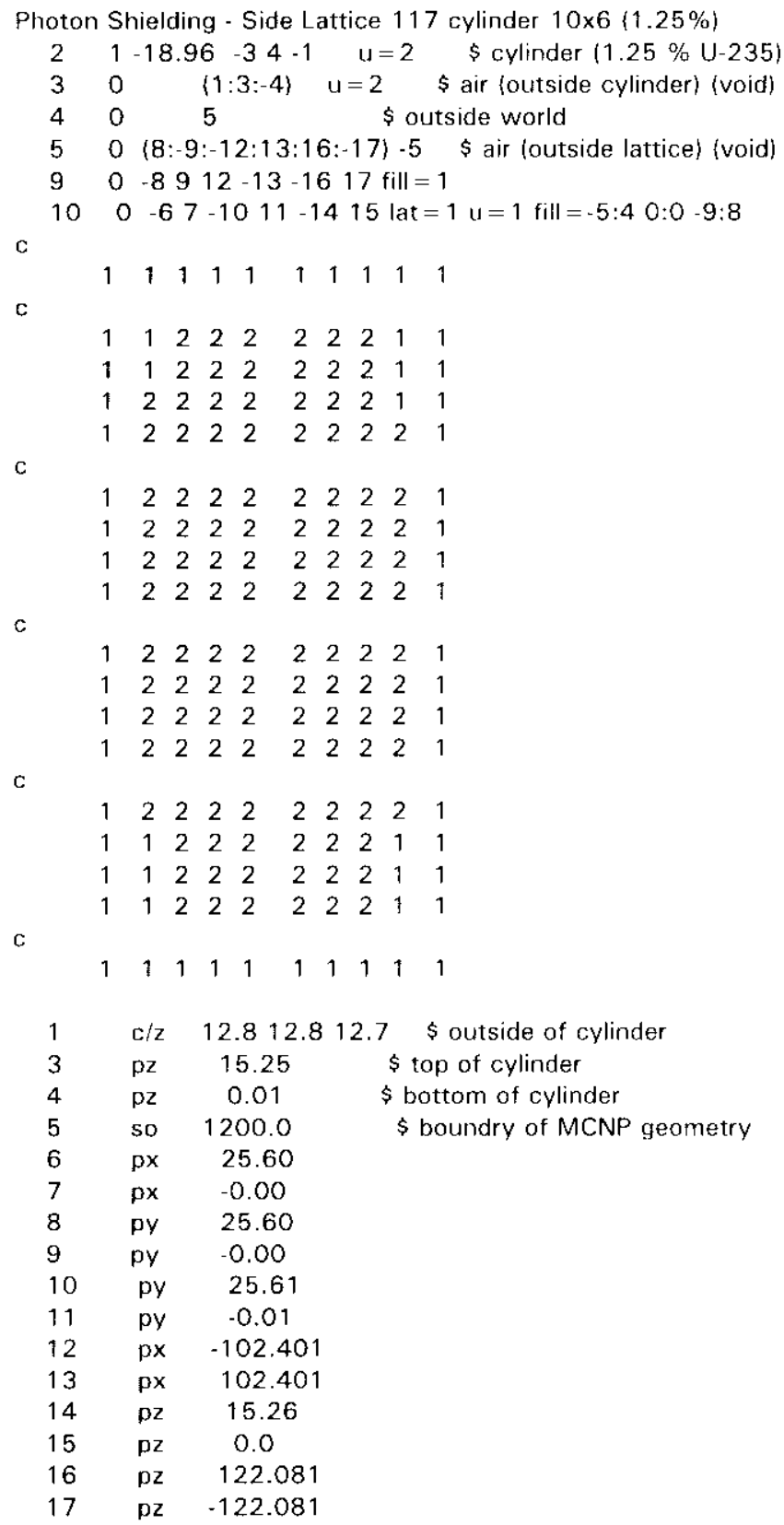




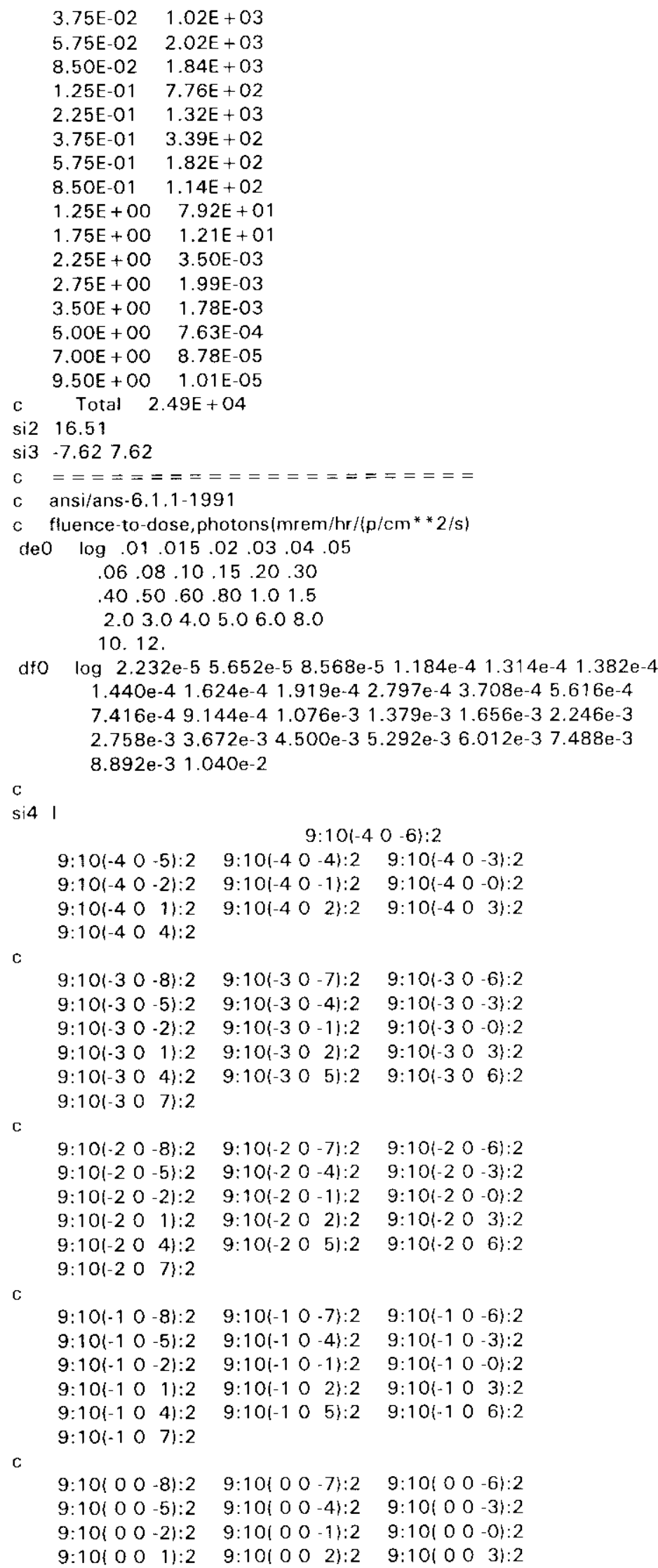


$9: 10(00 \quad 4): 2 \quad 9: 10(00 \quad 5): 2 \quad 9: 10(000): 2$

C $9: 10\left(\begin{array}{lll}0 & 0 & 7): 2\end{array}\right.$

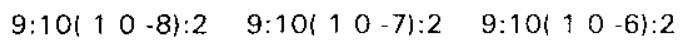

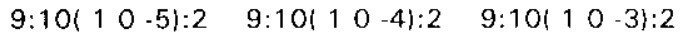
9:10(1 $10-2): 2 \quad 9: 10(10-1): 2 \quad 9: 10(10-0): 2$

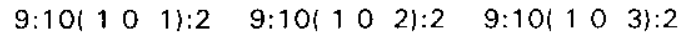
$9: 10\left(\begin{array}{lllllll}1 & 0 & 4): 2 & 9: 10(10 & 5): 2 & 9: 10(10 & 0\end{array}\right.$

c 9:10( 1 ( 0 7):2

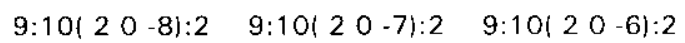
$9: 10(20-5): 2 \quad 9: 10(20-4): 2 \quad 9: 10(20-3): 2$ 9:10( $20-2): 2 \quad 9: 10(20-1): 2 \quad 9: 10(20-0): 2$ 9:10(2 2 O 1$): 2 \quad 9: 10(20 \quad 2): 2 \quad 9: 10(20) 3): 2$ $9: 10(20 \quad 4): 2 \quad 9: 10(20) 5): 2 \quad 9: 10(206): 2$

c $9: 10(207): 2$

$9: 10(30-5): 2$

$9: 10(30-2): 2 \quad 9: 10(30-1): 2 \quad 9: 10(30-0): 2$

9:10(30 1):2 $\quad 9: 10(30 \quad 2): 2 \quad 9: 10(30 \quad 3): 2$

c

$9: 10(30$ 4):2

sp4

$\begin{array}{llllll}1 & 1 & 1 & 1 & 1 & 1\end{array}$

111111

1111111

111111111

c

$\begin{array}{llllllll}1 & 1 & 1 & 1 & 1 & 1 & 1 & 1\end{array}$

111111111111

$\begin{array}{llllllll}1 & 1 & 1 & 1 & 1 & 1 & 1 & 1\end{array}$

11111111

c

$\begin{array}{llllllll}1 & 1 & 1 & 1 & 1 & 1 & 1\end{array}$

111111111

$\begin{array}{llllllll}1 & 1 & 1 & 1 & 1 & 1 & 1 & 1\end{array}$

111111111

c

11111111

111111

$\begin{array}{llllll}1 & 1 & 1 & 1 & 1 & 1\end{array}$

111111

c $=\mathrm{x}=\mathrm{=}=\mathrm{=}=\mathrm{x}=\mathrm{e}=\mathrm{e}=\mathrm{e}=\mathrm{=}=\mathrm{=}$

c $===== \pm=$ Tallies $========$

c

fc5 Dose 2" from array side surface offset

$f 5: p \quad 12.8-5.0800$

c

fc15 Dose 2" from array side surface

$f 15: p \quad 0-5.0800$

c

fc25 Dose 1 meter from array side surface

f25:p $\quad 0-10000$

$c$

fc35 Dose 2 meter from array side surface

f35:p $0-20000$

c

fc45 Dose 6 meter from array side surface

$f 45: p \quad 0-60000$

c

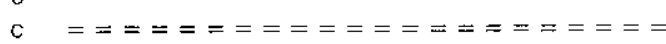

ctme 30 


\subsubsection{MCNP Input File for 117 Cylinder Lattice Top Dose Rate}

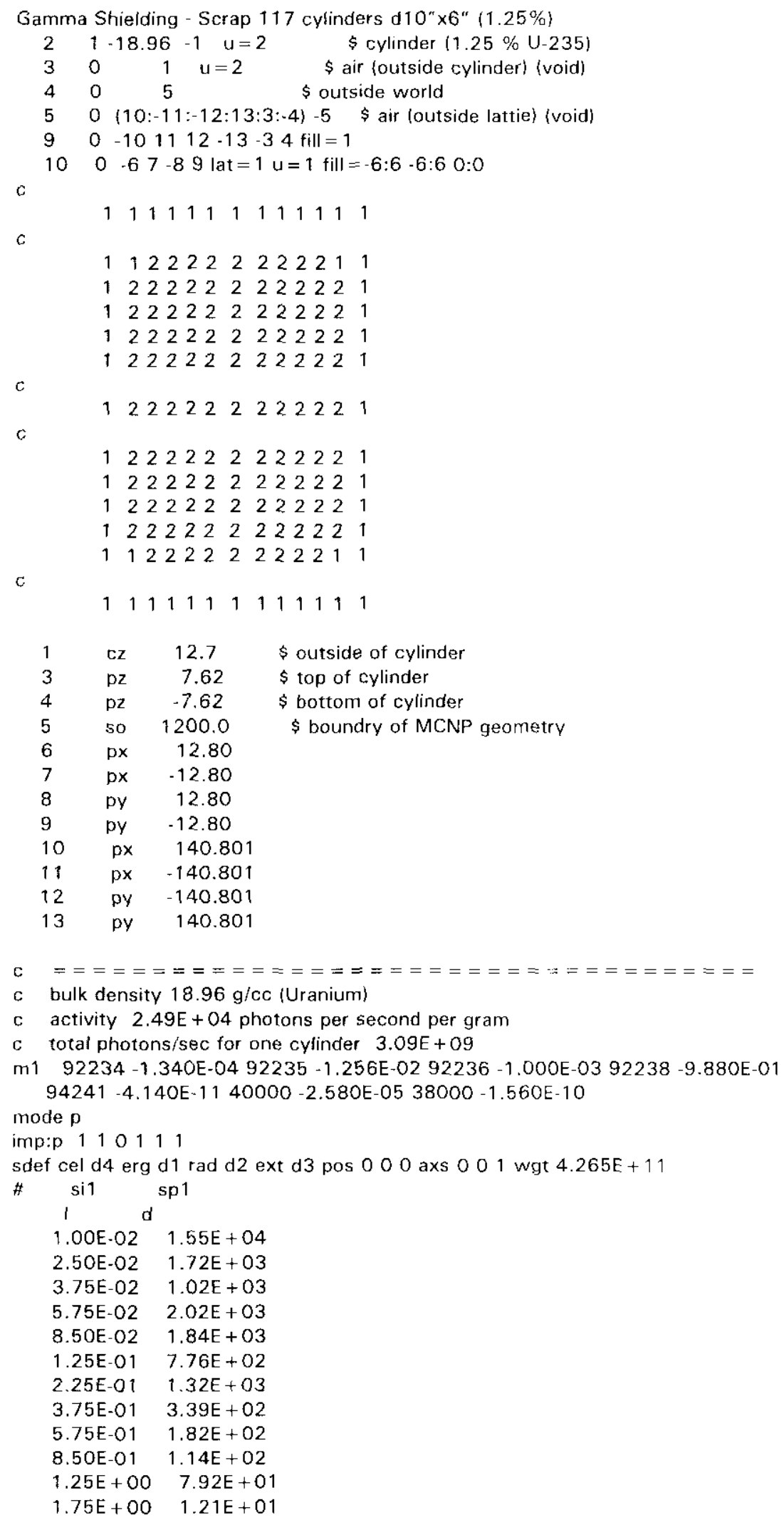


$9: 10(-5-4$ 0):2 9:10(-4 -4 0):2 9:10(-3-4 0):2 9:10( $-2-4$ 0):2 9:10( $-1-4$ 0):2 9:10( 0.40$): 2$ 9:10( $1-4$ o):2 9:10( $2-4$ 0):2 9:10( $3-4$ o):2 $9: 10\left(\begin{array}{l}4 \\ -4\end{array}\right): 2 \quad 9: 10(5-4$ 0):2

c

$9: 10(-5-3$ o):2 9:10( -4 -3 0):2 9:10( $-3-30): 2$ $9: 10(-2-3$ o):2 9:10(-1 -3 0):2 9:10( $0-30): 2$

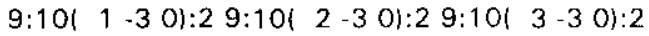
$9: 10(4-3$ ) $): 29: 10(5-30): 2$

c

$9: 10(-5-20): 29: 10(-4-20): 29: 10(-3-20): 2$ 9:10( - -2 - 0):2 9:10( - $1-2$ 0):2 9:10( $0-2$ 0):2

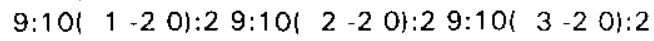
9:10( $4-2$ 0):2 9:10( $5-2$ 0):2

c

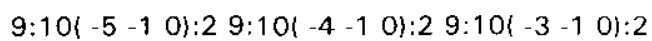
9:10 $-2-1$ 0):2 9:10( $-1-1 \quad 0): 2 \quad 9: 10(0-1 \quad 0): 2$

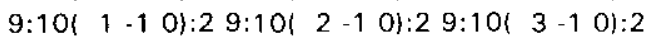
9:10( $4-1$ 0):2 9:10( $5-10): 2$

c

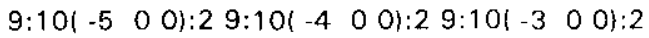

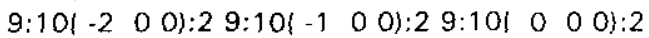

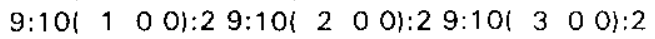
9:10( 4 0 0):2 9:10( 5 0 0):2

c

$9: 10(-5 \quad 10): 2$ 9:10(-4 1 0):2 9:10( $-3 \quad 1$ ) $: 2$

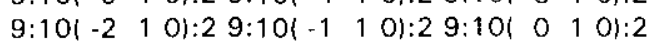
$9: 10$ 이 $1 \quad 1$ 0):2 9:10( $2 \quad 1$ 0):2 9:10( $3 \quad 1$ 0):2

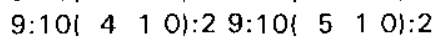

c

9:10( $-5 \quad 2$ 0):2 9:10(-4 2 0):2 9:10(-3 2 0):2 9:10( $-2 \quad 2$ 0):2 9:10(-1 2 0):2 9:10( 02 0):2 $9: 10$ ( 12 0):2 9:10( 22 0):2 9:10( 322 ) :2

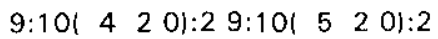

c

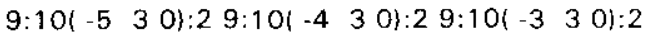
9:10(-2 3 0):2 9:10(-1 3 0):2 9:10( 03 0):2

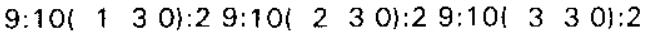

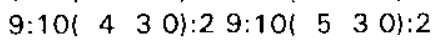

c

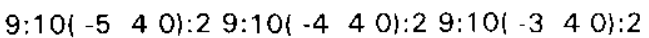
$9: 10(-2 \quad 4$ 0):2 9:10(-1 4 0):2 9:10( 04 0):2

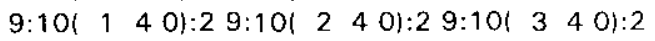
9:10 $4 \quad 4$ 아:2 9:10 $5 \quad 4$ 아:2

c

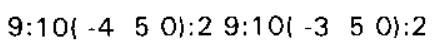
9:10( $-2 \quad 5$ 0):2 9:10(-1 5 0):2 9:10( 050 ) 5 :2 9:10( 15 0):2 9:10( 25 0):2 9:10( 350$): 2$ $9: 10(4 \quad 50): 2$

c

$\operatorname{sp} 4$ 


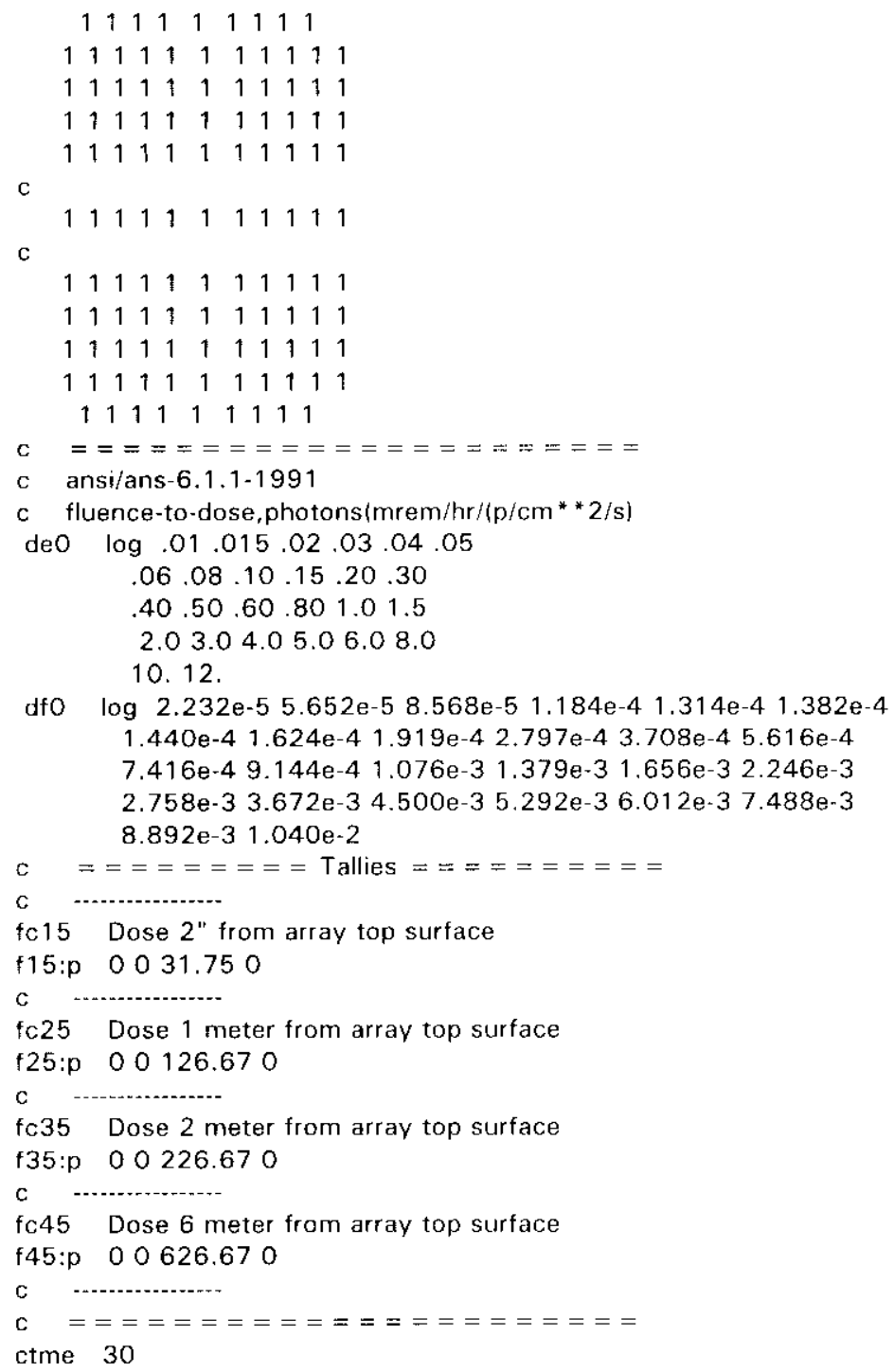




\subsection{CRITICALITY EVALUATION}

This chapter discusses and analyzes the principal criticality engineering-physics design of the steel banded wooden containers G-4214, G-4292, G-4245, G-4255, and G-4273 and contents important to safety and necessary to comply with $10 \mathrm{CFR} 71$. The performance requirements are specified in 10 CFR 71.55 and 10 CFR 71.59 and are summarized in Table 6.0-1.

TABLE 6.0-1. Performance Requirements.

\begin{tabular}{|c|c|}
\hline \multicolumn{2}{|c|}{ General Requirements } \\
\hline \multicolumn{2}{|r|}{ A package must be subcritical if water were to leak into the containment system under the following conditions: } \\
\hline 1 & Most reactive credible configuration consistent with the chemical and physical form of the material. \\
\hline 2 & Moderation by water to the most reactive credible extent. \\
\hline 3 & $\begin{array}{l}\text { Close full reflection of the containment system by water on all sides or such greater reflection of the system as } \\
\text { may be provided by the material of the packaging. }\end{array}$ \\
\hline \multicolumn{2}{|c|}{ Normal Conditions of Transport (NCT) } \\
\hline 1 & The contents would be subcritical. \\
\hline 2 & The geometric form of the package contents would not be substantially altered. \\
\hline 3 & $\begin{array}{l}\text { There would be no leakage of water into the containment system unless in the evaluation of undamaged } \\
\text { packages it is assumed that moderation is present to cause maximum reactivity. }\end{array}$ \\
\hline 4 & $\begin{array}{l}\text { No substantial reduction in the effectiveness of the packaging: } \\
\text { i) No more than } 5 \% \text { reduction in total volume. } \\
\text { ii) No more than } 5 \% \text { reduction in effective spacing. } \\
\text { iii) No occurrence of an aperture in the outer surface of the packaging large enough to admit a } 4^{\text {" cube. }}\end{array}$ \\
\hline \multicolumn{2}{|c|}{ Hypothetical Accident Conditions (HAC) } \\
\hline \multicolumn{2}{|c|}{ The package is subcritical under the following conditions: } \\
\hline 1 & Most reactive credible configuration consistent with the chemical and physical form of the material. \\
\hline 2 & Moderation by water to the most reactive credible extent. \\
\hline 3 & Full reflection by water on all sides. \\
\hline \multicolumn{2}{|c|}{ STANDARDS FOR ARRAYS } \\
\hline \multicolumn{2}{|r|}{$\begin{array}{l}\text { A package must be controlled to assure that an array remains subcritical. Derive a number } N \text { such that assuming } \\
\text { packages are stacked together in any arrangement and with close full reflection on all sides of the stack by water: }\end{array}$} \\
\hline 1 & 5 time $\mathrm{N}$ undamaged packages with nothing between the packages would be subcritical. \\
\hline 2 & 2 times $\mathrm{N}$ damaged packages would be subcritical with optimum interspersed hydrogenous moderation. \\
\hline 3 & $N \geq 0.5$ \\
\hline \multicolumn{2}{|c|}{ TRANSPORT INDEX (TI) } \\
\hline & by $N ; T=O$ if $N=$ infinity \\
\hline
\end{tabular}


The steel banded wooden containers are to be used to ship excess unirradiated uranium metal products that include low-enriched uranium ingots, billets, extrusions, and scrap materials. The materials are identified as (A) Mark I and Mark IV ingots, (B) RMI forged billets, (C) Mark 15 ingots, (D) miscellaneous material, including primary ingots, product ingots, ingot sections, and scrap, that is located at Fernald Environmental Restoration Management Corporation (FERMCO), and (E) FERMCO derbies. To avoid confusion, the criticality evaluation for each type of material is presented separately. Table 6.0-2 lists an alphabetic material designator used throughout this chapter for each material, the material and material configuration, the ${ }^{235} \mathrm{U} w \mathrm{wt} \%$ enrichment of the material, the container in which the material will be shipped, and the quantity per container.

TABLE 6.0-2. Wooden Boxes and Contents.

\begin{tabular}{|c|c|c|c|c|c|}
\hline & Material & $\begin{array}{l}W \mathrm{t} \% \\
235 \mathrm{U}\end{array}$ & Container & $\begin{array}{l}\text { Contents per } \\
\text { Container }\end{array}$ & $\begin{array}{l}\text { Containers per } \\
\text { Shipment (by } \\
\text { Weight Limit) }\end{array}$ \\
\hline \multirow{5}{*}{ A } & N Reactor Ingots & $\cdots$ & $\ldots$ & --- & --- \\
\hline & Mark I Inner & 0.95 & $G \cdot 4273-5$ & 2 ingots & 13 \\
\hline & Mark | Outer & 1.25 & G-4273-6 & 2 ingots & 13 \\
\hline & Mark IV Inner & 0.95 & G-4273-5 & 2 ingots & 13 \\
\hline & Mark IV Outer & 0.95 & G-4273-6 & 2 ingots & 13 \\
\hline \multirow{6}{*}{$\mathrm{B}$} & RMI Forged Billets & $-\cdots$ & ---- & $-\cdots$ & $\cdots$ \\
\hline & Mark I Inner & 0.95 & G-4255 & 4 billets & 27 \\
\hline & Mark I Outer & 1.25 & G-4255 & 2 billets & 24 \\
\hline & Mark IV Inner & 0.95 & G-4255 & 4 billets & 27 \\
\hline & Mark IV Outer & 0.95 & G-4255 & 2 billets & 24 \\
\hline & Hanford RMI Mark I Outer & 1.25 & G-4255 & 3 billets & 29 \\
\hline & Mark 15 Ingots & 1.1 & $\ldots$ & $\cdots$ & --- \\
\hline & Inner & $\cdots \cdot$ & G-4273-5 & 4 ingots & 16 \\
\hline & Outer & ---- & G-4273-5 & 2 ingots & 16 \\
\hline D & Misc. FERMCO & 1.25 & $\begin{array}{c}\text { G-4273-5 } \\
\text { G-4273-6 } \\
\text { G-4292 } \\
\text { G-4214 }\end{array}$ & Various & Various \\
\hline$E$ & FERMCO Derbies & 1.25 & $\begin{array}{l}\text { G-4214 } \\
\text { G-4292 }\end{array}$ & 2 derbies & 52 \\
\hline
\end{tabular}

Each type of material has separate Sections 6.1 through 6.4. Section 6.1 gives the discussion and results, Section 6.2 is the package fuel loading, Section 6.3 discusses model specifications, and Section 6.4 presents the criticality calculations. Section 6.5 discusses the critical benchmark experiments for the computer code used for the calculations and Section 6.6 is the appendix to the chapter. 
Most of the original calculations were made with the nominal enrichments and without the minor and trace isotopes in the uranium; i.e., just with ${ }^{235} \mathrm{U}$ and ${ }^{238} \mathrm{U}$. Calculations have shown that the minor and trace elements decrease the multiplication factor, but use of the upper limit ${ }^{235} \mathrm{U}$ enrichment instead of the nominal enrichment can slightly increase the multiplication factor. Hence, each final calculation on which a mass limit is based was also calculated by changing the nominal ${ }^{235} \mathrm{U}$ enrichent $(0.950 \mathrm{wt} \%, 1.100 \mathrm{wt} \%$, and $1.250 \mathrm{wt} \%$ for the three enrichments) to its upper limit of $0.956 \mathrm{wt} \%$, and $1.256 \mathrm{wt} \%$. A case name for an upper limit enrichment calculation is the same as that of the corresponding base (nominal) calculation except a " $u$ " has been added to the end of the case name in the tables. The enrichment uncertainty is only $0.006 \mathrm{wt} \%$ so the difference between the two calculated $k_{\text {eff }}$ values is typically smaller than the statistical uncertainties between the two cases; i.e., the difference may be positive or negative because of statistics, although theoretically an enrichment increase should lead to a $k_{\text {eff }}$ increase. Since all parameters are the same between the base (nominal) calculation and the corresponding upper limit enrichment calculation, the mass is not effected by this; however, the summary tables [6.4.3 $(A, B, C, D$, or E)] showing the maximum allowed mass by configuration will show whichever calculated $k_{\text {eff }}$ is higher for that mass.

\section{1(A) DISCUSSION AND RESULTS - N REACTOR MARK I AND MARK IV INGOTS}

Mark I and Mark IV N Reactor ingots are packaged for shipment in the steel banded wooden container G-4273. There are two ingots per container and a limit (due to weight restrictions) of 13 containers per shipment. Container dimensions are given in Section 1.2. There are no criticality design features incorporated into the boxes.

The steel banded wooden container criticality analyses were performed with the Monte Carlo Neutron Photon (MCNP) code (Breismeister 1993; Carter 1995) for all calculations. Table 6.11 (A) gives the $k_{\infty}$ and $k_{\infty}+2 \sigma+$ code bias for an infinite array of ingots with optimum moderation and pitch. It shows that shipments of the Mark I inner and Mark IV inner and outer ingots will remain safely subcritical $\left(k_{\infty}+\right.$ code bias $\left.+2 \sigma<0.95\right)$ for all NCT and HAC events. (As discussed in Section 6.5 the code bias is equal to 0.00258.) Tables 6.1-1(A) and 6.1-2(A) also show that a finite array of 43.5 Mark 1 outer ingots in a hexagonal array with optimum moderation and pitch and full reflection by water has $a k_{\text {eff }}+$ code bias $+2 \sigma$ of less than 0.95 .

TABLE 6.1-1(A). Summary of N Reactor Ingot Criticality Evaluation.

\begin{tabular}{|l|c|c|c|}
\hline \multicolumn{4}{|c|}{ Infinite array of ingots with optimum moderation and pitch } \\
\hline \hline Ingot & $\mathrm{Wt}^{2}{ }^{235} \mathrm{U}$ & $\mathrm{k}_{\infty}$ & $\mathrm{k}_{\infty}+2 \sigma+$ bias \\
\hline Mark I Inner (H069) & 0.95 & 0.8970 & 0.9116 \\
\hline Mark I Outer (H068) & 1.25 & 0.9407 & 0.9555 \\
\hline Mark IV Inner (H066 & 0.95 & 0.8970 & 0.9116 \\
\hline Mark IV Outer (H067) & 0.95 & 0.8728 & 0.8874 \\
\hline \hline \multicolumn{2}{|c|}{ Array of Mark I outer ingots with uranium mass of $64,478 \mathrm{lb}(29,247 \mathrm{~kg})$} \\
at optimum moderation and pitch \\
\hline Ingot & Wt \% ${ }^{235} \mathrm{U}$ & $\mathrm{k}_{\mathrm{eff}}$ & $\mathrm{k}_{\text {eff }}+2 \sigma+$ bias \\
\hline \hline Mark I Outer (H068) & 1.25 & 0.9222 & 0.9371 \\
\hline \hline
\end{tabular}


Table 6.1-2(A) summarizes the criticality transport index (TI) and $N$ values. The infinite array is subcritical for Mark I inner, Mark IV inner and Mark IV outer ingots and the TI equals 0. The $\mathrm{TI}$ for the Mark I outer ingots is based on the keff plus uncertainties and bias for an optimized mass of $64,478 \mathrm{lb}(29,247 \mathrm{~kg})$ and is equal to 4.6 .

TABLE 6.1-2(A). Criticality Transport Index for Mark I and Mark IV Ingots.

\begin{tabular}{|l|c|c|c|c|c|}
\hline \multicolumn{1}{|c|}{ Type } & Shipping Box & $\begin{array}{c}\text { Ingots per } \\
\text { Box }\end{array}$ & $\begin{array}{c}2 \times \mathrm{N}^{(\text {(a) }} \\
\text { Boxes }\end{array}$ & N & TI \\
\hline \hline Mark I Inner & G-4273 & 2 & $\infty$ & $\infty$ & 0 \\
\hline Mark I Outer & G-4273 & 2 & 21.75 & 10.87 & 4.6 \\
\hline Mark IV Inner & G-4273 & 2 & $\infty$ & $\infty$ & 0 \\
\hline Mark IV Outer & G-4273 & 2 & $\infty$ & $\infty$ & 0 \\
\hline
\end{tabular}

(a) Based on $\mathrm{k} \leq 0.95$ including bias and uncertainty $(2 \sigma)$. Represents optimum spacing and maderation of ingots and billets.

\section{2(A) PACKAGE FUEL. LOADING - N REACTOR MARK I AND MARK IV INGOTS}

N Reactor ingots will be loaded in steel banded wooden box G-4273. For conservatism, the banding and boxes were omitted from the criticality evaluations. The ingots were modeled in an array of optimum moderation and pitch with full reflection.

The fuel loading is defined as the amount of ${ }^{235} \mathrm{U}$ in an ingot. The dimensions, enrichment and mass of ${ }^{235} \mathrm{U}$ for each $\mathrm{N}$ Reactor ingot are presented in Table 6.2-1(A).

TABLE 6.2-1(A). Description of N Reactor Ingots.

\begin{tabular}{|l|c|c|c|c|c|}
\hline \multicolumn{1}{|c|}{ Ingot Type } & $\begin{array}{c}\text { Outer Diameter } \\
\text { in. (cm) }\end{array}$ & $\begin{array}{c}\text { Inner Diameter } \\
\text { in. }\{\mathrm{cm})\end{array}$ & $\begin{array}{c}\text { Length } \\
\text { in. }\{\mathrm{cm})\end{array}$ & $\begin{array}{c}\text { Wt } \% \\
235 U\end{array}$ & $\begin{array}{c}{ }^{235} \mathrm{U} \\
\mathrm{Ib}\langle\mathrm{g}\}\end{array}$ \\
\hline \hline Mark I Inner (HO69) & $10.85(27.56)$ & $1.38(3.493)$ & $24.75(62.87)$ & 0.95 & $14.65(6646)$ \\
\hline Mark I Outer (H068) & $13.05(33.15)$ & $2.87(7.290)$ & $17.00(43.18)$ & 1.25 & $18.53(8404)$ \\
\hline Mark IV Inner (H066) & $10.85(27.56)$ & $1.30(3.302)$ & $25.50(64.77)$ & 0.95 & $15.12(6859)$ \\
\hline Mark IV Outer (HO67) & $13.05(33.15)$ & $2.58(6.553)$ & $17.00(43.18)$ & 0.95 & $14.22(6449)$ \\
\hline
\end{tabular}




\section{3(A) MODEL SPECIFICATION - N REACTOR INGOTS}

This section describes the computer models used for the analyses.

\subsection{1(A) Description of Calculational Model}

$\mathrm{N}$ Reactor ingots are modeled as two concentric cylinders. The inner cylinder represents the ingot annulus and is filled with water when flooded, otherwise it is filled with air. The outer cylinder consists of enriched uranium metal.

Because the packages are not explicitly modeled, arrays of ingots represent the contents of the packages under NCT and HAC events. Infinite, dry ingot arrays at various pitches conservatively represent $5 \times \mathrm{N}$ undamaged packages with normal spacing and no moderation. For the $\mathrm{HAC}$ events, the ingot arrays are modeled using optimum conditions of spacing, moderation, and reflection. These arrays represent the contents of $2 \times \mathrm{N}$ damaged packages. For Mark $\mathrm{I}$ inner ingots and Mark IV inner and outer ingots, the infinite optimum array has a $k_{\infty}$ plus uncertainties and bias less than 0.95. For the Mark I outer ingots the finite array is required for a $k_{\text {eff }}$ plus uncertainties and bias less than 0.95. The value of $N$ is not necessarily the same for $5 \times N$ undamaged packages and $2 \times \mathrm{N}$ damaged packages. The most conservative $\mathrm{N}$ values for the packages are derived from the $2 \times N$ damaged package cases. Single package calculations are presented in Section 6.6.2.

Infinite hexagonal arrays of infinite length were modeled for each ingot type. The interstitial material between the ingots was water. Modeling of the infinite arrays was done by surrounding a single ingot with reflective surfaces. For the hexagonal array the ingot is surrounded radially by six reflective planar surfaces to create a hexagon. The distance between opposing parallel planes is equal to the lattice pitch. Reflective planes were positioned at the top and bottom ends of the ingot. The distance between these axial planes is equal to the length of the ingot. Lattice pitch and water density were varied to determine the optimum configuration for the array.

In the case where the $k_{\infty}$ plus uncertainties and bias value for the infinite array exceeds the limit for transportation, a finite array was analyzed. The finite array, as the infinite arrays, was modeled in a hexagonal lattice structure. However, for this case, the number of ingots is restricted by enclosing the array inside a hexagon in the preliminary finite array calculations. Optimum lattice pitch and water density were used for the finite array with a water reflector surrounding the array. The array was surrounded by $11.81 \mathrm{in} .(30 \mathrm{~cm})$ of water reflection. Figure $6.3 .1-1$ (A) shows arrays of $1 \times 7,1 \times 12,1 \times 17,1 \times 19,1 \times 37$, and $1 \times 61$ ingots. For each of these arrays, the first number represents the number of ingots stacked in the vertical direction.

Traditionally the same number of lattice elements are used for each of the tiers of the array as discussed in the previous paragraph. However, this is not necessarily an optimum assumption. For a fixed number of total elements, the $k_{\text {eff }}$ for an approximately spherical arrangement of the elements will be larger than the traditional more cylindrical arrangement. Hence, the spherical arrangement is the more conservative and is the approach utilized in the definitive finite array calculations rather than the uniform multi-tiers shown in Figure 6.3.1-1(A). 


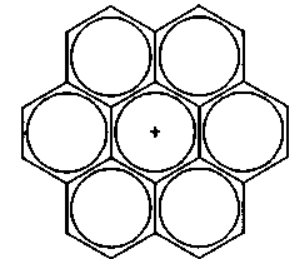

7 ELEMENT ARRANGEMENT

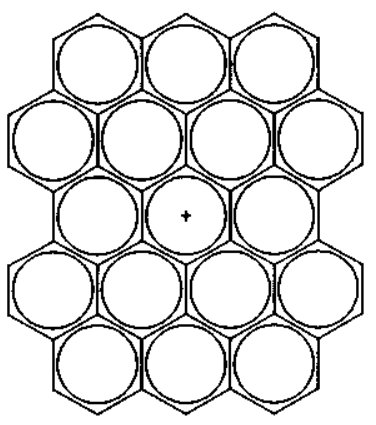

17 ELEMENT ARRANGEMENT

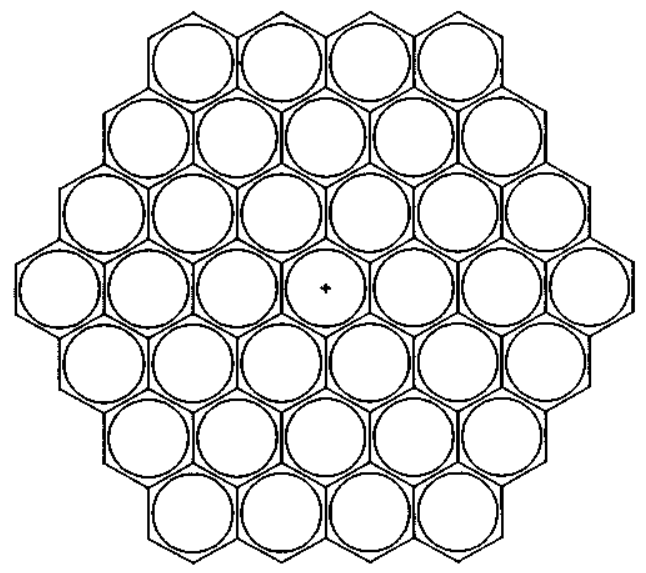

37 ELEMENT ARRANGEMENT

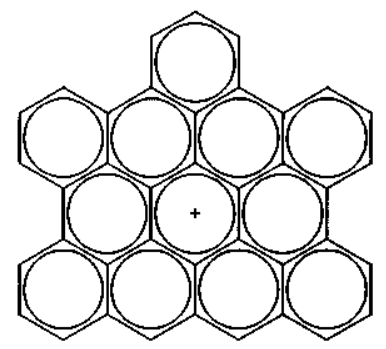

12 ELEMENT ARRANGEMENT

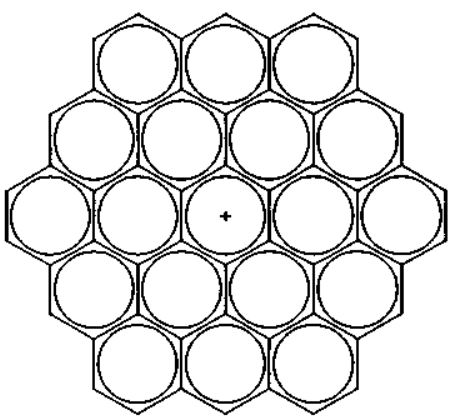

19 ELEMENT ARRANGEMENT

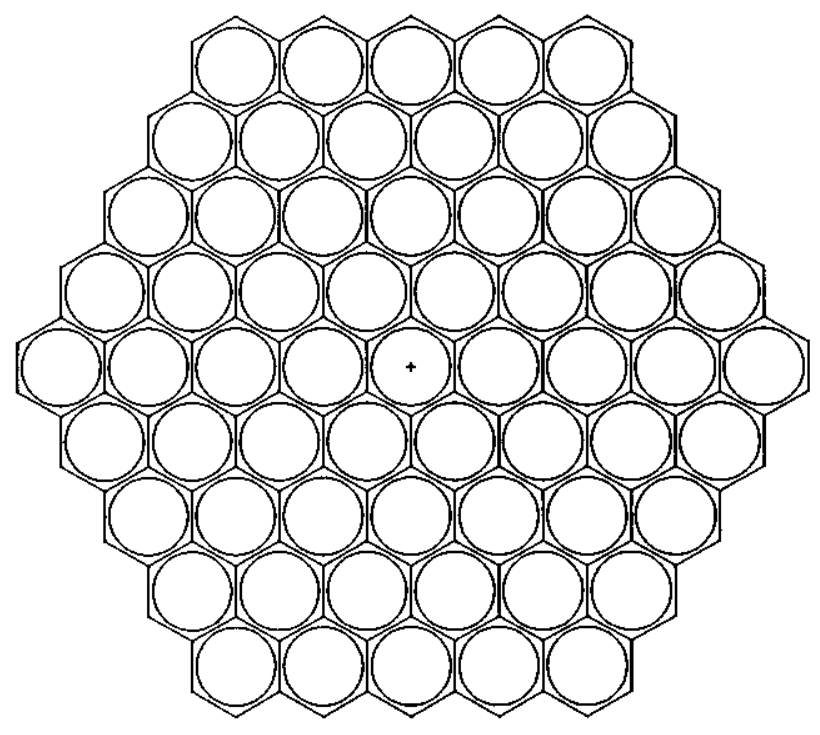

61 ELEMENT ARRANGEMENT

NOTE: DRAWING NOT TO SCALE

FIGURE 6.3.1-1(A). N Reactor Ingot Arrays of Varying Sizes. 
There can be a large number of possible near-spherical arrangements of the unit elements, each of which would need to be optimized with other parameters. The methods used in this finite array analysis is to conservatively assume a hexagonal array of lattice elements inside of a large sphere. These lattice elements completely fill up the sphere in both the horizontal (hexagonal) and vertical (stacked) directions; i.e., lattice elements at the boundary of the sphere will not be complete since they are cut by the sphere, see Figures 6.4.3-1(E) and 6.4.3-2(E) in Section 6.4.3(E) for elevation and plan views of a typical array within a sphere. However, this spherical treatment enables a conservative optimization with a calculational iteration on lattice parameters (pitch of hexagonal lattice, water density, and water thickness between vertical elements) while adjusting the radius of the sphere each time to obtain a constant uranium mass during the iteration. Once the optimum parameters are found to maximize $k$, the sphere radius with those optimum parameters can be decreased (or increased) to decrease (or increase) the uranium mass and obtain an optimized $\mathrm{k}$ that is below the limit for this mass. See Section 6.4.3(D) for an expanded discussion and illustration of this approach.

\subsection{2(A) Package Regional Densities}

$\mathrm{N}$ Reactor ingots are uranium metal enriched to $0.95 \pm 0.006 \mathrm{wt} \%{ }^{235} \mathrm{U}$ and $1.25 \pm 0.006$ $w t \%{ }^{235} \mathrm{U}$. Uranium density used is the theoretical uranium metal density of $18.96 \mathrm{~g} / \mathrm{cm}^{3}$. Material densities and atomic number densities for the constituent nuclides of all materials used in the $\mathrm{N}$ Reactor ingot calculations models are listed in Table 6.3.2-1(A).

TABLE 6.3.2-1(A). Material Densities and Atomic Number Densities - N Reactor Ingots.

\begin{tabular}{|l|c|c|c|}
\hline \multicolumn{1}{|c|}{ Isotope/Nuclide } & $\begin{array}{c}\text { Material Density } \\
\left(\mathrm{g} / \mathrm{cm}^{3}\right)\end{array}$ & \multicolumn{2}{|c|}{ Atomic Number Density (atoms/b-cm) } \\
\hline \hline \multirow{2}{*}{ Hydrogen } & \multirow{2}{*}{1.0 (water) } & \multicolumn{2}{|c|}{0.06689} \\
\cline { 3 - 4 } & \multirow{2}{*}{ Oxygen } & 0.03344 \\
\cline { 3 - 4 } & \multirow{2}{*}{18.96 (uranium) } & $4.616 \mathrm{wt} \%{ }^{235} \mathrm{U}$ & $1.25 \mathrm{wt} \%{ }^{235} \mathrm{U}$ \\
\cline { 3 - 4 } & & $4.752 \mathrm{E}-02$ & $6.073 \mathrm{E}-04$ \\
\hline${ }^{235} \mathrm{U}$ & & & $4.737 \mathrm{E}-02$ \\
\hline${ }^{238} \mathrm{U}$ & & &
\end{tabular}

\section{4(A) CRITICALITY CALCULATIONS - N REACTOR INGOTS}

This section describes the calculational method used for the analyses.

\subsection{1(A) Calculational Method}

The MCNP computer code was used for this criticality evaluation. MCNP was developed at the Los Alamos National Laboratory (LANL) and is now used extensively both in the United States and throughout the world. The MCNP code is a general-purpose, continuous-energy, generalized-geometry neutron and photon transport code that calculates eigenvalues for criticality evaluations. 
The MCNP code uses continuous energy cross-sections that are thoroughly documented in Appendix G of MCNP-A General Monte Carlo Code N-Particle Transport Code (Breismeister 1993 ). These cross-sections are defined with a high-energy resolution. All the cross-sections used for these analyses were generated from either Evaluated Nuclear Data Files (ENDF) or LANL evaluations. Processing this type of data is not required for different moderator-to-fuel ratio conditions.

\subsection{2(A) Contents Loading Optimization}

Steel banded wooden shipping containers were not tested under hypothetical accident conditions and therefore cannot be credited to maintain the payload. To assure subcriticality for any possible payload arrangement, a lattice pitch and water optimization search was made for each ingot type. Establishing the optimum lattice pitch and water density allows for the determination of the maximum number of ingots that would be safely subcritical. Continuous cross-sections were used in these evaluations; therefore, no cross-section adjustments were required for various geometric configurations and material compositions.

\subsection{3(A) Criticality Results}

$\mathrm{N}$ Reactor ingots are subcritical under both NCT and HAC. Calculations show that infinite arrays of all ingot types, except the Mark 1 outer, are below the maximum allowable under optimum conditions of moderation, reflection and configuration. The $k_{\infty}$ values for all ingot types are presented in Tables 6.4.3-1(A), 6.4.3-2(A), 6.4.3-3(A) and 6.4.3-4(A). Figures 6.4.3-1(A), 6.4.3$2(A), 6.4 .3-3(A)$ and $6.4 .3-4(A)$ show these calculational results graphically.

To assure criticality safety the calculated $k$ must be less than 0.95 minus code bias and uncertainties (Section 6.5). Infinite array $k_{\infty}$ 's of the Mark I inner ingot, Mark IV inner ingot and Mark IV outer ingot at optimum moderation and pitch are all less than 0.95 minus the code bias and uncertainties. These are all $0.95 \mathrm{wt} \%{ }^{235} \mathrm{U}$. The $\mathrm{k}_{\infty}$ for the infinite array of $1.25 \mathrm{wt} \%{ }^{235} \mathrm{U} \mathrm{Mark} 1$ outer ingots, at optimum moderation and pitch, is above the maximum allowable.

Since the infinite array $k_{\infty}$ for the Mark I outer ingots exceeded the limit, additional finite array calculations were needed. The method used in this finite array analysis is to conservatively assume a hexagonal array of lattice elements inside of a large sphere reflected with 12 in. $(30.48 \mathrm{~cm})$ of water. These lattice elements completely fill up the sphere in both the horizontal (hexagonal) and vertical (stacked) directions. The results are presented in Table 6.4.3-5(A).

The first part of Table 6.4.3-5(A) shows the iteration on the two parameters (pitch of the hexagonal lattice and water thickness between the elements in the vertical) to find the parameters that will optimized $\mathrm{k}$ for an intermediate water density of $0.62 \mathrm{~g} / \mathrm{cm}^{3}$-- cases $1317 \mathrm{a}$ to $1317 \mathrm{f}$. Prior experience has been that the maximum typically occurs for a water density of one. The iteration is therefore repeated in cases $1317 \mathrm{~h}$ to $1317 \mathrm{l}$ at the bottom of the table subject to the constraint that the water density is one. The optimized $k$ is higher with the water density of one than with the intermediate water density. Case $1317 \mathrm{n}$ is made with these optimized parameters and with a larger sphere radius to determine that the optimized $k$ plus bias and uncertainties is well under the limit for a uranium mass of $64,478 \mathrm{lb}(29,247 \mathrm{~kg})$. 
TABLE 6.4.3-1(A). Mark I Inner Ingots (HO69) (0.95 wt \% ${ }^{235} \mathrm{U}$ ).

\begin{tabular}{|c|c|c|c|c|}
\hline $\begin{array}{l}\text { Pitch } \\
\text { in. }(\mathrm{cm})\end{array}$ & $\begin{array}{c}\text { Water Density } \\
\text { Fraction }\end{array}$ & $k_{\infty}$ & $\mathrm{k}_{\infty}+2 \sigma+$ bias & Input File \\
\hline $10.87\{27.60\}$ & 1.0 & 0.7517 & 0.7665 & mk $1 i 1$ \\
\hline $10.87\{27.60\}$ & 0.7 & 0.6843 & 0.6991 & m17i1 \\
\hline $10.87(27.60)$ & 0.5 & 0.6229 & 0.6377 & $\mathrm{~m} 15 i 1$ \\
\hline $10.87(27.60)$ & 0.3 & 0.5547 & 0.5695 & m13i1 \\
\hline $10.87(27.60)$ & 0.0 & 0.4918 & 0.5065 & m10i1 \\
\hline $12.05(30.60)$ & 1.0 & 0.8696 & 0.8844 & mk1i4 \\
\hline $12.05(30.60)$ & 0.7 & 0.8704 & 0.8853 & $\mathrm{~m} 17 \mathrm{i} 4$ \\
\hline $12.05(30.60)$ & 0.5 & 0.8311 & 0.8459 & m15i4 \\
\hline $12.05(30.60\}$ & 0.3 & 0.7254 & 0.7402 & $\mathrm{~m} 13 \mathrm{i4}$ \\
\hline $12.05(30.60)$ & 0.0 & 0.4909 & 0.5057 & $\mathrm{~m} 10 \mathrm{i} 4$ \\
\hline $13.23(33.60)$ & 1.0 & 0.7702 & 0.7850 & $m k 1 i 5$ \\
\hline $13.23(33.60)$ & 0.7 & 0.8537 & 0.8685 & $\mathrm{~m} 17 \mathrm{i5}$ \\
\hline $13.23(33.60\}$ & 0.5 & 0.8879 & 0.9027 & $\mathrm{~m} 15 i 5$ \\
\hline $13.23(33.60)$ & 0.3 & 0.8453 & 0.8602 & $\mathrm{~m} 13 \mathrm{i} 5$ \\
\hline $13.23(33.60)$ & 0.0 & 0.4917 & 0.5064 & $\mathrm{~m} 10 \mathrm{i} 5$ \\
\hline $14.02(35.60)$ & 1.0 & 0.6951 & 0.7099 & $\mathrm{~m} 11 \mathrm{i} 6$ \\
\hline $14.02(35.60)$ & 0.7 & 0.7954 & 0.8102 & $m 17 i 6$ \\
\hline $14.02(35.60)$ & 0.5 & 0.8673 & 0.8822 & $\mathrm{~m} 15 \mathrm{i} 6$ \\
\hline $14.02(35.60)$ & 0.3 & 0.8831 & 0.8979 & $\mathrm{~m} 13 \mathrm{i6}$ \\
\hline $14.02(35.60)$ & 0.0 & 0.4933 & 0.5081 & $\mathrm{mi0i6}$ \\
\hline $14.80(37.60)$ & 1.0 & 0.6382 & 0.6530 & $\mathrm{~m} 11 \mathrm{i}$ \\
\hline $14.80(37.60)$ & 0.7 & 0.7327 & 0.7475 & $\mathrm{~m} 17 i 7$ \\
\hline $14.80(37.60)$ & 0.5 & 0.8302 & 0.8450 & $\mathrm{~m} 15 i 7$ \\
\hline $14.80(37.60)$ & 0.3 & 0.8946 & 0.9094 & $\mathrm{~m} 13 \mathrm{i} 7$ \\
\hline $14.80(37.60)$ & 0.3 & 0.8970 & 0.9116 & $m 13 i 7 u$ \\
\hline $14.80(37.60)$ & 0.0 & 0.4912 & 0.5059 & $\mathrm{~m} 10 \mathrm{i} 7$ \\
\hline $15.59(39.60)$ & 1.0 & 0.6010 & 0.6159 & $\mathrm{~m} 11 \mathrm{is}$ \\
\hline $15.59(39.60)$ & 0.7 & 0.6799 & 0.6948 & $m 17 i 8$ \\
\hline $15.59(39.60)$ & 0.5 & 0.7817 & 0.7965 & $\mathrm{~m} 15 \mathrm{i} 8$ \\
\hline $15.59(39.60)$ & 0.3 & 0.8886 & 0.9034 & $\mathrm{~m} 13 \mathrm{i} 8$ \\
\hline $15.59(39.60\}$ & 0.0 & 0.4910 & 0.5057 & $\mathrm{~m} 10 \mathrm{i} 8$ \\
\hline
\end{tabular}


TABLE 6.4.3-2(A). Mark I Outer Ingots (HO68) (1.25 wt $\left.\%{ }^{235} \mathrm{U}\right)$.

\begin{tabular}{|c|c|c|c|c|}
\hline $\begin{array}{l}\text { Pitch } \\
\text { in. }(\mathrm{cm})\end{array}$ & $\begin{array}{c}\text { Water Density } \\
\text { Fraction }\end{array}$ & $\mathrm{k}_{\infty}$ & $k_{\infty}+2 \sigma+$ bias & Input File \\
\hline $13.07(33.20)$ & 1.0 & 0.8499 & 0.8647 & $\mathrm{mk} 1 \mathrm{o} 1$ \\
\hline $13.07(33.20)$ & 0.7 & 0.7987 & 0.8135 & $\mathrm{~m} 1701$ \\
\hline $13.07(33.20)$ & 0.5 & 0.7278 & 0.7426 & $m 1501$ \\
\hline $13.07(33.20)$ & 0.3 & 0.6359 & 0.6507 & $\mathrm{~m} 1301$ \\
\hline $13.07(33.20)$ & 0.0 & 0.5337 & 0.5484 & $\mathrm{~m} 1001$ \\
\hline $13.86(35.20)$ & 1.0 & 0.9262 & 0.9410 & $\mathrm{mk} 1 \mathrm{o} 4$ \\
\hline $13.86(35.20)$ & 0.7 & 0.9084 & 0.9232 & $\mathrm{~m} 17 \mathrm{o} 4$ \\
\hline $13.86(35.20)$ & 0.5 & 0.8477 & 0.8626 & $\mathrm{~m} 1504$ \\
\hline $13.86(35.20)$ & 0.3 & 0.7345 & 0.7493 & $\mathrm{~m} 1304$ \\
\hline $13.86(35.20)$ & 0.0 & 0.5350 & 0.5497 & $\mathrm{~m} 1004$ \\
\hline $14.65(37.20)$ & 1.0 & 0.9038 & 0.9186 & $\mathrm{mk} 1 \mathrm{o} 7$ \\
\hline $14.65(37.20)$ & 0.7 & 0.9407 & 0.9555 & $\mathrm{~m} 17 \mathrm{o} 7$ \\
\hline $14.65(37.20)$ & 0.5 & 0.9213 & 0.9362 & $m 1507$ \\
\hline $14.65(37.20)$ & 0.3 & 0.8248 & 0.8396 & $\mathrm{~m} 13 \mathrm{o} 7$ \\
\hline $14.65(37.20)$ & 0.0 & 0.5353 & 0.5500 & $\mathrm{~m} 10 \mathrm{o} 7$ \\
\hline $15.43(39.20)$ & 1.0 & 0.8348 & 0.8496 & $m 1108$ \\
\hline $15.43(39.20)$ & 0.7 & 0.9112 & 0.9260 & $\mathrm{~m} 1708$ \\
\hline $15.43(39.20)$ & 0.5 & 0.9376 & 0.9524 & $m 1508$ \\
\hline $15.43(39.20)$ & 0.3 & 0.8905 & 0.9053 & $m 1308$ \\
\hline $15.43(39.20)$ & 0.0 & 0.5340 & 0.5487 & $\mathrm{~m} 1008$ \\
\hline $16.22(41.20)$ & 1.0 & 0.7675 & 0.7823 & $\mathrm{~m} 1109$ \\
\hline $16.22(41.20)$ & 0.7 & 0.8560 & 0.8709 & $m 17 \circ 9$ \\
\hline $16.22(41.20)$ & 0.5 & 0.9206 & 0.9355 & $m 1509$ \\
\hline $16.22(41.20)$ & 0.3 & 0.9263 & 0.9412 & m13o9 \\
\hline $16.22\{41.20\}$ & 0.0 & 0.5343 & 0.5491 & $\mathrm{~m} 10 \circ 9$ \\
\hline $17.01(43.20)$ & 1.0 & 0.7183 & 0.7331 & m11oa \\
\hline $17.01(43.20)$ & 0.7 & 0.7996 & 0.8144 & m17oa \\
\hline $17.01(43.20)$ & 0.5 & 0.8838 & 0.8986 & m15oa \\
\hline $17.01(43.20\}$ & 0.3 & 0.9389 & 0.9537 & m13oa \\
\hline $17.01(43.20)$ & 0.0 & 0.5351 & 0.5498 & m10oa \\
\hline $17.80(45.20)$ & 1.0 & 0.6891 & 0.7040 & $\mathrm{~m} 11 \mathrm{ob}$ \\
\hline $17.80(45.20)$ & 0.7 & 0.7492 & 0.7640 & $\mathrm{~m} 17 \mathrm{ob}$ \\
\hline $17.80(45.20)$ & 0.5 & 0.8382 & 0.8530 & $\mathrm{~m} 15 \mathrm{ob}$ \\
\hline $17.80(45.20)$ & 0.3 & 0.9340 & 0.9488 & $\mathrm{~m} 13 \mathrm{ob}$ \\
\hline $17.80(45.20)$ & 0.0 & 0.5341 & 0.5488 & $\mathrm{~m} 10 \mathrm{ob}$ \\
\hline
\end{tabular}


TABLE 6.4.3-3(A). Mark IV Inner Ingots (H066) (0.95 wt $\left.\%{ }^{235} \mathrm{U}\right)$.

\begin{tabular}{|c|c|c|c|c|}
\hline $\begin{array}{c}\text { Pitch } \\
\text { in. (cm) }\end{array}$ & $\begin{array}{c}\text { Water Density } \\
\text { Fraction }\end{array}$ & $k_{\infty}$ & $\mathrm{k}_{\infty}+2 \sigma+$ bias & Input File \\
\hline $10.87(27.60)$ & 1.0 & 0.7468 & 0.7616 & mkivi1 \\
\hline $10.87(27.60)$ & 0.7 & 0.6820 & 0.6968 & m47i1 \\
\hline $10.87(27.60)$ & 0.5 & 0.6205 & 0.6353 & m45i1 \\
\hline $10.87(27.60)$ & 0.3 & 0.5522 & 0.5670 & $\mathrm{~m} 43 \mathrm{i} 1$ \\
\hline $10.87(27.60)$ & 0.0 & 0.4916 & 0.5063 & m40i1 \\
\hline $11.65(29.60)$ & 1.0 & 0.8657 & 0.8805 & mkivi5 \\
\hline $11.65(29.60)$ & 0.7 & 0.8339 & 0.8487 & $m 47 i 5$ \\
\hline $11.65(29.60)$ & 0.5 & 0.7747 & 0.7896 & $\mathrm{~m} 45 \mathrm{i} 5$ \\
\hline $11.65(29.60)$ & 0.3 & 0.6689 & 0.6837 & $\mathrm{~m} 43 \mathrm{i} 5$ \\
\hline $11.65(29.60)$ & 0.0 & 0.4913 & 0.5060 & $\mathrm{~m} 40 \mathrm{i5}$ \\
\hline $12.05(30.60)$ & 1.0 & 0.8699 & 0.8847 & mkivi7 \\
\hline $12.05(30.60)$ & 0.7 & 0.8710 & 0.8858 & $\mathrm{~m} 47 i 7$ \\
\hline $12.05(30.60)$ & 0.5 & 0.8310 & 0.8458 & $\mathrm{~m} 45 i 7$ \\
\hline $12.05(30.60)$ & 0.3 & 0.7276 & 0.7423 & $\mathrm{~m} 43 \mathrm{i} 7$ \\
\hline $12.05(30.60)$ & 0.0 & 0.4913 & 0.5060 & $\mathrm{~m} 40 \mathrm{i} 7$ \\
\hline $13.23(33.60)$ & 1.0 & 0.7697 & 0.7846 & m41i9 \\
\hline $13.23(33.60)$ & 0.7 & 0.8541 & 0.8689 & $\mathrm{~m} 47 i 9$ \\
\hline $13.23\{33.60\}$ & 0.5 & 0.8866 & 0.9014 & $\mathrm{~m} 45 \mathrm{i9}$ \\
\hline $13.23(33.60)$ & 0.3 & 0.8457 & 0.8605 & $\mathrm{~m} 43 \mathrm{i} 9$ \\
\hline $13.23\{33.60\}$ & 0.0 & 0.4915 & 0.5063 & $\mathrm{~m} 40 \mathrm{i9}$ \\
\hline $14.02(35.60)$ & 1.0 & 0.6946 & 0.7095 & m41ia \\
\hline $14.02(35.50)$ & 0.7 & 0.7953 & 0.8101 & m47ia \\
\hline $14.02(35.60)$ & 0.5 & 0.8688 & 0.8835 & m45ia \\
\hline $14.02(35.60)$ & 0.3 & 0.8843 & 0.8991 & m43ia \\
\hline $14.02(35.60)$ & 0.0 & 0.4916 & 0.5064 & m40ia \\
\hline $14.80(37.60)$ & 1.0 & 0.6361 & 0.6510 & $\mathrm{~m} 41 \mathrm{ib}$ \\
\hline $14.80(37.60)$ & 0.7 & 0.7343 & 0.7491 & m47ib \\
\hline $14.80(37.60)$ & 0.5 & 0.8279 & 0.8427 & m45ib \\
\hline $14.80(37.60)$ & 0.3 & 0.8945 & 0.9094 & m43ib \\
\hline $14.80(37.60)$ & 0.3 & 0.8970 & 0.9116 & m43ibu \\
\hline $14.80(37.60)$ & 0.0 & 0.4911 & 0.5058 & m40ib \\
\hline $15.59(39.60)$ & 1.0 & 0.5980 & 0.6129 & $\mathrm{~m} 41 \mathrm{ic}$ \\
\hline $15.59(39.60)$ & 0.7 & 0.6799 & 0.6947 & m47ic \\
\hline $15.59(39.60)$ & 0.5 & 0.7795 & 0.7943 & m45ic \\
\hline $15.59(39.60)$ & 0.3 & 0.8894 & 0.9042 & $\mathrm{~m} 43 \mathrm{ic}$ \\
\hline $15.59(39.60)$ & 0.0 & 0.4918 & 0.5066 & m40ic \\
\hline
\end{tabular}


TABLE 6.4.3-4(A). Mark IV Outer Ingots (H067) (0.95 wt \% $\left.{ }^{235} \mathrm{U}\right)$.

\begin{tabular}{|c|c|c|c|c|}
\hline $\begin{array}{c}\text { Pitch } \\
\text { in. }(\mathrm{cm}) \\
\end{array}$ & $\begin{array}{c}\text { Water Density } \\
\text { Fraction }\end{array}$ & $k_{\infty}$ & $\mathrm{k}_{\infty}+2 \sigma+$ bias & Input File \\
\hline $13.07(33.20)$ & 1.0 & 0.7838 & 0.7986 & mkivo1 \\
\hline $13.07(33.20)$ & 0.7 & 0.7297 & 0.7445 & $\mathrm{~m} 47 \mathrm{o} 1$ \\
\hline $13.07(33.20)$ & 0.5 & 0.6661 & 0.6809 & $\mathrm{~m} 45 \circ 1$ \\
\hline $13.07(33.20)$ & 0.3 & 0.5793 & 0.5941 & $\mathrm{~m} 4301$ \\
\hline $13.07(33.20)$ & 0.0 & 0.4920 & 0.5068 & $m 4001$ \\
\hline $13.86\{35.20\}$ & 1.0 & 0.8595 & 0.8744 & mkivo 4 \\
\hline $13.86\{35.20\}$ & 0.7 & 0.8383 & 0.8531 & $\mathrm{~m} 47 \mathrm{o} 4$ \\
\hline $13.86(35.20)$ & 0.5 & 0.7835 & 0.7983 & $\mathrm{~m} 4504$ \\
\hline $13.86(35.20)$ & 0.3 & 0.6762 & 0.6910 & $\mathrm{~m} 4304$ \\
\hline $13.86(35.20)$ & 0.0 & 0.4923 & 0.5070 & $\mathrm{~m} 4004$ \\
\hline $14.65\{37.20\}$ & 1.0 & 0.8373 & 0.8521 & mkivo 7 \\
\hline $14.65(37.20)$ & 0.7 & 0.8687 & 0.8835 & $\mathrm{~m} 47_{0} 7$ \\
\hline $14.65(37.20)$ & 0.5 & 0.8519 & 0.8667 & $\mathrm{~m} 4507$ \\
\hline $14.65(37.20)$ & 0.3 & 0.7674 & 0.7824 & $\mathrm{~m} 4307$ \\
\hline $14.65(37.20)$ & 0.0 & 0.4923 & 0.5070 & $\mathrm{~m} 4007$ \\
\hline $15.43(39.20)$ & 1.0 & 0.7749 & 0.7897 & $\mathrm{~m} 41 \mathrm{o} 8$ \\
\hline $15.43(39.20)$ & 0.7 & 0.8456 & 0.8604 & $m 47 o 8$ \\
\hline $15.43(39.20)$ & 0.5 & 0.8723 & 0.8871 & $\mathrm{~m} 4508$ \\
\hline $15.43(39.20)$ & 0.5 & 0.8728 & 0.8874 & $\mathrm{~m} 45 \mathrm{o} 8 \mathrm{u}$ \\
\hline $15.43(39.20)$ & 0.3 & 0.8251 & 0.8399 & $\mathrm{~m} 4308$ \\
\hline $15.43(39.20)$ & 0.0 & 0.4915 & 0.5062 & $\mathrm{~m} 4008$ \\
\hline $16.22\{41.20\}$ & 1.0 & 0.7135 & 0.7283 & $\mathrm{~m} 4109$ \\
\hline $16.22(41.20)$ & 0.7 & 0.7934 & 0.8082 & $\mathrm{~m} 4709$ \\
\hline $16.22(41.20)$ & 0.5 & 0.8545 & 0.8693 & $m 4509$ \\
\hline $16.22(41.20)$ & 0.3 & 0.8607 & 0.8755 & $m 4309$ \\
\hline $16.22(41.20)$ & 0.0 & 0.4928 & 0.5076 & $\mathrm{~m} 4009$ \\
\hline $17.01(43.20)$ & 1.0 & 0.6642 & 0.6790 & m41oa \\
\hline $17.01(43.20)$ & 0.7 & 0.7400 & 0.7548 & m47oa \\
\hline $17.01(43.20)$ & 0.5 & 0.8181 & 0.8329 & m45oa \\
\hline $17.01(43.20)$ & 0.3 & 0.8705 & 0.8853 & m43oa \\
\hline $17.01(43.20)$ & 0.0 & 0.4930 & 0.5078 & m40oa \\
\hline $17.80(45.20)$ & 1.0 & 0.6365 & 0.6513 & $\mathrm{~m} 41 \mathrm{ob}$ \\
\hline $17.80(45.20)$ & 0.7 & 0.6927 & 0.7075 & $\mathrm{~m} 47 \mathrm{ob}$ \\
\hline $17.80(45.20)$ & 0.5 & 0.7762 & 0.7911 & $\mathrm{~m} 45 \mathrm{ob}$ \\
\hline $17.80(45.20)$ & 0.3 & 0.8686 & 0.8834 & $\mathrm{~m} 43 \mathrm{ob}$ \\
\hline $17.80(45.20)$ & 0.0 & 0.4914 & 0.5062 & $\mathrm{~m} 40 \mathrm{ob}$ \\
\hline
\end{tabular}




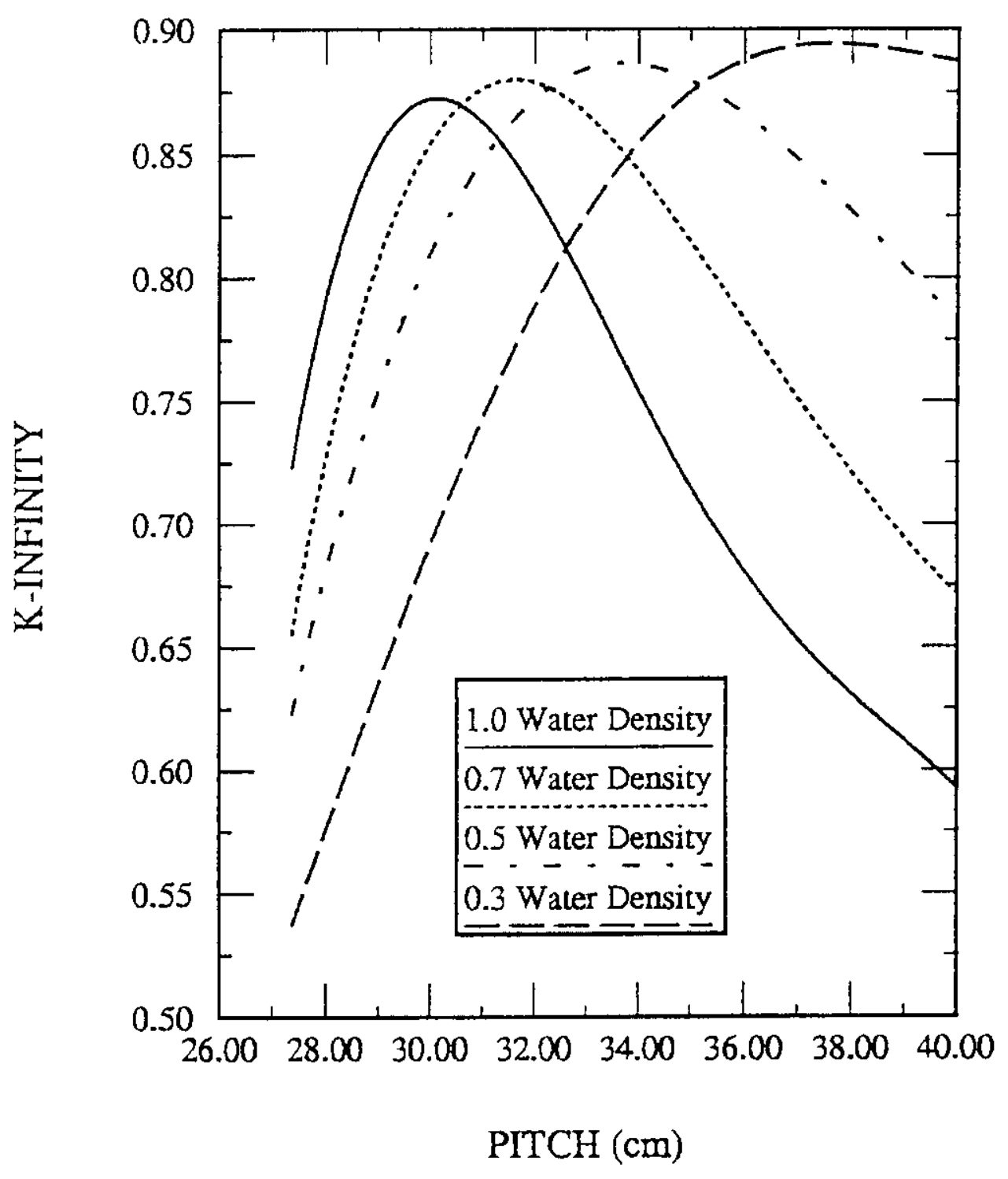

FIGURE 6.4.3-1(A). Mark I Infinite Array of Inner Ingots. 


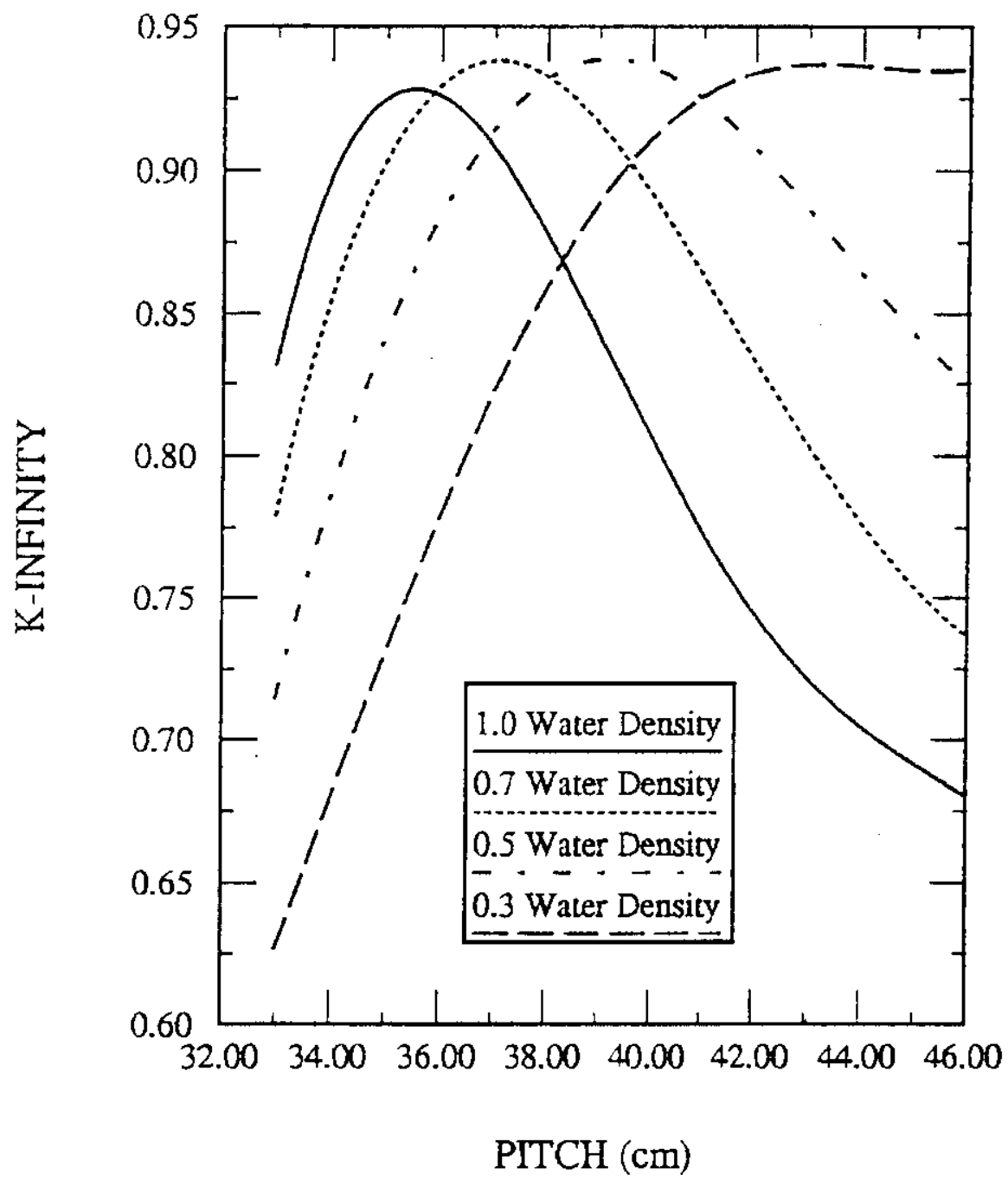

FIGURE 6.4.3-2(A). Mark I Infinite Array of Outer Ingots. 


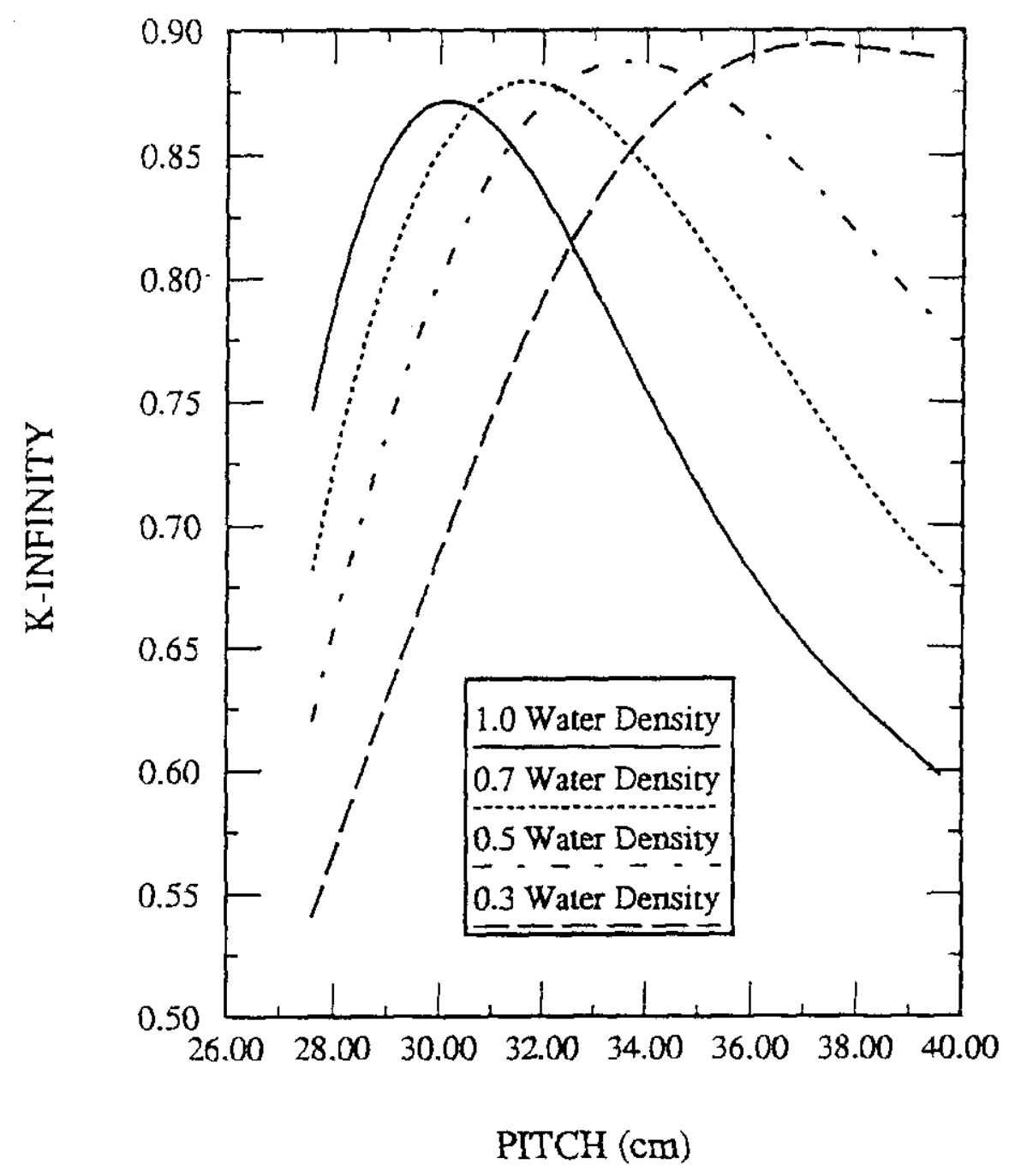

FIGURE 6.4.3-3(A). Mark IV Infinite Array of Inner Ingots. 


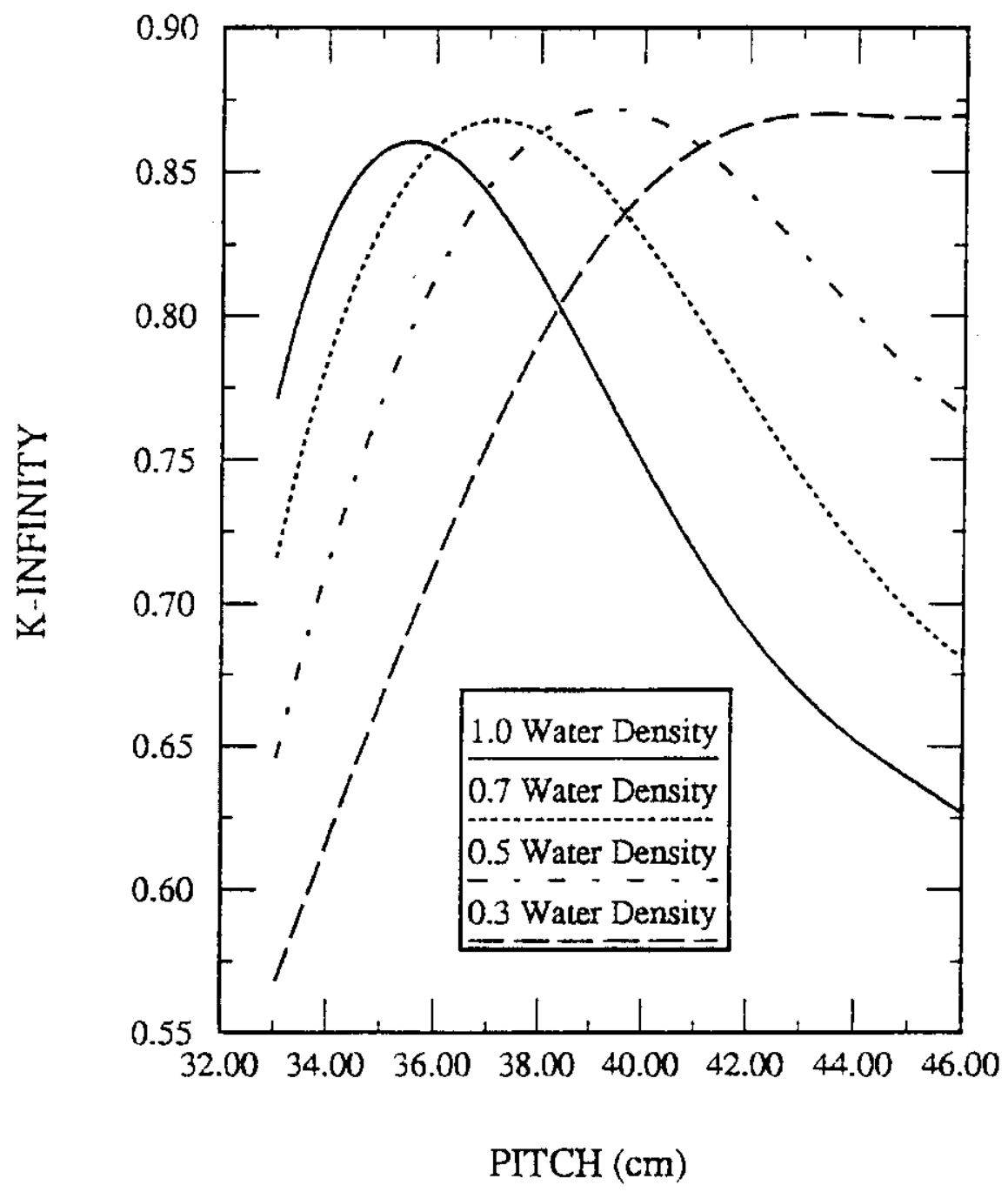

FIGURE 6.4.3-4(A). Mark IV Infinite Array of Outer Ingots. 
TABLE 6.4.3-5(A). Reflected Finite Arrays to Determine Optimum Parameters and Maximum Mass for Mark I Outer Ingots $\left(1.25 \mathrm{wt} \%{ }^{235} \mathrm{U}\right)$.

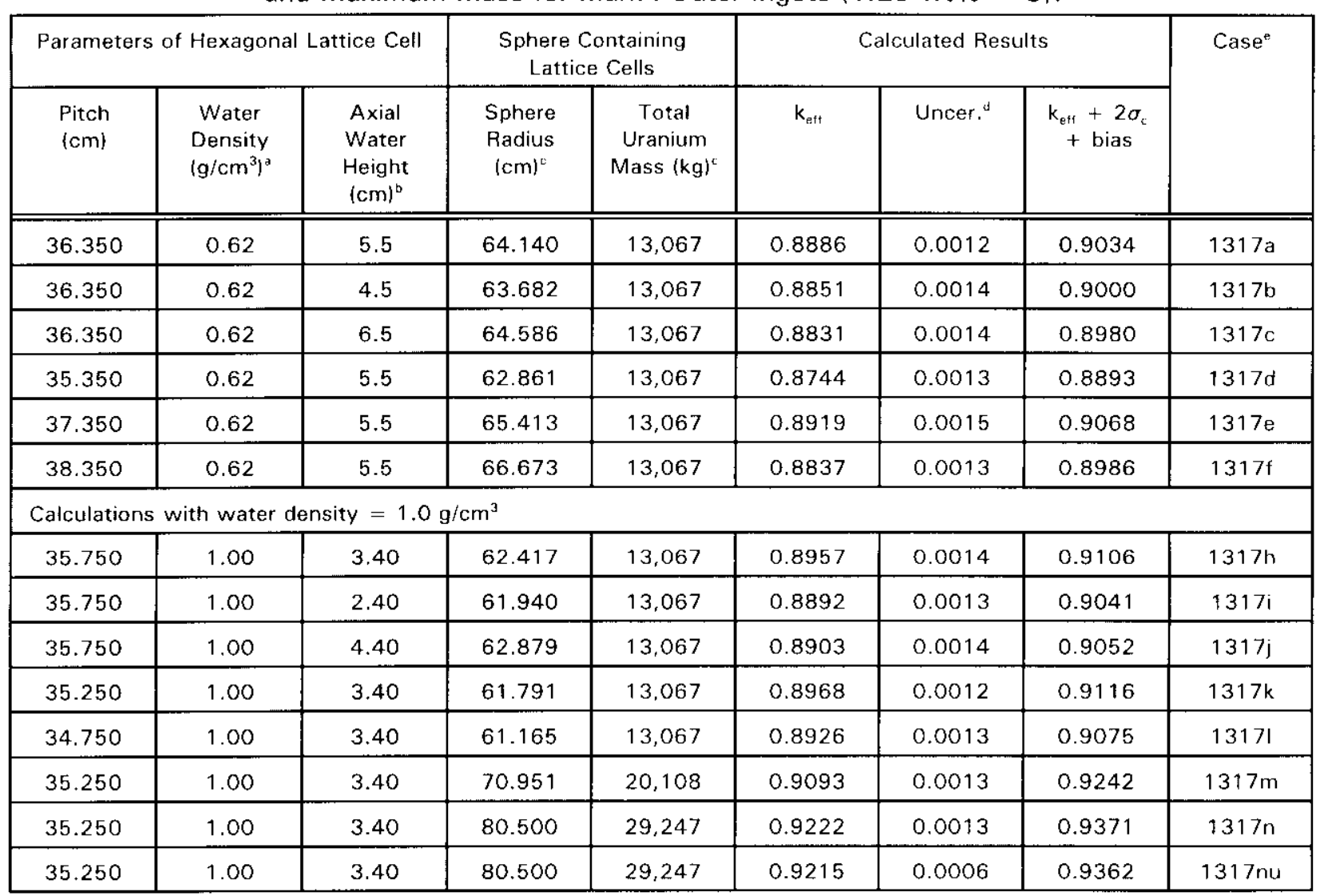

aDensity of both the radial water beyond the $13.05 \mathrm{in}$. diameter uranium and the axial water between uranium layers.

${ }^{D}$ Axial thickness of water between uranium layers.

'Sphere containing the hexagonal lattice and resulting total uranium mass in the lattice within the sphere.

'One standard deviation statistical uncertainty in the Monte Carlo calculation.

enput file names are this case identifier preceded with an $i$ and the corresponding MCNP output files are this case identifier preceded with an o. 
6.4.3.1(A) Transport Index. The $\mathrm{TI}$ is a dimensionless number placed on the label of a package to designate the degree of control to be exercised by the carrier during transportation. For criticality control purposes the $\mathrm{Tl}$ is the number obtained by dividing 50 by the number " $\mathrm{N}$ ". The number " $\mathrm{N}$ " is based on the following conditions being satisfied, assuming packages are stacked together in any arrangement and with close full reflection on all sides of the stack by water:

(1) $5 \times$ "N" undamaged packages with nothing between the packages would be subcritical;

(2) $2 \times \mathrm{N}^{\mathrm{N}}$ damaged packages, if each package were subcritical with optimum interspersed hydrogenous moderation; and The value of " $\mathrm{N}$ " cannot be less than 0.5 .

The results summarized in Table 6.1-1(A) show that infinite arrays, with optimum configuration and moderation, are safely subcritical for Mark I inner and Mark IV inner and outer ingots. Since an infinite number of each ingot type is safely subcritical under optimum conditions, " $\mathrm{N}$ " is infinite and the above three conditions are met. With " $\mathrm{N}$ " equal to infinity, the $\mathrm{Tl}$ for the ingots is 0 . A conservative uranium mass for the Mark I outer ingots is $64,478 \mathrm{lb}(29,247 \mathrm{~kg})$ from case $1317 \mathrm{n}$ of Table $6.4 .3-5 \mathrm{~A}$, or up to 43.5 Mark I ingots are safely subcritical. This will result in a $\mathrm{TI}$ of 4.6. Criticality transport indices are summarized in Table 6.4.3.1-1(A).

TABLE 6.4.3.1-1(A). Transport Index for N Reactor Ingots.

\begin{tabular}{|l|c|c|c|}
\hline \multicolumn{1}{|c|}{ Ingot } & Number of Ingot Subcritical & $\mathrm{N}$ & TI \\
\hline \hline Mark I Inner & Infinite & $\infty$ & 0 \\
\hline Mark I Outer & 43.5 & 10.87 & 4.6 \\
\hline Mark IV Inner & Infinite & $\infty$ & 0 \\
\hline Mark IV Outer & Infinite & $\infty$ & 0 \\
\hline
\end{tabular}

\section{1(B) DISCUSSION AND RESULTS - RMI BILLETS}

This section of the criticality evaluation analyzes the RMI forged billet and a specific type of these billets identified as the Hanford RMI billet. For the purpose of this document, a billet refers to the product of the extrusion process. The billets are packaged for shipment in the steel banded wooden package G-4255. Container dimensions are given in Section 1.2. There are no criticality design features incorporated into the boxes. The steel banding and boxes are conservatively omitted from the analyses.

Both infinite and finite array analyses were done for each billet type. The results are summarized in Table 6.1-1(B). At optimum moderation and pitch, the reactivity of the infinite arrays for all billet types exceed the maximum allowable value for transportation. Finite array analyses determined the maximum number of each billet type with $k_{\mathrm{eff} f} s$ plus uncertainties and bias that do not exceed the maximum allowable value for transportation. The results are also presented in Table 6.1-1(B). The finite array results determine the $\mathrm{N}$ and $\mathrm{Tl}$ values which are given in Table 6.1-2(B).

The Hanford RMI Mark I outer billets are Mark I outer RMI forged billets that weigh from 383 to $418 \mathrm{lb}(174$ to $189.5 \mathrm{~kg})$ and have lengths ranging from approximately 18 to $19 \mathrm{in}$. $(45.72$ to $48.26 \mathrm{~cm})$. The criticality evaluation of the Hanford RMI billets is conservatively based 
on the criticality evaluation performed for the Mark I outer RMI forged billets. Therefore, the maximum allowable shipping mass for the Hanford RMI billets is $6,466 \mathrm{lb}(2,933 \mathrm{~kg})$ as shown in Table 6.1-1(B).

TABLE 6.1-1(B). Summary of RMI Forged Billet Criticality Evaluation.

\begin{tabular}{|c|c|c|c|c|}
\hline \multicolumn{5}{|c|}{ Infinite array of billets with optimum moderation and pitch } \\
\hline \multicolumn{2}{|c|}{ Billet } & $\mathrm{Wt} \%{ }^{235} \mathrm{U}$ & $k_{\infty}$ & $\mathrm{k}_{\infty}+2 \sigma+$ bias \\
\hline \multicolumn{2}{|l|}{ Mark I Inner } & 0.95 & 0.9865 & 1.0013 \\
\hline \multicolumn{2}{|l|}{ Mark I Outer } & 1.25 & 1.0534 & 1.0682 \\
\hline \multicolumn{2}{|l|}{ Mark IV Inner } & 0.95 & 0.9842 & 0.9990 \\
\hline \multicolumn{2}{|l|}{ Mark IV Outer } & 0.95 & 0.9726 & 0.9874 \\
\hline \multicolumn{5}{|c|}{ Finite array of billets with optimum moderation and pitch } \\
\hline Billet & $\begin{array}{c}\text { Maximum U Mass } \\
\mathrm{lb}(\mathrm{kg})\end{array}$ & $\begin{array}{c}\text { Total Number } \\
\text { of Billets }\end{array}$ & $k_{\text {eff }}$ & $\mathrm{k}_{\mathrm{eff}}+2 \sigma+$ bias \\
\hline Mark I Inner & $24,216(10,984)$ & $79.2^{a}$ & 0.9271 & 0.9418 \\
\hline Mark I Outer & $6,466(2,933)$ & $14.0^{\mathrm{a}}$ & 0.9291 & 0.9438 \\
\hline Mark IV Inner & $24,216(10,984)$ & $76.0^{\mathrm{a}}$ & 0.9213 & 0.9361 \\
\hline Mark IV Outer & $24,216(10,984)$ & $50.4^{a}$ & 0.9192 & 0.9339 \\
\hline $\begin{array}{l}\text { Hanford RMI } \\
\text { Mark I Outer }\end{array}$ & $6,466(2,933)$ & 15.4 & 0.9291 & 0.9438 \\
\hline
\end{tabular}

(a) Based on 21 -in. long billets only, which conservatively covers billet lengths from 16-21 in.

TABLE 6.1-2(B). Criticality Transport Index for RMI Billets.

\begin{tabular}{|l|c|c|c|c|c|}
\hline \multicolumn{1}{|c|}{ Type } & Shipping Box & Billets per Box & $2 \times N^{\text {tal }}$ Damaged Boxes & N & TI \\
\hline \hline Mark I Inner & G-4255 & 4 & 19.8 & 9.9 & 5.1 \\
\hline Mark I Outer & G-4255 & 2 & 7.0 & 3.5 & 14.3 \\
\hline Mark IV Inner & G-4255 & 4 & 19.0 & 9.5 & 5.3 \\
\hline Mark IV Outer & G-4255 & 2 & 25.2 & 12.6 & 4.0 \\
\hline \multirow{2}{*}{$\begin{array}{l}\text { Hanford RMI } \\
\text { Mark I Outer }\end{array}$} & \multirow{2}{*}{ G-4255 } & 3 & 5.13 & 2.57 & 19.5 \\
\cline { 3 - 7 } & & 2 & 7.7 & 3.85 & 13.0 \\
\cline { 3 - 7 } & & 1 & 15.4 & 7.7 & 6.5 \\
\hline
\end{tabular}

(a) Based on $k \leq 0.95$ including bias and uncertainty $(2 \sigma)$. Assumes optimum spacing and moderation of ingot and billets. 


\section{2(B) PACKAGE FUEL LOADING - RMI BILLETS}

RMI Billets will be loaded in steel banded wooden box G-4255. For conservatism, the banding and boxes were omitted from the criticality evaluations. The billets were assumed to be in a hexagonal array of optimum moderation and pitch. The fuel loading is defined as the amount of ${ }^{235} \mathrm{U}$ in a billet. The dimensions, enrichment and mass of ${ }^{235} \mathrm{U}$ for each RMI billet are presented Table 6.2-1(B).

Although the analysis described in Section 6.4(B) covers billet lengths from 16 to $21 \mathrm{in.}$, the maximum allowable number of RMI forged billets shown in Table 6.1-1(B) was conservatively calculated using the maximum uranium mass and the billet mass for the 21 -in. billets. Because the criticality calculations determined the maximum allowable uranium mass loading, the number of allowable billets is lower for the 21 -in. billets than the 16 -in. billets since they weigh more than the 16 -in. billets.

TABLE 6.2-1(B). Description of RMI Forged Billets and Hanford RMI Billets.

\begin{tabular}{|c|c|c|c|c|c|}
\hline Billet Type & $\begin{array}{l}\text { Outer Diameter } \\
\text { in. }(\mathrm{cm})\end{array}$ & $\begin{array}{l}\text { Inner Diameter } \\
\text { in. }\{\mathrm{cm})\end{array}$ & $\begin{array}{l}\text { Length } \\
\text { in. }(\mathrm{cm})\end{array}$ & $\begin{array}{l}W t \% \\
{ }^{235} \mathrm{U}\end{array}$ & $\begin{array}{c}{ }^{235} \mathrm{U} \\
\mathrm{lb}(\mathrm{g})\end{array}$ \\
\hline Mark I Inner & $5.37(13.64)$ & $1.34(3.404)$ & $\begin{array}{l}16.00 \text { to } 21.00 \\
(40.64 \text { to } 53.34)\end{array}$ & 0.95 & $\begin{array}{l}2.21 \text { to } 2.90 \\
(1003 \text { to } 1316)\end{array}$ \\
\hline Mark I Outer & $6.98(17.73)$ & $2.80(7.112)$ & $\begin{array}{l}16.00 \text { to } 21.00 \\
(40.64 \text { to } 53.34)\end{array}$ & 1.25 & $\begin{array}{l}4.40 \text { to } 5.77 \\
(1995 \text { to } 2619)\end{array}$ \\
\hline Mark IV Inner & $5.46(13.88)$ & $1.26(3.213)$ & $\begin{array}{l}16.00 \text { to } 21.00 \\
(40.64 \text { to } 53.34)\end{array}$ & 0.95 & $\begin{array}{l}2.31 \text { to } 3.03 \\
(1049 \text { to } 1376)\end{array}$ \\
\hline Mark IV Outer & $6.98(17.73)$ & $2.51(6.375)$ & $\begin{array}{l}16.00 \text { to } 21.00 \\
(40.64 \text { to } 53.34)\end{array}$ & 0.95 & $\begin{array}{l}3.47 \text { to } 4.55 \\
\text { (1574 to } 2065)\end{array}$ \\
\hline $\begin{array}{l}\text { Hanford RMI } \\
\text { Mark I Outer }\end{array}$ & $6.98(17.73)$ & $2.80\{7.112\}$ & $\begin{array}{l}18.00 \text { to } 19.00 \\
(45.72 \text { to } 48.26)\end{array}$ & 1.25 & $\begin{array}{l}4.79 \text { to } 5.23 \\
\text { (2175 to } 2369)\end{array}$ \\
\hline
\end{tabular}

\section{3(B) MODEL SPECIFICATION - RMI BILLETS}

This section describes the computer models used for the analyses.

\subsection{1(B) Description of Calculational Model}

The RMI billets are modeled as two concentric cylinders. The inner cylinder represents the billet annulus and is filled with water when flooded, otherwise it is filled with air. The outer cylinder consists of enriched uranium metal.

Because the packages are not explicitly modeled, arrays of billets represent the contents of the packages under NCT and HAC events. Infinite, dry billet arrays at various pitches conservatively represent $5 \times \mathrm{N}$ undamaged packages with normal spacing and no moderation. For the HAC events, the billet arrays are modeled using optimum conditions of spacing, moderation, and reflection. These arrays represent the contents of $2 \times \mathrm{N}$ damaged packages. For the RMI billets the finite optimum array is required for a $k_{\text {eff }}$ plus uncertainties and bias of less than 0.95 . The value of $\mathrm{N}$ is not necessarily the same for $5 \times \mathrm{N}$ undamaged packages and $2 \times \mathrm{N}$ damaged 
packages. The most conservative $\mathrm{N}$ values for the packages are derived from the $2 \times \mathrm{N}$ damaged package cases. Single package calculations are presented in the Appendix 6.6.2.

Infinite hexagonal arrays of infinite length were modeled for each billet type. The interstitial material between the billets was water. Modeling of the infinite arrays was done by surrounding a single billet with reflective surfaces. For the hexagonal array the billet is surrounded radially by six reflective planar surfaces to create a hexagon. The distance between opposing parallel planes is equal to the lattice pitch. Reflective planes were positioned at the top and bottom ends of the billet. The distance between these axial planes is equal to the length of the billet. Lattice pitch and water density were varied to determine the optimum configuration for the array.

For each case the $k_{\infty}$ plus uncertainties and bias value for the infinite array exceeds the limit for transportation. Therefore further analyses of finite arrays of billets was required. The finite arrays, as the infinite arrays, were modeled in a hexagonal lattice structure. The method used in this finite array analysis is to conservatively assume a hexagonal array of lattice elements inside of a large sphere. These lattice elements completely fill up the sphere in both the horizontal (hexagonal) and vertical (stacked) directions. Optimum lattice pitch, axial water thickness, and water density were determined for the finite arrays. The arrays were surrounded by $12.0 \mathrm{in} .(30.48 \mathrm{~cm})$ of water reflection.

\subsection{2(B) Package Regional Densities}

RMI forged billets are uranium metal enriched to $0.95 \pm 0.006 \mathrm{wt} \%{ }^{235} \mathrm{U}$ and $1.25 \pm 0.006$ $w t \%{ }^{235} \mathrm{U}$. Uranium density used is the theoretical uranium metal density of $18.96 \mathrm{~g} / \mathrm{cm}^{3}$. Material densities and atomic number densities for the constituent nuclides of all materials used in the billet calculations models are listed in Table 6.3.2-1(B).

TABLE 6.3.2-1(B). Material Densities and Atomic Number Densities - RMI Forged Billets.

\begin{tabular}{|l|c|c|c|}
\hline \multicolumn{1}{|c|}{ Isotope/Nuclide } & $\begin{array}{c}\text { Material Density } \\
\left(\mathrm{g} / \mathrm{cm}^{3}\right)\end{array}$ & \multicolumn{2}{|c|}{ Atomic Number Density (atoms/b-cm) } \\
\hline \hline \multirow{2}{*}{ Hydrogen } & \multirow{3}{*}{1.0 (water) } & \multicolumn{2}{|c|}{0.06689} \\
\cline { 3 - 4 } & & \multicolumn{2}{|c|}{0.03344} \\
\cline { 3 - 4 } & & $0.95 \mathrm{wt} \%{ }^{235} \mathrm{U}$ & $1.25 \mathrm{wt} \%{ }^{235} \mathrm{U}$ \\
\hline \multirow{2}{*}{ Oxygen } & \multirow{2}{*}{18.96 (uranium) } & $4.616 \mathrm{E}-04$ & $6.073 \mathrm{E}-04$ \\
\cline { 3 - 4 } & & $4.752 \mathrm{E}-02$ & $4.737 \mathrm{E}-02$ \\
\hline
\end{tabular}

\section{4(B) CRITICALITY CALCULATIONS - RMI FORGED BILLETS}

This section describes the calculational method used for the analyses.

\subsection{1(B) Calculational Method}

The MCNP computer code (Breismeister 1993; Carter 1995) was used for this criticality evaluation. MCNP was discussed in Section 6.4.1(A). 


\subsection{2(B) Contents Loading Optimization}

Steel banded wooden shipping containers were not tested under hypothetical accident conditions and therefore cannot be credited to maintain the payload. To assure subcriticality for any possible payload arrangement, a lattice pitch, axial water thickness, and water density optimization search was made for each billet type. Establishing the optimum lattice pitch, axial water thickness, and water density allows for the determination of the maximum number of billets that can be safely subcritical. Continuous cross-sections were used in these evaluations; therefore, no cross-section adjustments were required for various geometric configurations and material compositions.

\subsection{3(B) Criticality Results}

Initial calculations show that the $\mathrm{k}_{\infty}$ of infinite arrays for all billet types exceed the limit for transportation. Consequently, finite arrays were evaluated to determine the uranium mass of each billet type that will meet the limit of transportation.

Table 6.4.3-1(B) presents the infinite array data for the Mark 1 inner billets. The data is plotted in Figure 6.4.3-1(B). The maximum $k_{\infty}$ plus uncertainties and bias is 1.0013 for the infinite array at an optimum pitch of $8.52 \mathrm{in.}(21.64 \mathrm{~cm})$ and optimum water density fraction of 0.3 . This value exceeds the limit for transportation. Further calculations were done for finite arrays of this billet type. The method used in this finite array analysis is to conservatively assume a hexagonal array of lattice elements inside of a large sphere. These lattice elements completely fill up the sphere in both the horizontal (hexagonal) and vertical (stacked) directions. The results presented in Table 6.4.3-2(B) show that a uranium mass of $24,216 \mathrm{lb}(10,984 \mathrm{~kg})$ has a $\mathrm{k}_{\text {eft }}$ plus uncertainty and bias that is well below the limit, where the billet lengths were conservatively modeled at the minimum length of $16.0 \mathrm{in}$. $(40.64 \mathrm{~cm})$. The last part of Table 6.4.3-2(B) shows the iteration of the two parameters (pitch of the hexagonal lattice and water thickness between the elements in the vertical) to find the parameters that will optimize $\mathrm{k}$ for a full water density of $1.00 \mathrm{~g} / \mathrm{cm}^{3}$-- cases $q 716 \mathrm{~b}$ to $\mathrm{q} 716 \mathrm{f}$. Prior experience has been that the maximum $k$ typically occurs for this water density of one. This is shown for the Mark I inner billets by cases q716x and q716y at the top of the table for reduced water densities, where the axial water thickness in these cases is increased to conserve the axial amount of water from the q716c optimized case and the pitch is computed to conserve the total amount of water. The optimized $k$ is higher with the water density of one.

Table 6.4.3-2(B) also includes a case for Mark I inner billets where all of the optimized parameters for the case with the highest $k_{\text {efl }}(q 716 \mathrm{c})$ were held constant and the billet length was increased to $21 \mathrm{in}$. In order to maintain the total uranium mass loading of $10,984 \mathrm{~kg}$, the radius of the sphere was slightly reduced to $61.47 \mathrm{~cm}$. This case, which is identified as mk $1 \mathrm{i} 21$ in Table 6.4.3-2(B), has a $k_{\text {eff }}$ plus uncertainty and bias that is slightly greater than that for 16 -in. billets with the same mass loading and is well below the limit. Therefore, the maximum uranium mass loading of $10,984 \mathrm{~kg}$ is shown to apply to Mark I inner billets with lengths ranging from 16 to $21 \mathrm{in.}$ 
TABLE 6.4.3-1(B). Mark I Inner Billets Infinite Array $\left(0.95 \mathrm{wt} \%{ }^{235} \mathrm{U}\right)$.

\begin{tabular}{|c|c|c|c|c|}
\hline $\begin{array}{l}\text { Pitch } \\
\text { in. (cm) }\end{array}$ & $\begin{array}{c}\text { Water Density } \\
\text { Fraction }\end{array}$ & $k_{\infty}$ & $\mathrm{k}_{\infty}+2 \sigma+$ bias & Input File \\
\hline $5.37(13.64)$ & 1.0 & 0.7627 & 0.7775 & b1i1 \\
\hline $5.37\{13.64\}$ & 0.7 & 0.6802 & 0.6950 & b7i1 \\
\hline $5.37\{13.64\}$ & 0.5 & 0.6119 & 0.6267 & b5i1 \\
\hline $5.37(13.64)$ & 0.3 & 0.5458 & 0.5606 & b3i1 \\
\hline $5.37(13.64)$ & 0.0 & 0.4925 & 0.5073 & b0i1 \\
\hline $6.16(15.64)$ & 1.0 & 0.9747 & 0.9895 & b1i3 \\
\hline $6.16(15.64)$ & 0.7 & 0.9243 & 0.9392 & b7i3 \\
\hline $6.16(15.64)$ & 0.5 & 0.8476 & 0.8624 & b5i3 \\
\hline $6.16(15.64)$ & 0.3 & 0.7225 & 0.7373 & b3i3 \\
\hline $6.16(15.64)$ & 0.0 & 0.4914 & 0.5062 & b0i3 \\
\hline $6.94(17.64)$ & 1.0 & 0.9344 & 0.9492 & b1i7 \\
\hline $6.94(17.64)$ & 0.7 & 0.9790 & 0.9937 & b7i7 \\
\hline $6.94(17.64)$ & 0.5 & 0.9636 & 0.9784 & b5i7 \\
\hline $6.94(17.64)$ & 0.3 & 0.8694 & 0.8843 & b3i7 \\
\hline $6.94(17.64)$ & 0.0 & 0.4925 & 0.5073 & bOi7 \\
\hline $7.34(18.64)$ & 1.0 & 0.8810 & 0.8959 & b1 18 \\
\hline $7.34(18.64)$ & 0.7 & 0.9594 & 0.9742 & b7i8 \\
\hline $7.34(18.64)$ & 0.5 & 0.9804 & 0.9953 & b5i8 \\
\hline $7.34(18.64)$ & 0.3 & 0.9188 & 0.9336 & b3i8 \\
\hline $7.34(18.64)$ & 0.0 & 0.4920 & 0.5067 & b0i8 \\
\hline $7.73(19.64)$ & 1.0 & 0.8179 & 0.8327 & b1ia \\
\hline $7.73(19.64)$ & 0.7 & 0.9264 & 0.9412 & b7ia \\
\hline $7.73(19.64)$ & 0.5 & 0.9789 & 0.9938 & b5ia \\
\hline $7.73(19.64\}$ & 0.3 & 0.9525 & 0.9673 & b3ia \\
\hline $7.73(19.64)$ & 0.0 & 0.4904 & 0.5051 & bOia \\
\hline $8.52(21.64)$ & 1.0 & 0.7051 & 0.7199 & b1ib \\
\hline $8.52\{21.64\}$ & 0.7 & 0.8355 & 0.8503 & b7ib \\
\hline $8.52\{21.64\}$ & 0.5 & 0.9354 & 0.9502 & b5ib \\
\hline $8.52\{21.64\}$ & 0.3 & 0.9865 & 1.0013 & b3ib \\
\hline $8.52(21.64)$ & 0.0 & 0.4927 & 0.5075 & bOib \\
\hline $9.31(23.64)$ & 1.0 & 0.6197 & 0.6345 & b1i9 \\
\hline $9.31(23.64)$ & 0.7 & 0.7430 & 0.7578 & b7i9 \\
\hline $9.31(23.64)$ & 0.5 & 0.8692 & 0.8840 & b5i9 \\
\hline $9.31\{23.64\}$ & 0.3 & 0.9810 & 0.9958 & b3i9 \\
\hline $9.31(23.64)$ & 0.0 & 0.4902 & 0.5049 & b0i9 \\
\hline
\end{tabular}




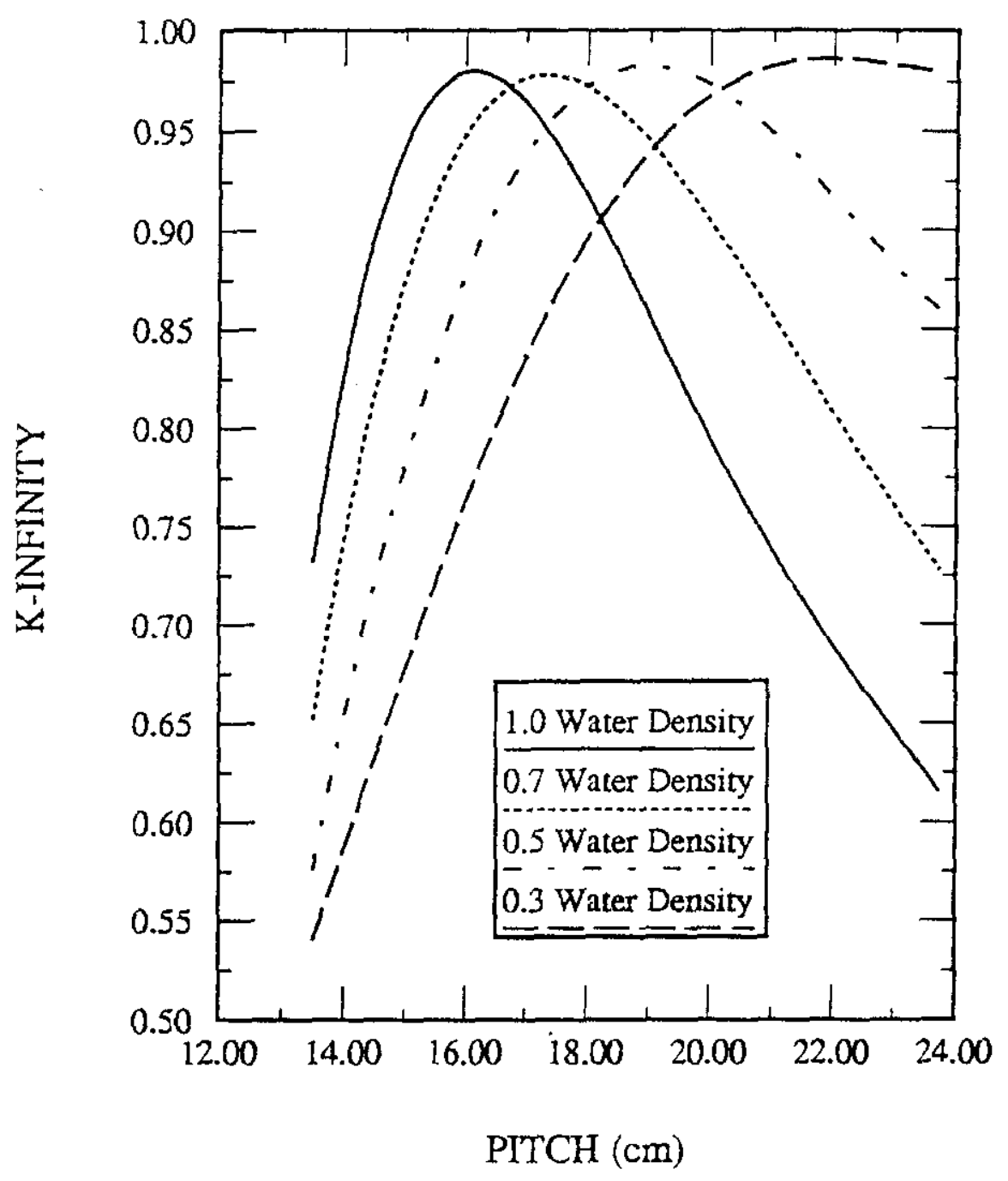

FIGURE 6.4.3-1(B). Mark I Infinite Array of Inner Billets. 
TABLE 6.4.3-2(B). Reflected Finite Arrays to Determine Optimum Parameters and Maximum Mass for Mark I Inner Billets (5.37-in. diameter and 1.34 -in. ID $\times 16$-in. long, $0.95 \mathrm{wt} \%{ }^{235} \mathrm{U}$ ).

\begin{tabular}{|c|c|c|c|c|c|c|c|c|}
\hline \multicolumn{3}{|c|}{ Parameters of Hexagonal Lattice Cell } & \multicolumn{2}{|c|}{$\begin{array}{l}\text { Sphere Containing } \\
\text { Lattice Cells }\end{array}$} & \multicolumn{3}{|c|}{ Calculated Results } & \multirow[t]{2}{*}{ Case $^{\theta}$} \\
\hline $\begin{array}{l}\text { Pitch } \\
\text { (cm) }\end{array}$ & $\begin{array}{c}\text { Water } \\
\text { Density } \\
\left\langle\mathrm{g} / \mathrm{cm}^{3}\right)^{\mathrm{a}}\end{array}$ & $\begin{array}{c}\text { Axial } \\
\text { Water } \\
\text { Height } \\
(\mathrm{cm})^{\mathrm{b}}\end{array}$ & $\begin{array}{c}\text { Sphere } \\
\text { Radius } \\
(\mathrm{cm})^{c}\end{array}$ & $\begin{array}{c}\text { Total } \\
\text { Uranium } \\
\text { Mass }(\mathrm{kg})^{\mathrm{c}}\end{array}$ & $k_{e f f}$ & Uncer. ${ }^{d}$ & $\begin{array}{c}k_{e f t}+2 \sigma \\
+ \text { bias }^{c}\end{array}$ & \\
\hline $17.233^{\prime}$ & 0.700 & $2.786^{t}$ & 65.260 & 10,984 & 0.9109 & 0.0014 & 0.9258 & $q 716 x$ \\
\hline $19.743^{\dagger}$ & 0.400 & $4.875^{\prime}$ & 72.771 & 10,984 & 0.8843 & 0.0011 & 0.8991 & q716y \\
\hline \multicolumn{9}{|c|}{ Calculations with water density $=1.0 \mathrm{~g} / \mathrm{cm}^{3}$} \\
\hline 16.040 & 1.00 & 2.450 & 90.000 & 33,702 & 0.9573 & 0.0010 & 0.9720 & q716a \\
\hline 16.040 & 1.00 & 2.450 & 62.000 & 10,984 & 0.9242 & 0.0011 & 0.9390 & q716b \\
\hline 16.040 & 1.00 & 1.950 & 61.753 & 10,984 & 0.9264 & 0.0011 & 0.9412 & $q 716 c$ \\
\hline 16.040 & 1.00 & 1.950 & 61.470 & 10,984 & 0.9269 & 0.0013 & 0.9417 & $\mathrm{mk} 1 \mathrm{i} 21^{9}$ \\
\hline 16.040 & 1.00 & 1.950 & 61.470 & 10,984 & 09.291 & 0.0006 & 0.9418 & $m k 1 i 21 u$ \\
\hline 16.040 & 1.00 & 1.450 & 61.506 & 10,984 & 0.9238 & 0.0013 & 0.9387 & $q 716 d$ \\
\hline 15.540 & 1.00 & 1.950 & 60.458 & 10,984 & 0.9198 & 0.0012 & 0.9346 & $q 716 e$ \\
\hline 16.540 & 1.00 & 1.950 & 63.049 & 10,984 & 0.9185 & 0.0011 & 0.9333 & $q 716 f$ \\
\hline
\end{tabular}

${ }^{a}$ Density of both the radial water beyond the 5.37-in. diameter uranium and the axial water between uranium layers.

${ }^{\mathrm{b}} \mathrm{Axial}$ thickness of water between uranium layers.

'Sphere containing the hexagonal lattice and resulting total uranium mass in the lattice within the sphere.

${ }^{d}$ One standard deviation statistical uncertainty in the Monte Carlo calculation.

enput file names are this case identifier preceded with an $i$ and the corresponding MCNP output files are this case identifier preceded with an o.

'Axial water height is computed to conserve the product of water density with axial water height compared to case $\mathrm{q} 716 \mathrm{c}$. Then the pitch is computed to conserve the total water mass within the unit lattice cell compared to case q716c.

${ }^{9}$ The billet length is increased to $21 \mathrm{in.} \mathrm{for} \mathrm{this} \mathrm{case} \mathrm{to} \mathrm{demonstrate} \mathrm{that} \mathrm{the} \mathrm{total} \mathrm{uranium} \mathrm{mass} \mathrm{limit} \mathrm{of}$ $10,984 \mathrm{~kg}$ for 16 -in. billets is also valid for 21 -in. billets. 
The $k_{\infty}$ values for infinite arrays of Mark 1 outer billets are presented in Table 6.4.3-3(B). The data is plotted in Figure 6.4.3-2(B). At an optimum pitch of $8.56 \mathrm{in} .(21.73 \mathrm{~cm})$ and optimum water density fraction of 0.7 the infinite array $k_{\infty}$ plus uncertainties and bias is 1.0682 . Further calculations were done for finite arrays of this billet type. The method used in this finite array analysis is to conservatively assume a hexagonal array of lattice elements inside of a large sphere. These lattice elements completely fill up the sphere in both the horizontal (hexagonal) and vertical (stacked) directions. The results presented in Table 6.4.3-4(B) show that a uranium mass of $6,466 \mathrm{lb}(2,933 \mathrm{~kg})$ has a $\mathrm{k}_{\text {eff }}$ plus uncertainty and bias that is well below the limit, where the billet lengths were conservatively modeled at the minimum length of $16.0 \mathrm{in} .(40.64 \mathrm{~cm})$. The last part of Table 6.4.3-4(B) shows the iteration on the two parameters (pitch of the hexagonal lattice and water thickness between the elements in the vertical) to find the parameters that will optimize $k$ for a full water density of $1.00 \mathrm{~g} / \mathrm{cm}^{3}$-. cases $0716 \mathrm{i}$ to $0716 \mathrm{~m}$. Then case 07160 is made with the optimum parameters, but at a reduced sphere radius (or mass), to obtain the optimized $k$ below the limit. Prior experience has been that the maximum $k$ typically occurs for this water density of one. This is shown for the Mark I outer billets by cases $0716 \mathrm{c}$ to $0716 \mathrm{~g}$ at the top of the table for an intermediate water density of $0.70 \mathrm{~g} / \mathrm{cm}^{3}$. The optimized $\mathrm{k}$ is higher with the water density of one.

Table 6.4.3-4(B) also includes a case for Mark I outer billets where all of the optimized parameters for the case with the highest $k_{\mathrm{cff}}(0716 \mathrm{o})$ were held constant and the billet length was increased to $21 \mathrm{in.}$ In order to maintain the total uranium mass loading of $2,933 \mathrm{~kg}$, the radius of the sphere was slightly reduced to $40.26 \mathrm{~cm}$. This case, which is identified as mk 1021 in Table 6.4.3-4(B), has a $k_{\text {eff }}$ plus uncertainty and bias that is slightly less than that for 16 -in. billets with the same mass loading and is well below the limit. Therefore, the maximum uranium mass loading of $2,933 \mathrm{~kg}$ is shown to apply to Mark I outer billets with lengths ranging from 16 to $21 \mathrm{in}$.

Mark IV inner billet infinite array $k_{\infty}$ values are presented in Table 6.4.3-5(B). The data is plotted in Figure 6.4.3-3(B). The $k_{\infty}$ plus uncertainties and bias value is 0.9990 at the optimum pitch of $8.62 \mathrm{in.}(21.90 \mathrm{~cm})$ and optimum water density of 0.3 . This value exceeds the limit for transportation. Further calculations were done for finite arrays of this billet type. The method used in this finite array analysis is to conservatively assume a hexagonal array of lattice elements inside of a large sphere. These lattice elements completely fill up the sphere in both the horizontal (hexagonal) and vertical (stacked) directions. The results presented in Table 6.4.3-6(B) show that a uranium mass of $24,216 \mathrm{lb}(10,984 \mathrm{~kg})$ has a $k_{\text {eff }}$ plus uncertainty and bias that is well below the limit, where the billet lengths were conservatively modeled at the minimum length of $16.0 \mathrm{in}$. $(40.64 \mathrm{~cm})$ and at the water density of one confirmed to maximize the previous two billet types.

Table 6.4.3-6(B) also includes a case for Mark IV inner billets where all of the optimized parameters for the case with the highest $k_{\text {eff }}(q 4 i 16 b)$ were held constant and the billet length was increased to $21 \mathrm{in}$. In order to maintain the total uranium mass loading of 10,984 $\mathrm{kg}$, the radius of the sphere was slightly reduced to $61.362 \mathrm{~cm}$. This case, which is identified as $\mathrm{mk} 4 \mathrm{i} 21 \mathrm{in}$ Table 6.4.3-6(B), has a $k_{\text {eff }}$ plus uncertainty and bias that is slightly less than that for 16 -in. billets with the same mass loading and is well below the limit. Therefore, the maximum uranium mass loading of $10,984 \mathrm{~kg}$ is shown to apply to Mark IV inner billets with lengths ranging from 16 to $21 \mathrm{in.}$

Table 6.4.3-7(B) presents the infinite array data for the Mark IV outer billets. The data is plotted in Figure 6.4.3-4(B). At the optimum pitch and water density $k_{\infty}$ plus uncertainties and bias is 0.9874 . This value exceeds the limit for transportation. Further calculations were done for finite arrays of this billet type. The method used in this finite array analysis is to conservatively assume a hexagonal array of lattice elements inside of a large sphere. These lattice elements completely fill up the sphere in both the horizontal (hexagonal) and vertical (stacked) directions. The results presented in Table 6.4.3-8(B) show that a uranium mass of $24,216 \mathrm{lb}(10,984 \mathrm{~kg})$ has a $k_{\text {eff }}$ plus uncertainty and bias that is well below the limit, where the billet lengths were conservatively modeled at the minimum length of $16.0 \mathrm{in} .(40.64 \mathrm{~cm})$ and the water density of one. 
TABLE 6.4.3-3(B). Mark I Outer Billets Infinite Array $\left(1.25 \mathrm{wt} \%{ }^{235} \mathrm{U}\right)$.

\begin{tabular}{|c|c|c|c|c|}
\hline $\begin{array}{c}\text { Pitch } \\
\text { in. }(\mathrm{cm})\end{array}$ & $\begin{array}{c}\text { Water Density } \\
\text { Fraction }\end{array}$ & $k_{\infty}$ & $\mathrm{k}_{\infty}+2 \sigma+$ bias & Input File \\
\hline $6.98(17.73)$ & 1.0 & 0.9316 & 0.9465 & b1o1 \\
\hline $6.98(17.73)$ & 0.7 & 0.8708 & 0.8857 & b7o1 \\
\hline $6.98(17.73)$ & 0.5 & 0.7939 & 0.8088 & b5o1 \\
\hline $6.98(17.73)$ & 0.3 & 0.6821 & 0.6969 & b3o1 \\
\hline $6.98(17.73)$ & 0.0 & 0.5333 & 0.5480 & b0o1 \\
\hline $7.77(19.73)$ & 1.0 & 1.0467 & 1.0615 & b1o3 \\
\hline $7.77(19.73)$ & 0.7 & 1.0159 & 1.0307 & b7o3 \\
\hline $7.77(19.73)$ & 0.5 & 0.9472 & 0.9620 & $b 503$ \\
\hline $7.77(19.73)$ & 0.3 & 0.8073 & 0.8221 & b3o3 \\
\hline $7.77(19.73)$ & 0.0 & 0.5353 & 0.5500 & $\mathrm{~b} 003$ \\
\hline $8.56(21.73)$ & 1.0 & 1.0084 & 1.0232 & b105 \\
\hline $8.56(21.73)$ & 0.7 & 1.0534 & 1.0682 & b7o5 \\
\hline $8.56(21.73)$ & 0.5 & 1.0319 & 1.0467 & b5o5 \\
\hline $8.56(21.73)$ & 0.3 & 0.9274 & 0.9423 & b3o5 \\
\hline $8.56(21.73)$ & 0.0 & 0.5342 & 0.5490 & b0o5 \\
\hline $8.95(22.73)$ & 1.0 & 0.9564 & 0.9712 & b1o6 \\
\hline $8.95(22.73)$ & 0.7 & 1.0347 & 1.0495 & b7o6 \\
\hline $8.95(22.73)$ & 0.5 & 1.0456 & 1.0604 & b5o6 \\
\hline $8.95(22.73)$ & 0.3 & 0.9715 & 0.9863 & b3o6 \\
\hline $8.95(22.73)$ & 0.0 & 0.5337 & 0.5484 & b0o6 \\
\hline $9.34(23.73)$ & 1.0 & 0.9038 & 0.9186 & b108 \\
\hline $9.34(23.73)$ & 0.7 & 1.0029 & 1.0177 & $\mathrm{~b} 7 \mathrm{o} 8$ \\
\hline $9.34(23.73)$ & 0.5 & 1.0431 & 1.0579 & b5o8 \\
\hline $9.34(23.73)$ & 0.3 & 1.0008 & 1.0156 & b3o8 \\
\hline $9.34(23.73)$ & 0.0 & 0.5338 & 0.5485 & b0o8 \\
\hline $10.13(25.73)$ & 1.0 & 0.8013 & 0.8161 & b109 \\
\hline $10.13(25.73)$ & 0.7 & 0.9200 & 0.9348 & b7o9 \\
\hline $10.13(25.73)$ & 0.5 & 1.0066 & 1.0214 & b5o9 \\
\hline $10.13\{25.73\}$ & 0.3 & 1.0356 & 1.0504 & b3o9 \\
\hline $10.13(25.73\}$ & 0.0 & 0.5356 & 0.5503 & b0o9 \\
\hline $10.92(27.73)$ & 1.0 & 0.7241 & 0.7390 & b1o7 \\
\hline $10.92(27.73)$ & 0.7 & 0.8362 & 0.8510 & 6707 \\
\hline $10.92(27.73)$ & 0.5 & 0.9472 & 0.9620 & b5o7 \\
\hline $10.92(27.73)$ & 0.3 & 1.0383 & 1.0531 & b307 \\
\hline $10.92(27.73)$ & 0.0 & 0.5341 & 0.5488 & b0o7 \\
\hline
\end{tabular}




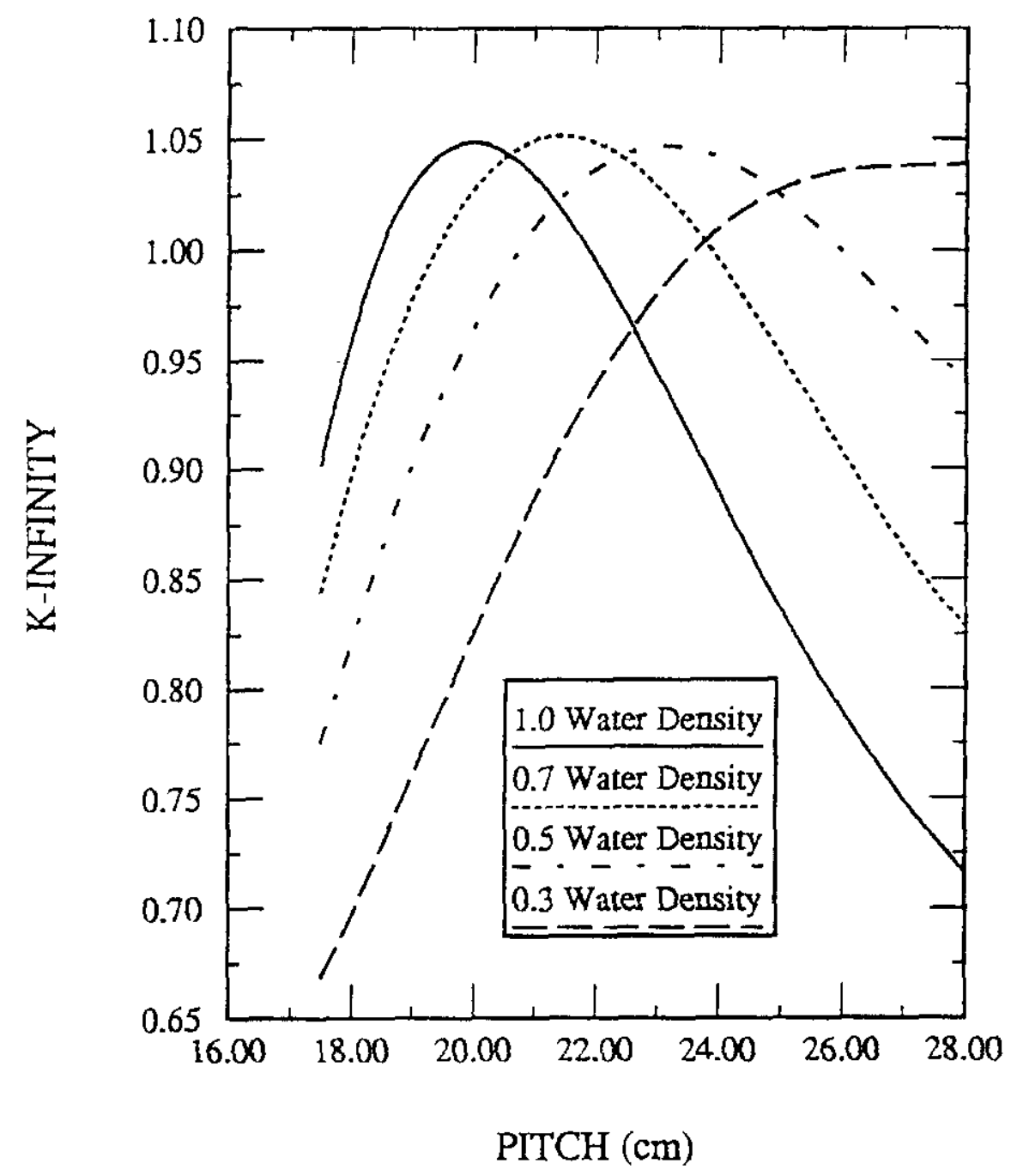

FIGURE 6.4.3-2(B). Mark I Infinite Array of Outer Billets. 
TABLE 6.4.3-4(B). Reflected Finite Arrays to Determine Optimum Parameters and Maximum Mass for Mark I Outer Billets (6.98-in. diameter and 2.80 -in. ID $\times 16$-in. long, $1.25 \mathrm{wt} \%{ }^{235} \mathrm{U}$ ).

\begin{tabular}{|c|c|c|c|c|c|c|c|c|}
\hline \multicolumn{3}{|c|}{ Parameters of Hexagonal Lattice Cell } & \multicolumn{2}{|c|}{$\begin{array}{c}\text { Sphere Containing } \\
\text { Lattice Cells }\end{array}$} & \multicolumn{3}{|c|}{ Calculated Results } & \multirow[t]{2}{*}{ Case $^{\theta}$} \\
\hline $\begin{array}{l}\text { Pitch } \\
\text { (cm) }\end{array}$ & $\begin{array}{l}\text { Water } \\
\text { Density } \\
\left(\mathrm{g} / \mathrm{cm}^{3}\right)^{\mathrm{a}}\end{array}$ & $\begin{array}{l}\text { Axial } \\
\text { Water } \\
\text { Height } \\
(\mathrm{cm})^{b}\end{array}$ & $\begin{array}{c}\text { Sphere } \\
\text { Radius } \\
(\mathrm{cm})^{\circ}\end{array}$ & $\begin{array}{c}\text { Total } \\
\text { Uranium } \\
\text { Mass }\langle\mathrm{kg})^{\mathrm{c}}\end{array}$ & $k_{\text {eff }}$ & Uncer. ${ }^{d}$ & $\begin{array}{l}\mathrm{k}_{\mathrm{eft}}+2 \sigma \\
+\operatorname{bias}^{\mathrm{c}}\end{array}$ & \\
\hline 21.730 & 0.70 & 5.5 & 71.951 & 13,067 & 0.9785 & 0.0016 & 0.9935 & $0716 a$ \\
\hline 21.730 & 0.70 & 5.5 & 55.000 & 5,894 & 0.9398 & 0.0012 & 0.9546 & $0716 b$ \\
\hline 21.730 & 0.70 & 5.5 & 50.500 & 4,607 & 0.9223 & 0.0012 & 0.9371 & $0716 \mathrm{c}$ \\
\hline 21.730 & 0.70 & 4.5 & 50.209 & 4,607 & 0.9342 & 0.0013 & 0.9491 & $0716 \mathrm{~d}$ \\
\hline 21.730 & 0.70 & 3.5 & 49.893 & 4,607 & 0.9352 & 0.0015 & 0.9501 & $0716 \mathrm{e}$ \\
\hline 20.730 & 0.70 & 3.5 & 48.322 & 4,607 & 0.9337 & 0.0010 & 0.9484 & $0716 f$ \\
\hline 22.730 & 0.70 & 3.5 & 51.362 & 4,607 & 0.9202 & 0.0013 & 0.9351 & $0716 \mathrm{~g}$ \\
\hline \multicolumn{9}{|c|}{ Calculations with water density $=1.0 \mathrm{~g} / \mathrm{cm}^{3}$} \\
\hline 20.158 & 1.00 & 2.450 & 47.086 & 4,607 & 0.9539 & 0.0014 & 0.9688 & $0716 \mathrm{i}$ \\
\hline 20.158 & 1.00 & 2.950 & 47.232 & 4,607 & 0.9534 & 0.0014 & 0.9683 & 0716j \\
\hline 20.158 & 1.00 & 1.950 & 46.931 & 4,607 & 0.9540 & 0.0013 & 0.9689 & $0716 \mathrm{k}$ \\
\hline 19.658 & 1.00 & 2.450 & 46.267 & 4,607 & 0.9531 & 0.0011 & 0.9679 & 07161 \\
\hline 20.658 & 1.00 & 2.450 & 47.881 & 4,607 & 0.9496 & 0.0012 & 0.9644 & $0716 \mathrm{~m}$ \\
\hline 20.158 & 1.00 & 2.450 & 38.770 & 2,593 & 0.9192 & 0.0012 & 0.9340 & $0716 n$ \\
\hline 20.158 & 1.00 & 2.450 & 40.300 & 2,933 & 0.9271 & 0.0012 & 0.9419 & 0716 o \\
\hline 20.158 & 1.00 & 2.450 & 40.260 & 2,933 & 0.9251 & 0.0011 & 0.9399 & $\mathrm{mk} 1021^{\dagger}$ \\
\hline 20.158 & 1.00 & 2.450 & 40.260 & 2,933 & 0.9291 & 0.0006 & 0.9438 & $\mathrm{mk} 1 \mathrm{o} 21 \mathrm{u}$ \\
\hline
\end{tabular}

${ }^{a}$ Density of both the radial water beyond the 6.98 -in. diameter uranium and the axial water between uranium layers.

${ }^{b}$ Axial thickness of water between uranium layers.

'Sphere containing the hexagonal lattice and resulting total uranium mass in the lattice within the sphere.

dOne standard deviation statistical uncertainty in the Monte Carlo calculation.

eInput file names are this case identifier preceded with an $i$ and the corresponding MCNP output files are this case identifier preceded with an 0 .

'The billet length is increased to $21 \mathrm{in.}$ for this case to demonstrate that the total uranium mass limit of $2,933 \mathrm{~kg}$ for 16 -in. billets is also valid for 21 -in. long billets. 
TABLE 6.4.3-5(B). Mark IV Inner Billets Infinite Array $\left(0.95\right.$ wt $\left.\%{ }^{235} \mathrm{U}\right)$.

\begin{tabular}{|c|c|c|c|c|}
\hline $\begin{array}{l}\text { Pitch } \\
\text { in. }(\mathrm{cm})\end{array}$ & $\begin{array}{c}\text { Water Density } \\
\text { Fraction }\end{array}$ & $k_{\infty}$ & $\mathrm{k}_{\infty}+2 \sigma+$ bias & Input File \\
\hline $5.47(13.90)$ & 1.0 & 0.7555 & 0.7703 & f1i1 \\
\hline $5.47(13.90)$ & 0.7 & 0.6689 & 0.6837 & f7i1 \\
\hline $5.47(13.90)$ & 0.5 & 0.6064 & 0.6213 & f5i1 \\
\hline $5.47(13.90)$ & 0.3 & 0.5435 & 0.5583 & 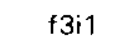 \\
\hline $5.47(13.90)$ & 0.0 & 0.4923 & 0.5070 & foi1 \\
\hline $6.26(15.90\}$ & 1.0 & 0.9681 & 0.9829 & $\mathrm{f} 1 \mathrm{i} 2$ \\
\hline $6.26(15.90)$ & 0.7 & 0.9201 & 0.9349 & $\mathrm{f} 7 \mathrm{i} 2$ \\
\hline $6.26(15.90)$ & 0.5 & 0.8453 & 0.8602 & f5i2 \\
\hline $6.26(15.90)$ & 0.3 & 0.7200 & 0.7348 & f3i2 \\
\hline $6.26(15.90)$ & 0.0 & 0.4926 & 0.5073 & fOi2 \\
\hline $6.65(16.90)$ & 1.0 & 0.9683 & 0.9831 & f1 i3 \\
\hline $6.65(16.90)$ & 0.7 & 0.9669 & 0.9817 & $f 7 i 3$ \\
\hline $6.65(16.90)$ & 0.5 & 0.9189 & 0.9337 & f5i3 \\
\hline $6.65(16.90)$ & 0.3 & 0.7998 & 0.8146 & f3i3 \\
\hline $6.65(16.90)$ & 0.0 & 0.4921 & 0.5068 & fOi3 \\
\hline $7.44(18.90)$ & 1.0 & 0.8735 & 0.8883 & $\mathrm{f} 1 \mathrm{i4}$ \\
\hline $7.44(18.90)$ & 0.7 & 0.9579 & 0.9727 & f7i4 \\
\hline $7.44\langle 18.90\}$ & 0.5 & 0.9771 & 0.9919 & $f 5 i 4$ \\
\hline $7.44(18.90)$ & 0.3 & 0.9157 & 0.9305 & $f 3 i 4$ \\
\hline $7.44(18.90)$ & 0.0 & 0.4935 & 0.5082 & fOi4 \\
\hline $7.83(19.90)$ & 1.0 & 0.8145 & 0.8293 & $f 1$ i6 \\
\hline $7.83(19.90)$ & 0.7 & 0.9227 & 0.9375 & f7i6 \\
\hline $7.83(19.90)$ & 0.5 & 0.9760 & 0.9908 & $f 5 i 6$ \\
\hline $7.83(19.90)$ & 0.3 & 0.9509 & 0.9657 & $f 3 i 6$ \\
\hline $7.83(19.90)$ & 0.0 & 0.4926 & 0.5074 & fOi6 \\
\hline $8.62(21.90)$ & 1.0 & 0.7018 & 0.7166 & $\mathrm{f} 1 \mathrm{i} 7$ \\
\hline $8.62\{21.90\}$ & 0.7 & 0.8352 & 0.8500 & $f 7 i 7$ \\
\hline $8.62(21.90)$ & 0.5 & 0.9349 & 0.9497 & $f 5 i 7$ \\
\hline $8.62(21.90)$ & 0.3 & 0.9842 & 0.9990 & $\mathfrak{f i 7}$ \\
\hline $8.62(21.90)$ & 0.0 & 0.4912 & 0.5060 & f0i7 \\
\hline $9.41(23.90)$ & 1.0 & 0.6198 & 0.6349 & $\mathrm{f} 1 \mathrm{i5}$ \\
\hline $9.41(23.90)$ & 0.7 & 0.7437 & 0.7585 & $f 7 i 5$ \\
\hline $9.41(23.90)$ & 0.5 & 0.8692 & 0.8840 & $\mathrm{f} 5 \mathrm{i} 5$ \\
\hline $9.41(23.90)$ & 0.3 & 0.9798 & 0.9946 & $f 3 i 5$ \\
\hline $9.41(23.90)$ & 0.0 & 0.4918 & 0.5066 & foi5 \\
\hline
\end{tabular}




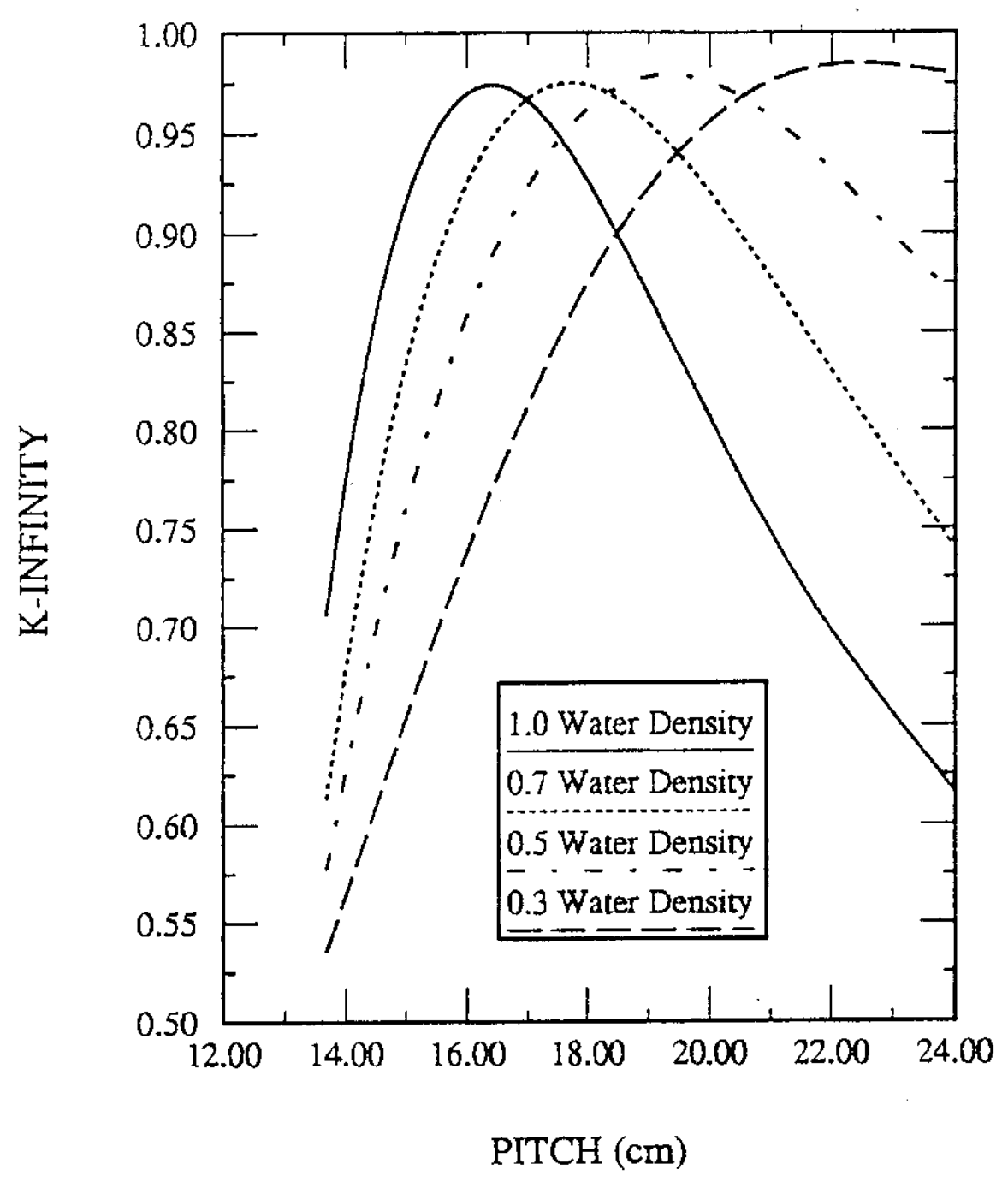

FIGURE 6.4.3-3(B). Mark IV Infinite Array of Inner Billets. 
TABLE 6.4.3-6(B). Reflected Finite Arrays to Determine Optimum Parameters and Maximum Mass for Mark IV Inner Billets (5.46-in. diameter and 1.26 -in. ID $\times 16$-in. long, 0.95 wt $\%{ }^{235} \mathrm{U}$ ).

\begin{tabular}{|c|c|c|c|c|c|c|c|c|}
\hline \multicolumn{3}{|c|}{ Parameters of Hexagonal Lattice Cell } & \multicolumn{2}{|c|}{$\begin{array}{l}\text { Sphere Containing } \\
\text { Lattice Cells }\end{array}$} & \multicolumn{3}{|c|}{ Calculated Results } & \multirow[t]{2}{*}{ Case $^{e}$} \\
\hline $\begin{array}{l}\text { Pitch } \\
\{\mathrm{cm}\}\end{array}$ & $\begin{array}{c}\text { Water } \\
\text { Density } \\
\left(\mathrm{g} / \mathrm{cm}^{3}\right)^{\mathrm{a}}\end{array}$ & $\begin{array}{l}\text { Axial } \\
\text { Water } \\
\text { Height } \\
(\mathrm{cm})^{\mathrm{b}}\end{array}$ & $\begin{array}{c}\text { Sphere } \\
\text { Radius } \\
(\mathrm{cm})^{\mathrm{c}}\end{array}$ & $\begin{array}{c}\text { Total } \\
\text { Uranium } \\
\text { Mass }(\mathrm{kg})^{\mathrm{c}}\end{array}$ & $\mathrm{k}_{\text {eft }}$ & Uncer. ${ }^{d}$ & $\begin{array}{c}\mathrm{k}_{\mathrm{Bff}}+2 \sigma \\
+ \text { bias }^{c}\end{array}$ & \\
\hline \multicolumn{9}{|c|}{ Calculations with water density $=1.0 \mathrm{~g} / \mathrm{cm}^{3}$} \\
\hline 16.269 & 1.00 & 2.450 & 61.748 & 10,984 & 0.9245 & 0.0009 & 0.9392 & $q 4 i 16 b$ \\
\hline 16.269 & 1.00 & 2.450 & 61.362 & 10,984 & 0.9212 & 0.0013 & 0.9361 & $m k 4 i 21^{\prime}$ \\
\hline 16.269 & 1.00 & 2.450 & 61.362 & 10,984 & 0.9213 & 0.0006 & 0.9361 & $m k 4 i 21 u$ \\
\hline 16.269 & 1.00 & 1.950 & 61.506 & 10,984 & 0.9242 & 0.0012 & 0.9390 & $q 4 i 16 c$ \\
\hline 16.269 & 1.00 & 2.950 & 61.987 & 10,984 & 0.9219 & 0.0011 & 0.9367 & $q 4 i 16 d$ \\
\hline 15.769 & 1.00 & 2.450 & 60.454 & 10,984 & 0.9167 & 0.0012 & 0.9315 & $q 4 i 16 e$ \\
\hline 16.769 & 1.00 & 2.450 & 63.029 & 10,984 & 0.9144 & 0.0011 & 0.9292 & $q 4 i 16 f$ \\
\hline
\end{tabular}

${ }^{a}$ Density of both the radial water beyond the 5.46 -in. diameter uranium and the axial water between uranium layers.

DAxial thickness of water between uranium layers.

'Sphere containing the hexagonal lattice and resulting total uranium mass in the lattice within the sphere.

${ }^{\mathrm{D}}$ One standard deviation statistical uncertainty in the Monte Carlo calculation.

Input file names are this case identifier preceded with an $i$ and the corresponding MCNP output files are this case identifier preceded with an o.

'The billet length was increased to $21 \mathrm{in.} \mathrm{for} \mathrm{this} \mathrm{case} \mathrm{to} \mathrm{demonstrate} \mathrm{that} \mathrm{the} \mathrm{total} \mathrm{uranium} \mathrm{mass} \mathrm{limit} \mathrm{of}$ $10,984 \mathrm{~kg}$ for 16 -in. billets is valid for 21 -in. billets. 
TABLE 6.4.3-7(B). Mark IV Outer Billets Infinite Array $\left(0.95 w t \%{ }^{235} \mathrm{U}\right)$.

\begin{tabular}{|c|c|c|c|c|}
\hline $\begin{array}{c}\text { Pitch } \\
\text { in. }\{\mathrm{cm}\}\end{array}$ & $\begin{array}{c}\text { Water Density } \\
\text { Fraction }\end{array}$ & $k_{\infty}$ & $\mathrm{k}_{\infty}+2 \sigma+$ bias & Input File \\
\hline $6.98(17.73)$ & 1.0 & 0.8503 & 0.8652 & f1o 1 \\
\hline $6.98(17.73)$ & 0.7 & 0.7843 & 0.7991 & $f 701$ \\
\hline $6.98(17.73\}$ & 0.5 & 0.7068 & 0.7216 & f5o1 \\
\hline $6.98(17.73)$ & 0.3 & 0.6045 & 0.6193 & f3o 1 \\
\hline $6.98(17.73)$ & 0.0 & 0.4914 & 0.5061 & foo 1 \\
\hline $7.77(19.73)$ & 1.0 & 0.9706 & 0.9854 & $\mathrm{f} 1 \mathrm{o} 2$ \\
\hline $7.77(19.73)$ & 0.7 & 0.9364 & 0.9512 & +702 \\
\hline $7.77(19.73)$ & 0.5 & 0.8661 & 0.8810 & f5o2 \\
\hline $7.77(19.73)$ & 0.3 & 0.7344 & 0.7492 & $\mathrm{f} 3 \circ 2$ \\
\hline $7.77(19.73)$ & 0.0 & 0.4915 & 0.5063 & f0o2 \\
\hline $8.56(21.73)$ & 1.0 & 0.9336 & 0.9484 & $f 108$ \\
\hline $8.56(21.73)$ & 0.7 & 0.9726 & 0.9874 & $f 708$ \\
\hline $8.56(21.73)$ & 0.5 & 0.9548 & 0.9696 & $f 508$ \\
\hline $8.56(21.73)$ & 0.3 & 0.8531 & 0.8679 & 1308 \\
\hline $8.56(21.73)$ & 0.0 & 0.4926 & 0.5074 & f0o8 \\
\hline $8.95(22.73)$ & 1.0 & 0.8853 & 0.9001 & $\mathrm{f} 1 \mathrm{o} 4$ \\
\hline $8.95(22.73)$ & 0.7 & 0.9592 & 0.9740 & $f 704$ \\
\hline $8.95(22.73)$ & 0.5 & 0.9672 & 0.9820 & $f 504$ \\
\hline $8.95(22.73\}$ & 0.3 & 0.8980 & 0.9128 & 1304 \\
\hline $8.95(22.73)$ & 0.0 & 0.4923 & 0.5070 & f0o4 \\
\hline $9.34(23.73)$ & 1.0 & 0.8363 & 0.8511 & $f 106$ \\
\hline $9.34(23.73)$ & 0.7 & 0.9289 & 0.9437 & †7०6 \\
\hline $9.34(23.73)$ & 0.5 & 0.9663 & 0.9811 & $f 506$ \\
\hline $9.34(23.73)$ & 0.3 & 0.9279 & 0.9427 & f3o6 \\
\hline $9.34(23.73)$ & 0.0 & 0.4917 & 0.5064 & f0o6 \\
\hline $10.13(25.73)$ & 1.0 & 0.7433 & 0.7582 & $f 107$ \\
\hline $10.13(25.73)$ & 0.7 & 0.8517 & 0.8665 & 1707 \\
\hline $10.13(25.73)$ & 0.5 & 0.9330 & 0.9478 & f5o7 \\
\hline $10.13(25.73)$ & 0.3 & 0.9579 & 0.9727 & $\{307$ \\
\hline $10.13(25.73)$ & 0.0 & 0.4921 & 0.5068 & f0o 7 \\
\hline $10.92(27.73)$ & 1.0 & 0.6708 & 0.6856 & $f 105$ \\
\hline $10.92(27.73)$ & 0.7 & 0.7742 & 0.7890 & f7o5 \\
\hline $10.92(27.73)$ & 0.5 & 0.8782 & 0.8930 & f505 \\
\hline $10.92(27.73)$ & 0.3 & 0.9612 & 0.9760 & $f 305$ \\
\hline $10.92(27.73\}$ & 0.0 & 0.4917 & 0.5065 & f0o5 \\
\hline
\end{tabular}




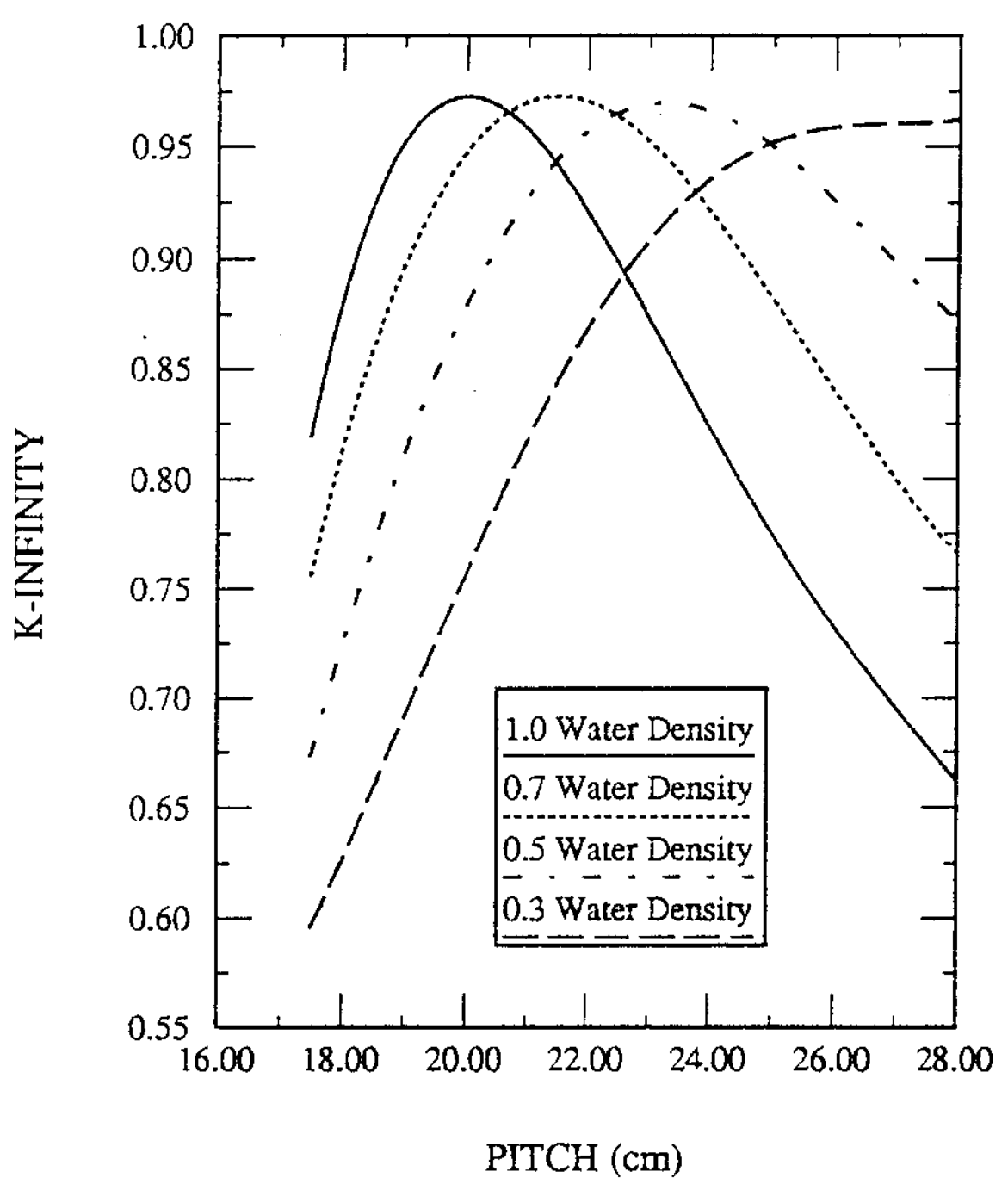

FIGURE 6.4.3-4(B). Mark IV Infinite Array of Outer Billets. 
TABLE 6.4.3-8(B). Reflected Finite Arrays to Determine Optimum Parameters and Maximum Mass for Mark IV Outer Billets (6.98-in. diameter and 2.51 -in. ID x 16 -in. long, $0.95 \mathrm{wt} \%{ }^{235} \mathrm{U}$ ).

\begin{tabular}{|c|c|c|c|c|c|c|c|c|}
\hline \multicolumn{3}{|c|}{ Parameters of Hexagonal Lattice Cell } & \multicolumn{2}{|c|}{$\begin{array}{c}\text { Sphere Containing } \\
\text { Lattice Cells }\end{array}$} & \multicolumn{3}{|c|}{ Calculated Results } & \multirow[t]{2}{*}{ Case $^{e}$} \\
\hline $\begin{array}{l}\text { Pitch } \\
\text { (cm) }\end{array}$ & $\begin{array}{c}\text { Water } \\
\text { Density } \\
\left(\mathrm{g} / \mathrm{cm}^{3}\right)^{\mathrm{a}}\end{array}$ & $\begin{array}{c}\text { Axial Water } \\
\text { Height } \\
\text { (cm) }^{\mathrm{b}}\end{array}$ & $\begin{array}{l}\text { Sphere } \\
\text { Radius } \\
(\mathrm{cm})^{\mathrm{c}}\end{array}$ & $\begin{array}{c}\text { Total } \\
\text { Uranium } \\
\text { Mass }(\mathrm{kg})^{\circ}\end{array}$ & $k_{\text {eft }}$ & Uncer. ${ }^{d}$ & $\begin{array}{l}\mathrm{k}_{\theta+1}+2 \sigma \\
+ \text { bias }^{\circ}\end{array}$ & \\
\hline \multicolumn{9}{|c|}{ Calculations with water density $=1.0 \mathrm{~g} / \mathrm{cm}^{3}$} \\
\hline 20.158 & 1.00 & 2.450 & 62.114 & 10,984 & 0.9187 & 0.0013 & 0.9336 & $q 4016 i$ \\
\hline 20.158 & 1.00 & 2.950 & 62.378 & 10,984 & 0.9198 & 0.0012 & 0.9346 & $\mathrm{q} 4 \mathrm{o} 16 \mathrm{j}$ \\
\hline 20.158 & 1.00 & 2.950 & 61.858 & 19,984 & 0.9174 & 0.0011 & 0.9322 & $\mathrm{mk} 4021^{\prime}$ \\
\hline 20.158 & 1.00 & 2.950 & 61.858 & 10,984 & 0.9192 & 0.0005 & 0.9339 & $\mathrm{mk} 4 \mathrm{o} 21 \mathrm{u}$ \\
\hline 20.158 & 1.00 & 3.450 & 62.645 & 10,984 & 0.9155 & 0.0012 & 0.9303 & $\mathrm{q} 4 \mathrm{o} 16 \mathrm{k}$ \\
\hline 19.658 & 1.00 & 2.950 & 61.390 & 10,984 & 0.9181 & 0.0011 & 0.9329 & $q 40161$ \\
\hline 20.658 & 1.00 & 2.950 & 63.362 & 10,984 & 0.9103 & 0.0011 & 0.9251 & $\mathrm{q} 4016 \mathrm{~m}$ \\
\hline
\end{tabular}

${ }^{a}$ Density of both the radial water beyond the $6.98 \mathrm{in}$. diameter uranium and the axial water between uranium

layers.

${ }^{\mathrm{b}}$ Axial thickness of water between uranium layers.

"Sphere containing the hexagonal lattice and resulting total uranium mass in the lattice within the sphere.

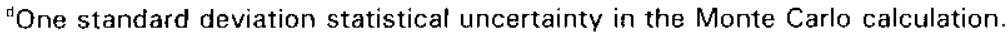

eInput file names are this case identifier preceded with an $i$ and the corresponding MCNP output files are this case identifier preceded with an o.

'The billet length was increased to $21 \mathrm{in.}$ for this case to demonstrate that the total uranium mass limit of $10,984 \mathrm{~kg}$ for 16 -in. billets is valid for 21 -in. billets.

Table 6.4.3-8(B) also includes a case for Mark IV outer billets where all of the optimized parameters for the case with the highest $k_{\text {eff }}(q 4016 \mathrm{j})$ were held constant and the billet length was increased to $21 \mathrm{in.} \mathrm{In} \mathrm{order} \mathrm{to} \mathrm{maintain} \mathrm{the} \mathrm{total} \mathrm{uranium} \mathrm{mass} \mathrm{loading} \mathrm{of} \mathrm{10,984} \mathrm{kg}$, the radius of the sphere was slightly reduced to $61.858 \mathrm{~cm}$. This case, which is identified as mk4021 in Table 6.4.3-8(B), has a $k_{\text {eff }}$ plus uncertainty and bias that is slightly less than that for 16 -in. billets with the same mass loading and is well below the limit. Therefore, the maximum uranium mass loading of $10,984 \mathrm{~kg}$ is shown to apply to Mark IV outer billets with lengths ranging from 16 to $21 \mathrm{in.}$

6.4.3.1(B) Transport Index. The $\mathrm{TI}$ is determined by the finite array analyses for each billet type. The optimization iterations to determine the maximum mass for each billet type are given in Tables 6.4.3-2(B), 6.4.3-4(B), 6.4.3-6(B), and 6.4.3-8(B). These mass values and the corresponding $\mathrm{N}$ and $\mathrm{TI}$ values are summarized in Table 6.4.3.1-1(B). 
TABLE 6.4.3.1-1(B). Criticality Transport Index for RMl Forged Billets and Hanford RMI Billets.

\begin{tabular}{|c|c|c|c|c|c|}
\hline \multirow[t]{2}{*}{ Billet } & \multicolumn{2}{|c|}{ Subcritical } & \multirow{2}{*}{$\begin{array}{c}\text { Billets per } \\
\text { Package }\end{array}$} & \multirow[t]{2}{*}{$\mathrm{N}$} & \multirow[t]{2}{*}{$\mathrm{TI}$} \\
\hline & $\begin{array}{c}\text { Maximum U Mass } \\
\mathrm{lb}(\mathrm{kg})\end{array}$ & $\begin{array}{l}\text { Number of } \\
\text { Billets }\end{array}$ & & & \\
\hline Mark I Inner & $24,216(10,984)$ & $79.2^{2}$ & 4 & 9.9 & 5.1 \\
\hline Mark I Outer & $6,466(2,933)$ & $14.0^{a}$ & 2 & 3.5 & 14.3 \\
\hline Mark IV Inner & $24,216(10,984)$ & $76.0^{\mathrm{a}}$ & 4 & 9.5 & 5.3 \\
\hline Mark IV Outer & $24,216(10,984)$ & $50.4^{\mathrm{a}}$ & 2 & 12.6 & 4.0 \\
\hline \multirow[t]{3}{*}{ Hanford RMI Mark I Outer } & \multirow[t]{3}{*}{$6,466(2,933)$} & \multirow[t]{3}{*}{15.4} & 3 & 2.57 & 19.5 \\
\hline & & & 2 & 3.85 & 13.0 \\
\hline & & & 1 & 7.7 & 6.5 \\
\hline
\end{tabular}

${ }^{\mathrm{a}}$ Based on billet length of $21 \mathrm{in}$.

\section{1(C) DISCUSSION AND RESULTS - MARK 15 INGOTS}

Mark 15 ingots are packaged for shipment in the steel banded wooden box G-4273. Either four inner ingots or two outer ingots fit in a packaging. One shipment may contain up to 10 packages. Container dimensions are listed in Section 1.2. There are no criticality design features incorporated into the boxes.

Table 6.1-1(C) presents a summary of the $k_{\infty}$ values for an infinite array of each ingot type. The infinite array $k_{\infty}$ including bias and uncertainty, for Mark 15 innor and outer ingots, exceeds the limit for transportation. Table 6.1-1(C) also presents the $k_{\text {eft }}$ values calculated with optimum geometry, moderation, and reflection for the maximum number of ingots which may be shipped. The criticality $\mathrm{Tl}$ for both inner and outer Mark 15 ingots are 10.6 and 9.2 respectively, as shown in Table 6.1-2(C).

TABLE 6.1-1(C). Summary of Mark 15 Ingot Criticality Evaluation.

\begin{tabular}{|c|c|c|c|c|}
\hline \multicolumn{5}{|c|}{ Infinite array of ingots with optimum moderation and pitch } \\
\hline Ingot & $\mathrm{Wt} \%{ }^{235} \mathrm{U}$ & & $k_{\infty}$ & $\mathrm{k}_{\infty}+2 \sigma+$ bias \\
\hline Mark 15 Inner & 1.10 & & 0.9758 & 0.9907 \\
\hline Mark 15 Outer & 1.10 & & 0.9880 & 1.0028 \\
\hline \multicolumn{5}{|c|}{ Finite arrays of Mark 15 ingots, optimum moderation and pitch } \\
\hline Ingot & $\begin{array}{l}\text { Maximum } \cup \text { Mass } \\
\mathrm{lb}(\mathrm{kg})\end{array}$ & $\begin{array}{l}\text { Number } \\
\text { of Ingots }\end{array}$ & $k_{\text {eff }}$ & $\mathrm{k}_{\mathrm{eff}}+2 \sigma+$ bias \\
\hline Mark 15 Inner & $24,216(10,984)$ & 39.60 & 0.9243 & 0.9392 \\
\hline Mark 15 Outer & $24,216(10,984)$ & 21.92 & 0.9207 & 0.9356 \\
\hline
\end{tabular}


TABLE 6.1-2(C). Criticality Transport Index for the Mark 15 Ingots.

\begin{tabular}{|l|c|c|c|c|c|}
\hline Type & $\begin{array}{c}\text { Shipping } \\
\text { Box }\end{array}$ & $\begin{array}{c}\text { Ingots per } \\
\text { Box }\end{array}$ & $\begin{array}{c}2 \times \mathrm{N}^{\text {(a) }} \\
\text { Boxes }\end{array}$ & $\mathrm{N}$ & $\mathrm{TI}$ \\
\hline \hline Inner & $\mathrm{G}-4273$ & 4 & 9.90 & 4.95 & 10.2 \\
\hline Outer & $\mathrm{G}-4273$ & 2 & 10.96 & 5.48 & 9.2 \\
\hline
\end{tabular}

${ }^{\mathrm{a}}$ Based on $\mathrm{k}_{\mathrm{eff}} \leq 0.95$ including bias and uncertainty $(2 \sigma)$.

\section{2(C) PACKAGE FUEL LOADING - MARK 15 INGOTS}

Mark 15 ingots will be loaded in steel banded wooden box G-4273. For conservatism, the banding and boxes were omitted from the criticality evaluations. The ingots were assumed to be in an array of optimum moderation and pitch.

The fuel loading is defined as the amount of ${ }^{235} \mathrm{U}$ in a billet. The dimensions, enrichment and mass of ${ }^{235} \mathrm{U}$ for the Mark 15 ingots are presented in Table 6.2-1(C).

TABLE 6.2-1(C). Description of Mark 15 Ingots.

\begin{tabular}{|c|c|c|c|c|c|}
\hline Ingot Type & $\begin{array}{c}\text { Outer Diameter } \\
\text { in. (cm) }\end{array}$ & $\begin{array}{c}\text { Inner Diameter } \\
\text { in. (cm) }\end{array}$ & $\begin{array}{c}\text { Length } \\
\text { in. (cm) }\end{array}$ & $\begin{array}{c}\text { Wt\% } \\
{ }^{235} \mathrm{U}\end{array}$ & $\begin{array}{c}{ }^{235} \mathrm{U} \\
\text { (b (g) }\end{array}$ \\
\hline \hline Mark 15 Inner & $8.00\{20.32)$ & $2.05(5.1943)$ & $19.00(48.26)$ & 1.10 & $6.73(3051)$ \\
\hline Mark 15 Outer & $9.00(22.86)$ & $3.19(8.1026)$ & $29.00(73.66)$ & 1.10 & $12.15(5513)$ \\
\hline
\end{tabular}

\section{3(C) MODEL SPECIFICATION - MARK 15 INGOTS}

This section describes the computer models used for the analyses.

\subsection{1(C) Description of Calculational Model}

Mark 15 ingots are modeled as two concentric cylinders. The inner cylinder represents the ingot annulus and is filled with water when represented as flooded, otherwise it is filled with air. The outer cylinder consists of enriched uranium metal.

Because the packages are not explicitly modeled, arrays of ingots represent the contents of the packages under NCT and HAC events. Infinite, dry ingot arrays at various pitches conservatively represent $5 \times \mathrm{N}$ undamaged packages with normal spacing and no moderation. Dry array calculations were not performed for the Mark 15 ingots. However, the dry array calculations done for the Mark I ingots bound the Mark 15 ingots. The Mark 15 dry infinite array $k_{\infty}$ values would be expected to be less than that for the Mark I outer ingot dry infinite array because of the higher enriched $U$ of the Mark I fuel. Also, examination of the Mark 15 infinite array data shows the decrease in $k_{\infty}$ as the array approaches the dry condition. 
For the HAC events, the ingot arrays are modeled using optimum conditions of spacing, moderation, and reflection. These arrays represent the contents of $2 \times \mathrm{N}$ damaged packages. For the Mark 15 ingots the finite optimum array is required for a $k_{\text {eff }}$ plus uncertainties and bias of less than 0.95 . The value of $N$ is not necessarily the same for $5 \times N$ undamaged packages and $2 \times N$ damaged packages. The most conservative $\mathrm{N}$ values for the packages are derived from the $2 \times \mathrm{N}$ damaged package cases. Single package calculations are presented in the Appendix 6.6.2.

Infinite hexagonal arrays of infinite length were modeled for each ingot type. The interstitial material between the ingots was water. Modeling of the infinite arrays was done by surrounding a single ingot with reflective surfaces. For the hexagonal array the ingot is surrounded radially by six reflective planar surfaces to create a hexagon. The distance between opposing parallel planes is equal to the lattice pitch. Reflective planes were positioned at the top and bottom ends of the ingot. The distance between these axial planes is equal to the length of the ingot. Lattice pitch and water density were varied to determine the optimum configuration for the array.

For both the inner and outer Mark 15 ingots the $k_{\infty}$ value for the infinite array exceeds the limit for transportation. Therefore, further analyses of finite arrays were required. The finite array, as the infinite arrays, was modeled in a hexagonal lattice structure. The method used in this finite array analysis is to conservatively assume a hexagonal array of lattice elements inside of a large sphere. These lattice elements completely fill up the sphere in both the horizontal (hexagonal) and vertical (stacked) directions. Optimum lattice pitch, axial water thickness, and water density were determined for the finite arrays. The arrays were surrounded by $12 \mathrm{in} .(30.48 \mathrm{~cm})$ of water reflection.

\subsection{2(C) Package Regional Densities}

Mark 15 ingots are uranium metal enriched to $1.10 \pm 0.006 \mathrm{wt} \%{ }^{235} \mathrm{U}$. Uranium density used is the theoretical uranium metal density of $18.96 \mathrm{~g} / \mathrm{cm}^{3}$. Material densities and atomic number densities for the constituent nuclides of all materials used in the Mark 15 ingot calculations models are listed in Table 6.3.2-1(C).

TABLE 6.3.2-1(C). Material Densities and Atomic Number Densities - Mark 15 Ingots.

\begin{tabular}{|l|c|c|}
\hline \multicolumn{1}{|c|}{ Isotope/Nuclide } & $\begin{array}{c}\text { Material Density } \\
\left(\mathrm{g} / \mathrm{cm}^{3}\right)\end{array}$ & $\begin{array}{c}\text { Atomic Number Density } \\
\text { (atoms/b-cm) }\end{array}$ \\
\hline \hline Hydrogen & \multirow{2}{*}{1.0 (water) } & 0.06689 \\
Oxygen & \multirow{2}{*}{18.96 (uranium) } & 0.03344 \\
& & $5.344 \mathrm{E}-04$ \\
\hline${ }^{235} \mathrm{U}$ & & $4.744 \mathrm{E}-02$ \\
\hline
\end{tabular}




\section{4(C) CRITICALITY CALCULATIONS - MARK 15 INGOTS}

This section describes the calculational method used for the analyses.

\subsection{1(C) Calculational Method}

The MCNP computer code (Breismeister 1993; Carter 1995) was used for this criticality evaluation. MCNP was discussed in Section 6.4.1(A).

\subsection{2(C) Contents Loading Optimization}

Steel banded wooden shipping containers were not tested under hypothetical conditions and therefore cannot be credited to maintain the payload. To assure subcriticality for any possible payload arrangement, a lattice pitch and water optimization search was made for both inner and outer ingots. Establishing the optimum lattice pitch and water density allows for the determination of the maximum number of ingots that can be safely subcritical. Continuous cross-sections were used in these evaluations; therefore, no cross-section adjustments were required for various geometric configurations and material compositions.

\subsection{3(C) Criticality Results}

Infinite array $k_{\infty}$ plus uncertainties and bias of both inner and outer Mark 15 ingots exceed the 0.95 limit for transportation. The $k_{\infty}$ plus uncertainties and bias for the infinite array of Mark 15 inner ingots, at optimum moderation and pitch, is 0.9907 . The $k_{\infty}$ plus uncertainties and bias for the infinite array of Mark 15 outer ingots, at optimum moderation and pitch, is 1.0028 . The results for the inner and outer ingots are presented in Table 6.4.3-1(C) and Table 6.4.3-2(C), respectively.

Because the infinite array $\mathrm{k}_{\infty}$ for both inner and outer ingots exceeded the limit, additional calculations for finite arrays were made. The method used in the finite array analysis is to conservatively assume a hexagonal array of lattice elements inside of a large sphere. These lattice elements completely fill up the sphere in both the horizontal (hexagonal) and vertical (stacked) directions. The results presented in Table 6.4.3-3(C) show that a uranium mass of $24,216 \mathrm{lb}$ $(10,984 \mathrm{~kg})$ has an optimized $k_{\text {eff }}$ plus uncertainty and bias that is well below the limit for the inner ingots. Similarly, the results presented in Table 6.4.3-4(C) show that a uranium mass of $24,216 \mathrm{lb}$ $(10,984 \mathrm{~kg})$ has an optimized $k_{\text {eff }}$ plus uncertainty and bias that is well below the limit for the outer ingots. 
TABLE 6.4.3-1(C). Mark 15 Inner Ingots Infinite Array $\left(1.10 \mathrm{wt} \%{ }^{235} \mathrm{U}\right)$.

\begin{tabular}{|c|c|c|c|c|}
\hline $\begin{array}{c}\text { Pitch } \\
\text { in. }(\mathrm{cm})\end{array}$ & $\begin{array}{c}\text { Water Density } \\
\text { Fraction }\end{array}$ & $k_{r o}$ & $\mathrm{k}_{\infty}+2 \sigma+$ bias & Input File \\
\hline $8.00(20.32)$ & 1.0 & 0.8320 & 0.8472 & $\mathrm{~m} 151 \mathrm{i1}$ \\
\hline $8.00(20.32)$ & 0.9 & 0.8087 & 0.8235 & m159i1 \\
\hline $8.00(20.32)$ & 0.7 & 0.7507 & 0.7655 & $\mathrm{~m} 157 i 1$ \\
\hline $8.00(20.32)$ & 0.5 & 0.6740 & 0.6888 & $\mathrm{~m} 155 \mathrm{i} 1$ \\
\hline $8.00(20.32\}$ & 0.3 & 0.5914 & 0.6062 & m153i1 \\
\hline $8.27(21.00)$ & 1.0 & 0.9020 & 0.9171 & $\mathrm{~m} 151 \mathrm{i} 2$ \\
\hline $8.27(21.00)$ & 0.9 & 0.8785 & 0.8934 & m159i2 \\
\hline $8.27(21.00)$ & 0.7 & 0.8188 & 0.8336 & m157i2 \\
\hline $8.27(21.00)$ & 0.5 & 0.7346 & 0.7495 & $m 155 i 2$ \\
\hline $8.27(21.00)$ & 0.3 & 0.6292 & 0.6440 & $\mathrm{~m} 153 \mathrm{i} 2$ \\
\hline $8.66(22.00)$ & 1.0 & 0.9579 & 0.9730 & $\mathrm{~m} 151 \mathrm{i3}$ \\
\hline $8.66(22.00)$ & 0.9 & 0.9505 & 0.9654 & $m 159 i 3$ \\
\hline $8.66\langle 22.00\}$ & 0.7 & 0.9043 & 0.9191 & m157i3 \\
\hline $8.66(22.00)$ & 0.5 & 0.8256 & 0.8404 & $\mathrm{~m} 155 \mathrm{i} 3$ \\
\hline $8.66(22.00)$ & 0.3 & 0.7025 & 0.7173 & $\mathrm{~m} 153 \mathrm{i} 3$ \\
\hline $9.06(23.00)$ & 1.0 & 0.9745 & 0.9897 & $\mathrm{~m} 151 \mathrm{i} 5$ \\
\hline $9.06(23.00)$ & 0.9 & 0.9758 & 0.9907 & $\mathrm{~m} 159 \mathrm{i} 5$ \\
\hline $9.06(23.00)$ & 0.7 & 0.9556 & 0.9705 & m157i5 \\
\hline $9.06(23.00)$ & 0.5 & 0.8952 & 0.9100 & $\mathrm{~m} 155 \mathrm{i5}$ \\
\hline $9.06(23.00)$ & 0.3 & 0.7721 & 0.7869 & m153i5 \\
\hline $9.45(24.00)$ & 1.0 & 0.9545 & 0.9692 & $\mathrm{~m} 151 \mathrm{i6}$ \\
\hline $9.45(24.00)$ & 0.9 & 0.9681 & 0.9829 & $m 159 i 6$ \\
\hline $9.45(24.00)$ & 0.7 & 0.9742 & 0.9890 & $\mathrm{~m} 157 \mathrm{i} 6$ \\
\hline $9.45(24.00)$ & 0.5 & 0.9431 & 0.9580 & $m 155 i 6$ \\
\hline $9.45(24.00)$ & 0.3 & 0.8324 & 0.8471 & $\mathrm{~m} 153 \mathrm{i6}$ \\
\hline $9.84(25.00)$ & 0.7 & 0.9701 & 0.9849 & m157i7 \\
\hline $9.84(25.00)$ & 0.5 & 0.9676 & 0.9824 & $\mathrm{~m} 155 i 7$ \\
\hline $9.84(25.00)$ & 0.3 & 0.8816 & 0.8964 & $\mathrm{~m} 153 \mathrm{i} 7$ \\
\hline $10.24(26.00)$ & 0.7 & 0.9480 & 0.9629 & m157i8 \\
\hline $10.24\{26.00\}$ & 0.5 & 0.9731 & 0.9880 & $\mathrm{~m} 155 \mathrm{i} 8$ \\
\hline $10.24(26.00)$ & 0.3 & 0.9180 & 0.9328 & m153i8 \\
\hline $10.63(27.00)$ & 0.5 & 0.9674 & 0.9822 & m155i9 \\
\hline $10.63(27.00)$ & 0.3 & 0.9448 & 0.9596 & m153i9 \\
\hline $11.02(28.00)$ & 0.5 & 0.9552 & 0.9702 & m155ia \\
\hline $11.02(28.00)$ & 0.3 & 0.9632 & 0.9780 & m153ia \\
\hline $11.42(29.00)$ & 0.3 & 0.9722 & 0.9870 & m153ib \\
\hline $11.81(30.00)$ & 0.3 & 0.9756 & 0.9904 & m153ic \\
\hline $12.60(32.00)$ & 0.3 & 0.9650 & 0.9798 & m153id \\
\hline $14.17(36.00)$ & 0.3 & 0.9061 & 0.9210 & m153ie \\
\hline
\end{tabular}


TABLE 6.4.3-2(C). Mark 15 Outer Ingots Infinite Array $\left(1.10 \mathrm{wt} \%{ }^{235} \mathrm{U}\right)$.

\begin{tabular}{|c|c|c|c|c|}
\hline $\begin{array}{c}\text { Pitch } \\
\text { in. (cm) }\end{array}$ & $\begin{array}{c}\text { Water Density } \\
\text { Fraction }\end{array}$ & $k_{n}$ & $\mathrm{k}_{\infty}+2 \sigma+$ bias & Input File \\
\hline $9.00(22.86)$ & 1.0 & 0.8776 & 0.8924 & $\mathrm{~m} 1501 \mathrm{i} 1$ \\
\hline $9.00(22.86)$ & 0.9 & 0.8657 & 0.8805 & m15o9i1 \\
\hline $9.00(22.86)$ & 0.7 & 0.8263 & 0.8411 & m15o7i1 \\
\hline $9.00(22.86)$ & 0.5 & 0.7560 & 0.7708 & $\mathrm{~m} 1505 \mathrm{i} 1$ \\
\hline $9.00(22.86)$ & 0.3 & 0.6484 & 0.6632 & $\mathrm{~m} 1503 \mathrm{i} 1$ \\
\hline $9.45(24.00)$ & 1.0 & 0.9470 & 0.9618 & $\mathrm{~m} 1501 \mathrm{i} 2$ \\
\hline $9.45(24.00)$ & 0.9 & 0.9403 & 0.9551 & $\mathrm{~m} 1509 i 2$ \\
\hline $9.45(24.00)$ & 0.7 & 0.9028 & 0.9176 & $m 1507 i 2$ \\
\hline $9.45(24.00)$ & 0.5 & 0.8322 & 0.8470 & $\mathrm{~m} 1505 \mathrm{i} 2$ \\
\hline $9.45(24.00)$ & 0.3 & 0.7058 & 0.7206 & $\mathrm{~m} 1503 i 2$ \\
\hline $9.84(25.00)$ & 1.0 & 0.9786 & 0.9934 & $\mathrm{~m} 1501 \mathrm{i3}$ \\
\hline $9.84(25.00)$ & 0.9 & 0.9748 & 0.9897 & $\mathrm{~m} 1509 \mathrm{i3}$ \\
\hline $9.84(25.00)$ & 0.7 & 0.9564 & 0.9712 & m15o7i3 \\
\hline $9.84(25.00)$ & 0.5 & 0.8915 & 0.9063 & $m 1505 i 3$ \\
\hline $9.84(25.00)$ & 0.3 & 0.7649 & 0.7797 & $\mathrm{~m} 1503 \mathrm{i} 3$ \\
\hline $10.24(26.00)$ & 1.0 & 0.9690 & 0.9839 & $\mathrm{~m} 1501 \mathrm{i5}$ \\
\hline $10.24(26.00)$ & 0.9 & 0.9793 & 0.9941 & $\mathrm{~m} 1509 \mathrm{i} 5$ \\
\hline $10.24(26.00)$ & 0.7 & 0.9824 & 0.9972 & $\mathrm{~m} 1507 \mathrm{i} 5$ \\
\hline $10.24(26.00\}$ & 0.5 & 0.9385 & 0.9533 & $\mathrm{~m} 15 \mathrm{o} 5 \mathrm{i} 5$ \\
\hline $10.24\{26.00\}$ & 0.3 & 0.8166 & 0.8314 & $\mathrm{~m} 1503 i 5$ \\
\hline $10.43(26.50)$ & 1.0 & 0.9531 & 0.9679 & $m 1501 i 6$ \\
\hline $10.43(26.50)$ & 0.9 & 0.9716 & 0.9865 & $m 1509 i 6$ \\
\hline $10.43(26.50)$ & 0.7 & 0.9880 & 1.0028 & m15o7i6 \\
\hline $10.43(26.50)$ & 0.5 & 0.9559 & 0.9707 & m15o5i6 \\
\hline $10.43(26.50)$ & 0.3 & 0.8410 & 0.8558 & $\mathrm{~m} 1503 i 6$ \\
\hline $10.63(27.00)$ & 1.0 & 0.9390 & 0.9539 & $\mathrm{~m} 1501 \mathrm{i} 7$ \\
\hline $10.63(27.00)$ & 0.9 & 0.9591 & 0.9739 & m15o9i7 \\
\hline $10.63(27.00)$ & 0.7 & 0.9846 & 0.9994 & $\mathrm{~m} 1507 i 7$ \\
\hline $10.63\{27.00\}$ & 0.5 & 0.9680 & 0.9828 & m15o5i7 \\
\hline $10.63(27.00)$ & 0.3 & 0.8674 & 0.8822 & m15o3i7 \\
\hline $11.02(28.00)$ & 0.7 & 0.9688 & 0.9836 & m15o7i9 \\
\hline $11.02(28.00)$ & 0.5 & 0.9799 & 0.9947 & m15o5i9 \\
\hline $11.22(28.50)$ & 0.7 & 0.9597 & 0.9745 & m15o7ia \\
\hline $11.22(28.50)$ & 0.5 & 0.9829 & 0.9977 & m15o5ia \\
\hline $11.22(28.50)$ & 0.3 & 0.9190 & 0.9338 & m15o3ia \\
\hline $11.42(29.00)$ & 0.7 & 0.9454 & 0.9602 & m15o7ib \\
\hline $11.42(29.00)$ & 0.5 & 0.9797 & 0.9945 & $\mathrm{~m} 1505 \mathrm{ib}$ \\
\hline $11.42(29.00)$ & 0.3 & 0.9301 & 0.9449 & m15o3ib \\
\hline $12.60(32.00)$ & 0.3 & 0.9716 & 0.9864 & m15x3ie \\
\hline $13.78(35.00)$ & 0.3 & 0.9585 & 0.9733 & $m 15 \times 3$ if \\
\hline $15.75(40.00)$ & 0.3 & 0.8819 & 0.8968 & m15x3ig \\
\hline
\end{tabular}


Table 6.4.3-3(C). Reflected Finite Arrays to Determine Optimum Parameters and Maximum Mass for Mark 15 Inner Ingots 18.00 in. diameter and $2.05 \mathrm{in.}$ ID $\times 19 \mathrm{in}$. long, $1.10 \mathrm{wt} \%{ }^{235} \mathrm{U}$ l.

\begin{tabular}{|c|c|c|c|c|c|c|c|c|}
\hline \multicolumn{3}{|c|}{ Parameters of Hexagonal Lattice Cell } & \multicolumn{2}{|c|}{$\begin{array}{c}\text { Sphere Containing } \\
\text { Lattice Cells }\end{array}$} & \multicolumn{3}{|c|}{ Calculated Results } & \multirow[t]{2}{*}{ Case $^{e}$} \\
\hline $\begin{array}{l}\text { Pitch } \\
(\mathrm{cm})\end{array}$ & $\begin{array}{l}\text { Water } \\
\text { Density } \\
\left(\mathrm{g} / \mathrm{cm}^{3}\right)^{\mathrm{a}}\end{array}$ & $\begin{array}{c}\text { Axial Water } \\
\text { Height } \\
(\mathrm{cm})^{\mathrm{b}}\end{array}$ & $\begin{array}{l}\text { Sphere } \\
\text { Radius } \\
(\mathrm{cm})^{\circ}\end{array}$ & $\begin{array}{c}\text { Total } \\
\text { Uranium } \\
\text { Mass }(\mathrm{kg})^{c}\end{array}$ & $k_{\text {eft }}$ & Uncer. ${ }^{d}$ & $\begin{array}{c}\mathrm{k}_{\mathrm{eH}}+2 \sigma_{\mathrm{c}} \\
+ \text { bias }\end{array}$ & \\
\hline \multicolumn{9}{|c|}{ Calculations with water density $=1.0 \mathrm{~g} / \mathrm{cm}^{3}$} \\
\hline 22.420 & 1.00 & 2.950 & 59.566 & 10,984 & 0.9243 & 0.0013 & 0.9392 & s0819a \\
\hline 22.420 & 1.00 & 2.950 & 59.566 & 10,984 & 0.9239 & 0.0006 & 0.9386 & s0819au \\
\hline 22.420 & 1.00 & 3.450 & 59.750 & 10,984 & 0.9205 & 0.0013 & 0.9354 & s0819b \\
\hline 22.420 & 1.00 & 2.450 & 59.375 & 10,984 & 0.9196 & 0.0012 & 0.9344 & s0819c \\
\hline 21.920 & 1.00 & 2.950 & 58.646 & 10,984 & 0.9119 & 0.0011 & 0.9267 & s0819d \\
\hline 22.920 & 1.00 & 2.950 & 60.472 & 10,984 & 0.9228 & 0.0015 & 0.9377 & s0819e \\
\hline
\end{tabular}

${ }^{\mathrm{a}}$ Density of both the radial water beyond the 8.00 in. diameter uranium and the axial water between uranium

layers.

'Axial thickness of water between uranium layers.

'Sphere containing the hexagonal lattice and resulting total uranium mass in the lattice within the sphere.

${ }^{\circ}$ One standard deviation statistical uncertainty in the Monte Carlo calculation.

einput file names are this case identifier preceded with an $i$ and the corresponding MCNP output files are this case identifier preceded with an $o$.

Table 6.4.3-4(C). Reflected Finite Arrays to Determine Optimum Parameters and Maximum Mass for Mark 15 Outer Ingots $(9.00$ in. diameter and $3.19 \mathrm{in.}$ ID $\times 29 \mathrm{in}$. long, $1.10 \mathrm{wt} \%{ }^{235} \mathrm{U}$ ).

\begin{tabular}{|c|c|c|c|c|c|c|c|c|}
\hline \multicolumn{3}{|c|}{ Parameters of Hexagonal Lattice Cell } & \multicolumn{2}{|c|}{$\begin{array}{l}\text { Sphere Containing } \\
\text { Lattice Cells }\end{array}$} & \multicolumn{3}{|c|}{ Calculated Results } & \multirow[t]{2}{*}{ Case $^{\mathrm{e}}$} \\
\hline $\begin{array}{l}\text { Pitch } \\
(\mathrm{cm})\end{array}$ & $\begin{array}{l}\text { Water } \\
\text { Density } \\
\left(\mathrm{g} / \mathrm{cm}^{3}\right)^{2}\end{array}$ & $\begin{array}{c}\text { Axial Water } \\
\text { Height } \\
(\mathrm{cm})^{\mathrm{b}}\end{array}$ & $\begin{array}{l}\text { Sphere } \\
\text { Radius } \\
(\mathrm{cm})^{\circ}\end{array}$ & $\begin{array}{c}\text { Total } \\
\text { Uranium } \\
\text { Mass }(\mathrm{kg})^{c}\end{array}$ & $\mathrm{k}_{\text {eHr }}$ & Uncer. ${ }^{d}$ & $\begin{array}{c}\mathrm{k}_{\mathrm{eff}}+2 \sigma_{\mathrm{c}} \\
+ \text { bias }\end{array}$ & \\
\hline \multicolumn{9}{|c|}{ Calculations with water density $=1.0 \mathrm{~g} / \mathrm{cm}^{3}$} \\
\hline 24.960 & 1.00 & 2.950 & 59.993 & 10,984 & 0.9186 & 0.0011 & 0.9334 & s0929a \\
\hline 24.960 & 1.00 & 3.450 & 60.116 & 10,984 & 0.9207 & 0.0013 & 0.9356 & s0929b \\
\hline 24.960 & 1.00 & 3.450 & 60.116 & 10,984 & 0.9194 & 0.0005 & 0.9340 & s0929bu \\
\hline 24.960 & 1.00 & 3.950 & 60.245 & 10,984 & 0.9169 & 0.0013 & 0.9318 & s0929c \\
\hline 24.460 & 1.00 & 3.450 & 59.310 & 10,984 & 0.9120 & 0.0010 & 0.9267 & s0929d \\
\hline 25.460 & 1.00 & 3.450 & 60.923 & 10,984 & 0.9197 & 0.0011 & 0.9345 & s0929e \\
\hline
\end{tabular}

${ }^{a}$ Density of both the radial water beyond the $9.00 \mathrm{in}$. diameter uranium and the axial water between uranium

layers.

${ }^{\mathrm{b}}$ Axial thickness of water between uranium layers.

'Sphere containing the hexagonal lattice and resulting total uranium mass in the lattice within the sphere.

One standard deviation statistical uncertainty in the Monte Carlo calculation.

eInput file names are this case identifier preceded with an $i$ and the corresponding MCNP output files are this case identifier preceded with an $o$. 
6.4.3.1(C) Transport Index. The $\mathrm{Tl}$ is determined by the finite array analyses for each ingot type. The optimization iterations to determine the maximum mass for each ingot type are given in Tables 6.4.3-3(C) and 6.4.3-4(C). These mass values and the corresponding $\mathrm{N}$ and $\mathrm{TI}$ values are summarized in Table 6.4.3.1-1(C).

TABLE 6.4.3.1-1(C). Transport Index.

\begin{tabular}{|l|c|c|c|c|c|}
\hline \multirow{2}{*}{ Ingot } & \multicolumn{2}{|c|}{ Subcritical } & Ingots per & $\mathrm{N}$ & $\mathrm{TI}$ \\
\cline { 2 - 4 } & $\begin{array}{c}\text { Maximum U Mass } \\
\text { Ib (kg) }\end{array}$ & $\begin{array}{c}\text { Number of } \\
\text { Ingots }\end{array}$ & & \\
\hline \hline Mark 15 Inner & $24,216(10,984)$ & 39.60 & 4 & 4.95 & 10.2 \\
\hline Mark 15 Outer & $24,216(10,984)$ & 21.92 & 2 & 5.48 & 9.2 \\
\hline
\end{tabular}

\section{1(D) DISCUSSION AND RESULTS - FERMCO MATERIAL}

Miscellaneous material at FERMCO, including primary ingots, product ingots, ingot sections, and scrap, are packaged for shipment in the steel banded wooden containers G-4214, G-4273, and G-4292. There are no criticality design features incorporated into the boxes. The FERMCO material criticality analyses were performed with the MCNP code (Breismeister 1993; Carter 1995) for both infinite and finite arrays of boxes. FERMCO derbies are addressed in Sections 6.1(E)-6.4(E).

The FERMCO material consists of unirradiated uranium metal with a maximum of $1.256 \mathrm{wt} \%{ }^{235} \mathrm{U}$ enrichment. All pieces are cylindrical but vary in diameter and length. Analyses show that $2,361 \mathrm{lb}(1,071 \mathrm{~kg})$ of $11 \mathrm{in} .(29.74 \mathrm{~cm})$ diameter and $1 \mathrm{in} .(2.54 \mathrm{~cm})$ long pieces optimally spaced and moderated meets the transportation limit of $k_{\text {eff }}+2 \sigma+$ bias less than 0.95. As the piece length increases, so does the mass that is safely subcritical, and with less sensitivity for the larger diameters involved, as the diameter increases, so does the mass that is safely subcritical. Product ingots are the same as $\mathrm{N}$ Reactor Mark I outer ingots, which are addressed in Sections 6.1(A) and 6.4.3(D). Table 6.1-1(D) summarizes the results and shows the maximum allowable mass for different diameters scrap lengths. Tables 6.1-2(D) and 6.1-2a(D) summarize the criticality transportation index and $\mathrm{N}$ values for the different sizes of FERMCO materials. 
TABLE 6.1-1(D). Summary of Results.

\begin{tabular}{|c|c|c|c|}
\hline Piece & $\begin{array}{c}\text { Maximum U Mass }{ }^{a} \\
\text { lb }(\mathrm{kg})\end{array}$ & $k_{\text {elt }}$ & $\mathrm{k}_{\mathrm{eff}}+2 \sigma+$ bias \\
\hline $\begin{array}{l}12 \text { in. }(30.48 \mathrm{~cm}) \text { OD } \times 17 \text { in. }(43.18 \mathrm{~cm}) \text { to } \\
26 \text { in. }(66.04 \mathrm{~cm})\end{array}$ & $18,585^{\circ}(8,430)$ & 0.9286 & 0.9432 \\
\hline $13 \mathrm{in.}(33.02 \mathrm{~cm}) \mathrm{OD} \times 30 \mathrm{in} .(76.20 \mathrm{~cm})$ & $26,772^{c}(12,144\}$ & 0.9259 & 0.9408 \\
\hline 9 in. $(22.86 \mathrm{~cm})$ OD $\times 30$ in. $(76.20 \mathrm{~cm})$ & $28,808^{d}(13,067)$ & 0.9252 & 0.9398 \\
\hline $13 \mathrm{in.}(33.02 \mathrm{~cm}) \mathrm{OD} \times 1 \mathrm{in} .(2.54 \mathrm{~cm})$ & $2,361(1,071)$ & 0.9309 & 0.9456 \\
\hline $13 \mathrm{in.}(33.02 \mathrm{~cm}) \mathrm{OD} \times 2 \mathrm{in.}(5.08 \mathrm{~cm})$ & $5,121(2,323)$ & 0.9294 & 0.9443 \\
\hline $13 \mathrm{in.}(33.02 \mathrm{~cm})$ OD $\times 3$ in. $(7.62 \mathrm{~cm})$ & $9,506(4,312)$ & 0.9284 & 0.9433 \\
\hline $13 \mathrm{in.}(33.02 \mathrm{~cm})$ OD $\times 4$ in. $(10.16 \mathrm{~cm})$ & $13,393(6,075)$ & 0.9263 & 0.9412 \\
\hline $13 \mathrm{in.}(33.02 \mathrm{~cm})$ OD $\times 6$ in. $(15.24 \mathrm{~cm})$ & $26,772(12,144)$ & 0.9259 & 0.9408 \\
\hline 10 in. $(25.40 \mathrm{~cm}) \mathrm{OD} \times 6$ in. $(15.24 \mathrm{~cm})$ & $15,593(7,073)$ & 0.9260 & 0.9406 \\
\hline $11 \mathrm{in.}(27.94 \mathrm{~cm})$ OD $\times 1$ in. $(2.54 \mathrm{~cm})$ & $2,361(1,071)$ & 0.9328 & 0.9474 \\
\hline $11 \mathrm{in.}(27.94 \mathrm{~cm})$ OD $\times 2$ in. $(5.08 \mathrm{~cm})$ & $5,121(2,323)$ & 0.9321 & 0.9468 \\
\hline 11 in. $(27.94 \mathrm{~cm})$ OD $\times 3$ in. $(7.62 \mathrm{~cm})$ & $7,901(3,584)$ & 0.9295 & 0.9443 \\
\hline $11 \mathrm{in.}(27.94 \mathrm{~cm}) \mathrm{OD} \times 4$ in. $(10.16 \mathrm{~cm})$ & $11,133(5,050)$ & 0.9294 & 0.9443 \\
\hline $11 \mathrm{in.}(27.94 \mathrm{~cm}) \mathrm{OD} \times 6 \mathrm{in} .(15.24 \mathrm{~cm})$ & $21,882(9,926)$ & 0.9314 & 0.9462 \\
\hline $\begin{array}{l}13.05 \mathrm{in} .(33.15 \mathrm{~cm}) \mathrm{OD} \times \\
2.87(7.29 \mathrm{~cm}) \mathrm{ID} \mathrm{x} \\
12 \mathrm{in.}(30.48 \mathrm{~cm}) \text { to } 17 \text { in. }(43.18 \mathrm{~cm})\end{array}$ & $55,380(25,120)$ & 0.9285 & 0.9431 \\
\hline
\end{tabular}

aaximum safe subcritical mass that can be shipped per exclusive use vehicle.

${ }^{b}$ Conservatively based on 5 in. length, Table 6.4.3-1(E).

${ }^{\mathrm{C}}$ Conservatively based on 6 in. length.

${ }^{\mathrm{d}}$ Conservatively based on 15 in. length. 
TABLE 6.1-2(D). Transportation Index for FERMCO Primary Ingots, Product Ingots and Ingot Sections.

\begin{tabular}{|c|c|c|c|c|c|c|}
\hline Piece & $\begin{array}{l}\text { Pounds/Piece } \\
(\mathrm{kg})\end{array}$ & Container & $\begin{array}{l}\text { Pieces per } \\
\text { Container }\end{array}$ & $2 \times N$ & $N$ & $\mathrm{TI}$ \\
\hline $\begin{array}{l}12 \mathrm{in} .(30.48 \mathrm{~cm}) \text { OD } \times 17 \mathrm{in} .(43.18 \mathrm{~cm}) \\
\text { to } 26 \text { in. }(66.04 \mathrm{~cm})\end{array}$ & $1298.2(588.9)$ & G-4273-6 & 2 & 7.16 & 3.58 & 14.0 \\
\hline $13 \mathrm{in.}(33.02 \mathrm{~cm}) \mathrm{OD} \times 30 \mathrm{in} .(76.20 \mathrm{~cm})$ & $2688.7(1219.6)$ & G-4273-6 & 1 & 9.96 & 4.98 & 10.1 \\
\hline $9 \mathrm{in.}(22.86 \mathrm{~cm}) \mathrm{OD} \times 30 \mathrm{in} .(76.20 \mathrm{~cm})$ & $1288.7(584.5)$ & G-4273-5 & 2 & 11.2 & 5.60 & 9.0 \\
\hline $\begin{array}{l}13.05 \mathrm{in.}(33.15 \mathrm{~cm}) \mathrm{OD} \times 2.87 \mathrm{in} . \\
(7.29 \mathrm{~cm}) \mathrm{ID} \times 12 \mathrm{in.}(30.48 \mathrm{~cm}) \text { to } 17 \mathrm{in} . \\
(43.18 \mathrm{~cm}) \text { (Product Ingots) }\end{array}$ & $\begin{array}{l}1046(474) \text { to } \\
1482(672)\end{array}$ & G-4273-6 & $3488 \mathrm{lb}$ & 15.88 & 7.94 & 6.3 \\
\hline $13 \mathrm{in.}(33.02 \mathrm{~cm})$ OD $\times 3$ in. $(7.62 \mathrm{~cm})$ & $273(124)$ & $\begin{array}{l}\text { G-4214 } \\
\text { G-4292 }\end{array}$ & 4 & 8.70 & 4.35 & 11.5 \\
\hline $13 \mathrm{in.}(33.02 \mathrm{~cm}) \mathrm{OD} \times 6$ in. $(15.24 \mathrm{~cm})$ & $546(248)$ & $\begin{array}{l}G-4214 \\
G-4292\end{array}$ & 2 & 24.5 & 12.26 & 4.1 \\
\hline $10 \mathrm{in} .(25.40 \mathrm{~cm}) \mathrm{OD} \times 6 \mathrm{in.}(15.24 \mathrm{~cm})$ & $318.2(144.3)$ & $\begin{array}{l}\mathrm{G}-4214 \\
\mathrm{G}-4292\end{array}$ & 2 & 24.5 & 12.2 & 4.1 \\
\hline
\end{tabular}

Table 6.1-2a(D). Transportation Index for FERMCO Scrap.

\begin{tabular}{|c|c|c|c|c|c|}
\hline Piece & $\begin{array}{l}\text { Length } \\
\text { in. (cm) }\end{array}$ & $\begin{array}{c}\text { Amount Per Package } \\
\text { Ib (kg) }\end{array}$ & Container & $\mathrm{N}$ & $\mathrm{TI}$ \\
\hline \multirow[t]{6}{*}{$\begin{array}{l}13 \mathrm{in.} \\
(33.02 \mathrm{~cm}) \mathrm{OD}\end{array}$} & $\begin{array}{c}1 \text { to }<2 \\
(2.54 \text { to }<5.08)\end{array}$ & $1180(535)$ & $\begin{array}{l}G-4292 \\
G-4214\end{array}$ & 1.0 & 50.0 \\
\hline & $\begin{array}{c}2 \text { to }<3 \\
(5.08 \text { to }<7.62)\end{array}$ & $1200(544)$ & $\begin{array}{l}G-4292 \\
G-4214\end{array}$ & 2.13 & 23.5 \\
\hline & $\begin{array}{c}3 \text { to }<4 \\
(7.62 \text { to }<10.16)\end{array}$ & $1200(544)$ & $\begin{array}{l}\text { G-4292 } \\
\text { G-4214 }\end{array}$ & 3.96 & 12.7 \\
\hline & $\begin{array}{c}4 \text { to }<6 \\
(10.16 \text { to }<15.24)\end{array}$ & $1200(544)$ & $\begin{array}{l}\text { G-4292 } \\
\text { G-4214 }\end{array}$ & 5.58 & 9.0 \\
\hline & $\begin{array}{c}6 \text { to }<12 \\
(15.24 \text { to }<30.48)\end{array}$ & $1252(568)$ & G-4292 & 10.69 & 4.7 \\
\hline & $\begin{array}{c}12 \text { to }<30 \\
(30.48 \text { to }<76.20)\end{array}$ & $3488(1582)$ & G-4273-6 & 3.84 & 13.1 \\
\hline \multirow[t]{6}{*}{$\begin{array}{l}11 \mathrm{in.} \\
(27.94 \mathrm{~cm}) \text { OD }\end{array}$} & $\begin{array}{c}1 \text { to }<2 \\
(2.54 \text { to }<5.08)\end{array}$ & $1180(535)$ & $\begin{array}{l}\text { G-4292 } \\
\text { G-4214 }\end{array}$ & 1.0 & 50.0 \\
\hline & $\begin{array}{c}2 \text { to }<3 \\
(5.08 \text { to }<7.62)\end{array}$ & $1200(544)$ & $\begin{array}{l}\text { G-4292 } \\
\text { G-4214 }\end{array}$ & 2.13 & 23.5 \\
\hline & $\begin{array}{c}3 \text { to }<4 \\
(7.62 \text { to }<10.16)\end{array}$ & $1200(544)$ & $\begin{array}{l}G-4292 \\
G-4214\end{array}$ & 3.29 & 15.2 \\
\hline & $\begin{array}{c}4 \text { to }<6 \\
(10.16 \text { to }<15.24)\end{array}$ & $1200(544)$ & $\begin{array}{l}\text { G-4292 } \\
\text { G-4214 }\end{array}$ & 4.64 & 10.8 \\
\hline & $\begin{array}{c}6 \text { to }<12 \\
(15.24 \text { to }<30.48)\end{array}$ & $1252(568)$ & G-4292 & 8.74 & 5.8 \\
\hline & $\begin{aligned} 12 \text { to } & <30 \\
(30.48 \text { to } & <76.20)\end{aligned}$ & $3488(1582)$ & G-4273-6 & 3.14 & 16.0 \\
\hline
\end{tabular}




\section{2(D) PACKAGE FUEL LOADING}

FERMCO material will be shipped in containers G-4255, G-4273, G-4214, and G-4292. For conservatism, the banding and boxes were omitted from the criticality evaluations. Optimum moderation and pitch was determined for arrays of each piece size. The number of pieces per container are listed in Table 6.1-2(D).

\section{3(D) MODEL SPECIFICATION}

This section describes the computer models used for the analyses.

\subsection{1(D) Description of Calculational Model}

The material consists of cylindrical pieces of uranium metal of various diameters and lengths. It is all $1.25 \mathrm{wt} \%{ }^{235} \mathrm{U}$. The diameters vary from a minimum of $9 \mathrm{in} .(22.86 \mathrm{~cm})$ to a maximum of $13 \mathrm{in.}(33.02 \mathrm{~cm})$ and the lengths vary from $1 \mathrm{in} .(2.54 \mathrm{~cm})$ to $30 \mathrm{in} .(76.2 \mathrm{~cm})$. All pieces are solid with the exception of FERMCO product ingots which have a $2.87 \mathrm{in.}(7.29 \mathrm{~cm})$ inside diameter. These ingots are identical to the $N$ Reactor Mark I outer ingots, except the length can vary from 12 to $17 \mathrm{in.}(30.48$ to $43.18 \mathrm{~cm})$. Each type is listed in Table 6.3-1(D).

TABLE 6.3-1(D). Material Dimensions.

\begin{tabular}{|l|l|l|}
\hline \multicolumn{1}{|c|}{ Type } & \multicolumn{1}{|c|}{$\begin{array}{c}\text { Diameter } \\
\text { in. (cm) }\end{array}$} & \multicolumn{1}{c|}{$\begin{array}{c}\text { Length } \\
\text { in. (cm) }\end{array}$} \\
\hline \hline FERMCO Primary Ingots & $13(33.02)$ & $30(76.2)$ \\
\hline $\begin{array}{l}\text { FERMCO Product Ingots } \\
\text { (N Reactor Mark I Outer Ingots) }\end{array}$ & $\begin{array}{l}13.05(33.15) \\
\text { ID } 2.87(7.29)\end{array}$ & $12(30.48)$ to $17(43.18)$ \\
\hline FERMCO Ingot Sections & $13(33.02)$ & $6(15.24)$ \\
\hline FERMCO Ingot Sections & $13(33.02)$ & $3(7.62)$ \\
\hline FERMCO Scrap & $13(33.02)$ & $1(2.54)$ to $30(76.2)$ \\
\hline FERMCO Primary Ingots & $12(30.48)$ & $17(43.18)$ to $26(66.04)$ \\
\hline FERMCO Scrap & $11(27.94)$ & $1(2.54)$ to $30(76.2)$ \\
\hline FERMCO Ingot Sections & $10(25.4)$ & $6(15.24)$ \\
\hline FERMCO Primary Ingots & $9(22.86)$ & $30(76.2)$ \\
\hline
\end{tabular}

\subsection{2(D) Package Regional Densities}

The material is uranium metal enriched to $1.25 \mathrm{wt} \%{ }^{235} \mathrm{U}$. The theoretical uranium density of $18.96 \mathrm{~g} / \mathrm{cm}^{3}$ is used for the calculations. Material densities and atomic number densities for the constituent nuclides of the materials used are listed in Table 6.3.2-1(D). 
TABLE 6.3.2-1(D). Material Densities and Atomic Number Densities - Scrap.

\begin{tabular}{|l|c|c|}
\hline \multicolumn{1}{|c|}{ Isotope/Nuclide } & $\begin{array}{c}\text { Material Density } \\
\left(\mathrm{g} / \mathrm{cm}^{3}\right)\end{array}$ & $\begin{array}{c}\text { Atomic Number Density } \\
(\text { atoms } / \mathrm{b}-\mathrm{cm})\end{array}$ \\
\hline \hline Hydrogen & \multirow{2}{*}{1.0 (water) } & 0.06689 \\
\cline { 1 - 1 } Oxygen & \multirow{2}{*}{18.96 (uranium) } & 0.03344 \\
\cline { 1 - 1 } & & $6.073 \mathrm{E}-04$ \\
\hline${ }^{235} \mathrm{U}$ & & $4.737 \mathrm{E}-02$ \\
\hline
\end{tabular}

\section{4(D) CRITICALITY CALCULATIONS}

This section describes the calculational method used for the analyses.

\subsection{1(D) Calculational Method}

The MCNP computer code (Breismeister 1993; Carter 1995) was used for this criticality evaluation. MCNP was discussed in Section 6.4.1(A).

\subsection{2(D) Contents Loading Optimization}

The steel banded wooden shipping containers were not tested under hypothetical conditions and therefore cannot be credited to maintain the payload. To assure subcriticality for any payload configuration, a spacing and optimization search was made. From the results of the search a maximum allowable mass was determined for various diameters and piece lengths.

\subsection{3(D) Criticality Results}

An initial optimization search was done on the $9 \mathrm{in.}(22.86 \mathrm{~cm})$ diameter pieces. Spacing and water moderation were varied for the infinite hexagonal array to determine optimization. The results are presented in Table 6.4.3-1(D). The optimum configuration for the $9 \mathrm{in.}(22.86 \mathrm{~cm})$ diameter pieces is at a pitch of $12.94 \mathrm{in} .(32.86 \mathrm{~cm})$ and a water density fraction of 0.3 . For this configuration $k_{\infty}$ plus uncertainties and bias is 1.0048 .

At this optimum configuration the moderator to fuel volume ratio is 1.278 . To determine the effect on $k_{\infty}$ of increasing diameter, calculations were done with larger diameters at the optimum configuration while maintaining a constant moderator to fuel volume ratio. The results are in Table 6.4.3-2(D). They show that increasing the diameter results in a reduction in $k_{\infty}$. Therefore, $k_{\infty}$ values at a diameter of $9 \mathrm{in} .(22.86 \mathrm{~cm})$ are conservative with respect to larger diameters and bounds the larger diameter material.

A series of calculations were then done with the 9 in. $(22.86 \mathrm{~cm})$ diameter pieces to determine the effect of piece length and axial separation on $k_{\infty}$. Table 6.4.3-3(D) presents the results. The calculations are for an infinite hexagonal array of pieces at optimum moderation and pitch for the given lengths and axial water gaps. From the data it is seen that as the pieces become shorter, $k_{\infty}$ increases. For each length $k_{\infty}$ maximizes at the axial water gap of $3 \mathrm{in} .(7.62 \mathrm{~cm})$. 
TABLE 6.4.3-1(D). Infinite Arrays of $22.86 \mathrm{~cm}$ (9 in.) Diameter Material.

\begin{tabular}{|c|c|c|c|c|}
\hline $\begin{array}{c}\text { Pitch } \\
\text { in. }(\mathrm{cm})\end{array}$ & $\begin{array}{l}\text { Water Density } \\
\text { Fraction }\end{array}$ & $k_{\infty}$ & $\mathrm{k}_{\infty}+\sigma_{\mathrm{c}}+$ bias & Input File \\
\hline $9.00(22.87)$ & 1.0 & 0.7782 & 0.7431 & $\mathrm{scO} 1$ \\
\hline $9.39(23.86)$ & 1.0 & 0.8956 & 0.9105 & $\mathrm{scO} 05$ \\
\hline $9.79(24.86)$ & 1.0 & 0.9553 & 0.9701 & $\mathrm{sc0} 2$ \\
\hline $9.79(24.86)$ & 0.9 & 0.9484 & 0.9633 & $\operatorname{sc} 92$ \\
\hline $9.79\{24.86\}$ & 0.7 & 0.9151 & 0.9299 & $\operatorname{sc} 72$ \\
\hline $9.79(24.86)$ & 0.5 & 0.8440 & 0.8588 & $\operatorname{sc5} 2$ \\
\hline $9.79(24.86)$ & 0.3 & 0.7252 & 0.7400 & $\operatorname{sc} 32$ \\
\hline $10.18(25.86)$ & 1.0 & 0.9605 & 0.9753 & $\mathrm{sc06}$ \\
\hline $10.18\{25.86\}$ & 0.9 & 0.9691 & 0.9839 & $\operatorname{sc} 96$ \\
\hline $10.18(25.86)$ & 0.7 & 0.9589 & 0.9737 & $\operatorname{sc7} 6$ \\
\hline $10.18(25.86)$ & 0.5 & 0.9140 & 0.9288 & sc56 \\
\hline $10.18(25.86)$ & 0.3 & 0.7938 & 0.8087 & $\operatorname{sc} 36$ \\
\hline $10.57(26.86\}$ & 1.0 & 0.9336 & 0.9484 & $\mathrm{sc0} 3$ \\
\hline $10.57\{26.86\}$ & 0.9 & 0.9520 & 0.9668 & $\operatorname{sc} 93$ \\
\hline $10.57(26.86)$ & 0.7 & 0.9760 & 0.9909 & $\mathrm{sc73}$ \\
\hline $10.57(26.86)$ & 0.5 & 0.9551 & 0.9699 & $\operatorname{sc} 53$ \\
\hline $10.57(26.86)$ & 0.3 & 0.8535 & 0.8684 & $\operatorname{sc} 33$ \\
\hline $11.36(28.86\}$ & 1.0 & 0.8385 & 0.8533 & $\mathrm{scO} 4$ \\
\hline $11.36(28.86)$ & 0.9 & 0.8766 & 0.8914 & $\operatorname{sc} 94$ \\
\hline $11.36(28.86)$ & 0.7 & 0.9432 & 0.9580 & $\operatorname{sc} 74$ \\
\hline $11.36\{28.86\}$ & 0.5 & 0.9827 & 0.9975 & $\operatorname{sc} 54$ \\
\hline $11.36(28.86)$ & 0.3 & 0.9363 & 0.9512 & sc34 \\
\hline $12.15(30.86)$ & 0.5 & 0.9607 & 0.9755 & $\operatorname{sc5} 5$ \\
\hline $12.15(30.86)$ & 0.3 & 0.9790 & 0.9939 & $\operatorname{sc} 37$ \\
\hline $12.94(32.86)$ & 0.5 & 0.9119 & 0.9267 & $\operatorname{sc} 58$ \\
\hline $12.94\{32.86\}$ & 0.3 & 0.9900 & 1.0048 & $\operatorname{sc} 38$ \\
\hline $13.72(34.86\}$ & 0.3 & 0.9811 & 0.9959 & $\operatorname{sc} 39$ \\
\hline $14.51(36.86)$ & 0.3 & 0.9568 & 0.9716 & $\operatorname{sc} 3 a$ \\
\hline
\end{tabular}


TABLE 6.4.3-2(D). $k_{\infty}$ as Diameter Increases - Constant Moderator to Fuel Ratio.

\begin{tabular}{|c|c|c|c|}
\hline $\begin{array}{c}\text { Diameter } \\
\text { in. (cm) }\end{array}$ & $k_{w_{\infty}}$ & $k_{\infty}+2 \sigma_{c}+$ bias & Input File \\
\hline \hline $9.00(22.86)$ & 0.9900 & 1.0048 & sc38 \\
\hline $10.00(25.40)$ & 0.9727 & 0.9875 & sca1 \\
\hline $11.00(27.94)$ & 0.9536 & 0.9685 & sca2 \\
\hline $12.00(30.48)$ & 0.9309 & 0.9454 & sca3 \\
\hline $13.00(33.02)$ & 0.9076 & 0.9223 & sca4 \\
\hline
\end{tabular}

TABLE 6.4.3-3(D). Effect on $k_{\infty}$ of Length And Axial Water Gap.

\begin{tabular}{|c|c|c|c|c|}
\hline $\begin{array}{l}\text { Scrap Length } \\
\text { in. }(\mathrm{cm})\end{array}$ & $\begin{array}{c}\text { Axial Water Gap } \\
\text { in. }(\mathrm{cm})\end{array}$ & $\infty$ & $\mathrm{k}_{\infty}+\sigma_{\mathrm{c}}+$ bias & Input File \\
\hline $30\{76.2\}$ & $1(2.54\}$ & 0.9936 & 1.0084 & aza 1 \\
\hline $30(76.2)$ & $2(5.08)$ & 1.0015 & 1.0164 & aza2 \\
\hline $30(76.2)$ & $3(7.62)$ & 1.0025 & 1.0173 & aza3 \\
\hline $30(76.2)$ & $4(10.16)$ & 0.9981 & 1.0128 & aza4 \\
\hline $30(76.2)$ & $5(12.7)$ & 0.9938 & 1.0086 & aza5 \\
\hline $30(76.2)$ & $7(17.78)$ & 0.9725 & 0.9873 & aza7 \\
\hline $17\{43.18\}$ & $7(2.54)$ & 0.9971 & 1.0119 & azb 1 \\
\hline $17(43.18)$ & $2(5.08\}$ & 1.0072 & 1.0220 & azb2 \\
\hline $17(43.18)$ & $3(7.62)$ & 1.0091 & 1.0239 & azb3 \\
\hline $17(43.18)$ & $4(10.16)$ & 1.0055 & 1.0203 & azb4 \\
\hline $17(43.18)$ & $5(12.7)$ & 0.9929 & 1.0077 & azb5 \\
\hline $17(43.18)$ & $7(17.78)$ & 0.9611 & 0.9759 & azb7 \\
\hline $6(15.24)$ & $1(2.54)$ & 1.0078 & 1.0226 & azc1 \\
\hline $6(15.24)$ & $2(5.08)$ & 1.0288 & 1.0436 & azc2 \\
\hline $6(15.24)$ & $3(7.62)$ & 1.0330 & 1.0478 & $\operatorname{azc} 3$ \\
\hline $6(15.24)$ & $4(10.16)$ & 1.0204 & 1.0352 & azc4 \\
\hline $6\{15.24\}$ & $5(12.7)$ & 0.9975 & 1.0123 & azc5 \\
\hline $6(15.24)$ & $7(17.78)$ & 0.9345 & 0.9493 & azc7 \\
\hline $4(10.16)$ & $1(2.54)$ & 1.0138 & 1.0286 & azd 1 \\
\hline $4\{10.16\}$ & $2(5.08)$ & 1.0381 & 1.0529 & azd2 \\
\hline $4\{10.16\}$ & $3(7.62)$ & 1.0389 & 1.0537 & azd3 \\
\hline $4(10.16)$ & $4(10.16)$ & 1.0219 & 1.0367 & azd4 \\
\hline $4(10.16)$ & $5(12.7)$ & 0.9908 & 1.0056 & azd5 \\
\hline $4(10.16)$ & $7(17.78)$ & 0.9189 & 0.9337 & azd7 \\
\hline
\end{tabular}


The infinite hexagonal array calculations previously summarized in Tables 6.4.3-1(D) to 6.4.3-3(D) provide information on optimal parameters for an infinite array. However, these optimal parameters may change for finite arrays because of leakage, so a separate optimization iteration is required for finite arrays.

The configuration for the finite array is chosen conservatively. A hexagonal lattice for each tier is more conservative that a square lattice since the hexagonal lattice has a higher packing fraction, so the hexagonal lattice is used in this analysis. Traditionally, the same number of lattice elements are used for each of the tiers of the array. However, this is not necessarily an optimum assumption. For a fixed number of total elements, the $\mathbf{k}_{\text {eff }}$ for an approximately spherical arrangement of elements will be larger than the traditional more cylindrical arrangement. Hence, the spherical arrangement is the more conservative.

There can be a large number of possible near-spherical arrangements of the unit elements, each of which would need to be optimized with the other parameters. The method used in this analysis is to conservatively assume a hexagonal array of lattice elements inside of a large sphere. These lattice elements completely fill up the sphere in both the horizontal (hexagonal) and vertical (stacked) directions; i.e., lattice elements at the boundary of the sphere will not be complete since they are cut by the sphere, see Figure 6.4.3-1(E) and 6.4.3-2(E) in Section 6.4.3(E) for elevation and plan views of a typical array within a sphere. However, this spherical treatment enables a conservative optimization with a calculational iteration on lattice parameters (pitch of hexagonal lattice, water density, and water thickness between vertical elements) while adjusting the radius of the sphere each time to obtain a constant uranium mass during the iteration. Once the optimum parameters are found to maximize $k$, the sphere radius with those optimum parameters can be decreased (or increased) to decrease (or increase) the uranium mass and obtain an optimized $k$ that is below the limit for this mass.

The calculations for each FERMCO material are summarized in Tables 6.4.3-4(D) to 6.4.3-7(D) for the large spheres containing the hexagonal lattices, where there is $12.0 \mathrm{in}$. $(30.48 \mathrm{~cm})$ of water reflector beyond each sphere. The first part of a table shows the iteration on the three parameters (pitch of the hexagonal lattice, water density, and water thickness between the elements in the vertical) to find the parameters that will approximately optimize $k$. However, there is a ridge in such a three-parameter optimization involving the water density, where there is a weak dependence of $k$ along the peak of this ridge with water density. Hence, this first iteration in each table does not attempt to follow this ridge, but rather obtains optimal parameters for an intermediate water density.

Prior experience has been that the maximum typically occurs for a water density of $1.0 \mathrm{~g} / \mathrm{cm}^{3}$ to minimize leakage. The iteration is therefore repeated in each table (once for each of the two lengths in Table 6.4.3-4(D) ) subject to the constraint that the water density is one. In all cases, the $k$ is either higher with the water density of one, or is within the statistical uncertainties of the maximum $\mathrm{k}$ for the intermediate water density. Therefore, the water density of one is the bounding situation. Cases 1303e, 1303k, 1303l, and 1303m in Table 6.4.3-4(D) show the optimized $k$ values along the water density ridge, where these water densities vary from 0.57 to $1,00 \mathrm{~g} / \mathrm{cm}^{3}$, and $\mathrm{k}$ increases slowly with increasing water density. Once optimum parameters are found for a given water density, the optimum parameters for another water density can be predicted quite accurately by conserving the product of water density and axial thickness to determine the axial parameter and conserving total water mass within a hexagonal lattice cell to determine the pitch. 
TABLE 6.4.3-4(D). Reflected Finite Arrays to Determine Optimum Parameters and Maximum Mass for FERMCO Ingot Sections. (13 in. diameter $x$ $3 \mathrm{in}$. long $U$ and 6 in. long $U)$. ( 2 sheets total)

\begin{tabular}{|c|c|c|c|c|c|c|c|c|}
\hline \multicolumn{3}{|c|}{ Parameters of Hexagonal } & \multicolumn{2}{|c|}{ Sphere Containing } & \multicolumn{3}{|c|}{ Calculated Results } & \multirow[t]{2}{*}{ Case $^{e}$} \\
\hline $\begin{array}{l}\text { Pitch } \\
\text { (cm }\end{array}$ & $\begin{array}{l}\text { Water } \\
\text { Density } \\
\left(\mathrm{g} / \mathrm{cm}^{3}\right)^{\mathrm{a}}\end{array}$ & $\begin{array}{c}\text { Axial } \\
\text { Water } \\
\text { Height } \\
(\mathrm{cm})^{\circ}\end{array}$ & $\begin{array}{c}\text { Sphere } \\
\text { Radius } \\
(\mathrm{cm})^{c}\end{array}$ & $\begin{array}{c}\text { Total } \\
\text { Uranium } \\
\text { Mass }(\mathrm{kg})^{\circ}\end{array}$ & $k_{\text {ett }}$ & Uncer. ${ }^{d}$ & $\begin{array}{c}\mathrm{k}_{\mathrm{eff}}+ \\
2 \sigma_{\mathrm{c}}+\text { bias }\end{array}$ & \\
\hline 37.353 & 0.57 & 5.500 & 67.000 & 9,659 & 0.9457 & 0.0013 & 0.9606 & $1303 a$ \\
\hline 37.353 & 0.52 & 5.500 & 67.000 & 9,659 & 0.9437 & 0.0013 & 0.9586 & $1303 b$ \\
\hline 37.353 & 0.62 & 5.500 & 67.000 & 9,659 & 0.9420 & 0.0011 & 0.9568 & $1303 \mathrm{c}$ \\
\hline 38.353 & 0.57 & 5.500 & 68.299 & 9,659 & 0.9318 & 0.0012 & 0.9466 & $1303 d$ \\
\hline 36.353 & 0.57 & 5.500 & 65.700 & 9,659 & 0.9556 & 0.0011 & 0.9704 & $1303 e$ \\
\hline 35.353 & 0.57 & 5.500 & 64.393 & 9,659 & 0.9549 & 0.0013 & 0.9698 & $1303 f$ \\
\hline 36.353 & 0.57 & 4.500 & 64.111 & 9,659 & 0.9505 & 0.0010 & 0.9652 & $1303 \mathrm{~g}$ \\
\hline 36.353 & 0.57 & 6.500 & 67.241 & 9.659 & 0.9509 & 0.0011 & 0.9657 & $1303 \mathrm{~h}$ \\
\hline 36.353 & 0.57 & 5.500 & 59.014 & 6,975 & 0.9330 & 0.0012 & 0.9478 & $1303 \mathrm{i}$ \\
\hline 35.553 & 0.75 & 4.180 & 62.565 & 9,659 & 0.9621 & 0.0013 & 0.9770 & $1303 \mathrm{k}$ \\
\hline 35.131 & 0.90 & 3.483 & 60.796 & 9,659 & 0.9635 & 0.0013 & 0.9784 & 13031 \\
\hline \multicolumn{9}{|c|}{ Calculations with water density $=1.0 \mathrm{~g} / \mathrm{cm}^{3}$} \\
\hline 34.920 & 1.00 & 3.135 & 59.901 & 9,659 & 0.9639 & 0.0012 & 0.9787 & $1303 \mathrm{~m}$ \\
\hline 34.920 & 1.00 & 3.635 & 60.813 & 9,659 & 0.9620 & 0.0013 & 0.9769 & $1303 n$ \\
\hline 34.920 & 1.00 & 2.635 & 58.939 & 9,659 & 0.9533 & 0.0013 & 0.9682 & 13030 \\
\hline 34.420 & 1.00 & 3.135 & 59.295 & 9,659 & 0.9696 & 0.0013 & 0.9845 & $1303 p$ \\
\hline 33.920 & 1.00 & 3.135 & 58.689 & 9,659 & 0.9704 & 0.0015 & 0.9853 & $1303 q$ \\
\hline 34.170 & 1.00 & 3.310 & 59.311 & 9,659 & 0.9669 & 0.0012 & 0.9817 & $1303 r$ \\
\hline 33.920 & 1.00 & 3.135 & 45.825 & 4,677 & 0.9333 & 0.0014 & 0.9482 & $1303 \mathrm{~s}$ \\
\hline 33.920 & 1.00 & 3.135 & 44.580 & 4,312 & 0.9284 & 0.0015 & 0.9433 & $1303 t$ \\
\hline 33.920 & 1.00 & 3.135 & 44.580 & 4,312 & 0.9276 & 0.0006 & 0.9422 & 1303 tu \\
\hline \multicolumn{9}{|c|}{13 in. diameter and 6 in. long } \\
\hline 36.353 & 0.57 & 5.500 & 60.732 & 9,659 & 0.9044 & 0.0012 & 0.9192 & $1306 a$ \\
\hline 36.353 & 0.57 & 6.500 & 61.753 & 9,659 & 0.9040 & 0.0012 & 0.9188 & $1306 \mathrm{~b}$ \\
\hline 36.353 & 0.57 & 4.500 & 59.747 & 9,659 & 0.8973 & 0.0012 & 0.9121 & $1306 c$ \\
\hline 35.353 & 0.57 & 5.500 & 59.576 & 9,659 & 0.9008 & 0.0015 & 0.9157 & $1306 \mathrm{~d}$ \\
\hline 37.353 & 0.57 & 5.500 & 61.911 & 9,659 & 0.9006 & 0.0013 & 0.9155 & $1306 \mathrm{e}$ \\
\hline 36.353 & 0.52 & 5.500 & 60.732 & 9,659 & 0.8985 & 0.0013 & 0.9134 & $1306 f$ \\
\hline
\end{tabular}


TABLE 6.4.3-4(D). Reflected Finite Arrays to Determine Optimum Parameters and Maximum Mass for FERMCO Ingot Sections. (13 in. diameter $x$ 3 in. long $U$ and 6 in. long $U)$. (2 sheets total)

\begin{tabular}{|c|c|c|c|c|c|c|c|c|}
\hline \multicolumn{3}{|c|}{ Parameters of Hexagonal } & \multicolumn{2}{|c|}{ Sphere Containing } & \multicolumn{3}{|c|}{ Calculated Results } & \multirow[t]{2}{*}{ Case $^{e}$} \\
\hline $\begin{array}{l}\text { Pitch } \\
\text { (cm) }\end{array}$ & $\begin{array}{l}\text { Water } \\
\text { Density } \\
\left(\mathrm{g} / \mathrm{cm}^{3}\right)^{\mathrm{a}}\end{array}$ & $\begin{array}{l}\text { Axial } \\
\text { Water } \\
\text { Height } \\
(\mathrm{cm})^{\circ}\end{array}$ & $\begin{array}{c}\text { Sphere } \\
\text { Radius } \\
(\mathrm{cm})^{5}\end{array}$ & $\begin{array}{c}\text { Total } \\
\text { Uranium } \\
\text { Mass }(\mathrm{kg})^{\mathrm{c}}\end{array}$ & $k_{e f f}$ & Uncer. ${ }^{d}$ & $\begin{array}{c}\mathrm{k}_{\mathrm{eff}}+ \\
2 \sigma_{\mathrm{c}}+\text { bias }\end{array}$ & \\
\hline 36.353 & 0.62 & 5.500 & 60.732 & 9,659 & 0.9078 & 0.0014 & 0.9227 & $1306 \mathrm{~g}$ \\
\hline 36.353 & 0.67 & 5.500 & 60.732 & 9,659 & 0.9077 & 0.0013 & 0.9226 & $1306 \mathrm{~h}$ \\
\hline 36.353 & 0.62 & 5.500 & 67.100 & 13,067 & 0.9227 & 0.0012 & 0.9375 & $1306 i$ \\
\hline \multicolumn{9}{|c|}{ Calculations with water density $=1.0 \mathrm{~g} / \mathrm{cm}^{3}$} \\
\hline 33.920 & 1.00 & 3.135 & 55.560 & 9,659 & 0.9071 & 0.0014 & 0.9220 & $1306 \mathrm{k}$ \\
\hline 33.920 & 1.00 & 3.635 & 56.049 & 9,659 & 0.9147 & 0.0012 & 0.9295 & 13061 \\
\hline 33.920 & 1.00 & 4.135 & 56.550 & 9,659 & 0.9083 & 0.0013 & 0.9232 & $1306 \mathrm{~m}$ \\
\hline 34.420 & 1.00 & 3.635 & 56.627 & 9,659 & 0.9154 & 0.0012 & 0.9302 & $1306 n$ \\
\hline 34.920 & 1.00 & 3.635 & 57.210 & 9,659 & 0.9137 & 0.0013 & 0.9286 & 13060 \\
\hline 34.420 & 1.00 & 3.635 & 61.215 & 12,144 & .9259 & 0.0014 & 0.9408 & $1306 p$ \\
\hline 34.420 & 1.00 & 3.635 & 61.215 & 12,144 & 0.9238 & 0.0007 & 0.9385 & $1306 \mathrm{pu}$ \\
\hline
\end{tabular}

layers.

${ }^{a}$ Density of both the radial water beyond the 13 in. diameter uranium and the axial water between uranium

${ }^{b}$ Axial thickness of water between uranium layers.

"Sphere containing the hexagonal lattice and resulting total uranium mass in the lattice within the sphere.

One standard deviation statistical uncertainty in the Monte Carlo calculation.

Input file names are this case identifier preceded with an $i$ and the corresponding MCNP output files are this case identifier preceded with an 0. 
TABLE 6.4.3-4a(D). Reflected Finite Arrays to Determine Optimum Parameters and Maximum Mass for FERMCO Scrap (13-in. diameter $x$ shorter than 3-in. long $U$ and 4-in. long $U$ ).

\begin{tabular}{|c|c|c|c|c|c|c|c|c|}
\hline \multicolumn{3}{|c|}{ Parameters of Hexagonal } & \multicolumn{2}{|c|}{ Sphere Containing } & \multicolumn{3}{|c|}{ Calculated Results } & \multirow[t]{2}{*}{ Case $^{\mathrm{a}}$} \\
\hline $\begin{array}{l}\text { Pitch } \\
(\mathrm{cm})\end{array}$ & $\begin{array}{l}\text { Water } \\
\text { Density } \\
\left(\mathrm{g} / \mathrm{cm}^{3}\right)^{2}\end{array}$ & $\begin{array}{c}\text { Axial } \\
\text { Water } \\
\text { Height } \\
(\mathrm{cm})^{b}\end{array}$ & $\begin{array}{c}\text { Sphere } \\
\text { Radius } \\
(\mathrm{cm})^{\circ}\end{array}$ & $\begin{array}{c}\text { Total } \\
\text { Uranium } \\
\text { Mass }(\mathrm{kg})^{\circ}\end{array}$ & $K_{e t t}$ & Uncer. $^{d}$ & $\begin{array}{c}\mathrm{K}_{\mathrm{eH}}+ \\
2 \sigma_{c}+\text { bias }\end{array}$ & \\
\hline \multicolumn{9}{|c|}{1 -in. Uranium Length } \\
\hline 33.920 & 1.00 & 2.500 & 32.678 & 1,185 & 0.9318 & 0.0012 & 0.9466 & $1301 \mathrm{a}$ \\
\hline 33.920 & 1.00 & 2.000 & 31.614 & 1,185 & 0.9154 & 0.0014 & 0.9303 & $1301 b$ \\
\hline 33.920 & 1.00 & 3.000 & 33.599 & 1,185 & 0.9300 & 0.0015 & 0.9449 & $1301 \mathrm{c}$ \\
\hline 33.920 & 1.00 & 2.750 & 33.131 & 1,185 & 0.9331 & 0.0015 & 0.9480 & $1301 d$ \\
\hline 33.420 & 1.00 & 2.750 & 32.769 & 1,185 & 0.9371 & 0.0013 & 0.9520 & $1301 \mathrm{e}$ \\
\hline 34.420 & 1.00 & 2.750 & 33.513 & 1,185 & 0.9301 & 0.0012 & 0.9449 & $1301 \mathrm{f}$ \\
\hline 33.030 & 1.00 & 2.750 & 32.492 & 1,185 & 0.9384 & 0.0013 & 0.9533 & $1301 \mathrm{~g}$ \\
\hline 33.420 & 1.00 & 2.750 & 31.750 & 1.071 .2 & 0.9288 & 0.0007 & 0.9435 & $1301 \mathrm{~h}$ \\
\hline 33.420 & 1.00 & 2.750 & 31.750 & 1.071 .2 & 0.9309 & 0.0007 & 0.9456 & $1301 \mathrm{hu}$ \\
\hline \multicolumn{9}{|c|}{ 2-in. Uranium Length } \\
\hline 33.920 & 1.00 & 3.000 & 37.721 & 2,323 & 0.9294 & 0.0015 & 0.9443 & $1302 i$ \\
\hline 33.920 & 1.00 & 3.000 & 37.721 & 2,323 & 0.9274 & 0.0007 & 0.9421 & $1302 \mathrm{iu}$ \\
\hline 33.920 & 1.00 & 2.500 & 36.888 & 2,323 & 0.9151 & 0.0013 & 0.9300 & $1302 j$ \\
\hline 33.920 & 1.00 & 3.500 & 38.534 & 2,323 & 0.9271 & 0.0015 & 0.9420 & $1302 k$ \\
\hline 33.920 & 1.00 & 3.250 & 38.131 & 2,323 & 0.9275 & 0.0012 & 0.9423 & 13021 \\
\hline \multicolumn{9}{|c|}{ 4-in. Uranium Length } \\
\hline 34.100 & 1.00 & 3.400 & 49.167 & 6,075 & 0.9238 & 0.0012 & 0.9386 & $1304 n$ \\
\hline 34.100 & 1.00 & 2.900 & 48.542 & 6,075 & 0.9165 & 0.0013 & 0.9314 & 1304 o \\
\hline 34.100 & 1.00 & 3.900 & 49.777 & 6,075 & 0.9263 & 0.0013 & 0.9412 & $1304 p$ \\
\hline 34.100 & 1.00 & 3.900 & 49.777 & 6.075 & 0.9245 & 0.0006 & 0.9391 & $1304 \mathrm{pu}$ \\
\hline 34.100 & 1.00 & 3.700 & 49.534 & 6,075 & 0.9246 & 0.0014 & 0.9395 & $1304 q$ \\
\hline 33.600 & 1.00 & 3.700 & 49.078 & 6,075 & 0.9236 & 0.0014 & 0.9385 & $1304 r$ \\
\hline 34.600 & 1.00 & 3.700 & 49.988 & 6,075 & 0.9215 & 0.0011 & 0.9363 & $1304 \mathrm{~s}$ \\
\hline \multicolumn{9}{|c|}{ 1.5-in. Uranium Length } \\
\hline 33.670 & 1.00 & 2.875 & 30.347 & 1.071 .2 & 0.8937 & 0.0015 & 0.9086 & $131.5 x$ \\
\hline
\end{tabular}

"Density of both the radial water beyond the 13-in. diameter uranium and the axial water between uranium iayers.

'Axial thickness of water between uranium layers.

"Sphere containing the hexagonal lattice and resulting total uranium mass in the lattice within the sphere.

${ }^{\mathrm{S}}$ One standard deviation statistical uncertainty in the Monte Carlo calculation.

"Input file names are this case identifier preceded with an $i$ and the corresponding MCNP output files are this case identifier preceded with an $o$. 
TABLE 6.4.3-5(D). Reflected Finite Arrays to Determine Optimum Parameters and Maximum Mass for FERMCO Scrap (11 in. diameter $\times 4$ in. long U).

\begin{tabular}{|c|c|c|c|c|c|c|c|c|}
\hline \multicolumn{3}{|c|}{ Parameters of Hexagonal } & \multicolumn{2}{|c|}{ Sphere Containing } & \multicolumn{3}{|c|}{ Calculated Results } & \multirow[t]{2}{*}{ Case $^{e}$} \\
\hline $\begin{array}{l}\text { Pitch } \\
(\mathrm{cm})\end{array}$ & $\begin{array}{l}\text { Water } \\
\text { Density } \\
\left\{\mathrm{g} / \mathrm{cm}^{3}\right\}^{\mathrm{a}}\end{array}$ & $\begin{array}{l}\text { Axial } \\
\text { Water } \\
\text { Height } \\
(\mathrm{cm})^{\mathrm{b}}\end{array}$ & $\begin{array}{c}\text { Sphere } \\
\text { Radius } \\
(\mathrm{cm})^{\circ}\end{array}$ & $\begin{array}{c}\text { Total } \\
\text { Uranium } \\
\text { Mass }(\mathrm{kg})^{c}\end{array}$ & $k_{\text {ett }}$ & Uncer. ${ }^{\text {f }}$ & $\begin{array}{c}\mathrm{k}_{\mathrm{elf}}+ \\
2 \sigma_{\mathrm{c}}+\text { bias }\end{array}$ & \\
\hline 32.273 & 0.57 & 5.500 & 64.882 & 9,659 & 0.9392 & 0.0012 & 0.9540 & $1104 a$ \\
\hline 32.273 & 0.57 & 6.500 & 66.140 & 9,659 & 0.9309 & 0.0012 & 0.9457 & $1104 b$ \\
\hline 32.273 & 0.57 & 4.500 & 63.600 & 9,659 & 0.9378 & 0.0013 & 0.9527 & $1104 \mathrm{c}$ \\
\hline 31.273 & 0.57 & 5.500 & 63.502 & 9,659 & 0.9455 & 0.0014 & 0.9604 & $1104 d$ \\
\hline 30.273 & 0.57 & 5.500 & 62.141 & 9,659 & 0.9419 & 0.0013 & 0.9568 & $1104 \mathrm{e}$ \\
\hline 31.273 & 0.62 & 5.500 & 63.502 & 9.659 & 0.9450 & 0.0014 & 0.9599 & $1104 f$ \\
\hline 31.273 & 0.52 & 5.500 & 63.502 & 9,659 & 0.9402 & 0.0017 & 0.9553 & $1104 \mathrm{~g}$ \\
\hline 31.273 & 0.59 & 5.500 & 57.488 & 6,975 & 0.9281 & 0.0017 & 0.9432 & $1104 \mathrm{~h}$ \\
\hline \multicolumn{9}{|c|}{ Calculations with water density $=1.0 \mathrm{~g} / \mathrm{cm}^{3}$} \\
\hline 29.906 & 1.00 & 3.250 & 58.726 & 9,659 & 0.9543 & 0.0012 & 0.9691 & $1104 j$ \\
\hline 29.906 & 1.00 & 3.750 & 59.398 & 9.659 & 0.9552 & 0.0012 & 0.9700 & $1104 k$ \\
\hline 29.906 & 1.00 & 2.750 & 58.027 & 9,659 & 0.9490 & 0.0014 & 0.9639 & 11041 \\
\hline 29.906 & 1.00 & 4.250 & 60.055 & 9,659 & 0.9447 & 0.0011 & 0.9595 & $1104 m$ \\
\hline 29.406 & 1.00 & 3.500 & 58.391 & 9,659 & 0.9565 & 0.0012 & 0.9713 & $1104 n$ \\
\hline 30.406 & 1.00 & 3.500 & 59.739 & 9,659 & 0.9479 & 0.0013 & 0.9628 & 11040 \\
\hline 29.906 & 1.00 & 3.500 & 59.065 & 9,659 & 0.9538 & 0.0011 & 0.9686 & $1104 p$ \\
\hline 29.406 & 1.00 & 3.500 & 44.630 & 4,312 & 0.9200 & 0.0011 & 0.9348 & $1104 q$ \\
\hline 29.406 & 1.00 & 3.500 & 47.250 & 5,050 & 0.9294 & 0.0014 & 0.9443 & $1104 r$ \\
\hline 29.406 & 1.00 & 3.500 & 47.250 & 5,050 & 0.9279 & 0.0007 & 0.9426 & 1104 ru \\
\hline
\end{tabular}

"Density of both the radial water beyond the $11 \mathrm{in.} \mathrm{diameter} \mathrm{uranium} \mathrm{and} \mathrm{the} \mathrm{axial} \mathrm{water} \mathrm{between} \mathrm{uranium}$

layers.

${ }^{\mathrm{t}}$ Axial thickness of water between uranium layers.

"Sphere containing the hexagonal lattice and resulting total uranium mass in the lattice within the sphere.

"One standard deviation statistical uncertainty in the Monte Carlo calculation.

'Input file names are this case identifier preceded with an $i$ and the corresponding MCNP output files are this case identifier preceded with an o. 
TABLE 6.4.3-5a(D). Reflected Finite Arrays to Determine Optimum Parameters and Maximum Mass for FERMCO Scrap $111 \mathrm{in}$. diameter $\mathrm{x}$ other lengths of U). (2 sheets total)

\begin{tabular}{|c|c|c|c|c|c|c|c|c|}
\hline \multicolumn{3}{|c|}{ Parameters of Hexagonal } & \multicolumn{2}{|c|}{ Sphere Containing } & \multicolumn{3}{|c|}{ Calculated Results } & \multirow[t]{2}{*}{ Case $^{e}$} \\
\hline $\begin{array}{l}\text { Pitch } \\
\text { (cm) }\end{array}$ & $\begin{array}{l}\text { Water } \\
\text { Density } \\
\left(\mathrm{g} / \mathrm{cm}^{3}\right)^{\mathrm{a}}\end{array}$ & $\begin{array}{c}\text { Axial } \\
\text { Water } \\
\text { Height } \\
(\mathrm{cm})^{\mathrm{b}}\end{array}$ & $\begin{array}{c}\text { Sphere } \\
\text { Radius } \\
(\mathrm{cm})^{\circ}\end{array}$ & $\begin{array}{c}\text { Total } \\
\text { Uranium } \\
\text { Mass }(\mathrm{kg})^{\circ}\end{array}$ & $k_{\text {eff }}$ & Uncer. ${ }^{d}$ & $\begin{array}{c}\mathrm{k}_{\mathrm{elf}}+ \\
2 \sigma_{\mathrm{c}}+\text { bias }\end{array}$ & \\
\hline \multicolumn{9}{|c|}{ 1-in. Uranium Length } \\
\hline 29.406 & 1.00 & 3.500 & 56.949 & 5,050 & 1.0053 & 0.0013 & 1.0202 & $1101 \mathrm{a}$ \\
\hline 29.406 & 1.00 & 2.750 & 54.627 & 5,050 & 1.0204 & 0.0012 & 1.0352 & $1101 \mathrm{~b}$ \\
\hline 29.406 & 1.00 & 4.250 & 59.096 & 5,050 & 0.9723 & 0.0011 & 0.9871 & $1101 \mathrm{c}$ \\
\hline 29.406 & 1.00 & 2.000 & 52.015 & 5,050 & 1.0143 & 0.0011 & 1.0291 & $1101 \mathrm{~d}$ \\
\hline 29.406 & 1.00 & 2.250 & 52.877 & 5,050 & 1.0194 & 0.0012 & 1.0342 & $1101 \mathrm{e}$ \\
\hline 29.406 & 1.00 & 2.500 & 53.752 & 5,050 & 1.0256 & 0.0012 & 1.0404 & $1101 \mathrm{f}$ \\
\hline 28.906 & 1.00 & 2.500 & 53.141 & 5,050 & 1.0280 & 0.0011 & 1.0428 & $1101 \mathrm{~g}$ \\
\hline 29.906 & 1.00 & 2.500 & 54.380 & 5,050 & 1.0141 & 0.0014 & 1.0290 & $1101 \mathrm{~h}$ \\
\hline 29.406 & 1.00 & 2.500 & 30.000 & 886 & 0.9063 & 0.0013 & 0.9212 & $1101 \mathrm{i}$ \\
\hline 29.406 & 1.00 & 2.500 & 36.000 & 1.555 & 0.9552 & 0.0015 & 0.9701 & $1101 \mathrm{j}$ \\
\hline 29.406 & 1.00 & 2.500 & 33.000 & 1,185 & 0.9301 & 0.0014 & 0.9450 & $1101 \mathrm{k}$ \\
\hline 29.406 & 1.00 & 2.500 & 31.913 & 1.071 .2 & 0.9225 & 0.0008 & 0.9372 & 11011 \\
\hline 29.406 & 1.00 & 2.750 & 32.343 & 1.071 .2 & 0.9234 & 0.0007 & 0.9381 & $1101 \mathrm{~m}$ \\
\hline 28.906 & 1.00 & 2.750 & 31.975 & 1.071 .2 & 0.9292 & 0.0007 & 0.9439 & $1101 n$ \\
\hline 28.406 & 1.00 & 2.750 & 31.594 & $1,071.2$ & 0.9316 & 0.0007 & 0.9463 & 11010 \\
\hline 27.950 & 1.00 & 2.750 & 31.276 & $1,071.2$ & 0.9328 & 0.0006 & 0.9474 & $1101 p$ \\
\hline 27.950 & 1.00 & 2.750 & 31.276 & 11.071 .2 & 0.93190 & 0.0006 & 0.9465 & $1101 \mathrm{pu}$ \\
\hline \multicolumn{9}{|c|}{ 2-in. Uranium Length } \\
\hline 29.406 & 1.00 & 2.833 & 38.000 & 2,323 & 0.9286 & 0.0010 & 0.9433 & $1102 \mathrm{~m}$ \\
\hline 29.406 & 1.00 & 2.333 & 37.170 & 2,323 & 0.9195 & 0.0013 & 0.9344 & $1102 n$ \\
\hline 29.406 & 1.00 & 3.333 & 38.825 & 2,323 & 0.9313 & 0.0015 & 0.9462 & 11020 \\
\hline 29.406 & 1.00 & 3.333 & 38.825 & 2,323 & 0.9321 & 0.0007 & 09468 & 1102 ou \\
\hline 29.406 & 1.00 & 3.833 & 39.622 & 2,323 & 0.9261 & 0.0012 & 0.9409 & $1102 p$ \\
\hline \multicolumn{9}{|c|}{ 3-in. Uranium Length } \\
\hline 29.406 & 1.00 & 3.167 & 42.500 & 3,584 & 0.9295 & 0.0012 & 0.9443 & $1103 q$ \\
\hline 29.406 & 1.00 & 3.167 & 42.500 & 3,584 & 0.9282 & 0.0006 & 0.9428 & $1103 q u$ \\
\hline 29.406 & 1.00 & 3.667 & 43.181 & 3,584 & 0.9271 & 0.0014 & 0.9420 & $1103 r$ \\
\hline 29.406 & 1.00 & 2.667 & 41.857 & 3,584 & 0.9191 & 0.0012 & 0.9339 & $1103 \mathrm{~s}$ \\
\hline
\end{tabular}


TABLE 6.4.3-5a(D). Reflected Finite Arrays to Determine Optimum Parameters and Maximum Mass for FERMCO Scrap $(11$ in. diameter $x$

other lengths of $U)$. (2 sheets total)

\begin{tabular}{|c|c|c|c|c|c|c|c|c|}
\hline \multicolumn{3}{|c|}{ Parameters of Hexagonal } & \multicolumn{2}{|c|}{ Sphere Containing } & \multicolumn{3}{|c|}{ Calculated Results } & \multirow[t]{2}{*}{ Case $^{e}$} \\
\hline $\begin{array}{l}\text { Pitch } \\
(\mathrm{cm})\end{array}$ & $\begin{array}{l}\text { Water } \\
\text { Density } \\
\left(\mathrm{g} / \mathrm{cm}^{3}\right)^{a}\end{array}$ & $\begin{array}{l}\text { Axial } \\
\text { Water } \\
\text { Height } \\
(\mathrm{cm})^{\circ}\end{array}$ & $\begin{array}{c}\text { Sphere } \\
\text { Radius } \\
(\mathrm{cm})^{\circ}\end{array}$ & $\begin{array}{c}\text { Total } \\
\text { Uranium } \\
\text { Mass }(\mathrm{kg})^{\text {C. }}\end{array}$ & $k_{e H}$ & Uncer. & $\begin{array}{c}k_{\text {eff }}+ \\
2 \sigma_{c}+\text { bias }\end{array}$ & \\
\hline \multicolumn{9}{|c|}{ 1.5-in. Uranium Length } \\
\hline 29.406 & 1.00 & 2.667 & 31.296 & 1,185 & 0.9012 & 0.0013 & 0.9161 & $111.5 \mathrm{u}$ \\
\hline \multicolumn{9}{|c|}{ 6-in. Uranium Length } \\
\hline 29.406 & 1.00 & 3.500 & 57.184 & 9,926 & 0.9280 & 0.0011 & 0.9428 & $1106 a$ \\
\hline 29.406 & 1.00 & 4.000 & 57.651 & 9,926 & 0.9270 & 0.0013 & 0.9419 & $1106 \mathrm{~b}$ \\
\hline 29.406 & 1.00 & 3.750 & 57.419 & 9,926 & 0.9297 & 0.0016 & 0.9447 & $1106 \mathrm{c}$ \\
\hline 29.406 & 1.00 & 3.000 & 56.708 & 9,926 & 0.9270 & 0.0012 & 0.9418 & $1106 \mathrm{~d}$ \\
\hline 29.906 & 1.00 & 3.750 & 58.091 & 9,926 & 0.9314 & 0.0012 & 0.9462 & $1106 \mathrm{e}$ \\
\hline 29.906 & 1.00 & 3.750 & 58.091 & 9,926 & 0.9308 & 0.0007 & 0.9455 & $1106 \mathrm{eu}$ \\
\hline 30.406 & 1.00 & 3.750 & 58.760 & 9,926 & 0.9243 & 0.0013 & 0.9392 & $1106 f$ \\
\hline \multicolumn{9}{|c|}{ 10-in. Uranium Length } \\
\hline 29.906 & 1.00 & 3.750 & 56.500 & 9,926 & 0.9062 & 0.0014 & 0.9211 & $1110 p$ \\
\hline
\end{tabular}

aDensity of both the radial water beyond the $11 \mathrm{in}$. diameter uranium and the axial water between uranium

layers.

"Axial thickness of water between uranium layers.

'Sphere containing the hexagonal lattice and resulting total uranium mass in the lattice within the sphere.

"One standard deviation statistical uncertainty in the Monte Carlo calculation.

eInput file names are this case identifier preceded with an $i$ and the corresponding MCNP output files are this case identifier preceded with an o. 
TABLE 6.4.3-6(D). Reflected Finite Arrays to Determine Optimum Parameters and Maximum Mass for FERMCO Ingot Sections. (10 in. diameter $x 6$ in. long U).

\begin{tabular}{|c|c|c|c|c|c|c|c|c|}
\hline \multicolumn{3}{|c|}{ Parameters of Hexagonal } & \multicolumn{2}{|c|}{ Sphere Containing } & \multicolumn{3}{|c|}{ Calculated Results } & \multirow[t]{2}{*}{ Case $^{\mathrm{e}}$} \\
\hline $\begin{array}{l}\text { Pitch } \\
(\mathrm{cm})\end{array}$ & $\begin{array}{l}\text { Water } \\
\text { Density } \\
\left(\mathrm{g} / \mathrm{cm}^{3}\right)^{a}\end{array}$ & 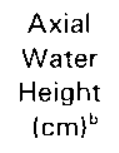 & $\begin{array}{c}\text { Sphere } \\
\text { Radius } \\
(\text { crn })^{c}\end{array}$ & $\begin{array}{c}\text { Total } \\
\text { Uranium } \\
\text { Mass }(\mathrm{kg})^{\mathrm{c}}\end{array}$ & $\mathrm{k}_{\mathrm{eft}}$ & Uncer. ${ }^{d}$ & $\begin{array}{c}\mathrm{k}_{\mathrm{efl}}+ \\
2 \sigma_{\mathrm{c}}+\text { bias }\end{array}$ & \\
\hline 29.733 & 0.62 & 5.500 & 69.766 & 13,067 & 0.9344 & 0.0013 & 0.9493 & $1006 \mathrm{a}$ \\
\hline 29.733 & 0.62 & 6.500 & 70.822 & 13,067 & 0.9260 & 0.0012 & 0.9408 & $1006 \mathrm{~b}$ \\
\hline 29.733 & 0.62 & 4.500 & 68.623 & 13,067 & 0.9407 & 0.0012 & 0.9555 & $1006 \mathrm{c}$ \\
\hline 29.733 & 0.62 & 3.500 & 67.350 & 13,067 & 0.9279 & 0.0014 & 0.9428 & $1006 \mathrm{~d}$ \\
\hline 28.733 & 0.62 & 4.500 & 67.081 & 13,067 & 0.9427 & 0.0013 & 0.9576 & $1006 \mathrm{e}$ \\
\hline 29.150 & 0.62 & 4.500 & 67.728 & 13,067 & 0.9410 & 0.0013 & 0.9559 & $1006 f$ \\
\hline 29.150 & 0.57 & 4.500 & 67.728 & 13,067 & 0.9399 & 0.0011 & 0.9547 & $1006 \mathrm{~g}$ \\
\hline 29.150 & 0.67 & 4.500 & 67.728 & 13,067 & 0.9421 & 0.0012 & 0.9569 & $1006 \mathrm{~h}$ \\
\hline 29.150 & 0.72 & 4.500 & 67.728 & 13,067 & 0.9401 & 0.0012 & 0.9549 & $1006 i$ \\
\hline 29.150 & 0.67 & 4.500 & 61.300 & 9,931 & 0.9306 & 0.0013 & 0.9455 & $1006 j$ \\
\hline 29.150 & 0.67 & 4.500 & 58.156 & 8,388 & 0.9259 & 0.0016 & 0.9409 & $1006 \mathrm{k}$ \\
\hline \multicolumn{9}{|c|}{ Calculations with water density $=1.0 \mathrm{~g} / \mathrm{cm}^{3}$} \\
\hline 26.800 & 1.00 & 3.635 & 54.215 & 8,388 & 0.9286 & 0.0011 & 0.9434 & 10061 \\
\hline 26.800 & 1.00 & 4.135 & 54.702 & 8,388 & 0.9265 & 0.0013 & 0.9414 & $1006 \mathrm{~m}$ \\
\hline 26.800 & 1.00 & 3.135 & 53.725 & 8,388 & 0.9286 & 0.0015 & 0.9435 & $1006 n$ \\
\hline 27.300 & 1.00 & 3.635 & 54.863 & 8,388 & 0.9350 & 0.0012 & 0.9498 & 10060 \\
\hline 27.800 & 1.00 & 3.635 & 55.524 & 8,388 & 0.9301 & 0.0015 & 0.9450 & $1006 p$ \\
\hline 27.300 & 1.00 & 3.635 & 52.049 & 7,073 & 0.9254 & 0.0014 & 0.9403 & $1006 \mathrm{q}$ \\
\hline 27.300 & 1.00 & 3.635 & 52.049 & 7,073 & 0.9260 & 0.0006 & 0.9406 & $1006 \mathrm{qu}$ \\
\hline
\end{tabular}

${ }^{3}$ Density of both the radial water beyond the 10 in. diameter uranium and the axial water between uranium layers.

${ }^{b}$ Axial thickness of water between uranium layers.

'Sphere containing the hexagonal lattice and resulting total uranium mass in the lattice within the sphere.

"One standard deviation statistical uncertainty in the Monte Carlo calculation.

"Input file names are this case identifier preceded with an $i$ and the corresponding MCNP output files are this case identifier preceded with an o. 
TABLE 6.4.3-7(D). Reflected Finite Arrays to Determine Optimum Parameters and Maximum Mass for FERMCO Primary Ingots. (9 in. diameter x 15 in. long U).

\begin{tabular}{|c|c|c|c|c|c|c|c|c|}
\hline \multicolumn{3}{|c|}{ Parameters of Hexagonal } & \multicolumn{2}{|c|}{ Sphere Containing } & \multicolumn{3}{|c|}{ Calculated Results } & \multirow[t]{2}{*}{ Case $^{\mathrm{e}}$} \\
\hline $\begin{array}{l}\text { Pitch } \\
\text { (cm) }\end{array}$ & $\begin{array}{l}\text { Water } \\
\text { Density } \\
\left(\mathrm{g} / \mathrm{cm}^{3}\right)^{\circ}\end{array}$ & $\begin{array}{c}\text { Axial } \\
\text { Water } \\
\text { Height } \\
(\mathrm{cm})^{\circ}\end{array}$ & $\begin{array}{c}\text { Sphere } \\
\text { Radius } \\
(\mathrm{cm})^{\circ}\end{array}$ & $\begin{array}{c}\text { Total } \\
\text { Uranium } \\
\text { Mass }(\mathrm{kg})^{\circ}\end{array}$ & $k_{\text {eft }}$ & Uncer. ${ }^{d}$ & $\begin{array}{c}k_{\text {eff }}+ \\
2 \sigma_{c}+\text { bias }\end{array}$ & \\
\hline 26.193 & 0.67 & 4.500 & 64.536 & 13,067 & 0.9229 & 0.0012 & 0.9377 & $0915 a$ \\
\hline 26.193 & 0.62 & 4.500 & 64.536 & 13,067 & 0.9132 & 0.0015 & 0.9281 & $0915 b$ \\
\hline 26.193 & 0.72 & 4.500 & 64.536 & 13,067 & 0.9252 & 0.0013 & 0.9401 & $0915 c$ \\
\hline 27.193 & 0.72 & 4.500 & 66.158 & 13,067 & 0.9180 & 0.0013 & 0.9329 & $0915 d$ \\
\hline 25.193 & 0.72 & 4.500 & 62.883 & 13,067 & 0.9075 & 0.0012 & 0.9223 & $0915 \mathrm{e}$ \\
\hline 26.193 & 0.72 & 5.500 & 65.086 & 13,067 & 0.9208 & 0.0013 & 0.9357 & $0915 f$ \\
\hline 26.193 & 0.72 & 3.500 & 63.977 & 13,067 & 0.9206 & 0.0015 & 0.9355 & $0915 \mathrm{~g}$ \\
\hline 26.193 & 0.77 & 4.500 & 64.536 & 13,067 & 0.9236 & 0.0013 & 0.9385 & $0915 \mathrm{~h}$ \\
\hline \multicolumn{9}{|c|}{ Calculations with water density $=1.0 \mathrm{~g} / \mathrm{cm}^{3}$} \\
\hline 25.000 & 1.00 & 3.500 & 62.019 & 13,067 & 0.9248 & 0.0015 & 0.9397 & $0915 j$ \\
\hline 25.000 & 1.00 & 3.500 & 62.019 & 13,067 & 0.9252 & 0.0006 & 0.9398 & $0915 j u$ \\
\hline 25.000 & 1.00 & 4.000 & 62.291 & 13,067 & 0.9211 & 0.0015 & 0.9360 & $0915 k$ \\
\hline 25.000 & 1.00 & 3.000 & 61.746 & 13,067 & 0.9222 & 0.0014 & 0.9371 & 09151 \\
\hline 24.500 & 1.00 & 3.500 & 61.192 & 13,067 & 0.9165 & 0.0011 & 0.9313 & $0915 \mathrm{~m}$ \\
\hline 25.500 & 1.00 & 3.500 & 62.843 & 13,067 & 0.9226 & 0.0015 & 0.9375 & $0915 n$ \\
\hline
\end{tabular}

${ }^{a}$ Density of both the radial water beyond the 9 in. diameter uranium and the axial water between uranium layers.

${ }^{\mathrm{b}}$ Axial thickness of water between uranium lavers.

"Sphere containing the hexagonal lattice and resulting total uranium mass in the lattice within the sphere.

${ }^{d}$ One standard deviation statistical uncertainty in the Monte Carlo calculation.

"Input file names are this case identifier preceded with an $i$ and the corresponding MCNP output files are this case identifier preceded with an 0 . 
The search for the two optimum parameters that will maximize $k$ for a water density of one involves a small uncertainty in the final result since statistical uncertainties are involved along with the practical problem of keeping the total number of calculations to a reasonable amount. To account for this type of uncertainty in the optimization, the radius (to obtain the maximum allows mass) is adjusted in a final calculation with the optimized parameters to give some additional margin of typically about 0.006 in $\mathrm{k}$. This margin is in addition to the above discussed conservatism of using the sphere instead of multi-tiers with the same number of elements per tier.

Following is some pertinent information for Tables $6.4 .3-4(D)$ to $6.4 .3-7(D)$ :

- The optimization calculations for the $13 \mathrm{in.}(33.02 \mathrm{~cm})$ diameter FERMCO Ingot Sections included 6 in. $(15.24 \mathrm{~cm})$ lengths, where lengths longer than 6 in. $(15.24 \mathrm{~cm})$ are to conservatively use the optimized mass for the $6 \mathrm{in} .(15.24 \mathrm{~cm})$ length. The maximum mass for the $13 \mathrm{in.}(33.02 \mathrm{~cm})$ diameter FERMCO Primary Ingots of Table $6.3-1(\mathrm{D})$ with $30 \mathrm{in} .(76.2 \mathrm{~cm})$ length will conservatively use the maximum mass from the shorter 6 in. $(15.24 \mathrm{~cm})$ length.

- The maximum mass for the $12 \mathrm{in.}(30.48 \mathrm{~cm})$ diameter FERMCO Primary Ingots of Table 6.3-1(D) with a minimum of $17 \mathrm{in.}(43.18 \mathrm{~cm}$ ) lengths will conservatively use the maximum mass for the FERMCO Derbies calculations given in Section $E$ with their $5 \mathrm{in.}(12.7 \mathrm{~cm})$ length.

- Three calculations are typically made for a parameter while holding the other two parameters constant. The intent is to bracket the peak in the variation of the multiplication factor with the parameter; i.e., the multiplication factor is largest for the case with the mid-value of the parameter and less for the two wing values of the parameter (in some cases, the values of the multiplication factors are about the same for two or three of the parameter values indicating that there is a broad slowly-varying peak). Then this optimized parameter is held constant while the next parameter is varied. Of course, the water density parameter is not varied for the bottom set of calculations in each table for a water density of one.

- The axial water thickness and the pitch are nearly independent parameters since basically either the axial water thickness or radial water thickness are involved. However, a change in the water density changes the amount of water both axially and radially so it is more complicated to vary the water density parameter. No serious attempt was made to iterate on water density in the top part of each table since the calculations at the bottom part of the table with the water density of one were made to verify that it maximizes $k$ (to within the statistics) compared to the intermediate water density. Cases $1303 \mathrm{e}, 1303 \mathrm{k}, 1303 \mathrm{l}$, and $1303 \mathrm{~m}$ in Table 6.4.3-4(D) were included to illustrate the optimized $k$ values along the water density ridge, where these water densities vary from 0.57 to $1.00 \mathrm{~g} / \mathrm{cm}^{3}$, and $\mathrm{k}$ increases slowly with increasing water density.

Following is some pertinent information for Table 6.4.3-4a(D), where optimized $\mathrm{K}_{\mathrm{eff}}$ values are determined for the 13 -in. $(33.02 \mathrm{~cm})$ diameter FERMCO scrap with lengths of 1,2 and 4 in.

- Cases $1301 \mathrm{a}$ to $1301 \mathrm{~g}$ for the $1 \mathrm{in.}(2.54 \mathrm{~cm})$ uranium length are for a total uranium mass of $1,185 \mathrm{~kg}$ to find the optimum parameters. Case 1301 a begins this iteration with the optimized water thickness of $2.50 \mathrm{~cm}$ from previous calculations for 11 " diamter FERMCO scrap with 1 -in. uranium thickness and the optimized pitch for the 13" diameter FERMCO scrap with a 3-in. uranium thickness. The optimized parameters of case $1301 \mathrm{e}$ [same as case $1301 \mathrm{~g}$ to within the statistical 
uncertainties] were used with a reduced sphere radius to obtain the limiting mass of $1,071.2 \mathrm{~kg}$ of case $1301 \mathrm{~h}$ for the 1 -in. $(2.54 \mathrm{~cm})$ thick uranium.

- $\quad$ Case 1302i of Table 6.4.3-4a(D) for a 2-in. $(5.08 \mathrm{~cm})$ uranium thickness uses an axial water thickness obtained by interpolating between the optimum cases $1301 \mathrm{~h}$ for $1 \mathrm{in.}(2.54 \mathrm{~cm})$ and case 1303t of Table 6.4.3-4(D) for $3 \mathrm{in.}(10.16)$ uranium thickness. Then cases $1302 \mathrm{j}$ to $1302 \mathrm{l}$ use other axial water thicknesses while modifying the sphere radius to keep the uranium mass constant. These cases show that the multiplication factor remains under the criticality limit for a total uranium mass limit of $2,323 \mathrm{~kg}$ for the $2-i n .(5.08 \mathrm{~cm})$ uranium thickness. Similarly, cases $1304 \mathrm{n}$ to $1304 \mathrm{~s}$ show that the multiplication factor remains under the criticality limit for a total uranium mass limit of $6,075 \mathrm{~kg}$ for the 4 -in. $(10.16 \mathrm{~cm})$ uranium thickness.

- $\quad$ Case $131.5 \mathrm{x}$ at the bottom of Table 6.4.3-4a(D) uses an axial water thickness for the 1.5 -in. $(3.81 \mathrm{~cm})$ thick uranium that is between case $1301 \mathrm{~h}$ for the 1 -in. $(2.54 \mathrm{~cm})$ thick uranium and case $1302 \mathrm{i}$ for the 2 -in. $(5.08 \mathrm{~cm})$ thick uranium. The $\mathrm{k}_{\mathrm{eff}}$ for the 1.5-in. uranium thickness descreases compared to case $1301 \mathrm{~h}$ for the 1 -in. uranium thickness at the same mass of $1,071.2 \mathrm{~kg}$. Hence, the mass for a 1 -in. uranium thickness may be conservatively used for uranium lengths anywhere between 1 in. and 2 in.

- The allowed uranium mass would decrease even further for uranium thicknesses less than $1 \mathrm{in.}(2.54 \mathrm{~cm})$. Calculations are not reported here for uranium thicknesses less than $1 \mathrm{in}$. so this analysis does not cover thicknesses less than $1 \mathrm{in}$.

- Additional calculations not shown in Table 6.4.3-4a(D) were made to show that the allowed total uranium mass would increase to more than $30,000 \mathrm{~kg}$ for a uranium thickness of $10 \mathrm{in} .(25.4 \mathrm{~cm})$. Then an additional calculation was made to show that for the optimum parameters of the 10-in. length, the multiplication factor decreases as the length is increased to $17 \mathrm{in.}(43.18 \mathrm{~cm})$. Hence, using the limiting uranium mass of $12,144 \mathrm{~kg}$, obtained for the 6 -in. $(15.24 \mathrm{~cm})$ uranium legnth, is a conservative mass to use for the longer lengths of up to $30 \mathrm{in} .(76.2 \mathrm{~cm})$.

Following is some pertinent information for Table 6.4.3-5a(D), where optimized $k_{\text {eff }}$ values are determined for uranium lengths shorter than $6 \mathrm{in.}(15.24 \mathrm{~cm})$ for the 11 " diamter FERMCO scrap:

- $\quad$ Cases $1101 \mathrm{a}$ to $1101 \mathrm{~h}$ for the 1 -in. $(2.54 \mathrm{~cm})$ uranium length are made at the same $5,050 \mathrm{~kg}$ total uranium mass that was obtained as the mass limit for the 4-in. $(10.16 \mathrm{~cm})$ length from case $1104 \mathrm{r}$ in Table 6.4.3-5(D). These $\mathrm{k}_{\text {eff }}$ values for the 1 -in. uranium length are much larger and most of them actually exceed unity. These cases vary the radial pitch and axial water thickness. The optimum axial water thickness for the 1 -in. uranium length decreases compared to case $1104 \mathrm{r}$ for the 4 in. length. There is very little sensitivity to the radial pitch for this small uranium length, where to within the statistical uncertainty of the Monte Carlo calculations, the optimum pitch does not change from that for the 4 -in. length. Finally, cases $1101 \mathrm{i}$ to $1101 \mathrm{l}$ used the optimized parameters of case $1101 \mathrm{f}$ while changing the sphere radii to obtain the mass limit of $1,071.2 \mathrm{~kg}$ of case 11011 . This total uranium mass limit of $1,071.2 \mathrm{~kg}$ will be used for uranium thicknesses between $1 \mathrm{in}$. 22.54 $\mathrm{cm})$ and 2 in. $(5.08 \mathrm{~cm})$.

This same mass limit of $1,071.2 \mathrm{~kg}$ was also obtained in Table 6.4.3-4a(D) for the 13-in. diameter $\times 1$-in. thick uranium. However, there is a substanital mass change 
between the $5,050 \mathrm{~kg}$, where the parametric optimization was made, and the final $1,071.2 \mathrm{~kg}$ of case 11011 in Table 6.4.3-5a(D). Also, the optimum $k_{\text {eff }}$ for 11-in. diameter $\times 1$-in. length uranium is unexpectedly a little lower than the optimum $k_{\text {eff }}$ for 13-in. diameter $\times 1$-in. length uranium [case 1301h of Table 6.4.3-4a(D)]. Therefore, the additional cases $1101 \mathrm{~m}$ to $1101 \mathrm{p}$ were made to determine whether the parametric optimization at the lower mass has changed. The axial water height is increased to $2.750 \mathrm{~cm}$ in case $1101 \mathrm{~m}$, but the change in $k_{\text {eff }}$ is within the statistical uncertainties of the MCNP code. When the radial pitch is decreased in cases $1101 \mathrm{n}$ to $1101 \mathrm{p}$ (case $1101 \mathrm{p}$ has the uranium pieces tight packed), the $\mathrm{k}_{\text {eff }}$ does increase a little more than the statistical uncertainties. Cases $1101 /$ to $1101 \mathrm{p}$ are all for the same uranium mass of $1,071.2$ so this is still the limiting mass for the 11 -in. diameter $\times 1$-in. length uranium, but the $k_{\text {eff }}$ for case $1101 \mathrm{p}$ is the maximum $k_{\text {eff }}$, and it is now greater than the $k_{\text {eff }}$ for 13 -in. diameter $\times 1$-in. length uranium [case $1301 \mathrm{~h}$ of Table $6.4 .3-4 \mathrm{a}(\mathrm{D})]$. Cases $1101 \mathrm{l}$ to $1101 \mathrm{p}$ and case $1301 \mathrm{~h}$ were all run with four times as many histories as usual in the Monte Carlo calculations in order to reduce the statistical uncertainties for this comparison.

- Case $1102 \mathrm{~m}$ of Table 6.4.3-5a(D) for a 2-in. $(5.08 \mathrm{~cm})$ uranium thickness uses an axial water thickness obtained by interpolating between the optimum cases 11011 for $1 \mathrm{in} .(2.54 \mathrm{~cm})$ and case $1104 \mathrm{r}$ for 4 -in. (10.16) uranium thickness. Then cases $1102 \mathrm{n}$ to $1102 \mathrm{p}$ use other axial water thicknesses while modifying the sphere radius to keep the uranium mass constant. These cases show that the multiplication factor remains under the criticality limit for a total uranium mass limit of $2,323 \mathrm{~kg}$ for the 2 -in. $(5.08 \mathrm{~cm})$ uranium thickness. Similarly, cases $1103 \mathrm{q}$ to $1103 \mathrm{~s}$ show that the multiplication factor remains under the criticality limit for a total uranium mass limit of $3,584 \mathrm{~kg}$ for the $3-\mathrm{in}$. $(7.62 \mathrm{~cm})$ uranium thickness.

- $\quad$ Case 111.5u of Table 6.4.3-5a(D) uses an axial water thickness for the 1.5-in. $(3.81 \mathrm{~cm})$ thick uranium that is between case $1101 \mathrm{k}$ for the 1 -in. $(2.54 \mathrm{~cm})$ thick uranium and case $1102 \mathrm{~m}$ for the $2 \mathrm{in} .(5.08 \mathrm{~cm})$ thick uranium. The $\mathrm{k}_{\mathrm{eff}}$ for the 1.5 -in. uranium thickness decreases compared to case $1101 \mathrm{k}$ for the 1 -in. uranium thickness at the same mass of $1,185 \mathrm{~kg}$. Hence, the mass for a 1 -in. uranium thickness may be conservatively used for uranium lengths anywhere between 1 in. and 2 in.

- $\quad$ The allowed uranium mass would decrease even further for uranium thicknesses less than $1 \mathrm{in.}(2.54 \mathrm{~cm})$. Calculations are not reported here for uranium thicknesses less than $1 \mathrm{in.}$ so this analysis does not cover thicknesses less than $1 \mathrm{in.}$

- $\quad$ Cases 1106a to $1106 \mathrm{f}$ of Table 6.4.3-5a(D) for a 6-in. $(15.24 \mathrm{~cm})$ uranium length optimize for a total uranium mass of $9,926 \mathrm{~kg}$, where case 1106 a starts with the optimized parameters for $4 \mathrm{in} .(10.16 \mathrm{~cm})$ uranium length. These cases show that the $9,926 \mathrm{~kg}$ uranium mass may be used as the limiting mass for the 6 -in. length. Finally, case $1110 \mathrm{p}$ at the bottom of Table 6.4.3-5a(D) verifies that $k_{\text {eff }}$ decreases when the optimized parameters and limiting mass for the 6 -in. $(15.24 \mathrm{~cm})$ length are used for the 10 -in. $(25.4 \mathrm{~cm})$ length. The $9,926 \mathrm{~kg}$ total uranium mass may conservatively be used as the limiting mass when the uranium length exceeds 6 in. $(15.24 \mathrm{~cm})$ for the 11 -in. diameter FERMCO scrap.

The FERMCO product ingots are the same as the $\mathrm{N}$ Reactor Mark I outer ingots, except that the ingot length varies from 12 to $17 \mathrm{in}$. $(30.48$ to $43.18 \mathrm{~cm})$. Calculations for the 17 -in. $(43.18 \mathrm{~cm}) \mathrm{N}$ Reactor Mark I outer ingots are given in Section 6.4.3(A). Calculations for the FERMCO product ingots with a shorter length of $12 \mathrm{in.}(30.48 \mathrm{~cm})$ were performed and are summarized in Table 6.4.3-10(D). The radial pitch and axial water thickness are varied for the same 
total uranium mass of $64,478 \mathrm{lb}(29,247 \mathrm{~kg})$ that was obtained as the limiting mass for the 17-in. $(43.18 \mathrm{~cm}$ ) length. Cases $1312 \mathrm{a}$ to $1312 \mathrm{e}$ show that the optimum parameters have not changed from those for the 17-in. length. The $k_{\text {eff }}$ values increase for the 12-in. length compared to the 17 in. length as expected. Since the $k_{\text {eff }}$ value for case $1312 \mathrm{a}$ is close to the limit, the calculation for case $1312 \mathrm{f}$ was made with a reduced total uranium mass. This mass of $55,380 \mathrm{lb}(25,120 \mathrm{~kg})$ is the limiting mass for the 12 -in. $(30.48 \mathrm{~cm})$ length. Finally, a calculation was made for a 15 -in. $(38.1 \mathrm{~cm})$ length, case $1315 \mathrm{~h}$, to further demonstrate that the multiplication factor decreases as the length is increased while holding the total uranium mass constant. Hence, the mass of $55,380 \mathrm{lb}$ $(25,120 \mathrm{~kg})$ is the conservative limiting mass for uranium lengths from $12 \mathrm{in}$. $(30.48 \mathrm{~cm})$ to $17 \mathrm{in}$. $(43.18 \mathrm{~cm})$. The larger uranium mass of $64,478 \mathrm{lb}(29,247 \mathrm{~kg})$ can be used for the 17-in. (43.18 $\mathrm{cm})$ length.

The $\mathrm{k}_{\text {eff }}$ for a single box of each material type with full moderation and reflection is presented in Table 6.4.3-8(D). These $k_{\text {eff }}$ values range from 0.5508 for a box of FERMCO primary ingots to 0.6660 for a box of FERMCO ingot sections.

6.4.3.1(D) Transport Index. The $2 \times \mathrm{N}$ number of damaged packages is determined by dividing the maximum mass from Tables 6.4.3-4(D) through 6.4.3-7(D), 6.4.3-4a(D), 6.4.3-5a(D), 6.4.3-10(D), and Table $6.4 .3-1$ (E) that falls within the transportation criterion of less than 0.95 by the mass per container calculated from Tables 6.1-2(D) and 6.1-2a(D). The $N$ value is then found by dividing the number by 2 . Five times $\mathrm{N}$ undamaged packages with nothing between the packages is modeled as an unmoderated array. An infinite unmoderated array of $1.25 \mathrm{wt} \%{ }^{235} \mathrm{U}$ enriched material is well subcritical, as shown in the ingot and billet sections. Therefore, the conservative $\mathrm{Tl}$ value is derived from $2 \times \mathrm{N}$ damaged packages. The masses, $\mathrm{N}$ and $\mathrm{TI}$ values are tabulated in Tables 6.4.3-9(D) and 6.4.3-9a(D).

FERMCO material corresponding to a row entry in Tables 6.4.3-9(D) and 6.4.3-9a(D), but differing only in being a longer length than that row of the table, may be conservaitvely treated using the corresponding entry in the "Maximum Mass" column of Tables 6.4.3-9(D) and 6.4.3-9a(D). This is because the mass limit increases with increasing length for lengths greater than $1 \mathrm{in.}(2.54 \mathrm{~cm})$ for these large diameters.

Scrap material with a diameter equal to or greater than a diameter given in Table 6.4.3-9a(D) may be conservatively treated using the corresponding entry in the "Maximum Mass" column of Table 6.4.3-9a(D), provided the length of the scrap material is at least as great as the corresponding length given in the table; i.e., the scrap material has a diameter and a length that are each as large or larger than the corresponding pair of entries in the table. 
TABLE 6.4.3-8(D). Single Boxes of FERMCO Material Fully Water Moderated and Reflected.

\begin{tabular}{|c|c|c|c|c|}
\hline Type & $\begin{array}{l}\text { Pieces } \\
\text { Modelled }\end{array}$ & $k_{\text {eff }}$ & $\begin{array}{c}\mathrm{k}_{\mathrm{e} 11}+2 \sigma_{c}+ \\
\text { bias }\end{array}$ & Input File \\
\hline $\begin{array}{l}\text { FERMCO Primary Ingots } \\
13 \mathrm{in.}(33.02 \mathrm{~cm}) \text { OD } \times 30 \text { in. }(76.20 \mathrm{~cm})\end{array}$ & 1 & 0.5508 & 0.5657 & $\mathrm{fco} 7$ \\
\hline $\begin{array}{l}\text { FERMCO Ingot Sections } \\
13 \mathrm{in.}\{33.02 \mathrm{~cm}) \text { OD } \times 6 \text { in. }(15.24 \mathrm{~cm})\end{array}$ & 6 & 0.5588 & 0.5736 & $f c o 1$ \\
\hline $\begin{array}{l}\text { FERMCO Ingot Sections } \\
13 \text { in. }(33.02 \mathrm{~cm}) \text { OD } \times 3 \text { in. }(7.62 \mathrm{~cm})\end{array}$ & 12 & 0.5536 & 0.5685 & $f \operatorname{co} 2$ \\
\hline $\begin{array}{l}\text { FERMCO Scrap } \\
13 \text { in. }(33.02 \mathrm{~cm}) \text { OD } \times 4 \text { in. }(10.16 \mathrm{~cm})\end{array}$ & $1252 \mathrm{lb}$ & 0.6087 & 0.6237 & $\operatorname{fes} 1$ \\
\hline $\begin{array}{l}\text { FERMCO Primary Ingots } \\
12 \mathrm{in.}(30.48 \mathrm{~cm}) \mathrm{OD} \times 17 \text { in. }(43.18 \mathrm{~cm})-26 \mathrm{in} . \\
(66.04 \mathrm{~cm})\end{array}$ & 2 & 0.6235 & 0.6383 & $f \cos$ \\
\hline $\begin{array}{l}\text { FERMCO Scrap } \\
11 \mathrm{in.}(27.94 \mathrm{~cm}) \text { OD } \times 4 \text { in. }(10.16 \mathrm{~cm})\end{array}$ & $1252 \mathrm{lb}$ & 0.6587 & 0.6736 & $f \operatorname{cs} 2$ \\
\hline FERMCO Ingot Sections & 9 & 0.6660 & 0.6809 & $f \operatorname{co} 5$ \\
\hline $\begin{array}{l}\text { FERMCO Primary Ingots } \\
9 \text { in. }(22.86 \mathrm{~cm}) \text { OD } \times 30 \mathrm{in} .(76.20 \mathrm{~cm})\end{array}$ & 2 & 0.5525 & 0.5673 & $f \cos$ \\
\hline
\end{tabular}

TABLE 6.4.3-9(D). Calculation of $\mathrm{N}$ and TI for FERMCO Primary Ingots, Product Ingots, and Ingot Sections.

\begin{tabular}{|c|c|c|c|c|c|c|c|}
\hline \multirow[t]{2}{*}{ Piece } & \multirow{2}{*}{$\begin{array}{l}\text { Container } \\
\text { Mass } \\
\text { lb }(\mathrm{kg})\end{array}$} & \multicolumn{3}{|c|}{ Maximum Mass Calculation } & \multirow[t]{2}{*}{$2 \times N$} & \multirow[t]{2}{*}{$N$} & \multirow[t]{2}{*}{$\mathrm{TI}$} \\
\hline & & Table & Case & $\begin{array}{l}\text { Maximum U } \\
\text { Mass } \\
\text { lb }(\mathrm{kg})\end{array}$ & & & \\
\hline $\begin{array}{l}12 \mathrm{in} .(30.48 \mathrm{~cm}) \text { OD } \times 17 \mathrm{in.} \\
(43.18 \mathrm{~cm}) \text { to } 26 \text { in. }(66.04 \mathrm{~cm})\end{array}$ & $\begin{array}{c}2,596 \\
(1,178)\end{array}$ & $6.4 .3-1(\varepsilon)$ & $1205 \mathrm{cc}$ & $\begin{array}{l}18,585 \\
(8,430)\end{array}$ & 7.16 & 3.58 & 14.0 \\
\hline $\begin{array}{l}13 \mathrm{in.}(33.02 \mathrm{~cm}) \text { OD } \times 30 \mathrm{in} . \\
(76.20 \mathrm{~cm})\end{array}$ & $\begin{array}{r}2,689 \\
(1,220)\end{array}$ & $6.4 .3-4(0)$ & $1306 p$ & $\begin{array}{c}26,772 \\
(12,144)\end{array}$ & 9.96 & 4.98 & 10.1 \\
\hline $\begin{array}{l}9 \text { in. }(22.86 \mathrm{~cm}) \text { OD } \times 30 \mathrm{in} . \\
(76.20 \mathrm{~cm})\end{array}$ & $\begin{array}{c}2,577 \\
(1,169)\end{array}$ & $6.4 .3-7(D)$ & $0915 j$ & $\begin{array}{r}28,808 \\
\{13,067\} \\
\end{array}$ & 11.2 & 5.60 & 9.0 \\
\hline $\begin{array}{l}13 \mathrm{in.}(33.02 \mathrm{~cm}) \text { OD } \times 3 \mathrm{in} . \\
(7.62 \mathrm{~cm})\end{array}$ & $\begin{array}{l}1092 \\
(496)\end{array}$ & $6.4 .3-4\{D\}$ & $1303 t$ & $\begin{array}{c}9,506 \\
(4,312)\end{array}$ & 8.70 & 4.35 & 11.5 \\
\hline $\begin{array}{l}13 \text { in. }(33.02 \mathrm{~cm}) \text { OD } \times 6 \text { in. } \\
(15.24 \mathrm{~cm})\end{array}$ & $\begin{array}{l}1,092 \\
(496)\end{array}$ & $6.4 .3-4\{D\}$ & $1306 p$ & $\begin{array}{c}26,772 \\
(12,144)\end{array}$ & 24.5 & 12.26 & 4.1 \\
\hline $\begin{array}{l}10 \text { in. }(25.40 \mathrm{~cm}) \text { OD } \times 6 \text { in. } \\
(15.24 \mathrm{~cm})\end{array}$ & $\begin{array}{c}636.4 \\
(288.6)\end{array}$ & $6.4 .3-6(D)$ & $1006 q$ & $\begin{array}{l}15,593 \\
(7,073) \\
\end{array}$ & 24.5 & 12.2 & 4.1 \\
\hline $\begin{array}{l}13.05 \mathrm{in} .(33.15 \mathrm{~cm}) \text { OD } \times 2.87 \\
\text { in. }(7.29 \mathrm{~cm}) I D \times 12 \mathrm{in} \text {. to } 17 \\
\text { in. }(30.48 \text { to } 43.18 \mathrm{~cm}) \text { Long } \\
\text { (Product Engots })^{3}\end{array}$ & $\begin{array}{c}3488 \\
\{1582\}\end{array}$ & $\begin{array}{l}6.4 .3- \\
10(D)\end{array}$ & $1312 f$ & $\begin{array}{c}55,380 \\
(25,120)\end{array}$ & 15.88 & 7.94 & 6.3 \\
\hline
\end{tabular}

${ }^{a}$ The maximum uranium mass to be shipped is conservatively based on the criticality evlauation of the 12 -in. long ingot. 
TABLE 6.4.3-9a(D). Calculation of $\mathrm{N}$ and $\mathrm{Tl}$ for FERMCO Scrap.

\begin{tabular}{|c|c|c|c|c|c|c|c|}
\hline \multirow[t]{2}{*}{ Piece } & \multirow{2}{*}{$\begin{array}{c}\text { Amount Per } \\
\text { Package } \\
\text { lb }(\mathrm{kg})\end{array}$} & \multicolumn{3}{|c|}{ Maximum Mass Calculation } & \multirow[t]{2}{*}{$2 \times N$} & \multirow[t]{2}{*}{$N$} & \multirow[t]{2}{*}{$\mathrm{Tl}$} \\
\hline & & Table & Case & $\begin{array}{c}\text { Maximum } \\
\text { U Mass } \\
\text { lb (kg) }\end{array}$ & & & \\
\hline $\begin{array}{l}13 \text { in. }(33.02 \mathrm{~cm}) \text { OD } \times 1 \text { in. } \\
(2.54 \mathrm{~cm})\end{array}$ & $\begin{array}{l}1180 \\
(535)\end{array}$ & $6 \cdot 4 \cdot 3-4 a(D)$ & $1301 \mathrm{~h}$ & $\begin{array}{c}2,361 \\
(1,071)\end{array}$ & 2.0 & 1.0 & 50.0 \\
\hline $\begin{array}{l}13 \mathrm{in.}(33.02 \mathrm{~cm}) \text { OD } \times 2 \mathrm{in.} \\
(5.08 \mathrm{~cm})\end{array}$ & $\begin{array}{l}1200 \\
(544)\end{array}$ & $6.4 .3-4 a(D)$ & $1302 i$ & $\begin{array}{c}5,121 \\
(2,323)\end{array}$ & 4.27 & 2.13 & 23.5 \\
\hline $\begin{array}{l}13 \mathrm{in.}(33.02 \mathrm{~cm}) \text { OD } \times 3 \mathrm{in} . \\
(7.62 \mathrm{~cm})\end{array}$ & $\begin{array}{r}1200 \\
(544)\end{array}$ & $6.4 .3-4(D)$ & $1303 t$ & $\begin{array}{c}9,506 \\
(4,312)\end{array}$ & 7.92 & 3.96 & 12.7 \\
\hline $\begin{array}{l}13 \mathrm{in} .(33.02 \mathrm{~cm}) \text { OD } \times 4 \mathrm{in} . \\
(10.16 \mathrm{~cm})\end{array}$ & $\begin{array}{l}1200 \\
(544)\end{array}$ & $6 \cdot 4 \cdot 3-4 a(D)$ & $1304 p$ & $\begin{array}{l}13,393 \\
\{6,075\}\end{array}$ & 11.16 & 5.58 & 9.0 \\
\hline $\begin{array}{l}13 \mathrm{in} .(33.02 \mathrm{~cm}) \text { OD } \times 6 \mathrm{in} . \\
(15.24 \mathrm{~cm})\end{array}$ & $\begin{array}{l}1252 \\
(568) \\
\end{array}$ & $6.4 .3-4\{D\}$ & $1306 p$ & $\begin{array}{c}26,772 \\
(12,144\} \\
\end{array}$ & 21.4 & 10.69 & 4.7 \\
\hline $\begin{array}{l}11 \text { in. }\{27.94 \mathrm{~cm}) \text { OD } \times 1 \text { in. } \\
(2.54 \mathrm{~cm})\end{array}$ & $\begin{array}{r}1180 \\
(535)\end{array}$ & $6.4 .3-5 a(D)$ & $1101 \mathrm{i}$ & $\begin{array}{c}2,361 \\
(1,071)\end{array}$ & 2.0 & 1.0 & 50.0 \\
\hline $\begin{array}{l}11 \text { in. }(27.94 \mathrm{~cm}) \text { OD } \times 2 \text { in. } \\
(5.08 \mathrm{~cm})\end{array}$ & $\begin{array}{r}1200 \\
(544)\end{array}$ & $6 \cdot 4.3-5 a(0)$ & 11020 & $\begin{array}{c}5,121 \\
(2,323)\end{array}$ & 4.27 & 2.13 & 23.5 \\
\hline $\begin{array}{l}11 \text { in. }(27.94 \mathrm{~cm}) \text { OD } \times 3 \text { in. } \\
(7.62 \mathrm{~cm})\end{array}$ & $\begin{array}{r}1200 \\
\{544\} \\
\end{array}$ & $6.4 .3-5 \mathrm{a}(\mathrm{D})$ & $1103 q$ & $\begin{array}{l}7,901 \\
(3,584) \\
\end{array}$ & 6.58 & 3.29 & 15.2 \\
\hline $\begin{array}{l}11 \mathrm{in} .(27.94 \mathrm{~cm}) \text { OD } \times 4 \mathrm{in} . \\
(10.16 \mathrm{~cm})\end{array}$ & $\begin{array}{r}1200 \\
\{544\rangle\end{array}$ & 6.4.3-5(D) & $1104 r$ & $\begin{array}{r}11,133 \\
(5,050) \\
\end{array}$ & 9.28 & 4.64 & 10.8 \\
\hline $\begin{array}{l}13 \mathrm{in.}(33.02 \mathrm{~cm}) \text { OD } \times 12 \mathrm{in.} \\
(30.48)\end{array}$ & $\begin{array}{r}1344 \\
(610) \\
\end{array}$ & $6.4 .3-4(D)$ & $1306 p$ & $\begin{array}{c}26,777 \\
\{12,144\} \\
\end{array}$ & 19.9 & 9.96 & 5.1 \\
\hline $\begin{array}{l}13 \mathrm{in.}(33.02 \mathrm{~cm}) \mathrm{OD} \times 30 \mathrm{in} . \\
(76.20 \mathrm{~cm})\end{array}$ & $\begin{array}{c}1344(610) \\
3488(1582)\end{array}$ & $6.4 .3-4(D)$ & $1306 p$ & $\begin{array}{c}26,777 \\
\{12,144\}\end{array}$ & $\begin{array}{l}19.9 \\
7.67\end{array}$ & $\begin{array}{l}9.96 \\
3.84\end{array}$ & $\begin{array}{c}5.1 \\
13.1\end{array}$ \\
\hline $\begin{array}{l}11 \mathrm{in} .(27.94 \mathrm{~cm}) \text { OD } \times 6 \mathrm{in} . \\
(15.24 \mathrm{~cm})\end{array}$ & $\begin{array}{r}1252 \\
(568) \\
\end{array}$ & $6.4 .3-5 a(D)$ & $1106 \mathrm{e}$ & $\begin{array}{l}21,882 \\
(9,926) \\
\end{array}$ & 17.48 & 8.74 & 5.8 \\
\hline $\begin{array}{l}11 \mathrm{in.}(27.94 \mathrm{~cm}) \text { OD } \times 12 \mathrm{in} . \\
(30.48 \mathrm{~cm})\end{array}$ & $\begin{array}{r}1344 \\
(610)\end{array}$ & $6.4 .3-5 a\langle D\rangle$ & $1106 \mathrm{e}$ & $\begin{array}{l}21,882 \\
(9,926)\end{array}$ & 16.28 & 8.14 & 6.2 \\
\hline $\begin{array}{l}11 \mathrm{in} .(27.94 \mathrm{~cm}) \text { OD } \times 30 \mathrm{in} . \\
(76.20 \mathrm{~cm})\end{array}$ & $\begin{array}{c}1344(610) \\
3488(1582)\end{array}$ & $6.4 .3-5 a(D)$ & $1106 \mathrm{e}$ & $\begin{array}{l}21,882 \\
(9,926)\end{array}$ & $\begin{array}{c}16.28 \\
6.27\end{array}$ & $\begin{array}{l}8.14 \\
3.14\end{array}$ & $\begin{array}{c}6.2 \\
16.0\end{array}$ \\
\hline
\end{tabular}


TABLE 6.4.3-10(D). Reflected Finite Arrays to Determine Optimum Parameters and Maximum Mass for Mark I Outer Ingots with Lengths from $12 \mathrm{in.}$ to $17 \mathrm{in.}\left(1.25 \mathrm{wt} \%{ }^{235} \mathrm{U}\right)$.

\begin{tabular}{|c|c|c|c|c|c|c|c|c|}
\hline \multicolumn{3}{|c|}{ Parameters of Hexagonal Lattice Cell } & \multicolumn{2}{|c|}{$\begin{array}{l}\text { Sphere Containing } \\
\text { Lattice Cells }\end{array}$} & \multicolumn{3}{|c|}{ Calculated Results } & \multirow[t]{2}{*}{ Case $^{e}$} \\
\hline $\begin{array}{l}\text { Pitch } \\
\text { (cm) }\end{array}$ & $\begin{array}{l}\text { Water } \\
\text { Density } \\
\left(\mathrm{g} / \mathrm{cm}^{3}\right)^{\mathrm{a}}\end{array}$ & $\begin{array}{c}\text { Axial } \\
\text { Water } \\
\text { Height } \\
(\mathrm{cm})^{b}\end{array}$ & $\begin{array}{c}\text { Sphere } \\
\text { Radius } \\
(\mathrm{cm})^{\mathrm{c}}\end{array}$ & $\begin{array}{c}\text { Total } \\
\text { Uranium } \\
\text { Mass }(\mathbf{k g})^{\mathrm{c}}\end{array}$ & $\mathrm{K}_{\mathrm{ett}}$ & Uncer. $^{d}$ & $\begin{array}{c}\mathrm{K}_{\mathrm{eff}}+2 \sigma_{c} \\
\quad+\text { bias }\end{array}$ & \\
\hline \multicolumn{9}{|c|}{ Uranium length $=12 \mathrm{in.}$} \\
\hline 35.250 & 1.00 & 3.40 & 81.372 & 29,247 & 0.9326 & 0.0013 & 0.9475 & $1312 a$ \\
\hline 35.250 & 1.00 & 3.90 & 81.770 & 29,247 & 0.9288 & 0.0013 & 0.9437 & $1312 b$ \\
\hline 35.250 & 1.00 & 2.90 & 80.957 & 29,247 & 0.9265 & 0.0014 & 0.9414 & $1312 \mathrm{c}$ \\
\hline 35.750 & 1.00 & 3.40 & 82.140 & 29,247 & 0.9269 & 0.0014 & 0.9418 & $1312 d$ \\
\hline 34.750 & 1.00 & 3.40 & 80.601 & 29,247 & 0.9287 & 0.0016 & 0.9437 & $1312 \mathrm{e}$ \\
\hline 35.250 & 1.00 & 3.40 & 77.226 & 25,120 & 0.9263 & 0.0013 & 0.9412 & $1312 f$ \\
\hline 35.250 & 1.00 & 3.40 & 77.226 & 25,120 & 0.9285 & 0.0006 & 0.9431 & $1312 \mathrm{fu}$ \\
\hline \multicolumn{9}{|c|}{ Uranium length $=15 \mathrm{in}}$. \\
\hline 35.250 & 1.00 & 3.40 & 76.572 & 25,120 & 0.9189 & 0.0015 & 0.9339 & $1315 \mathrm{~h}$ \\
\hline
\end{tabular}

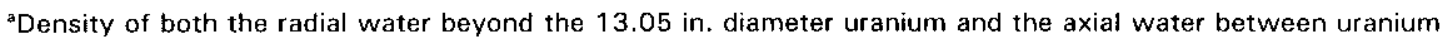
layers.

'Axial thickness of water between uranium layers.

'Sphere containing the hexagonal lattice and resulting total uranium mass in the lattice within the sphere.

One standard deviation statistical uncertainty in the Monte Carlo calculation.

eInput file names are this case identifier preceded with an $i$ and the corresponding MCNP output files are this case identifier preceded with an o.

\section{1(E) DISCUSSION AND RESULTS - FERMCO DERBIES MATERIAL}

Some of the miscellaneous material at FERMCO includes derbies material, which are packaged for shipment in the steel banded wooden containers G-4214 and G-4292. There are no criticality design features incorporated into the boxes. The FERMCO criticality analyses for the derbies material were performed with the MCNP code (Breismeister 1993; Carter 1995) for both infinite and finite arrays.

The FERMCO derbies material consists of unirradiated uranium metal with a maximum of $1.25 \mathrm{wt} \%{ }^{235} \mathrm{U}$ enrichment. Each piece is modeled as a cylindrical shape with a 12.0 inch $(30.48 \mathrm{~cm})$ diameter and 5.0 inch $(12.7 \mathrm{~cm})$ length. Analyses show that $18,585 \mathrm{lb}(8,430 \mathrm{~kg})$ of the optimally spaced and moderated pieces meets the transportation limit of $k_{\text {eff }}+2 \sigma+$ bias less than 0.95 . Table 6.1-1(E) summarizes the results and shows this maximum allowable mass. Table 6.1-2(E) summarizes the $\mathrm{N}$ value and criticality transportation index for the FERMCO derbies material. 
TABLE 6.1-1(E). Summary of Results for FERMCO Derbies.

\begin{tabular}{|c|c|c|c|c|}
\hline $\begin{array}{c}\text { Diameter } \\
\text { in. }(\mathrm{cm})\end{array}$ & $\begin{array}{c}\text { Length } \\
\text { in. }(\mathrm{cm})\end{array}$ & $\begin{array}{c}\text { Maximum Mass } \\
\mathrm{lb}(\mathrm{kg})\end{array}$ & $\mathrm{k}_{\mathrm{etl}}$ & $\mathrm{k}_{\mathrm{ett}}+2 \sigma+\mathrm{bias}$ \\
\hline \hline $12.0(30.48)$ & $5.00(12.7)$ & $18,585(8,430)$ & 0.9286 & 0.9432 \\
\hline
\end{tabular}

TABLE 6.1-2(E). Transportation Index for FERMCO Derbies.

\begin{tabular}{|c|c|c|c|c|c|c|}
\hline \multicolumn{1}{|c|}{ Piece } & $\begin{array}{c}\text { Mass/Piece } \\
\mathrm{lb}(\mathrm{kg})\end{array}$ & Container & $\begin{array}{c}\text { Pieces per } \\
\text { Container }\end{array}$ & $2 \times \mathrm{N}$ & $\mathrm{N}$ & $\mathrm{TI}$ \\
\hline \hline $\begin{array}{l}12 \mathrm{in} .(30.48 \mathrm{~cm}) \text { OD } \times 5 \mathrm{in.} \\
(12.70 \mathrm{~cm})\end{array}$ & $382(173)$ & $\begin{array}{l}\mathrm{G}-4214 \\
\mathrm{G}-4292\end{array}$ & 2 & 24.36 & 12.18 & 4.1 \\
\hline
\end{tabular}

\section{2(E) PACKAGE FUEL LOADING}

FERMCO material will be shipped in container G-4214 and G-4292. For conservatism, the banding and box were omitted from the criticality evaluations. Optimum moderation and pitch was determined for arrays of the pieces. There are two pieces per container as given in Table 6.1-2(E).

\section{3(E) MODEL SPECIFICATION}

This section describes the computer models used for the analyses.

\subsection{1(E) Description of Calculational Model}

The material consists of cylindrical pieces of uranium metal. Each piece is cylindrical with a 12.0 inch $(30.48 \mathrm{~cm})$ diameter and 5.0 inch $(12.7 \mathrm{~cm})$ length. It is all $1.25 \mathrm{wt} \%{ }^{235} \mathrm{U}$, and all pieces are solid. The dimensions of the uranium metal are given in Table 6.3.1-1(E).

TABLE 6.3.1-1(E). Dimensions of Uranium Metal.

\begin{tabular}{|c|c|c|}
\hline Type & $\begin{array}{c}\text { Diameter } \\
\text { in. (cm) }\end{array}$ & $\begin{array}{c}\text { Length } \\
\text { in. (cm) }\end{array}$ \\
\hline \hline FERMCO Derbies & $12.0(30.48)$ & $5.0(12.7)$ \\
\hline
\end{tabular}

\subsection{2(E) Package Regional Densities}

The uranium metal is enriched to $1.25 \mathrm{wt} \%{ }^{235} \mathrm{U}$, where the theoretical uranium density of $18.96 \mathrm{~g} / \mathrm{cm}^{3}$ is used for the calculations. Material densities and atomic number densities for the constituent nuclides of the materials used are listed in Table 6.3.2-1(E). 
TABLE 6.3.2-1(E). Material Densities and Atomic Number Densities Used in the Calculations.

\begin{tabular}{|l|c|c|}
\hline \multicolumn{1}{|c|}{ Isotope/Nuclide } & $\begin{array}{c}\text { Material Density } \\
\left(\mathrm{g} / \mathrm{cm}^{3}\right)\end{array}$ & $\begin{array}{c}\text { Atomic Number Density } \\
\text { (atoms/b-cm) }\end{array}$ \\
\hline \hline Hydrogen & \multirow{2}{*}{1.0 (water) } & 0.06689 \\
\cline { 1 - 1 } Oxygen & \multirow{2}{*}{18.96 (uranium) } & 0.03344 \\
\cline { 1 - 1 } & & $6.073 \mathrm{E}-04$ \\
\hline${ }^{235} \mathrm{U}$ & ${ }^{238} \mathrm{U}$ & $4.737 \mathrm{E}-02$ \\
\hline
\end{tabular}

\section{4(E) CRITICALITY CALCULATIONS}

This section describes the calculational method used for the analyses.

\subsection{1(E) Calculational Method}

The MCNP computer code (Breismeister 1993; Carter 1995) was used for this criticality evaluation. MCNP was discussed in Section 6.4.1(A).

\subsection{2(E) Contents Loading Optimization}

The steel banded wooden shipping containers were not tested under hypothetical conditions and therefore cannot be credited to maintain the payload. To assure subcriticality for any payload configuration, a spacing and optimization search was made. From the results of the search a maximum allowable mass was determined for FERMCO derbies.

\subsection{3(E) Criticality Results}

The infinite hexagonal array calculations previously summarized in Tables 6.4.3-1(D) to 6.4.3-3(D) provide information on optimal parameters for an infinite array. However, these optimal parameters may change for finite arrays because of leakage, so a separate optimization iteration is required for finite arrays.

The configuration for the finite array is chosen conservatively. A hexagonal lattice for each tier is more conservative than a square lattice since the hexagonal lattice has a higher packing fraction, so the hexagonal lattice is used in this analysis. Traditionally the same number of lattice elements are used for each of the tiers of the array. However, this is not necessarily an optimum assumption. For a fixed number of total elements, the $k_{\text {eff }}$ for an approximately spherical arrangement of the elements will be larger than the traditional more cylindrical arrangement. Hence, the spherical arrangement is the more conservative.

There can be a large number of possible near-spherical arrangements of the unit elements, each of which would need to be optimized with the other parameters. The method used in this analysis is to conservatively assume a hexagonal array of lattice elements inside of a large sphere. These lattice elements completely fill up the sphere in both the horizontal (hexagonal) and vertical (stacked) directions; i.e., lattice elements at the boundary of the sphere will not be complete since 
they are cut by the sphere, see Figures 6.4.3-1(E) and 6.4.3-2(E) for elevation and plan views. However, this enables a conservative optimization with a calculational iteration on lattice parameters (pitch of hexagonal lattice, water density, and water thickness between vertical elements) while adjusting the radius of the sphere each time to obtain a constant uranium mass during the iteration. Once the optimum parameters are found to maximize $k$, the sphere radius with those optimum parameters can be decreased (or increased) to decrease (or increase) the uranium mass and obtain an optimized $k$ that is below the limit for this mass.

The results of the iteration are summarized in Table 6.4.3-1(E) for the FERMCO derbies. The calculations include $12.0 \mathrm{in} .(30.48 \mathrm{~cm})$ of water reflector beyond the sphere containing the lattice. The first calculation in Table 6.4.3-1(E) is for a water density, axial water thickness between elements, and radial water-to-uranium area ratio (for determining the pitch) that was previously determined to be near-optimal for finite arrays of 9.0 -in. $(22.86 \mathrm{~cm})$ diameter and 3.0-in. $(7.62 \mathrm{~cm}$ ) long uranium cylinders that had a $\mathrm{k}$ around the limit for a uniform stacking per tier. This first calculation was made for a total uranium mass within the sphere of $42,379 \mathrm{lb}(19,240 \mathrm{~kg})$ so the sphere radius was computed to obtain this same mass in subsequent iterations.

The next three calculations in Table 6.4.3-1(E) vary the water density within the lattice cells and this optimized water density of $0.57 \mathrm{~g} / \mathrm{cm}^{3}$ was then utilized in the next iteration on the pitch. Calculations five to seven (Cases $1205 \mathrm{e}$ to $1205 \mathrm{~g}$ ) in Table 6.4.3-1(E) vary the pitch with the sphere radius determined each time to keep the uranium mass constant at the $19,240 \mathrm{~kg}$. This optimum pitch of $13.71 \mathrm{in.}(34.813 \mathrm{~cm})$ was then utilized in calculations eight and nine (Cases $1205 \mathrm{~h}$ and $1205 \mathrm{i}$ ) to vary the axial water thickness between the uranium pieces and obtain the final optimized parameters used in the tenth calculation (Case 1205j) in Table 6.4.3-1(E). This tenth calculation was made with a reduced radius to reduce the optimum $k$ to a value well below the limit.

The calculations for Cases 1205k and 1205I in Table 6.4.3-1(E) were made to determine what the optimum $k$ would be for uranium masses nearer to the limit, where Case $1205 k$ is actually over the limit and Case $1205 \mathrm{I}$ is very near the limit. Since the masses of Cases $1205 \mathrm{j}$ to $1205 \mathrm{I}$ are quite a bit less than the mass that was used in the first nine cases to find the optimum parameters, the calculations of Cases $1205 \mathrm{n}$ to $1205 \mathrm{~s}$ were made to verify that these parameters are still approximately optimum at a reduced mass; i.e., optimum for Case $1205 \mathrm{l}$ at a mass of $27,013 \mathrm{lb}$ $(12,264 \mathrm{~kg})$. Cases $1205 \mathrm{n}$ and 12050 show that the water density of Case $1205 \mathrm{l}$ is nearoptimum, but does not exclude the possibility that a water density of one might lead to a higher $k$ as we will discuss later. Cases $1205 p$ and $1205 q$ show that the pitch is also near-optimum Case $1205 p$ has a slightly higher $k$ than Case 12051 , but the difference is comparable to the statistical uncertainties involved. Finally, Cases $1205 \mathrm{r}$ and $1205 \mathrm{~s}$ show that the axial water thickness of Case 1205 I is also near-optimal. Since one of these optimization cases (Case 1205p) slightly exceeds the limit and others are right at the limit, the radius was reduced to obtain an optimized k (Case 1205t) with a mass between Case 1205j and 12051.

One calculation was made with multi-tiers and the same number of hexagonal lattice elements per tier to determine approximately how conservative the "sphere" treatment is compared to this traditional treatment. The lattice parameters of Case $1205 \mathrm{j}$ were used in this calculation, but 10 elements were used per tier with six tiers. This gives a total uranium mass of $10,542 \mathrm{~kg}$ and an effective height to diameter ratio of approximately 0.945 , which is reasonably close to unity. The calculated $k_{\text {eff }}+2 \sigma_{c}+$ bias for these six tiers (Case tierj) reflected with water was 0.91532 . Interpolating in Table 6.4.3-1(E) between Cases $1205 \mathrm{j}$ and $1205 \mathrm{I}$ to obtain the corresponding multiplication factor for spheres at the same mass of $10,542 \mathrm{~kg}$ results in $\mathrm{k}_{\mathrm{eft}}+2 \sigma_{\mathrm{c}}+$ bias $=$ 0.93880 . Hence, the conservatism in the multiplication factor with the sphere treatment is about 0.02348 compared to the multi-tier treatment. 


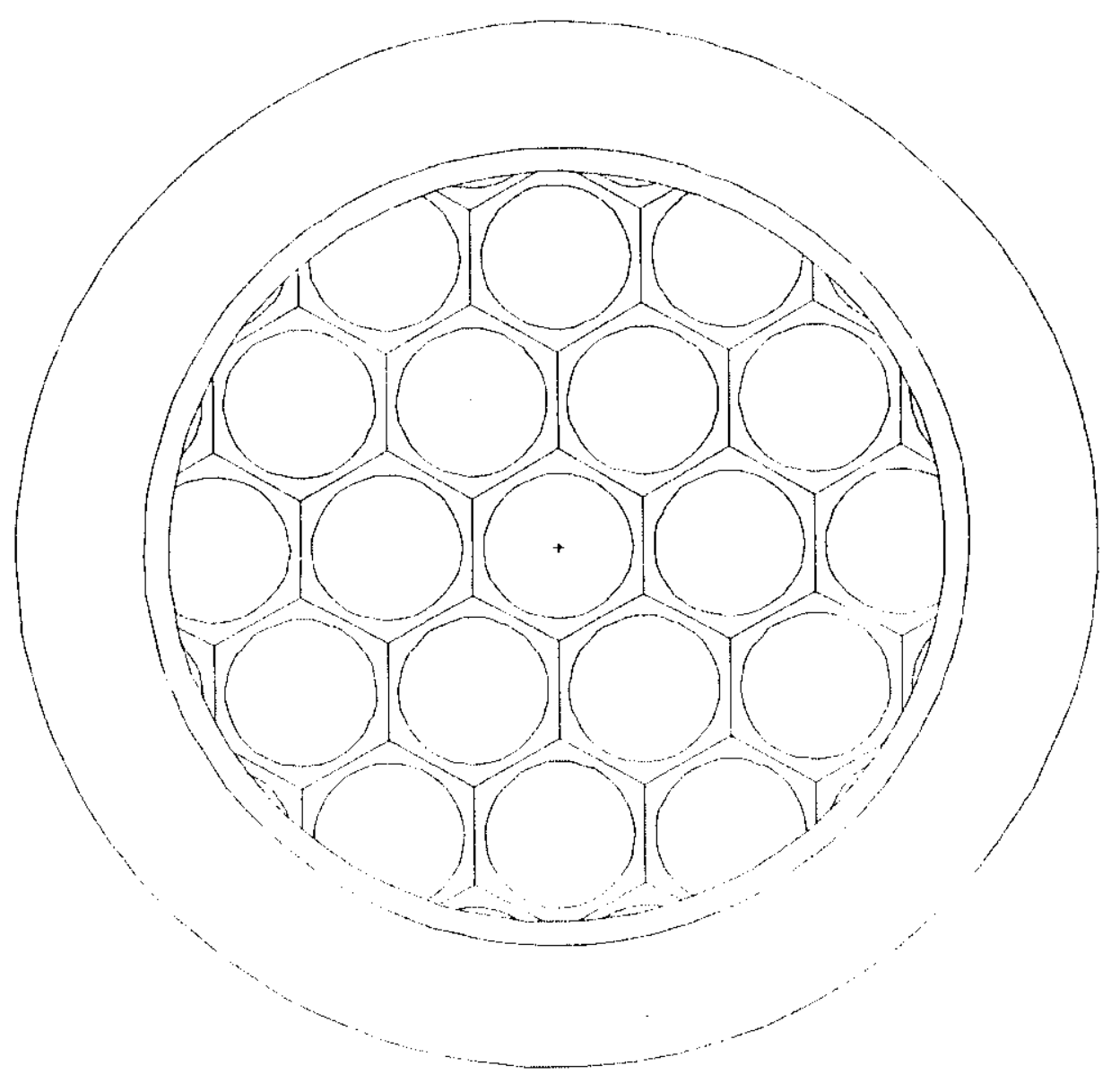

Figure 6.4.3-1(E). Plan View of FERMCO Derbies. 


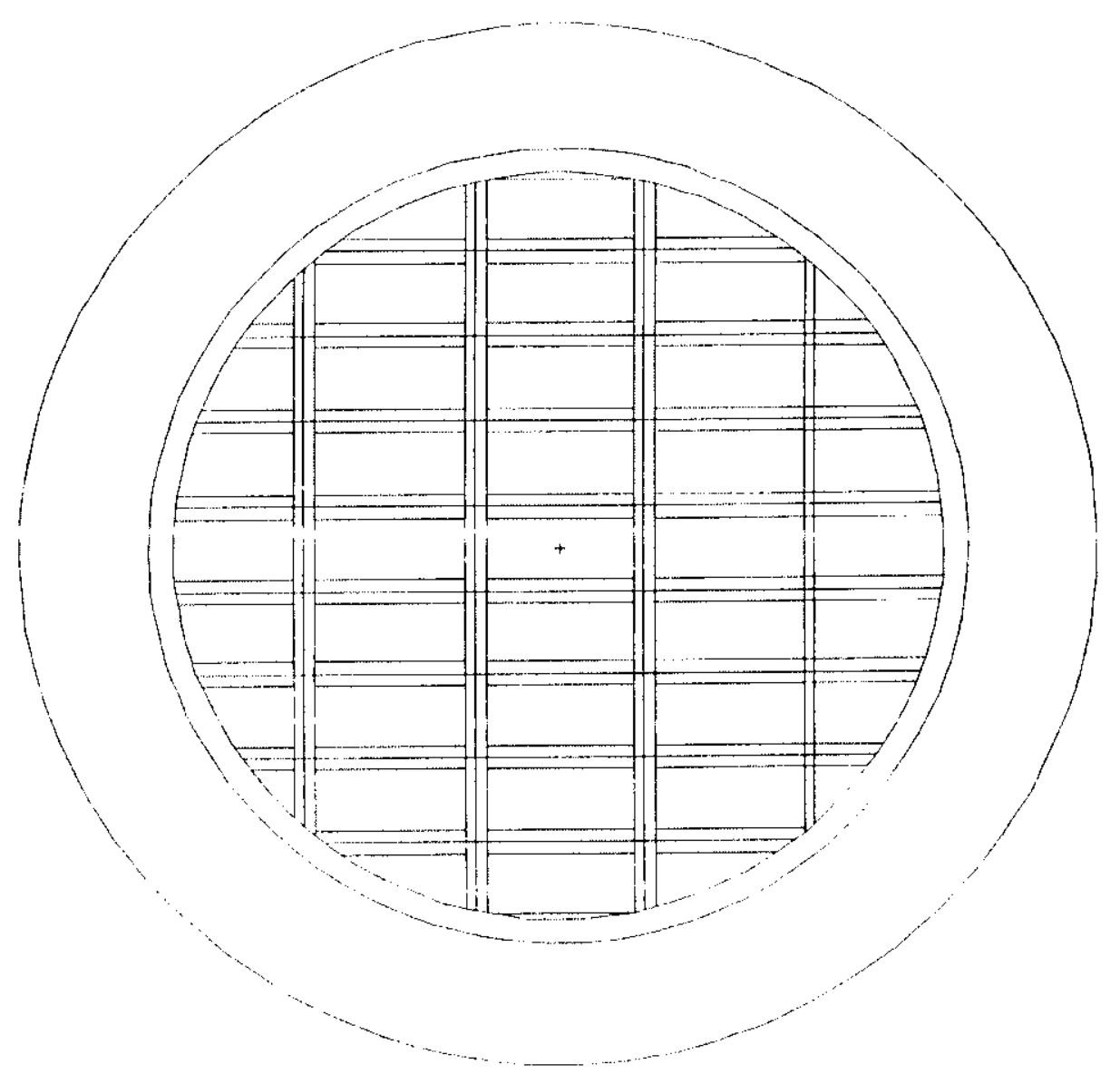

Figure 6.4.3-2(E). Elevation View of FERMCO Derbies. 
TABLE 6.4.3-1(E). Reflected Finite Arrays to Determine Optimum Parameters and Maximum Mass for FERMCO Derbies (12 in. Diameter $\times 5$ in. Long U). (2 sheets total)

\begin{tabular}{|c|c|c|c|c|c|c|c|c|}
\hline \multicolumn{3}{|c|}{ Parameters of Hexagonal } & \multicolumn{2}{|c|}{ Sphere Containing } & \multicolumn{3}{|c|}{ Calculated Results } & \multirow[b]{2}{*}{ Case $^{\mathrm{e}}$} \\
\hline $\begin{array}{l}\text { Pitch } \\
\text { (cm) }\end{array}$ & $\begin{array}{l}\text { Water } \\
\text { Density } \\
\left(\mathrm{g} / \mathrm{cm}^{3}\right)^{\mathrm{a}}\end{array}$ & $\begin{array}{l}\text { Axial } \\
\text { Water } \\
\text { Height } \\
(\mathrm{cm})^{\mathrm{b}}\end{array}$ & $\begin{array}{c}\text { Sphere } \\
\text { Radius } \\
(\mathrm{cm})^{\mathrm{c}}\end{array}$ & $\begin{array}{l}\text { Total } \\
\text { Uranium } \\
\text { Mass }(\mathrm{kg})^{\circ}\end{array}$ & $k_{\text {elt }}$ & Uncer." & $\begin{array}{l}\mathrm{k}_{\mathrm{eff}}+ \\
2 \sigma_{\mathrm{c}}+\text { bias }\end{array}$ & \\
\hline 35.813 & 0.70 & 4.0 & 78.1817 & 19,240 & 0.9181 & 0.0014 & 0.933 & $1205 a$ \\
\hline 35.813 & 0.60 & 4.0 & 78.1817 & 19,240 & 0.9302 & 0.0015 & 0.94515 & $1205 b$ \\
\hline 35.813 & 0.50 & 4.0 & 78.1817 & 19,240 & 0.9272 & 0.0014 & 0.9421 & $1205 \mathrm{c}$ \\
\hline 35.813 & 0.57 & 4.0 & 78.1817 & 19,240 & 0.9335 & 0.0015 & 0.94845 & $1205 d$ \\
\hline 34.813 & 0.57 & 4.0 & 76.8264 & 19,240 & 0.9431 & 0.0014 & 0.958 & $1205 \mathrm{e}$ \\
\hline 33.813 & 0.57 & 4.0 & 75.4504 & 19,240 & 0.9407 & 0.0013 & 0.95556 & $1205 f$ \\
\hline 34.400 & 0.57 & 4.0 & 76.2700 & 19,240 & 0.9410 & 0.0011 & 0.95578 & $1205 \mathrm{~g}$ \\
\hline 34.813 & 0.57 & 5.0 & 78.4562 & 19,240 & 0.9486 & 0.0014 & 0.9635 & $1205 \mathrm{~h}$ \\
\hline 34.813 & 0.57 & 6.0 & 80.0796 & 19,240 & 0.9482 & 0.0012 & 0.96302 & $1205 i$ \\
\hline 34.813 & 0.57 & 5.5 & 65.0000 & 10,517 & 0.9238 & 0.0013 & 0.93866 & $1205 j$ \\
\hline 34.813 & 0.57 & 5.5 & 69.7000 & 13,157 & 0.9369 & 0.0012 & 0.95172 & $1205 k$ \\
\hline 34.813 & 0.57 & 5.5 & 69.7000 & 13,157 & 0.9369 & 0.0012 & 0.95172 & $1205 \mathrm{k}$ \\
\hline 34.813 & 0.57 & 5.5 & 68.2000 & 12,264 & 0.9337 & 0.0011 & 0.94848 & 12051 \\
\hline 34.813 & 0.62 & 5.5 & 68.2000 & 12,264 & 0.9292 & 0.0015 & 0.94415 & $1205 n$ \\
\hline 34.813 & 0.52 & 5.5 & 68.2000 & 12,264 & 0.9333 & 0.0012 & 0.94812 & 12050 \\
\hline 34.213 & 0.57 & 5.5 & 67.3916 & 12,264 & 0.9354 & 0.0014 & 0.9503 & $1205 p$ \\
\hline 35.413 & 0.57 & 5.5 & 69.0069 & 12,264 & 0.9219 & 0.0012 & 0.93672 & $1205 q$ \\
\hline 34.813 & 0.57 & 4.5 & 67.0726 & 12,264 & 0.9277 & 0.0015 & 0.94265 & $1205 r$ \\
\hline 34.813 & 0.57 & 6.5 & 69.2843 & 12,264 & 0.9254 & 0.0014 & 0.9403 & $1205 \mathrm{~s}$ \\
\hline 34.813 & 0.57 & 5.5 & 66.8000 & 11,470 & 0.9270 & 0.0011 & 0.94178 & $1205 t$ \\
\hline \multicolumn{9}{|c|}{ Calculations with water density $=1.0 \mathrm{~g} / \mathrm{cm}^{3}$} \\
\hline 32.950 & 1.00 & 3.15 & 59.920 & 10,517 & 0.9320 & 0.0013 & 0.94686 & $\$ 205 u$ \\
\hline 32.950 & 1.00 & 4.15 & 61.059 & 10,517 & 0.9246 & 0.0012 & 0.93942 & $1205 v$ \\
\hline 32.950 & 1.00 & 2.15 & 58.709 & 10,517 & 0.9134 & 0.0013 & 0.92826 & $1205 w$ \\
\hline 32.950 & 1.00 & 3.65 & 60.505 & 10,517 & 0.9314 & 0.0014 & 0.9463 & $1205 x$ \\
\hline 32.450 & 1.00 & 3.15 & 59.270 & 10,517 & 0.9342 & 0.0013 & 0.94906 & $1205 y$ \\
\hline
\end{tabular}


TABLE 6.4.3-1(E). Reflected Finite Arrays to Determine Optimum Parameters and Maximum Mass for FERMCO Derbies (12 in. Diameter $\times 5$ in. Long U). (2 sheets total)

\begin{tabular}{|c|c|c|c|c|c|c|c|c|}
\hline \multicolumn{3}{|c|}{ Parameters of Hexagonal } & \multicolumn{2}{|c|}{ Sphere Containing } & \multicolumn{3}{|c|}{ Calculated Results } & \multirow[b]{2}{*}{ Case $^{\mathrm{e}}$} \\
\hline $\begin{array}{l}\text { Pitch } \\
\text { (cm) }\end{array}$ & $\begin{array}{l}\text { Water } \\
\text { Density } \\
\left(\mathrm{g} / \mathrm{cm}^{3}\right)^{\mathrm{a}}\end{array}$ & $\begin{array}{l}\text { Axial } \\
\text { Water } \\
\text { Height } \\
(\mathrm{cm})^{\mathrm{b}}\end{array}$ & $\begin{array}{c}\text { Sphere } \\
\text { Radius } \\
(\mathrm{cm})^{\mathrm{c}}\end{array}$ & $\begin{array}{l}\text { Total } \\
\text { Uranium } \\
\text { Mass }(\mathrm{kg})^{\mathrm{c}}\end{array}$ & $k_{e l f}$ & Uncer. ${ }^{d}$ & $\begin{array}{l}\mathrm{k}_{\mathrm{eft}}+ \\
2 \sigma_{\mathrm{c}}+\text { bias }\end{array}$ & \\
\hline 33.450 & 1.00 & 3.15 & 60.566 & 10,517 & 0.9204 & 0.0014 & 0.9353 & $1205 z$ \\
\hline 31.950 & 1.00 & 3.15 & 58.627 & 10,517 & 0.9389 & 0.0013 & 0.95376 & 1205 aa \\
\hline 31.450 & 1.00 & 3.15 & 57.977 & 10,517 & 0.9323 & 0.0013 & 0.94716 & $1205 \mathrm{bb}$ \\
\hline 31.950 & 1.00 & 3.15 & 54.523 & 8,430 & 0.9282 & 0.0012 & 0.94302 & $1205 \mathrm{cc}$ \\
\hline 31.950 & 1.00 & 3.15 & 54.523 & 8,430 & 0.9286 & 0.0005 & 0.9432 & $1205 \mathrm{ccu}$ \\
\hline
\end{tabular}

${ }^{a}$ Density of both the radial water beyond the $12 \mathrm{in.} \mathrm{diameter} \mathrm{uranium} \mathrm{and} \mathrm{the} \mathrm{axial} \mathrm{water} \mathrm{between} \mathrm{uranium}$

layers.

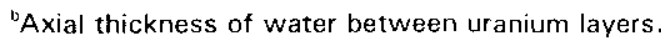

'Sphere containing the hexagonal lattice and resulting total uranium mass in the lattice within the sphere.

${ }^{d}$ One standard deviation statistical uncertainty in the Monte Carlo calculation.

"Input file names are this case identifier preceded with an $\mathrm{i}$ and the corresponding MCNP output files are this case identifier preceded with an 0 .

Prior experience has been that the maximum often occurs for a water density of one, and there are sometimes theoretical reasons for this. For example, consider a slab infinite in two dimensions with alternating layers of water and uranium. Then $k$ will be the same in systems where the water density times its thickness is a constant; i.e., many different water densities can lead to the same $k$. It follows that for a similar system finite in the two dimensions, $k$ will decrease for the lower water densities (with density times thickness constant) because of leakage. The derbies geometry resembles slabs in the axial dimension and cylinders in the transverse dimension so there are considerable complexities, and it is wise to also consider the optimum obtained subject to the constraint of a water density of one. Cases 1205I, 1205n, and 12050 do not sample enough of parameter space to exclude the possibility that a water density of one may lead to an even higher $\mathrm{k}$.

The iteration was repeated in Cases $1205 \mathrm{u}$ to $1205 \mathrm{bb}$ of Table $6.4 .3-1(\mathrm{E})$ with the water density constrained to be one. This iteration indeed shows that optimization with the water density of one leads to a somewhat higher $k$ than was obtained in the previous iteration by case $1205 j$ for the same mass of $23,165 \mathrm{lb}(10,517 \mathrm{~kg})$. Hence, the parameters of Case 1205aa are utilized with a reduced sphere radius in Case $1205 \mathrm{cc}$ to reduce the optimum $\mathrm{k}$ to a value well below the limit. This uranium mass of $18,585 \mathrm{lb}(8,430 \mathrm{~kg})$ is the maximum allowed uranium mass for the FERMCO derbies.

The search for the three optimum parameters in Table 6.4.3-1(E) that will maximize $k$ involves some uncertainty in the final result since statistical uncertainties are involved along with the practical problem of keeping the total number of calculations to a reasonable amount. To account for this type of uncertainty in the optimum parameter search, the mass was reduced in case $1205 \mathrm{cc}$ to $18,585 \mathrm{lb}(8,430 \mathrm{~kg})$ so there is a margin between this case in $k_{\text {eff }}+2 \sigma_{\mathrm{c}}+$ bias compared to the 0.95 limit of 0.0070 . This margin is in addition to the above discussed conservatism of using the sphere instead of multi-tiers with the same number of elements per tier. 
Since the nominal mass of a uranium piece for the FERMCO derbies from Table 1.2.3-1 is $382(173 \mathrm{~kg})$, the $18,585 \mathrm{lb}(8,430 \mathrm{~kg})$ restriction on total mass corresponds to 48.72 pieces or 24.36 containers for two pieces per container. The $k$ is well below the limit for the optimized spherical configuration so it will be even more conservative for other configurations.

The calculations for a single box of FERMCO derbies with full moderation and reflection are summarized in Table 6.4.3-2(E). Calculations were performed for 12 derbies assuming that a larger box would be used. The calculation will bound the actual shipment of 2 derbies in the smaller boxes. The $\mathrm{k}_{\text {eff }}+2 \sigma_{\mathrm{c}}+$ bias value is 0.7593 for the box of FERMCO derbies.

TABLE 6.4.3-2(E). Single Boxes of FERMCO Derbies Fully Water Moderated and Reflected.

\begin{tabular}{|l|c|c|c|c|}
\hline \multicolumn{1}{|c|}{ Type } & $\begin{array}{c}\text { Pieces } \\
\text { Modelled }\end{array}$ & $k_{\text {efl }}$ & $\begin{array}{c}k_{\text {eff }}+2 \sigma_{c}+ \\
\text { bias }\end{array}$ & Input File \\
\hline $\begin{array}{l}\text { FERMCO Derbies } \\
12 \text { in. }(30.48 \mathrm{~cm}) \text { OD } \times 5 \text { in. }(12.70 \mathrm{~cm})\end{array}$ & $12^{\circ}$ & 0.7445 & 0.7593 & fco4 \\
\hline
\end{tabular}

*Actual shipments will be two pieces per box.

6.4.3.1(E) Transport Index. The $2 \times \mathrm{N}$ number of damaged packages is determined by dividing the finite array mass for which the optimized $k_{\text {eff }}+2 \sigma_{c}+$ bias is within the transportation criterion of less than 0.95 by the mass per container of $764 \mathrm{lb}(346 \mathrm{~kg})$, assuming two pieces per container. The $\mathrm{N}$ value is then found by dividing the number by 2 . Five times $\mathrm{N}$ undamaged packages with nothing between the packages is modeled as an unmoderated array. An infinite unmoderated array of $1.25 \mathrm{wt} \%{ }^{235} \mathrm{U}$ enriched material is well subcritical, as shown in the ingot and billet sections. Therefore, the conservative TI value is derived from the $2 \times \mathrm{N}$ damaged packages of the finite array calculations derbies material. The masses, $\mathrm{N}$ and $\mathrm{Tl}$ values are tabulated in Table 6.4.3-3(E).

TABLE 6.4.3-3(E). Calculation of $\mathrm{N}$ and $\mathrm{TI}$ for FERMCO Derbies.

\begin{tabular}{|c|c|c|c|c|c|}
\hline Piece & $\begin{array}{c}\text { Container Mass } \\
\mathrm{lb}(\mathrm{kg})\end{array}$ & $\begin{array}{c}\text { Maximum Mass } \\
\mathrm{lb}(\mathrm{kg})\end{array}$ & $2 \times \mathrm{N}$ & $\mathrm{N}$ & $\mathrm{TI}$ \\
\hline $12 \mathrm{in.}(30.48 \mathrm{~cm}) \mathrm{OD} \times 5 \mathrm{in} .(12.70 \mathrm{~cm})$ & $764(346)$ & $18.585(8,430)$ & 24.36 & 12.18 & 4.1 \\
\hline
\end{tabular}

\subsection{CRITICAL BENCHMARK EXPERIMENTS}

The MCNP computer code (Breismeister 1993) is utilized all over the world and has been extensively tested with its ENDF/B-V based cross-sections. The code development group at LANL, where MCNP was developed, has a set of 25 calculational benchmarks that extensively test various options within the code. Additionally, MCNP has been certified for use on Hanford computer platforms (Carter 1995). This section justifies the validity of the calculational methods and neutron cross-sections used by reporting the results of critical benchmark experiment analyses.

\subsubsection{Benchmark Experiments and Applicability}

Benchmark analyses have been performed with MCNP and the associated cross-sections as documented in Appendix G of MCNP--A General Monte Carlo Code N-Particle Transport Code, 
Version 4a (Breismeister 1993). These analyses were performed for both fast and thermalized benchmark problems (Whalen 1991). Six problems were for various uranium critical systems.

\subsubsection{Details of Benchmark Calculations}

The first critical experiment analyzed was a bare uranium sphere called Godiva. It was a $115.57 \mathrm{lb}(52.42 \mathrm{~kg})$ uranium sphere with a density of $18.74 \mathrm{~g} / \mathrm{cm}^{3}$ and $93.17 \%{ }^{235} \mathrm{U}$ enriched.

Two low enrichment critical experiments were done with bare uranium cylinders. The first cylinder was for uranium enriched to $10.9 \%{ }^{235} \mathrm{U}$ with a density of $18.63 \mathrm{~g} / \mathrm{cm}^{3}$, a height of $47 \mathrm{in}$. $(119.392 \mathrm{~cm})$ and a radius of $10.49 \mathrm{in} .(26.65 \mathrm{~cm})$. The second was for uranium enriched to $14.11 \%{ }^{235} \mathrm{U}$ with a density of $18.41 \mathrm{~g} / \mathrm{cm}^{3}$. The cylinder had a radius of $10.49 \mathrm{in} .\{26.65 \mathrm{~cm}$ ) and a height of $17.42 \mathrm{in.}(44.239 \mathrm{~cm})$.

Two reflected sphere critical experiments were done. The first was a sphere composed of $93.5 \%$ enriched ${ }^{235} \mathrm{U}$ with a density of $18.8 \mathrm{~g} / \mathrm{cm}^{3}$. The reflecting layer was $2 \mathrm{in} .(5.1 \mathrm{~cm})$ of graphite at $1.67 \mathrm{~g} / \mathrm{cm}^{3}$. The second was a water-reflected uranium sphere. It had a $2.58 \mathrm{in}$. $\left(6.5537 \mathrm{~cm}\right.$ ) radius and uranium enriched to $97.67 \%{ }^{235} \mathrm{U}$ with a density of $18.794 \mathrm{~g} / \mathrm{cm}^{3}$. The sphere was immersed in a tank of water of radius $11.81 \mathrm{in.}(30 \mathrm{~cm})$ and height $27.56 \mathrm{in} .(70 \mathrm{~cm})$. The tank represented an effectively infinite water reflector.

A critical experiment was done with three interacting units. The units consisted of three unreflected aluminum cylinders containing $\mathrm{U}(93.2) \mathrm{O}_{2} \mathrm{~F}_{2}$ water solutions. The inside cylinder diameter and critical height measured $7.99 \mathrm{in.}(20.3 \mathrm{~cm})$ and $16.30 \mathrm{in} .(41.4 \mathrm{~cm})$, respectively. The aluminum container had a density of $2.71 \mathrm{~g} / \mathrm{cm}^{3}$ and was $0.059 \mathrm{in} .(0.15 \mathrm{~cm})$ thick. The three cylinders were set in an equilateral configuration with a surface separation of $0.15 \mathrm{in} .10 .38 \mathrm{~cm})$. The solution concentration parameters were $0.090 \mathrm{~g}{ }^{235} \mathrm{U} / \mathrm{cm}^{3}$ and a hydrogen to ${ }^{235} \mathrm{U}$ atomic ratio of 309 .

\subsubsection{Results of Benchmark Calculations}

The results of these benchmark calculations are shown in Table 6.5.3-1. MCNP accurately evaluated all critical experiments.

TABLE 6.5.3-1. MCNP Comparison to Critical Experiments.

\begin{tabular}{|l|c|c|}
\hline \multicolumn{1}{|c|}{ Benchmark Experiment } & $\%{ }^{235}$ U Enrichment & MCNP Calculated $k_{\text {eff }}$ \\
\hline \hline Godiva-Bare Sphere & 93.71 & $0.9976 \pm 0.0011$ \\
\hline Bare Cylinder & 10.9 & $1.0024 \pm 0.0013$ \\
\hline Bare Cylinder & 14.11 & $1.0003 \pm 0.0014$ \\
\hline Graphite-Reflected Sphere & 93.5 & $0.9981 \pm 0.0010$ \\
\hline Water-Reflected Sphere & 97.67 & $0.9956 \pm 0.0022$ \\
\hline Three Interacting Cylinders & 93.2 & $0.9991 \pm 0.0011$ \\
\hline
\end{tabular}


Although the logic within MCNP has been checked with the 25 benchmarks and the general reliability of the code with its cross-section data base has also been compared to numerous experimental measurements, it is important to also quantify its performance with comparisons to experiments relevant to the present application. Such a comparison to relevant experiments is typically used to determine a bias in the calculation (due to the cross-section data base) as well as an uncertainty in this bias. Then the calculated multiplication factor, $k_{\text {calc }}$, must satisfy the following inequality

$$
k_{\text {calc }}<k_{\text {limit }}+\Delta k_{b}-2\left(\sigma_{b}^{2}+\sigma_{c}^{2}\right)^{0.5}
$$

where $k_{\text {limit }}$ is the desired limit in $k$ including a margin $\left(0.95\right.$ for shipment of fuel), $\Delta k_{b}$ is the bias in the calculations based upon calculational comparisons to relevant experiments, $\sigma_{b}$ is the one standard deviation uncertainty in this bias including the uncertainties in the experimental measurements and the statistical uncertainties in the Monte Carlo calculations of these measurements, and $\sigma_{\mathrm{c}}$ is the one standard deviation statistical uncertainty in the Monte Carlo design calculation that obtained $k_{\text {calc }}$. The factor of 2 allows for $95 \%$ confidence limits. Thus, there is not only the margin involved by using the $k_{\text {linit }}$ value, but the bias and its uncertainties are also conservatively included.

A criticality study of irradiated fuel (Wittekind 1992) estimated an MCNP bias of -0.005 for $\mathrm{K}$-basin fuel based upon $1.0059 \mathrm{wt} \%{ }^{235} \mathrm{U}$ homogeneous $\mathrm{UO}_{3}-\mathrm{H}_{2} \mathrm{O}$ solution experiments and lattice experiments (fuel pins in water) with Mark IA fuel. The bias factor was chosen conservatively and did not include the combined statistical and measurement uncertainties in the above equation.

Because of fuel requirements, the lattice experiments were not taken very close to critical, but they tend to be a confirmation that reasonable answers are obtained for fuel pins in water. Using the results for the solution experiments, a bias of -0.00258 and a one standard deviation uncertainty of 0.0060 are determined. Therefore the above equation becomes

$$
k_{c a l c}<k_{\text {limit }}+(-0.00258)-2\left(0.0060^{2}+\sigma_{c}^{2}\right)^{0.5}
$$

The $k_{\text {linnit }}$ for transportation is 0.95 . 


\subsection{APPENDIX}

\subsubsection{References}

10 CFR 71, 1995, "Packaging and Transportation of Radioactive Materials," Code of Federal Regulations, as amended.

Breismeister, J. F., Editor, 1993, MCNP--A General Monte Carlo Code N-Particle Transport Code, Version 4a, LA-12625, Los Alamos National Laboratory, Los Alamos, New Mexico, November 1993.

Carter, L. L., 1995, Certification of Version 4A for WHC Computer Platforms, WHC-MP-SD-30001, Rev. 7, Westinghouse Hanford Company, Richland, Washington, January 1995.

Whalen, D. J., 1991, MCNP: Neutron Benchmark Problems, LA-12212, Los Alamos National Laboratory, Los Alamos, New Mexico.

Wittekind, W. D., 1992, K Basin Criticality Evaluation for Irradiated Fuel Canisters in S/udge, EDT 109187, WHC-SD-NR-CSER-001, Rev. 0, Westinghouse Hanford Company, Richland, Washington, August 1992. 


\subsubsection{Single Package Analyses}

The $\mathrm{k}_{\text {eft }}$ values for single containers of ingots, billets and FERMCO material were determined under conditions of water moderation and close full reflection.

6.6.2.1 Discussion and Results. Mark I, Mark IV, and Mark $15 \mathrm{~N}$ Reactor ingots are packaged for shipment in the steel banded wooden container G-4273. Mark I and Mark IV RMI forged billets are packaged for shipment in the steel banded container G-4255. The miscellaneous FERMCO material is packaged for shipment in the steel banded containers G-4273, G-4292, and G-4214.

Calculations for the majority of the FERMCO material were made assuming the larger G-4273 boxes would be used to ship the material. However, as noted in Table 6.6.2.2-1, certain FERMCO material is required to be transported in the smaller $\mathrm{G}-4214$ box. Since the $\mathrm{G}-4214$ box holds a lesser amount of material, the calculations performed are conservative.

For each single container loading of ingots, billets or FERMCO material, $k_{\text {eff }}$ was calculated with water moderation and close full water reflection conditions as specified by 10 CFR 71.55 . Results of these calculations show that a single container of ingots, billets or FERMCO material is well subcritical including bias and $2 \sigma$ uncertainty. All calculations were performed with the MCNP code (Breismeister 1993; Carter 1995).

6.6.2.2 Package Fuel Loading. Table 6.6.2.2-1 presents the package fuel loading for each ingot and billet type, and FERMCO material. The table gives the number of each type allowed in each package except for the FERMCO scrap. In the case of the FERMCO scrap 1,252 lb (568 kg) of the material is allowed in the package.

TABLE 6.6.2.2-1. Package Fuel Loading.

\begin{tabular}{|c|c|c|}
\hline Type & Packaging & Amount Per Package \\
\hline Mark I Inner Ingots & G-4273-5 & 2 \\
\hline Mark I Outer Ingots & G-4273-6 & 2 \\
\hline Mark IV inner ingots & G-4273-5 & 2 \\
\hline Mark IV Outer Ingots & $\mathrm{G}-4273-6$ & 2 \\
\hline Mark I RMI Inner Billets & G-4255 & 5 \\
\hline Mark I RMI Outer Billets & $G .4255$ & 4 \\
\hline Mark IV RMI Inner Billets & G-4255 & 5 \\
\hline Mark IV RMI Outer Billets & G-4255 & 4 \\
\hline Mark 15 Inner Ingots & G-4273-5 & 4 \\
\hline Mark 15 Outer Ingots & G-4273-5 & 2 \\
\hline FERMCO Primary Ingots $(13 \mathrm{in} .[33.02 \mathrm{~cm}] \mathrm{OD} \times 30 \mathrm{in.}[76.20 \mathrm{~cm})\}$ & G-4273-6 & 1 \\
\hline FERMCO Ingot Sections $(13 \mathrm{in} .[33.02 \mathrm{~cm}]$ OD $\times 6 \mathrm{in.}[15.24 \mathrm{~cm}])$ & $\mathrm{G}-4214$ & $6^{*}$ \\
\hline FERMCO Ingot Sections $(13 \mathrm{in.}[33.02 \mathrm{~cm}]$ OD $\times 3 \mathrm{in.}[7.62 \mathrm{cml})$ & G-4214 & 2 \\
\hline FERMCO Scrap (13 in. $[33.02 \mathrm{~cm}]$ OD $\times 4$ in. $[10.16 \mathrm{~cm}])$ & G-4292 & $1,252 \mathrm{lb}(568 \mathrm{~kg})$ \\
\hline $\begin{array}{l}\text { FERMCO Primary Ingots }(12 \mathrm{in.}[30.48 \mathrm{~cm}] \text { OD } \times 17 \text { in. }[43.18 \\
\mathrm{cm}]-26 \text { in. }[66.04 \mathrm{~cm}])\end{array}$ & G-4273-6 & 2 \\
\hline FERMCO Derbies $(12 \mathrm{in.}[30.48 \mathrm{~cm}] 00 \times 5 \mathrm{in.}[12.70 \mathrm{~cm}])$ & $\begin{array}{l}G-4214 \\
G-4292\end{array}$ & 2 \\
\hline FERMCO Scrap (11 in. $[27.94 \mathrm{~cm}]$ OD $\times 4 \mathrm{in} .[10.16 \mathrm{~cm}])$ & G-4292 & $1,252 \mathrm{lb}(568 \mathrm{~kg})$ \\
\hline FERMCO Ingot Sections $\{10$ in. $\{25.40 \mathrm{~cm}]$ OD $\times 6$ in. $[15.24 \mathrm{~cm}\})$ & G-4214 & $9^{\circ}$ \\
\hline FERMCO Primary Ingots (9 in. [22.86 cm] OD x $30 \mathrm{in.}[76.20 \mathrm{~cm}]$ ) & G-4273-5 & 2 \\
\hline
\end{tabular}

* Calculations were performed assuming the shipment would be made in the G-4273-5 or -6 and are conservative for smaller masses contained in the G-4214. 


\subsubsection{Model Specification.}

6.6.2.3.1 Description of Calculational Model. Dimensions of ingots, billets and FERMCO material are described in the main body of this chapter. A single container of each type was modeled as described in Table 6.6.2.2-1 of Section 6.6.2.2. All calculations were done with water moderation and close full reflection. Container material was conservatively ignored in the modeling.

6.6.2.3.2 Package Regional Densities. Material densities and isotopic compositions are described in the main body of this chapter.

\subsubsection{Criticality Calculation.}

6.6.2.4.1 Calculational Method. All calculations were performed with the MCNP code (Breismeister 1993; Carter 1995).

6.6.2.4.2 Fuel Loading Optimization. The contents of each package were loaded uniformly within the package volume. When feasible, the contents were spaced near optimal as allowed by the constraints imposed by the package dimensions. Water moderation and close full water reflection were used.

6.6.2.4.3 Criticality Results. Results of the single container analyses show that for all cases the $k_{\text {eff }} s$ are well below 0.95 . Results for single boxes of ingots and billets are presented in Table 6.6.2.4.3-1. Results for single boxes of FERMCO material are presented in Table 6.6.2.4.3-2.

TABLE 6.6.2.4.3-1. $k_{\text {eff }}$ for Single Boxes of Ingots and Billets Fully Water Moderated and Reflected.

\begin{tabular}{|c|c|c|c|c|}
\hline Type & Box & $k_{\text {elt }}$ & $k_{\text {eff }}+2 \sigma+$ bias & $\begin{array}{l}\text { Input } \\
\text { Files }\end{array}$ \\
\hline Mark I inner ingots & G-4273-5 & 0.5365 & 0.5513 & $x m 1 i 2$ \\
\hline Mark I outer ingots & G-4273-6 & 0.6433 & 0.6581 & $m b \times 01$ \\
\hline Mark IV inner ingots & G-4273-5 & 0.5389 & 0.5537 & $x m 4 i 2$ \\
\hline Mark IV outer ingots & G-4273-6 & 0.5986 & 0.6135 & $x \mathrm{~m} 401$ \\
\hline Mark I inner billets & G-4255 & 0.5867 & 0.6015 & $x b 1 i 1$ \\
\hline Mark I outer billets & G-4255 & 0.6808 & 0.6958 & $\mathrm{xb} 101$ \\
\hline Mark IV inner billets & G-4255 & 0.5863 & 0.6012 & $x b 4 i 1$ \\
\hline Mark IV outer billets & G-4255 & 0.6329 & 0.6477 & $\mathrm{xb} 401$ \\
\hline Mark 15 inner ingots & $G-4273-5$ & 0.6388 & 0.6537 & $\mathrm{n} 15 \mathrm{i} 1$ \\
\hline Mark 15 outer ingots & G-4273-5 & 0.6070 & 0.6219 & $\mathrm{n} 1501$ \\
\hline
\end{tabular}


TABLE 6.6.2.4.3-2. Single Boxes of FERMCO Material Fully Water Moderated and Reflected.

\begin{tabular}{|c|c|c|c|c|}
\hline Type & Box & $k_{\text {elf }}$ & $k_{e f f}+2 \sigma_{c}+$ bias & Input File \\
\hline $\begin{array}{l}\text { FERMCO Primary Ingots } \\
13 \mathrm{in.}(33.02 \mathrm{~cm}) \text { OD } \times 30 \mathrm{in} .(76.20 \mathrm{~cm})\end{array}$ & G-4273-6 & 0.5508 & 0.5657 & $f \operatorname{co} 7$ \\
\hline $\begin{array}{l}\text { FERMCO Ingot Sections } \\
13 \mathrm{in.}(33.02 \mathrm{~cm}) \text { OD } \times 6 \text { in. }(15.24 \mathrm{~cm})\end{array}$ & G-4273-6 & 0.5588 & 0.5736 & $f \cot$ \\
\hline $\begin{array}{l}\text { FERMCO Ingot Sections } \\
13 \mathrm{in.}(33.02 \mathrm{~cm}) \text { OD } \times 3 \text { in. }(7.62 \mathrm{~cm})\end{array}$ & $\mathrm{G}-4273-6^{\circ}$ & 0.5536 & 0.5685 & fco 2 \\
\hline $\begin{array}{l}\text { FERMCO Scrap } \\
13 \mathrm{in.}(33.02 \mathrm{~cm}) \text { OD } \times 4 \mathrm{in.}(10.16 \mathrm{~cm})\end{array}$ & G-4292 & 0.6087 & 0.6237 & $f \operatorname{cs} 1$ \\
\hline $\begin{array}{l}\text { FERMCO Primary Ingots } \\
12 \text { in. }(30.48 \mathrm{~cm}) \text { OD } \times 17 \text { in. }(43.18 \mathrm{~cm})-26 \mathrm{in} . \\
(66.04 \mathrm{~cm})\end{array}$ & G-4273-6 & 0.6235 & 0.6383 & $\mathrm{fco} 3$ \\
\hline $\begin{array}{l}\text { FERMCO Derbies } \\
12 \mathrm{in.}(30.48 \mathrm{~cm}) \text { OD } \times 5 \mathrm{in} .(12.70 \mathrm{~cm})\end{array}$ & $\begin{array}{l}\text { G-4214 } \\
\text { G-4292 }\end{array}$ & 0.7445 & 0.7593 & fco 4 \\
\hline $\begin{array}{l}\text { FERMCO Scrap } \\
11 \mathrm{in.}(27.94 \mathrm{~cm}) \text { OD } \times 4 \text { in. }(10.16 \mathrm{~cm}\}\end{array}$ & G-4292 & 0.6587 & 0.6736 & $\operatorname{fcs} 2$ \\
\hline $\begin{array}{l}\text { FERMCO Ingot Sections } \\
10 \mathrm{in.}(25.40 \mathrm{~cm}) \text { OD } \times 6 \text { in. }(15.24 \mathrm{~cm})\end{array}$ & G. $4273-5^{\circ}$ & 0.6660 & 0.6809 & $f \cos$ \\
\hline $\begin{array}{l}\text { FERMCO Primary Ingots } \\
9 \text { in. }(22.86 \mathrm{~cm}) \text { OD } \times 30 \text { in. }(76.20 \mathrm{~cm})\end{array}$ & G-4273-5 & 0.5525 & 0.5673 & $f \operatorname{co} 6$ \\
\hline
\end{tabular}

* Calculations were performed using the box indicated. However, these materials will be shipped in the G-4214 box. 


\subsubsection{MCNP Code Input Listings}

Thirty-one sample MCNP input files are presented in this section. These files can be easily modified to create input files for all calculations done for this chapter. The first input file listed is for the Mark I outer ingot infinite array case at optimum moderation and pitch. This file can be used to create the input files for various other pitches and water densities simple by changing the lattice pitch input and the water density fraction. Since the other fuel types are also cylinders, input files for them can be created by changing the inner and outer diameters along with the appropriate fuel enrichment.

Each final calculation on which a mass limit is based was also calculated by changing the nominal ${ }_{235} \mathrm{U}$ enrichment to its upper limit $[0.956 \mathrm{wt} \%, 1.106 \mathrm{wt} \%$, and $1.256 \mathrm{wt} \%$ for the three enrichments]. A case name for an upper limit enrichment calculation is the same as that of the corresponding base (nominal) calculation except a " $u$ " has been added to the end of the case name in the tables in the main part of Chapter 6 . The input file for the case with a " $u$ " on the end of the filename is the same as that for the base (nominal) calculation except the material card for uranium is changed as follows:

$\begin{array}{lll}1.25 \%: & \begin{array}{l}\mathrm{m} 20092235.50 \mathrm{c}-0.012560 \\ \text { instead of }\end{array} & 92238.50 \mathrm{c}-0.987440 \\ & \mathrm{~m} 20092235.50 \mathrm{c}-0.012500 & 92238.50 \mathrm{c}-0.987500 \\ 1.10 \mathrm{wt} \%: & \begin{array}{l}\mathrm{m} 20092235.50 \mathrm{c}-0.01106 \\ \text { instead of }\end{array} & 92238.50 \mathrm{c}-0.988940 \\ & \begin{array}{l}\mathrm{m} 20092235.50 \mathrm{c}-0.011000 \\ \text { m200 92235.50c-0.009560 }\end{array} & 92238.50 \mathrm{c}-0.989000 \\ & \begin{array}{l}\text { instead of } \\ \mathrm{m} 20092238.50 \mathrm{c}-0.990440\end{array} \\ & \end{array}$

The first $\mathrm{i}$ input file $\mathrm{m} 1707$.

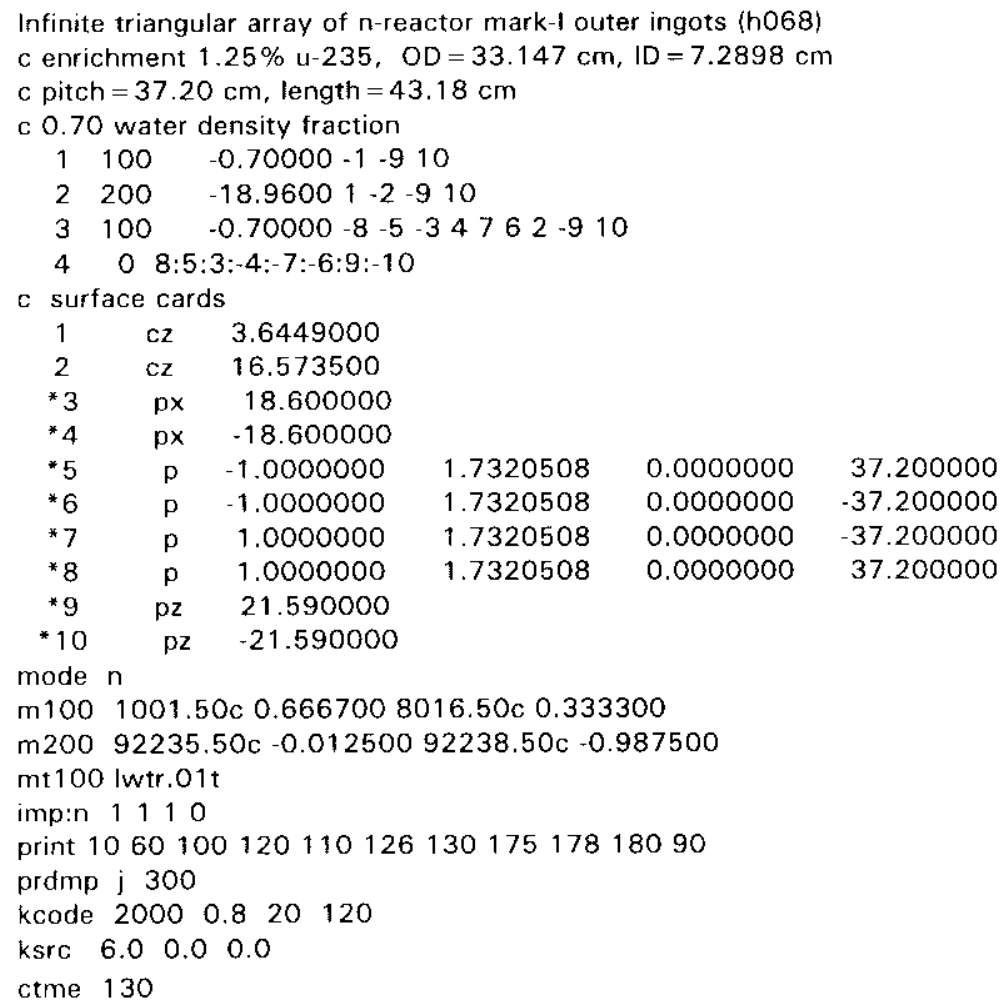


The second input file is for the $2 \times 12$ hexagonal array of Mark I outer ingots at optimum moderation and pitch. Input file an 109 .

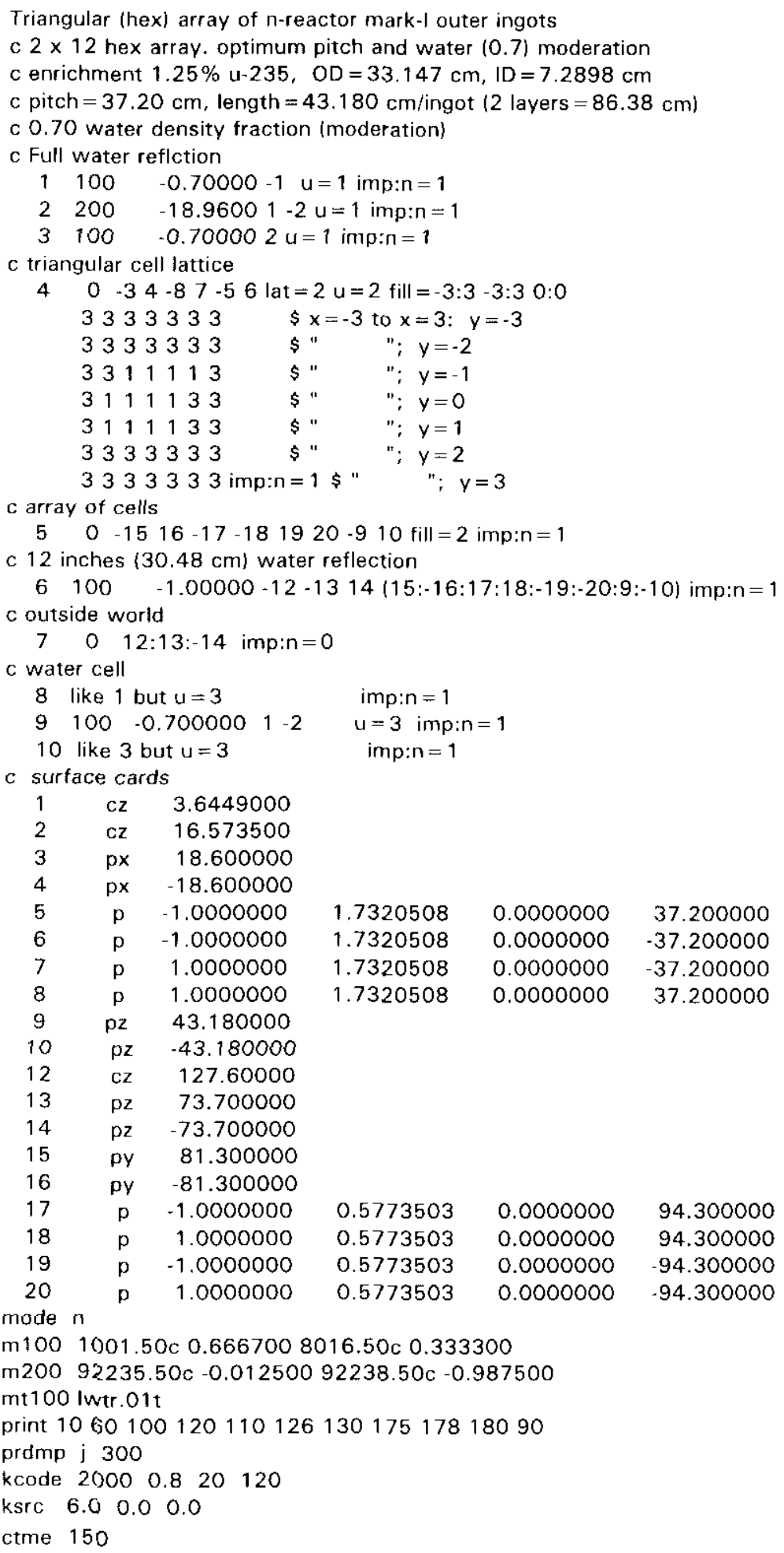


The third MCNP input file is the $3 \times 169$ hexagonal array of Mark I inner billets at optimum moderation and pitch. Input file a1i3.

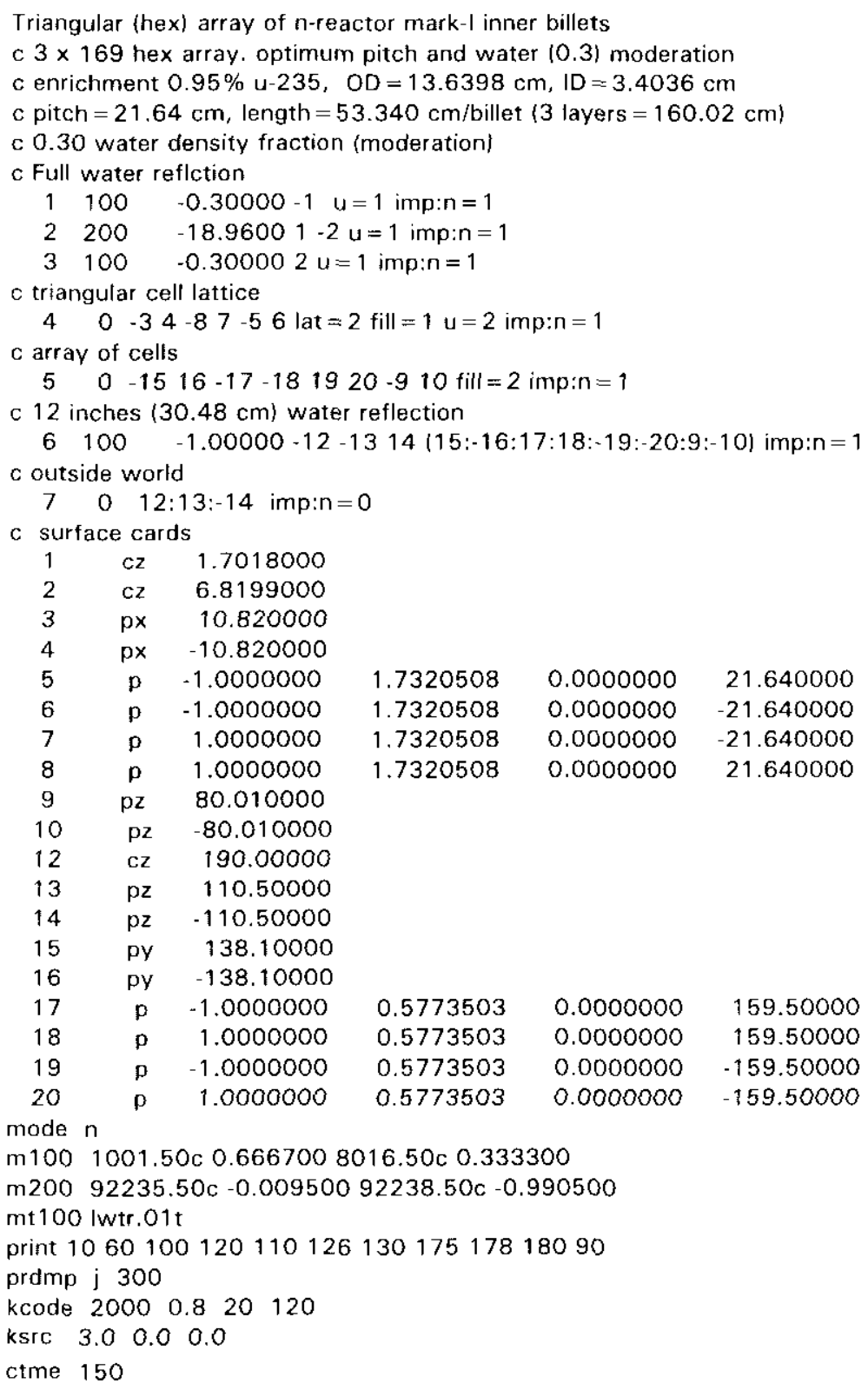


The fourth MCNP input file is the $2 \times 17$ hexagonal array of Mark I outer billets at optimum moderation and pitch. Input file a105.

Triangular (hex) array of n-reactor mark-l outer billets

c $2 \times 17$ hex array. optimum pitch and water (0.7) moderation

$c$ enrichment $1.25 \% \mathrm{u}-235, O D=17.7292 \mathrm{~cm}, 1 \mathrm{D}=7.1120 \mathrm{~cm}$

c pitch $=21.73 \mathrm{~cm}$, length $=53.340 \mathrm{~cm} /$ billet $(2$ layers $=106.68 \mathrm{~cm})$

c 0.70 water density fraction (moderation)

c Full water reflction

$1 \quad 100 \quad-0.70000-1 \mathrm{u}=1 \mathrm{imp}: \mathrm{n}=1$

$2200-18.96001-2 \mathrm{u}=1 \mathrm{imp}: \mathrm{n}=1$

$3100 \quad-0.700002 \mathrm{u}=1 \mathrm{imp}: \mathrm{n}=1$

C triangular cell lattice

$4 \quad 0-34-87-56$ lat $=2 u=2$ fill $=-3: 3-3: 30: 0$

$$
\begin{aligned}
& 3333333 \quad \$ x=-3 \text { to } x=3: y=-3 \\
& 3331133 \quad \text { " " } ; y=-2 \\
& 3311113 \quad \text { \$ " "; } y=-1 \\
& 3111113 \quad \text { \$ } \quad " ; y=0 \\
& 3111133 \quad \text { \$ " "; } y=1 \\
& 3311333 \quad \$ " \quad " ; y=2 \\
& \text { 3 } 333333 \mathrm{imp}: n=1 \text { \$ } \quad " ; y=3
\end{aligned}
$$

c array of cells

$5 \quad 0 \quad-15 \quad 16-17-18 \quad 1920-9 \quad 10$ fill $=2$ imp: $n=1$

c 12 inches $(30.48 \mathrm{~cm})$ water reflection

$6100-1.00000-12-1314(15:-16: 17: 18:-19:-20: 9:-10)$ imp:n=1

c outside world

$7 \quad 0 \quad 12: 13:-14$ imp:n $=0$

c water cell

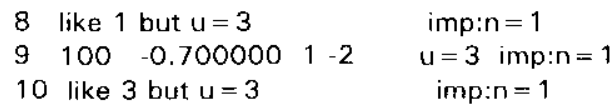

c surface cards

$\begin{array}{ccrcrr}1 & \mathrm{cz} & 3.5560000 & & & \\ 2 & \mathrm{cz} & 8.8646000 & & & \\ 3 & \mathrm{px} & 10.865000 & & & \\ 4 & \mathrm{px} & -10.865000 & & & \\ 5 & \mathrm{p} & -1.0000000 & 1.7320508 & 0.0000000 & 21.730000 \\ 6 & \mathrm{p} & -1.0000000 & 1.7320508 & 0.0000000 & -21.730000 \\ 7 & \mathrm{p} & 1.0000000 & 1.7320508 & 0.0000000 & -21.730000 \\ 8 & \mathrm{p} & 1.0000000 & 1.7320508 & 0.0000000 & 21.730000 \\ 9 & \mathrm{pz} & 53.340000 & & & \\ 10 & \mathrm{pz} & -53.340000 & & & \\ 12 & \mathrm{cz} & 127.60000 & & & \\ 13 & \mathrm{pz} & 83.820000 & & & \\ 14 & \mathrm{pz} & -83.820000 & & & \\ 15 & \mathrm{py} & 46.600000 & & & \\ 16 & \mathrm{py} & -46.600000 & & & \\ 17 & \mathrm{p} & -1.0000000 & 0.5773503 & 0.0000000 & 54.000000 \\ 18 & \mathrm{p} & 1.0000000 & 0.5773503 & 0.0000000 & 54.000000 \\ 19 & \mathrm{p} & -1.0000000 & 0.5773503 & 0.0000000 & -54.000000 \\ 20 & \mathrm{p} & 1.0000000 & 0.5773503 & 0.0000000 & -54.000000\end{array}$

mode $n$

$\mathrm{m} 1001001.50 \mathrm{c} 0.6667008016 .50 \mathrm{c} 0.333300$

$\mathrm{m} 20092235.50 \mathrm{c}-0.01250092238 .50 \mathrm{c}-0.987500$

mt100 lwtr.01t

print 106010012011012613017517818090

prdmp i 300

kcode $2000 \quad 0.8 \quad 20120$

$\begin{array}{lllll}\text { ksrc } & 6.0 & 0.0 & 0.0\end{array}$

ctme 150 
The fifth MCNP input file is the $3 \times 169$ hexagonal array of Mark IV inner billets at optimum moderation and pitch. Input file a4i5.

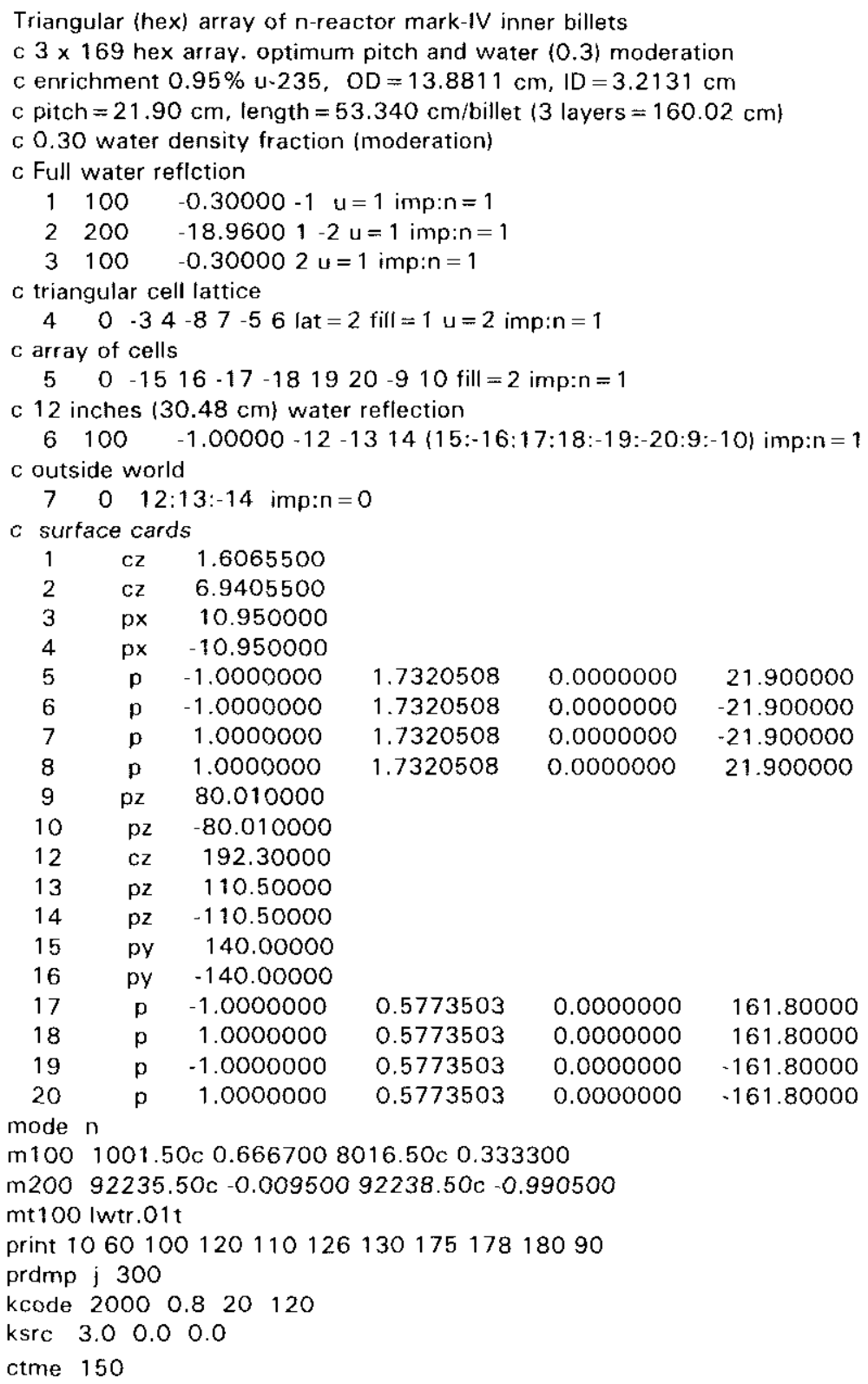


The sixth MCNP input file is the $3 \times 61$ hexagonal array of Mark IV outer billets at optimum moderation and pitch. Input file a4o1.

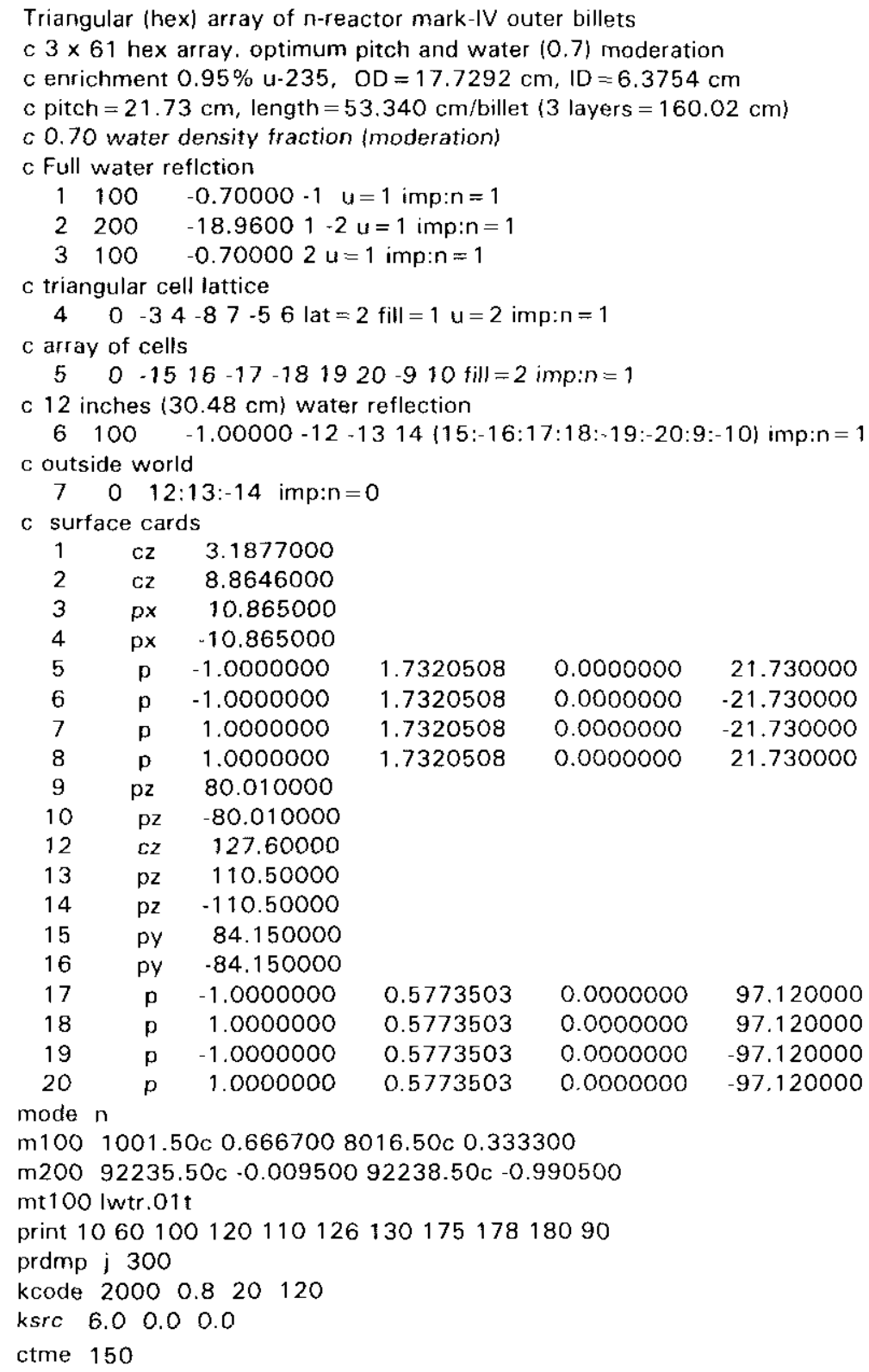


The seventh MCNP input file is the $2 \times 30$ hexagonal array of Mark 15 inner ingots at optimum moderation and pitch. Input file m15i1.

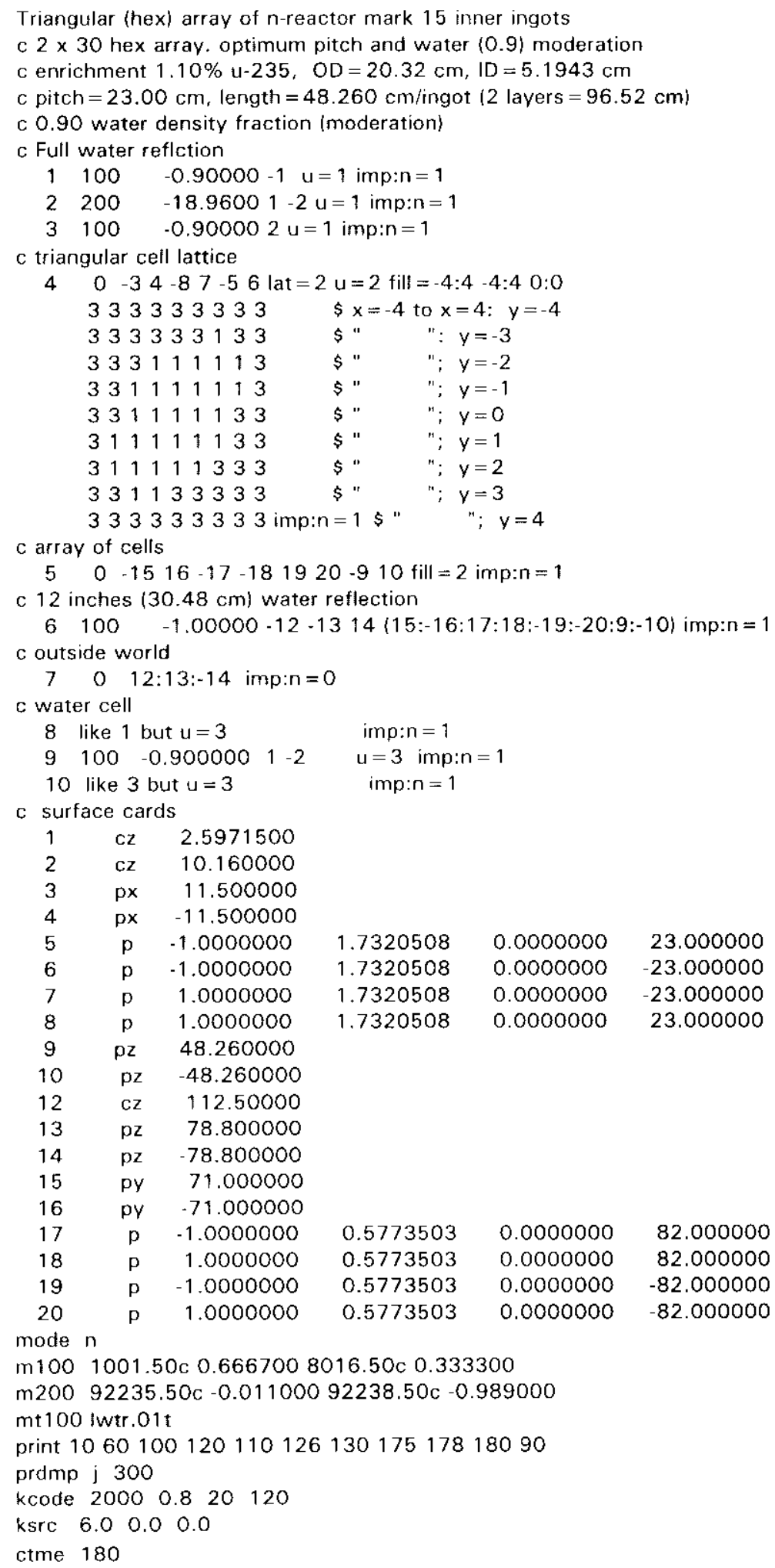


The eighth MCNP input file is the $2 \times 16$ hexagonal array of Mark 15 outer ingots at optimum moderation and pitch. Input file m15o1.

Triangular (hex) array of n-reactor mark 15 outer ingots

c $2 \times 16$ hex array. optimum pitch and water (0.7) moderation

c enrichment $1.10 \% \mathrm{u}-235, \mathrm{OD}=22.86 \mathrm{~cm}, \mathrm{ID}=8.1026 \mathrm{~cm}$

c pitch $=26.50 \mathrm{~cm}$, length $=73.66 \mathrm{~cm} /$ ingot $(2$ layers $=147.32 \mathrm{~cm})$

c 0.70 water density fraction (moderation)

c. Full water reflction

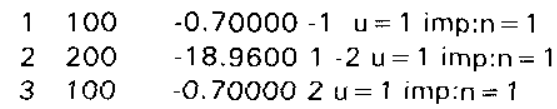

c triangular cell lattice

$4 \quad 0-34 \begin{array}{llllll}4 & -5 & 6 \text { lat }=2 \mathrm{u}=2 \text { fill }=-3: 3 & -3: 3 & 0: 0\end{array}$

$3333333 \quad \$ x=-3$ to $x=3: y=-3$

$3333133 \quad$ \$n $\quad ; y=-2$

$3311113 \quad \$ n \quad n ; y=-1$

$311111113 \quad \$ n \quad " ; y=0$

$311111133 \quad$ \$ $\quad " ; y=1$

$33111333 \quad$ \$ " "; $y=2$

3 $333333 \mathrm{imp}: \mathrm{n}=1$ \$" $" ; y=3$

c array of cells

$5 \quad 0 \quad-15 \quad 16-17-18 \quad 1920-9 \quad 10$ fill = 2 imp: $n=1$

c 12 inches $(30.48 \mathrm{~cm})$ water reflection

$6100-1.00000-12-1314(15:-16: 17: 18:-19:-20: 9:-10\}$ imp:n=1

c. outside world

$7 \quad 0 \quad 12: 13:-14$ imp: $n=0$

c. water cell

8 like 1 but $u=3 \quad$ imp: $n=1$

$9100-0.700000 \quad 1-2 \quad u=3$ imp:n=1

10 like 3 but $u=3 \quad$ imp: $n=1$

c surface cards

$1 \quad c z \quad 4.0513000$

$2 \mathrm{cz} \quad 11.430000$

$3 \quad \mathrm{px} \quad 13.250000$

$4 \quad p \times \quad-13.250000$

$5 \quad \mathrm{p} \quad-1.0000000$

$-1.0000000$

$\begin{array}{llllll}7 & \mathrm{p} & 1.0000000 & 1.7320508 & 0.0000000 & -26.500000\end{array}$

$\begin{array}{lll}1.7320508 & 0.0000000 & 26.500000\end{array}$

$\begin{array}{lll}1.7320508 & 0.0000000 & -26.500000\end{array}$

p 1.0000000

pz 73.660000

$\begin{array}{lll}1.7320508 & 0.0000000 \quad 26.500000\end{array}$

pz $\quad-73.660000$

cz $\quad 96.700000$

pz 104.20000

pz $\quad-104.20000$

py $\quad 58.000000$

py -58.000000

p -1.0000000

p $\quad 1.0000000$

0.5773503

0.0000000

67.000000

0.5773503

0.0000000

67.000000

$-1.0000000$

0.5773503

0.0000000

$-67.000000$

20

p 1.0000000

0.5773503

0.0000000

$-67.000000$

mode $n$

m100 1001.50c $0.6667008016 .50 \mathrm{c} 0.333300$

m200 92235.50c $-0.01100092238 .50 c-0.989000$

$\mathrm{mt} 100$ Iwtr.01t

print 106010012011012613017517818090

prdmp ; 300

kcode $2000 \quad 0.8 \quad 20 \quad 120$

$\begin{array}{lllll}\text { ksrc } & 6.0 & 0.0 & 0.0\end{array}$

c.tme 150 
The ninth MCNP input file represents a $8 \times 19$ hexagonal array of 6 in $(15.24 \mathrm{~cm})$ FERMCO material with a $22.86 \mathrm{~cm}(9 \mathrm{in}) O D$ and $7.62 \mathrm{~cm}(3 \mathrm{in})$ axial separation. Fully water moderated and reflected. Input file afp6.

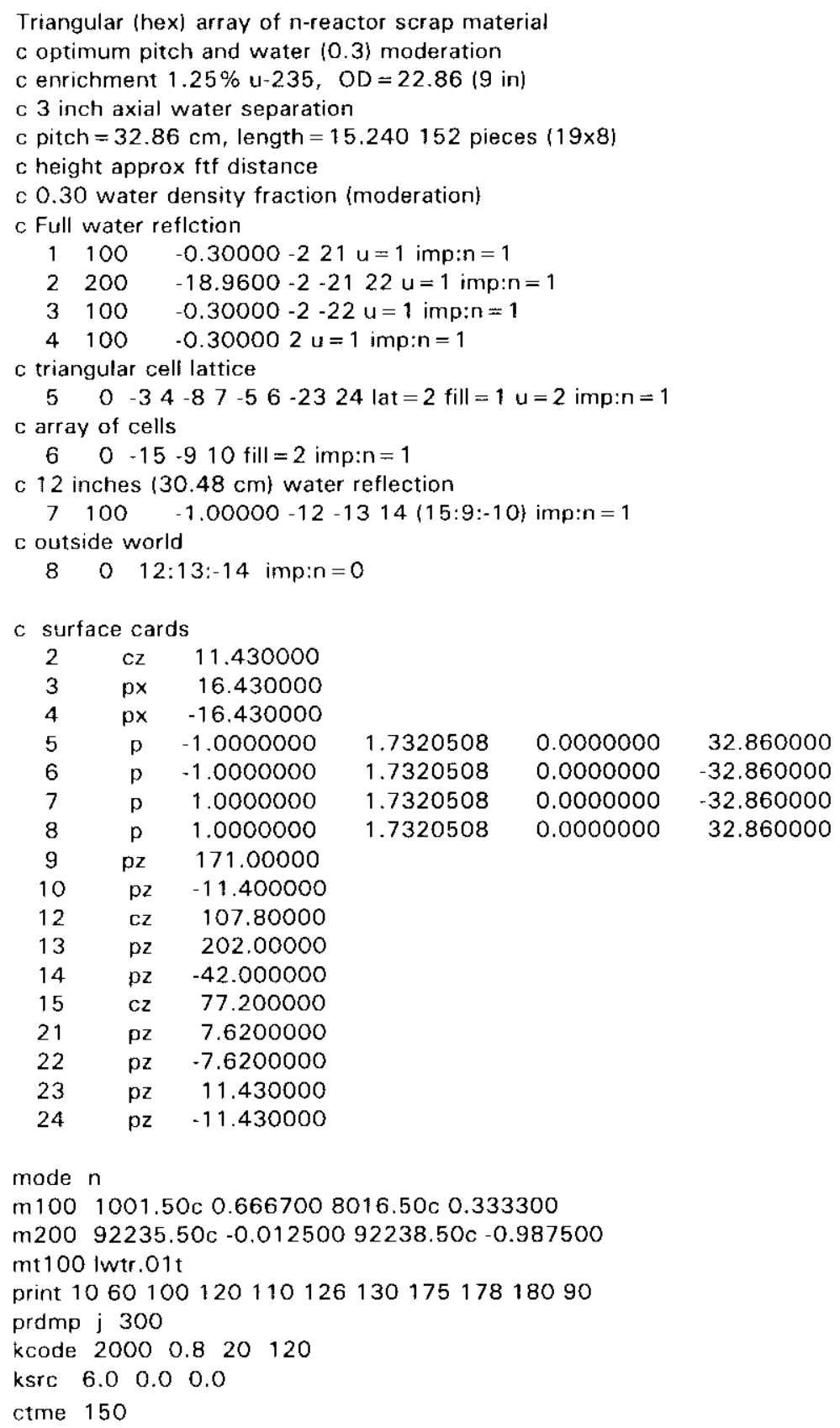


The tenth MCNP input file represents a $19 \times 12$ hexagonal array of 3 in $(7.62 \mathrm{~cm})$ FERMCO

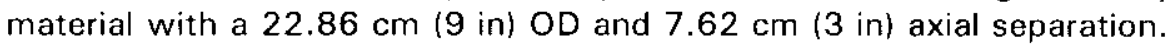
Fully water moderated and reflected. Input file aft 6 .

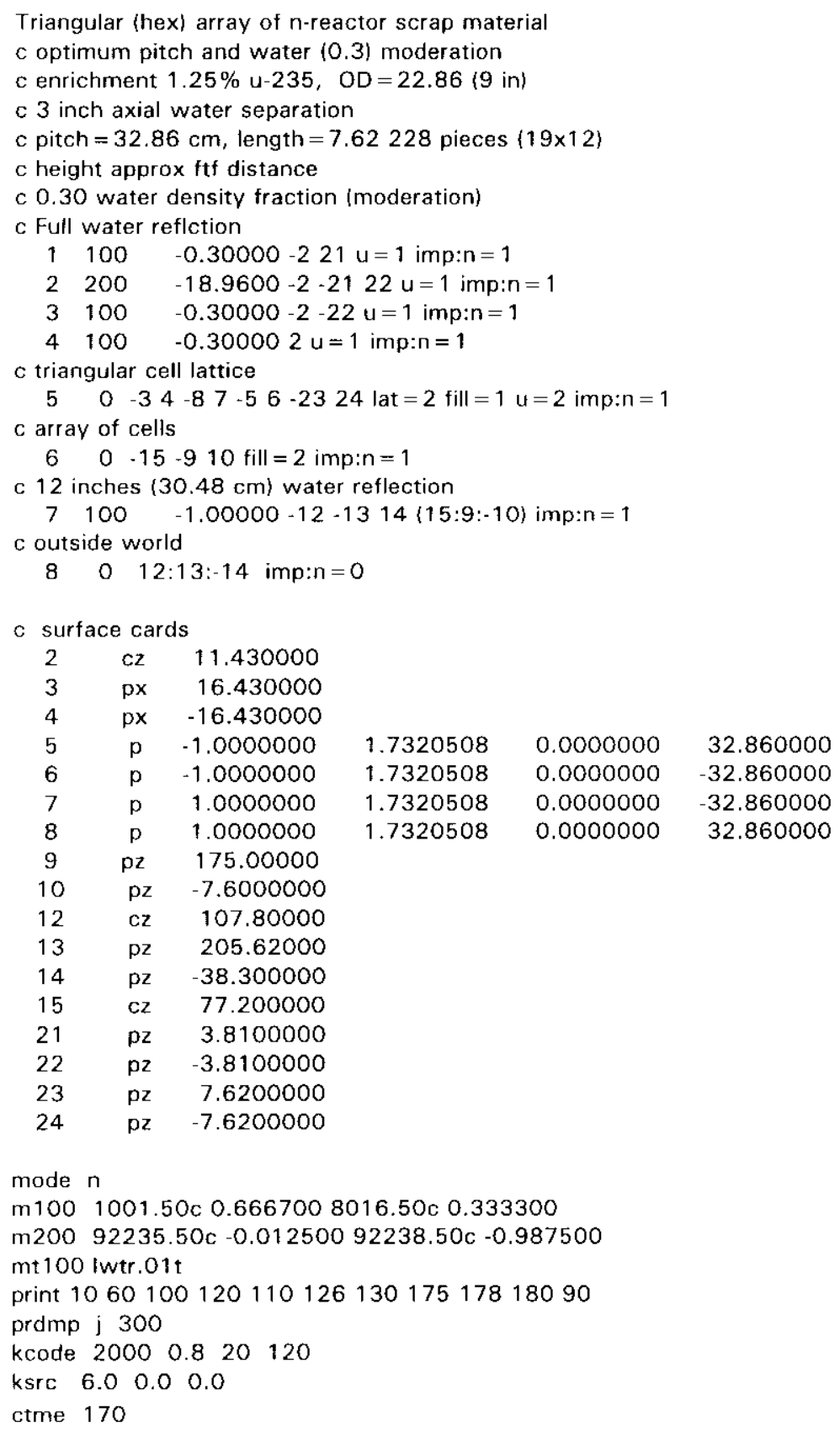


The 11 th MCNP input file represents a finite array of 5 in $(12.70 \mathrm{~cm})$ FERMCO derbies material with a 12 in $(30.48 \mathrm{~cm})$ OD and $5.5 \mathrm{~cm}$ axial separation.

Fully water moderated and reflected. Input file $1205 \mathrm{j}$.

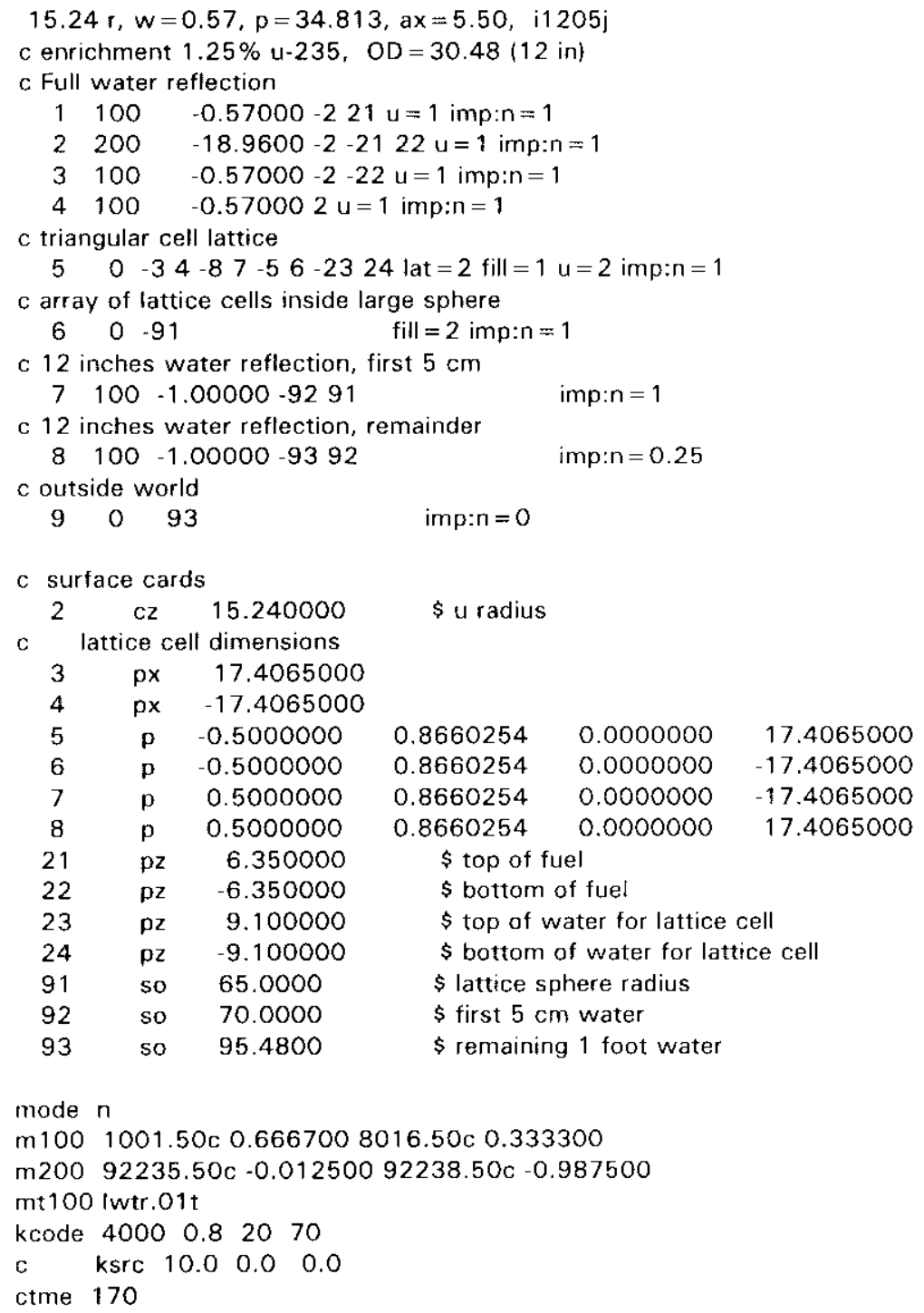


The 12th MCNP input file represents a finite spherical array of Mark I outer ingots at optimum parameters. Fully water moderated and reflected. Input file i1317n.

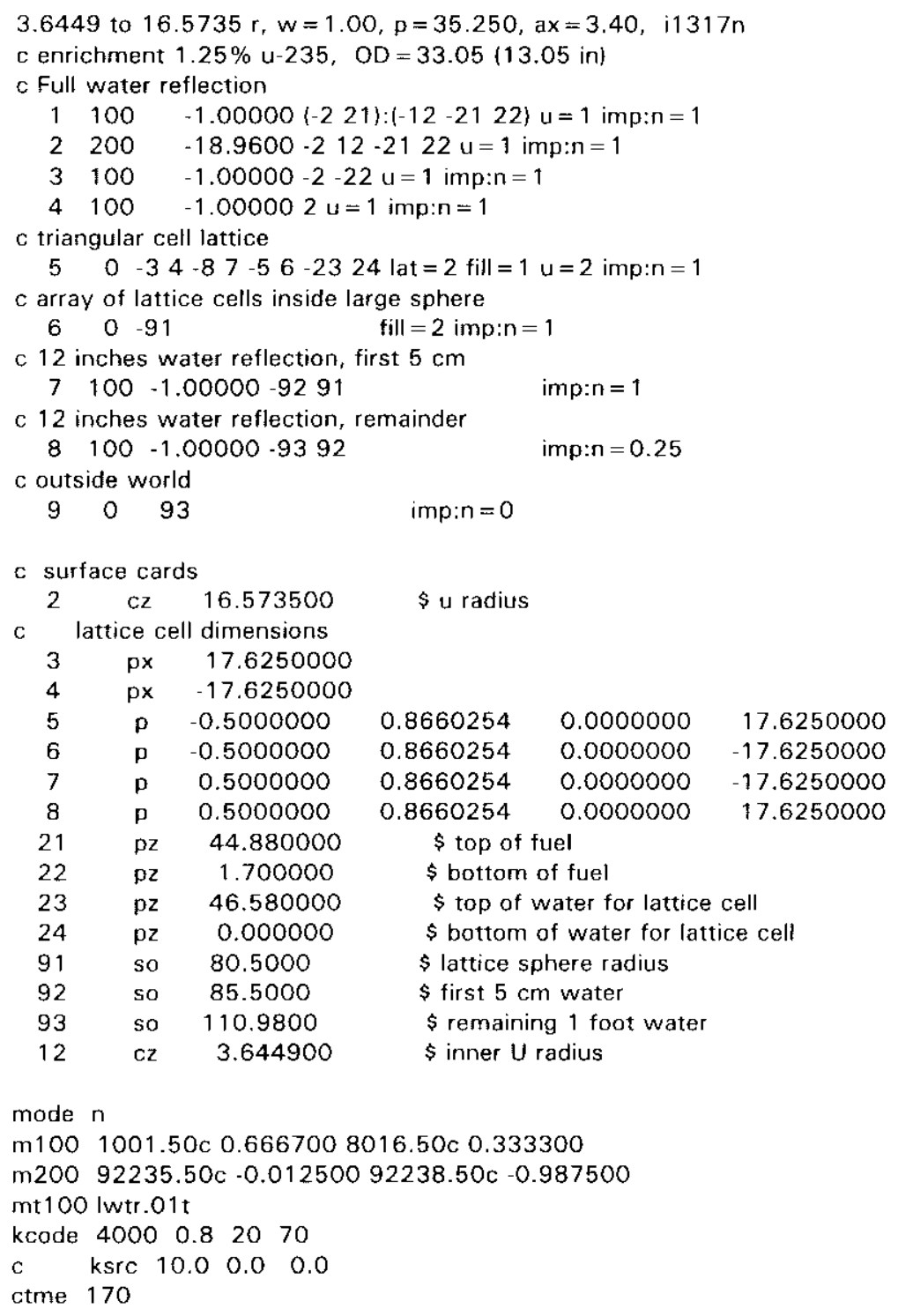


The 13th MCNP input file represents a finite spherical array of Mark I inner billets at optimum parameters. Fully water moderated and reflected. Input file iq716c.

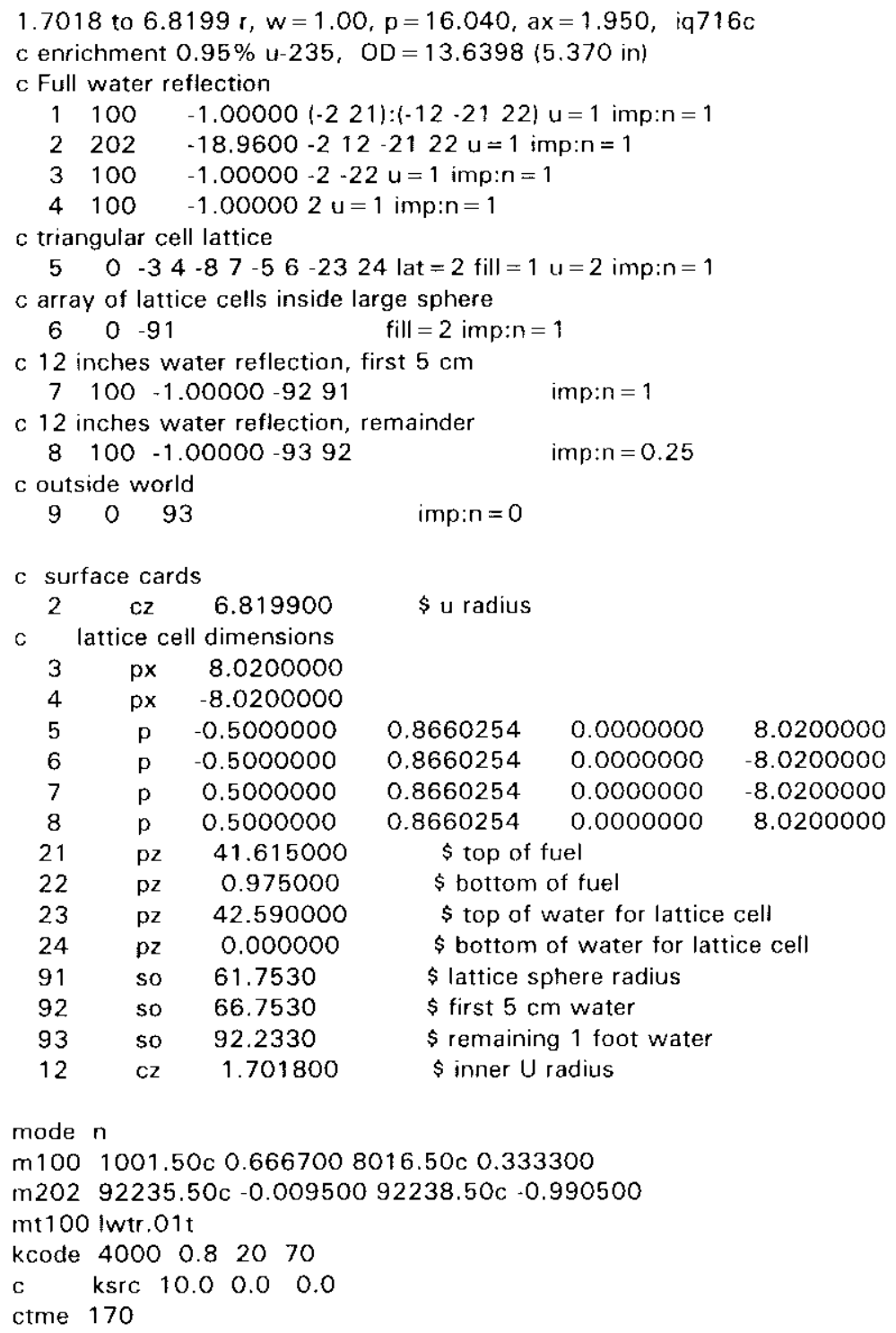


The 14th MCNP input file represents a finite spherical array of Mark I outer billets at optimum parameters. Fully water moderated and reflected. Input file i0716o.

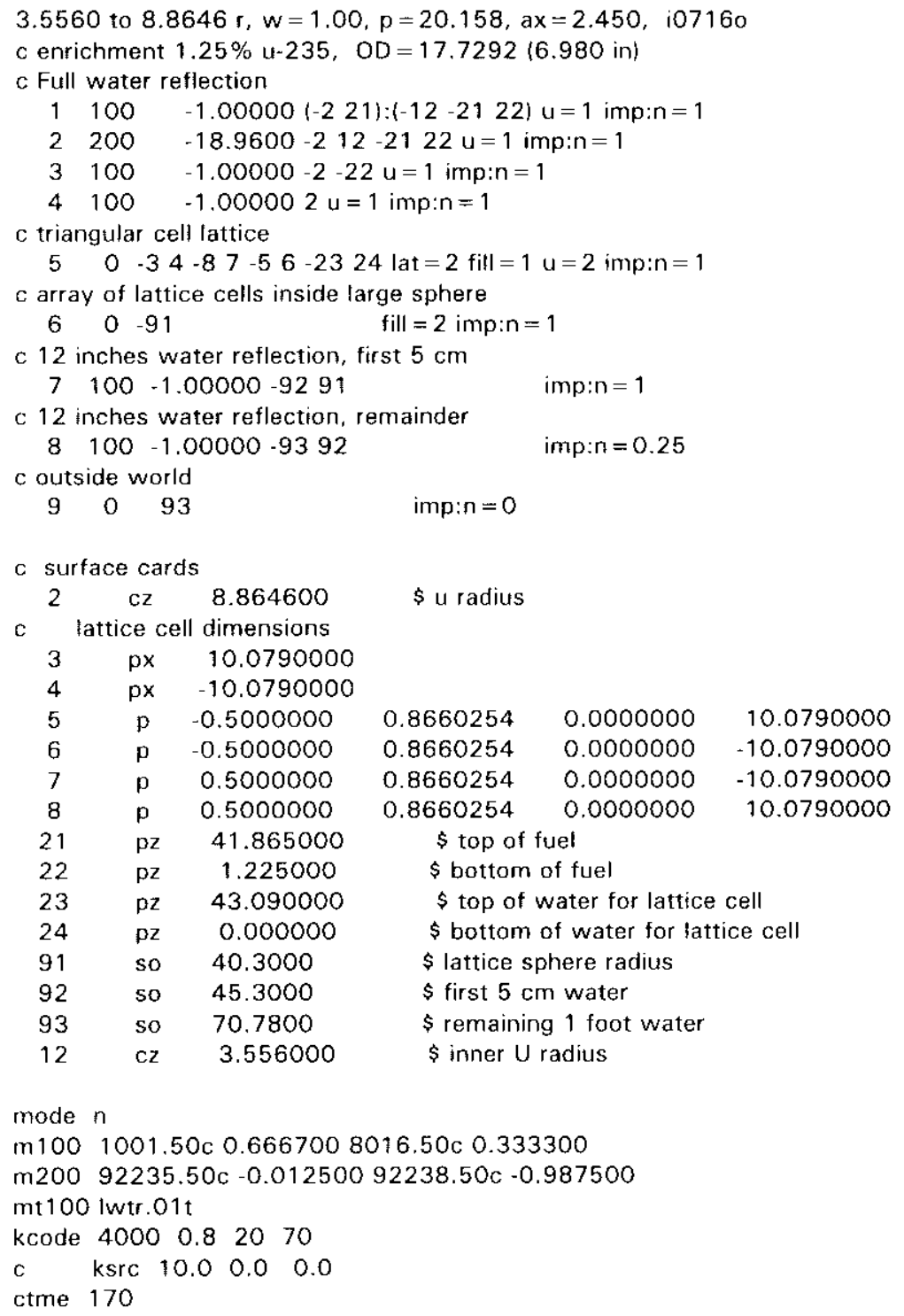


The 15th MCNP input file represents a finite spherical array of Mark IV inner billets at optimum parameters. Fully water moderated and reflected. Input file iq4i16b.

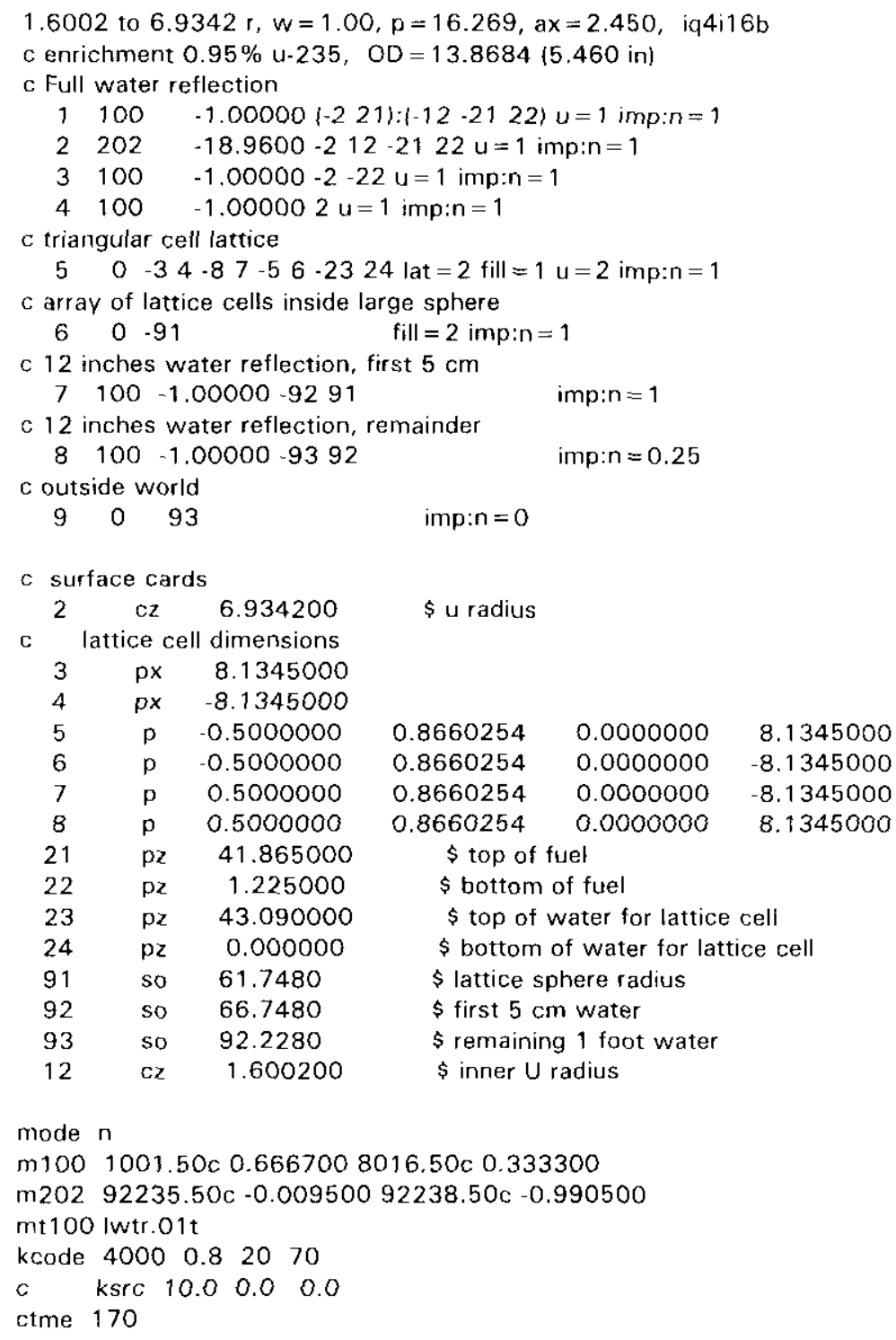


The 16th MCNP input file represents a finite spherical array of Mark IV outer billets at optimum parameters. Fully water moderated and reflected. Input file iq4o16j.

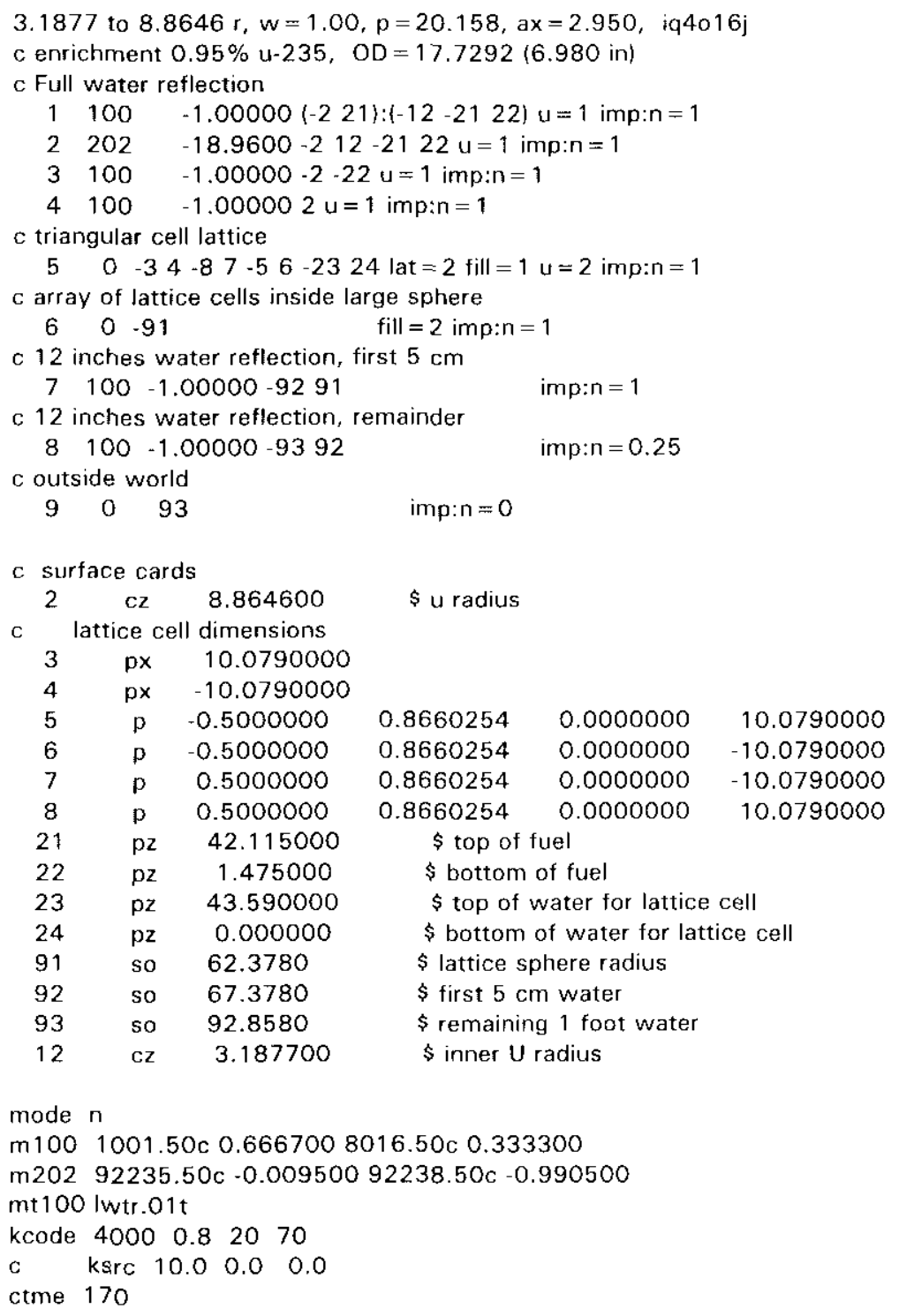


The 17th MCNP input file represents a finite spherical array of Mark 15 inner ingots at optimum parameters. Fully water moderated and reflected. Input file is0819a.

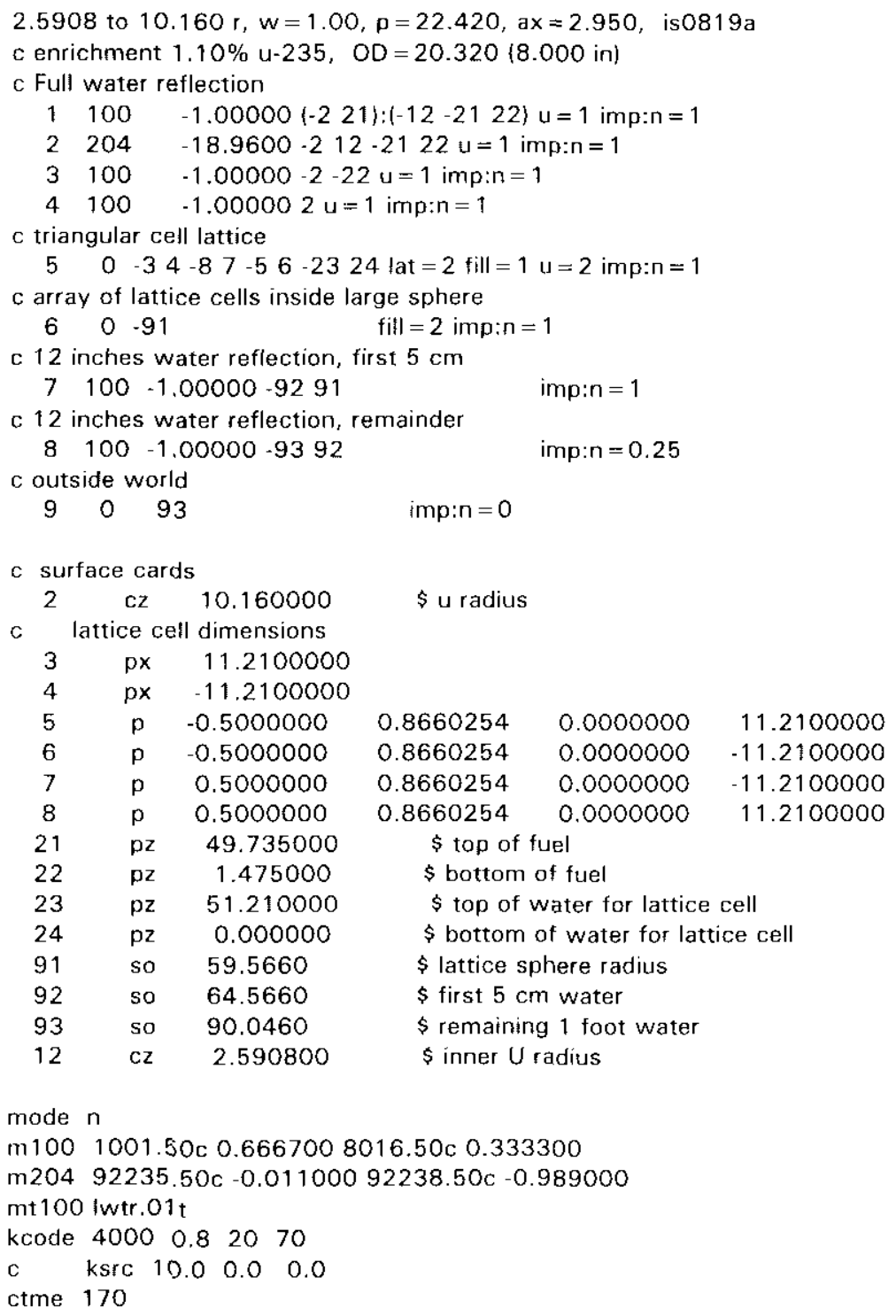


The 18th MCNP input file represents a finite spherical array of Mark 15 outer ingots at optimum parameters. Fully water moderated and reflected. Input file is0929b.

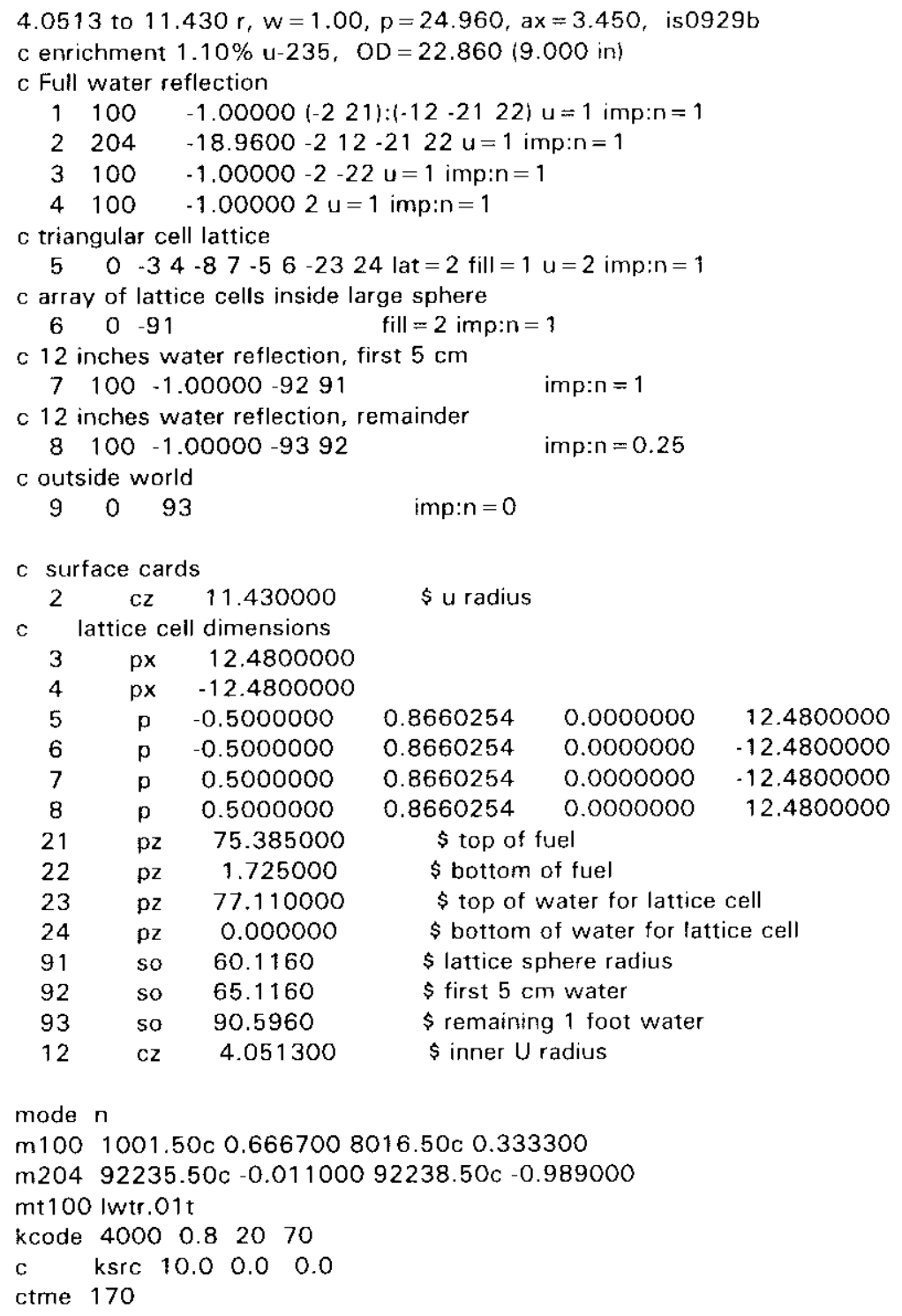


The 19th MCNP input file represents a finite spherical array of FERMCO ingot sections (13" Diameter and 3" long $U$ ) at optimum parameters. Fully water moderated and reflected. Input file i1303t.

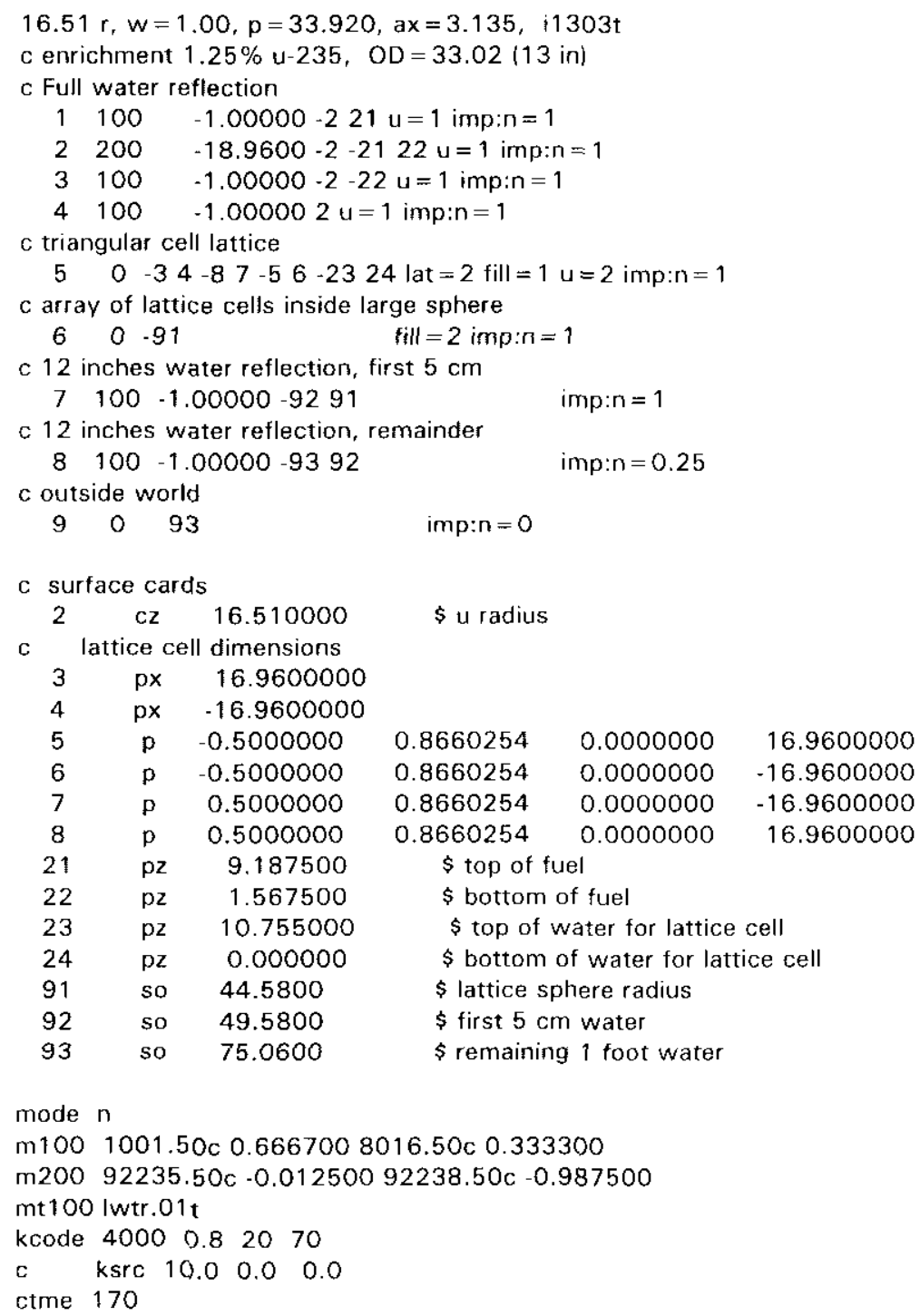


The 20th MCNP input file represents a finite spherical array of FERMCO scrap (11" Diameter and 4" long $\mathrm{U}$ ) at optimum parameters. Fully water moderated and reflected. Input file i1104r.

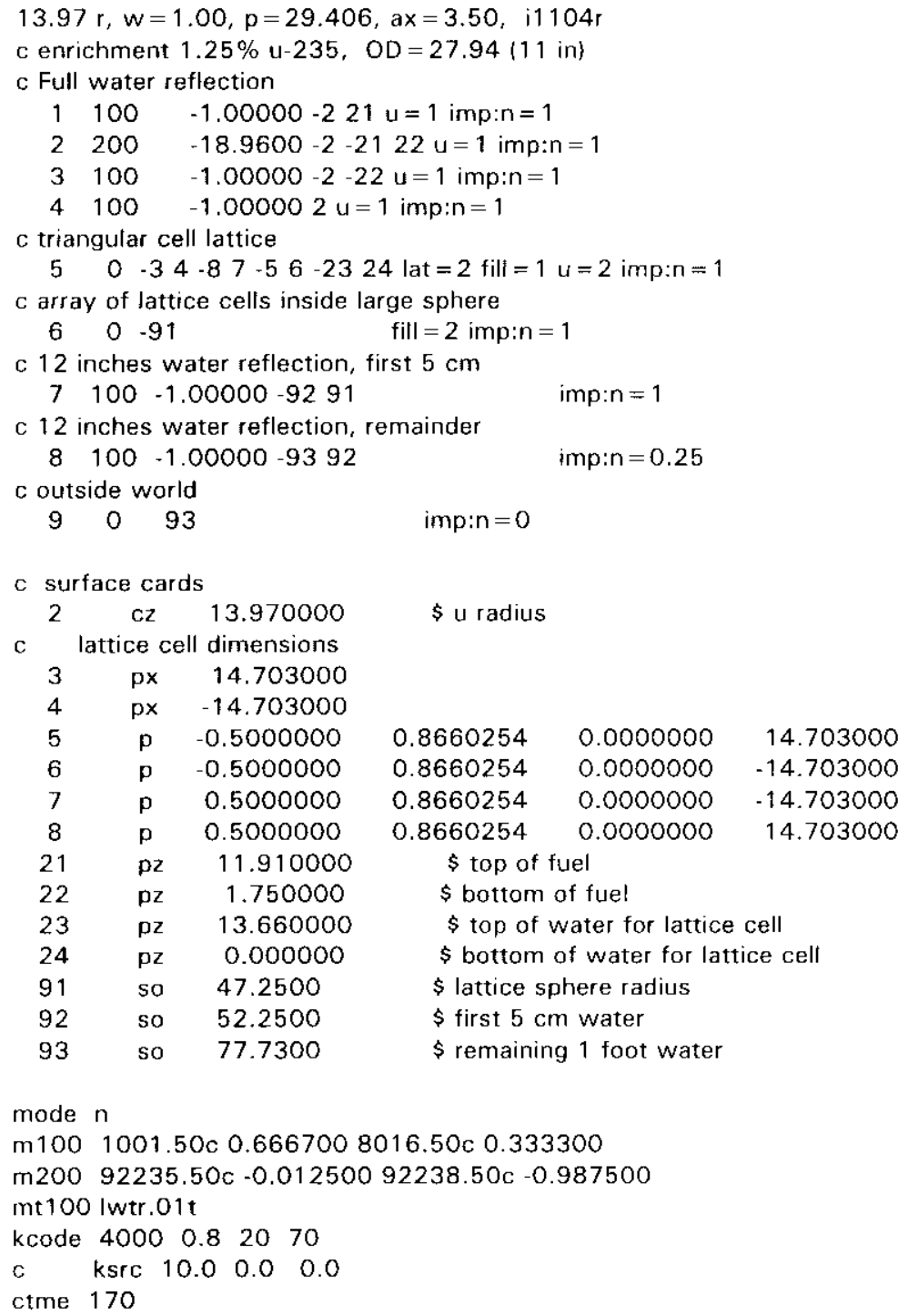


The 21st MCNP input file represents a finite spherical array of FERMCO ingot sections (10" Diameter and 6" long U) at optimum parameters. Fully water moderated and reflected. Input file i1006q.

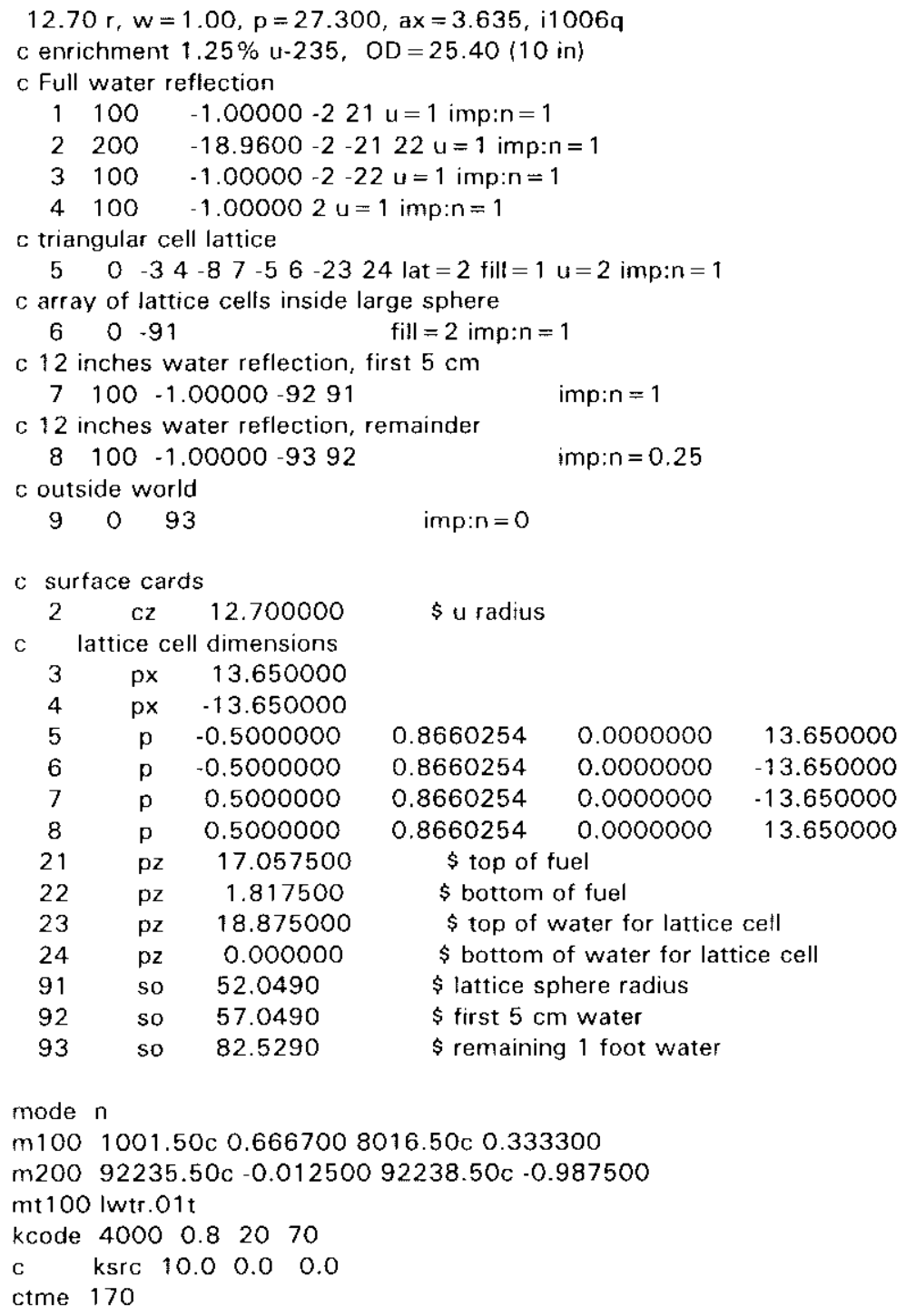


The 22nd MCNP input file represents a finite spherical array of FERMCO primary ingots (9" Diameter and $15^{\prime \prime}$ long $\mathrm{U}$ ) at optimum parameters. Fully water moderated and reflected. Input file i0915j.

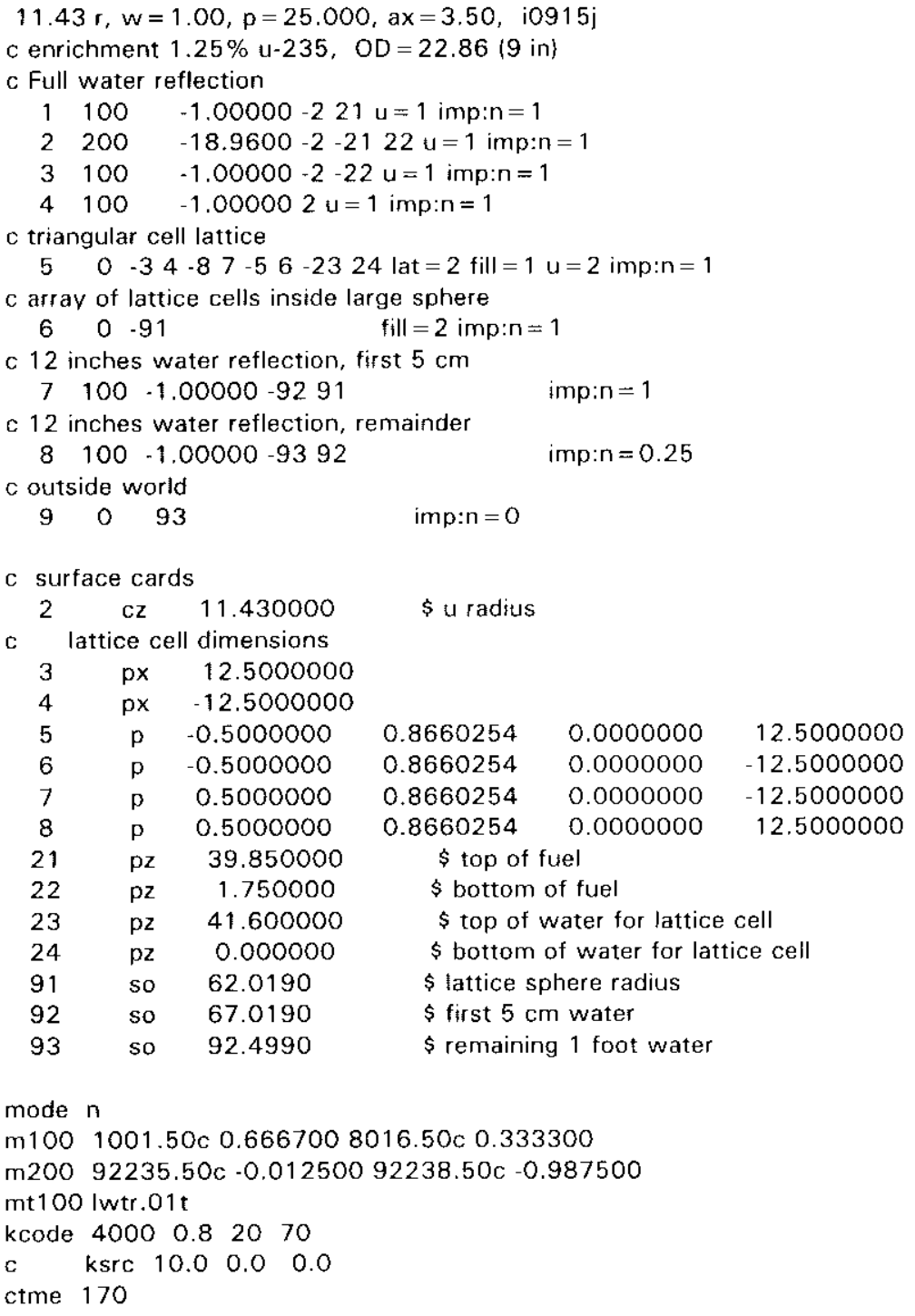

END OF MCNP INPUT FILE LISTING 
The $23^{\text {rd }}$ MCNP input file represents a finite spherical array of 21 -in. long Mark I outer billets at optimum parameters. Fully water moderated and reflected. Input file mk $1 \circ 21$.

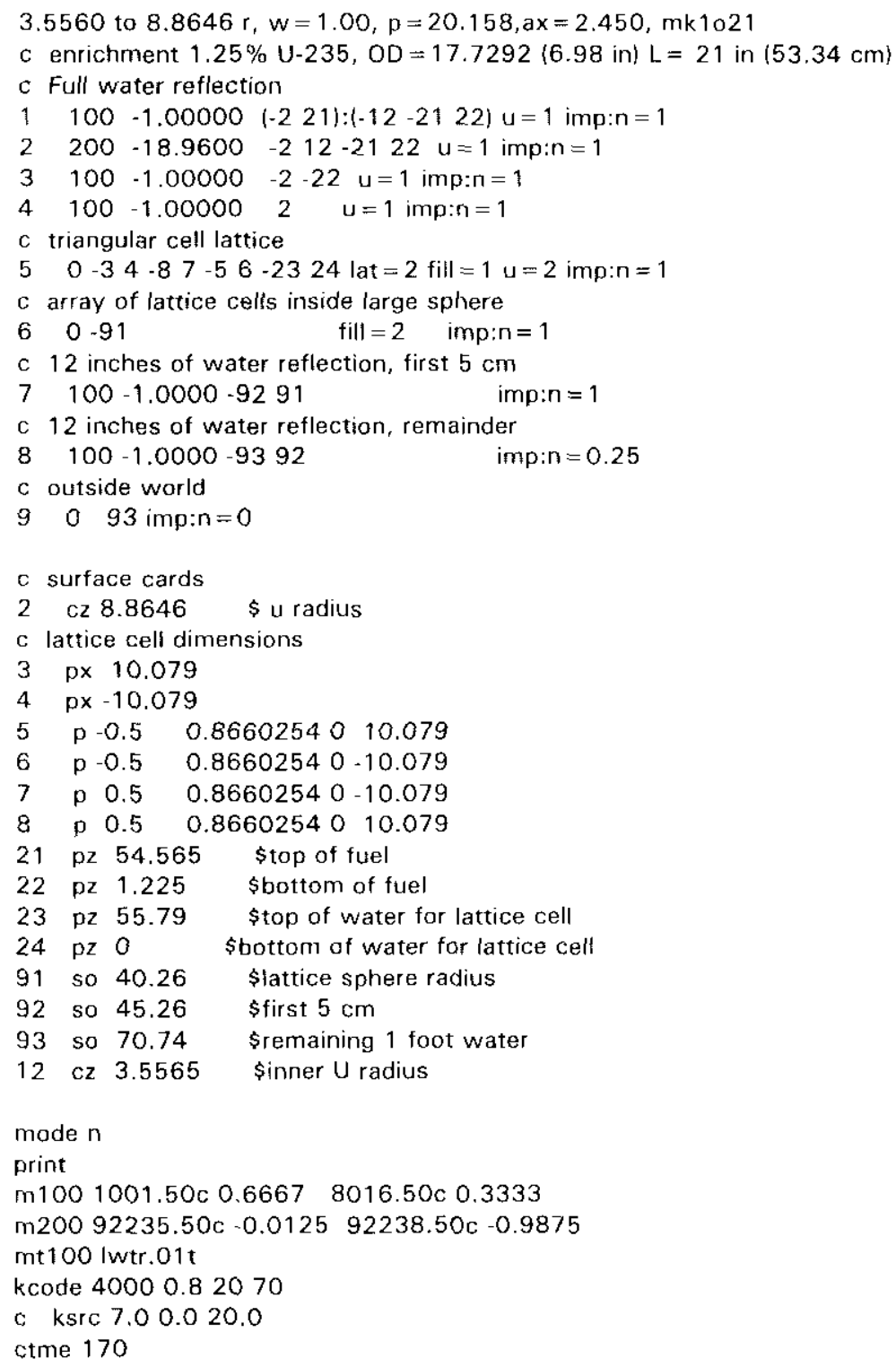


The 24th MCNP input file represents a finite spherical array of FERMCO Scrap (13" Diameter and 1 " long $U$ ) at optimum parameters. Fully water moderated and reflected. Input file i1301h.

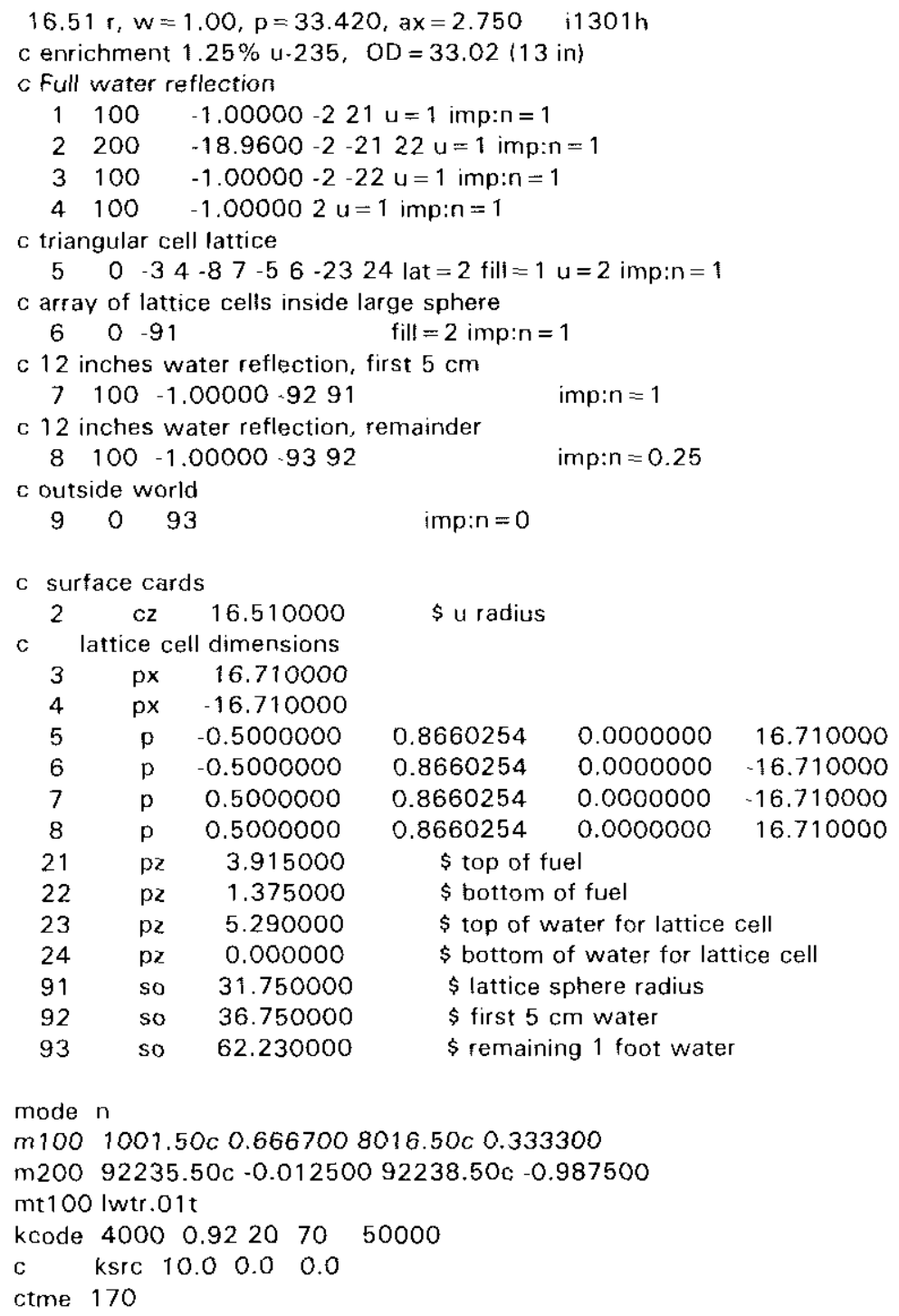


The 25th MCNP input file represents a finite spherical array of FERMCO Scrap (13" Diameter and 2" long $U$ ) at optimum parameters. Fully water moderated and reflected. Input file i13021.

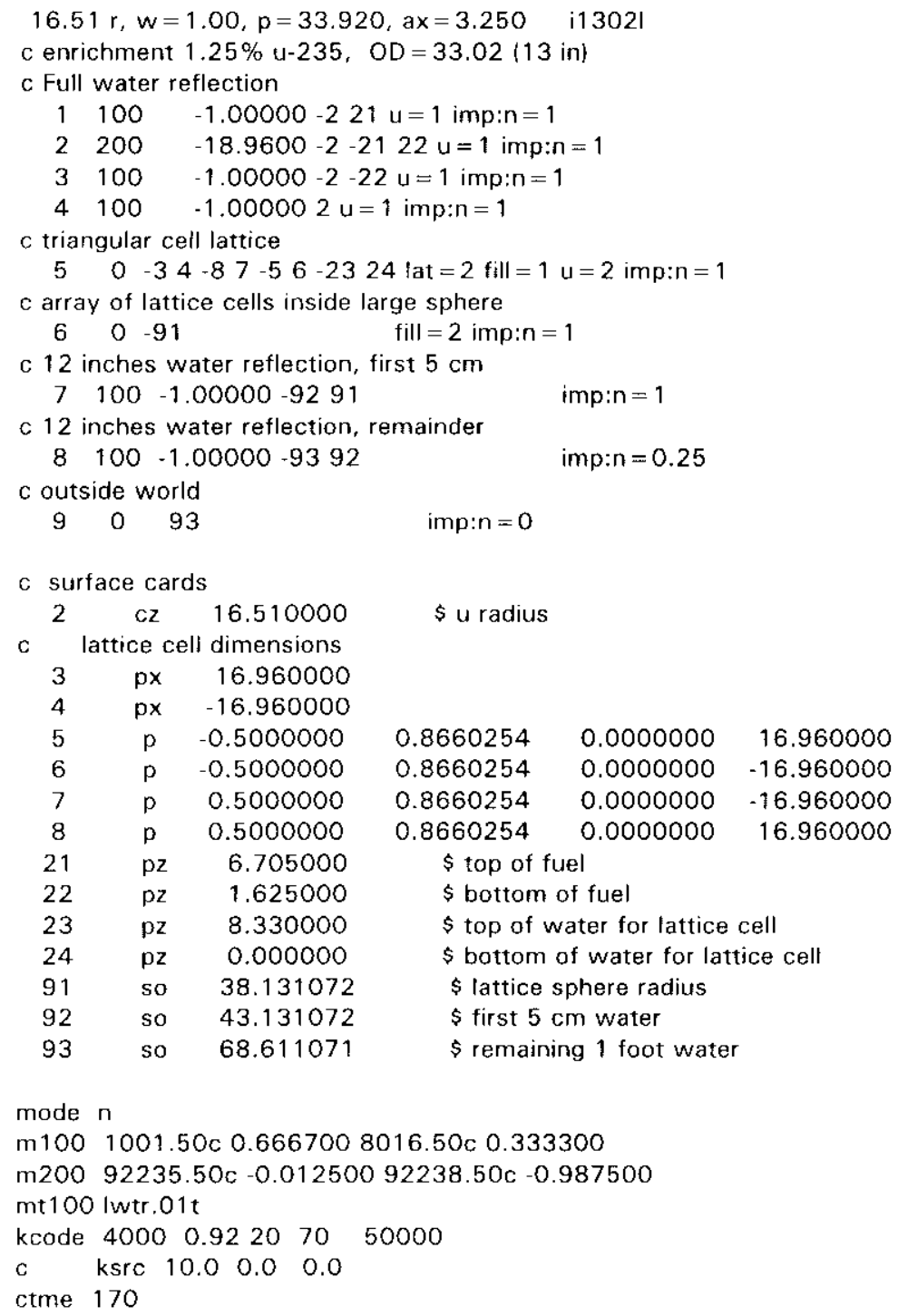


The 26th MCNP input file represents a finite spherical array of FERMCO Scrap (13" Diameter and 4 " long $\mathrm{U}$ ) at optimum parameters. Fully water moderated and reflected. Input file i1304n.

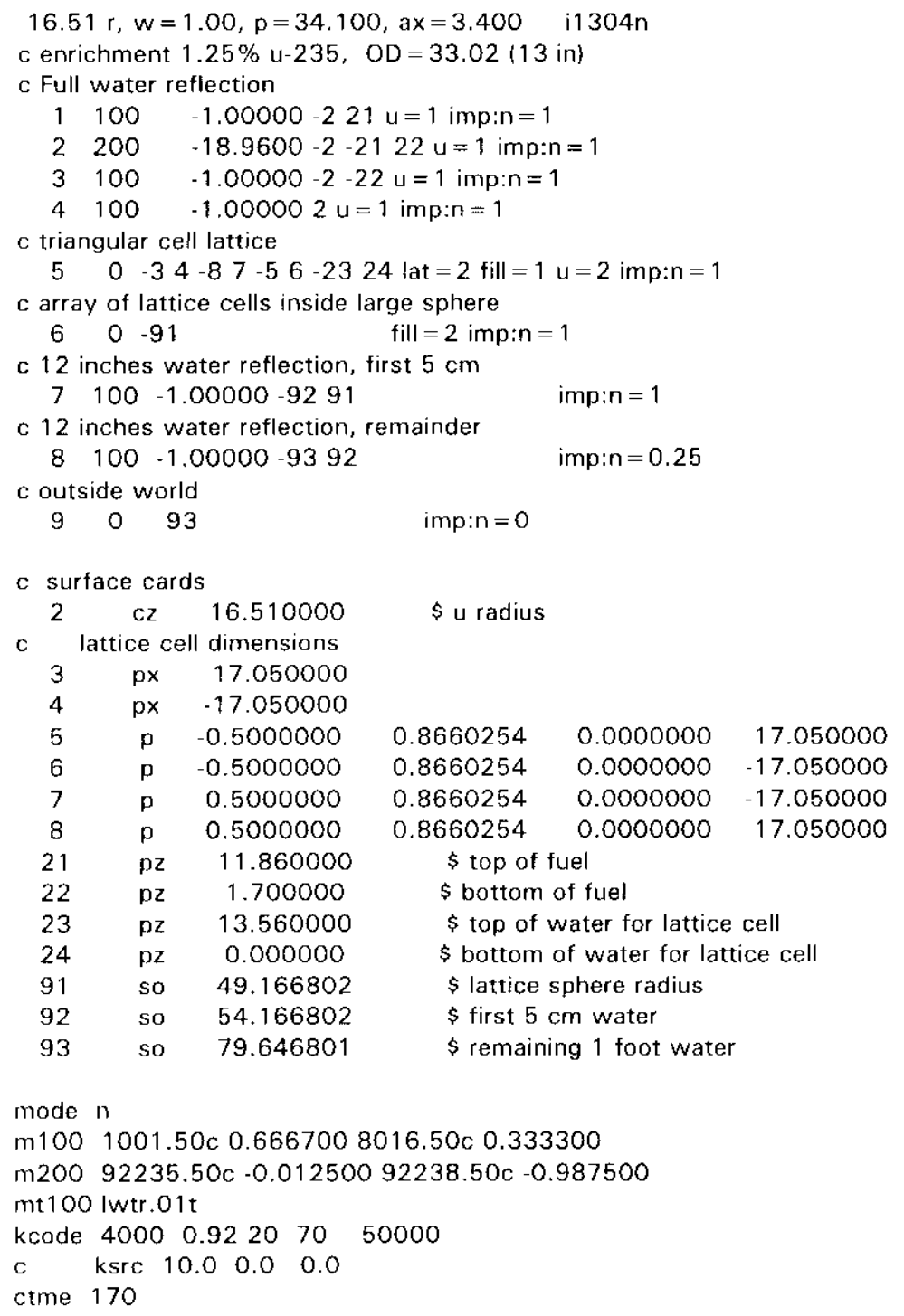


The 27th MCNP input file represents a finite spherical array of FERMCO Scrap (11" Diameter and 1" long $U$ ) at optimum parameters. Fully water moderated and reflected. Input file i11011.

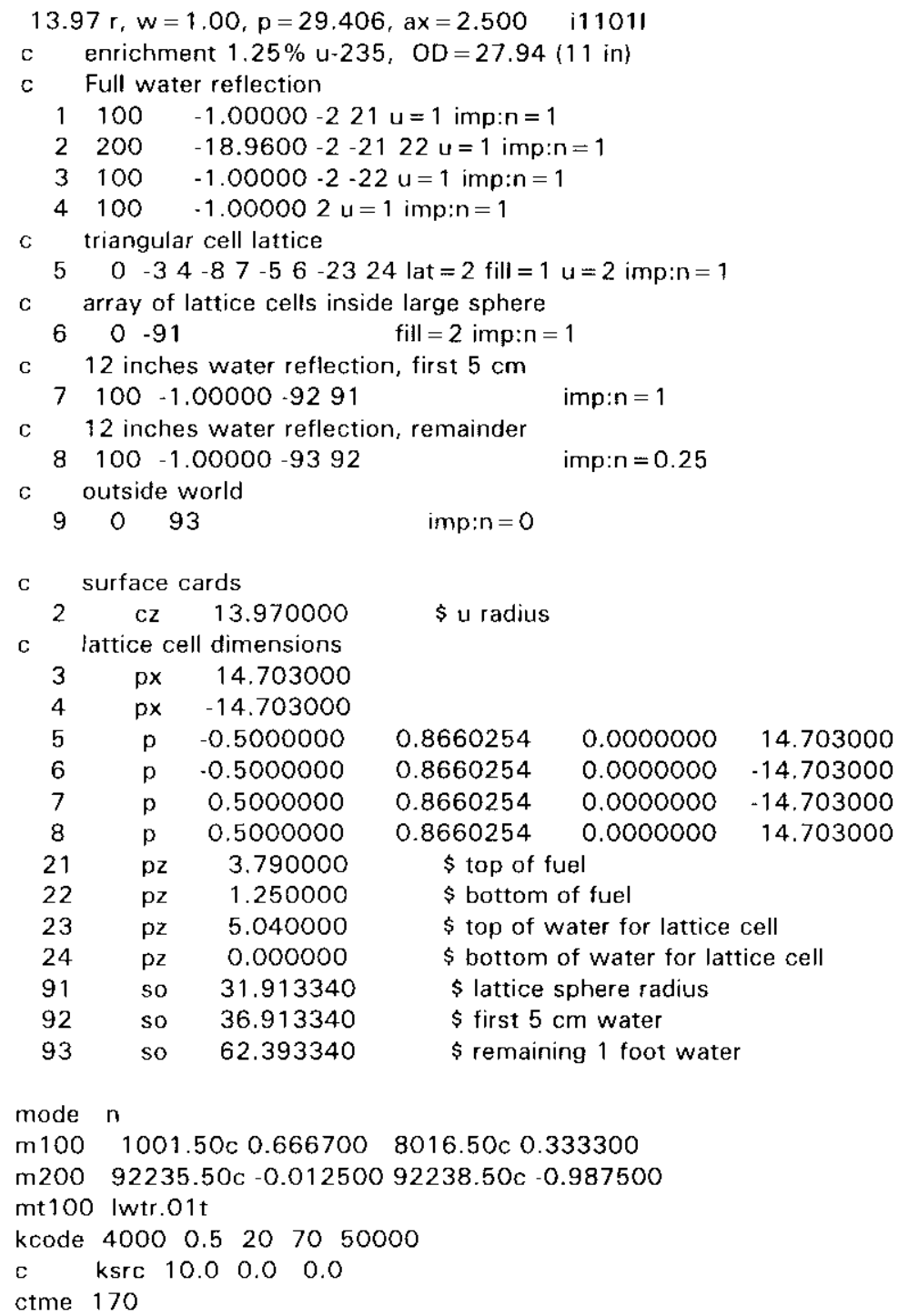


The 28th MCNP input file represents a finite spherical array of FERMCO Scrap (11" Diameter and 2 " long $\mathrm{U}$ ) at optimum parameters. Fully water moderated and reflected. Input file i1102m.

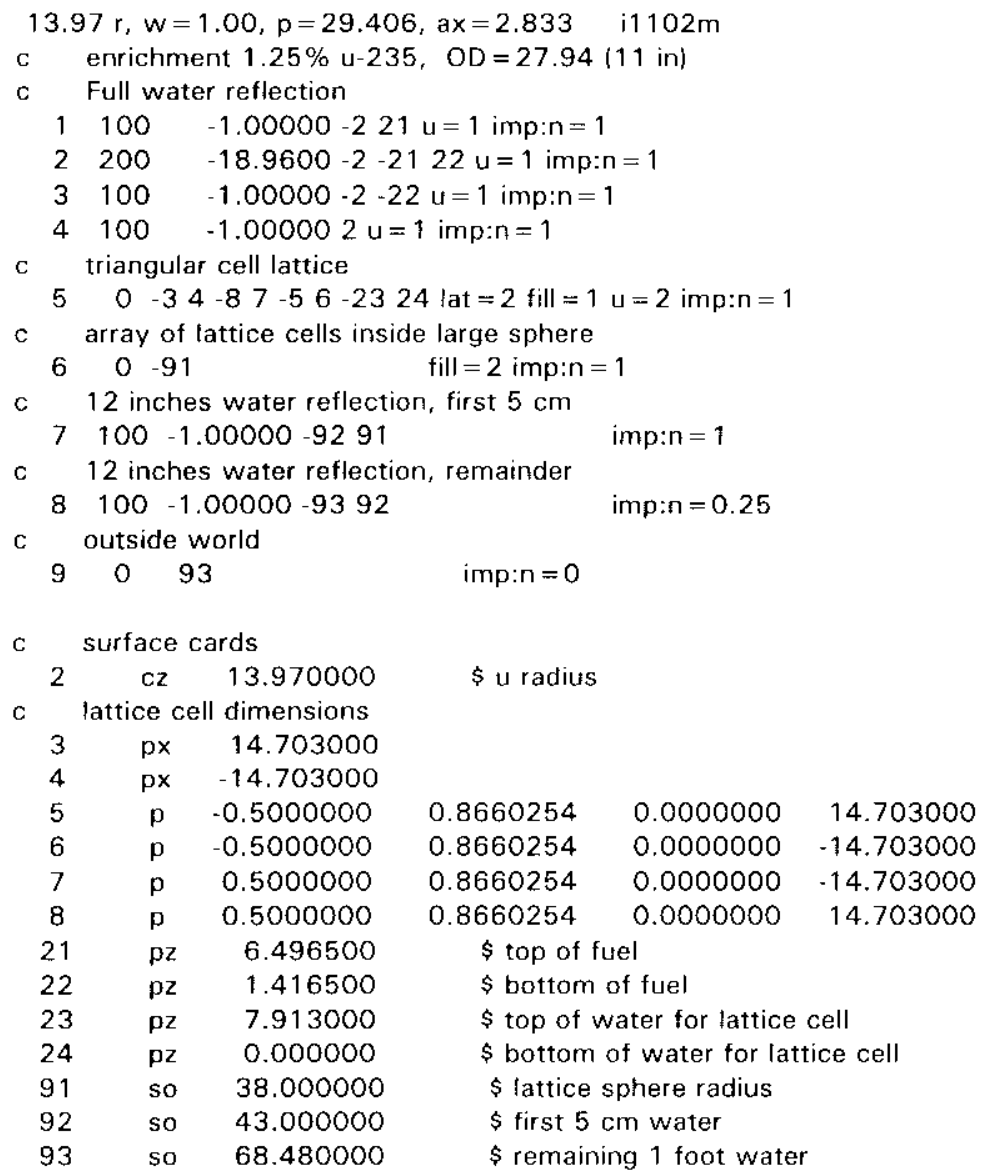

mode $n$

$\mathrm{m} 100 \quad 1001.50 \mathrm{c} \quad 0.666700 \quad 8016.50 \mathrm{c} 0.333300$

$\mathrm{m} 200 \quad 92235.50 \mathrm{c}-0.01250092238 .50 \mathrm{c}-0.987500$

mt100 iwtr.01t

kcode $4000 \quad 0.5 \quad 2070 \quad 50000$

$\begin{array}{lllll}\text { c } & \text { ksrc } & 10.0 & 0.0 & 0.0\end{array}$

ctme 170 
The 29th MCNP input file represents a finite spherical array of FERMCO Scrap (11" Diameter and 3" long $U$ ) at optimum parameters. Fully water moderated and reflected. Input file i1103q.

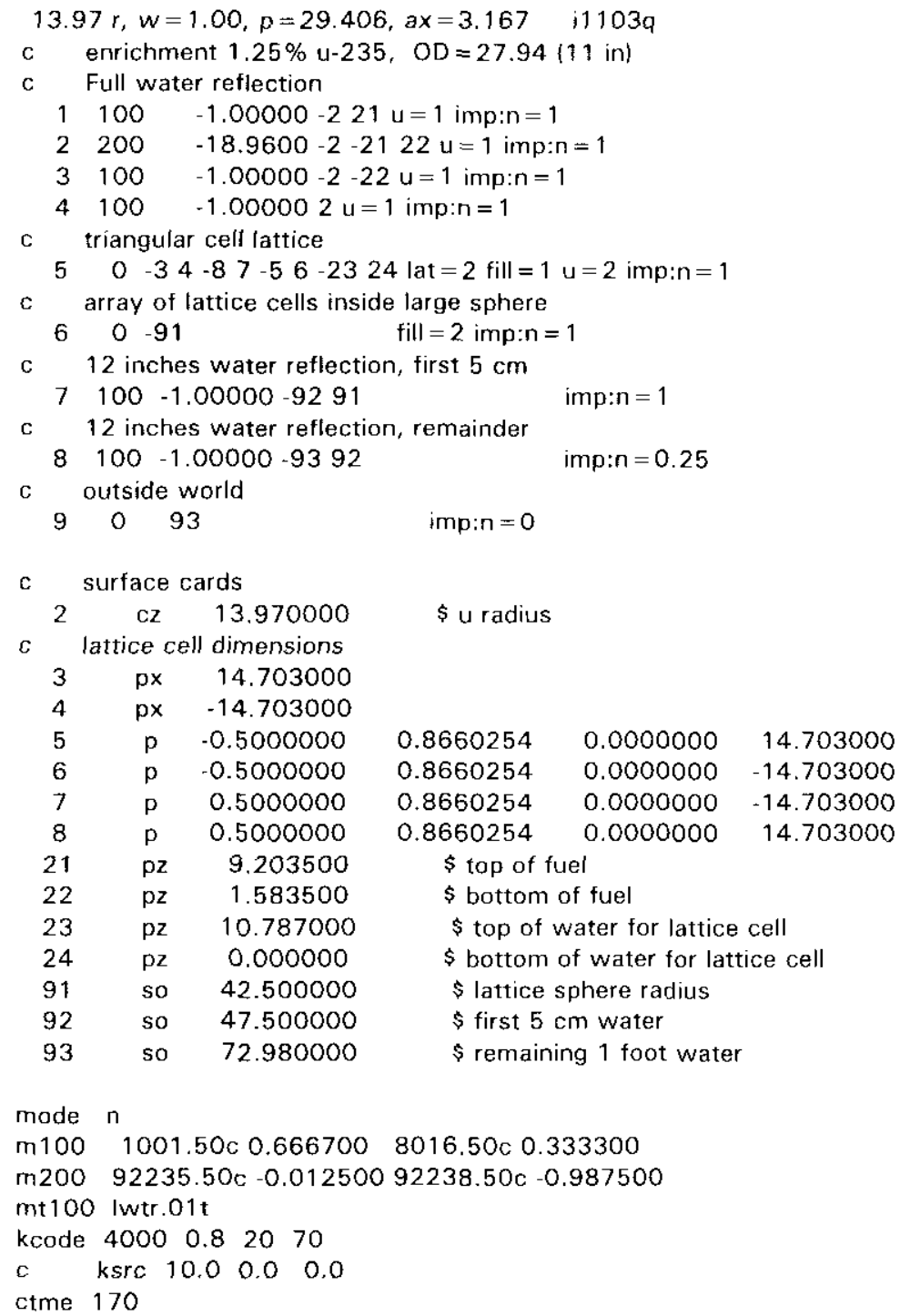


The 30th MCNP input file is an example of the volume calculation for the $32^{\text {nd }}$ MCNP input file [a finite spherical array of FERMCO Scrap (11" Diameter and 3" long $U$ ) at optimum parameters. Fully water moderated and reflectedl. Input file i1103qv.

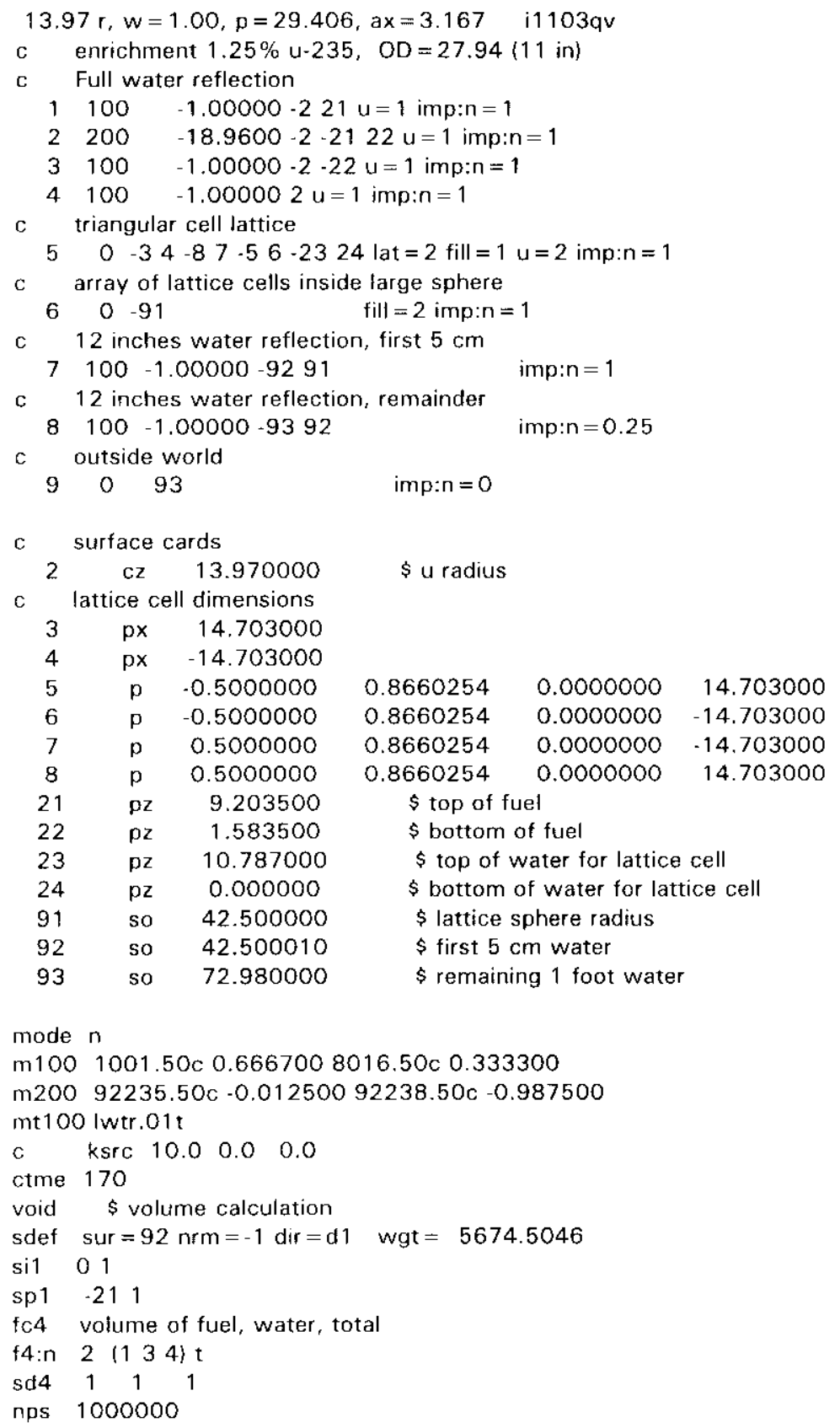


The 31st MCNP input file represents a finite spherical array of Mark I Outer Ingots (13.05" Diameter and 12" long $\mathrm{U}$ ) at optimum parameters. Fully water moderated and reflected. Input file i1312f.

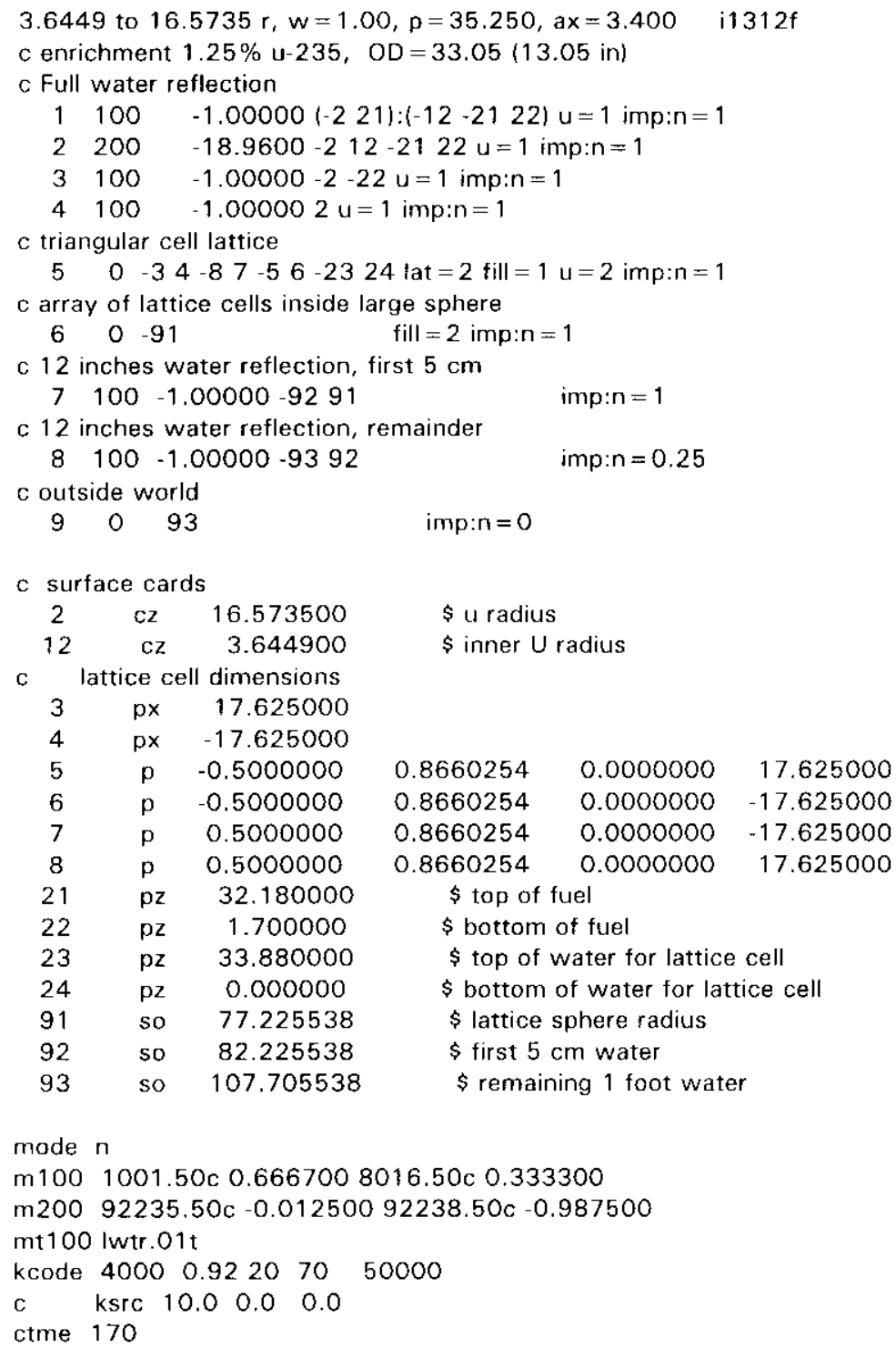




\subsection{OPERATING PROCEDURES}

\subsection{PROCEDURE FOR LOADING THE PACKAGES}

\subsubsection{General Information}

The following general information establishes the preliminary activities needed to conduct the specific operating procedures listed in Sections 7.1 through 7.3.

1. Written, traceable, and approved procedures shall be used throughout the operation.

2. All applicable OA requirements of Chapter 9 shall be followed.

3. Only trained and qualified (per Chapter 9) packaging and shipping personnel may load the package or direct its loading.

4. QA personnel shall observe and record the placement of the payload into the packaging. A final inspection result card indicating acceptable chemistry must be received for each piece of material being shipped.

5. Prior to any shipment, the shipper shall ensure that the package with its contents satisfies the requirements of the Certificate of Compliance and this SARP.

6. Prior to loading, the package components shall be visually inspected to ensure that they are in unimpaired physical condition. The package shall be visually inspected to ensure that all components are in place per the fabrication drawings and that the requirements in Table 8.2-1 of Chapter 8 are met. Packages with damaged or missing components shall be repaired to the requirements of the fabrication drawings.

7. The package shall be surveyed for radiation level and smearable contamination. The level of non-fixed radioactive contamination shall not exceed the limits specified in 49 CFR 173.443. Prior to shipment, the package radiation levels shall meet the requirements of 49 CFR 173.441 for exclusive use shipments.

8. Verify that the package name plate meets the requirements of $10 \mathrm{CFR} 71.85(\mathrm{c})$ and is attached to the package in such a manner that it would not be easily removed.

\subsubsection{Loading the Package}

1. Prior to loading the payload into the package, verify that the preliminary activities listed in Section 7.1.1 have been completed.

2. For the G-4214 box, if aluminum lining is required for certain types of uranium payload, inspect to see that the aluminum lining is in place.

3. For the N Reactor ingots, RMI forged billets, Mark 15 ingots, and FERMCO primary ingots, FERMCO product ingots, and FERMCO scrap (with lengths of $12 \mathrm{in.}[30.48 \mathrm{~cm}$ ] or greater), load the ingots and billets into the packages and band the payload to the package base according to the drawing for the package being used. Shoring, when necessary, is used to secure the payload within the box. Payload material less than $12 \mathrm{in.}(30.48 \mathrm{~cm})$ in length 
shall not be shipped in the G-4273 or G-4255 boxes. See Table 1.2.3-2 in Chapter 1 for recommended packagings.

4. FERMCO derbies, ingot sections, and scrap material (with lengths less than 12 in. [30.48 cm]) shall be loaded into either the G-4214 or G-4292 boxes. Wood shoring shall be placed in the box to prohibit movement of the contents. Banding of the scrap material to the box base is optional and is not required.

5. Place the cover or lid on the box or pallet and band in place per the applicable drawings. For the G-4214 and G-4292 boxes, install the plastic cover (see drawing OOF-5500-X-01753) before banding the lids in place.

6. The steel banding used on each box shall meet the requirements of ASTM D-3953 (ASTM $1991)$ and shall have a minimum tensile strength of $6,750 \mathrm{lb}(30,025 \mathrm{~N})$. Each steel band shall be secured with at least one seal that is closed with two pairs of notches per ASTM D3953, Figure 1. The steel bands shall be installed per the manufacturers guidelines and the guidelines in ASTM D-4675 (ASTM 1993).

7. The maximum payload and loaded package weights are listed in Table 7.1-1. When FERMCO scrap is transported, the maximum payload weights for the G-4214 and G-4292 boxes are listed in Table 1.2.3-2. The authorized payloads are listed in Chapter 1.0.

8. Complete all necessary shipping papers in accordance with 49 CFR 172 Subpart C (49 CFR 172, 1996); package marking with be in accordance with 49 CFR 172 Subpart D; labeling will be accordance with 49 CFR 172 Subpart $E$; and placarding will be in accordance with Subpart F of 49 CFR 172. Radiation monitor each package per the requirements of Subpart I of 49 CFR 173.441 (49 CFR 173, 1996) and determine that surface contamination levels meet the requirements of 49 CFR 173.443.

9. Load the packages onto the transport vehicle and secure the packages per the requirements of 49 CFR 393, Subpart I.

10. Perform a radiation survey of the transport vehicle in accordance with 49 CFR 173.441 for exclusive use shipments.

11. Ensure that an uniquely identified tamper-indicating device is in place on each package. If a closed transport vehicle or cargo container is used, the uniquely identified tamper-indicating device may be placed on the vehicle or cargo container door.

TABLE 7.1-1. Maximum Payload and Gross Weight for Each Wooden Box.

\begin{tabular}{|l|c|c|}
\hline \multicolumn{1}{|c|}{ Wooden Box } & $\begin{array}{c}\text { Maximum Payload Weight } \\
(\mathrm{lb}[\mathrm{kg}])\end{array}$ & $\begin{array}{c}\text { Maximum Package Gross } \\
\text { Weight }(\mathrm{lb}[\mathrm{kg}])\end{array}$ \\
\hline \hline G-4214 & $1,200(544)$ & $1,260(572)$ \\
\hline G-4255 & $1,344(610)$ & $1,464(664)$ \\
\hline G-4273-5 & $2,880(1,306)$ & $3,020(1,370)$ \\
\hline G-4273-6 & $3,488(1,582)$ & $3,632(1,647)$ \\
\hline G-4292 & $1,252(568)$ & $1,332(604)$ \\
\hline
\end{tabular}




\subsection{PROCEDURES FOR UNLOADING THE PACKAGE}

Unloading the package is essentially the reverse of the loading operation. The following steps provide the detailed requirements that are to be included in the unloading procedures.

1. Upon receipt, the condition and identification of each package or trailer tamper-indicating seal shall be checked. If any tamper-indicating seal is broken or the identification is not correct, the trailer is to be monitored for radiation level and smearable contamination per the requirements of Step 2 of this section. The trailer contents are to be inventoried and if items are missing, the proper authorities are to be notified. Documentation of the incident is to be in accordance with the Chapter 9 QA Plan.

2. Upon receipt, the trailer and each package shall be monitored for radiation level per Subpart I of 49 CFR 173.441, and for smearable contamination per 49 CFR 173.443.

3. Before and during unloading, visually inspect the package for damage. If package components are damaged, the package is to be repaired to the requirements of the fabrication drawing prior to reuse. The visual inspection and acceptance criteria in Table 8.2-1 is to be met prior to reuse of the package.

4. Remove the strapping that secures each package to the trailer.

5. Remove the package from the trailer, remove the longitudinal steel bands, and remove the package cover or lid.

6. Remove any banding over the payload and remove the payload from the package.

7. The package can now be prepared for 1) storage, 2) shipment as an empty package per Section 7.3 , or 3 ) readied for a shipment of another authorized payload per Section 7.1. If the package is to be stored, an "Empty" label is to be placed on the package and all other labels are to be removed.

\subsection{PREPARATION OF EMPTY PACKAGE FOR TRANSPORT}

When transported empty, the package is to be shipped with the lid or cover held in place with at least one $1 \frac{1}{4} \mathrm{in}$. steel band. No other special preparations are needed. The empty package shall be prepared for shipment in accordance with 49 CFR 173.428 and meet the external radiation levels listed in 10 CFR 71.47. 


\subsection{APPENDIX}

\subsubsection{Reference}

49 CFR 172, 1996, "Hazardous Material Tables and Hazardous Material Communications Regulations," Code of Federal Regulations, as amended.

49 CFR 173, 1996, "Shippers-General Requirements for Shipments and Packagings," Code of Federal Regulations, as amended.

49 CFR 393, 2000, "Subpart I--Protection Against Shifting or Falling Cargo," Code of Federal Regulations, as amended.

ASTM, 1993, Standard Guide for Selection and Use of Flat Strapping Materials, ASTM D-4675, American Society for Testing and Materials, Philadelphia, Pennsylvania.

ASTM, 1991, Specification for Strapping, Flat Steel and Seals, ASTM D-3953, American Society for Testing and Materials, Philadelphia, Pennsylvania. 


\subsection{ACCEPTANCE TESTS AND MAINTENANCE PROGRAM}

\subsection{ACCEPTANCE TESTS}

Wooden boxes of specified quality are procured from approved vendors. Fabrication drawings, listed in Chapter 1, Appendix 1.3.2, are supplied to the vendor who is required to comply with the drawing specifications by contractual agreement. A qualified inspector checks the boxes for compliance with the manufacturing specifications.

\subsubsection{Visual Inspection}

All packagings and their components are visually inspected before they are accepted from the manufacturer. Packagings and their components are inspected for proper construction, dimensions, material specifications (including mill specifications), and quality of workmanship. The manufacturer is required to make adjustments which are required to bring a packaging into compliance with specifications. If the manufacturer could not, or failed, to do so, the packaging is not accepted. Check the packages to ensure that they are marked in accordance with 10 CFR 71.85(c).

\subsubsection{Structural and Pressure Tests}

The packagings require no structural or pressure tests. The packagings are not pressure vessels.

\subsubsection{Leak Tests}

The packagings require no leak tests. The packagings are not water-tight nor can they contain gas under pressure.

\subsubsection{Component Tests}

Components, such as covers or lids, are inspected as part of the entire packaging.

\subsubsection{Tests for Shielding Integrity}

Tests for shielding integrity are not required because shielding is not designed into the packagings.

\subsection{MAINTENANCE PROGRAM}

Each wooden box shall be inspected prior to each use. The required inspections and acceptance criteria are listed in Table 8.2-1. If the acceptance criteria is not met, the box is either repaired to meet the requirements of the fabrication drawings located in Chapter 1, Appendix 1.3.2, or taken out of service. Because of the design and material components of the wooden boxes, no periodic testing is performed and there are no components that need regular replacement. Acceptable maintenance consists of storing the boxes out of the weather in a dry environment. 
Table 8.2-1. Maintenance Inspections Prior to Each Use.

\begin{tabular}{|l|c|l|}
\hline \multicolumn{1}{|c|}{ Item Inspected } & \multicolumn{1}{|c|}{$\begin{array}{c}\text { Inspection } \\
\text { Method }\end{array}$} & \multicolumn{1}{|c|}{ Acceptance Criteria } \\
\hline \hline Box Wood & Visual & $\begin{array}{l}\text { No dry rot, no fractured or broken } \\
\text { wood. Slight fracturing of wood at } \\
\text { corners under the steel bands is } \\
\text { acceptable. }\end{array}$ \\
\hline Steel Bands & Visual & $\begin{array}{l}\text { Installed per fabrication drawings, no } \\
\text { tears, fractures, or visible rust. }\end{array}$ \\
\hline $\begin{array}{l}\text { Box Fasteners } \\
\text { (Nails, Bolts, and Screws) }\end{array}$ & Visual & $\begin{array}{l}\text { All fasteners in place per fabrication } \\
\text { drawings. }\end{array}$ \\
\hline Contamination & Radiological Swipes & $\begin{array}{l}\text { Does not exceed contamination limits } \\
\text { of 49 CFR 173.428. }\end{array}$ \\
\hline
\end{tabular}




\subsection{QUALITY ASSURANCE}

\subsection{INTRODUCTION}

A Quality Assurance Program (QAP) was established to meet the QA requirements of the DOE Orders 5700.6C, Quality Assurance (DOE 1991) and 460.1A, Packaging and Transportation Safety (DOE 1996). The QAP defines quality activities necessary to produce shipping containers that comply with 10 CFR 71, Packaging and Transportation of Radioactive Material. The program was developed according to the guidance provided by NRC Regulatory Guide 7.10, Revision 1, Establishing Quality Assurance Programs for Packaging Used in the Transport of Radioactive Material.

\subsection{SCOPE}

The QAP addresses the following quality elements: organization; QAP; design control; procurement document control; instructions, procedures, and drawings; document control; control of purchased items and services; identification and control of items; control of processes; inspection; test control; control of measuring and test equipment; handling, storage, and shipping; inspection, test, and operating status; control of nonconforming items; corrective actions; quality assurance records; and audits. All elements of the QAP apply to subcontractors and subtier suppliers.

\subsection{QUALITY ASSURANCE PLAN}

\subsubsection{Quality Element 1.0, Organization}

The Fluor Hanford OA manager has delegated the direct responsibility for quality of the package to the QA technical support organization. The QA technical support management hierarchy is independent of management responsible for conduct of the packaging development. The QA personnel are independent from other personnel and organizations. An example of this independence is shown in Figure 9.3.1-1.

\subsubsection{Quality Element 2.0, Quality Assurance Program}

All support departments and service organizations shall comply with this QAP. Suppliers of services and equipment that affect the quality of the packagings shall have a $Q A$ program in accordance with the applicable QA of this QAP. Audits of supplier's QA programs shall be per the requirements of this QAP applicable to the goods and services provided. A determination about invoking the contractual clauses that require a QAP, Quality Assurance Plan Index (QAP)), or Preaward Surveys shall be made before placing a Request for Quote (RFQ) and shall be approved by QA.

All systems and major equipment designed, fabricated, or procured shall be evaluated and the appropriate documents shall be used to approve Environmental, Safety, and Quality Affecting Documents. 


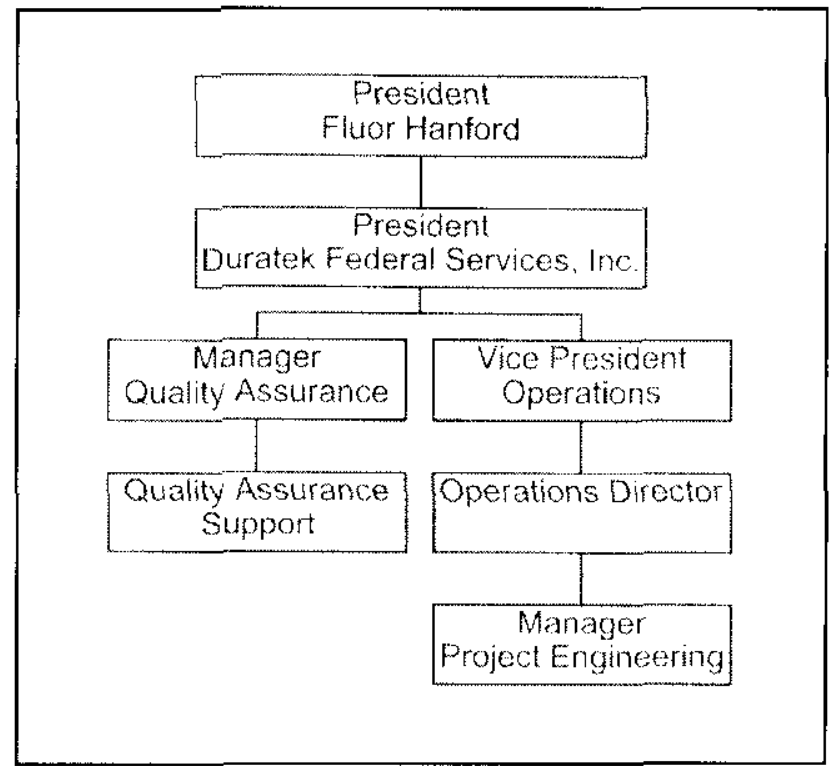

FIGURE 9.3.1-1. Reporting Independence of QA Organization.

Quality levels shall be assigned to all packaging components. Quality level assignment shall consider the impact to safety if the component were to fail or perform outside of design parameters. The three levels of $Q A$ categories from Appendix A, of NRC Regulatory Guide 7.10, are as follows:

- QA Category A (Critical): This level includes those items with a critical impact to safety, such as structures, components, and systems whose failure or malfunction could result directly in a condition adversely affecting public health and safety. This includes loss of shielding or an unsafe geometry compromising criticality control.

- QA Category B (Major): This level includes those items with a major impact to safety, such as structures, components, and systems whose failure or malfunction could result indirectly in a condition adversely affecting public health and safety. An unsafe condition could result only if the primary event occurs in conjunction with a secondary event or other failure or environmental occurrence. This also includes the loss of shielding or an unsafe geometry compromising critical control concerning important to safety items.

- $\quad$ QA Category C (Minor): This level includes those items with a minor impact to safety, such as structures, components, and systems whose failure or malfunction would not significantly reduce the packaging effectiveness and would be unlikely to create a condition adversely affecting public health and safety. This also includes the loss of shielding or an unsafe geometry compromising criticality control concerning important to safety items.

Adherence to appropriate design criteria (regulatory guides, safety, performance, maintainability, operability, lifetime) shall be the measure of quality and are to be evaluated in reviews of designs and related activities for the scope of this QAP. The graded approach assessment of the steel banded wooden boxes is listed in Table 9.3.2-1. 
TABLE 9.3.2-1. Quality Assurance Levels for the Wooden Box Packagings.

\begin{tabular}{|l|l|c|}
\hline \multicolumn{1}{|c|}{ Component } & \multicolumn{1}{|c|}{ Subcomponent } & OA Level \\
\hline \hline \multirow{5}{*}{ Box Lids } & Plywood/Wood & $\mathrm{C}$ \\
\cline { 2 - 3 } & Nails & $\mathrm{C}$ \\
\cline { 2 - 3 } & Glue & $\mathrm{C}$ \\
\cline { 2 - 3 } & Steel Bands and Seals & $\mathrm{B}$ \\
\cline { 2 - 3 } & All Other Components & $\mathrm{C}$ \\
\hline \multirow{5}{*}{ Box Bases } & Plywood/Wood & $\mathrm{C}$ \\
\cline { 2 - 3 } & Lag Screws/Bolts & $\mathrm{C}$ \\
\cline { 2 - 3 } & Blocks/Chocks & $\mathrm{C}$ \\
\cline { 2 - 3 } & All Other Components & $\mathrm{C}$ \\
\hline
\end{tabular}

Personnel performing special processes, such as nondestructive examination, shall be qualified to the American Society for Nondestructive Testing (ASNT) recommended practice number SNT-TC-1A. Personnel performing other critical operations, such as crimping the steel bands, shall be trained.

\subsubsection{Quality Element 3.0, Package Design Control}

Design control activities are performed in accordance with approved engineering practices. Verification or checking of the design is performed using one or more of the following: design review, computer codes, the use of alternate or simplified calculation methods, and the performance of suitable model qualification tests. Design verification is performed by individuals or groups other than the original designer and the designer's immediate supervisor.

Modifications to the design undergo the same level or review and approval as the original design and in conjunction with the identified impact level. All changes are reviewed for consistency with the SARP.

Computer codes used to verify components or systems that are Quality Level A or B are evaluated before use. This evaluation includes, but is not limited to, the following items:

- A review of previous applications of the code.

- Benchmark evaluation of the code.

- Correlation of the code results against data obtained in the field.

\subsubsection{Quality Element 4.0, Procurement Document Control}

A graded approach shall be implemented for procurement of equipment and services based on safety, performance, and regulatory criteria. QA shall ensure that procurement documents are adequate for their intended purpose. 
Where extensive procurement detail is required, technical requirements and acceptance criteria shall normally be established by approved functions and specifications and/or design drawings. Where the procurement does not require extensive detail, requirements and criteria may be specified in the body of the purchase order or data sheets referenced by and attached to the purchase order. Certain items, such as "off-the-shelf equipment" and "catalog items, "may not require listing of the technical requirements and acceptance criteria and may be specified by model number or equivalent.

Supplier documentation requirements shall be included with the procurement documents identifying which items must be submitted by the supplier. A submittal list shall specify which documents shall be submitted for approval and which documents shall be submitted for information during the contract period. Examples of documents include fabrication and inspection procedures, equipment installation instructions, calibration procedures, operating and maintenance manuals, and spare parts lists.

For procurement involving vendor designs, vendor design control, document control, and change control shall be in accordance with approved methods of document control or equivalent to the requirements of this QAP.

\subsubsection{Quality Element 5.0, Instructions, Procedures, and Drawings}

All instructions, procedures, and drawings shall be approved according to the quality level and approval designation assigned by the cognizant design/project engineer and verified by $\mathrm{QA}$ as adequate for their intended purpose. $Q A$ shall ensure that approved and correct documents are employed.

QA shall approve witness points and hold points before the procurement, fabrication, or installation documentation approval. Witness and hold points, as a minimum, will be identified in inspection plans prepared per Section 9.3.10. Requirements for instructions, manuals, and equipment data shall be specified in the procurement document.

\subsubsection{Quality Element 6.0, Document Control}

All documents used to perform or verify quality related activities, e.g., design, procurement, fabrication, testing, assembly, maintenance, and modification, shall be controlled. All documents applicable to and used for the package shall be reviewed and approved per the requirements of the assigned safety quality level, and applicable administrative, engineering, or technical document approval procedures. Changes to documents shall be controlled according to approved change control procedures applicable to each type of document, and are governed by control measures equal to those applied to the original documents.

\subsubsection{Quality Element 7.0, Control of Purchased Material, Equipment and Services}

This quality element applies to the purchase of items and services that affect quality. Procurement controls provide for source evaluation and selection, evaluation of objective evidence of quality furnished by the supplier, source inspection, audit, and examination of items or services upon delivery or completion. 
Procurement activities are performed according to documented procedures to ensure a systematic approach and, as a minimum, address the following:

- Preparation, review, and release of procurement documents.

- Selection of procurement sources.

- Bid evaluation and award.

- Supplier performance evaluation.

- Control of supplier-generated documents.

- $\quad$ Source and/or receiving inspections.

- $\quad$ Control of changes to procurement documents for items and services.

- Material identification and control.

- Acceptance of items and services.

\subsubsection{Quality Element 8.0, Identification and Control of Material, Parts and Components}

Material control, where required, shall be specified in procurement documents, fabrication specifications, and construction specifications, so that only correct and accepted items are used and installed. These controls provide identification on items or in documents to ensure traceability. Each participant and subcontractor/supplier are responsible for implementing appropriate portions of the QAP program to identify and control items. The QAP complies with the requirements of DOE 5700.6C.

Items of production (i.e., batch, lot, component, or part) are identified from the initial receipt and fabrication through storage, installation, and use. This relates items to applicable design or other specifying documents.

Physical identification is the preferred method. Where physical identification is insufficient or not practical, control will be established by other approved and appropriate means, such as procedural control and physical separation. Markings, when used, shall be applied using materials and methods that provide clear and legible identification that will not affect the function or service life of the item. Markings will be transferred to each part of an item before subdividing. Caution shall be exercised to prevent obliteration by any surface treatment or coating.

Items that have limited calendar or operating life cycles or shelf life shall be controlled to preclude the use of expired items, and to replace installed items before failure or expiration.

\subsubsection{Quality Element 9.0, Control of Special Processes}

Processes affecting quality of items and services during fabrication and installation shall be controlled. The process control requirements shall be established in the design documents or in instructions, procedures, or drawings applicable to the process. Procedures that may be prepared to control and ensure the quality of processes shall have detail, based on the level of complexity or unique properties of the process. Stringency of review and approvals of process procedures that may be prepared shall be based on the safety quality level established in Section 9.3.2. Examples of processes that may require procedures are nondestructive examination, chemical analyses, metal finishing and coatings, heat treating, and cleaning. Personnel who perform special processes shall be qualified or certified as required to ensure quality.

All qualification records and support data are retained in the QA data file and maintained in a current status by QA personnel. These documents are controlled as delineated in Section 9.3.6, Document Control. 


\subsubsection{Quality Element 10.0, Inspection}

Inspections shall be required to verify conformance of an item or activity to specified requirements. Inspection requirements shall be identified during the design and in the design documents. Inspection requirements shall be specified in procurement documents.

Inspections shall be performed with approved inspection plans and documented according to approved procedures. Inspectors shall be qualified or certified per the inspection requirements and shall be independent from the activity, process, or product being inspected.

Critical operational activities for loading and unloading the wooden boxes:

- $\quad$ Prior to loading, verify that the containers have been visually inspected for damage and that the maintenance inspections in Table 8.2-1 of Chapter 8.0 of the SARP have been performed.

- Verify that the container is approved for use and that it is appropriate for the selected payload. The authorized payloads and containers are listed in Chapter 1.0 of the SARP.

- Verify that the maximum payload weight, listed in Table 7.1-1 of Chapter 7.0 of the SARP, is not exceeded.

- Verify that the payload is properly secured per the drawings in Section 1.3.2 of Chapter 1.0 of the SARP. For boxes G-4255 and G-4273, the payload is banded in place. For boxes G-4214, G-4245, and G-4292, the payload is to be shored in place to prevent movement.

- Verify that the container is properly closed and banded per the drawings in Section 1.2 .3 of Chapter 1.0 of the SARP.

- Verify that the maximum package gross weight, listed in Table 7.1-1 of Chapter 7.0 of the SARP, is not exceeded.

Critical verification points for use of the wooden boxes are:

- $\quad$ Packages are properly assembled.

- $\quad$ All shipping papers are properly completed.

- Operational procedures are properly completed.

- $\quad$ Packages are marked as required by DOT regulations.

Critical verification points for the maintenance and repair of the packages are:

- $\quad$ Ensure that the maintenance inspections listed in Table 8.2-1 are performed.

- Ensure that all repairs comply with the requirements of the fabrication drawings.

\subsubsection{Quality Element 11.0, Test Control}

Tests are required when it is necessary to demonstrate that items or processes will perform satisfactorily. Test procedures shall specify the objectives of the tests, testing methods, required documentation, acceptance criteria, and shall be approved per the safety quality level established in Section 9.3.2. 
Tests conducted by vendors at vendor plants shall be specified in the procurement documents. The Buyer test approvals and required test observations shall be specified in test documents of vendor tests.

\subsubsection{Quality Element 12.0, Control of Measuring and Test Equipment}

All equipment used for measuring or testing shall be calibrated in accordance with the required test or measuring accuracy and repeatability and to approved standards of calibration. Calibrations and calibration records shall be traceable to the required calibration standard and the National Institute of Standards and Technology (NIST), and the equipment shall be marked with calibration expiration dates.

Measuring and test equipment control shall be required for all suppliers that provide equipment or services that will be used to accept or test equipment or materials for the package. Requirements to be invoked on suppliers in accordance with the QAP shall be specified in procurement documents.

\subsubsection{Quality Element 13.0, Handling, Storage, and Shipping Control}

All items that are part of the package shall be controlled to prevent damage or loss, to protect against damage or deterioration, and to provide adequate safety of personnel involved in the material handling and storage operations.

Preshipment planning with suppliers shall be required for preservation, packaging, shipping, handling, and receiving in accordance with the complexity of equipment and systems for the package. Requirements shall be specified in the procurement document. The planning will be dependent on whether an item will require special or unique handling, storage, or special planning because of vulnerability to damage by the environment or physical damage that could result from normal handling.

Information pertaining to shelf life, environment, packaging, temperature, cleaning, handling, and preservation is included as required to meet design, regulatory package approval, and/or DOT shipping requirements.

\subsubsection{Quality Element 14.0, Inspection, Test, and Operating Status}

Work instructions, travelers, and similar documents will help maintain status during procurement and fabrication by the fabricator. In-process inspections, and inspection of incomplete items and activities shall be performed where necessary to verify quality and to ensure required inspections, verifications, and tests are performed.

Planning shall be performed before the turnover of the packaging to the Buyer upon completion of required assembly by the contractor. This planning will take into account the acceptance testing to be performed by the contractor to verify conformance to the specifications.

\subsubsection{Quality Element 15.0, Nonconforming Materials, Parts, or Components}

The control of nonconforming items, equipment, or conditions for the package is accomplished by Nonconformance Reports (NCR). The NCR procedures promote consistency, timeliness of problem resolution, and processing of all necessary documentation. 
Items or practices that do not meet specified requirements, or whose conformance is indeterminate, are documented on NCRs and controlled to prevent inadvertent installation or use. Controls are provided to notify affected organizations and for the identification, documentation, evaluation, segregation, and disposition of the items or conditions. The NCRs are tracked to completion and the verification of corrective action is documented.

9.3.15.1 Identification. Nonconforming items are identified by marking, tagging, or other methods that do not adversely affect the item. When identification of nonconforming items is not practical, the container or package is marked, or segregated storage is provided.

9.3.15.2 Segregation. Nonconforming items are segregated by placing them in a designated and identified holding area until disposition is complete. When segregation is impossible or not practical because of size, weight, or access limitations, other precautions are used on a case by case basis.

9.3.15.3 Disposition. Documentation to identify, review, and disposition nonconforming items is controlled according to approved procedures that specify responsibilities and authority. Personnel who perform evaluations and approve dispositions must be competent in the specific areas they are evaluating, understand the requirements, and have access to the pertinent background information. Each organization identifies, in writing, the personnel by job title who are authorized to evaluate proposed NCR dispositions.

Control of further processing, delivery, installation, or use of nonconforming items is imposed pending resolution of NCRs.

\subsubsection{Quality Element 16.0, Corrective Action}

Conditions adverse to quality shall be identified and corrected as soon as practicable. An unsatisfactory condition or nonconformance may be revealed by an audit, an unusual occurrence, a random observation, during inspection, or from trend analyses of other reports. The controls shall be implemented in accordance with this QAP. Corrective action requirements are described in approved QA procedures.

\subsubsection{Quality Element 17.0, Quality Assurance Records}

Records that document evidence of quality are specified, prepared, and maintained. The quality records may be either the originals or copies. Copies must be capable of microfilming when used. Microfilm is acceptable, except for radiographs. Records shall be legible, identifiable, and retrievable. Records shall be protected from damage, deterioration, or loss. Lost or damaged records shall be replaced, restored, or substituted to the extent possible.

Requirements and responsibilities for record generation, transmittal, evaluation, distribution, retention, maintenance, and disposition are established and documented in QA procedures. Each organization is responsible for generating records that furnish documentary evidence of quality, according to scoping statements appearing in work authorizing documents. The description of controls for records only applies to $\mathrm{OA}$ records that have been completed. Incomplete documentary evidence is not subject to the controls described.

Documents are considered valid records only if stamped, initialed, or signed, and dated by authorized personnel or otherwise authenticated. 
9.3.17.1 Classification. Records are classified as "lifetime" or "nonpermanent." Lifetime records are required to be maintained by, or for, the owner for the life of the package plus three years while it is installed or in service. Lifetime records are those that meet one or more of the following criteria:

- $\quad$ Those specified for lifetime retention by regulatory or contractual requirements.

- $\quad$ Those that would be of significant value in demonstrating capability for safe operation.

- Those that would be of significant value in maintaining, reworking, repairing, replacing, or modifying an item.

- Those that would be of significant value in determining the cause of an accident or malfunction of an item.

- Those that provide required baseline data for inservice inspections.

- Those that substantiate development or major decisions involving safety and the environment.

- $\quad$ Those that evidence conformance to codes and specifications.

Examples of lifetime records are as follows: calculations, drawings, results of design reviews, inspections, tests, and audits. Nonpermanent records are those required to show evidence that an activity was performed according to the applicable requirements, but need not be retained for the life of the item because they do not meet the criteria for lifetime.

\subsubsection{Quality Element 18.0, Audits}

Quality audits shall be conducted on package activities (internal audits) and on the equipment suppliers (external audits) as required. Audits shall be conducted by qualified auditors and may be performed on a team basis as required by the audit scope. 


\subsection{APPENDIX}

\subsubsection{References}

10 CFR 71, 1995, "Packaging and Transportation of Radioactive Materials," Code of Federal Regulations, as amended.

DOE, 1991, Quality Assurance, DOE Order 5700.6C, U.S. Department of Energy, Washington, D.C., August 21, 1991.

DOE, 1996, Packaging and Transportation Safety, DOE Order 460.1A, U.S. Department of Energy, Washington, D.C., October 2, 1996.

NRC, 1986, Establishing Quality Assurance Programs for Packaging Used in the Transport of Radioactive Material, NRC Regulatory Guide 7.10, Rev. 1, U.S. Nuclear Regulatory Commission, Washington, D.C. 